
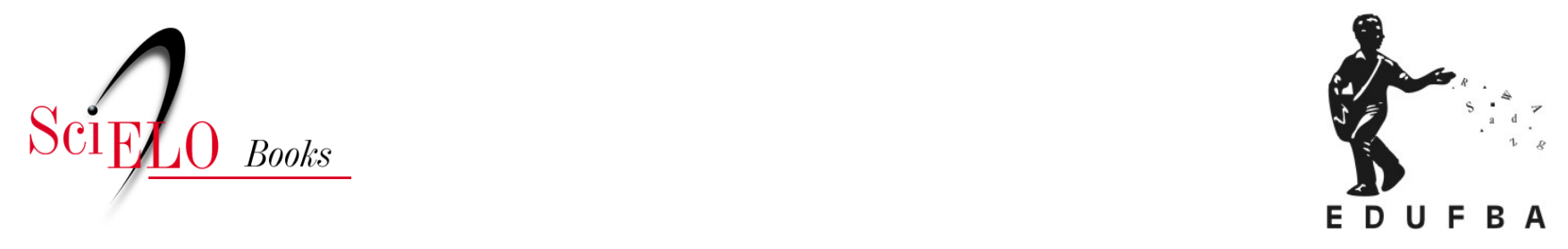

\title{
Questões sociocientíficas \\ fundamentos, propostas de ensino e perspectivas para ações sociopolíticas
}

\author{
Dália Melissa Conrado \\ Nei Nunes-Neto \\ (Organizadores)
}

\section{SciELO Books / SciELO Livros / SciELO Libros}

CONRADO, D.M., and NUNES-NETO, N. Questões sociocientíficas: fundamentos, propostas de ensino e perspectivas para ações sociopolíticas [online]. Salvador: EDUFBA, 2018, 570 p. ISBN 978-85-2322017-4. https://doi.org/10.7476/9788523220174.

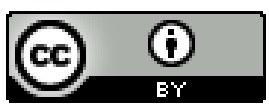

All the contents of this work, except where otherwise noted, is licensed under a Creative Commons Attribution 4.0 International license.

Todo o conteúdo deste trabalho, exceto quando houver ressalva, é publicado sob a licença Creative Commons Atribição 4.0. 



\section{UNIVERSIDADE FEDERAL DA BAHIA}

Reitor

João Carlos Salles Pires da Silva

Vice-reitor

Paulo Cesar Miguez de Oliveira

Assessor do Reitor

Paulo Costa Lima

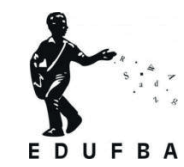

EDITORA DA UNIVERSIDADE FEDERAL DA BAHIA

Diretora

Flávia Goulart Mota Garcia Rosa

Conselho Editorial

Alberto Brum Novaes

Angelo Szaniecki Perret Serpa

Caiuby Alves da Costa

Charbel Niño El Hani

Cleise Furtado Mendes

Evelina de Carvalho Sá Hoisel

José Teixeira Cavalcante Filho

Maria do Carmo Soares de Freitas

Maria Vidal de Negreiros Camargo 


\section{Dália Melissa Conrado \\ Nei Nunes-Neto \\ (Organizadores)}

\section{QUESTÕES SOCIOCIENTIIFICAS \\ FUNDAMENTOS, PROPOSTAS DE ENSINO E PERSPECTIVAS \\ PARA AÇÕES SOCIOPOLITICAS}

Salvador

Edufba

2018 
20I8, Autores.

Direitos para esta edição cedidos à Edufba.

Feito o Depósito Legal.

Grafia atualizada conforme o Acordo Ortográfico da Língua Portuguesa de I990, em vigor no Brasil desde 2009.

\author{
Capa e Projeto Gráfico \\ Rodrigo Oyarzábal Schlabitz
}

\author{
Revisão \\ Maísa Costa
}

Normalização

Sandra Batista

Sistema de Bibliotecas - UFBA

Questões sociocientíficas : fundamentos, propostas de ensino e perspectivas para ações sociopolíticas / Dália Melissa Conrado, Nei Nunes-Neto (Org.). - Salvador: EDUFBA, 2018. $570 \mathrm{p}$.

ISBN: 978-85-232-I656-6

I. Ciência - Estudo e ensino. 2. Educação - Finalidades e objetivos. I. Conrado, Dália Melissa.

Il. Nunes-Neto, Nei F.

CDD -370.7

Editora afiliada à

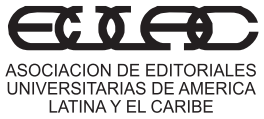

LATINA Y EL CARIBE
LATARIAS DE AMER

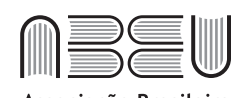

Associação Brasileira das Editoras Universitárias
$\mathrm{CBaL}$

Editora da UFBA

Rua Barão de Jeremoabo, s/n - Campus de Ondina

40I70-II5 - Salvador - Bahia

Tel.: +55 7I 3283-6I64

www.edufba.ufba.br / edufba@ufba.br 
A nossos pais

A todos aqueles comprometidos com pensamentos e ações mais altruístas 


\section{SUMÁRIO}

11 PREFÁCIO

Irlan Von Linsingen

15 APRESENTAÇÃO

Nei Nunes-Neto

Dália Melissa Conrado

PARTE I: FUNDAMENTOS TEÓRICOS

27 REALÇANDO O PAPEL DA ÉTICA E DA POLÍTICA NA EDUCAÇÃO CIENTÍFICA:

ALGUMAS CONSIDERAÇÕES TEÓRICAS E PRÁTICAS SOBRE QUESTÕES SOCIOCIENTIIFICAS

Derek Hodson

59 PENSAMIENTO CRÍTICO DESDE CUESTIONES SOCIO-CIENTÍFICAS

Nidia Torres

Jordi Solbes

77 QUESTÕES SOCIOCIENTÍFICAS E DIMENSÕES CONCEITUAIS, PROCEDIMENTAIS E ATITUDINAIS DOS CONTEÚDOS NO ENSINO DE CIÊNCIAS

Dália Melissa Conrado

Nei Nunes-Neto

\section{PARTE II: PROPOSTAS DE ENSINO}

121 USO DE AGROTÓXICOS: UMA QUESTÃO SOCIOCIENTÍFICA PARA O ENSINO MÉDIO Maria Aparecida da Silva Andrade

Nei Nunes-Neto

Rosiléia Oliveira de Almeida

145 DECLÍNIO DE POLINIZADORES COMO QUESTÃO SOCIOCIENTÍFICA NO ENSINO DE BIOLOGIA

Dália Melissa Conrado

Nei Nunes-Neto

Blandina F. Viana

Charbel N. El-Hani

173 PESCA DA LAGOSTA: QUESTÕES SOCIOCIENTÍFICAS NO CONTEXTO DE UMA INTERVENÇÃO DE EDUCAÇÃO AMBIENTAL MULTICULTURAL EM COMUNIDADE TRADICIONAL

Clívio Pimentel-Júnior

Wellington Bittencourt

191 POLUIÇÃO HÍDRICA: UMA QUESTÃO SOCIOCIENTÍFICA PARA ABORDAR ÉTICA AMBIENTAL NO ENSINO FUNDAMENTAL DE CIÊNCIAS

Jéssica Santos

Dália Melissa Conrado

Nei Nunes-Neto 
213 DOENÇA DE CHAGAS A PARTIR DE QUESTÕES SOCIOCIENTÍFICAS NA EDUCAÇÃO EM SAÚDE

Liziane Martins

Grégory Alves Dionor

Lucas Vinícius Ferraz

Helaine Silva Souza

231 TIPOS DE PRÓTESES COMO TEMA SOCIOCIENTÍFICO PARA A PROMOÇÃO DA ARGUMENTAÇÃO NO ENSINO DE QUÍMICA

Luciana Passos Sá

Salete Linhares Queiroz

245 MEDICALIZAÇÃO DA VIDA E ANÁLISE DO COMPORTAMENTO A PARTIR DE QUESTÕES SOCIOCIENTÍFICAS

Felipe Melo Souza Santos

Mateus de Mattos Souza

Maurício Cardoso Borges Lacerda Moura

Tiago Alfredo da Silva Ferreira

261 DOPING GENÉTICO: UMA QUESTÃO SOCIOCIENTÍFICA PARA O ENSINO SUPERIOR Shirley Margareth Buffon da Silva

277 TRANSGÊNICOS, LEIS E A CIÊNCIA: TRAZENDO A LEGISLAÇÃO PARA A SALA DE AULA DE BIOLOGIA

Ítalo Nascimento de Carvalho

Dália Melissa Conrado

Charbel N. El-Hani

Nei Nunes-Neto

303 COTAS RACIAIS, GENES E POLIITICA: UMA QUESTÃO SOCIOCIENTÍFICA PARA O ENSINO DE CIÊNCIAS

Thiago Leandro da Silva Dias

Kelly Meneses Fernandes

Juanma Sánchez Arteaga

Claudia Sepúlveda

325 UNIVERSALIZAÇÃO DE ENERGIA ELÉTRICA EM UMA QUESTÃO SOCIOCIENTÍFICA PARA O ENSINO TÉCNICO

Regina Palácio

Mônica Silveira

Dália Melissa Conrado

345 GEOENGENHARIA DO CLIMA: UMA CONTROVÉRSIA SOCIOCIENTÍFICA SOBRE A RESPONSABILIDADE NA MANIPULAÇÃO DO CLIMA

Ana Rita Marques

Pedro Reis

363 LA EXPLOTACIÓN DEL COLTÁN: UNA CUESTIÓN SOCIOCIENTIÍFICA PARA EL DESARROLLO DE COMPETENCIAS

Martha Nury Bonilla Castañeda

Leonardo Fabio Martínez Pérez

375 ENERGÍA NUCLEAR: UNA CUESTIÓN SOCIOCIENTÍFICA PARA EL DESARROLLO DEL PENSAMIENTO CRÍTICO

Jordi Solbes

Nidia Torres 


\section{PARTE III: PERSPECTIVAS E EXPERIÊNCIAS}

397 GRUPOS COLABORATIVOS PARA CONSTRUÇÃO E APLICAÇÃO DE QUESTÕES SOCIOCIENTÍFICAS NA EDUCAÇÃO BÁSICA: POSSIBILIDADES E DESAFIOS

Ana Paula Miranda Guimarães

Anna Cássia Sarmento

Cássia Regina Reis Muniz

Charbel N. El-Hani

427 PERSPECTIVAS E DESAFIOS DE ESTUDOS DE QSC NA EDUCAÇÃO CIENTÍFICA BRASILEIRA

Wildson Luiz Pereira dos Santos

Karolina Martins Almeida e Silva

Shirley Margareth Buffon da Silva

453 CONTRIBUCIONES Y DESAFÍOS QUE POSEEN LOS PROFESORES DURANTE LA ARTICULACIÓN DE CUESTIONES SOCIOCIENTIIFICAS EN EL CURRÍCULO DE CIENCIAS

Ingrid Ximena Arias Hodge

Leonardo Fabio Martínez Pérez

473 QUESTÕES SOCIOCIENTÍFICAS EM PROJETOS ESTUDANTIS NO ENSINO MÉDIO: CONSTRUINDO INOVAÇÕES EDUCACIONAIS NO PROGRAMA CIÊNCIA NA ESCOLA Rosiléia Oliveira de Almeida

Amanda Amantes

Charbel N. El-Hani

491 O DESENVOLVIMENTO DE EXPOSIÇÕES CIENTÍFICAS COMO ESTRATÉGIA DE ATIVISMO EM CONTEXTO ESCOLAR: RESULTADOS DO PROJETO IRRESISTIBLE EM PORTUGAL

Ana Rita Marques

Pedro Reis

515 ESTUDANTES AGINDO PARA ABORDAR DANOS PESSOAIS, SOCIAIS E AMBIENTAIS RELACIONADOS À CIÊNCIA E À TECNOLOGIA

Larry Bencze

Sarah El Halwany

Mirjan Krstovic

Minja Milanovic

Christina Phillips

Majd Zouda

561 SOBRE OS AUTORES 


\section{PREFÁCIO}

O campo da educação em ciências e tecnologias é um dos mais importantes para a construção de uma sociedade mais justa, equânime e democrática. A articulação deste campo e o dos estudos sociais da ciência e da tecnologia (Estudos CTS) tem produzido algo novo, muito significativo em termos educacionais, na medida em que os conhecimentos a ensinar passam a incorporar aspectos das realidades sociais e culturais locais, regionais e globais. Como resultado, conhecimentos locais, ancestrais e consuetudinários passam a ser reconhecidos como válidos, o que reduz a verticalidade nas relações de saber/poder, a percepção de neutralidade da ciência e de autonomia da tecnologia.

As possibilidades oferecidas pelas controvérsias presentes nas Questões Sociocientíficas e Sociotecnológicas, frutos de pesquisas desses campos e suas articulações, anteriormente silenciadas ou tratadas como não pertinentes ao ensino tradicional de ciências e tecnologias, provocam mudanças muito significativas na forma e no conteúdo educacionais. Uma educação científica e tecnológica com essa perspectiva é emancipadora e muito mais próxima de uma formação para o pleno exercício da cidadania em um universo que se deseja democrático. Trata-se de superar definitivamente um ensino de ciências e tecnologias descontextualizado e aquilo que Paulo Freire identificou como educação bancária.

Como bem aponta o livro, todas as socioculturas estão, de alguma maneira, envolvidas com aspectos e produtos da atividade científico-tecnológica. Entretanto, em muitos casos, esses envolvimentos não são percebidos criticamente pelos diferentes grupos sociais. Em muitas situações, os seus efeitos são sentidos, mas não associados aos produtos daquela atividade. Aqui há algo que aponta para a extrema necessidade da presença das Questões Sociocientíficas e Sociotecnológicas na educação científica e tecnológica.

A formação tradicional de cientistas e tecnólogos, favorecida pela abordagem fragmentada do conhecimento e pela afirmação da neutralidade que constrói a não existên- 
cia da sua natureza social e cultural, produz efeitos de sentido que tendem a amortecer a responsabilidade social e ambiental sobre as consequências nocivas que suas atividades profissionais podem ajudar a produzir.

Por outro lado, a percepção hegemônica de que há conhecimentos superiores e inferiores acaba por induzir os fazedores de políticas públicas a tratar de forma verticalizada os problemas e as soluções. Por conta disso, as soluções a problemas identificados como de natureza científica e tecnológica são construídas em uma instância alheia à dos chamados usuários/beneficiários daquelas soluções, sem que estes tenham participado da construção do problema e, assim, podem não reconhecer nem o problema, nem a solução. Em tais contextos, a perspectiva educacional, tanto formal quanto não-formal, apresentada nesse livro, torna-se uma via substantiva também para a formação de cientistas e tecnólogos e para uma crescente participação dos grupos sociais na construção coletiva de problemas e de soluções.

A potencialidade transformadora dessa coletânea está relacionada à sua perspectiva educacional crítica, solidamente construída nos diversos textos, através da explicitação de aspectos normalmente silenciados ou deliberadamente ocultados sobre a Natureza da Ciência e da tecnologia e dos produtos a elas associados.

Os textos estão organizados em três partes. A primeira é dedicada aos fundamentos teóricos da Educação Ciência-Tecnologia-Sociedade-Ambiente (Educação CTSA), das Questões Sociocientíficas, do pensamento crítico e da formação de pessoas para ações sociopolíticas. A segunda apresenta 14 propostas de ensino baseadas em Questões Sociocientíficas (e Questões Sociotecnológicas), explorando temas diversos e atuais de expressiva repercussão que põem em questão a sustentabilidade em sentido amplo, como aqueles provocados pelo uso de agrotóxicos, poluição hídrica, medicalização da vida, transgênicos, as questões de produção e uso de energia (hidráulica, eólica, nuclear), a exploração de minérios e a manipulação climática.

De todos os significativos temas abordados no livro, cito aqui como exemplo a impactante e dramática questão da exploração do mineral Coltan, de onde são extraídos o Tântalo e o Nióbio, essenciais, entre outras, para as áreas de informática, telefonia celular, aeronáutica e bélica. $\mathrm{O}$ assunto envolve acontecimentos que conectam essas substâncias aos interesses sociopolíticos e econômicos de grupos e países como os Estados Unidos da América do Norte, a Alemanha, a Bélgica, os Países Baixos e o Cazaquistão, e aos conflitos étnicos e bélicos na República Democrática do Congo e seus vizinhos, Ruanda e Uganda. Assim como as outras abordadas no livro, essa Questão Sociocientífica e Sociotecnológica evidencia o comprometimento e a inseparabilidade entre Ciência-Tecnologia-Sociedade-Ambiente e também aspectos da colonialidade do saber/poder entre países do norte e do sul global. Todos esses ingredientes fazem parte da configuração dos artefatos tecnológicos e a educação CTS deve ter isso em conta.

As propostas, com esses vieses na Educação CTS desenvolvidos no livro, podem ser potenciais indutores do desenvolvimento de outras propostas baseadas em temas si- 
tuados ou problemas locais, como o do acidente radiológico com o Césio-137 em Goiânia (1987), a exploração do Nióbio no Brasil (país que detém uma das maiores reservas mundiais do mineral), e tantos outros que ainda se situam na zona do "não problema" - ou seja, um problema que não é sequer percebido pelos sujeitos de uma determinada comunidade, país ou mesmo de um continente.

A terceira e última parte é dedicada à abordagem de perspectivas e experiências para a construção de possibilidades educativas, a partir da articulação de Questões Sociocientíficas e Sociotecnológicas nos diversos níveis da educação em ciências e tecnologias na construção de propostas de ensino, envolvendo resultados de pesquisas realizadas no Brasil, em Portugal, na Colômbia e no Canadá.

Há muitos anos, temos nos empenhado em mostrar a inadequação de uma educação que não considera a pluralidade de saberes, que trata de forma assimétrica e verticalizada os conhecimentos, que defende a universalidade da ciência e a autonomia da tecnologia, que as considere como conhecimentos superiores e, portanto, que constrói a não existência de outros saberes, fomentando atitudes não apenas acríticas, mas sobretudo preconceituosas em relação aos diferentes saberes. Questões desse tipo são também postas à disposição do leitor ao abordar as Questões Sociocientíficas a partir de diversos olhares referenciais (da filosofia crítica, da política, da educação, da sociologia, da antropologia e dos estudos CTS).

Questões éticas são fundamentais na educação científica e tecnológica e, neste particular momento histórico de acontecimentos dramáticos no cenário brasileiro e mundial, realçar a natureza política da educação científica e tecnológica é não apenas uma necessidade da educação CTS, mas um desafio para o processo de formação em todos os campos de saber. Seja para preparar aqueles que seguirão carreiras científicas e tecnológicas, seja para a educação em geral, todos deverão estar capacitados a assumir suas responsabilidades pela preservação da vida e pela sustentabilidade, como cidadãos em um mundo finito.

Este livro oferece aos seus leitores a oportunidade de compartilhar saberes e de construir novos sentidos sobre os conhecimentos em um universo diverso, multicultural, pluriétnico, plurilíngue e, sobretudo, pleno de conhecimentos diferentes aos quais se deve dar igual importância.

Bons livros de um campo interdisciplinar tão amplo como o dos Estudos CTS carregam a marca de sua época. Atentos aos eventos sócio-históricos, oferecem percepções consistentes da realidade e normalmente tornam-se referências de trabalhos e ações futuros e, desse modo, possuem potencial capacidade para transformar, participando assim dos processos de construção/transformação histórica.

Essa coletânea não é diferente. Questões Sociocientíficas: fundamentos, propostas de ensino e perspectivas para ações sociopolíticas reflete o que há de mais atual, não apenas de mais novo, na abordagem de temas relevantes e controversos que se relacionam com ciência e tecnologia, fundamentais para a reflexão e a ação na educação da área. 
A intencionalidade e a potencialidade emancipatórias estão já presentes no título, ao provocar para ações sociopolíticas por intermédio da articulação de Questões Sociocientíficas e Sociotecnológicas com a educação científica e tecnológica.

Esta obra chega em boa hora e contribui significativamente para reduzir a carência de publicações em língua portuguesa sobre a temática que envolve controvérsias relevantes na educação científica e tecnológica, sendo de extrema importância para o campo da Educação CTS, em geral, e da Educação CTSA, em particular. As contribuições de um grande número de especialistas de diferentes países, reconhecidos no campo das Questões Sociocientíficas, corroboram a sua qualidade.

O capítulo 19 conta, entre outros pesquisadores, com a participação do meu caro Wildson Luiz Pereira dos Santos, incansável defensor do campo CTS na educação em ciências no Brasil e no exterior, cujo falecimento precoce no ano de 2016 abre uma lacuna na pesquisa em educação emancipatória em ciências. Deixo aqui uma singela homenagem ao querido colega.

Cumprimento os colegas Dália e Nei pela iniciativa e pelo esforço em oferecer aos pesquisadores, professores, estudantes e interessados pelo campo da educação em ciências e tecnologias esta abrangente e oportuna coletânea sobre Questões Sociocientíficas e Sociotecnológicas para a educação, e aproveito ainda para agradecer a oportunidade de fazer parte dessa coletânea.

Florianópolis, 20 de outubro de 2017

Prof. Irlan von Linsingen 


\section{APRESENTAÇÃO}

Questões Sociocientíficas (QSC) são problemas ou situações controversas e complexos, que podem ser transpostos para a educação científica, por permitir uma abordagem contextualizada de conteúdos interdisciplinares ou multidisciplinares, sendo os conhecimentos científicos fundamentais para a compreensão e a busca de soluções para estes problemas. Todavia, além dos conhecimentos científicos, particularmente, conhecimentos de história e de filosofia (sobretudo de ética) são relevantes e geralmente mobilizados na abordagem desses problemas. Além dos conhecimentos científicos, o uso das QSC, no ensino, contribui para mobilizar valores, habilidades e atitudes. Aspectos culturais, econômicos e políticos são também comuns na discussão de QSC, sendo particularmente interessantes para contextualizar a ciência e a tecnologia, ensinadas em tal perspectiva. Muitos dos problemas de saúde pública ou os problemas socioambientais atuais são bons exemplos de QSC. Tais problemas evidenciam as complexas relações entre os campos Ciência, Tecnologia, Sociedade e Ambiente (CTSA), abordadas no âmbito do ensino de ciências pela educação CTSA. Apesar do campo da educação CTSA e, em alguma medida, do campo das QSC contarem com uma quantidade significativa de trabalhos publicados, ainda há poucos livros de divulgação sobre o uso de QSC na educação científica em língua portuguesa. Esta situação de escassez de literatura em língua portuguesa é especialmente importante, tendo em vista as contribuições que discussões sobre QSC oferecem para a melhoria da educação como um todo, sobretudo para a superação de problemas das abordagens pedagógicas tradicionais e tecnicistas na educação científica e tecnológica.

Nesse contexto, cabe destacar que a necessidade de melhorias na formação de indivíduos capazes de avaliar criticamente QSC, tomar decisões socioambientalmente responsáveis e agir, no sentido de resolvê-las, é cada vez mais urgente no contexto atual, de agravamento de problemas socioambientais e expansão de ideais e valores hegemôni- 
cos de consumismo, competição e individualismo. Com base neste cenário, parece-nos muito importante que a abordagem de QSC considere os conhecimentos e habilidades propriamente científicos, porém, também, de modo fundamental, os valores e posicionamentos éticos consistentes, associados a percepções e análises abrangentes dos condicionantes sociais e ambientais das QSC. Para isso, é essencial a disponibilização de materiais didáticos e obras de apoio, sobretudo para professores e pesquisadores da área de ensino de ciências, acerca de métodos e estratégias de ensino capazes de abordar as QSC, tanto no ensino formal como não-formal.

Assim, com base neste contexto, o livro que aqui apresentamos pretende-se como uma pequena contribuição para os campos da educação e do ensino de ciências, principalmente para a educação CTSA e a educação baseada em QSC.

Os antecedentes do livro dizem respeito às pesquisas sobre educação CTSA e QSC, realizadas no Laboratório de Ensino, Filosofia e História da Biologia (LEFHBio), no Instituto de Biologia da Universidade Federal da Bahia (UFBA), a partir do ano 2009, tanto no âmbito do ensino básico (fundamental e médio), quanto do ensino superior (graduação e pós-graduação). Mais recentemente, em 2014, foi criada a disciplina Questões Sociocientíficas e Argumentação no Ensino de Ciências (FISC19) junto ao Programa de Pós-Graduação em Ensino, Filosofia e História das Ciências (PPGEFHC), da Universidade Federal da Bahia (UFBA) e da Universidade Estadual de Feira de Santana (UEFS). Nesta disciplina, têm sido desenvolvidas reflexões de natureza teórica sobre a educação CTSA, o uso de QSC no ensino de ciências, o desenvolvimento de habilidades de argumentação, a explicitação de valores da educação e da ciência e as iniciativas de ações sociopolíticas na educação, assim como têm sido construídas propostas de ensino, sobre temas diversos do ensino de ciências, e voltadas para diferentes níveis, desde a educação básica até a educação da pós-graduação. Essa disciplina, apesar de recente, nos tem oferecido, assim, experiências muito ricas em que conhecimentos, habilidades, valores e práticas têm sido discutidos e construídos de forma cooperativa com os estudantes de pós-graduação. Em particular, a disciplina tem proporcionado três principais contribuições:

- construir uma base teórico-filosófica útil para a formação de pesquisadores no campo da educação CTSA e QSC;

- viabilizar a produção de propostas de ensino aplicáveis;

- $\quad$ estimular estudantes de pós-graduação, pesquisadores em formação - muitos dos quais também professores da educação básica ou superior - quanto à produção de pesquisa em educação científica e áreas correlatas.

Assim, neste contexto, desde 2014, têm sido produzidas e, em alguns casos, aplicadas no contexto educativo, diversas propostas de ensino envolvendo educação CTSA, uso de QSC e argumentação no ensino de ciências e tecnologias. Algumas dessas aplica- 
ções foram orientadas e planejadas no âmbito da pesquisa acadêmica, com resultados já publicados. Este livro, em parte, é uma compilação de algumas das propostas sugeridas e elaboradas ao longo e após os estudantes terem cursado a disciplina. As propostas dos estudantes que cursaram a disciplina somaram-se, ainda, a outras propostas de pesquisadores que trabalham com educação CTSA, QSC e argumentação no ensino de ciências, assim como temas próximos.

Em suma, esperamos que este livro traga as seguintes contribuições: um aprofundamento no contexto da literatura de língua portuguesa acerca dos fundamentos teóricos da educação CTSA, das QSC e da ação sociopolítica na educação; uma apresentação de modo claro, desde diferentes perspectivas disciplinares e interdisciplinares, de casos sobre QSC desenhados para diversos níveis da educação e potencialmente aplicáveis em contextos educacionais formais e não formais; uma discussão de desafios, oportunidades e experiências de aplicação de propostas de ensino baseadas em QSC e uma discussão do problema da lacuna pesquisa-prática na educação e de modos de superá-la; a divulgação de trabalhos de pós-graduandos da área de ensino, filosofia e história das ciências, o que consideramos como um exercício da autonomia destes professores e/ ou pós-graduandos; e, por fim, um "manual" de casos sobre QSC para intervenções na educação, com base na perspectiva da educação CTSA.

O livro foi elaborado visando estabelecer alguma integração entre seus capítulos. Assim, ainda que cada capítulo possa ser lido independentemente dos outros (pois encerra um sentido em si mesmo), os diferentes capítulos estão organizados em um todo integrado, oferecendo alguma complementação uns aos outros.

O livro está organizado em três partes, que focalizam respectivamente: fundamentos teóricos, propostas de ensino, e, por fim, perspectivas e experiências.

A parte um dedica-se aos fundamentos teóricos da educação CTSA, das QSC, do pensamento crítico e da formação de indivíduos para ações sociopolíticas.

O capítulo 1, de autoria de Derek Hodson, dedica-se a enfatizar o papel da ética e da política na educação científica, a partir de considerações sobre os fundamentos teóricos das QSC, assim como sobre algumas estratégias didáticas que podem ser utilizadas por professores. A partir de discussões sobre compreensão da ciência presente nas QSC, da ciência como uma prática social e ainda de questões relativas ao uso da linguagem científica, o autor apresenta sua proposta de um currículo de ciências em quatro níveis de sofisticação, culminando com o exercício de ações sociopolíticas pelos estudantes. A partir da discussão de várias QSC reais, o autor sugere meios para que - apesar de todas as dificuldades - o professor de ciências possa abordar QSC em sua prática educativa, visando o engajamento de seus estudantes em ações sociopolíticas.

O capítulo 2, de autoria de Nidia Torres e Jordi Solbes, apresenta uma definição de pensamento crítico, acompanhada de uma explicação de como desenvolver habilidades relacionadas ao pensamento crítico a partir de QSC. Para isso, os autores abordam campos de estudo da filosofia, da pedagogia crítica e da didática das ciências, para justificar 
a importância de uma perspectiva interdisciplinar, na educação científica, no desenvolvimento do pensamento crítico pelos estudantes. Além disso, eles apresentam alguns obstáculos para a promoção do pensamento crítico no ensino de ciências a partir do uso de QSC na formação de professores.

O capítulo 3, de Dália Conrado e Nei Nunes-Neto, apresenta um quadro teórico para a abordagem de QSC, como parte da educação CTSA, em sala de aula, que tem sido utilizado para a construção de algumas propostas de ensino. O quadro teórico indica a articulação de três elementos: a representação de QSC como casos particulares, conectados à realidade sociocultural dos estudantes; o uso de questões norteadoras colocadas pelo professor para orientar discussões em sala de aula sobre a QSC; e, por fim, a definição dos objetivos de aprendizagem considerando as dimensões conceitual, procedimental e atitudinal dos conteúdos. A concepção dos conteúdos da perspectiva multidimensional apontada insere-se como uma síntese de propostas de autores da área e pode ser caracterizada como parte de um movimento filosófico a favor da desocultação do currículo oculto, sobretudo por explicitar a dimensão atitudinal do conteúdo. Uma contribuição do capítulo, assim, consiste em uma elaboração teórica acerca das dimensões constituintes do conteúdo, assim como de seus fundamentos filosóficos, além de tratar dos meios para avaliar as diferentes dimensões em sala de aula.

$\mathrm{Na}$ parte dois, são apresentadas as propostas de ensino baseadas em QSC. A fim de oferecer aos leitores deste livro certa clareza quanto à composição das propostas, buscamos manter uma determinada estrutura para esses capítulos, que, ainda assim, permitiu variação em função de especificidades de tema, de estilo dos autores etc. Desse modo, todos os capítulos da parte dois do livro explicitam, em alguma medida, em suas propostas de ensino: um caso sobre uma QSC; algumas questões norteadoras para a aplicação do caso e a discussão da QSC; alguns objetivos de aprendizagem, discriminados, didaticamente, em conceituais, procedimentais e atitudinais; e, por fim, alguns meios para a aplicação da proposta nos âmbitos formal ou não-formal da educação.

Nesta parte do livro, o capítulo 4, de autoria de Maria Aparecida Andrade, Nei Nunes-Neto e Rosiléia Almeida, considera a relevância do debate sobre o agronegócio no Brasil, discutindo consequências socioambientais do uso de agrotóxicos e vantagens da agroecologia para a produção de alimentos, além de abordar essa QSC na educação científica, a fim de contribuir para a formação de cidadãos capazes de se posicionar criticamente e participar ativamente de decisões e ações sociopolíticas que envolvam o tema.

Ainda considerando o uso de agrotóxicos, Dália Conrado, Nei Nunes-Neto, Blandina Viana e Charbel El-Hani discutem, no capítulo 5, possibilidades de abordar uma QSC sobre polinização, com base em informações atuais sobre o declínio de polinizadores, enfocando o desaparecimento mundial de abelhas e suas consequências socioambientais. Os autores apresentam algumas relações CTSA e alguns materiais de apoio para auxiliar na aplicação do caso proposto em sala de aula. 
Por sua vez, no capítulo 6, de Clívio Pimentel-Júnior e Wellington Bittencourt, é apresentada uma proposta de intervenção pedagógica baseada em QSC, no contexto de um espaço educacional não-formal, explorando interfaces dialógicas entre saberes e culturas relacionadas à pesca da lagosta, inspirados em uma análise dos conflitos socioambientais e culturais vividos por moradores do vilarejo de Garapuá, na Bahia, com fundamentação em perspectivas críticas e pós-colonialistas.

Ainda considerando questões associadas a ambientes aquáticos, no capítulo 7, Jéssica Santos, Dália Conrado e Nei Nunes-Neto abordam aspectos ambientais, sociais, culturais e econômicos relacionados à poluição das águas, discutindo conhecimentos, sobre ética ambiental, essenciais para uma abordagem filosófica sobre os problemas socioambientais atuais, no ensino fundamental de ciências, sob uma perspectiva CTSA. A proposta destes autores constitui, assim, tanto uma contribuição para a transposição ou a recontextualização didática de elementos de ética ambiental no ensino de ciências, quanto para o tratamento do tema poluição das águas de forma contextualizada no ensino fundamental.

No capítulo 8, Liziane Martins, Grégory Dionor, Lucas Ferraz e Helaine Souza discutem, no âmbito da educação em saúde, a importância do modelo socioecológico de saúde para o empoderamento e a participação ativa dos indivíduos, visando a promoção da saúde individual, coletiva e ambiental. Nessa perspectiva, os autores abordam a Doença de Chagas e sua influência com os condicionantes de saúde nos processos de prevenção e tratamento dessa doença parasitária, além de discussões acerca da necessidade de ampliar as concepções de educação em saúde, no ensino de ciências, superando uma visão restrita ao modelo biomédico de saúde.

Também em relação aos aspectos de saúde humana e consequências socioambientais, Luciana Sá e Salete Queiroz discutem, no capítulo 9, o uso de uma QSC, no ensino superior de química, para a promoção de habilidades argumentativas, relacionadas à mobilização de conteúdos sobre os diferentes tipos de próteses utilizados para substituir partes do corpo e as implicações econômicas, sociais e éticas envolvidas em sua produção e distribuição, indicando modos de avaliar a qualidade da argumentação, considerando aspectos sociocientíficos. Em particular, merecem destaque as ferramentas para uso e análise da argumentação em sala de aula, discutidas pelas autoras.

Ainda considerando elementos relacionados a uma abordagem mais ampla sobre a saúde humana do que o modelo biomédico de saúde, o capítulo 10, de Felipe Santos, Mateus Souza, Maurício Moura e Tiago Ferreira, contempla, no contexto do ensino de psicologia, uma QSC sobre a medicalização da vida, discutindo a relação de tal questão com a transformação de condições humanas em transtornos ou doenças, o que tem levado a uma simplificação e a uma descontextualização das causas e soluções para problemas sociais complexos, tais como são os de saúde.

Sobre a saúde humana relacionada às terapias genéticas, Shirley da Silva propõe, no capítulo 11, a abordagem de uma QSC sobre doping genético para o ensino de ciências, 
discutindo os riscos do uso indevido da terapia gênica entre atletas, além de aspectos econômicos, políticos, ambientais, éticos e culturais sobre o tema, de modo a capacitar os estudantes para analisar os possíveis impactos da engenharia genética para as futuras e presentes atividades humanas em sociedade.

Ainda abordando os avanços e desafios relacionados à engenharia genética, o capítulo 12, de Ítalo de Carvalho, Dália Conrado, Charbel El-Hani e Nei Nunes-Neto, discute, no âmbito da produção de alimentos transgênicos, a relevância da participação ativa do cidadão nas decisões políticas sobre o desenvolvimento científico e tecnológico, sobretudo em casos como a manipulação genética para situações cotidianas, explorando relevantes questões de Natureza da Ciência e o desenvolvimento de habilidades argumentativas, além de apresentar o uso de projetos de lei para aproximar o ensino formal de ciências ao engajamento informado dos estudantes, visando o exercício de sua cidadania.

No contexto da educação sobre relações étnico-raciais, o capítulo 13, de Thiago Dias, Kelly Fernandes, Juanma Sánchez Arteaga e Claudia Sepúlveda, explora historicamente o desenvolvimento do conceito de raça pelas ciências biológicas e suas consequências sociais, assim como os discursos e ideologias atuais associados aos estudos sobre a composição étnica da população brasileira, com base na investigação genética contemporânea, refletindo sobre o papel social e político dos conhecimentos científicos e tecnológicos, com destaque para discussões em torno da implementação de sistemas de cotas raciais.

O capítulo 14, de Regina Palácio, Mônica Silveira e Dália Conrado, aborda uma proposta de QSC para o ensino médio técnico profissionalizante, a partir de um caso sobre a universalização do acesso à energia elétrica e sua relação com alguns impactos econômicos, sociais e ambientais, discutindo a importância da contextualização de temas técnicos de modo a estimular os estudantes e permitir a aprendizagem de conceitos aliada a um desenvolvimento de pensamento crítico, discussão sobre valores e reflexão moral sobre implicações relacionadas ao tema.

No capítulo 15, partindo da estratégia de ensino de ciências baseado em pesquisa, que adota determinados princípios de responsabilidade, Ana Rita Marques e Pedro Reis apresentam uma QSC sobre Geoengenharia do Clima para estimular o desenvolvimento de habilidades de investigação e de tomada de decisão responsável, além de processos de desenvolvimento, construção e apresentação de exposições, pelos estudantes, de iniciativas de ativismo coletivo fundamentado em investigação.

No capítulo 16, Martha Bonilla Castañeda e Leonardo Martínez Pérez indicam possibilidades de abordar uma QSC sobre a exploração do Coltán, atribuindo significado na mobilização de conhecimentos, a partir de um contexto do cotidiano dos estudantes. Para isso, os autores exploram formas de identificação e avaliação dos problemas socioambientais relacionados ao tema, assim como esquemas de atuação para a resolução de problemas, delineando ações individuais e coletivas, locais e globais. 
No capítulo 17, da autoria de Jordi Solbes e Nidia Torres, é proposto o ensino de conceitos básicos de física a partir de um tema com enfoque na energia nuclear e consequências socioambientais. Os autores discutem diversos temas controversos relacionados, como as bombas atômicas e o papel dos cientistas na sua construção, sempre atentando para aspectos referentes à compreensão da Natureza da Ciência, ao desenvolvimento do pensamento crítico e à explicitação da história das ciências.

Quanto às propostas de ensino da parte dois do livro, é importante esclarecer que elas são muito mais o ponto de partida do que o ponto de chegada das intervenções didáticas no ensino. Ainda que muitas das propostas apresentadas já tenham sido ou estejam sendo aplicadas (muitas com bons resultados) ao ensino, nós pretendemos, como parte dos esforços colaborativos, construir um conjunto de propostas de ensino baseadas nas QSC em português e espanhol. Esperamos que essas propostas possam servir para aplicações diretas no ensino ou, ainda, para um trabalho colaborativo que vise à adaptação ou à reformulação dessas propostas de ensino a fim de atender aos interesses de pesquisa e ensino específicos associados aos seus contextos particulares.

Por fim, a parte três do livro é dedicada a experiências e perspectivas do uso de QSC no ensino de ciências, envolvendo os resultados de pesquisas realizadas no Brasil, Portugal, Colômbia e Canadá. Destacamos, nesta parte, a importância da colaboração mútua entre universidade e escola para uma maior troca de práticas, experiências e conhecimentos entre pesquisadores e professores.

No capítulo 18, de Ana Paula Guimarães, Anna Cássia Sarmento, Cássia Muniz e Charbel El-Hani, são discutidas as características para a construção de inovações educacionais orientadas por QSC, dentro do escopo da pesquisa de design; são apontados os desafios para a implementação de práticas e intervenções educacionais voltadas para a formação de cidadãos capazes de ações sociopolíticas informadas e são sugeridos modos de superar obstáculos atuais impostos pelo sistema educacional e pela lacuna entre pesquisa e prática na educação, a partir da formação de grupos colaborativos entre diferentes profissionais dos meios escolares e acadêmicos.

No capítulo 19, Wildson dos Santos, Karolina Almeida e Silva e Shirley da Silva realizam uma retrospectiva histórica da introdução das QSC no currículo de ciências, a partir da caracterização das principais pesquisas na educação científica, apresentando uma revisão em periódicos, dissertações e teses brasileiras sobre a temática, além de discutirem elementos para a definição de um conceito sobre as QSC na educação científica e perspectivas e desafios para a educação científica no Brasil, destacando a necessidade da formação de professores, para concretizar o uso de QSC conforme objetivos curriculares, e do avanço das pesquisas na área, para melhor compreensão dos processos relacionados à aplicação de propostas baseadas em QSC em sala de aula e suas consequências para a formação de cidadãos capazes de posicionamento crítico diante dos dilemas e problemas socioambientais atuais. 
No capítulo 20, Ingrid Arias Hodge e Leonardo Martínez Pérez partem do pressuposto de que uma perspectiva contextualizadora do conteúdo, no ensino de ciências, é imprescindível para uma aprendizagem integrada e, consequentemente, uma formação mais ampla do cidadão, sendo as relações CTSA um modo de abranger aspectos sociais, culturais, históricos, políticos, econômicos e éticos, relacionados ao conteúdo científico e tecnológico. Eles destacam a importância da interface universidade e escola, refletida no trabalho conjunto entre professores, estudantes de pós-graduação e pesquisadores, orientados ao desenvolvimento de estratégias e à busca de soluções para os obstáculos e dificuldades na abordagem de QSC em sala de aula, com a finalidade de melhorar a qualidade dos processos educativos. Particularmente, os autores mostram alguns avanços, oportunidades e obstáculos de professores participantes de um grupo de investigação, além de experiências de investigação coletiva entre docentes e pesquisadores, fortalecendo a interlocução entre a universidade e a escola.

Partindo da definição de importantes conceitos relacionados aos fundamentos da educação CTSA, como inovação, protagonismo juvenil e cidadania, Rosiléia de Almeida, Amanda Amantes e Charbel El-Hani, no capítulo 21, discutem a importância da colaboração entre pesquisadores acadêmicos e professores atuantes em escolas para a valorização e o empoderamento destes, de modo a contribuir na implementação de inovações pedagógicas geradas em grupos colaborativos de pesquisa; além de resultados obtidos em um programa de formação continuada de professores do ensino médio, a partir da construção de projetos de pesquisa por professores da escola básica, envolvendo QSC.

No capítulo 22, Ana Rita Marques e Pedro Reis discutem a importância do letramento científico para o ativismo, defendendo uma formação de estudantes para atuar sobre os problemas socioambientais, aprendendo a investigar, refletir, confrontar e argumentar sobre modos de resolver esses problemas, mobilizando o conhecimento científico e tecnológico, juntamente com o reconhecimento de valores condizentes com a justiça social. Eles relatam alguns resultados de experiências docentes e discentes no desenvolvimento de iniciativas de ativismo, no âmbito do projeto IRRESISTIBLE e sua contribuição para a compreensão da Natureza da Ciência e para o desenvolvimento cognitivo e moral dos estudantes, discutindo a importância do engajamento dos estudantes como cidadãos do presente, que podem e devem promover ações para a transformação da sociedade, quanto aos problemas socioambientais, além da promoção de atividades educativas de investigação, de modo a fomentar uma cidadania ativa fundamentada.

No capítulo 23, Larry Bencze, Sarah El Halwany, Mirjan Krstovic, Minja Milanovic, Christina Phillips e Majd Zouda recomendam que sejam dadas oportunidades aos estudantes de ciências para que estes se dediquem, ao menos parte de seu tempo escolar, a esforços altruístas para construir um mundo melhor. Os autores apresentam e elaboram sobre o STEPWISE, uma estrutura teórica criada para "encorajar e permitir, aos estudantes, ações sociopolíticas autodirigidas para abordar os danos que eles percebem, associados aos campos da ciência e da tecnologia”. No capítulo, são apresentados alguns 
exemplos de casos de QSC e ainda materiais didáticos que podem ser utilizados por professores de ciências - e mesmo de outras áreas - para fomentar ações sociopolíticas pelos próprios estudantes, visando o bem estar de indivíduos, sociedades e/ou ambientes. Os autores expõem e exploram a ideia de projetos de ações negociadas e informadas por pesquisas realizadas pelos próprios estudantes como um meio de colocar o conhecimento científico em prática e como uma forma de ativismo sociopolítico.

De um modo geral, o livro oferece subsídios para aplicações de sequências didáticas ou propostas de ensino de ciências formal ou não-formal, com o intuito de superar problemas de uma educação tradicional e tecnicista. Além disso, pretendemos com ele oferecer também subsídios para o desenvolvimento de ações sociopolíticas pelos estudantes e, de forma mais abrangente, em longo prazo, a própria formação de ativistas sociopolíticos, cidadãos capazes de utilizar o conhecimento científico e também de articulá-lo com conhecimentos e práticas de outras áreas, como ética, política e comunicação, a fim de agir de forma mais altruísta com relação a outros indivíduos, sociedades e ambientes.

Nesse contexto, esta obra se destina, principalmente, aos educadores em formação inicial ou continuada, além de outros profissionais relacionados com o ensino e a pesquisa sobre as QSC em geral.

Para concluir esta apresentação, explicitamos nossos agradecimentos a todas e todos que contribuíram, de forma direta e indireta, fisicamente próximos ou não, para a produção deste livro. Em primeiro lugar, agradecemos aos autores dos capítulos, pelo interesse, tempo e energia que dispensaram para produzir seus textos, além da paciência que tiveram conosco. Em segundo lugar, agradecemos a todas e todos que têm contribuído com reflexões teóricas, pesquisas empíricas, experiências ou ainda com práticas educativas inovadoras que assim colaboram para, efetivamente, transformar a educação no sentido de formar indivíduos capazes de avaliar criticamente sua situação como ser humano, sua inserção na sociedade e suas relações com o meio ambiente, de modo a tomar decisões e agir considerando, explicitamente, conhecimentos, valores, habilidades e atitudes para construir, de fato, um mundo melhor.

Nei Nunes-Neto

Dália Melissa Conrado

Salvador, dezembro de 2017. 


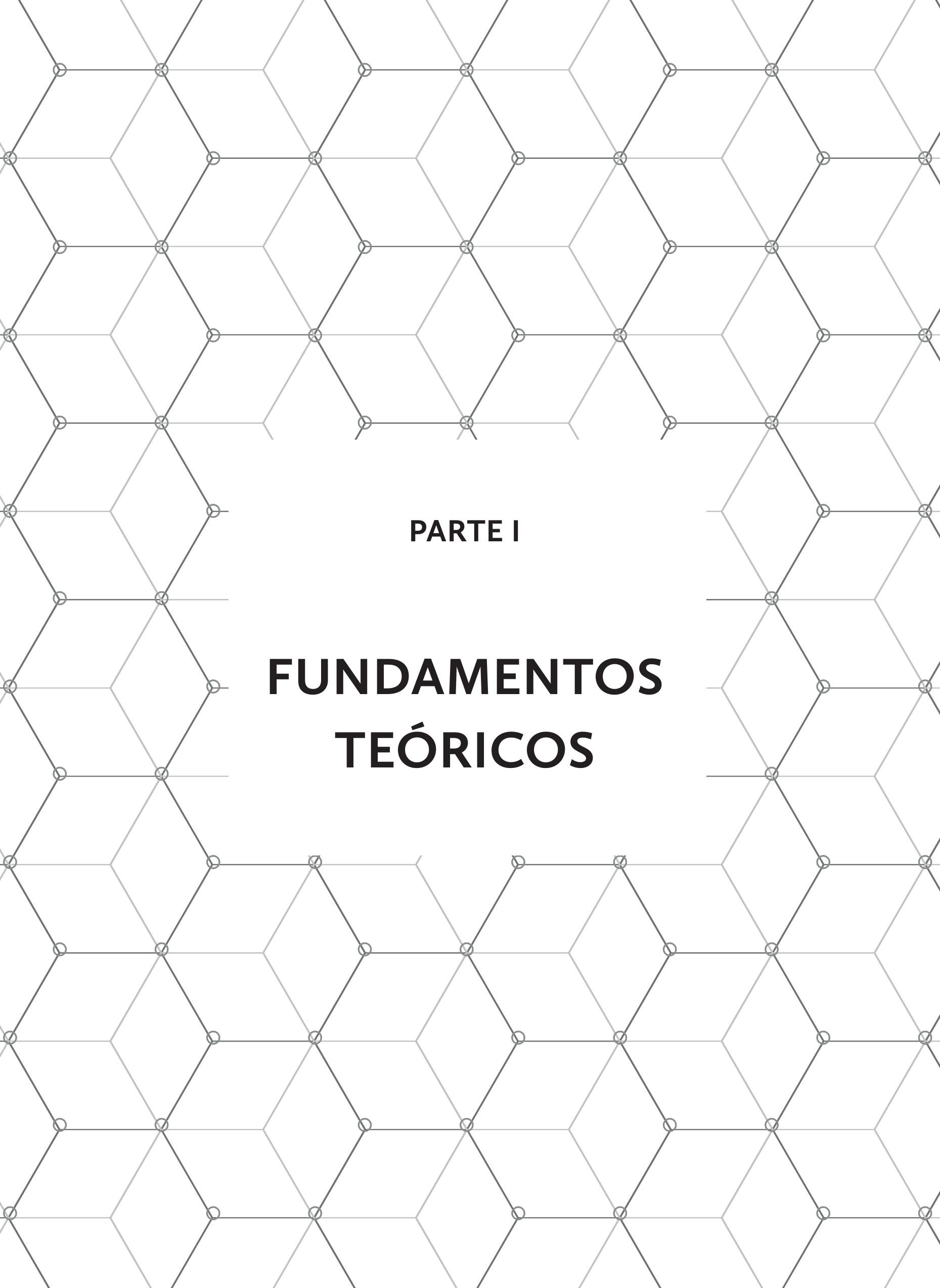




\title{
REALÇANDO O PAPEL DA ÉTICA E DA POLIITICA NA EDUCAÇÃO CIENTÍFICA ALGUMAS CONSIDERAÇÕES TEÓRICAS E PRÁTICAS SOBRE QUESTÕES SOCIOCIENTIIFICAS ${ }^{1}$
}

\author{
Derek Hodson
}

\section{Introdução}

Um argumento convincente para proporcionar aos estudantes oportunidades para enfrentar as Questões Sociocientíficas (QSC), no currículo de ciências e tecnologia, pode ser construído sobre a base de que isto motiva os estudantes, personaliza a aprendizagem, melhora a aprendizagem de conteúdos científicos, contextualiza o entendimento da Natureza da Ciência (NdC) ou Nature of Science (NoS) e envolve os estudantes em situações baseadas em problemas reais, que auxiliam o desenvolvimento de habilidades de pensamento de ordem superior. Alternativamente, pode-se argumentar que não se faz necessária nenhuma outra justificação, além do reconhecimento de que um dos principais objetivos do ensino de ciências é a realização do que Shen (1975) chama de "letramento científico cívico", ou seja, os conhecimentos, habilidades, atitudes e valores para lidar com questões do cotidiano que têm uma dimensão de ciência e/ou tecnologia e, na vida adulta, desempenhar um papel ativo nas tomadas de decisão e na definição de

1 O texto original, em inglês, foi construído a partir de modificações de Hodson (2013). A tradução para o português foi realizada por Nei Nunes-Neto. (N. do O.). 
políticas. Estes argumentos não serão revisados aqui. Em vez disso, a atenção é dirigida para formas nas quais os professores podem construir um currículo coerente e teoricamente justificado, orientado por QSC e planejar uma pedagogia adequada. Primeiro, é necessário selecionar QSC apropriadas. Quais devem ser os critérios de seleção? Deveria ser o interesse do estudante, ou a importância percebida pela sociedade contemporânea, ou a ciência e a tecnologia de ponta, ou a controvérsia viva e pública? Ou deveria ser dada prioridade à disponibilidade imediata de recursos curriculares ou, inversamente, à falta de materiais disponíveis (uma vez que isso exigiria que os estudantes pesquisassem, em busca de mais conhecimento e informação, em si mesmo, um importante objetivo de aprendizagem)? Uma vez que todos estes critérios têm legítimas razões de ser, o ideal pode ser uma combinação equilibrada e consciente de questões significativas, locais, regionais/nacionais e globais, juntamente com uma variedade de QSC escolhidas pelos estudantes de acordo com os seus interesses pessoais.

Parece autoevidente que a maneira mais eficaz de aprender a enfrentar QSC é pelo próprio enfrentamento das QSC, desde que existam níveis adequados de orientação, crítica e apoio de um professor experiente. Especificamente, no contexto de questões pedagógicas e de apoio aos estudantes, o que eu tenho em mente é uma abordagem em três fases, que envolve "modelagem" (o professor demonstra e explica uma abordagem adequada), "prática guiada" (os estudantes executam tarefas específicas com ajuda, crítica e apoio do professor) e "aplicação" (os estudantes realizam a tarefa independentemente do professor). A modelagem do professor (primeira fase) baseia-se na suposição de que a observação e o questionamento de alguém qualificado para enfrentar QSC facilitarão a aprendizagem de estratégias investigativas bem-sucedidas. Na segunda fase (prática guiada), os professores fornecem um programa cuidadosamente sequenciado de investigações durante o qual o papel deles é agir como fonte de aprendizagem, facilitador, consultor e crítico. A suposição é que os estudantes se tornarão mais qualificados para lidar com QSC como uma consequência da prática e da experiência, através do feedback avaliativo fornecido pelo professor e gerado em críticas e discussões intergrupos e, também, através de reflexão intragrupos sobre a atividade, tanto à medida em que ela progride quanto na sua conclusão. Para serem intelectualmente autônomos, no entanto, os estudantes devem, ao final, ser capazes de gerir as situações sem a ajuda do professor e assumir a responsabilidade por planejar, conduzir e relatar suas próprias investigações (a fase de aplicação).

\section{Compreendendo a Ciência}

Para que os estudantes abordem QSC em suas vidas diárias, em qualquer nível além do meramente superficial, eles precisam de, pelo menos, algum conhecimento científico relevante. $\mathrm{O}$ senso comum nos diz que aqueles que conhecem mais sobre a ciência subjacente a uma determinada QSC estarão melhor posicionados para entender os pro- 
blemas, avaliar diferentes posições, chegar às suas próprias conclusões, tomar uma decisão informada sobre onde se encontram em relação à questão e argumentar a favor de seus pontos de vista. Questões cruciais sobre o currículo dizem respeito à profundidade de conhecimento exigida e ao modo pelo qual este deve ser adquirido. Parece quase trivial afirmar que o nível de conhecimento científico necessário é o que é suficiente para capacitar os estudantes a compreender a natureza do problema e que poderia constituir evidência apropriada sobre a qual eles poderiam basear suas tomadas de decisão, e que este nível variará substancialmente de questão para questão. Se o conhecimento científico deve ser adquirido através da instrução prévia ou, alternativamente, à medida em que a necessidade surge, é algo que deve ser decidido caso a caso. Como é frequente o caso na educação, não existe uma resposta universal; diferentes situações exigem diferentes abordagens e diferentes QSC criam necessidades bastante diferentes de conhecimento. Muito depende de se todo o currículo está baseado numa abordagem orientada por QSC ou se as QSC são incluídas como meros ítens acessórios para um currículo, na verdade, orientado por conteúdo, e, ainda, se esse conteúdo particular de ciência será, provavelmente, ensinado e utilizado em outras partes do currículo.

Às vezes, um conhecimento especializado bem além da ciência é necessário. Por exemplo, a fim de abordar a "crise da fossa séptica" em sua escola, os estudantes, no estudo de Pedretti (1997), necessitaram de conhecimento técnico sobre sistemas de fossa séptica, práticas de gestão de resíduos, métodos de filtração, riscos ambientais e regulamentações do governo local. Da mesma forma, aqueles que pretendem avaliar os riscos à saúde, devido às linhas de transmissão de energia elétrica, centrais nucleares ou ao despejo de resíduos tóxicos, necessitarão de um considerável e relevante conhecimento tecnológico. Tentar determinar de forma antecipada exatamente que conhecimento tecnológico será necessário para lidar com uma variedade de QSC é praticamente impossível, especialmente se as questões da atualidade são estudadas apenas por um curto período de tempo. Proporcionar tal conhecimento, à medida em que a necessidade surge, parece a única abordagem prática.

É impossível dotar os estudantes com um conhecimento completo em primeira mão de toda a ciência subjacente a cada QSC relevante. Além disso, dado o ritmo de desenvolvimento científico e tecnológico, é provável que alguma parte do conhecimento científico que os estudantes necessitarão para tomar decisões informadas acerca de uma QSC relevante - que podem encontrar mais tarde na vida - pode, ainda, estar para ser descoberta. No entanto, nós, de fato, sabemos quais são os conhecimentos, as habilidades e as atitudes essenciais para uma apreciação de relatórios científicos e uma avaliação de argumentos científicos em particular, uma compreensão do estatuto de conhecimento científico específico, a forma pela qual este é gerado, comunicado e cuidadosamente analisado pela comunidade de cientistas e a medida de acordo com a qual ele pode ser mobilizado para informar decisões críticas sobre QSC. Os estudantes precisam saber o que constitui uma investigação bem planejada e uma conclusão com bom 
suporte argumentativo. Eles precisam da capacidade de interpretar relatórios, dar sentido a desacordos, avaliar declarações de conhecimento, examinar argumentos, distinguir entre fatos, argumentos e opiniões, fazer julgamentos sobre boa ciência, má ciência e não-ciência, detectar erros, preconceitos e interesses escusos, e assim por diante - tudo aquilo que nós viemos a conhecer como uma compreensão da NdC. (ALLCHIN, 2013; ERDURAN; DAGHER, 2014; HODSON, 2009)

Kolstø (2001) resume o conhecimento e a compreensão sobre NdC necessários para abordar QSC em termos de oito elementos principais:

- distinção entre ciência-em-construção (science-in-the-making), na qual a disputa, o desacordo e a incerteza são esperados, e a ciência pronta e acabada (ready-made science), em que podemos confiar;

- reconhecimento de que fatores socioculturais, políticos, econômicos e religiosos podem ter impacto sobre as prioridades para a pesquisa e o desenvolvimento científico e sobre as declarações de conhecimento que são aceitas;

- habilidade para avaliar a qualidade da evidência científica e estatística, e para julgar a adequação do conhecimento anedótico e do conhecimento experiencial;

- habilidade para avaliar o grau de apoio a uma declaração de conhecimento e a qualidade do argumento que estabelece a garantia para a crença;

- ter uma abordagem cética, ou seja, uma postura crítica, questionadora e um compromisso de resistir a tirar conclusões precipitadas até que evidências e argumentos adequados tenham sido reunidos;

- consciência da importância de fatores contextuais ao avaliar declarações de conhecimento, incluindo o estatuto social dos atores e de suas lealdades institucionais;

- sensibilidade para os valores, ideologias e potenciais para vieses subjacentes, no planejamento e na elaboração de relatórios de investigações científicas; e

- consciência dos constrangimentos que podem limitar a aplicação de conhecimentos teóricos generalizados a situações particulares do mundo real.

Uma simples lista de checagem pode ser extremamente útil para os estudantes que lêem relatórios de estudos de investigação específicos. Quem conduziu a pesquisa e onde ela foi realizada? Como a pesquisa foi financiada? Foi a pesquisa patrocinada e, em caso afirmativo, por quem? O que está sendo reivindicado? Que evidência apoia a reivindicação? Como a evidência foi coletada? Como a evidência foi interpretada? Que suposições são feitas e que teorias são utilizadas na argumentação a partir da evidência para a conclusão? Será que os autores usam teorias bem estabelecidas ou, ao invés, eles desafiam tais teorias? São possíveis interpretações e conclusões alternativas? Que 
evidência adicional ajudaria a esclarecer ou resolver as questões? Houve outros estudos realizados por estes cientistas, ou por outros?

\section{Questões de linguagem}

Se os estudantes devem abordar QSC cuidadosa e criticamente, eles precisam de uma compreensão robusta da linguagem científica e de como ela é utilizada na comunicação e na argumentação científica. A comunicação científica pode ser categorizada como:

- a comunicação entre os cientistas através de periódicos científicos e textos de conferências;

- a popularização e a divulgação do conhecimento gerado pela comunidade científica através de jornais, revistas, televisão e sites de internet; e

- a educação formal, através de livros didáticos e de outros materiais curriculares.

Temos de garantir que os estudantes desenvolvam habilidades de leituras proficientes e críticas para todos os três tipos de texto, ou seja, a capacidade de:

- determinar quando algo é uma observação, uma inferência, uma hipótese, uma conclusão ou um pressuposto;

- distinguir entre uma explicação e a evidência para ela; e

- reconhecer quando o autor está enunciando uma “verdade científica”, manifestando as suas dúvidas ou realizando uma especulação. Habilidades de leitura crítica precisam ser modeladas e ensinadas, cuidadosamente e de forma sistemática.

Especificamente, os alunos precisam de conselhos, críticas e apoio nos seus esforços para conectar elementos de informação dentro e através de textos, avaliar a validade e a confiabilidade de toda a informação utilizada, pesar os méritos das alternativas rivais, avaliar consistência e inconsistência e procurar resolver inconsistências, recolhendo mais informações. Eles precisam conhecer a forma, a estrutura e a linguagem dos argumentos científicos, o tipo de prova invocado e como esta prova é organizada e mobilizada, as formas nas quais a teoria é usada e o trabalho de outros cientistas é citado para fortalecer o argumento.

A necessidade de acessar informações de uma ampla variedade de fontes levanta a importante questão do letramento sobre mídia. ${ }^{2}$ (BURBULES; CALLISTER, 2000) Os

2 Alfabetização, literacia ou letramento sobre mídia é um assunto de extrema importância para a educação, como um todo, e para a educação científica, em particular. Ainda, no caso do Brasil, em particular, dado o constante e sistemático bloqueio que grandes veículos de comunicação exercem sobre questões políticas, sociais e ambientais de interesse social abrangente e até mesmo o viés indisfarçadamente político e propagandístico de grande parte do noticiário de tais veículos, é salutar 
estudantes que são letrados em mídia são capazes de acessar, compreender, analisar, avaliar, comparar e contrastar a informação de uma variedade de fontes, além de utilizar essa informação criteriosamente e de forma adequada para sintetizar sua própria visão detalhada do tópico ou da questão sob consideração. Eles podem reconhecer que a mobilização de linguagens, imagens, símbolos e sons particulares em uma apresentação multimídia pode, para cada uma delas, desempenhar um papel na determinação do impacto de uma mensagem e terá uma profunda influência sobre seu valor e sua credibilidade percebidos. Eles são capazes de verificar as intenções do escritor de determinar qualquer subtexto e significado implícito, detectar vieses e interesses escusos e distinguir entre, de um lado, informações boas e confiáveis e, de outro lado, aquelas pobres e não confiáveis. Eles estão alertas para o fato de que os especialistas dos meios de comunicação impressos, gráficos e falados usam vocabulários, gramáticas, sintaxes, metáforas e referências particulares, com o objetivo de capturar a nossa atenção, acionar nossas emoções, persuadir-nos de um ponto de vista e, em certas ocasiões, ignorar por completo as nossas faculdades críticas. Eles entendem que o material sob análise pode ser tendencioso e pode usar uma variedade de técnicas jornalísticas, tais como linguagem emotiva, hipérbole e insinuações, fotos e imagens provocadoras e música de fundo emocionalmente manipuladora, para persuadir os leitores, telespectadores e ouvintes de um ponto de vista particular. Para que os estudantes desenvolvam estas capacidades, é preciso haver um programa sistemático de instrução, prática, apoio e crítica.

\section{Ciência como uma prática social}

A ciência é uma prática social em dois sentidos distintos: em primeiro lugar, ela está localizada dentro de um ambiente social, político e econômico que tem grande impacto sobre as suas práticas e prioridades; em segundo lugar, ela é governada, dirigida e monitorada por decisões tomadas no seio da comunidade de praticantes. Em outras palavras, a prática da ciência é profundamente influenciada por forças sociais tanto externas quanto internas. No que diz respeito a forças externas, é importante para os estudantes que eles reconheçam que a ciência não é impulsionada apenas por sua própria lógica interna ou por uma simples busca da verdade; em vez disso, ela é motivada e moldada pelas necessidades, os interesses, as motivações, as crenças pessoais, os valores, as aspirações e atitudes políticas dos cientistas, os pontos de vista dos indivíduos, os grupos e organizações dispostos a fornecer o financiamento necessário e, ainda, a opinião pública. Necessariamente, ela reflete a história, a estrutura de poder e o clima político da co-

- a bem da própria democracia - que o professor de ciências utilize ampla variedade de meios de comunicação (por exemplo, TV, jornais, internet), sobretudo, fazendo uso de veículos alternativos à mídia hegemônica, como Mídia Ninja (Narrativas Independentes, Jornalismo e Ação; https:// ninja.oximity.com/), Estúdio Fluxo (http://www.fluxo.net/; https://www.youtube.com/user/estudiofluxo) e Agência Pública (Agência de Reportagem e Jornalismo Investigativo; http://apublica. org/). (N. do O.). 
munidade mais ampla na qual ela está inserida. Necessariamente, ela reflete as atitudes e os valores sociais, econômicos, políticos e ético-morais predominantes daquela comunidade. Em outras palavras, a ciência é, em grande parte, um produto do seu tempo e lugar. As palavras de Young (1987, p. 18-19) fornecem um resumo sucinto da situação:

Não há nenhuma outra ciência além daquela ciência que é feita. A ciência que existe é o registro das perguntas que ocorreram aos próprios cientistas, as propostas que foram financiadas, os caminhos que foram perseguidos [...] os assuntos que importam para uma dada sociedade, seu sistema educacional, o seu sistema de patrocínio e os seus órgãos de financiamento.

Vários pontos importantes seguem. Em primeiro lugar, o corpo do conhecimento científico existe como uma tradição, com uma história durante a qual muitos objetivos, atitudes e valores diferentes terão deixado uma marca. Segundo, para serem admitidas no corpus do conhecimento científico aprovado, as teorias têm que ser socialmente, culturalmente e politicamente aceitáveis, bem como cientificamente justificáveis. Terceiro, nós podemos e provavelmente devemos trazer "diferentes" objetivos, atitudes e valores para suportar futuras tomadas de decisão. Em quarto lugar, a ciência é tanto culturalmente dependente quanto culturamente transformadora, surgindo diretamente dos problemas que nós encontramos, as necessidades e os interesses que nós desenvolvemos e as perguntas que nós fazemos, e impactam muito direta e profundamente no tecido social, cultural e econômico da sociedade, incluindo a língua em que expressamos nossos pensamentos e as maneiras pelas quais conduzimos nossas vidas diárias.

É muito mais fácil para os estudantes reconhecerem como a tecnologia é determinada pelo contexto sociocultural em que ela está localizada do que ver como a ciência é conduzida por tais fatores e, ainda, é muito mais fácil que eles vejam o impacto ambiental da tecnologia do que as formas pelas quais a ciência impacta a sociedade e o meio ambiente. De fato, a tecnologia é por vezes definida como o meio pelo qual as pessoas modificam a natureza para satisfazer as suas necessidades e desejos e melhor servir aos seus interesses, moldando, assim, a vida das pessoas e das outras espécies e impactando de forma significativa sobre o meio ambiente como um todo. No mundo ocidental contemporâneo, a tecnologia é onipresente; o seu impacto social e ambiental é claro; as suas desconcertantes implicações sociais e seus perturbadores dilemas ético-morais são mostrados quase todos os dias através dos tabloides e noticiários de TV. Por estes tipos de razões, faz bastante sentido incluir QSC com forte presença das dimensões tecnológicas e de engenharia no currículo.

Voltando-nos para as dimensões sociais internas da ciência, necessitamos auxiliar os estudantes na apreciação de normas, valores e tradições internos que informam e dirigem a prática científica. Como uma série de procedimentos rigorosos e cuidadosamente monitorados, a ciência encarna um conjunto de valores: ordem, cuidado e precisão, atenção meticulosa e crítica, precisão, confiabilidade e replicabilidade. O co- 
nhecimento gerado por cientistas tem de obedecer a certos valores: clareza, coerência, universalismo, estabilidade, cautela e fecundidade (no sentido de resolver problemas e ter capacidade preditiva). Elegância, simplicidade e parcimônia também podem ser fatores significativos para a obtenção de apoio para uma teoria. Além disso, espera-se que os praticantes mostrem e pratiquem certos valores pessoais: objetividade, racionalidade, integridade intelectual, precisão, diligência, mente aberta (open-mindedness), autocrítica, ceticismo e prudência (no sentido de suspender o julgamento até que toda a evidência esteja em mãos). Adicionalmente, espera-se que eles sejam racionais. Questões críticas são feitas por outros praticantes sobre a adequação, o alcance e a precisão dos dados, como eles foram coletados e interpretados, e se as conclusões decorrem diretamente dos dados. A explicação é examinada com relação à sua consistência interna e também quanto à consistência com outras teorias aceitas. Atenção particular é dirigida para a teoria de fundo, para os pressupostos subjacentes ao planejamento da pesquisa e para a mobilização de teorias auxiliares, assim como para a escolha dos métodos de instrumentação e medição.

Uma vez que os estudantes reconheceram que a investigação científica é influenciada pelo contexto sociocultural em que ela está situada, o próximo e óbvio passo é direcionar a atenção dos estudantes para as formas nas quais a ciência e a tecnologia são influenciadas por determinados interesses setoriais e as maneiras pelas quais as normas e os valores da prática científica são, por vezes, subordinados aos interesses comerciais ou mesmo violados em busca deles. A intenção é ajudar os estudantes a olhar criticamente para o tipo de ciência e tecnologia em que nos envolvemos e os valores sociais, políticos, econômicos e ético-morais que orientam o desenvolvimento, e perguntar o que pode e deve ser alterado, a fim de alcançar democracias socialmente mais justas e assegurar estilos de vida ambientalmente mais sustentáveis. Este ponto de vista da educação científica é manifestada e assumidamente político. Ele, de todo o coração, endossa as opiniões expressas pelos autores da Education for citizenship and the teaching of democracy in schools. (QCA, 1998, p. 13, grifo nosso)

Não apenas a educação sobre cidadania, mas a educação para a cidadania [...] educação cidadã é educação para a cidadania, comportar-se e agir como um cidadão, portanto, não é apenas o conhecimento da cidadania e da sociedade civil; ela implica, também, o desenvolvimento de valores, habilidades e compreensão.

\section{Reconhecendo as dimensões políticas das QSC}

Em Hodson (2011), eu discuti o valor de uma abordagem que constrói a capacidade dos estudantes para a ação sociopolítica sobre QSC, através de um modelo de quatro estágios. 
- Estágio 1: a apreciação dos impactos sociais e ambientais da mudança científica e tecnológica e o reconhecimento de que a ciência e a tecnologia são, até certo ponto, culturalmente determinadas;

- Estágio 2: o reconhecimento de que as decisões sobre o desenvolvimento científico e tecnológico são tomadas na busca de interesses particulares e que benefícios para alguns podem ser às custas de outros. $\mathrm{O}$ reconhecimento de que os desenvolvimentos em ciência e tecnologia são inextricavelmente ligados à distribuição de riqueza e poder;

- Estágio 3: abordar a controvérsia, esclarecer valores, resolver dilemas éticos, formular e desenvolver suas próprias opiniões e justificá-las através da discussão e do argumento;

- Estágio 4: preparar-se para agir e agir sobre questões sociocientíficas e ambientais.

No estágio 4, estudos de caso de grandes inovações tecnológicas, tais como a máquina a vapor, o motor de combustão interna e/ou o computador, são ideais para traçar os fatores sociais e econômicos que impulsionam a inovação e para a sensibilização das maneiras em que a tecnologia molda as vidas das pessoas, impacta significativamente $\mathrm{o}$ ambiente e pode, às vezes, mudar muito radicalmente as formas como as pessoas pensam, falam e agem. Sobre este último ponto, os próprios estudantes têm vivido e experimentado as mudanças maciças trazidas pela tecnologia da computação e pelo desenvolvimento dos meios de comunicação social. Desenvolvimentos na engenharia genética têm questionado as nossas noções de vida e morte e os nossos pontos de vista sobre o que é natural e o que é artificial e tem nos apresentado profundos problemas ético-morais. Ambos os desenvolvimentos têm colocado grandes desafios para os nossos conceitos de liberdade, igualdade, democracia e identidade pessoal.

Estudos de casos bem escolhidos mostram aos estudantes que a inovação tecnológica é complexa, de grande alcance e não é totalmente previsível, às vezes trazendo benefícios ou custos inesperados e riscos imprevistos. Os benefícios das inovações científicas e tecnológicas são, por vezes, acompanhados de problemas: a necessidade urgente para muitas pessoas desenvolverem novas habilidades, mudanças sociais difíceis e, às vezes, desconcertantes, mudanças radicais no estilo de vida, riscos para a saúde humana, a degradação ambiental, os principais dilemas ético-morais e, às vezes, restrição, ao invés de ampliação, da liberdade e da escolha individual. As tecnologias quase sempre se desenvolvem mais rapidamente do que a nossa consciência dos problemas; do que nossa compreensão das questões éticas associadas e dos desenvolvimentos de restrições legais. A percepção de toda a extensão dos riscos, muitas vezes, vem muito tarde, como no caso do DDT (diclorodifeniltricloroetano) e dos CFCs (clorofluorcarboneto ou clorofluorcarbono). Significativamente, o impacto pode afetar principalmente aqueles com pouco ou nenhum poder para protestar, organizar contra-ações concertadas, demandar mudanças e/ou buscar compensações. Por estas razões, é importante assegurar que haja 
um escrutínio mais amplo e mais crítico de nossas políticas e prioridades para a investigação científica e o desenvolvimento tecnológico, assim como de um acompanhamento mais próximo de todos os ensaios e implementações por parte de um grupo mais diversificado de pessoas. É comum que o poder sedutor das tecnologias novas e poderosas nos cegue quanto a possíveis consequências adversas inesperadas e nos desvie da consideração dos valores que as acompanham. Mais preocupante ainda, os riscos podem ser conhecidos, mas eles são ignorados, porque é mais conveniente manter o status quo e esperar que os problemas desapareçam ou que sejam resolvidos por novas descobertas científicas ou inovações tecnológicas.

Inovações em Tecnologias da Informação e da Comunicação (TIC), como os telefones celulares, correios eletrônicos (e-mail) e a internet, criaram oportunidades, possibilidades e perigos que seriam inimagináveis há duas décadas. Tecnologias baratas, leves e portáteis mudaram, ampliaram, fragmentaram e redefiniram a base do poder das comunicações, e mostraram que os governos, as Organizações não Governamentais (ONG), as grandes corporações financeiras e o setor militar já não podem mais explorar a ignorância pública ou exercer controle absoluto sobre as notícias e as informações. Já não há mais um abismo de tempo entre um evento e o surgimento de um registro do próprio evento, durante o qual a história pode ser editada e manipulada para refletir interesses particulares. Dentro de minutos, o público tem acesso às impressões vívidas e autênticas do que está acontecendo, até mesmo em partes remotas do mundo. Não há mais tempo para que os governos e outras partes interessadas se antecipem, mediem ou suprimam informações. Porque essas novas tecnologias portáteis estão disponíveis para quase todos, uma nova capacidade de escrutínio imediato e um concomitante chamado por uma maior responsabilização surgiu, como graficamente ilustrado pelo episódio de Freddie Gray, em Baltimore, Estados Unidos. ${ }^{3}$ Novos modos de desenho das comunicações criaram um espaço para políticas, culturas e vozes alternativas e criaram novas oportunidades para a intervenção coletiva para abordar questões e problemas comuns. Ao mesmo tempo, no entanto, eles têm aumentado substancialmente a capacidade dos empregadores e governos para monitorar as comunicações e atividades de empregados e cidadãos, criando alguns dos principais problemas de privacidade e propriedade. Devido à atribuição de códigos numéricos rastreáveis às mensagens de e-mail, quase qualquer mensagem pode ser rastreada e disponibilizada para outras pessoas, possivelmente em forma modificada, como as revelações de Edward Snowden têm mostrado. ${ }^{4}$

3 Nota dos organizadores: em particular, no caso do Brasil, por exemplo, os vídeos da Mídia Ninja, site mencionado na nota 2, oferecem acesso bastante direto a eventos de interesse político, sejam regionais ou nacionais. A cobertura e as interpretações ágeis de tais veículos alternativos de comunicação, como ocorreu nas Jornadas de Junho de 2013 ou noutras manifestações políticas mais recentes, nas ruas do Brasil contemporâneo, oferecem uma boa ilustração do ponto levantado pelo autor. Ver link: <www.democracynow.org $>$.

4 Veja em: <www.democracynow.org $>$ ou em $<$ www.theguardian.com $>$. 
No estágio curricular 2, o objetivo é ajudar os estudantes a reconhecer que as decisões científicas e tecnológicas são normalmente tomadas na busca de interesses particulares, justificadas por valores particulares e, às vezes, implementadas por aqueles com o poder econômico ou político para sobrepujar as necessidades e os interesses dos outros. Consequentemente, os estudantes devem ser encorajados a perguntar uma série de questões-chave sobre cada inovação científica ou tecnológica. Por que esta investigação científica, em particular, foi financiada e esta tecnologia foi perseguida? Qual é a lógica e qual a justificativa subjacentes para essas decisões? Quais são os efeitos sociais, econômicos e ambientais percebidos? Quais são as questões ético-morais levantadas e quais são os prováveis impactos adversos? Quem são os principais atores envolvidos? Quais são os seus interesses? As vozes de quem são ouvidas e as de quem são marginalizadas ou ignoradas? Que intenções ou motivos orientam a tomada de decisão? Quem se beneficia? Quem é prejudicado? Isto é justo e equitativo? Será que esta decisão promove o bem comum e serve às necessidades de proteção ambiental? Devemos apoiar ou nos opormos a este desenvolvimento? Respostas a estas perguntas, muitas vezes, revelam que a ciência e a tecnologia servem aos ricos e aos poderosos de maneiras que são prejudiciais para os interesses e bem-estar dos pobres e desempoderados, às vezes, dando origem a mais desigualdades e injustiças. Por exemplo, o lixo resultante do consumo urbano, nos países ocidentais, é enviado para instalações de incineração, depósitos e aterros localizados predominantemente em comunidades urbanas e rurais de maior pobreza e desvantagem social. Os ricos podem reduzir o seu próprio nível de risco e exposição ao efluente tóxico mudando de casa; os politicamente poderosos podem fazê-lo garantindo que a instalação seja situada em outros lugares; os mais pobres e os mais fracos são expostos aos perigos e têm de sofrer os problemas. De uma perspectiva internacional, torna-se rapidamente claro que os benefícios materiais do Ocidente (Norte) são muitas vezes conseguidos às custas daquelas pessoas que vivem no mundo em desenvolvimento (Sul), com um estilo de vida orientado para o consumo das nações industrializadas, criando ambientes contaminados que impactam desproporcionalmente sobre aqueles menos capazes de se proteger. Por exemplo, como Agyeman e Carmin (2011) e Bisschop (2014) relataram, grande parte do lixo eletrônico gerado na União Europeia é exportado para depósitos de lixo na África Ocidental, no Sudeste Asiático e na Índia, onde muitas vezes é desmontado por catadores e trabalhadores mal equipados, incluindo muitas crianças, em busca de sucata de metal. O restante do material é, geralmente, queimado ou despejado em locais desprotegidos, resultando em contaminação substancial do ar, da água e do solo por chumbo, cádmio, ftalatos e dioxinas cloradas - todos com propriedades cancerígenas e impactos neurológicos adversos. (GREENPEACE, 2008)

A frequência com que a degradação ambiental impacta os pobres, desfavorecidos, marginalizados e desempoderados muito mais do que os ricos e poderosos justifica o uso do termo "racismo ambiental". Por exemplo, as substâncias consideradas perigosas para o ambiente, e, portanto, proibidas em países ricos do Norte, ainda são exportadas 
para países em desenvolvimento no Sul, economicamente mais vulneráveis (MARTINEZ-ALIER, 2003), enquanto que os produtos farmacêuticos proibidos nos países industrializados são vendidos, distribuídos e utilizados, frequentemente, nos países em desenvolvimento, porque eles são rentáveis para os fabricantes. Resíduos altamente tóxicos são rotineiramente enviados da Europa e dos Estados Unidos, onde são criados, para países pobres, como Guiné-Bissau e Serra Leoa, em troca de ajuda econômica. (BROOKE, 1988; IBITAYO, 2008) Por muitos anos, instalações industriais, localizadas ao longo da fronteira Estados Unidos e México (conhecidas localmente como maquiladoras), rotineiramente despejam resíduos tóxicos em esgotos e rios, inclusive, aqueles nos quais as comunidades locais obtêm sua água potável. Nas cidades fronteiriças de Brownsville (Texas) e Matamoras (México), a incidência de crianças que nascem com anencefalia, ou seja, nascidos sem o prosencéfalo, é quatro vezes a média nacional. Bullard e Johnson (2000) relatam que famílias afetadas apresentaram ações judiciais contra 88 das 100 maquiladoras da área por terem exposto a comunidade ao xileno - considerado a causa desses defeitos de nascença e conhecido por causar hemorragias cerebrais, assim como danos aos pulmões e rins. Mais informações sobre os danos à saúde humana e a problemas ambientais relacionados às maquiladoras podem ser encontradas em Rai e Norton (2007).

Outras questões dizem respeito ao papel desempenhado pelos governos ocidentais e os interesses das empresas no controle da produção e da distribuição de recursos nos países em desenvolvimento, incluindo exemplos de apropriação sistemática dos recursos da terra e da água para a produção de culturas de alto rendimento para exportação para os países mais industrializados, muitas vezes, resultando em: preços mais baixos para os agricultores; aumento da vulnerabilidade das culturas a pragas (e um consequente aumento da dependência de controles químicos); empobrecimento do solo e esgotamento do solo superficial; aumento de pobreza, insegurança e eventuais desapropriações. Os países em desenvolvimento são muitas vezes obrigados a aceitar as tecnologias e práticas agrícolas dos países desenvolvidos ou mais industrializados, incluindo o amplo uso de fertilizantes, para aumentar o rendimento das culturas; herbicidas e inseticidas, para plantas daninhas e controle de pragas; agricultura mecanizada e práticas de irrigação; e até mesmo a adoção de culturas geneticamente modificadas, em troca de outras formas de ajuda econômica e apoio militar. Tais insumos de alto custo podem não ser economicamente acessíveis ou ecologicamente sustentáveis. Chopra (2009) descreve como a introdução dos métodos do agronegócio dos países desenvolvidos - incluindo o uso generalizado de fertilizantes químicos, agrotóxicos, hormônios de crescimento e antibióticos; o extenso desmatamento; a introdução de plantas e animais geneticamente modificados; e a reutilização dos rejeitos de matadouros para a alimentação dos animais - teve um impacto ecológico desastroso em muitas partes da Índia. O lençol freático caiu para níveis alarmantemente baixos; a população de minhocas foi devastada, com grande impacto negativo sobre a qualidade do solo superficial; muitas 
espécies de abelhas, borboletas e pássaros, essenciais para o processo de polinização, estão em sério declínio; bactérias fixadoras de nitrogênio estão quase extintas; e os números de animais insetívoros, tais como sapos e lagartos, estão muito reduzidos, com o consequente declínio do número de predadores que se alimentam deles (águias, falcões etc.) e dos abutres que se alimentam das "sobras". Igualmente desastroso tem sido o impacto negativo sobre a vida de agricultores de subsistência.

\section{Abordando questões controversas}

O estágio curricular 3 centra-se em apoiar os estudantes em suas tentativas de formular suas próprias opiniões sobre questões importantes e frequentemente controversas e, ainda, estabelecer as suas próprias posições de valor. Este estágio também envolve empenhar-se na luta para estabelecer práticas socialmente mais justas e ambientalmente mais sustentáveis e construir a confiança, a mentalidade, os insights e habilidades necessários para uma defesa e uma agência a favor de mudanças efetivas e responsáveis. O trabalho em tal estágio concentra-se no esclarecimento dos valores, no desenvolvimento de fortes sentimentos sobre questões sociais e em pensar ativamente sobre o que significa agir sábia, justa e "corretamente" em contextos sociais, políticos e ambientais particulares. A educação em tal estágio tem muito em comum com os objetivos de educação para a paz, educação multicultural e antirracista, educação global e educação humanitária. Ela começa com a promoção da autoestima e do bem-estar pessoal, acolhendo e escutando a uma diversidade de ideias, opiniões, perspectivas, práticas e valores; preocupações com o bem-estar dos outros; o respeito aos direitos dos outros; a construção de empatia e confiança mútua; a busca de justiça, equidade e liberdade, tomadas de decisão cooperativas, resoluções criativas de divergências e conflitos entre as pessoas, dentro e entre as comunidades e em todo o mundo. Ela é dirigida por um profundo compromisso com a educação antidiscriminatória, isto é, aquela educação que expõe as raízes comuns do sexismo, do racismo, da homofobia, do especismo, do eurocentrismo e dos vieses do Ocidente (ou do Norte) na tendência a dicotomizar e gerar uma sensação de outro ou de alterização e de trabalhar ativamente para enfrentar a mentalidade focada em uma diferença entre "nós e eles", a qual, invariavelmente, vê a "nós" como a norma, o desejável e o superior. Ela culmina em um compromisso com a crença de que vozes alternativas podem e devem ser ouvidas, a fim de que as decisões em ciência e tecnologia reflitam sabedoria e justiça, em vez de interesses setoriais poderosos.

A controvérsia pode ser interna à ciência, isto é, a informação científica necessária para formular um juízo sobre ela é incompleta, insuficiente, inconclusiva ou extremamente complexa e difícil de interpretar, ou pode ser externa à ciência, ou seja, enraizada em preocupações, crenças, valores e sentimentos sociais, políticos, econômicos, culturais, religiosos, ambientais, estéticos e/ou ético-morais. A capacidade de resolver a controvérsia interna depende crucialmente dos conhecimentos e habilidades de leitura 
crítica dos estudantes sobre $\mathrm{NdC}$, como discutido acima; a capacidade e a vontade para resolver as controvérsias externas dependem de uma análise cuidadosa das emoções, dos sentimentos, e de questões ético-morais e/ou posição política.

Uma vez que uma decisão foi tomada, para incluir questões externamente controversas no currículo, os professores têm de decidir a forma mais adequada para resolvê-las. Deveriam eles tomar uma posição neutra, adotar o papel de advogado do diabo ou tentar apresentar uma visão equilibrada? Uma forma de neutralidade, a neutralidade afirmativa, descreve uma situação em que os professores apresentam vários lados de uma controvérsia sem revelar que lado eles suportam. Na neutralidade procedimental, as informações sobre a controvérsia e os diferentes pontos de vista são solicitados aos estudantes, possivelmente após oportunidades para pesquisa em bibliotecas ou na internet. Para além do perigo de incentivar o relativismo, no qual qualquer ideia é aceita, desde que ela seja a opinião de alguém, a neutralidade é uma posição que ameaça seriamente a credibilidade do professor e convida a uma pergunta razoável: você não tem um ponto de vista, senhorita/senhor? É um absurdo fingir que os professores não têm um ponto de vista; é lamentável que os professores se recusem a enunciar sua opinião ao mesmo tempo em que encorajam ou até mesmo exigem que os estudantes apresentem as suas. A noção de imparcialidade ou de apresentar uma visão supostamente equilibrada também é extremamente problemática. O que conta como equilíbrio? O julgamento de equilíbrio e a seleção de perspectivas de quem deve contar? Quem decide o que conta como relevante ou não relevante, preciso ou impreciso, admissível ou inadmissível, importante ou não importante? Quem decide o que deve ser considerado fato e o que deve ser considerado opinião? Se todos os estudantes expressam uma visão semelhante, de onde virão os pontos de vista alternativos? A noção de imparcialidade exige que os professores dêem tempo, consideração, assim como pesos iguais, aos pontos de vista e aos argumentos que claramente não são de igual mérito e impede os estudantes de desenvolverem as habilidades críticas necessárias para julgar o valor e a validade das diferentes posições. Alguns anos atrás, Kelly (1986) defendeu a imparcialidade comprometida (committed impartiality), em que os professores apresentam vários lados de uma questão ou argumento e, em algum momento, partilham os seus próprios pontos de vista com a classe. Em minha opinião, é fundamental que os professores ajudem os estudantes a identificar, a esclarecer e a desafiar os pressupostos de todas as posições (incluindo a sua própria), reconhecer a influência do contexto sociocultural, crenças religiosas, emoções e sentimentos, abordar questões de racionalidade, equidade e justiça social e se envolver em reflexão crítica em grupos. Quando os estudantes são encorajados a debater e a desafiar todos os pontos de vista, incluindo o do seu professor, eles não apenas desenvolvem habilidades de argumentação, mas também constróem a coragem essencial para o compromisso social. ${ }^{5}$

5 Neste parágrafo, o autor discute uma questão muito importante para a educação pública no Brasil atual: a discussão de assuntos com teor ético e político nas salas de aula. Em especial, aqui merece 
Algumas QSC estão distantes das vidas imediatas dos alunos, tornando difícil a geração de interesse, preocupação e compromisso para/em desafiar o status quo. Filmes, histórias, teatro, dramatização, poesia, materiais multimídia e atividades baseadas na linguagem, de vários tipos, podem ser usados para estimular o interesse em uma questão, provocar uma resposta emocional, apresentar posições alternativas, desafiar valores e precipitar o debate. Histórias justapõem diferentes opiniões, vozes e perspectivas, estimulando o leitor (ou ouvinte) a deliberar, avaliar e decidir sobre onde eles estão ou adotar uma postura diferente. Através de histórias e, especialmente, através do teatro, os estudantes são estimulados a abordar questões e eventos a partir das perspectivas dos outros, explorar e desenvolver a compreensão, estabelecer novas relações e consolidar as já existentes. Em outras palavras, envolver-se com a narrativa é tanto uma forma de conhecer a nós mesmos, como também uma forma de compreender os pontos de vista dos outros. $\mathrm{O}$ teatro improvisado permite aos estudantes enriquecer essas explorações com experiências pessoais, pensamentos e preferências linguísticas. Incentivar os estudantes a escrever poesia e histórias cria oportunidades para eles explorarem as suas ideias, expressá-las em linguagem menos formal, manipulá-las e criticá-las, colocando-as na boca dos outros, explorar a ambiguidade e a incerteza, enfrentar dilemas e, crucialmente, expressar a maneira como eles se sentem com relação às suas ideias e às ideias dos outros.

A discussão sobre QSC não apenas levanta questões sobre o que nós "podemos" ou "poderíamos" fazer, mas também sobre qual é a decisão "certa" e o que "devemos" fazer, desta forma, levantando algumas dimensões éticas centrais. Os desenvolvimentos recentes na biotecnologia, por exemplo, levantam muitas questões e preocupações importantes sobre se determinadas linhas de pesquisa devem ser permitidas. Um indivíduo com uma condição genética incapacitante deveria estar apto a ser submetido à terapia gênica, utilizando o material a partir de células-tronco embrionárias? Os testes genéticos pré-natais deveriam estar prontamente disponíveis e o aborto seletivo de um feto com uma doença genética deveria ser permitido? Os pais já podem escolher o sexo de seu filho; em breve, poderá ser possível isolar e remover genes que aumentam a probabilidade de esquizofrenia, obesidade, alcoolismo, Transtorno do Déficit de Atenção e Hiperatividade (TDAH) e de uma série de condições letais ou incapacitantes. Esta engenharia genética deveria ser permitida? Talvez seja possível, em breve, para os futuros pais, escolher a cor do cabelo e dos olhos de uma criança ou selecionar quaisquer outras características que considerem desejáveis. Estas ações iriam colocar valor em um tipo de pessoa em detrimento de outro - isto é, uma intenção eugenista clara. Isso deve ser

menção o movimento autointitulado "Escola Sem Partido", vinculado a alguns projetos de lei do Congresso nacional brasileiro e que ameaça a liberdade dos próprios professores, para ensinar, e a qualidade da educação do país como um todo. Para mais detalhes sobre o assunto, pode-se consultar: <https://liberdadeparaensinar.wordpress.com/> e <https://liberdadeparaensinar.wordpress. com/category/carta-de-repudio/>. (N. do O.). 
permitido? Deve haver restrições sobre o trabalho de Craig Venter, que desloca o foco da leitura de um código genético para escrever um código genético - isto é, não apenas modificar um organismo já existente para garantir "características mais favoráveis", mas construir um totalmente novo. ${ }^{6}$

Determinar a resposta certa (o que nós devemos fazer) levanta questões e preocupações sobre a moralidade (o que é certo ou errado fazer) e a ética (as razões e justificativas para julgar essas ações como certas ou erradas). Eu certamente não estou argumentando que os estudantes devam seguir um curso rigoroso de filosofia moral, não mais do que eu defenderia quanto à promoção de uma moralidade baseada em uma religião em particular ou em um conjunto de leis e precedentes culturais, mas eu defendo que eles sejam equipados com algumas ferramentas intelectuais para enfrentar e resolver questões polêmicas, que não podem ser resolvidas unicamente por considerações científicas, econômicas ou ambientais. No mínimo, os estudantes precisam de algum conhecimento básico acerca do egoísmo, das noções consequencialistas (incluindo o utilitarismo), da ética deontológica, da teoria do construto social (ou teoria do contrato social) e da ética das virtudes. (BONJOUR; BAKER, 2007; HURSTHOUSE, 1999; SINGER, 1991)

Fullick e Ratcliffe (1996) descrevem uma série de estratégias que podem ajudar a dirigir a atenção dos estudantes às preocupações éticas presentes nas QSC e ajudá-los a lidar com dilemas éticos de uma forma sistemática e racional. As estratégias incluem:

- construção de árvores de decisão ou de cenários futuros (através dos quais os estudantes são convidados a considerar uma série de implicações pessoais, sociais, econômicas, legais, ambientais e éticas em torno de uma questão e das possíveis respostas a ela);

- frameworks sobre objetivos, direitos e deveres (goals, rights and duties frameworks) (para cada participante ou setor envolvido em uma polêmica, os estudantes consideram as intenções, os direitos/expectativas e as obrigações em relação aos outros e ao meio ambiente); e

- grupos de discussão sobre questões cuidadosamente focadas (questões orais ou escritas dirigem a atenção dos estudantes para a natureza do problema, as soluções possíveis, as razões por que uma solução pode ser preferível a outra, e estimulam a reflexão sobre as posições de valor dos próprios estudantes).

O Centro de Aprendizagem em Biotecnologia da Nova Zelândia ${ }^{7}$ fornece suporte para os estudantes abordarem questões éticas na forma de duas ferramentas interativas de pensamento. A ferramenta de raciocínios em ética (ethics thinking tool) permite que

6 Ver em: <www.jcvi.org $>$ e $<w w w . t i g r . o r g>$.

7 Ver em: <www.biotechlearn.org.nz>. 
os estudantes estruturem e avaliem suas ideias em relação a quatro conjuntos de diretrizes/orientações éticas: benefícios e malefícios; direitos e responsabilidades; liberdade de escolha; virtudes. A ferramenta de raciocínios sobre os cenários futuros (futures thinking tool) encoraja os estudantes a considerar a situação existente, analisar as tendências, identificar as forças motrizes e as causas dessas tendências, identificar possíveis e prováveis futuros e selecionar futuros preferenciais.

A pesquisa sobre células-tronco coloca toda uma série de problemas éticos sobre os quais os estudantes podem exercitar suas habilidades em desenvolvimento. (FRANCE; MORA; BAY, 2012; HALVERSON; SIEGEL; FREYERMUTH, 2009) Em primeiro lugar, uma importante distinção pode ser estabelecida entre, de um lado, células-tronco adultas, derivadas do sangue, da medula óssea, da gordura e dos outros tecidos e, de outro, células-tronco embrionárias de culturas descartadas de Fertilização in Vitro (FIV), fetos abortados ou de embriões criados em laboratório. As células-tronco embrionárias são mais abundantes e mais fáceis de extrair; elas podem ser cultivadas e multiplicadas no laboratório mais facilmente; elas são mais flexíveis e, por isso, têm muito mais potencial regenerativo. Em resumo, elas são de valor muito maior em pesquisas e mais prováveis de resultar no desenvolvimento de tratamentos médicos inovadores. No entanto, para algumas pessoas, a distinção entre as células-tronco embrionárias e as células-tronco adultas também constitui uma fronteira entre a prática eticamente aceitável e a eticamente inaceitável. Para outros, o limite pode estar na distinção entre células-tronco de descartes de FIV e aquelas dos embriões clonados especificamente para fins de pesquisa. Aqueles que estabelecem a distinção ética neste momento argumentam que o uso de células a partir de embriões que sobram de tratamentos de FIV, que de outra forma seriam destruídos, é substancialmente menos condenável do que a clonagem de um embrião, a fim de colher suas células e depois destruí-lo. Em última análise, o debate gira em torno da questão filosófica sobre o que constitui um ser humano e a questão ética acerca dos direitos de quem deve ter prioridade. A vida humana começaria no ponto da concepção, no momento da implantação no útero, no início do processo de desenvolvimento, no ponto em que uma espinha dorsal e órgãos começam a se desenvolver ou no momento em que o feto é capaz de sobreviver fora da mãe, com ou sem apoio tecnológico sofisticado? Esses problemas são muito mais complexos do que a questão dos direitos relativos da mãe e do feto, que os estudantes terão que (ou poderão) abordar na discussão do aborto.

Em uma questão estreitamente relacionada à agricultura, os estudantes podem ser solicitados a considerar por que a utilização de plantas geneticamente modificadas está sendo amplamente promovida por empresas multinacionais como a Monsanto. (KNIGHT, 2009) Será que é porque a produção agrícola não pode ser mantida em níveis necessários para satisfazer as necessidades nutricionais da população mundial em crescimento? Será que é porque grande parte da colheita anual é perdida para as pragas e doenças que as plantas geneticamente modificadas podem ser desenhadas para resistir? 
Ou seria porque a dependência crescente de agricultores com relação às plantas geneticamente modificadas está nos interesses financeiros das companhias que mantêm as patentes? Os estudantes podem ser convidados a considerar os riscos ambientais que inevitavelmente resultariam da perda de riqueza e variância genética e se esses riscos devem ser tomados sem consulta pública mais ampla. Eles podem olhar para a possibilidade de riscos imprevistos, particularmente mutações e extinções decorrentes de interações de plantas geneticamente modificadas com insetos e outras plantas. No que diz respeito à avaliação dos riscos, os estudantes podem considerar a eficácia provável de protocolos para garantir que os riscos ambientais associados à introdução de organismos transgênicos sejam minimizados. Eles podem considerar quem fixaria os procedimentos e normas e se é provável que os protocolos sejam fielmente executados e monitorados por todos os agricultores. Obviamente, os métodos-padrão de avaliação de riscos não abordam os riscos sociais em torno da monopolização do abastecimento de alimentos do mundo nas mãos de uma ou duas empresas gigantes e o empobrecimento e o deslocamento das comunidades agrícolas de pequena escala, mas estas são considerações importantes para serem apresentadas aos estudantes.

Além disso, sobre questões de saúde, pode-se solicitar aos estudantes que considerem por que as empresas farmacêuticas consistentemente recusam-se a participar da pesquisa e do desenvolvimento orientados para o combate e o tratamento de doenças como a malária, a tripanossomíase (doença do sono) e a esquistossomose (bilharziose), enquanto destinam recursos maciços para a pesquisa sobre as doenças cardíacas e o câncer. A atenção dos estudantes deve ser dirigida para as formas em que os interesses comerciais, muitas vezes, influenciam o modo como os resultados da pesquisa são tornados públicos (conferências de imprensa, em vez de publicação em revistas acadêmicas, por exemplo) e os modos pelos quais o impacto dos dados negativos é minimizado, marginalizado, escondido ou ignorado. Por exemplo, na divulgação do valor de contraceptivos orais e terapia de reposição hormonal, o aumento dos riscos de câncer cervical, câncer de mama e tromboembolismo recebem, muitas vezes, pouca atenção. Seguindo o exame crítico de 70 artigos de pesquisa voltados para os Bloqueadores dos Canais de Cálcio (CCB), do inglês calcium channel blockers, utilizados para tratar a hipertensão, Stelfox e colaboradores (1998) concluíram que havia uma forte associação entre opiniões dos autores sobre a segurança dos CCB e as suas relações financeiras com fabricantes de produtos farmacêuticos. Táticas desleais, por vezes, vão muito além de manipulação da opinião pública através da imprensa. Por exemplo, em 2001, a Farmacêutica TAP foi multada em 875 milhões de dólares por fraude na assistência médica em relação ao seu medicamento anticâncer Lupron. Angell (2004) relatou que as acusações para as quais a TAP se declarou culpada incluíam subornar médicos com televisores, videocassetes, viagens para resorts, dinheiro sob a forma de "bolsas de estudo" (para ser usado para qualquer finalidade) e medicamentos gratuitos ou com grandes descontos, para que os médicos fossem encorajados a cobrar o 
Medicare pelo preço comercial total. ${ }^{8}$ Em setembro de 2009, a Pfizer foi multada em 2,3 bilhões de dólares por fornecer recompensas financeiras e outros incentivos para encorajar os clínicos gerais a prescrever medicamentos para usos não aprovados pelo Foods and Drugs Administration (FDA), ${ }^{9}$ principalmente, o uso do Bextra, uma droga desenvolvida para tratar a artrite, sendo prescrita como um analgésico geral. Curiosamente, a droga foi agora completamente retirada de uso. Outras acusações são aquelas relacionadas ao uso indevido da droga antipsicótica Geodon, do antibiótico Zyvox e da droga Lyrica, para tratamento da epilepsia. Em 2012, a GlaxoSmithKline (GSK) foi multada em 3 bilhões de dólares por subornar médicos e incentivar a prescrição de antidepressivos inadequados (Paxil) para crianças. No ano seguinte, a empresa incorreu em uma penalidade de 229 milhões de dólares pela comercialização indevida de um medicamento para diabetes (Avandia) e, em 2014, incorreu em outra de 490 milhões de dólares após a admissão de uma acusação de subornar médicos chineses para prescrever produtos da GSK.

\section{Agindo}

O estágio final (quarto), nesta abordagem baseada em questões, preocupa-se com os estudantes, buscando maneiras de colocar seus valores e convicções em ação, ajudando-os a preparar-se para (e se envolver em) uma ação responsável; e, ainda, ajudá-los no desenvolvimento de habilidades, atitudes e valores que irão permitir-lhes tomar o controle de suas próprias vidas, cooperar com os outros para realizar a mudança e trabalhar em direção a um mundo mais justo e sustentável, no qual o poder, a riqueza e os recursos são mais equitativamente partilhados. Não é o suficiente que os estudantes aprendam que ciência e tecnologia são influenciados por forças sociais, políticas e econômicas; eles precisam aprender como participar e eles precisam experimentar a participação. Além disso, eles precisam encorajar outros a participar: pais, avós, amigos, parentes, vizinhos e empresas locais. Não é o suficiente que estudantes sejam críticos de sofá! Assim, como Kyle Jr. (1996, p. 1) coloca:

A educação deve ser transformada da orientação passiva, técnica e apolítica, que é o reflexo de experiências baseadas na escola da maioria dos estudantes, para um esforço ativo, ao longo da vida, crítico e politizado, que transcende as fronteiras das salas de aula e das escolas.

8 Medicare é o sistema de seguros de saúde gerido pelo Governo Federal dos Estados Unidos (N. do O.).

9 FDA é o órgão governamental dos Estados Unidos responsável pelo controle dos alimentos, suplementos alimentares, medicamentos, cosméticos, equipamentos médicos, materiais biológicos e produtos derivados do sangue humano. Ver em: <www.fda.gov $\rangle$. (N. do O.). 
Com isso em mente, tenho muita simpatia pela noção de cidadão científico radical de Elam e Bertilssons (2003, p. 245):

O cidadão científico radical está totalmente preparado para participar em manifestações [...] marchas de rua, boicotes e resistências pacíficas e outros meios de confrontar publicamente aqueles que governam sobre ciência e tecnologia [...] Enquanto o cidadão científico como ativista pode tomar uma posição em defesa de um determinado indivíduo ou grupo na sociedade, eles também são entendidos como assumindo uma postura moral em defesa de princípios ético-políticos gerais [...] que são aceitos como existindo através de muitas interpretações diferentes e conflitantes [...] e sujeitando-os a uma contestação contínua.

Os estudantes irão tornar-se ativistas se eles se sentirem pessoalmente empoderados para efetuar a mudança, acreditarem que eles podem fazer a diferença e saber como fazê-lo. Além disso, a probabilidade de os estudantes se tornarem cidadãos ativos aumentará substancialmente, por meio do encorajamento destes a agirem agora (na escola), proporcionando oportunidades para que eles o façam e fornecendo exemplos detalhados de ações bem-sucedidas e intervenções desenvolvidas pelos outros. Ações apropriadas incluem: fazer declarações públicas; construir websites e boletins informativos; escrever para jornais; organizar petições e reuniões da comunidade; trabalhar para grupos locais de ação e coletivos de ação civil (citizen working groups); fazer cartazes; distribuir folhetos; protestar; produzir materiais multimídia informativos para a educação pública; divulgar conselhos aos proprietários de imóveis, agricultores e indústrias locais sobre a eliminação segura de resíduos tóxicos; estabelecer iniciativas, como a de um observatório da natureza (Nature Watch); instituir programas de reciclagem de vidro, papel e latas de alumínio; organizar boicotes de consumidores de produtos e práticas ambientalmente inseguros; trabalhar em projetos de limpeza ambiental (clean-up); criar trilhas naturais, lagoas de conservação e jardins de borboletas; plantar árvores; construir uma horta comunitária; criar um programa de almoço livre que não produza lixo; assumir a responsabilidade pela melhoria ambiental do terreno da escola (incluindo plantio de espécies indígenas e incentivo da biodiversidade); monitorar o consumo dos recursos energéticos e materiais da escola, a fim de formular práticas mais adequadas (incluindo o uso de painéis solares, por exemplo); reduzir o consumo de água por meio de planos de reciclagem; monitorar a utilização e a eliminação de materiais potencialmente perigosos dentro da escola; criar uma rede de compras verde; e assim por diante.

Às vezes, é útil distinguir entre ação direta e ação indireta. A primeira inclui coisas como a reciclagem, a limpeza de um riacho ou uma praia, usar uma bicicleta em vez de um carro ou de ônibus, desligar as luzes e usar sacos ou sacolas reutilizáveis e recicláveis no supermercado; enquanto a segunda inclui a compilação de petições, a distribuição de folhetos, escrever para jornais e fazer submeter propostas às auto- 
ridades locais. Enquanto a ação direta pode ser extremamente importante e pode ter algum impacto significativo, pode também desviar a atenção das causas do problema em consideração. Ela falha em não enfrentar as causas e os agentes reais da degradação ambiental, evita crítica e questionamento de nossas atividades sociais, políticas e econômicas. Em outras palavras, ela despolitiza os problemas e transfere o ônus da responsabilidade para indivíduos e famílias e está longe de governos, das corporações e das políticas que podem ter impacto significativo e a longo prazo, assim como das negociações políticas que podem levar à mudança. A limpeza de uma praia terá efeitos imediatos benéficos, é claro, mas sem uma investigação das causas e uma intervenção adequada destinada a essas causas não haverá solução duradoura. A criação de um programa de reciclagem pode prolongar a vida ativa de um ou dois aterros, mas não trata (e certamente não muda) a economia insustentável de uso, produção e consumo dos recursos naturais. Investigar os níveis de poluição do nitrato e do fosfato nos cursos de água é uma atividade importante; boicotar produtos agrícolas baseados em agrotóxicos e promover o uso de fertilizantes orgânicos pode ter mais impacto sobre o meio ambiente; realizar uma análise dos cursos de água, divulgando os dados dela decorrentes, identificar a causa provável da poluição, como o escoamento a partir de fazendas e parques locais, alertando os agricultores, o pessoal de manutenção do solo em instalações desportivas, os guardas do parque, assim como jardineiros domésticos para as causas e o impacto ambiental adverso de agrotóxicos, tornando-os conscientes de alternativas orgânicas, e incentivar os fornecedores agrícolas e centros de jardinagem para promover essas alternativas orgânicas é o ideal.

Preparar os estudantes para a ação necessariamente significa garantir que eles ganhem uma compreensão clara de como as decisões são tomadas dentro do governo local, regional, nacional e, ainda, dentro de vários grupos sociais, indústria, comércio e do setor militar. Sem o conhecimento de onde e com quem o poder de tomada de decisão está localizado e uma conscientização dos mecanismos pelos quais as decisões são alcançadas, a intervenção não é possível. Os estudantes precisam identificar as possibilidades de ação, avaliar a sua viabilidade e adequação, verificar restrições e barreiras, resolver as divergências entre aqueles que estarão envolvidos, olhar mais de perto as ações tomadas por outros (e o quanto elas têm sido bem sucedidas) e estabelecer prioridades em termos de quais ações são mais urgentes (e podem ser realizadas rapidamente) e que ações são necessárias a longo prazo. É essencial, também, que todas as ações tomadas pelos estudantes sejam avaliadas criticamente e contribuam para um banco de dados sobre ações, para uso por outros. A partir de uma perspectiva do ensino, é importante que cuidados sejam tomados para garantir a adequação de um conjunto de ações para os estudantes envolvidos, em particular, e a viabilidade geral do projeto, em termos de tempo e recursos. Distinções entre a aprendizagem sobre a ação, a aprendizagem através da ação e aprendizagem a partir da ação (MCCLAREN; HAMMOND, 2005) podem ser úteis no planejamento de intervenções. 


\section{Aprendendo sobre, através e a partir da ação}

A aprendizagem sobre a ação se concentra em aprender as habilidades e estratégias de ação sociopolítica através de filmes, biografias e autobiografias, estudos de caso e simulações, role-play e reconstruções dramáticas. Oferecer aos estudantes exemplos de ações bem-sucedidas, de preferência envolvendo outros estudantes, fomenta a crença de que eles podem mudar as coisas também. É aqui que um banco de dados de ações pode ser especialmente útil. Os estudantes podem aprender a partir das experiências dos outros, isto é, ouvindo e/ou lendo as histórias daqueles que têm estado intimamente envolvidos em tais projetos e abordagens detalhadas de ações realizadas por indivíduos, grupos e comunidades. Schusler e colaboradores (2009) fornecem muitos conselhos úteis sobre como os pesquisadores podem proceder à coleta desse tipo de história oral, fazendo perguntas, tais como: o que lhe motivou ou lhe inspirou a se envolver neste tipo de trabalho? Quais foram os seus objetivos, esperanças e expectativas? Como é que este projeto aconteceu? Quem esteve envolvido? Que barreiras e problemas foram encontrados? Como eles foram abordados? Que sucessos ocorreram? Que falhas ocorreram? $\mathrm{O}$ que você aprendeu? O que surpreendeu, encantou ou decepcionou você? O que você faria diferente se estivesse começando de novo? Você faria isso de novo?

Aprender através da ação compreende o envolvimento direto em projetos orientados para a ação fora da sala de aula que são susceptíveis de ter desfechos e consequências palpáveis. Enquanto alguns projetos podem ser escolhidos e organizados pelo professor, especialmente nos primeiros anos, é importante que os estudantes estejam eles mesmos envolvidos, tão logo seja possível, na seleção e no planejamento das ações a serem tomadas. É importante envolver os estudantes em atividades de pesquisa orientadas por QSC e apoiá-los na participação em organizações de base comunitária que concentram os cidadãos para lidar com questões locais graves, em particular aquelas questões muitas vezes esquecidas pelas agências ou instituições governamentais. Ao enfrentar as questões locais reais diretamente, os estudantes ganham valiosa experiência em primeira mão das maneiras em que interesses sociais, políticos e econômicos concorrentes impactam na tomada de decisões. Através da participação em atividades baseadas na comunidade, eles ganham acesso às ideias, às experiências, às pessoas, às instituições e às estruturas sociopolíticas que constroem tanto a capacidade individual quanto a coletiva para abordar QSC e as questões ambientais de forma responsável, profunda, crítica e politicamente efetiva e construir o compromisso de se engajar na luta por maiores liberdade, igualdade e justiça social.

Ao se envolverem nos assuntos públicos a nível local, os estudantes veem os processos democráticos em ação; trabalhando ao lado de outros, eles aprendem sobre as demandas e dificuldades de agir e aprender a desenvolver estratégias eficazes de enfrentamento. Uma pesquisa sugere que a participação nesses tipos de atividades na infância e na adolescência está associada a níveis de participação cívica, serviços à comunidade e ativismo político na idade adulta até quatro vezes maior do que a norma. (CHAWLA; 
FLANDERS CUSHING, 2007) Através do envolvimento em audiências públicas e em reuniões da câmara municipal, conferências de consenso, círculos de estudo, grupos focais, painéis/júris de cidadãos, fóruns para elaboração de regras negociáveis e comitês de aconselhamento público, os estudantes ganham autonomia, um senso de valor e competência, uma sensação de identidade pessoal e cívica, o respeito pelos outros pontos de vista das pessoas, habilidades de negociação e assim por diante. Ao trabalhar em uma subtarefa, dentro de um esforço de grupo, os indivíduos adquirem um nível de conhecimento que não seria alcançado sozinho, pelo menos não tão rapidamente e de forma indolor. Eles também entram em contato com perspectivas sobre questões e problemas que diferem das suas. Compartilhar experiências, estratégias de ação e histórias de sucesso, bem como construir amizades, pode ser inspirador e altamente motivador e pode levar ao ativismo sociopolítico ao longo da vida.

A aprendizagem a partir da ação ocorre quando os estudantes avaliam os planos, estratégias, processos e resultados dos seus próprios projetos de ação e aqueles dos outros. A análise leva à compilação de um registro do que aconteceu ou do que os estudantes percebem como tendo acontecido, das tentativas para identificar o porquê sim ou o porquê não de uma ação ter sido bem-sucedida, e a uma reflexão por todas as partes envolvidas sobre a importância da ação para si e para a comunidade. O processo é facilitado pela manutenção de registros cuidadosos e também de jornais sobre o assunto, consulta com outros, compartilhamento de experiências e sentimentos e comunicação com todos aqueles envolvidos. É importante que uma determinada ação não seja vista como um fim em si. Os estudantes precisam de oportunidades para avaliar as ações realizadas, para refletir sobre sua natureza e impacto e, possivelmente, reformular a ação. A questão, de modo simples, é que uma orientação positiva para a ação sociopolítica seja estabelecida ao longo do tempo e esteja enraizada na prática reflexiva.

Os estudantes podem ganhar experiência de ação e, assim, aprender através da ação e também a partir da ação, por meio da abordagem já conhecida de aprendizagem em três fases, compreendendo modelagem, prática guiada e aplicação, como discutido acima. Ao se envolver em intervenções e projetos orientados para a ação, em paralelo com uma crítica qualificada e confiável, os estudantes aumentam tanto a sua compreensão do que constitui a ação sociopolítica, quanto sua capacidade de praticá-la com sucesso. Em outras palavras, o ativismo social é uma atividade reflexiva: conhecimento e perícia informam e determinam a condução da atividade e, simultaneamente, o envolvimento em ações (e reflexão crítica sobre elas) refina o conhecimento e aguça a perícia. Ao longo de todas estas atividades, o papel do professor é crucial: um ativista modelo, um orientador, um recurso de aprendizagem, um facilitador, um consultor, um suporte emocional e também um crítico. Também, porque os alunos têm a oportunidade de experimentar o fracasso, bem como o sucesso, é imperativo que a atmosfera das aulas seja tanto tolerante quanto solidária e que exista um diálogo permanente sobre a forma como a atividade está progredindo, incluindo uma discussão franca dos problemas encontrados, 
rotas de investigação que se mostram estéreis e barreiras ao progresso que se mostram intransponíveis. Crucial também, se o objetivo é que os estudantes ganhem uma compreensão da autêntica ação sociopolítica, seria uma comparação constante entre o que os estudantes estão fazendo em seu projeto e o que os outros fizeram. Da mesma forma que é importante ensinar aos estudantes a necessidade de serem resilientes e determinados para tentar novamente, experiências de fracasso também podem lhes mostrar a necessidade de mobilizar os outros e de se envolver em uma ação coletiva. Ações coletivas são quase sempre mais efetivas que ações individuais e, em algumas circunstâncias, podem ser o único meio de conduzir à mudança.

\section{Considerações finais}

Se estamos a preparar os estudantes para lidar com questões controversas de forma racional, diligente, tolerante e moral, é preciso garantir que eles tenham os conhecimentos, habilidades, atitudes e confiança para investigar diversos pontos de vista, analisá-los e avaliá-los, reconhecer inconsistências, contradições e insuficiências, chegar a suas próprias conclusões, argumentar de forma coerente e persuasiva sobre os seus pontos de vista, usá-los nas tomadas de decisões sobre o que é certo, bom e justo num contexto ou situação particular e formular cursos adequados e eficazes de ação. Este capítulo centra-se sobre o tipo de educação científica necessária como preparação para a realização de ações adequadas, responsáveis e eficazes em questões de interesse social, econômico, ambiental e ético-moral. O principal objetivo é permitir que os cidadãos jovens observem criticamente a sociedade que temos, os valores que a sustentam, e que perguntem o que pode e o que deve ser alterado, a fim de alcançar uma democracia socialmente mais justa e resultar em estilos de vida ambientalmente mais sustentáveis.

$\mathrm{Na}$ defesa de um modelo de currículo em quatro estágios, a minha intenção não é sugerir que toda a ação seja atrasada até os anos finais da escolaridade. Ao invés disso, os estudantes devem seguir, a qualquer que seja o estágio apropriado para a QSC específica sob consideração, as oportunidades de aprendizagem que ela apresenta e o nível de desenvolvimento intelectual e emocional dos estudantes, tendo em conta o princípio de gerenciamento de aulas que consiste em, para cada tópico, investir em uma variedade de abordagens. Em algumas áreas de atuação, é relativamente fácil que os estudantes se organizem para a ação; em outras áreas, é mais difícil. Para algumas QSC, o estágio 3 é mais trabalhoso do que o estágio 4. Por exemplo, é mais fácil realizar uma ação sobre a reciclagem do que alcançar um juízo crítico e de alta reputação acerca da reciclagem versus o consumo reduzido versus o uso de materiais alternativos. Além disso, é improvável que todos os estudantes sejam motivados pelas mesmas questões, problemas ou situações, e é provável que os indivíduos variem substancialmente em suas disposições para agir. Claramente, essas diferenças tornam difícil planejar um currículo orientado para a ação, para todos. Mas não há nenhuma razão pela qual devemos esperar que diferentes 
estudantes e grupos de estudantes participem do mesmo projeto. Diferentes pontos de vista e diferentes prioridades poderiam, e possivelmente devem, levar à participação em diferentes projetos.

Os estudantes que estão acostumados com um currículo de ciências tradicional estarão familiarizados com a ciência sendo apresentada como inteiramente racional, sistemática, analítica, despersonalizada e sem emoção, com poucas oportunidades para explorar sentimentos, sensibilidades e emoções. Quando confrontados com uma abordagem orientada a QSC, tais estudantes poderão ser surpreendidos por suas respostas emocionais para QSC e questões ambientais controversas pelo debate vívido e excitante em sala de aula. Se os aprendizes não têm capacidade para lidar com seus distúrbios emocionais ou para lidar com seus impulsos, torna-se difícil para eles se envolverem em atividades de aprendizagem, avaliar diferentes opções, aplicar julgamentos maduros e fundamentados e assumir a responsabilidade para sintetizarem seus pontos de vista. O contexto social em que o estudante está, localizado fora da escola, pode ser um importante fator de impacto sobre a aprendizagem. Rejeitar conhecimentos e crenças que são fortemente sustentados dentro de grupos sociais aos quais o estudante pertence, ou pretende ser incluído, pode ser tão emocionalmente estressante que se torna praticamente impossível. Da mesma forma, aceitar pontos de vista que estão em oposição às visões dominantes dentro desses grupos pode ser uma tarefa descomunal. $O$ senso de identidade de um estudante, incluindo etnia, gênero, classe social, relações familiares e comunitárias, estatuto econômico e experiências pessoais se estendendo ao longo de muitos anos vai necessariamente ter impacto sobre seus valores, prioridades e preferências. É aqui que as noções de inteligência emocional, de letramento emocional e de competência emocional, e as estratégias de ensino para promovê-las, podem ser úteis - temas bem fora do foco deste capítulo, ainda que possamos notar que o envolvimento emocional pode ser promovido através de estudos de caso, teatro, encenações, literatura, arte, fotografias, filmes e música, visitas a lugares específicos, entrevistas com aqueles diretamente afetados e assim por diante. Atividades de escrita podem também desempenhar um papel importante no desenvolvimento do investimento pessoal em uma questão e na sensibilização crescente dos estudantes para a necessidade de ação sociopolítica, especialmente quando os estudantes assumem o papel de um jornalista investigativo. Visitas a locais específicos (hospitais, fazendas industriais, laboratórios etc.) e experiências guiadas em áreas de importância ecológica podem desempenhar um papel profundo na sensibilização e no engajamento emocional dos estudantes.

Um papel central pode ser desempenhado pela familiaridade dos estudantes com mídias sociais, como o Facebook e o Twitter, para estabelecer redes, expressar preocupações, partilhar pensamentos e espalhar mensagens sobre a necessidade de ações. As mídias sociais permitem formas de participação que não eram possíveis anteriormente e podem engajar números significativos de pessoas que de outra forma não seriam envolvidas. Elas têm o potencial de facilitar a construção de uma sociedade mais inclusiva, 
participativa, socialmente justa e politicamente engajada. Remtulla (2008) identifica três categorias de atividade política online:

- o uso consciente e comprometido da internet e de outras formas de TIC como um meio de acessar fontes independentes e alternativas de informação que podem ser ignoradas ou suprimidas pela mídia hegemônica - por exemplo, o Centro de Mídia Independente, ${ }^{10}$ Wikinotícias $^{11}$ e DemocracyNow; ${ }^{12}$

- sites orientados para a comunidade que buscam difundir conscientização, compartilhar experiências e ideias e construir redes dentro das comunidades; e

- grupos de ação aumentam o apoio público para as ações relacionadas com questões específicas (locais, regionais, nacionais e internacionais).

Nós precisamos estar cientes, no entanto, de que as desigualdades sociais e o acesso diferenciado aos recursos tecnológicos podem restringir as oportunidades para aqueles que já são marginalizados, não ouvidos ou desconsiderados. Eles podem ser ainda mais desfavorecidos, silenciados ou mesmo excluídos da participação na abordagem dos problemas que mais os afetam. Serão necessários esforços massivos para assegurar que os espaços online e as comunidades que os utilizam sejam abertos a todos.

Os estudantes devem ser encorajados e habilitados a utilizar os aspectos da cultura da juventude para espalhar uma mensagem orientada para os jovens, sobre a responsabilidade cívica e ambiental. A música pode ser importante na construção e na consolidação da identidade, ajudando os estudantes a obter uma melhor compreensão das suas próprias experiências e das experiências dos outros, melhorando a conscientização política e construindo a solidariedade e o senso de comunidade/pertencimento que pode levar ao ativismo. Para muitos jovens urbanos nos Estados Unidos, a música rap da cultura hip-hop pode ser um veículo particularmente poderoso, permitindo-lhes colocar seus sentimentos, emoções, necessidades, aspirações, esperanças, alegrias, medos, desilusões e raiva em uma forma que respeita as suas experiências culturais imediatas e será facilmente entendida por seus pares. ${ }^{13}$ Por exemplo, Ginwright e Cammarota (2007) descrevem como jovens em Oakland (Califórnia, Estados Unidos) organizaram o que eles chamam de "hip-hop de guerrilha urbana" - concertos móveis improvisados com música, rap, distribuição de folhetos e outras formas de educação política em parques locais, centros comerciais, esquinas e outros lugares para onde os jovens costumam sair.

10 Ver em: <www.indymedia.org>; <http://www.midiaindependente.org/>.

11 Ver em: <en.wikinews.org>; <https://pt.wikipedia.org/wiki/Wikinot\%C3\%ADcias>.

12 Para fontes de informação brasileiras, sugerimos consultar notas 3 e 4, dos organizadores, acima. Ver em: <www.democracynow.org $\rangle$. (N. do O.).

13 Assim como também ocorre em muitas grandes cidades latino-americanas. (N. do O.). 
É claro que nem todas as atividades orientadas por QSC, baseadas na comunidade, serão bem-sucedidas na promoção, no desenvolvimento e na manutenção de uma postura ativista. Existe o perigo de que as ações reflitam a agenda do professor e não os interesses e as preocupações dos estudantes, que simplesmente seguiriam o movimento, indo com a maioria, sem engajamento na ação, sem qualquer compromisso real ou sentimento de poder, simplesmente para satisfazer os requisitos do curso ou atender às expectativas do professor. No caso extremo, os professores podem ser levados a compilar uma lista de ações aprovadas, roteirizadas e politicamente seguras nas quais envolveriam grupos sucessivos de estudantes sem sequer envolvê-los no debate crítico que deve preceder e determinar a ação. Os estudantes podem ser dirigidos para questões incontroversas, guiados para longe do conflito, dissuadidos do debate político e censurados quando suas propostas parecem propensas a desafiar práticas escolares, políticas governamentais locais ou os interesses de empresas locais. Estas situações devem ser evitadas. Simovska (2008) distingue entre a participação simbólica e a participação genuína em termos de "foco" (conteúdo especificados versus a construção do conhecimento através de crítica e reflexão), "resultados" (aceitação de um determinado conjunto de crenças, valores e comportamentos versus a autonomia e a consciência crítica do estudante, assim como sua capacidade de lidar com questões novas e complexas) e "objetivos de mudanças" (indivíduos e seus respectivos estilos de vida versus indivíduos em contexto, tendo em conta as relações interpessoais, os fatores socioculturais, as dimensões ético-morais e as estruturas organizacionais existentes). As mesmas preocupações estão presentes na insistência de Roth (2009) de que os professores não subordinem a experiência de ativismo aos objetivos mais gerais de escolaridade e também tenham em conta - através da observação de Sammel e Zandvliet (2003) - de que a maioria das abordagens de QSC nas escolas são realizadas dentro da percepção dos limites do politicamente aceitável para os professores. É imperativo que os professores encontrem a coragem, recrutem o apoio de outras pessoas e mobilizem os recursos para serem muito mais desafiadores, críticos e politizados em suas abordagens. Muitos professores consideram que evitar questões controversas, especialmente aquelas com dimensões políticas muito significativas, é assumir uma posição neutra. Na realidade, não é neutra. Porque ela falha ou deixa de enfrentar e desafiar as causas sociopolíticas subjacentes dos problemas ambientais, por exemplo, ela suporta implicitamente práticas sociais vigentes, as instituições e os valores atuais. Não existe tal coisa como não envolvimento político. Não envolvimento é, em si, uma forma de envolvimento pelo que é padrão, pelo que é norma e constitui, assim, um apoio implícito à ideologia dominante. Evitar questões políticas é, com efeito, deixar tais questões para que outros decidam.

Claro, há professores que vão argumentar que a politização não é uma meta legítima da educação em ciência e tecnologia (ou de qualquer educação baseada na escola, na medida em que possa ser considerada) e que a ação sociopolítica não tem qualquer lugar na escola. Abordar QSC controversas em sala de aula pode provocar a oposição 
de outros professores, administradores escolares, pais e membros da comunidade local. Engajar os estudantes em ações sociopolíticas pode provocar ainda mais oposição. Apesar de que a reciclagem, a limpeza de praia, a construção de caixas-ninho ou o trabalho no banco local (local foodbank) ou em um abrigo para pessoas sem-teto podem ser ações consideradas seguras, benignas e não controversas, desafiar autoridades locais, organizar manifestações, realizar vigílias e organizar boicotes pode elevar os níveis de ansiedade dos pais, ofender a comunidade local e levar a uma oposição continuada. Os professores precisam estar preparados para a repercussão, e eles precisam de coragem para ir claramente contra esta oposição. Muitos vão perceber a capacidade para efetuar uma mudança social localizada em um corpo de estudantes que são cientificamente letrados, ambientalmente conscientes, socialmente críticos e politicamente letrados como uma ameaça ao invés de um benefício, como uma ameaça à ordem estabelecida de poder e controle. De fato, o próprio sucesso da educação advogada neste livro é o que é susceptível de atrair a maior parte da oposição, de modo que o envolvimento dos estudantes em ações políticas potencialmente bem-sucedidas poderá ser vigorosamente resistido. Como observado em Hodson (2014), aqueles professores que promovem o envolvimento e desenvolvem capacidades para a ação estão montando um tigre, mas é um tigre que pode muito bem ter de ser montado, se realmente queremos dizer o que nós dizemos sobre a educação para a participação cívica. Eu não procuro minimizar as dificuldades que os professores enfrentam para implementar um currículo orientado para a ação ou a coragem que eles precisarão para se colocar de forma contrária a esta resistência potencialmente muito forte. No entanto, faço um clamor aos professores e aos estudantes para que tenham a coragem e a força de vontade para fazer o que eles acreditam que é correto, bom e justo. Nas palavras de Alberto Rodriguez (2001, p. 290), nós precisamos de coragem para "expandir o nosso olhar [...] e enfrentar o desafio de nos tornarmos guerreiros culturais para a mudança social”.

\section{Referências}

AGYEMAN, J.; CARMIN, J. Introduction: Environmental injustice beyond borders. In: CARMIN, J.; AGYEMAN, J. (Ed.). Environmental inequalities beyond borders: local perspectives on global injustices. Cambridge, MA: MIT Press, 2011. p. 1-15.

ALLCHIN, D. Teaching the nature of science: perspectives and resources. Saint Paul, MN: SHiPS Education Press, 2013.

ANGELL, M. The truth about the drug companies: how they deceive us and what to do about it. New York: Random House, 2004.

BISSCHOP, L. How e-waste challenges environmental governance. International Journal for Crime, Justice and social Democracy, Brisbane, v. 3, n. 2, p. 81-95, 2014.

BONJOUR, L.; BAKER, A. (Ed.). Philosophical problems: an annotated anthology. New York: Pearson Longman, 2007. (Specifically, chapter 5: Morality and moral problems). 
BROOKE, J. Waste dumpers turn to West Africa. The New York Times, New York, Jul. 1988.

BULLARD, R. D.; JOHNSON, G. S. Environmental justice: grassroots activism and its impact on public policy decision making. Journal of Social Issues, Malden, v. 56, n. 3, p. $555-578,2000$.

BURBULES, N. C.; CALLISTER, T. A. Watch it: the risks and promises of information technologies for education. Boulder, CO: Westview Press, 2000.

CHAWLA, L.; FLANDERS CUSHING, D. Education for strategic environmental behavior. Environmental Education Research, Abingdon, v. 13, n. 4, p. 437-452, 2007.

CHOPRA, S. Globalisation, food security, public health \& prosperity focus on India. Journal of Activist Science \&Technology Education, [S.1.], v. 1, n. 1, p. 61-64, 2009.

ELAM, M.; BERTILSSON, M. Consuming, engaging and confronting science: The emerging dimensions of scientific citizenship. European Journal of Social Theory, London, v. 6, n. 2, p. 233-251, 2003.

ERDURAN, S.; DAGHER, Z. R. Reconceptualizing the nature of science for science education. Dordrecht: Springer, 2014.

FRANCE, B.; MORA, H. A.; BAY, J. B. Changing perspectives: Exploring a pedagogy to examine other perspectives about stem cell research. International Journal of Science Education, London, v. 34, n. 5, p. 803-824, 2012.

FULLICK, P.; RATCLIFFE, M. (Ed.). Teaching ethical aspects of science. Totton: Bassett Press, 1996.

GINWRIGHT, S.; CAMMAROTA, J. Youth activism in the urban community: Learning critical civic praxis within community organizations. International Journal of Qualitative Studies in Education, Basingstoke, v. 20, n. 6, p. 693-710, 2007.

GREENPEACE. Poisoning the poor: electronic waste in Ghana. Amsterdam, 2008.

HALVERSON, K. L.; SIEGEL, M. A.; FREYERMUTH, S. K. Lenses for framing decisions: undergraduates' decision making about stem cell research. International Journal of Science Education, London, v. 31, n. 9, p. 1249-1268, 2009.

HODSON, D. Becoming part of the solution: learning about activism, learning through activism, learning from activism. In: BENCZE, L.; ALSOP, S. (Ed.). Activist science and technology education. Dordrecht: Springer, 2014. p. 67-98.

HODSON, D. Don't be nervous, don't be flustered, don't be scared: be prepared. Canadian Journal of Science, Mathematics and Technology Education, Toronto, v. 13, n. 4, p. 313-331, 2013.

HODSON, D. Looking to the future: building a curriculum for social activism. Rotterdam: Sense Publishers, 2011.

HODSON, D. Teaching and learning about science: language, theories, methods, history, traditions and values. Rotterdam: Sense, 2009. 
HURSTHOUSE, R. On virtue ethics. Oxford: Oxford University Press, 1999.

IBITAYO, W. C. G. Transboundary dumping of hazardous waste. In: THE ENCYCLOPAEDIA of earth. Washington: Environmental Information Coalition, National Council for Science and the Environment, 2008.

KELLY, T. Discussing controversial issues: four perspectives on the teacher's role. Theory and Research in Social Education, New York, n. 14, p. 113-138, 1986.

KNIGHT, A. J. Perceptions, knowledge and ethical concerns with GM foods and the GM process. Public Understanding of Science, Bristol, n. 18, p. 177-188, 2009.

KOLSTØ, S. D. Scientific literacy for citizenship: tools for dealing with the science dimension of controversial socioscientific issues. Science Education, New York, v. 85, n. 3, p. 291-310, 2001.

KYLE JR., W. C. Editorial: the importance of investing in human resources. Journal of Research in Science Teaching, New York, n. 33, n. 1, p. 1-4, 1996.

MARTINEZ-ALIER, J. The environmentalism of the poor: a study of ecological conflicts and valuation. Northhampton, MA: Edward Elgar Publishing, 2003.

MCCLAREN, M.; HAMMOND, B. Integrating education and action in environmental education. In: JOHNSON, E. A.; MAPPIN, M. J. (Ed.). Environmental education and advocacy: changing perspectives of ecology and education. Cambridge: Cambridge University Press, 2005. p. 267-291.

PEDRETTI, E. Septic tank crisis: a case study of science, technology and society education in an elementary school. International Journal of Science Education, London, v. 19, n. 10, p. 1211-1230, 1997.

QUALIFICATIONS AND CURRICULUM AUTHORITY-QCA. Education for citizenship and the teaching of democracy in schools. London, 1998.

RAI, T.; NORTON, T. Discourses of sustainability in today's public sphere. In: MAY, S. K.; CHENEY, G.; ROPER, J. The Debate over Corporate Social Responsibility. Oxford: Oxford University Press, 2007, p. 351-364.

REMTULLA, K. A. Democracy or digital divide? the pedagogical paradoxes of online activism. In: LIND, D. E.; CARR, P. R. (Ed.). Doing democracy: striving for political literacy and social justice. New York: Peter Lang, 2008. p. 267-280.

RODRIGUEZ, A. J. Courage and the researcher's gaze: (re)defining our roles as cultural warriors for social change. Journal of Science Teacher Education, New York, v. 12, n. 3, p. 277-294, 2001.

ROTH, W-M. On activism and teaching. Journal of Activist Science and Technology Education, [S.1.], v. 1, n. 2, p. 33-47, 2009.

SAMMEL, A.; ZANDVLIET, D. Science reform or science conform: problematic epistemological assumptions with/in Canadian science reform efforts. Canadian Journal of Science, Mathematics and Technology Education, Toronto, v. 3, n. 4, p. 513-520, 2003. 
SCHUSLER, T. M. et al. Developing citizens and communities through youth environmental action. Environmental Education Research, Abingdon, v. 15, n. 1, p. 111-127, 2009.

SHEN, B. S. P. Scientific literacy and the public understanding of science. In: DAY, S. B. (Ed.). The communication of scientific information. Basel: Karger, 1975. p. 44-52.

SIMOVSKA, V. Learning in and as participation: a case study from health-promoting schools. In: REID, A. et al. (Ed.). Participation and Learning: perspectives on education and the environment, health and sustainability. New York: Springer, 2008. p. 61-80.

SINGER, P. (Ed.). Companion to ethics. Oxford: Basil Blackwell, 1991.

STELFOX, H. T. et al. Conflict of interest in the debate over calcium channel antagonists. New England Journal of Medicine, Boston, v. 338, n. 1, p. 101-106, 1998.

YOUNG, R. M. Racist society, racist science. In: GILL, D.; LEVIDOW; L. (Ed.). Antiracist science teaching. London: Free Association Books, 1987. p. 16-42. 


\title{
PENSAMIENTO CRÍTICO DESDE CUESTIONES SOCIO-CIENTÍFICAS
}

\author{
Nidia Torres \\ Jordi Solbes
}

\section{El concepto de pensamiento crítico: una habilidad o un conjunto de competencias}

En este capítulo, partimos de conceptualizar lo que entendemos por pensamiento crítico en el ámbito de las Cuestiones Socio-científicas (CSC). Para ello, consideramos algunos conceptos que parten de definir el pensamiento crítico como habilidad o conjunto de habilidades. Por ejemplo, McMillan (1987) manifiesta que el pensamiento crítico es el que involucra el reconocimiento, la evaluación de los argumentos y la realización de inferencias. Otros, como Perry (1970), Zoller (1993) y Halpern (2006), asumen el pensamiento crítico en relación con el uso eficaz de habilidades implicadas en resolver problemas, en formular inferencias, en calcular probabilidades y en tomar decisiones.

Diversos estudios reconocen la complejidad del concepto. Al respecto, Ennis (1993) señala que es un pensamiento de orden superior y, como tal, no es automático sino que requiere autodeterminación, reflexión, esfuerzo, autocontrol y metacognición. Peter Facione, Noreen Facione y Caro Giancarlo (2000) señalan que una persona que posee pensamiento crítico es habitualmente inquisitiva, bien informada, confía en la razón, de mente abierta, flexible, justa cuando se trata de evaluar, honesta cuando confronta sus sesgos personales, prudente al emitir juicios, dispuesta a reconsiderar y si es necesario 
a retractarse, clara respecto a los problemas o las situaciones que requieren la emisión de un juicio, ordenada cuando se enfrenta a situaciones complejas, diligente en la búsqueda de información relevante, razonable en la selección de criterios, enfocada en preguntar, indagar e investigar, persistente en la búsqueda de resultados tan precisos como las circunstancias y el problema o la situación lo permitan. Por otra parte, Richard Paul y Linda Elder (2006) manifiestan que el pensamiento crítico es el modo de pensar sobre cualquier tema, contenido o problema en el cual el pensante mejora la calidad de su pensamiento al apoderarse de las estructuras inherentes del acto de pensar y al someterlas a estándares intelectuales. Estas alternativas dejan claro que el pensamiento crítico supone someterse a rigurosos esquemas de excelencia y dominio, siendo conscientes de su uso. También implica comunicación efectiva, habilidades de solución de problemas y un compromiso de superar el egocentrismo del ser humano.

Por ejemplo, Laburu (1996) destaca que el pensamiento crítico genera una manera de pensar y actuar reflexivamente frente a una situación determinada. El pensamiento crítico, como proceso cognitivo, permite la construcción de un nuevo conocimiento y la utilización estratégica del mismo en la solución de problemas presentes en la vida cotidiana. Así mismo, diversos estudios (HANNEL; HANNEL, 1998; NICKERSON, 1994) afirman que el pensamiento crítico genera personas más analíticas que promoverían el mejoramiento de la calidad de vida y que serían capaces de transformar su realidad, solucionando diferentes situaciones a nivel personal, familiar y laboral. Presseisen (1986) define el pensamiento crítico como un pensamiento racional centrado en el análisis y la evaluación para facilitar la comprensión de significados e interpretaciones.

En la enseñanza de las ciencias respecto al pensamiento crítico, Yager (1993) lo relaciona con la capacidad de hacer elecciones racionales y juicios fundamentados como elementos de las decisiones que se emplean para resolver problemas. Jiménez-Aleixandre (2010, p. 39) afirma que "es la capacidad de desarrollar una opinión independiente, adquiriendo la facultad de reflexionar sobre la sociedad y participar en ella”. Señala que tiene componentes de argumentación, como la búsqueda y uso de pruebas. También cuestiona la autoridad y destaca aspectos emancipatorios, como la opinión independiente y el análisis crítico de discursos legitimadores. Vieira, Tenreiro-Vieira y Martins (2010) mencionan las capacidades de cuestionar la validez de los argumentos, rechazar conclusiones no basadas en razones válidas, detectar tendencias y errores de pensamiento, y evaluar la credibilidad de las fuentes de información.

Las perspectivas anteriores nos permiten plantear una definición propia del pensamiento crítico. Desde nuestro punto de vista, el pensamiento crítico es un conjunto de competencias de las personas para estructurar una manera de pensar propia que les permite distinguir la validez de los argumentos, tomar posiciones frente a las situaciones sociales y tener un papel activo en las decisiones culturales y científicas asumidas desde una responsabilidad social (SOLBES; TORRES, 2012), dichas competencias requieren la movilización de varias capacidades (identificación, cuestionamiento de discursos dominantes, 
análisis, argumentación, toma de decisiones, elaboración de conclusiones, interrelación de los saberes científicos con aspectos ambientales, políticos, económicos, filosóficos y sociales, identificar valores morales, hacer juicios morales, es decir involucrar la dimensión actitudinal). Al respecto, la propia educación Ciencia-Tecnología-Sociedad-Ambiente (CTSA) pone énfasis en la ética en la toma de decisiones del ciudadano. (SOLBES; VILCHES, 1997)

En nuestro estudio (SOLBES; TORRES, 2012), hemos planteado una serie de competencias y sus dificultades (ver Cuadro 1) desde un enfoque dialectico, que permiten valorar el desarrollo del pensamiento crítico, en un programa de intervención con el uso de CSC. Estas competencias las hemos denominado competencias críticas asumidas como capacidades que permiten prepararse para: emitir juicios propios, como resultado de cuestionamientos, confrontaciones de puntos de vista, buscar procesos de indagación frente a problemas, ideologías e información, abrir espacios dialógicos y críticos como una forma de manifestación e intervención social.

Cuadro 1 - Competencias que se requieren para el desarrollo del pensamiento crítico en el ámbito de las CSC

\begin{tabular}{|c|c|}
\hline $\begin{array}{l}\text { Una persona con pensamiento crítico que aborde CSC } \\
\text { sería capaz de: }\end{array}$ & Dificultades que impiden el PC \\
\hline $\begin{array}{l}\text { 1. Comprender la naturaleza de la ciencia como actividad } \\
\text { humana con múltiples relaciones con la tecnología, } \\
\text { la sociedad y el ambiente. Asumir la existencia de } \\
\text { problemáticas socio-científicas, es decir, controversias } \\
\text { sociales que tienen su base en nociones científicas. }\end{array}$ & $\begin{array}{l}\text { 1. Asumir la ciencia como un } \\
\text { conocimiento de elite, lejano de ellos y } \\
\text { descontextualizado. No ser conscientes } \\
\text { de los problemas a los que se enfrenta } \\
\text { hoy la humanidad, ni del papel de la } \\
\text { ciencia y la tecnología en los mismos. }\end{array}$ \\
\hline $\begin{array}{l}\text { 2. Estar informado sobre el tema, no limitarse a discursos } \\
\text { dominantes, conocer posturas alternativas, cuestionar la } \\
\text { validez de los argumentos rechazando conclusiones no } \\
\text { basadas en pruebas, detectar falacias argumentativas, } \\
\text { evaluar la credibilidad de las fuentes teniendo en cuenta } \\
\text { los intereses subyacentes y crear argumentaciones sólidas. }\end{array}$ & $\begin{array}{l}\text { 2. Tener disposición para cuestionar } \\
\text { las opiniones y creencias personales } \\
\text { basadas en discursos legitimadores } \\
\text { (o en la ideología dominante). } \\
\text { Desconocimiento de los intereses } \\
\text { subyacentes. }\end{array}$ \\
\hline $\begin{array}{l}\text { 3. Estudiar el problema socio-científico de manera } \\
\text { integral, en su complejidad, de manera que se involucren } \\
\text { dimensiones científicas, técnicas, éticas, culturales, } \\
\text { filosóficas, sociales econômicas, ambientales etc. }\end{array}$ & $\begin{array}{l}\text { 3. Discurso unidimensional y } \\
\text { descontextualizado de la ciencia. } \\
\text { Dificultad para cuestionar y valorar } \\
\text { los efectos e implicaciones de los } \\
\text { desarrollos científicos y tecnológicos en } \\
\text { la sociedad. }\end{array}$ \\
\hline $\begin{array}{l}\text { 4. Valorar y realizar juicios éticos en torno a la CSC } \\
\text { atendiendo a la contribución de los mismos a la } \\
\text { satisfacción de necesidades humanas, a la solución de los } \\
\text { problemas del mundo. }\end{array}$ & $\begin{array}{l}\text { 4. Visión neutral de la ciencia. No } \\
\text { poner en cuestionamiento las razones } \\
\text { morales, políticas o personales ni } \\
\text { permitir pensar estas frente a las CSC. }\end{array}$ \\
\hline $\begin{array}{l}\text { 5. Construir planteamientos y conclusiones, } \\
\text { adecuadamente sustentados, que lleven a tomar } \\
\text { decisiones fundamentadas, a promover acciones para } \\
\text { el mejoramiento de la calidad de vida y a ser capaces } \\
\text { de transformar su realidad solucionando diferentes } \\
\text { situaciones a nivel personal, familiar y laboral. }\end{array}$ & $\begin{array}{l}\text { 5. Pasividad, comodidad, actitud } \\
\text { conformista frente a los discursos } \\
\text { dominantes. }\end{array}$ \\
\hline
\end{tabular}

Fuente: Solbes y Torres (2012). 
El planteamiento anterior, permite apartarnos de la denominación de pensamiento crítico como habilidad, pues este concepto hace referencia al talento o la aptitud para efectuar alguna tarea. Por ello, se asocia con procesos mediante los cuales se realizan tareas y actividades con eficacia y eficiencia, mientras que el concepto de competencia supone una serie de conocimientos, capacidades, habilidades, destrezas, actitudes y disposiciones que alguien debe poseer para intervenir en la formación integral de un individuo. (PEDRINACCI et al., 2012)

Una diferencia entre habilidad y competencia se establece en el Centro Europeo para el Desarrollo de la Formación Profesional de la Comisión Europea. (CEDEFOP, 2001) La habilidad se define como la capacidad de realizar tareas y solucionar problemas, mientras que una competencia es la capacidad de aplicar los resultados del aprendizaje en un determinado contexto (educación, trabajo, desarrollo personal o profesional). Una competencia no está limitada a elementos cognitivos (uso de la teoría, conceptos o conocimiento implícito). Abarca, además, aspectos funcionales (habilidades técnicas), atributos interpersonales (habilidades sociales $u$ organizativas) y valores. Este punto de vista hace necesario, el uso de situaciones complejas contextualizadas que permitan asumir posturas sociales. Una de las estrategias utilizadas para ello, en la didáctica de las ciencias han sido las CSC, asumidas como situaciones controvertidas que relacionan asuntos científicos con implicaciones sociales.

Las CSC han sido vistas como problemas mal estructurados o cuestiones de naturaleza abierta, compleja que se componen de dilemas controversiales. (SADLER, 2004; TOPCU, 2010) Por ser situaciones que relacionan aspectos de la ciencia, las CSC tienen múltiples dimensiones: econômica, política, ética, religiosa y ambiental. Así permiten que los estudiantes sean capaces de razonar desde diversas perspectivas, lo que involucra un constante análisis y una restructuración de la información. (HODSON, 2006; TOPCU, 2010)

Las características anteriores han hecho adecuadas las CSC para el desarrollo de procesos argumentativos, es decir, relacionarlas con el carácter dialógico que tiene lugar en el aula, en el cual los individuos involucran en sus discursos diferentes consideraciones, para defender y sustentar ideas, elaborar contraargumentos o refutaciones, evaluar tesis de oposición, reafirmando o elaborando opiniones. Es decir, permitiendo que los estudiantes se involucrasen en prácticas de elaboración de conocimiento, reflexión y razonamiento.

Consideramos que las CSC se constituyen en escenarios de práctica no solo de la argumentación sino para el desarrollo del pensamiento crítico, puesto que problematizan en las aulas diversos temas sociales y permiten dirigir la atención hacia el aprendizaje de las ciencias y, además, por estar relacionadas con la vida, se puede percibir su utilidad y relevancia. (SADLER; DONNELLY, 2006) Del mismo modo, brindan herramientas críticas a los estudiantes, por ejemplo, asumir posturas individuales y colectivas alrededor de las CSC estudiadas. (TORRES; MARTÍNEZ, 2011) Son posibi- 
litadoras de la promoción de la autonomía de los estudiantes y del empoderamiento, del desarrollo de una opinión independiente y permiten desarrollar una mente abierta y reflexionar críticamente. (JIMÉNEZ-ALEIXANDRE; PUIG 2010; MARTÍNEZ, 2010) Estas consideraciones van en consonancia con los propósitos de la Filosofía crítica y la pedagogía critica que se explican a continuación.

\section{La filosofía crítica como punto de partida para pensar escenarios de formación del pensamiento crítico en la educación científica}

El concepto presentado anteriormente enlaza varios aportes de la filosofía (en especial, la teoría crítica), la pedagogía crítica, la psicología (HALPERN, 2006) y, nuestro campo de estudio, la didáctica de las ciencias.

En el primer caso, los planteamientos de filósofos de la teoría crítica o escuela de Frankfurt como Horkheimer (1973), Horkheimer y Adorno (1994), Marcuse (1984), Habermas (1987) aportan elementos importantes sobre las implicaciones de una ciencia lineal que no atiende a las verdaderas necesidades humanas, lo que impide ver la realidad como es. Por ejemplo, Horkheimer (2000) critica cómo los hombres se dejan guiar por pensamientos unidireccionales que no les permiten comprender múltiples manifestaciones culturales y sociales y solo favorecen una enajenación de la realidad. Este aspecto implica una acción racional que no se reduzca a lo mero instrumental, sino que cuestione los fines y se haga mayor énfasis en los medios. En el caso del avance científico, es necesario reconocer que la ciencia solo puede ser entendida en relación a la sociedad para la que funciona, por ende, se requiere una continua autorreflexión sobre las implicaciones de los desarrollos científicos y tecnológicos.

Marcuse (1984) señala la necesidad de sospechar de las afirmaciones de quienes representan los intereses dominantes. Por tanto, es necesario enseñar a desconfiar de los intereses ideológicos de quienes han accedido a este tipo de discursos y promover la duda y el cuestionamiento de la información. Insiste en reflexiones acerca de la opresión que puede generar la sociedad industrial y hace una fuerte crítica al señalar que los medios de comunicación enajenan al ser humano de la realidad. Manifiesta la necesidad no solo de reconocer el conocimiento científico producido por las ciencias naturales sino comprender y aceptar otras formas de conocimiento.

Afirma que los conocimientos tecnificados "crean formas de vida y de poder que parecen reconciliar las fuerzas que se oponen al sistema y derrotar o refutar toda protesta" (MARCUSE, 1984, p. 22) y una sociedad tecnificada "destruye el libre desarrollo de las necesidades y facultades humanas" (MARCUSE, 1984, p. 20) imponiendo a sus ciudadanos fuerzas superfluas que los alejan cada vez más de la reflexión; por tanto, en esta sociedad tecnificada se producen hombres unidireccionales, automáticos, mecánicos, irreflexivos e irracionales. 
Insiste en que el hombre no debe estudiarse como un objeto más de la naturaleza, razón por la cual él hace énfasis en la necesidad de humanizar más la ciencia. Es aquí donde se requieren espacios que nos permitan pensar sobre los impactos de la ciencia, esto significa ir más allá de lo que aparentemente es evidente y analizar la ciencia en el aula como una actividad cultural. Al respecto (ABD-EL-KHALICK, 2003; RATCLIFFE; GRACE, 2003; REIS; GALVÃO, 2004; SADLER; ZEIDLER, 2005) tienen particular interés por la formación ciudadana que considere importantes dimensiones éticas y sociales como un objetivo central de la enseñanza de la ciencias, donde los estudiantes puedan influir en la sociedad en que viven.

Sadler (2004) manifiesta que la discusión de CSC en el aula puede ser un paso importante para la formación de ciudadanos que entiendan la naturaleza de la ciencia, sus aplicaciones, sus implicaciones sociales y las políticas del conocimiento científico. Además, es necesario que la escuela forme en los conocimientos científicos mínimos para que los ciudadanos tengan condiciones de juzgar el contexto científico en el que están insertados y tomar decisiones fundamentadas.

Otro autor que resulta interesante para fundamentar nuestro concepto de pensamiento crítico es Habermas (1972), quien nos permite analizar las implicaciones del uso de las CSC en el aula, es decir en entender como considerar los aspectos éticos, sociales, ambientales y políticos que implican el abordaje de CSC. Al respecto, Habermas (1972) hace aclaraciones indicando que el papel del investigador no debe guiarse solo por el sentido común, o solo direccionarse hacia un conocimiento netamente objetivo. Propone entender que cada campo del conocimiento, incluido el científico-técnico, presuntamente objetivo y neutral y que cada conjunto de disciplinas específicas tiene ámbitos propios de investigación que conducen a diferentes manifestaciones de la racionalidad.

Esta perspectiva permite discutir la inclusión de otros campos de estudio en la educación científica, y que su incorporación no se reduzca a una invasión de las ciencias empírico analíticas en los ámbitos de las demás ciencias. Por ello, una importante reflexión que se debe efectuar en los programas de formación docente de educación científica seria como posibilitar escenarios educativos que muestren la multidimensionalidad de las ciencias y, a la vez, posibiliten marcos de referencia para la comprensión de los objetos de estudio de diversas ciencias, pues como señala Habermas (1987) no todas las ciencias se pueden comprenderse desde un ámbito empírico analítico.

Los aportes de Habermas (1987) desde la teoría de la acción comunicativa permiten encontrar un aspecto en común, el lenguaje. Este autor afirma que incluso las teorías empírico analíticas tienen que ganar su validez por medio del lenguaje cotidiano, pues partir de ese lenguaje llegan a acuerdos las comunidades científicas. En este punto, Habermas propone que es el lenguaje el que hay que analizar para continuar la crítica sistemática al positivismo. Lo anterior implicaría dar paso al estudio de los escenarios dialógicos en las aulas. 
Habermas (1987) indica que la racionalidad tiene que ver con el uso del conocimiento que hacen los sujetos capaces del lenguaje y acción. Estos tienen tres características principales:

- Están precedidas de un saber previo;

- A pesar de ese saber previo son susceptibles de crítica;

- Ante la crítica la única defensa posible es la argumentación.

Lo anterior, nos permiten asociar a características propias de las CSC, como manera de aproximarnos al desarrollo del pensamiento crítico. En el primer caso se requiere que las CSC utilizadas formen parte del contexto de los estudiantes donde ellos tengan la oportunidad de plantear discursos propios. Esto significa que conocen su desarrollo a través de noticias en medios de comunicación o que son CSC que existen en ambientes próximos.

Por ejemplo, en nuestro estudio (TORRES, 2014) iniciamos el programa de intervención desde una CSC muy controversial en la época y bien conocida por los estudiantes referida a la "privatización de la energía eléctrica en su departamento, Boyacá" (Colombia). La puesta en común de estos saberes previos en el aula de clase permite valorar las implicaciones de la construcción de centrales térmicas e hidroeléctricas junto con los argumentos de personajes involucrados en la parte política de esta CSC. Esto da lugar a la manifestación de puntos de vista diferentes entre los estudiantes, unos a favor o en contra de la privatización que solo pueden ser defendidos desde la argumentación, donde los estudiantes demuestran capacidad de crear enunciados y justificarlos adecuadamente.

Esta perspectiva lleva a reconocer los espacios dialógicos en el aula para vincular diversos conocimientos que traen los estudiantes y acercarlos en nuestro caso a la enseñanza de los conceptos científicos. En este sentido, Habermas (1972) indica que diversas formas de argumentación corresponden a diversas formas de validez, que a su vez se refieren a diversas formas de manifestaciones objetivas en la vida cotidiana.

Hasta ahora hemos visto como los aportes de Habermas (1972) nos permiten reconocer la importancia de la argumentación como punto legítimo de diversas formas de racionalidad. Sin embargo, otro punto que permite complementarlo con nuestro abordaje sobre desarrollo del pensamiento crítico es la "emancipación", como sinónimo de libertad y subjetividad. Por tanto, la emancipación refiere a la liberación de la sumisión a poderes dominantes o ajenos, represiones que se apropian de la autonomía.

Desde los aportes de Ranciére (2003), el pensamiento crítico adquiere connotaciones políticas que involucran reconocer la importancia de la emancipación intelectual. Esta última debe entenderse como el acceso de cualquier individuo a experimentarse como un ser capaz de pensar, una actividad identificadora, que se distancia del saber existente y que transciende los roles y funciones preestablecidas. 
La idea de generar espacios que den lugar al pensamiento crítico de los estudiantes, es una posibilidad de interrogar al mundo natural, social y subjetivo para aprender a ver los problemas desde una dimensión multidimensional que permita entender diferentes puntos de vista. Posibilitar mentes abiertas a nuevas ideas pero sometiéndolas a un constante cuestionamiento es decir interrogar, entender e discutir ideas a partir del dialogo tiene como fin el establecimiento y el entendimiento de la vida en sociedad, a partir de posicionamientos y acciones críticos, pues solo el entendimiento no genera acciones para la resolución de los problemas sociales e ambientales. Hay que participar, negociar y llegar a un común acuerdo sobre nuestras acciones individuales y colectivas y sus consecuencias para el medio ambiente y para la supervivencia humana.

Hemos visto que estas perspectivas cuestionan la concepción cientificista de las ciencias y se promueve la puesta en cuestión y el examen de los fenômenos cotidianos. Del mismo modo, se suscitan valores, posibilidades y se descubren alternativas a su alcance para participar en la toma de decisiones. Además de esto, el pensamiento crítico no se conforma con los discursos establecidos, contribuye a descubrir las contradicciones y se permite proponer alternativas posibles. El pensamiento crítico promueve la profundidad de las cosas, de manera que exhibe las acciones del ser humano. En consecuencia, propende a escapar de las limitaciones construidas para configurar un pensamiento liberador para la vida individual y social.

Desde esta perspectiva, la existencia de una actitud acrítica no permite tener los elementos para tomar decisiones fundamentadas que llevan actuar en consecuencia con desigualdades e injusticias sociales. Por ello, el pensamiento crítico implica la emisión de juicios fundamentados, la crítica a la autoridad y a los discursos dominantes. La ciencia nos ayuda a comprender mejor el mundo pero se hacen necesarios escenarios de reflexión ética frente a las implicaciones de su uso y abuso que conlleven la toma de decisiones.

Las anteriores perspectivas dejan claro que no hay conocimientos absolutos. Solo conjeturas que pueden ser mejoradas y una disposición para refutar creencias, puntos de vista personales, discursos dominantes. Esto exige poner en tela de juicios las propias creencias y hace necesaria la combinación de rasgos racionales, escépticos, con una actitud de emancipación como requerimientos del pensamiento crítico. De esta forma, el futuro ciudadano puede decidir por sí mismo, ser creativo, emitir opiniones propias, desarrollar un crecimiento intelectual continuo, pensar y actuar en consecuencia. Esto último está en consonancia con la perspectiva de emancipación que puede denotarse con las contribuciones de la pedagogía crítica y que se analizará a continuación.

\section{Pedagogía crítica y pensamiento crítico}

Los planteamientos, entre otros de Freire (1970), Apple (1986) Carr y Kemmis (1986), Mclaren (1994), Giroux (2003) y Kincheloe (2008), rechazan la idea de un su- 
jeto unificado y racional producto de una cultura dominante, caracterizada por reduccionismos conceptuales y dogmáticos, y proponen procesos educativos para que las personas, en un ambiente liberador y de emancipación, piensen y valoren las realidades sociales. Esto implica valorar el lenguaje de lo ético para comprender cómo las relaciones sociales desarrollan juicios que exigen y conforman diferentes modos de respuesta al otro.

Desde los planteamientos de Giroux (2003), el conocimiento se convierte en contenidos educativos necesarios para que el alumno pueda negociar, de manera crítica, los límites culturales que le ofrece la sociedad y, en consecuencia, proceder a transformar el mundo en que vive.

Kincheloe (2008, p. 6-10) señala que la pedagogía critica "está basada en una visión social y educativa de justicia e igualdad", "está construida en la creencia de que la educación es inherentemente política", "está dedicada al alivio del sufrimiento humano". También hace énfasis en la importancia de evitar la desinformación, el adoctrinamiento y desprender a los estudiantes de la forma de conocimiento que traen de sus contextos.

Estas perspectivas hacen énfasis en que los docentes y estudiantes expongan razones para defender puntos de vistas; razones de validez que no se consideren absolutas, sino criticables para examinarlas a la luz de otras razones, alejadas de manipulaciones que solo favorece intereses particulares. (MONTOYA, 1989)

El planteamiento anterior permite plantear estrategias importantes que hagan tangible el aporte de la didáctica de las ciencias desde escenarios de Aula, esto nos ha conducido a valorar las características propias de las CSC, no solo como alternativa para el desarrollo de procesos de argumentación científica sino como una posibilidad para desarrollar el pensamiento crítico. Lo anterior sugiere formas críticas de reconocimiento que permitan mantener posturas frente a las desigualdades sociales, reconocer las injusticias y generar acciones. Por ende, la pedagogía critica procura la emancipación del ser humano. Al respecto Paulo Freire (1970), uno de los principales exponentes de esta pedagogía, defiende que la educación tiene que desempeñar un papel importante para llegar a la conciencia de los estudiantes y a sus condiciones de vida, de manera que se les permitan diversas posibilidades de participación. La educación, desde una perspectiva freireana, tiene como objetivo dar a los educandos instrumentos para que tengan una mayor comprensión de diversas condiciones. Debe ser fundada para las condiciones humanas y considerar un mundo en el cual los hombres y mujeres están involucrados. También sugiere una educación problematizadora, de carácter reflexivo acerca de la realidad, por lo que es necesaria una reflexión en la que el diálogo permite una educación para la práctica de la libertad.

Estas características ponen de manifiesto la humanización de la educación como actividad esencial. De esta forma, el sujeto se comprende en relación con el mundo y se manifiesta desde una conciencia social que lo lleve actuar con responsabilidad. Se insiste en una educación para una participación responsable sobre la vida en sociedad 
alejada de la neutralidad, con problemas abiertos que da lugar a relaciones de dialogo basados en la autonomía y la libertad.

Quintanilla (2005) señala que uno de los aspectos especialmente conflictivos del conocimiento científico enseñado se refiere a la consideración de propuestas curriculares que favorezcan el desarrollo de personas que, desde un modelo de apropiación crítica de la didáctica de las ciencias, valoricen el conocimiento científico en una dimensión globalizadora. Es decir, estudiantes que se motiven por una permanente búsqueda de la verdad y la autenticidad. También se pretende que sean capaces de valorar su autoestima y desarrollar la autonomía y compromiso responsable frente a la tarea de aprender las ciencias, ser ciudadanos conscientes de los problemas coyunturales de su época y tolerantes con la diversidad religiosa, étnica y cultural.

Por su parte, Schön (1983) señala que la educación es un proceso que incorpora la conciencia sobre las implicaciones sociales, econômicas y prácticas del proceso de enseñanza y aprendizaje. Es preciso, así mismo, comprender que el profesor, como profesional reflexivo, no puede limitarse solo al aula de clase. Debe proponerse hacer una integración de sus prácticas pedagógicas y su práctica como ciudadano comprometido, como ser social que toma posturas frente a la opresión, la justicia social, la libertad, la igualdad y la convivencia con el ambiente.

\section{Pensamiento crítico en la educación científica}

La vinculación del conocimiento científico a aspectos cotidianos para lograr una apropiación, podría decirse es una de las inquietudes más importantes e interesantes en el quehacer docente. Para ello, se han considerado procesos desde una perspectiva sistémica y compleja que tiene en cuenta una visión crítica de los procesos sociales y educativos en la formación de profesores. Como ejemplos, se pueden citar la perspectiva socio-constructivista del conocimiento, la concepción investigativa del trabajo docente, la definición del saber profesional deseable, el conocimiento práctico complejo en torno a problemas interconectados en ámbitos docentes. (GARCÍA; PORLÁN, 2000; SOLBES et al., 2012) También, el enfoque Ciencia, Tecnología y Sociedad (CTS), la historia de las ciencias y la investigación dirigida.

Dentro de este campo, se han planteado varios estudios acerca del pensamiento crítico. Desde los estudios de Newton, Driver y Osborne (1999), Solbes y Vilches (2004), Kolstø (2006), Vieira y Nascimento (2007) y Jiménez-Aleixandre (2010), se toman elementos que permiten cuestionar la necesidad de implicación en discusiones públicas acerca de asuntos importantes relacionados con la ciencia y la tecnología. Estos autores coinciden en que es posible mostrar el papel social de la ciencia, tanto en sus aspectos internos como externos, cuando se trabaja una cuestión problemática. De esta forma, se favorecerá el desarrollo del pensamiento crítico. 
Los anteriores estudios, hacen énfasis en la necesidad de promover ambientes de debate en el aula, para que los estudiantes se involucren en discusiones públicas y globales, en especial los relacionados con el estudio de la ciencia y la tecnología.

La generación de debates para promover la argumentación en el aula ha cobrado importancia en la didáctica de las ciencias y ha sido señalada como una contribución al desarrollo del pensamiento crítico. Los trabajos de Deanna Kuhn (1991) definen la argumentación como una práctica cognitiva del proceso de pensamiento que requiere operaciones cognitivas como enunciar una conclusión, llegar a pruebas que apoyen o juzguen un enunciado etc. En estudios de Jiménez-Aleixandre (2010), la argumentación es definida como la capacidad de evaluar los enunciados en base a las pruebas. Reconoce que las conclusiones y los enunciados científicos deben estar justificados, sustentados en pruebas.

Los estudios de Carlsen (1991) y Lemke (1997) sugieren que la argumentación, como actividad social, permite la interacción entre los estudiantes y contribuye a la co-construcción de argumentos. En la medida en que esos argumentos valoran y cuestionan las ideas de los demás, se constituyen en una posibilidad para desarrollar puntos de vista de los estudiantes, requerimiento importante en el desarrollo del pensamiento crítico. Esta perspectiva permite también destacar lo señalado por Habermas (1987, p. 367), quien indica que, "en las acciones comunicativas, los participantes no se coordinan por el éxito, sino por actos de entendimiento, que tienen como base una definición compartida de la situación”. Esto implica la comprensión hacia el otro, discutir sus puntos de vista, puesto que somos sujetos capaces del lenguaje y de la acción. Esto lleva a comprender que nuestros discursos son productos de influencia contextuales que van más allá de datos.

Esta perspectiva, de acuerdo con Hmelo-Silver y Barrows (2008), puede apoyar la construcción del conocimiento y permite que los participantes negocien y ajusten sus propias ideas y las de otros. Así mismo, al confrontar contra-argumentos, los estudiantes mejoran la estructura y la integridad de sus propios argumentos. (KUHN, 2010, 1991; LIMÓN; CARRETERO, 1997)

Los estudios señalados permiten reconocer la necesidad de propiciar discusiones abiertas y libres para que los alumnos tengan escenarios de participación democrática. Esos escenarios les permitirán ver la ciencia como una construcción humana, susceptible al cambio e histórica, que deja de lado discursos memorísticos, repetitivos, cerrados y contribuye a la formación de ciudadanos científicamente alfabetizados. Esta perspectiva ha permitido que los estudios en el campo de la didáctica de las ciencias se enfoquen en promover una articulación entre el contexto y lo social.

Finalmente, siguiendo a Ratcliffe y Grace (2003), Aikenhead (2005) y Cachapuz et al. (2005) puede considerarse que para una contribución importante al desarrollo del pensamiento crítico en la enseñanza de las ciencias, es preciso considerar elementos controversiales que permitan desarrollar habilidades de argumentación. También debe 
tenerse en cuenta la toma de decisiones, trabajo cooperativo, además de utilizar una metodología para desarrollar el pensamiento crítico y la independencia intelectual.

Los planteamientos presentados anteriormente permiten comprender diferentes manifestaciones de la racionalidad científica y nos amplían el concepto de argumentación no solo por hecho de efectuar afirmaciones y defenderlas sino por justificar acciones frente a una crítica a la luz de expectativas legítimas de comportamiento, autenticada en vivencias. Esto significa promover la formación de personas que expresan opiniones bien fundadas y actúan con eficacia y coherencia.

\section{Obstáculos en la promoción del pensamiento crítico en la educación científica}

Nuestro estudio (SOLBES; TORRES, 2012) nos permitió encontrar los siguientes obstáculos: inclusión del pensamiento crítico en la educación científica y el estudio de la multidimensionalidad en el uso de las CSC.

\section{La persistencia de metodología trasmisivas en la educación científica}

La palabra pensamiento crítico resulta ser usual en el discurso de docentes en ejercicio y docentes en formación. Sin embargo, no se hace tangible el uso de herramientas didácticas en su desarrollo, así se evidencia que los docentes reconocen la importancia del pensamiento crítico en los procesos académicos y que difícilmente el mismo escenario educativo fomenta este tipo de pensamiento. (SOLBES; TORRES, 2013) Es decir, hay un reconocimiento que la enseñanza de las ciencias se centra en la transmisión de contenidos y difícilmente se desarrollan estrategias o actividades que promuevan el pensamiento crítico.

Se enseña una ciencia lineal, olvidando la parte histórica y social y se tiende a trasmitir conceptos como verdaderos, se inculcan modelos que se presentan como la verdad, sin discutir su validez y con métodos estandarizados. Se presentan primero los conceptos teóricos y luego los ejemplos. Esto prepara a los alumnos a recibir los conceptos como dogmas. En resumen, se realizan una transmisión, en las clases de ciencias, de conocimientos acabados, sin cuestionamientos previos, que no permitan entender el progreso de la ciencia y la influencia de ésta en la sociedad.

En el caso de profesores en formación se observa que el desarrollo de este tipo de pensamiento en las asignaturas disciplinares no es notable para los estudiantes. Lo anterior pone de manifiesto que, desde las disciplinas, hay una fragmentación del saber dedicado a su especialidad y se desconocen los saberes de otras disciplinas. Esto puede contribuir a integrar los campos del conocimiento, facilitando una educación interdisciplinar.

Por ello, en estudios del proyecto "Enseñando a pensar" de Zohar (2006), se pone de manifiesta la importancia de formular objetivos no sólo desde los contenidos. También 
es necesario proponer cuestiones formadas por objetivos de pensamiento, lo cual hace necesarios vincular tal dimensión en la estructuración de planes de clase.

\section{La dificultad del estudio de la multidimensionalidad de las ciencias}

En nuestro estudio sobre el uso de CSC para desarrollar competencias de pensamiento crítico, encontramos que una de las competencias que sigue ubicándose en el último lugar (SOLBES; TORRES, 2012), es la competencia relacionada con la multidimensionalidad de las ciencias. Dicha competencia se enunció así: Estudiar el problema socio-científico de manera integral, en su complejidad, de forma que se involucren dimensiones científicas, técnicas, éticas, culturales, sociales, econômicas y ambientales. Esta competencia sigue ubicándose entre las de mayor complejidad. Esto puede ser debido a que las relaciones entre conceptos científicos y cotidianos exige un mayor nivel de comprensión y claridad en el lenguaje utilizado para el establecimiento de analogías pertinentes.

Esto permite inferir que una de las principales dificultades para los estudiantes es precisamente hacer esa relación entre distintos aspectos de lo que nosotros denominamos multidimensionalidad, la cual puede ser facilitada en la medida que se utilicen situaciones contextuales.

Esta apreciación permite valorar las CSC desde diferentes perspectivas. Esto implica estudiarlos desde su complejidad, considerando que una mirada unidimensional no evidencia la realidad. Por ello, mostrar que las cosas tienen incidencia en distintas dimensiones contribuirá a una formación integral, a enriquecer las perspectivas y los horizontes de los estudiantes.

\section{Conclusiones y perspectivas}

Desde los planteamientos antes realizados por la filosofía y la pedagogía crítica, junto con la didáctica de las ciencias se pueden plantear algunas características del pensamiento crítico, que es un conjunto de competencias de las personas para estructurar una manera de pensar propia que les permite distinguir la validez de los argumentos, tomar posiciones frente a las situaciones sociales y tener un papel activo en las decisiones culturales y científicas asumidas desde una responsabilidad social. (SOLBES; TORRES, 2012) De igual forma, desde la filosofía crítica, se busca que los sujetos se liberen de presiones externas e internas a partir de la crítica y la autorreflexión, para así decir que existe un carácter emancipatorio también reconocido en la pedagogía critica.

En muchas ocasiones, se expresan juicios sin tener conocimiento en profundidad de los temas, por lo que se emiten opiniones sin razón ni justificación alguna de los hechos. La capacidad de expresar juicios es importante como contribución para asumir una actitud intelectual que parta de la duda, la pregunta y el cuestionamiento. Desde una perspectiva filosófica esa capacidad pone al descubierto relaciones de poder y propende a la emancipación y lo alternativo. El cuestionamiento constante permite elegir mejor, vis- 
lumbrar las falacias del mercado, de la política y de los medios de comunicación. Configura cierta autonomía e independencia intelectual, al emitir juicios y razones propias.

En rasgos generales, es evidente que los docentes consideran que la ausencia de pensamiento crítico hace que el aprendizaje sea simple, mecanizado y homogéneo. Estas características perjudican la evolución de la ciencia. También lo consideran como una necesidad en la sociedad actual, dado que es una forma de preparar a los estudiantes para comprobar la veracidad de información proveniente de diversas fuentes.

Como perspectivas, indicamos formar al profesorado con pensamiento crítico en la enseñanza de las ciencias mediante la inclusión de CSC, puesto solo así se consigue desarrollen en sus alumnos preparándoles no solo como futuros científicos sino como futuros ciudadanos.

\section{Referencias}

ABD-EL-KHALICK, F. Socioscientific issues in pre-college science classrooms: the primacy of learners' epistemological orientations and views of nature of science. In: ZEIDLER, D. (Ed.). The role of moral reasoning on socioscientific issues and discourse in science education. The Netherlands: Kluwer Academic Publishers, 2003. p. 41-61.

AIKENHEAD, G. Educación Ciencia-Tecnología-Sociedad (CTS): una buena idea o como quiera que se le llame. Educación Química, México, v. 16, n. 2, p. 114-124, 2005.

APPLE, M. Ideología y currículo. Madrid: Akal, 1986.

CACHAPUZ, A. et al. (Org.). A necessária renovação do ensino de ciências. São Paulo: Cortez, 2005.

CARLSEN, W. S. Questioning in classrooms: A sociolinguistic perspective. Review of Educational Research, Washington, v. 61, n. 2, p. 157-178, 1991.

CARR, W.; KEMMIS, S. Teoría crítica de la enseñanza: la investigación-acción en la formación del profesorado. Barcelona: Martínez Roca, 1986.

CENTRO EUROPEO PARA EL DESARROLLO DE LA FORMACIÓN-PROFESIONALCEDEFOP. Directrices para el desarrollo curricular: nuevos currículos de TIC para el siglo XXI: el diseño de la educación del mañana. Luxemburgo: Oficina de Publicaciones Oficiales de las Comunidades Europeas, 2001.

ENNIS, R. Critical thinking assessment. Theory into practice, Columbus, n. 32, p. 179186, 1993.

FACIONE, P. A.; FACIONE N. C.; GIANCARLO, C. The Disposition toward critical thinking: its character, measurement, and relationship to critical thinking skills. Journal of Informal Logic, [Windsor], v. 20, n. 1, p. 61-84, 2000.

FREIRE, P. Pedagogia do oprimido. Tierra Nueva: Siglo XXI Editores S.A., 1970.

GARCÍA DÍAZ, J. E.; PORLÁN, R. Ensino de ciências e prática docente: uma teoria do conhecimento professional. Caderno pedagógico, Lajeado, v. 1, n. 3, p. 7-42, 2000. 
GIROUX, H. Pedagogy of the depressed: beyond the new politics of cynicism. In: PETERS, M.; LANKSHEAR, C.; OLSSEN, M. (Ed.). Critical theory and the human condition: founders and praxis. New York: Peter Lang, 2003. p. 143-168.

HABERMAS, J. Teoría analítica de la ciencia y dialéctica. In: ADORNO, T. et al. La disputa del positivismo en la sociología Alemana. Barcelona: Grijalbo, 1972. p. 140-180.

HABERMAS, J. Teoría de la acción comunicativa. Madrid: Taurus, 1987. 2 tomo.

HALPERN, D. Halpern critical thinking assessment using everyday situations: background and scoring standards ( $2^{\circ}$ Report). Unpublished manuscript. Claremont, CA: Claremont McKenna College, 2006.

HANNEL G.; HANNEL, L. Seven steps to teach critical thinking: a practical application of critical thinking skills. Nassp Bulletin, Reston v. 82, n. 598, p. 87-93, 1998.

HMELO-SILVER, C. E.; BARROWS, H. S. Facilitating collaborative knowledge building. Cognition \& Instruction, Mahwah, v. 26, n. 1, p. 48-94, 2008.

HODSON, D. Why we should prioritize learning about science. Canadian Journal of Science, Mathematics and Technology Education, Toronto, v. 6, n. 3, p. 293-311, 2006.

HORKHEIMER, M. Crítica de la razón instrumental. Buenos Aires: Sur, 1973.

HORKHEIMER, M.; ADORNO, T. W Dialéctica de la ilustración: fragmentos filosóficos. Madrid: Trotta, 1994.

HORKHEIMER, M. Teoría tradicional y teoría crítica. Barcelona: Paidós I.C.E./U.A.B, 2000 .

JIMÉNEZ-ALEIXANDRE, M. P. 10 ideas clave: competencias en argumentación y uso de pruebas. Barcelona: Graó, 2010.

JIMENEZ-ALEIXANDRE, M. P.; PUIG, B. Argumentation, evidence evaluation and critical thinking. In: FRASSER, B. J.; TOBIN, K.; MCROBBIE, C. (Ed.). Second international handbook for science education. Dordrecht: Springer, 2010.

KOLST $\varnothing$, S. D. Patterns in students' argumentation confronted with a risk-focused Socio-scientific Issue. International Journal of Science Education, London, v. 28, n. 14, p. 1689-1716, 2006.

KINCHELOE, J. Critical pedagogy. $2^{\text {nd }}$ New York: Peter Lang, 2008.

KUHN, D. The skills of argument. Cambridge: Cambridge University Press, 1991.

KUHN, D. Teaching and learning science as argument. Science Education, [S.l.], v. 94, n. 5 , p. 810-824, 2010.

LABURU, C. E. La crítica en la enseñanza de las ciencias: constructivismo y contradicción. Enseñanza de las ciencias: revista de investigación y experiencias didácticas, Barcelona, n. 14, p. 93-101, 1996.

LEMKE, J. Aprender a hablar ciencia: lenguaje, aprendizaje y valores. Barcelona: Paidós, 1997. 
LIMÓN, M.; CARRETERO, M. Conceptual change and anomalous data: a case study in the domain of natural sciences. European Journal of Psychology of Education, Lisboa, v. 12, n. 2, p. 213-230, 1997.

MARCUSE, H. El hombre unidimensional. Barcelona: Ariel, 1984.

MARTÍNEZ, L. A abordagem de questões sociocientíficas na formação continuada de professores de ciências: contribuições e dificuldades. 2010. $351 \mathrm{f}$. Tesis (Doctorado en Educación para la Ciencia) - Faculdade de Ciências, Universidade Estadual Paulista, São Paulo, 2010.

MCLAREN, P. Pedagogía Crítica y Cultura depredadora. Buenos Aires: Aique, 1994.

MCMILLAN, J. Enhancing college students' critical thinking: a review of studies. Research in Higher Education, New York, n. 26, p. 3-29, 1987.

MONTOYA, J. Acción comunicativa y acción estratégica: en lecciones de noviembre. Colômbia: Universidad de Antioquia, 1989.

NEWTON, P.; DRIVER, R.; OSBORNE, J. The place of argumentation in the pedagogy of school science. International Journal of Science Education, London, v. 21, n. 5, p. 553 $576,1999$.

NICKERSON, R. The teaching of thinking and problem solving. In: STERNBERG, R. J. (Ed.). Thinking and problem solving. San Diego, CA: Academic Press, 1994, p. 409-449.

PAUL, R.; ELDER, L. The miniature guide to critical thinking concepts and tools. Foundation for critical thinking: Tomales, CA, 2006.

PEDRINACCI, A. et al. El desarrollo de la competencia científica. Barcelona: Graó, 2012.

PERRY, W. Los formularios del W. G. del desarrollo intelectual en los años de la universidad, un plan. New York: Holt, Rinehart \& Winston, 1970.

PRESSEISEN, B. Critical thinking and thinking skills: state of the art definitions and practice in public schools. Philadelphia: Research for Better, 1986.

RANCIERE, J. El maestro ignorante: cinco lecciones sobre la emancipación intelectual. Barcelona: Laertes, 2003.

RATCLIFFE, M.; GRACE, M. Science education for citizenship: teaching socio-scientific issues. Philadelphia: Open University Press, 2003.

REIS, P.; GALVÃO, C. The impact of socio-scientific controversies in Portuguese natural science teachers' conceptions and practices. Research in Science Education, Amsterdam, v. 34, n. 2, p. 153-171, 2004.

QUINTANILLA, M. Historia de la ciencia y formación docente: una necesidad irreducible. Tecne, Episteme y Didaxis, Bogotá, p. 34-43, 2005. Número Extra.

SADLER, T. D. Informal reasoning regarding socioscientific issues: a critical review of research. Journal of Research in Science Teaching, New York, v. 41, n. 5, p. 513-536, 2004. 
SADLER, T. D.; ZEIDLER, D. L. Patterns of informal reasoning in the context of socioscientific decision making. Journal of Research in Science Teaching, New York, v. 42 , n. 1, p. 112-138, 2005.

SADLER, T. D.; DONNELLY, L. A. Socioscientific argumentation: the effects of content knowledge and morality. International Journal of Science Education, London, n. 28, n. 12, p. 1463-1488, 2006.

SCHÖN, D. A. The reflective practitioner: how professionals think in action. New York: Basic Books, 1983.

SOLBES, J. et al. What factors have an influence on a quality teaching practice in Sciences? Procedia-Social and Behavioral Sciences, Red Hook, NY, n. 46, p. 4513-4517, 2012.

SOLBES, J.; TORRES, N. Y. Análisis de las competencias de pensamiento crítico desde el aborde de las cuestiones socio-científicas: un estudio en el ámbito universitario Didáctica de las Ciencias Experimentales y Sociales, Valencia, n. 26, p. 247-269, 2012.

SOLBES, J.; TORRES, N. ¿Cuáles son las concepciones de los docentes de ciencias en formación y en ejercicio sobre el pensamiento crítico? Tecné, Episteme y Didaxis, Bogotá, n. 33, p. 61-85, 2013.

SOLBES, J.; VILCHES, A. STS interactions and the teaching of physics and chemistry. Science Education, New York, v. 4, n. 81, p. 377-386, 1997.

SOLBES, J.; VILCHES, A. Papel de las relaciones entre ciencia, tecnología, sociedad y ambiente en la formación ciudadana. Enseñanza de las Ciencias, Barcelona, v. 3, n. 22 , p. 337-348, 2004.

TOPCU, M. S. Development of attitudes towards socioscientific issues scale for undergraduate students. Evaluation and Research in Education, [S.1.], v. 1, n. 23, p. 5167, 2010.

TORRES, N.; MARTÍNEZ, L. Desarrollo del pensamiento crítico en estudiantes de Fisioterapia, a partir del estudio de las implicaciones socio-científicas de los xenobioticos. Tecne, Episteme y Didaxis, Bogotá, n. 29, p. 65-84, 2011.

TORRES, N. Pensamiento crítico y cuestiones socio-científicas: un estudio en escenarios de formación docente. 2014. 374 p. Tesis (Doctorado) - Universidad de Valencia, España, 2014. Disponible en: <http://roderic.uv.es/handle/10550/36116>. Acceso en: 11 maio 2016.

VIEIRA, R. D.; NASCIMENTO, S. A argumentação no discurso de um professor e seus estudantes sobre um tópico de mecânica newtoniana. Caderno Brasileiro de Ensino de Física, Florianópolis, v. 2, n. 24, p. 174-193, 2007.

VIEIRA, M. R.; TENREIRO-VIEIRA, C.; MARTINS, E. Pensamiento crítico y literária científica. Alambique, Barcelona, n. 65, p. 96-104, 2010. 
YAGER, R. Science and critical thinking. In: CLARKE, J. H.; BIDDLE, A. W. (Ed.).

Teaching critical thinking: reports from across the curriculum. Englewood Cliffs, NJ:

Prentice Hall, 1993.

ZOHAR, A. El pensamiento de orden superior en las clases de ciencias: objetivos, medios y resultados de investigación. Enseñanza de las ciencias, Barcelona, v. 2, n. 24, p. $157-172,2006$.

ZOLLER, U. Lecture and Learning: are they compatible? Maybe for LOCS; unlikely for HOCS. Journal of Chemical Education, Washington, v. 70, n. 3, p. 195-197, 1993. 


\title{
QUESTÕES SOCIOCIENTIIFICAS E DIMENSÕES CONCEITUAIS, PROCEDIMENTAIS E ATITUDINAIS DOS CONTEÚDOS NO ENSINO DE CIÊNCIAS
}

\author{
Dália Melissa Conrado \\ Nei Nunes-Neto
}

\section{Introdução}

Diante de tantos problemas socioambientais que têm sido vivenciados no mundo contemporâneo (associados a doenças - como dengue e zika -, mudanças climáticas, perda de biodiversidade, altos níveis de insegurança social, desigualdades socioeconômicas e de acesso a direitos sociais etc.), cabe considerar quais têm sido (isto é, uma análise descritiva) e quais devem ser (isto é, uma proposta normativa) os papéis ou as contribuições da educação, em geral, e da educação científica, em particular, para os contextos sociais mais amplos nos quais elas se inserem.

Uma vez que os sistemas educativos (com seus diversos agentes em interação, como estudantes, professores, diretores de escola, entre outros) sempre estabelecem relações com os problemas socioambientais, seja contribuindo para seu agravamento ou para sua mitigação, não é razoável o discurso de uma postura "supostamente" neutra (ou indiferente) com relação a estes problemas. (TAN, 2009) Dado que os seres humanos individualmente ou em agrupamentos coletivos, em maior ou menor grau, com maior 
ou menor explicitude - sempre se inclinam a favor ou contra certa posição ética e política, o que se manifesta pela emissão de juízos valorativos - as instituições e as práticas humanas carregarão sempre esta marca. Com a educação não é diferente. Disso segue como já nos advertia Paulo Freire (1996) - que não é possível neutralidade na educação. A própria expectativa de neutralidade da educação com relação aos problemas socioambientais consiste numa contribuição para manutenção do status quo, pois uma educação que se pretenda neutra, por omissão, contribui para a manutenção dos problemas tal como eles estão. Por exemplo, uma educação que pretenda manter-se neutra em relação às questões de gênero, por não abordar o sexismo explicitamente nos processos de ensino e aprendizagem (exemplo, em discussões sobre consideração moral, alterização, violência de gênero, identidade sexual e determinismo genético) e nas políticas educacionais (por exemplo, com a inclusão desse tema no currículo escolar), é uma educação que exclui ou negligencia o tema do universo escolar/acadêmico. Uma vez que ainda não há equidade na convivência social entre pessoas de diferentes gêneros, em diferentes contextos, tal omissão contribui para a perpetuação de práticas sociais que aumentam a gravidade do problema em foco, como maior frequência de eventos de preconceito ou segregação de gênero, manifestados concretamente nos atos violentos contra mulheres, por exemplo.

Em particular, cabe notar que a assunção desta suposta neutralidade na educação é comum na perspectiva pedagógica tradicional. Aqui, seguindo Aranha (2006), entendemos educação "tradicional" como aquela que (sendo predominante desde a popularização das escolas, na Idade Moderna, nos séculos XVI e XVII, no Ocidente, associada a ordens religiosas) mantém um grupo de conhecidas estratégias e métodos de ensino consolidados e que ainda persistem atualmente em muitas salas de aula. Algumas características gerais da educação tradicional, principalmente quanto à sua organização social, são: a disposição enfileirada das carteiras dos estudantes; o uso de um sinal sonoro para indicar mudança de disciplina (com analogia ao sinal de fábrica que indica mudança de turno); a autoridade para a transmissão ativa do conhecimento centrada no professor; a obediência e a passividade como características desejadas no estudante; a homogeneização dos êxitos, expressos no alcance da memorização de conceitos etc. Por sua vez, em particular, a educação científica sob uma perspectiva da abordagem tradicional (também considerada aqui como educação científica tradicional-tecnicista, pois, no ensino de ciências, é predominante o ensino de técnicas e procedimentos) pode ser descrita a partir das seguintes características: ênfase na transmissão de conhecimentos científicos consolidados culturalmente - isto é, educação bancária, conforme Freire (1996) -; descontextualização social e ambiental - isto é, que não considera, ao menos não explicitamente, a ciência como uma atividade humana relacionada a um contexto sociocultural e ambiental mais complexo e abrangente, no qual há influências mútuas entre ciência, tecnologia, sociedade e ambiente -; conceitualismo - isto é, predomínio de exposição, pelo professor, e memorização, pelos estudantes, de fatos, termos e 
definições científicos, os quais são assumidos como o verdadeiro objeto da educação, em detrimento de aprendizagem de valores, normas e atitudes -; e tecnicismo - isto é, predomínio de apresentação e reprodução de procedimentos técnicos e experimentos científicos, em detrimento de valores, normas e atitudes presentes na ciência e na tecnologia. Em suma, tal educação assume como seu objetivo a transmissão eficiente (pelo professor) e a suposta aprendizagem (pelo estudante) de informações acumuladas ao longo da história e, por isso mesmo, não deixa espaço para um incentivo à crítica, à criatividade ou à reflexão sobre valores, ideologias e contextos relacionados à ciência $\mathrm{e}$ à tecnologia. (ARANHA, 2006; BARRETT; PEDRETTI, 2006; CONRADO; EL-HANI, 2010; FOUREZ, 2008, 1995; HODSON, 2004; KNIGHT; WOOD, 2005; MARTÍNEZ PÉREZ; CARVALHO, 2012; MATTHEWS, 1994)

A crítica que fazemos à educação científica tradicional-tecnicista precisa ser colocada de modo qualificado. Isto significa reconhecer que as estratégias de ensino da abordagem tradicional-tecnicista não são inadequadas, em absoluto, para a aprendizagem de fatos, conceitos e técnicas. Contudo, o predomínio dessas estratégias e dos modelos de ensino baseados na abordagem tradicional-tecnicista no meio escolar/acadêmico tem dificultado o cumprimento de muitos dos objetivos educacionais estabelecidos para a educação científica, pois apenas reproduz modelos e ideologias dominantes do sistema social vigente (FOUREZ, 2008; LUCKESI, 2011), reduzindo a contribuição da escola/ academia para a criatividade, a criticidade, o diálogo, a tomada de decisão informada e possíveis transformações positivas das sociedades, em relação a seus problemas, tais como os citados acima. Isso significa que, para formar cidadãos capazes de mobilizar, nas práticas cotidianas, determinados conhecimentos, habilidades e valores voltados à superação de problemas socioambientais em sociedades democráticas, a educação tradicional-tecnicista, apesar de conter elementos que oferecem contribuições positivas, não é suficiente. (BORTOLETTO; CARVALHO, 2012; HODSON, 2004)

Contudo, não é suficiente, também, fomentar uma educação para a democracia, quando não se esclarecem os valores presentes nos diversos grupos sociais e que valores devem ser fomentados em detrimento de outros. Este não esclarecimento pode levar, por exemplo, à aceitação acrítica de raciocínios contraditórios, pois inadvertidamente podem-se assumir bases éticas (em termos dos fundamentos teóricos sobre ações e valores) incompatíveis com certos ideais sociais. Trata-se de assumir, por escassez de uma reflexão crítica sobre valores, uma incompatibilidade entre, de um lado, os fundamentos e os meios (isto é, as bases éticas, nos valores e ações) e, de outro, os fins (isto é, os ideais sociais a serem alcançados). Por exemplo, uma democracia que - com base em certos fundamentos ideológicos - privilegie ações como o individualismo, a competição, a alterização, a manipulação, o consumismo, fundamentadas em uma tendência ética egoísta e concretizadas numa maior valorização do bem privado sobre o bem público, é incompatível com os fins de justiça social e sustentabilidade ambiental, ideais, via de regra, associados a maior altruísmo. (SINGER, 2011) Tal incoerência entre fun- 
damentos, meios e fins pode, até mesmo, nos fazer desconfiar da própria efetividade da democracia, nestes casos, que pode não passar de uma democracia meramente formal, longe, ainda, da democracia real (SAVIANI, 1987), esta última um regime em que os representantes e os representados, de fato, em suas ações, sejam orientados pela vontade e pelos interesses da maioria, ao invés de serem orientados por interesses sinistros.

O altruísmo tem relação com um conjunto de valores que precisa ser mais fomentado, seja nas relações sociais em geral, seja nas instituições de ensino, em particular. Neste sentido, valores associados ao altruísmo, como respeito, solidariedade, comprometimento com a política local, justiça e não-violência, estão vinculados à aprendizagem e ao exercício da cidadania. (LODI; ARAÚJO, 2007) Para isso, Sadler (2004a), Zeidler e colaboradores (2005), Lodi e Araújo (2007), Guimarães; Carvalho e Oliveira (2010); Conrado; El-Hani; Nunes-Neto (2013); Silva e Santos (2014) e outros enfatizam a importância do desenvolvimento moral do estudante. Além disso, faz-se necessária também, em articulação com uma educação moral, uma educação política efetiva, já que, sem esse estímulo na educação, os cidadãos podem se tornar politicamente apáticos e não participativos. (PINZANI, 2013)

Tentativas de superação dos problemas da educação científica tradicional-tecnicista têm acontecido em diversas frentes de atuação, por diferentes atores sociais. Por exemplo, alguns têm recomendado investir na qualidade da formação de professores que atuarão ou atuam na educação científica (MARTíNEZ PÉREZ, 2012); outros, na elaboração colaborativa de materiais instrucionais, sequências didáticas e recursos pedagógicos (MARTÍNEZ PÉREZ; VILLAMIZAR FÚQUENE, 2014; SÁ; QUEIROZ, 2007; SARMENTO et al., 2013; VELLOSO, 2009); além das ações para a promoção de mudanças em nível jurídico ou político. (BRASIL 1997, 1998) Certamente, tais recomendações não são mutuamente excludentes, sendo razoável imaginar que uma solução mais profunda e duradoura para aumentar a qualidade dos processos de ensino e aprendizagem, assim como da formação de professores e estudantes críticos e participativos, dependa de uma articulação equilibrada e consciente de diversas destas frentes de atuação, em esforços coletivos, de longo prazo.

Neste âmbito, no presente capítulo, apesar das referências às diferentes frentes de atuação, colocaremos nossa ênfase sobre as bases teóricas de uma abordagem de educação científica contextualizada por problemas socioambientais, objetivando uma formação mais crítica e integral dos estudantes. Assim, o objetivo deste capítulo é apresentar um modelo para a educação científica alternativo ao modelo tradicional-tecnicista e fundamentado na educação em Ciência, Tecnologia, Sociedade e Ambiente (CTSA), voltado para o ensino sobre Questões Sociocientíficas (QSC), considerando os conteúdos em três dimensões (conceituais, procedimentais e atitudinais). Um esboço do modelo, que aqui apresentamos, serviu como base para as propostas de ensino que são apresentadas na parte dois deste livro. 
Para alcançar o objetivo, discutiremos e articularemos uma série de temas distintos, estruturando o argumento do capítulo do seguinte modo: na seção "Tendências da educação CTSA”, exporemos as características da educação sobre as relações entre CTSA e como ela, pelo menos em potência, supera limitações importantes da educação científica tradicional-tecnicista. Na nossa proposta, certas vertentes da educação CTSA constituem um contexto pedagógico geral dentro do qual as propostas de ensino e aprendizagem terão lugar. Na seção seguinte, abordaremos as questões sociocientíficas, cujo tratamento em propostas de ensino permite concretizar ideais ou objetivos de formação de cidadãos responsáveis, já vislumbrados ou situados pelas vertentes que adotamos da educação CTSA. Na seção "Aprendizagem de ciências considerando três dimensões dos conteúdos”, apresentamos o esboço para uma abordagem dos conteúdos científicos, que, possivelmente, estende-se para conteúdos da educação como um todo. Esta abordagem concebe os conteúdos (isto é, os objetos dos processos de ensino e aprendizagem) de um modo multidimensional. Em particular, concebemos os conteúdos com três dimensões: conceitual, procedimental e atitudinal, e seus respectivos subtipos, seguindo, mas também elaborando sobre, a tipologia de Zabala (1998) e Coll e colaboradores (1992). A partir do exposto, construiremos uma síntese da nossa abordagem, na qual as propostas de ensino sobre QSC são compostas de três elementos principais, articulados: histórias ou casos, questões norteadoras e objetivos de aprendizagem, nas suas diferentes dimensões. Ainda nessa seção, discutiremos um modo de avaliar essas diferentes dimensões dos conteúdos, considerando os níveis de letramento científico de Hodson (2004), a relevância da dimensão ética na educação científica e o potencial deste movimento para o fomento de ações sociopolíticas e ativismo, de acordo com nossa abordagem. Por fim, na última seção, lançaremos nossas considerações finais.

\section{Tendências da educação CTSA}

Desde seu surgimento, na década de 1960, o movimento Ciência, Tecnologia e Sociedade (CTS), de acordo com Von Linsingen (2007), esteve associado a três principais campos: primeiro, à pesquisa acadêmica, seguindo uma mudança da concepção de ciência e tecnologia e sua relação com a sociedade, com destaque para críticas ao positivismo clássico; segundo, às políticas públicas, com a promoção de maior participação da população sobre questões sociais, envolvendo ciência e tecnologia; e terceiro, à educação, com a defesa de programas e currículos orientados para as relações entre ciência, tecnologia e sociedade, capazes de formar cidadãos aptos para compreender e controlar o desenvolvimento científico e tecnológico. (VON LINSINGEN, 2007)

Aqui cabe notar que, apesar de algumas considerações sobre o ambiente estarem presentes no surgimento da crítica à educação científica tradicional-tecnicista, entre as décadas de 1960 e 1970 (para isto, basta notar os movimentos de educação ambien- 
tal e do próprio ambientalismo, nos anos 1960 e 1970), a inclusão explícita de uma dimensão ambiental, nos estudos que relacionam ciência, tecnologia e sociedade, passa a ser defendida por alguns autores preocupados com a gravidade da crise ambiental, apenas mais recentemente. (PEDRETTI; FORBES, 2000; VILCHES; GIL-PÉREZ; PRAIA, 2011) Vilches, Gil-Pérez e Praia (2011), por exemplo, defendem a inclusão do A, de ambiente, resultando na expressão CTSA, em razão de que não é suficiente assumir que considerações sobre o ambiente já estão, diretamente, presentes quando falamos da sociedade. Concordamos com esses autores no sentido de que é preciso reconhecer explicitamente o ambiente como um elemento em relação com CTS, pois o Ambiente - através dos seus componentes bióticos (animais, plantas, microrganismos etc.) e abióticos (oceanos, rios, lagos, montanhas, atmosfera, solos etc.), por exemplo - é a própria condição de possibilidade natural para qualquer sociedade. Afinal, trata-se de reconhecer uma obviedade, inconveniente para os processos produtivos predatórios do capitalismo atual, mas absolutamente necessária: a natureza ou o ambiente impõe limites - e não apenas oferece "recursos" - às sociedades (MEADOWS et al., 1972; WWF, 2014; MEADOWS et al., 1972) e estes limites naturais precisam ser respeitados. Pelas razões expostas, daqui em diante, utilizaremos apenas a expressão CTSA para nos referirmos tanto ao movimento CTSA quanto ao CTS.

No âmbito do movimento CTSA, a educação sob esta perspectiva (educação CTSA) busca, a partir de maior contextualização, interdisciplinaridade e criticidade, alcançar um ensino mais humanitário e menos tecnocrático, em especial no âmbito da educação científica e tecnológica. (AULER; BAZZO, 2001; AULER; DELIZOICOV, 2006; VON LINSINGEN, 2007) Pretende-se que as situações (que contextualizam os conteúdos científicos) contribuam para o aumento do interesse e o reconhecimento da importância desses conteúdos pelos estudantes para a solução de problemas do seu próprio cotidiano. (TORRES-MERCHÁN, 2011)

Quando falamos em educação CTSA, pode parecer que estamos nos referindo a um movimento coeso na educação, sem divergências internas, sem diferentes enfoques, ênfases ou tendências. Pedretti e Nazir (2011) nos ajudam a entender melhor este ponto e mostram que tal coesão não é necessariamente o caso. As autoras ofereceram uma contribuição importante para o entendimento da diversidade de abordagens sob o rótulo de CTSA, do ponto de vista do foco, dos objetivos da educação científica, das abordagens dominantes e, ainda, das estratégias de cada vertente mobilizadas para aplicar a educação CTSA. Em sua análise sobre o desenvolvimento do movimento CTSA na educação, Pedretti e Nazir (2011) descrevem a existência de seis vertentes ou tendências da educação CTSA que se estabeleceram nos últimos 40 anos e, ainda, apontam algumas objeções, na literatura, dirigidas a cada uma delas. Embora essas vertentes não sejam mutuamente excludentes, nem a análise das autoras se pretenda exaustiva, como elas próprias reconhecem, essa caracterização pode auxiliar na compreensão de um pano- 
rama geral das tendências da educação CTSA. Cabe então analisar tal panorama, pois é dentro dele que situaremos, mais claramente, nossa abordagem.

A primeira vertente, de acordo com Pedretti e Nazir (2011), tem foco na aplicação dos conhecimentos científicos e tecnológicos na resolução de problemas sociais do cotidiano. A principal crítica a essa vertente, segundo as autoras, relaciona-se ao estímulo a uma ideia de que a ciência e a tecnologia são imprescindíveis para resolver problemas sociais, gerando, principalmente, uma dependência tecnológica do estudante/cidadão, o que seria uma visão pouco crítica acerca dos problemas socioambientais. Exemplos de trabalhos e autores nesta vertente são: Solomon (1993) e Layton (1988). A segunda categoria apresentada pelas autoras destaca o aspecto histórico e sociocultural da ciência e sua conexão com a compreensão da atividade científica no contexto social interno à própria ciência. A principal crítica a esta vertente está no estímulo a uma visão de ciência desconexa de um contexto social mais amplo, externo à própria ciência, como, por exemplo, os problemas socioambientais atuais, podendo reforçar estereótipos ou histórias mainstream, isto é, dominantes, tanto acerca da ciência, quanto de outras formas de conhecimento. Alguns autores que podem ser situados nesta vertente são: Matthews (1994) e Ziman (1994). Na terceira vertente, prioriza-se o raciocínio lógico e a argumentação. Para alguns autores - por exemplo, Jiménez-Aleixandre; Pereiro-Muñoz (2002) -, tais elementos são muito relevantes e acreditamos que, por isso mesmo, precisam estar cada vez mais presentes nas salas de aulas, sobretudo por contribuições que podem oferecer para o desenvolvimento do pensamento crítico dos estudantes. Contudo, tal vertente tem sido criticada por superestimar aspectos epistemológicos, não reconhecendo outros fatores relacionados à tomada de decisão, como emoções e valores. Segundo as autoras, a priorização sobre técnicas de comunicação e organização do pensamento, na educação científica, presente nesta vertente, pode reduzir a sensibilidade e gerar alienação (a aspectos não epistemológicos) nos estudantes. Driver, Newton e Osborne (2000), Osborne, Eduran e Simon (2004) e Jiménez-Aleixandre e Frederico-Agraso (2006) são alguns exemplos de trabalhos nesta vertente.

As próximas vertentes se desenvolveram a partir das críticas às primeiras. A quarta está centrada no reconhecimento dos valores relacionados à ciência, com ênfase sobre os aspectos éticos e ao desenvolvimento cognitivo e moral do estudante. As críticas a essa vertente estão associadas à ideia de relativismo ético e à necessidade de se estabelecer um consenso global de valores. Zeidler e Keefer (2003) e Sadler (2004a, 2004b) são alguns trabalhos de representantes desta vertente. Por sua vez, a quinta vertente enfatiza aspectos socioculturais da ciência e da tecnologia, sendo estas compreendidas como parte da sociedade e integradas às atividades políticas, econômicas e culturais. A desvalorização do conhecimento científico é uma das principais críticas, devido à consideração, por igual, na sala de aula, de múltiplos contextos culturais. Exemplos de trabalhos nesta vertente são os de Carter (2008) e Brown-Acquaye (2001). Por fim, a última vertente refere-se à formação de ativistas, no sentido de cidadãos capazes de agir 
para transformar a sociedade em direção a maior justiça social e ambiental. Para isso, a educação científica deve explicitar: as influências mútuas entre política, economia e ciência; os fundamentos dos juízos morais; além de desenvolver responsabilidade cívica e pensamento crítico para a realização de ações sociopolíticas que, muitas vezes, ultrapassam os limites físicos da escola. As críticas a essa vertente referem-se à relativização do que seria justo, bom e correto, além da própria adoção de um tipo de democracia como forma padronizada de organização da sociedade. Outra objeção seria no sentido da adoção de um framework filosófico específico (como, por exemplo, a teoria crítica ou as correntes pós-estruturalistas) para justificar a necessidade de empoderamento e emancipação do cidadão, o que excluiria outros frameworks filosóficos da educação, com propósitos distintos, como o de obediência às tradições culturais e a manutenção do status quo. Trabalhos e autores relevantes desta vertente são os de Reis (2013), Hodson (2004, 2011) e Bencze e Alsop (2009), entre outros.

Ainda que possamos considerar contribuições positivas de outras vertentes, a abordagem que apresentamos neste capítulo é preponderantemente alinhada com a quarta e a sexta vertentes, da análise de Pedretti e Nazir (2011). Por isso, dedicaremos mais espaço a responder a críticas levantadas a tais vertentes.

Assim, consideremos, inicialmente, a quarta vertente. Com relação às objeções de que normas éticas (associadas ao que se considera bom, justo e correto) são relativas e, também, sobre a dificuldade de estabelecer um consenso global de valores, acreditamos que podemos responder com base em reflexões provenientes da filosofia moral. A esse respeito, Rachels (2006), ao discutir os problemas associados à assunção de um relativismo ético, aborda que uma das origens da ética está relacionada ao controle da violência entre os seres humanos que viviam em grupos e, dessa forma, há critérios universais para o estabelecimento de regras morais que independem de códigos morais de diferentes culturas, o que se configura como condição de possibilidade para a convivência social: segundo o autor, a prática social que não cause danos e sofrimento a quem é afetado por ela. Para Rachels (2010), este é um padrão ético independente de cultura, porque considera o valor intrínseco da vida dos envolvidos, de modo a determinar padrões de certo e errado que estão presentes nas diferentes tradições culturais. Assim, apesar de J. Rachels e S. Rachels (2014) assumirem a possibilidade de um relativismo cultural, isso não significa assumir um relativismo ético, uma vez que muitas práticas culturais são apenas convenções sociais e, portanto, produtos culturais, que podem mudar com a transformação da sociedade, ao longo do tempo; já os critérios universais, que estão no surgimento e na "razão de ser" da ética, estes não são meras convenções sociais e muitas vezes são a base de valores para determinadas tradições. Dito de outro modo, um problema da relativização da ética em relação aos padrões culturais está em assumir que os critérios para o que se deve fazer são dados pela cultura, não por algum padrão supracultural. Nesse sentido, aquele que defende uma relativização do certo e do erra- 
do, do que se deve e do que não se deve fazer, somente com base na cultura, precisaria responder, assim, duas difíceis questões:

- como justificar relações de opressão, ou até mesmo de violência física, que, historicamente, fazem parte de certas culturas? Por exemplo, seria correto permitir a clitorectomia, isto é, a retirada do clitóris, em algumas regiões, com base no fato de que isto é parte de uma tradição cultural, mesmo sabendo que as vítimas desse procedimento sentem dores e são susceptíveis a infecções e sofrimento, por conta de determinados costumes? Outro exemplo ilustra o mesmo ponto: seria correto continuar a permitir touradas, nos países onde ocorrem, porque isto é parte de uma tradição cultural, mesmo sabendo que as vítimas dessa atividade sentem dores e são submetidas a grande estresse e sofrimento, pelo entretenimento humano? Se o certo e o errado fossem relativos à cultura, não poderíamos fazer nenhum juízo moral sobre a cultura alheia e nem sobre o que consideramos errado nas tradições de nossa própria cultura, da mesma forma que não poderíamos condenar moralmente as duas práticas acima;

- se aceitarmos que as culturas já possuem, internamente, os critérios para o julgamento do certo e do errado, do que devemos ou não fazer, então não seria possível, por definição, encontrarmos critérios comuns a diferentes culturas, portanto, trans ou supraculturais, pois isto envolveria uma contradição, uma vez que cada critério seria totalmente particular e único de uma determinada cultura. E isso, de fato, não ocorre. Em outras palavras, ao relativizar o juízo moral com base na cultura, em geral, se assume uma representação das culturas como entidades isoladas, no sentido que cada cultura teria seus próprios critérios para determinação de certo e errado. O equívoco dessa representação estaria na simplificação excessiva da complexidade cultural, desconsiderando critérios para atribuição de juízo moral que são compartilhados entre diferentes culturas. Assim, nesse sentido, será que não existiriam padrões que transcendem ou abrangem diferentes culturas, que se baseiem em nossas similaridades enquanto seres humanos ou enquanto seres que devem ser moralmente considerados? Por exemplo, a violência contra uma mulher brasileira é um erro, precisamente, porque é parte de uma cultura ou porque é um ato de violência, que desrespeita um direito básico, que é o direito de não ser agredido (ou não sofrer nenhum tipo de violência), seja no Brasil, seja em qualquer outro país do mundo?

Parece-nos mais razoável pensar, contra um relativismo ético, seguindo a Rachels (2006), assumindo que as manifestações culturais, no que dizem respeito ao que devemos fazer são, muito mais, instanciações nas diversas culturas específicas, com todas as riquezas, os vieses e as dinâmicas, que estas apresentam, de padrões morais mais amplos, que, em última instância, são éticos e transcendem as culturas. 
Por sua vez, com relação às críticas à sexta vertente, que se aproximam das críticas à quarta, cabe notar que será a partir de uma reflexão ética e política adequada que poderemos definir o justo, o bom e o correto. Recomendamos realizar tal reflexão a partir da filosofia moral, que oferecerá critérios para decidir sobre os ideais mencionados (como exemplificaremos ao final do capítulo, para um caso), o que implicará assumir explicitamente certas posições políticas. Assim, o mais importante, neste ponto, nos parece, é o estabelecimento de critérios claros para definir o bom, o justo e o correto, entendendo que a adoção de um critério claro, de um certo ponto de vista, com certos interesses, como não poderia deixar de ser, por tratar-se de discussões filosóficas, não excluirá a possibilidade de novas visões, de novos critérios, potencialmente divergentes. Com relação à objeção que aponta para uma aparente tensão entre empoderamento e emancipação, de um lado, e a adoção de um framework teórico específico, de outro, acreditamos que ela não seja, de fato, problemática, desde que se aceite a perspectiva de uma relação dialética - e assim, possivelmente, tensionada - entre a teoria filosófica específica, subjacente, e a prática social (práxis) do empoderamento, da reflexão e do ativismo. Afinal, não há razão para supor que os verdadeiros empoderamento e emancipação humanos dependerão da existência de uma teoria prévia que lhe dê sentido, como condição de possibilidade, e ainda o faça de modo completamente harmônico. De certa forma, nos parece mais profícuo explorar as possíveis contribuições mútuas entre teoria e prática social. Neste sentido, a prática do pensamento crítico em sala de aula, com todas as possibilidades filosóficas que lhe fundamentam, parece ter um papel muito relevante, uma vez que é uma manifestação da emancipação e do empoderamento, com relação aos problemas (como os que temos apontado).

Além disso, a própria explicitação de ideologias, fundamentos filosóficos e valores é um pressuposto necessário para compreender e esclarecer as finalidades da educação e, a partir disso, assumir compromissos e métodos condizentes com a formação pretendida para o sujeito. Nesse contexto, a formação de cidadãos capazes de agir em favor de maior justiça social e sustentabilidade ambiental tem sido apontada como um importante objetivo da educação científica, conhecida como letramento científico crítico. (BENCZE, 2014; CONRADO; NUNES-NETO; EL-HANI, 2016; HODSON, 2011)

Como bem notam Barrett e Pedretti (2006), a educação CTSA, por si mesma, não é uma educação transformadora, uma vez que ela se apresenta concretamente dentro de uma ou mais vertentes, as quais possuem objetivos diferentes. Além disso, uma educação CTSA pode ser implementada muito mais para manter o status quo social e político do que para promover mudanças efetivas rumo a maior igualdade, justiça e sustentabilidade. Contudo, pensamos que, na educação CTSA, a promoção do letramento científico deve estar alinhada a uma educação transformadora, tomando como inspiração a pedagogia crítica de Paulo Freire (BARRETT; PEDRETTI, 2006; FREIRE, 1996; SANTOS, 2009), no sentido de superar a mera transmissão das informações sobre CTSA. Assim, uma educação CTSA orientada para a transformação social positiva deve promover con- 
dições para que os estudantes avaliem criticamente valores e interesses das estruturas sociais, engajando-se em ações para a promoção de uma sociedade mais justa e ambientalmente mais sustentável. Isso significa ampliar o escopo da educação científica, em um contexto interdisciplinar e voltado aos problemas socioambientais atuais.

De um modo geral, apesar de suas particularidades, em todas as suas vertentes, o enfoque da educação CTSA na educação científica tem permitido uma melhor compreensão dos papéis docentes e discentes voltados ao "[...] desenvolvimento de atitudes e valores correspondentes à compreensão da ciência como uma atividade cultural" (MARTÍNEZ PÉREZ; PARGA LOZANO, 2013, p. 25), combatendo os denominados mitos do cientificismo (CONRADO; EL-HANI, 2010; CONRADO; CONRADO, 2016a, 2016b; SANTOS; MORTIMER, 2002), assim como possibilitou a integração explícita de aspectos éticos e políticos no ensino de ciências. Neste contexto, uma reorganização curricular é necessária, e estratégias de ensino inovadoras, como as voltadas ao ativismo e a ações sociopolíticas, têm sido propostas e desenvolvidas nos últimos anos a fim de atender a estas demandas. (BENCZE; CARTER; KRSTOVIC, 2014; MARTÍNEZ PÉREZ, 2012; REIS; NG-A-FOOK; GLITHERO, 2015; REIS, 2013, 2014) O método que propomos neste capítulo, para aplicar pressupostos da educação CTSA, inspira-se no uso de QSC, o que abordaremos a seguir.

\section{Questões sociocientíficas na educação CTSA}

Um modo de promover a educação CTSA, nas aulas de ciências, é a partir do uso de temas controversos, mais precisamente por meio de QSC. QSC são problemas ou situações geralmente complexos e controversos, que podem ser utilizados em uma educação científica contextualizadora, por permitir uma abordagem de conteúdos inter ou multidisciplinares, sendo os conhecimentos científicos fundamentais para a compreensão e a busca de soluções para estes problemas. Além do conhecimento científico, particularmente, conhecimentos de filosofia (sobretudo de ética) e história são relevantes e geralmente mobilizados na abordagem das QSC, além de diferentes habilidades, valores e atitudes, pois a proximidade com situações do contexto real aumenta o interesse, o diálogo e o engajamento dos estudantes. Quando associado, em alguma medida, às ações sociopolíticas, podemos considerar que o ensino a partir de QSC se classifica como uma metodologia ativa ou participativa. (CONRADO, 2017; SADLER; BARAB; SCOTT, 2007) Bons exemplos de QSC são: aquecimento global, perda de biodiversidade, extinção de abelhas com consequente redução da produção de vegetais, poluição hídrica, racismo, entre outros. As propostas de ensino apresentadas na parte dois deste livro focalizam diferentes QSC.

Ainda, cabe ressaltar que, no intuito de potencializar a aprendizagem sobre algum tema, a conexão afetiva/emocional entre a controvérsia sociocientífica e o estudante é um fator essencial para seu engajamento na resolução do problema e na busca de fer- 
ramentas e conhecimentos relacionados ao tema. (KERCKHOFF; REIS, 2014; SADLER, 2004b) O engajamento e a aproximação afetiva/emocional auxiliam na percepção de que o estudante é um responsável direto e, por isso, capaz de (e necessário para) promover mudanças no sentido de resolver ou mitigar os problemas socioambientais atuais. Nesse sentido, segundo Reis (2013), as QSC são úteis para uma melhor aprendizagem de conteúdos científicos aliados ao desenvolvimento cognitivo e ético dos estudantes.

As QSC podem ser transpostas para o ensino, no âmbito de uma estratégia didática ou um método de ensino que permita aos estudantes mobilizar e aprender sobre determinados conteúdos, de modo contextualizado, assim como compreender criticamente a Natureza da Ciência e desenvolver habilidades relacionadas ao pensamento crítico. (CONRADO; CONRADO, 2016a, 2016b; KRSTOVIC, 2014; MARTÍNEZ PÉREZ; PARGA LOZANO, 2013; SOLBES, 2013) As propostas de ensino baseadas em QSC, quando adotadas como uma estratégia ou um método de ensino, na educação científica, tendem a estar associadas às seguintes características:

- estimulam discussões interdisciplinares sobre um tema, geralmente, veiculado nos meios de comunicação de massa, capaz de promover argumentação (HODSON, 2013; MARTÍNEZ PÉREZ; CARVALHO, 2012);

- explicitam implicações éticas (SADLER; ZEIDLER, 2004) e ambientais (CONRADO, 2013; MARTÍNEZ PÉREZ; PARGA LOZANO, 2013);

- mobilizam conhecimentos científicos de fronteira, bem como aqueles associados à compreensão da Natureza da Ciência (HODSON, 2013; RATCLIFFE; GRACE, 2003; REIS; NG-A-FOOK; GLITHERO, 2015);

- envolvem discussão de valores morais, interesses e opiniões (BERKOWITZ; SIMMONS, 2003; CONRADO, 2013; HODSON, 2004; SADLER, 2004a; ZEIDLER et al., 2005); e por fim,

- possibilitam tomada de decisão e ação dos participantes (HODSON, 2011, 2013; MARTÍNEZ PÉREZ; PARGA LOZANO, 2013; RATCLIFFE; GRACE, 2003).

No âmbito da educação científica formal, sobretudo voltada ao letramento científico crítico, as propostas de ensino baseadas em QSC podem ser utilizadas para desenvolver nos estudantes:

- compreensão e reflexão crítica sobre as relações entre a ciência, a tecnologia, a sociedade e o ambiente, uma vez que se exploram diferentes dimensões e pontos de vista sobre um conteúdo científico (HODSON, 2013; SOLBES, 2013);

- habilidades de busca, seleção, análise, discussão e avaliação de informações sobre um tema controverso, o que envolve o estudante em um processo in- 
vestigativo e de desenvolvimento de habilidades argumentativas (KRSTOVIC, 2014; REIS, 2014; TORRES-MERCHÁN, 2011);

- capacidade de raciocínio moral para avaliar, julgar e se posicionar sobre a situação, a partir da explicitação de valores e diferentes cursos de ação envolvidos (GUIMARÃES; CARVALHO; OLIVEIRA, 2010; TORRES-MERCHÁN, 2011; REIS, 2013; ZEIDLER et al., 2005);

- maior envolvimento e senso de responsabilidade da população sobre o desenvolvimento científico e tecnológico e seus impactos sociais (LEVINSON, 2006; REIS, 2013; SANTOS, 2009);

- oportunidades para que realizem ações sociopolíticase iniciativas de ativismo, o que pode conduzir a transformações de suas identidades enquanto pessoas (BENCZE; ALSOP, 2009; BENCZE; CARTER; KRSTOVIC, 2014; HODSON, 2011, 2013; REIS; NG-A-FOOK; GLITHERO, 2015).

No contexto da aplicação das propostas de ensino baseadas em QSC, a aprendizagem de ciências para a formação de cidadãos mais autônomos e participativos deve considerar não apenas o conhecimento científico, mas também conhecimentos prévios e valores socioculturais do entorno do sujeito. (HODSON, 2004) Por fim, em uma estrutura curricular com base em QSC, pode-se superar uma relação do estudante passivo e receptor de informação com o professor centralizador e transmissor da informação, para uma relação em que o estudante constrói ativamente seus conhecimentos, estimulado para mobilizar dados, teorias, técnicas e valores para a resolução de um problema real, que the interessa. $O$ professor, nessa relação, atua muito mais como um consultor crítico, que orienta e facilita a aprendizagem, além de fornecer apoio emocional e teórico, a partir de atividades de reflexão sobre as informações, sofisticação de argumentos, entre outras. A esse tipo de relação, Hodson (2014) denomina comunidade de aprendizagem, a qual depende, para seu próprio funcionamento, do esclarecimento de regras ou normas sociais como respeito, responsabilidade, tolerância e boa vontade.

Inspirando-nos em Sá e Queiroz (2007), Lima e Linhares (2008) e Velloso e colaboradores (2009), assim como em trabalhos prévios nossos (CONRADO, 2013; CONRADO et al., 2012; CONRADO; EL-HANI; NUNES-NETO, 2015; CONRADO et al., 2015, 2016), nos parece adequado abordar QSC na forma de casos, construídos como histórias curtas, contendo, se possível, diálogos e personagens que se aproximam do(s) contexto(s) sociocultural(is) dos estudantes. A este elemento das propostas de ensino baseadas em QSC, denominamos simplesmente caso ou história.

A organização de uma sequência de eventos na forma de uma história, como no uso de narrativas, é um modo de explicitar diferentes interpretações, pontos de vista, crenças e juízos de valor, além de permitir a aproximação do tema controverso com o estudante, contribuindo para sua sensibilização e seu engajamento. (LEVINSON, 2006; ZEIDLER et al., 2005) Contudo, o caso por si só pode ser mal ou subutilizado 
para o desenvolvimento de habilidades, conhecimentos e atitudes. Deste modo, a fim de mobilizar determinados aspectos dos problemas sociocientíficos presentes no caso, de acordo com nossa abordagem, sugerimos a utilização do que chamamos de questões norteadoras. Estas são, simplesmente, questões, claramente colocadas como perguntas sobre o caso (e/ou sobre aspectos globais que podem estar instanciados no caso) e que demandarão dos estudantes ações condizentes com objetivos de aprendizagem previamente definidos. As questões norteadoras aproximam-se da estratégia, proposta por Fullick e Ratcliffe (1996), de discussões em grupos sobre questões que dirigem, de modo equilibrado, a atenção dos estudantes para a natureza do problema e as possíveis soluções, incluindo um debate crítico acerca dos valores que fundamentam as diferentes soluções. Desse modo, conforme os objetivos de ensino e de aprendizagem, é possível, a partir das questões norteadoras: perceber diferentes complexidades e múltiplas perspectivas; desenvolver argumentos sobre o caso; compreender teorias e conceitos científicos e investigar técnicas e tecnologias relacionadas à QSC; entender implicações e influências de sociedade, política e valores de atores sociais envolvidos; emitir juízos sobre esses atores sociais e consequências socioambientais das diferentes decisões; e, por fim, posicionar-se claramente a respeito da QSC relacionada ao caso e tomar decisões socioambientalmente responsáveis. (CONRADO, 2017)

A estes dois elementos, constituintes da nossa perspectiva, articulamos, ainda, um terceiro, os objetivos de aprendizagem, definidos a partir de uma concepção tridimensional dos conteúdos. Assim, na próxima seção, explicitaremos as relações das QSC com dimensões do conteúdo escolar/acadêmico, em uma perspectiva de educação CTSA.

\section{Aprendizagem de ciências considerando três dimensões dos conteúdos}

Nesta seção, defenderemos que as dimensões Conceituais, Procedimentais e Atitudinais (CPA) dos conteúdos da educação científica são objetos adequados para uma educação científica com base na perspectiva da educação CTSA e que poderão ser buscados a partir da adoção de estratégias ou métodos de ensino (ou, ainda, na estrutura política mais profunda da educação, representada pelos currículos) baseados em QSC. Para isso, apresentaremos uma concepção mais ampla dos conteúdos escolares/acadêmicos, especificamente em três dimensões e que abrangem o desenvolvimento de conhecimentos, habilidades, valores e atitudes essenciais voltados para uma formação mais integral dos sujeitos enquanto indivíduos efetivamente engajados em participação social.

É importante notar que a diferenciação dos conteúdos em suas dimensões CPA é artificial e metodológica, criada para auxiliar na compreensão de um fenômeno complexo, que ocorre de maneira integral - cognitiva, comportamental e socialmente - que é a aprendizagem do conteúdo. De fato, como bem nota Zabala (1998, p. 39, grifo nosso), ao invés de ser a realidade tal como ela é, "[...] a tipificação das características 
destes elementos, que denominamos conteúdos, é uma construção intelectual para compreender o pensamento e o comportamento das pessoas".

Zabala (1998) organiza uma tipologia de conteúdos de forma a esclarecer critérios que orientem a prática educativa para alcançar determinados fins da educação. Assim, é importante saber o que se ensina e por que motivos. Nesse contexto, Coll e colaboradores (1992) apontam que a falta de ênfase na discussão sobre os conteúdos didáticos está relacionada a uma interpretação de que os processos de ensino e de aprendizagem estariam ligados às atividades de transmissão e acumulação de conhecimentos. Segundo tais autores, com o surgimento de novas estratégias pedagógicas, a rejeição das estratégias tradicionais levou também à desvalorização dos conteúdos e da forma em que eram aprendidos. Subjacente à crítica de Coll e colaboradores (1992), está o problema da própria definição do objeto dos processos de ensino e de aprendizagem; em suma, a questão filosófica de definir o próprio objeto da educação. Sobre a questão do que é e do que não é conteúdo, Zabala e Arnau (2010, p. 20-21), claramente, afirmam que:

[a] pressão do saber teórico acadêmico e das ideias errôneas sobre a aprendizagem e a transferência dos saberes determinaram a preponderância dos conhecimentos factuais e conceituais, tanto é assim que para a maioria dos professores a expressão 'conteúdos de ensino' se limita apenas aos conhecimentos, ou seja, ao saber, dando por certo que os procedimentos, as habilidades, as estratégias, as atitudes e os valores são outra coisa, quer dizer, não são objetos da educação e, portanto, não são conteúdo do ensino.

Em convergência com esta análise, Zabala (1998) aponta uma generalização normalmente aceita de que os conteúdos se referem somente a conceitos, teorias e princípios, restringindo-se a uma dimensão cognitiva do conteúdo de aprendizagem na educação. É comum, de fato, ouvirmos de professores que um determinado currículo ou livro didático é muito "conteudista", sendo que, normalmente, se está compreendendo conteúdo, nestes casos, como sinônimos de conceitos, conhecimentos ou algum objeto similar. Entretanto, no âmbito de uma formação integral do sujeito, as intenções educacionais devem estar para além da aprendizagem de conceitos, teorias e princípios, pois, segundo Zabala (1998) - na medida em que contribui para uma formação mais integral dos estudantes, dando conta de uma diversidade de inteligências, de interesses, potencialidades e necessidades (seja individual ou coletivamente) -, tudo aquilo que desenvolva capacidades motoras, afetivas, de relação interpessoal e de inserção social deve também ser considerado como conteúdo de aprendizagem. Nesse contexto, o autor destaca a importância de se explicitar aprendizagens que geralmente estão implícitas nos currículos e, principalmente, nos planos e nas salas de aula, o que é conhecido por alguns como "currículo oculto" (KENTLY, 2009), as normas, valores e crenças não declarados ou explicitados como parte do currículo, mas que, de fato, são transmitidas aos estudantes através de regras sociais subjacentes ou subliminares às próprias rotinas e modos de organização do 
processo educativo nas salas de aula e nas escolas. (GIROUX, 2001) É necessário desocultar o "currículo oculto" e proceder a este movimento a partir da explicitação detalhada, mas equilibrada, dos conteúdos que se pretende ensinar. Assim, é possível se estabelecer uma relação mais clara e honesta entre três elementos: os próprios conteúdos em suas dimensões, os meios ou métodos para se abordá-los no dia a dia dos processos educativos e a finalidade que se pretende para a educação no todo social.

Assim, para nós, propostas explícitas de desocultação do currículo oculto e, nesta linha, de ampliação da concepção de conteúdos do ensino ou dos objetivos da aprendizagem são muito bem-vindas, uma vez que, para além de formar pessoas de modo mais integral, é preciso abordar, de alguma forma, as dimensões não-conceituais dos problemas socioambientais atuais, os que nos colocam em situação de enorme crise. De fato, diante dos problemas socioambientais atuais e da necessidade de indivíduos comprometidos, responsáveis e capazes de participar ativamente para a redução ou a solução desses problemas, apenas o acúmulo de conhecimentos, seja científicos, tecnológicos ou mesmo filosóficos, não é suficiente. (CONRADO, 2013; HEMPEL, 2014; SAVIN-BADEN; MAJOR, 2004) Ainda, para Villa e Poblete (2007), o aumento do conhecimento científico e das tecnologias tem acompanhado o crescimento das desigualdades sociais em todo o planeta, ao invés de melhorarmos nossas formas de conviver. No contexto da educação científica, Noss (2007) discute as dificuldades de se cumprir uma formação adequada de cidadãos quando se coloca ênfase apenas na aprendizagem de conceitos e procedimentos, negligenciando valores e normas presentes no campo da ciência, quando esta interage com a sociedade.

Além disso, na educação tradicional-tecnicista, não há reconhecimento da complexidade e da multidimensionalidade dos conteúdos e dos objetivos educativos, pois as estratégias e os métodos de ensino não permitem questionar os próprios conhecimentos científico e tecnológico, sua inserção e necessidade na sociedade, assim como interesses e ideologias envolvidos. Por exemplo, ainda há grande necessidade de refletir e discutir mais sobre questões éticas referentes aos processos de produção, uso e descarte de agrotóxicos, sobretudo no caso do Brasil, o maior consumidor mundial de agrotóxicos. (ANDRADE et al., 2016; CARNEIRO et al., 2015; FERNANDES; STUANI, 2015; OLIVEIRA, 2010)

Neste sentido, a educação científica tradicional-tecnicista comete o que podemos chamar de vícios conceitualista e tecnicista, ou seja, concebe o conteúdo de modo unidimensional, priorizando ou mesmo assumindo como as únicas legítimas, respectivamente, a dimensão conceitual e a dimensão procedimental dos conteúdos. Deve-se notar que tal crítica faz sentido à luz de uma concepção mais ampla de conteúdo.

Coll e colaboradores (1992) e Zabala (1998) diferenciam e caracterizam, metodologicamente, com base em processos cognitivos e condutais da aprendizagem, três tipos de conteúdos: conceituais, procedimentais e atitudinais (CPA). Assim, neste trabalho, a definição das dimensões CPA dos conteúdos foi inspirada nas propostas de Coll e cola- 
boradores (1992), Zabala (1998) e Zabala e Arnau (2010), mas também em algumas convergências desses autores com os trabalhos de Clément (2006) e Villa e Poblete (2007).

No âmbito da síntese que propomos, assumimos a terminologia de Coll e colaboradores (1992) e de Zabala (1998) para os elementos constituintes das dimensões CPA dos conteúdos, pois esta nos parece a proposta mais bem elaborada e precisa, tendo, inclusive, influenciado a formulação dos parâmetros curriculares nacionais do Brasil. (BRASIL, 1997) Assim, mostraremos como as dimensões CPA dos conteúdos podem ser utilizadas para a definição dos objetivos de aprendizagem no ambiente escolar ou acadêmico e como podem ser buscados a partir da adoção de propostas de ensino baseadas em QSC. Na Figura 1, pode ser visualizada uma síntese da concepção de Clément com a de Coll e Zabala, a fim de orientar a organização dos objetivos de aprendizagem dos conteúdos.

Figura 1 - Representação das dimensões CPA do conteúdo escolar/acadêmico que podem ser didaticamente separadas em objetivos de aprendizagem

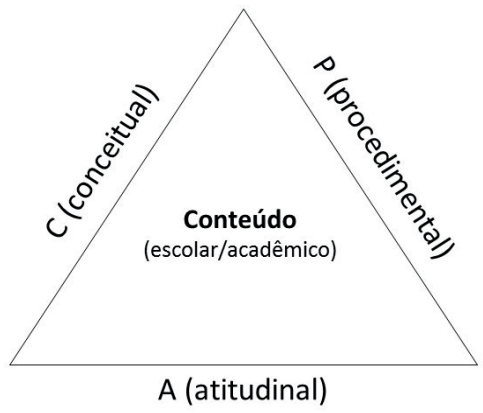

Fonte: elaborada pelos autores com base em Conrado (2017), Coll e colaboradores (1992), Zabala (1998), Clément (2006), Conrado e colaboradores $(2015,2016)$ e Conrado e Nunes-Neto (2015).

Conforme Villa e Poblete (2007), podemos organizar os objetivos de aprendizagem em três categorias de competências:

- instrumentais, que são habilidades motoras e cognitivas que possibilitam o exercício da profissão (por exemplo: capacidades de pensamento lógico, planejamento e comunicação verbal e escrita);

- interpessoais, que estão relacionadas a atitudes para uma boa convivência social (por exemplo: capacidades para trabalho em equipe e automotivação), o que envolve aprendizagem e prática de virtudes, epistêmicas ou morais (como, por exemplo: racionalidade, precisão semântica, honestidade, responsabilidade, autorreflexão, solidariedade, compaixão, empatia); e

- sistêmicas, que podem ser consideradas como aquelas capacidades de compreensão e participação no todo (por exemplo, capacidade de gestão, criatividade e liderança); além do sentido de pertencimento e da ação humana para 
a manutenção de um sistema como um todo (por exemplo, uma cidade, uma sociedade, um ecossistema, um planeta). (MARTÍN, 2006)

Essas três categorias organizadas por Villa e Poblete (2007) podem ser visualizadas em convergência com a tipologia de conteúdos de Coll e colaboradores (1992) e Zabala (1998) na Figura 2. Nessa figura, podemos visualizar que a abordagem das dimensões conceituais e procedimentais do conteúdo, na educação científica tradicional-tecnicista, restringe o foco dos processos educativos ao aprendizado do que Villa e Poblete (2007) chamam de competências instrumentais. Apesar de não considerarmos os conteúdos CPA como tipos de conteúdos, e nem as categorias instrumentais, interpessoais e sistêmicas como competências (que consideramos muito mais como capacidades e habilidades), utilizamos uma síntese das ideias dos autores supracitados, com fim didático, para visualizar os elementos a serem abordados explicitamente como objetivos de aprendizagem na educação científica, para que esta possa contribuir, de fato, para formar indivíduos capazes de tomada de decisão socioambientalmente responsável (CONRADO, 2013, 2017) e ação sociopolítica (HODSON, 2011, 2013; REIS, 2013) sobre problemas socioambientais que envolvem a ciência e a tecnologia.

Figura 2 - Uma síntese das convergências de objetivos de aprendizagem

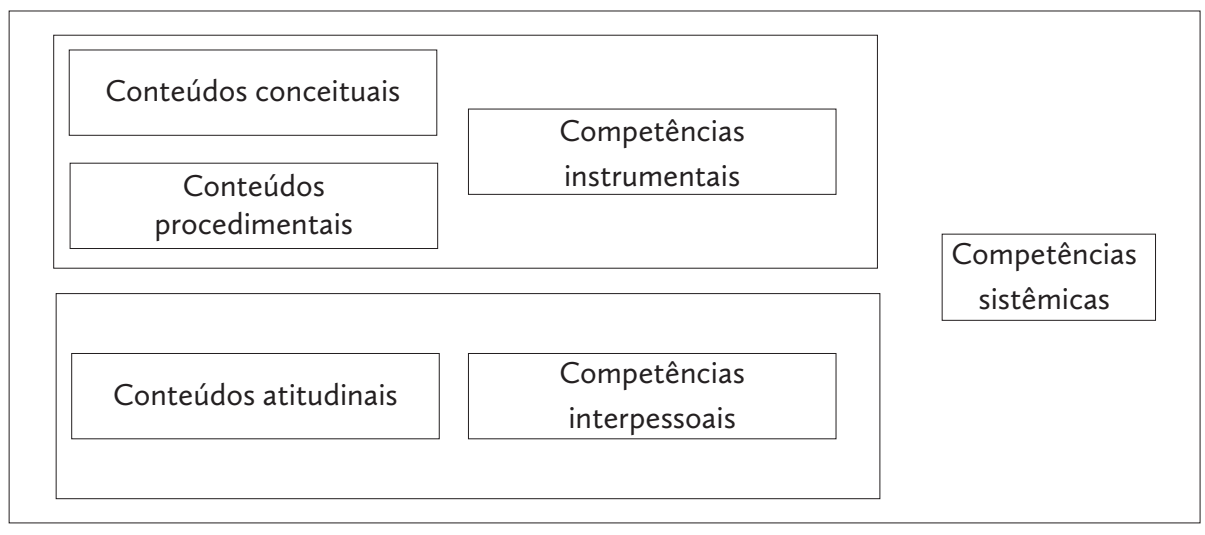

Fonte: adaptada de Conrado (2017), Coll e colaboradores (1992), Zabala (1998) e Villa e Poblete (2007).

Deste modo, para o estabelecimento de objetivos de aprendizagem, em vistas do desenvolvimento de capacidades e habilidades instrumentais, interpessoais e sistêmicas, recomendamos considerar os conteúdos a serem aprendidos em diferentes fases da unidade/intervenção didática.

Assim, em determinados momentos, um conteúdo terá uma dimensão conceitual predominante (por exemplo, em atividades de leitura e de definição de termos), em outros momentos dos processos de ensino e aprendizagem terá destaque a dimensão procedimental (por exemplo, em atividades de investigação, elaboração de argumen- 
tos ou uso de equipamentos) e, por fim, em outros, a dimensão atitudinal será a preponderante (por exemplo, em atividades de discussão de legislação e valores morais, emissão de juízo moral, trabalho colaborativo ou organização de ações sociopolíticas). No Quadro 1, podemos visualizar um exemplo que explicita diferentes dimensões desses conteúdos, em diferentes áreas do conhecimento, considerando uma QSC sobre agrotóxicos.

Quadro 1 - Exemplo de relações entre dimensões dos conteúdos e áreas para uma QSC sobre agrotóxicos

\begin{tabular}{|c|c|c|c|c|}
\hline ÁREA & Conteúdo & $\begin{array}{l}\text { Dimensão } \\
\text { conceitual }\end{array}$ & $\begin{array}{c}\text { Dimensão } \\
\text { procedimental }\end{array}$ & Dimensão atitudinal \\
\hline Ecologia & Biodiversidade & $\begin{array}{l}\text { C: conceito de } \\
\text { biodiversidade }\end{array}$ & $\begin{array}{l}\text { P: medida de } \\
\text { biodiversidade }\end{array}$ & $\begin{array}{l}\text { A: legislação ambiental } \\
\text { sobre conservação da } \\
\text { biodiversidade }\end{array}$ \\
\hline Evolução & $\begin{array}{l}\text { Seleção } \\
\text { Natural }\end{array}$ & $\begin{array}{l}\text { C: teoria de } \\
\text { seleção natural }\end{array}$ & $\begin{array}{l}\text { P: cálculo de } \\
\text { frequência alélica }\end{array}$ & $\begin{array}{l}\text { A: uso adequado de } \\
\text { agrotóxicos, após reflexão } \\
\text { crítica }\end{array}$ \\
\hline Ética & Biocentrismo & $\begin{array}{l}\text { C: definição de } \\
\text { biocentrismo }\end{array}$ & $\begin{array}{l}\text { P: procedimentos } \\
\text { de lógica e } \\
\text { argumentação }\end{array}$ & $\begin{array}{l}\text { A: reflexão, discussão e } \\
\text { ação, segundo ampliação de } \\
\text { consideração moral }\end{array}$ \\
\hline $\begin{array}{l}\text { Fisiologia } \\
\text { humana }\end{array}$ & $\begin{array}{l}\text { Ação dos } \\
\text { agrotóxicos }\end{array}$ & $\begin{array}{l}\text { C: fatos sobre } \\
\text { agrotóxicos no } \\
\text { organismo }\end{array}$ & $\begin{array}{l}\text { P: mensuração } \\
\text { de resíduos de } \\
\text { agrotóxicos }\end{array}$ & $\begin{array}{l}\text { A: discussão sobre valor da } \\
\text { vida e direitos humanos }\end{array}$ \\
\hline Economia & Valor & $\begin{array}{l}\text { C: fatos históricos } \\
\text { sobre transações } \\
\text { comerciais }\end{array}$ & $\begin{array}{l}\text { P: precificação e } \\
\text { codificação }\end{array}$ & $\begin{array}{l}\text { A: valoração dos serviços } \\
\text { ecossistêmicos afetados } \\
\text { pelos agrotóxicos }\end{array}$ \\
\hline
\end{tabular}

Fonte: elaborado pelos autores com base em Conrado (2017).

\section{Dimensão conceitual dos conteúdos ${ }^{1}$}

A dimensão conceitual dos conteúdos refere-se predominantemente a um campo epistemológico e pode ser compreendida, inicialmente, a partir de três categorias: fatos, conceitos e princípios.

Fatos são informações, acontecimentos, dados, eventos ou fenômenos concretos que geralmente são repetidos, de modo a serem memorizados e integrados nas estruturas de conhecimento do estudante. Compreendem os eventos de natureza empírica, como fenômenos particulares, e instanciações de padrões gerais. Não precisam, necessariamente, ser compreendidos, mas é suficiente que sejam memorizados e reprodu-

1 Apesar de adotarmos a mesma terminologia de Zabala (1998) para os elementos constituintes das dimensões dos conteúdos, propomos reinterpretações ou reelaborações dos significados dos termos colocados pelos autores, no sentido de tornar mais precisa a abordagem que considera as dimensões CPA dos conteúdos e ainda mais claramente fundamentada nos seus pressupostos teóricos-filosóficos. 
zidos, por exemplo, a partir de exercícios de repetição. São exemplos de fatos: na anatomia, os nomes de músculos; na evolução, o ano da publicação da obra $A$ origem das espécies; na geologia, a classificação das rochas; e na química, o número atômico do elemento hidrogênio.

Os conceitos se referem, segundo Zabala (1998, p. 42), ao "[...] conjunto de fatos, objetos ou símbolos que têm características comuns [...]”. Contudo, aqui nós consideramos que um conceito deve ser entendido como um termo com seu significado preciso, uma vez que um determinado termo como "banco", pode assumir, a depender dos contextos particulares, diferentes significados (por exemplo, instituição financeira, assento, ou ainda pode ser um verbo). Uma característica importante dos conceitos, que os diferenciam dos fatos, ainda que não dos princípios, é sua generalidade, ou seja, conceitos são entidades teóricas que se referem a um conjunto amplo de eventos, fenômenos ou fatos, ao invés de um particular. Exemplos de conceitos relevantes nas ciências da vida são: biodiversidade (riqueza e abundância de espécies); gene (fragmento funcional do material genético); função (capacidade de uma parte de um sistema que contribui para uma capacidade do sistema que a contém); nicho ecológico (hipervolume n-dimensional que contém condições e recursos que limitam a sobrevivência e a reprodução dos organismos). ${ }^{2}$

Por sua vez, os princípios se referem, conforme Zabala (1998, p. 42), às “[...] mudanças que se produzem num fato, objeto ou situação em relação a outros fatos, objetos ou situações [...]”. Zabala (1998) destaca, em sua definição, o aspecto de mudança, de relação, associado aos princípios, com o que estamos de acordo. Entretanto, mais precisamente, em nossa concepção, adequada para a educação científica, além de tratarem do aspecto da mudança ou da relação, os princípios devem ser compreendidos também com relação aos objetivos da ciência. Assim, eles são elementos teóricos que possibilitam explicações, previsões e descrições de fatos e, como tais, são componentes importantes de teorias, modelos, generalizações ou normas naturais (como as regularidades naturais, em forma de lei). De modo geral, assim, em termos epistemológicos, no que cabe às explicações científicas, eles cumprem o papel de explanans, isto é, a estrutura teórica destinada a explicar certos fatos ou fenômenos, estes últimos, por sua vez, o explanandum. Ainda, os princípios podem ser entendidos como constituintes de representações ou modelos de natureza teórica e como sendo compostos de conceitos e instanciados em fatos. Estes são alguns exemplos de princípios: na biologia, seleção

2 Cabe notar que a própria lista dos conceitos, que compõe uma determinada teoria na ciência, ou, ainda, as definições particulares dos termos dependerão sempre da perspectiva teórica assumida no campo, o que não caracteriza os conceitos como imutáveis e independentes de um contexto sócio-histórico da ciência. Isto é claro, por exemplo, com relação aos termos biodiversidade, gene, função e nicho, mencionados acima. Todos eles dependem de certa perspectiva teórica (como um paradigma, programa de pesquisa ou tradição de pesquisa) construídos num determinado período histórico, por determinados sujeitos e com base em determinados valores, necessidades e interesses. 
natural e exclusão competitiva; na física, a segunda lei da termodinâmica; na química, lei ou princípio da conservação da energia.

Diferentemente dos fatos, os conceitos e princípios são elementos abstratos, que necessitam ser compreendidos (sobretudo quanto a seu significado) e não meramente memorizados pelos estudantes. Da nossa perspectiva, a compreensão ocorre, sobretudo, a partir da mobilização em situações concretas em que eles são necessários, como, por exemplo, no oferecimento de explicações científicas, na articulação entre diferentes fatos, conceitos e princípios; na interpretação de fatos novos; ou até mesmo na elaboração de novos conceitos ou princípios.

A seleção de atividades, em uma intervenção didática com base em QSC, para a aprendizagem da dimensão conceitual dos conteúdos, deve considerar, além da possibilidade de estimular o estudante, a mobilização de fatos, conceitos, princípios em contextos distintos daquele apresentado no tema, ou no caso particular, no qual se expõe a QSC; a conexão com conhecimentos prévios do estudante; e a quantidade de informações possíveis de se abordar no tempo escolar/acadêmico disponível.

Ainda, é relevante levar em conta que, em geral, nos currículos escolares e acadêmicos, a maior parte do conteúdo explícito é composto de fatos, conceitos e princípios, o que reforça o viés conceitualista (como já apontamos acima) e, por isso mesmo, relega a segundo plano as outras dimensões do conteúdo. Na medida em que há excesso da dimensão conceitual dos conteúdos, faz-se necessária uma seleção dos conteúdos no ensino de ciências - a fim de promover uma redução consciente e equilibrada da quantidade de fatos, conceitos e princípios no ensino de ciências (CARVALHO, 2016; CARVALHO; NUNES-NETO; EL-HANI, 2011), tanto para melhor aproveitamento da aprendizagem da própria dimensão conceitual dos conteúdos (uma vez que, supomos, ensinar menor quantidade de fatos, conceitos e princípios pode permitir que ensinemos apenas aqueles que são de fato centrais, estruturantes, aos estudantes), quanto para permitir - a partir desta redução - maior presença explícita das dimensões procedimental e atitudinal dos conteúdos nas aulas de ciências.

Contudo, para que seja possível considerar as dimensões CPA dos conteúdos, no ensino de ciências, é necessário aumentar o uso de técnicas não tradicionais de ensino e reduzir a quantidade de conceitos no currículo e no planejamento didático, de forma a promover uma maior qualidade da aprendizagem e permitir uma educação mais integral dos sujeitos. (CARVALHO; NUNES-NETO; EL-HANI, 2011) Este é um desafio importante para o ensino de ciências atualmente.

\section{Dimensão procedimental dos conteúdos}

A dimensão procedimental dos conteúdos refere-se predominantemente a um campo metodológico e pode ser compreendida, inicialmente, a partir de três categorias: técnicas, procedimentos e métodos. De um modo geral, Coll e colaboradores (1992, p. 101) definem os conteúdos procedimentais como "[...] conjuntos de ações, de formas de atuar e 
de chegar a resolver tarefas [...] solucionar problemas, para chegar a objetivos ou metas, para satisfazer propósitos e para conseguir novos aprendizados".

Procedimentos representam ações (cognitivas e motoras) ordenadas, para se alcançar um fim determinado, com base em técnicas e métodos consensualmente aceitos. (ZABALA, 1998) Exemplos de procedimentos são: elaboração de um argumento; construção de um gráfico; ou, ainda, confecção de uma maquete.

Técnicas são as atividades necessárias para se realizar um procedimento. São exemplos de técnicas: resenha de uma obra, a partir do destaque de pontos principais; análise um argumento, por meio de sua estrutura; seleção de materiais, conforme palavras-chave do assunto; realização de medidas com régua; classificação de elementos em um conjunto com base em algum critério.

Métodos, em nossa perspectiva, representam uma perspectiva mais geral de uma ação, que envolve técnicas e procedimentos variados, em categorias específicas de acordo com seus objetivos. De um modo geral, nos parece adequado organizar hierarquicamente estes elementos: os métodos podem ser compostos por procedimentos e estes podem ser compostos por técnicas. Exemplos de métodos são: descrição; comparação; explicação; experimentação.

Os conteúdos, quando abordados nessa dimensão mais metodológica, são melhor compreendidos quando ocorre uma exemplificação prévia à realização da tarefa, além de ser necessário que essas ações sejam repetidas, exercitadas, em diferentes contextos, e consideradas também a partir da reflexão sobre sua prática. Nesse sentido, as atividades relacionadas aos conteúdos procedimentais devem partir de situações significativas para que o estudante perceba claramente a função e a importância do procedimento, do método ou da técnica. Por isso, e particularmente em relação à resolução de QSC, recomenda-se, na intervenção didática, haver momentos de "modelagem" (HODSON, 2011), de modo a explicar os diferentes procedimentos, assim como momentos de auxílio orientado - similar à fase de prática guiada, de Hodson (2011) -, de modo a acompanhar o desempenho do estudante na execução e no domínio das tarefas relacionadas ao conteúdo. Por exemplo, se um objetivo de aprendizagem for o desenvolvimento de habilidades argumentativas, é importante que os procedimentos, os critérios e as técnicas para um bom argumento sejam ensinados e demonstrados, para depois serem praticados e avaliados em termos da aprendizagem do estudante. Contudo, algumas tarefas podem ter como objetivo de aprendizagem a própria elaboração do procedimento (COLL et al., 1992), a partir dos conhecimentos e capacidades prévios dos estudantes. Nesse caso, o estudante precisará construir, pouco a pouco, o caminho metodológico, selecionando técnicas e métodos para se alcançar a meta estabelecida. Então, nestes casos, o conteúdo a ser aprendido não se limitaria ao conhecimento e à execução de uma sequência de passos, mas à criação destes para alcançar um resultado geral ou específico associado à resolução do problema. 
Coll e colaboradores (1992) observam que os procedimentos, técnicas e métodos possuem graus de automatização. Isso significa que o estudante, inicialmente, ao aprender sobre essa dimensão do conteúdo, poderá apresentar dificuldades iniciais e executar as atividades desde um modo mais rudimentar até uma maneira mais precisa e automática. Por exemplo, a aprendizagem sobre o procedimento de manipulação do microscópio, que demanda o domínio de técnicas manuais, pode ser inicialmente difícil para um estudante de biologia, ou trivial para um estudante de pós-graduação da área, que lida diariamente com esse aparelho em suas atividades de pesquisa. Além disso, o domínio de um procedimento, uma técnica ou um método pode ocorrer para diferentes contextos, como, por exemplo, o uso adequado do microscópio para observar lâminas de diferentes materiais. Considerando que há níveis de dificuldade, complexidade, aplicação e tempo para a realização de tarefas, podemos organizar tabelas para avaliar o progresso do estudante com base nesses critérios. (VILLA; POBLETE, 2007; ZABALA, 1998)

Ainda nesse contexto, também esclarecemos que a dimensão procedimental do conteúdo deve ser compreendida, como Zabala (1998) propõe, em um eixo cognitivo-motor (de ação técnica). Desse modo, a execução dos procedimentos, técnicas e métodos será por ora mais cognitiva e linguística (como, por exemplo, uma explicação de um fenômeno) e por outras vezes mais motora (como, por exemplo, uma experimentação ou manipulação de reagentes em laboratório).

Por fim, Coll e colaboradores (1992) alertam os professores para que saibam distinguir entre, de um lado, os procedimentos, técnicas e métodos como objetivos de aprendizagem para os estudantes e, de outro, os recursos, métodos e estratégias para os professores, como veículos da prática pedagógica em sala de aula, ou seja, o recurso ou o método adotado para o ensino e a aprendizagem (esperada) nem sempre é equivalente ao procedimento ou ao método que o estudante precisa aprender. Por exemplo, o uso de textos de divulgação pode ser um recurso didático adotado pelo docente para facilitar a aprendizagem de determinados conceitos, enquanto a elaboração de um texto de divulgação para a aprendizagem de procedimentos pode ser um objetivo de aprendizagem estabelecido para o estudante.

\section{Dimensão atitudinal dos conteúdos}

A dimensão atitudinal dos conteúdos refere-se predominantemente a um campo axiológico; e, neste âmbito, do nosso ponto de vista, principalmente, ético-político. Assim, ela pode ser compreendida, inicialmente, a partir de três categorias: valores, normas e atitudes.

Os valores são parâmetros ou critérios para juízo moral sobre condutas com base na ética. As normas são padrões ou regras de comportamento estabelecidos e compactuados para um grupo ou coletividade. As atitudes são tendências ou predisposições de conduta dos sujeitos com base em normas e valores. (VILLA; POBLETE, 2007; ZABALA, 1998) Esses elementos dos conteúdos precisam ser vivenciados em situações concretas 
e simuladas para que se exercite e se reflita sobre as próprias ações e as de outros atores sociais.

Para Zabala (1998), o valor é aprendido quando, além da compreensão sobre o conceito do valor, são relacionados e assumidos critérios morais para seu juízo. Assim, esses critérios morais permitirão a avaliação da própria atuação do sujeito e das ações de outros. Todos os valores que consideramos nesta dimensão atitudinal são fundamentados na ética e, por conseguinte, são condições para as ações em que cabem juízo moral. Neste sentido, da perspectiva ético-política que caracteriza a dimensão atitudinal, as ações são examinadas e devem ser realizadas de um ponto de vista normativo ético-político, não apenas técnico. Para nós, aqui está uma diferença relevante entre as ações vistas de uma perspectiva ético-política (isto é, desde uma dimensão atitudinal) e as ações técnicas ou procedimentos (dimensão procedimental).

Conforme Zabala (1998, p. 47), aprende-se uma atitude “[...] quando a pessoa pensa, sente e atua de uma forma mais ou menos constante frente ao objeto concreto a quem dirige essa atitude”. Quanto às normas, para Zabala (1998, p. 47):

Podemos dizer que se aprendeu uma norma em diferentes graus: num primeiro grau, quando se trata de uma simples aceitação, embora não se entenda a necessidade de cumpri-la (além da necessidade de evitar uma sanção); em segundo grau, quando existe uma conformidade que implica certa reflexão sobre o que significa a norma e que pode ser voluntária ou forçada; e em último grau, quando se interiorizaram as normas e se aceitam como regras básicas de funcionamento da coletividade que regem.

Elaborando sobre isso, podemos dizer que quanto maior a reflexão sobre as razões que justificam a ação, o conhecimento sobre normas e a consciência sobre valores morais relacionadas às atitudes, menor a ocorrência de disposições intuitivas e, assim, podemos dizer, maior a reflexividade crítica sobre as ações. Esta maior reflexividade crítica sobre os elementos constituintes da dimensão atitudinal dos conteúdos relaciona-se positivamente com o grau de autonomia do estudante, de nossa perspectiva.

De modo geral, para ocorrer aprendizagem da dimensão atitudinal dos conteúdos, é necessário, além de conhecer, refletir, analisar e avaliar as normas e os valores envolvidos na situação-problema, "[...] uma tomada de posição, um envolvimento afetivo e uma revisão e avaliação da própria atuação”. (ZABALA, 1998, p. 48) Nesse sentido, a aprendizagem de valores, normas e atitudes é, via de regra, a mais complexa, pois:

- envolve, em maior grau, elementos de afetividade e interesse;

- influencia a compreensão e a reflexão sobre as dimensões conceituais e procedimentais relacionadas ao conteúdo; e, ainda,

- $\quad$ abrange a rede de relações estabelecidas no ambiente educativo. 
Devido a essas características, é importante considerar a dinâmica das relações entre a comunidade escolar, envolvendo ativamente os estudantes e professores em processos de sensibilização e de participação quanto às normas e aos valores promovidos na unidade educativa, seja a sala de aula, seja a escola, seja uma comunidade de aprendizagem mais abrangente. Apesar da importância de se abordar explicitamente valores, normas e atitudes em sala de aula, a seleção dos objetivos de aprendizagem relacionados a essa dimensão deve ocorrer de acordo com as necessidades, os interesses, os conteúdos prévios e os contextos sociais envolvidos.

\section{Valores, normas e atitudes no ensino de ciências}

A educação científica, quando privilegia apenas a aprendizagem das dimensões conceituais e procedimentais dos conteúdos científicos, está contribuindo para a formação de cidadãos acríticos em relação às influências mútuas entre ciência, tecnologia, sociedade e ambiente (VON LINSINGEN; CASSIANI, 2010), pois desprivilegia ou negligencia dimensões éticas que inevitavelmente estarão presentes tanto na atividade científica quanto nas escolhas e ações cotidianas dos cidadãos. (FOUREZ, 1995, 2008) Não estamos dizendo, é importante destacar, que na abordagem didática de alguns casos estariam presentes apenas as dimensões conceitual e procedimental dos conteúdos e, assim, estariam simplesmente ausentes elementos de dimensão atitudinal dos conteúdos. Todos os conteúdos possuem, de nossa perspectiva, as três dimensões invariavelmente; o que variará entre os conteúdos será a predominância ou a explicitude de uma dimensão sobre as outras. Deste modo, o problema é, precisamente, a falta de explicitação, nos processos de ensino e aprendizagem, dos elementos dos conteúdos ("sobre" e "de" valores, normas e atitudes), em suas qualidades e quantidades, que estão e sempre estarão, de fato, presentes.

Muitos trabalhos têm ressaltado a importância de serem explicitados os valores associados à ciência e à tecnologia, indicando a relevância da dimensão atitudinal do conteúdo - ou algo similar - no ensino de ciências (GOERGEN, 2007; HODSON, 2004; SADLER, 2004a; SANTOS, 2012; ZEIDLER et al., 2005), sobretudo para: dar conta da diversidade de interesses e capacidades dos estudantes, que não podem ser reduzidos a uma dimensão puramente conceitual e/ou procedimental (ZABALA, 1998); uma melhor compreensão da atividade científica (LACEY, 2010); a mobilização de conteúdos científicos no cotidiano (CONRADO, 2013); o reconhecimento da influência de valores no desenvolvimento científico e tecnológico (SADLER, 2004a); a percepção de pertencimento a uma comunidade e responsabilidade em relação aos problemas socioambientais que afetam esta comunidade, por exemplo. (MARTíN, 2006)

No âmbito do trabalho com QSC, devemos considerar os conflitos e as controvérsias como oportunidades de promover o debate e a reflexão crítica sobre valores, normas, atitudes, pontos de vista e tomadas de decisão distintos. Mas como tais elementos do conteúdo CPA podem ser abordados no ensino? 
O uso de casos - como temos defendido - nos permite observar possíveis tomadas de decisão, que envolverão os elementos da dimensão atitudinal, por exemplo, vejamos um caso que pode ser aplicado no âmbito de uma proposta de ensino curta, para ensino médio ou ensino superior. Trata-se do caso de Beckert (2004), sobre a descoberta de uma embarcação antiga naufragada com obras de arte intactas. É solicitado aos estudantes que optem pela: recuperação de artefatos culturais antigos, com impactos no ecossistema natural; ou recuperação de artefatos culturais antigos, com o uso de tecnologias que permitem a conservação de golfinhos que habitam o local; ou, por fim, pela não recuperação dos artefatos e preservação da integridade e da estabilidade do ecossistema local. Na discussão sobre razões que influenciam a tomada de decisão, além dos conhecimentos científicos e tecnológicos, elementos de ética poderão ser colocados pelo professor, como: as teorias éticas que fundamentam a justificativa para a decisão tomada (RACHELS, 2006; SINGER, 2011); e a ontologia moral para a consideração moral dos envolvidos. (FELIPE, 2009; SINGER, 2011) Consideremos, em separado, a seguir, as teorias éticas e a ontologia moral.

Apenas com fim didático e de modo muito simplificado, podemos dizer que as principais teorias éticas da filosofia moral ocidental são três: a ética das virtudes, o utilitarismo (principal corrente do consequencialismo) e a deontologia ou ética Kantiana. (BONJOUR; BAKER, 2010; SINGER, 2011; WARBURTON, 2007)

A ética das virtudes, que, no Ocidente, surge com Aristóteles, apela às virtudes necessárias aos sujeitos para uma boa conduta, mas, sobretudo, para uma boa vida. Da perspectiva das virtudes, importa muito o encaixe de cada agente humano no todo social, no cosmos, poderíamos dizer. Por esta razão, esta é uma ética funcionalista, acerca da função, do papel que cada um cumpre no todo, o que está em pleno acordo com a metafísica e a epistemologia de Aristóteles. De acordo com a ética das virtudes, desde que voltada às ações individuais como seu objeto, a pergunta "o que devo fazer?" deve ser respondida apelando àquilo que um agente considerado virtuoso faria. (BECKERT, 2012; BONJOUR; BAKER, 2010; HURTSHOUSE, 2013)

Por sua vez, a ética consequencialista - cujos principais representantes foram J. Bentham e J. S. Mill, nos séculos XVIII e XIX, proponentes do utilitarismo - defende que uma ação é boa quando ela tem uma consequência boa. Da perspectiva consequencialista utilitarista, em particular, importa que a ação tenha consequências que maximizem o bem (medido em termos de prazer ou evitando a dor, por exemplo), para o máximo possível de envolvidos. (BONJOUR; BAKER, 2010; SINGER, 2004)

Por fim, a ética deontológica, cujo representante máximo na modernidade foi Kant, também nos séculos XVIII e XIX, está baseada numa análise da própria ação, não das suas consequências, como critério para justificá-la; nem tampouco nas virtudes dos agentes. Kant baseava o julgamento das ações humanas no imperativo categórico, que já foi formulado de diferentes maneiras, uma delas sendo que cada um de nós deve agir 
de acordo com a máxima de tratar cada ser humano como um fim em si mesmo, não

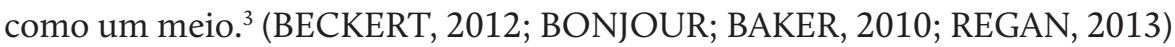

Didaticamente, nos parece importante destacar, como ponto central da discussão sobre as teorias éticas, o foco sobre o critério para atribuição de valor à ação. Enquanto o critério, para o defensor da ética das virtudes, é o que um agente virtuoso faria, para o utilitarista seria buscar a consequência da ação que maximiza o bem do máximo de envolvidos, e para o deontológico, não se basear nas consequências possíveis, nem nas virtudes, mas sim seguir um princípio que se alinhe ao imperativo categórico. É importante perceber que enquanto teorias que oferecem critérios para atribuir valor à ação humana, tais teorias não se referem explicitamente ao alcance da consideração moral, isto é, a "quais" ou "quem" devem ser aqueles considerados pela ação, quando do julgamento ou da atribuição de valor sobre ela. Em outras palavras, as teorias morais não explicitam, por si mesmas, os envolvidos, isto é, os seres com os quais devemos nos preocupar quando formulamos juízos éticos sobre o valor das nossas ações e quando agimos.

A fim de contemplar quais ou quem devem ser aqueles considerados pela ação, portanto quem tem valor, devemos focalizar o campo da ontologia moral. Aqui, podemos distinguir entre três grandes tendências: antropocentrismo, biocentrismo e ecocentrismo. (FELIPE, 2009; SILVA, 2009; VAZ; DELFINO, 2010)

A perspectiva antropocêntrica assume que somente os seres humanos merecem consideração moral e somente ações que afetam os humanos merecem um exame moral. Desse modo, e sob essa perspectiva, por exemplo, os benefícios que os humanos adquirem através dos ecossistemas possuem relevância quando promovem o bem-estar dos seres humanos. De acordo com Bryan Norton (2003), dois tipos de antropocentrismo podem existir neste contexto: um fraco e um forte. $\mathrm{O}$ antropocentrismo forte considera que o valor atribuído a algo é determinado e explicado pela referência à satisfação de preferências sentidas (qualquer desejo que possa ser saciado, pelo menos temporariamente) dos humanos. Por outro lado, o antropocentrismo fraco, apesar de considerar algumas preferências sentidas, reconhece que estas podem estar ou não de acordo com uma visão de mundo racional, permitindo, dessa forma, o estabelecimento de críticas a sistemas de valores que objetivam a exploração da natureza. Ao passo em que rejeita o antropocentrismo forte, Norton (2003) argumenta que o antropocentrismo fraco auxilia na promoção de ideais de comportamento humano que exaltam a harmonia com a natureza e também projeta a natureza como um agente que inspira e influencia a formação de valores dos indivíduos humanos através do contato direto desses indivíduos com a natureza não perturbada.

A perspectiva biocêntrica, por sua vez, caracteriza-se por propor a consideração moral de organismos individuais humanos e não-humanos. Esses organismos vivos pos-

3 Cabe notar que o imperativo categórico pode ser reinterpretado, como, de fato, o foi para incluir também outros seres, não-humanos. (REGAN, 2013) 
suem a mesma relevância (valor) que os seres humanos e, por isso, o desenvolvimento e o bem-estar de todos os seres vivos são valiosos e devem ser respeitados, ou seja, os seres humanos possuem uma obrigação moral para com os outros seres vivos. O biocentrismo pode ser considerado uma ampliação da ética animal, uma vez que ele considera que não apenas os animais (ou alguns deles) têm um valor próprio, mas as plantas também, assim como qualquer outro ser vivo que possui interesses de bem-estar e desenvolvimento; logo, também devem ser considerados como pacientes morais, pelos agentes morais. (BECKERT, 2004; VAZ; DELFINO, 2010) A fim de ilustrar a perspectiva biocêntrica e a ética animal, consideremos, brevemente, a posição elaborada por Tom Regan. Regan (2013) é um reconhecido teórico defensor da ideia dos direitos dos animais, segundo a qual os animais, assim como os humanos, são sujeitos-de-uma-vida (e não vidas sem sujeitos), por também apresentarem, de forma autônoma, desejos, sensações de prazer e sofrimento; logo, também possuem valor inerente como os humanos e, por isso, devem ser tratados com respeito. Em outras palavras, os humanos possuem deveres diretos em relação aos animais, e não apenas deveres indiretos, como argumentam defensores da perspectiva antropocêntrica, no âmbito da ética animal. Ainda, como tem sido extensivamente documentado na literatura desde os anos 1970, Regan (2013) afirma que os direitos dos animais têm sido violados sistematicamente, devido à prevalência de um sistema que permite que os animais sejam vistos como seres desprovidos de valor inerente e explorados como recursos renováveis a serviço dos interesses humanos. Portanto, medidas para redução do sofrimento dos animais na pecuária ou na ciência - ainda que possam ser benéficas no curto prazo - não resolvem o problema, de acordo com Regan (2013). De sua perspectiva, somente a abolição total do uso de animais na ciência, a dissolução total da pecuária comercial, a eliminação total da caça comercial e esportiva e do aprisionamento corrigirão o erro do tratamento dado aos animais não-humanos. Regan (2013) também critica a posição defendida por Peter Singer (2010) para fundamentar a defesa dos animais como objetos de consideração moral, pois, segundo Regan, apesar de não permitir nenhum tipo de discriminação e considerar os interesses de todos com igual relevância (no caso de Singer, com base no critério da senciência), reconhece como importante a satisfação dos interesses do indivíduo, e não o valor do sujeito em si. $^{4}$

A perspectiva ecocêntrica, por sua vez, nos orienta para expandir a consideração moral a entidades ambientais coletivas, inclusive a elementos abióticos, espécies e ecossistemas. Uma implicação dessa perspectiva é a defesa de que sejam considerados moralmente reprováveis quaisquer atos humanos que possam interferir na integridade e

4 Além disso, Regan (2013) critica a característica agregadora do utilitarismo, presente no pensamento de Singer, que nos ordena totalizar ou somar as frustrações e satisfações de diferentes indivíduos a fim de poder tomar a melhor decisão que represente um equilíbrio entre as satisfações e frustrações totalizadas. Entretanto, a melhor decisão não necessariamente representa as melhores consequências para cada indivíduo, o que se coloca como um argumento contrário à perspectiva utilitarista senciocêntrica, de Singer. 
estabilidade dos ecossistemas, pois a realização ou manutenção do bem-estar dessas entidades ambientais coletivas possui relevância; em outras palavras, elas possuem um bem ou valor intrínseco. Aldo Leopold (2003), representante bem conhecido dessa corrente ética, argumenta que, na perspectiva da ética da terra (terra, aqui, sendo compreendida não como planeta, mas com um sentido aproximado de "território"), os seres humanos são considerados simples membros e cidadãos da comunidade da terra que deveriam respeitar tanto os membros companheiros quanto a comunidade como tal. Ainda de acordo com essa perspectiva, as entidades naturais e as comunidades bióticas devem ter asseguradas as condições para sua existência continuada. Logo, da perspectiva de Leopold, uma ação é correta quando tende a preservar a integridade, estabilidade e beleza da comunidade biótica; e é errada quando não o faz.

Em relação ao caso colocado acima, pode-se adotar diferentes posições com relação às justificações para atribuição do valor à ação e também com relação ao escopo da consideração moral. Por exemplo, com relação às teorias éticas, os estudantes podem assumir uma perspectiva consequencialista individualista (quando, por exemplo, a prioridade é o lucro individual), utilitarista (quando, por exemplo, deve haver a concordância sobre uma ação que beneficie o máximo possível de envolvidos) ou deontológica (quando, por exemplo, o princípio da não maleficência, associado a alguma interpretação do imperativo categórico, orienta as ações) ou, ainda, de ética das virtudes (quando, por exemplo, a virtude da não-violência [ahimsa] é prioridade para a ação). Por sua vez, eles podem assumir diferentes perspectivas quanto ao alcance da consideração moral: antropocêntrica (quando tendem a priorizar as preferências exclusivamente humanas, associadas às obras de arte), biocêntrica (quando tendem a priorizar os organismos vivos, sobretudo aqueles capazes de sentir dor, como, por exemplo, os golfinhos; é interessante notar que esta perspectiva também inclui os humanos) e ecocêntrica (quando tendem a priorizar o ecossistema como totalidade, o que permite incluir as algas, o leito oceânico etc.).

A fim de discutir estas possibilidades de posicionamentos, cabem algumas questões norteadoras, a serem colocadas pelo professor no âmbito de uma sequência didática, como:

- Que decisão você tomaria com relação ao caso? Por quê?

- Com base em seus conhecimentos de ética, que teoria ética (consequencialismo individualista, utilitarismo, deontologia ou ética das virtudes) justificaria a sua tomada de decisão com relação ao caso? Explique.

- Quais ou quem são os envolvidos no caso? Que perspectiva sobre o alcance da consideração moral (antropocentrismo, biocentrismo, ecocentrismo) você adotaria?

- Você acredita ser possível conciliar interesses da natureza não-humana (golfinhos, algas, ecossistemas etc.) com interesses humanos (direitos sociais, acesso à cultura etc.)? Justifique. 
A partir da colocação, pelo professor, das questões norteadoras para abordar o caso, podem ser explicitados os objetivos de aprendizagem em termos das dimensões CPA. No caso apresentado por Beckert (2004), podemos fixar, por exemplo, como objetivos de aprendizagem, as dimensões CPA do conteúdo "relações entre humanos e a natureza não-humana", mais comumente conhecida como "relações homem-natureza":

- Conceituais:

- memorizar fatos acerca da história da arte, dos naufrágios, do uso de recursos naturais por seres humanos; compreender os conceitos e princípios associados à ciência, como senciência, autonomia biológica, organismos, interações ecológicas, ecossistemas e fluxo de matéria e energia; além daqueles conceitos e princípios associados à ética, como valor instrumental e valor intrínseco; virtudes, consequencialismo individualista, consequencialismo utilitarista e deontologia; antropocentrismo, biocentrismo e ecocentrismo.

- Procedimentais:

- praticar técnicas, procedimentos e métodos relacionados a: levantamento e organização de informações bibliográficas em bases de dados acadêmicas, a fim de obter textos sobre o assunto; construção de textos dissertativos com clara exposição de ideias e argumentos; uso adequado dos procedimentos de citação e referenciação ao longo dos textos produzidos; análise e construção de argumentos sobre o caso, seja examinando-o, seja visando a elaboração de uma solução para ele; ou ainda, se os ambientes permitirem, prática de procedimentos técnicos, laboratoriais ou de campo, associados ao caso, que envolveria procedimentos, técnicas e métodos de biologia marinha, por exemplo.

- Atitudinais:

- mobilizar e aplicar de forma crítica valores, atitudes e normas, em suas dimensões ético-políticas explícitas, relacionados à consideração moral de humanos e não-humanos, aos critérios para atribuição de valor moral às ações humanas, de acordo com teorias éticas; ser capaz de considerar criticamente e profundamente os diversos valores e interesses sustentados pelos seres humanos nas suas relações com outros seres humanos e com a natureza não-humana, além de repensar e, se necessário, modificar seus próprios valores e ações.

Em suma, este é um breve exemplo do modelo de propostas de ensino com três elementos (caso, questões norteadoras e objetivos CPA de aprendizagem), que pode ser utilizado para a aplicação das QSC no contexto da educação CTSA, sob certas vertentes, em sala de aula. Para um diagrama, ver Figura 3 que representa graficamente esta abordagem. 
Figura 3 - Estrutura de três elementos (caso, questões norteadoras e objetivos CPA de aprendizagem) para abordagem de QSC em sala de aula, a partir do contexto pedagógico da educação CTSA

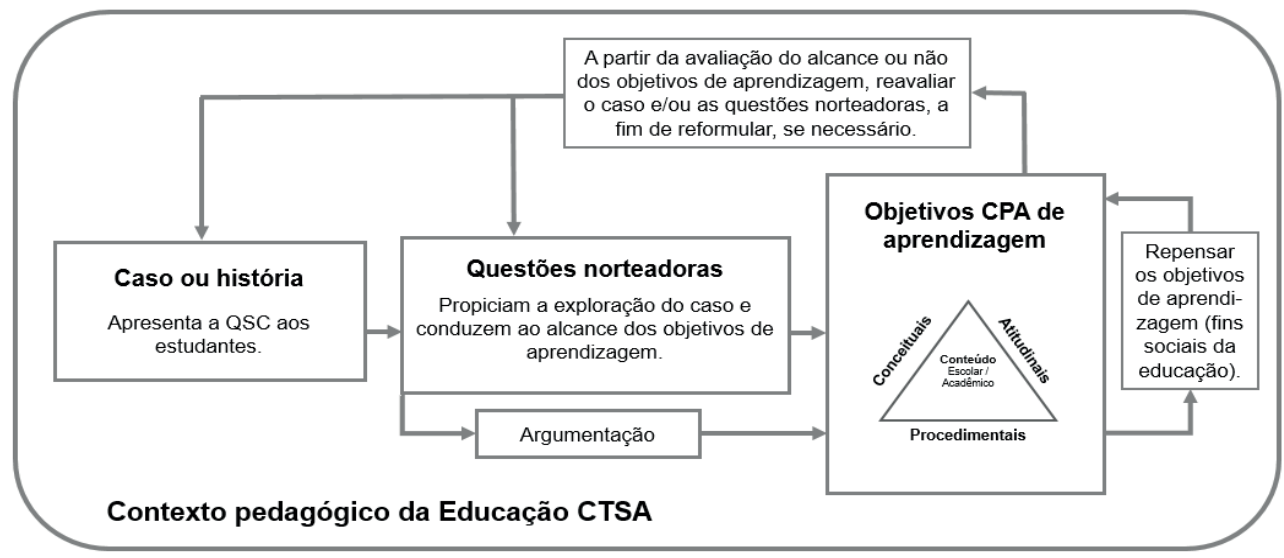

Fonte: elaborada pelos autores com base em Conrado (2017).

Propomos que as análises do papel da ética no ensino de ciências devem estar articuladas, do nosso ponto de vista, com o fomento do raciocínio lógico e do pensamento crítico. Em especial, com relação ao pensamento crítico, Villa e Poblete (2007, p. 76) afirmam que:

El pensamiento crítico va más allá de las destrezas del análisis lógico ya que, como señala Brookfield (1987), implica poner en cuestión los supuestos subyacentes en nuestras formas habituales de pensar y actuar $\mathrm{y}$, en base a ese cuestionamiento crítico, estar preparado para pensar y hacer de forma diferente. Para Moya (2005) el pensamiento crítico es el pensamiento de los interrogantes: ¿por qué las cosas son así?, ¿por qué las cosas no pueden ser de otro modo?, ¿por qué tú crees que las cosas son así?, ¿por qué alguien puede querer que las cosas sean así? [...] En consecuencia, diremos que una persona ha desarrollado la competencia de pensamiento crítico en la medida en que se interroga sobre las cosas y se interesa por los fundamentos en los que se asientan las ideas, las acciones, las valoraciones y juicios tanto propios como ajenos.

Por fim, em relação a um posicionamento neutro ou a uma não tomada de decisão sobre uma QSC, Hodson $(2011,2013)$ advoga o termo “imparcialidade comprometida”, que significa assumir uma posição, mas também não deixar de considerar mais possibilidades e promover a discussão. Deste modo, o professor pode, por um lado, posicionar-se e se comprometer, mostrando a importância de assumir posicionamentos em questões controversas, porém, de outro lado, sem impor sua posição aos estudantes, indicando as possibilidades da forma mais equilibrada possível; além de considerar argumentos e tolerar outros pontos de vista, numa discussão crítica, com atitudes relacionadas à empatia e à não-violência. (COLUCCI-GRAY et al., 2006) 
Uma questão fundamental e constantemente colocada é aquela sobre a avaliação da aprendizagem sobre valores, normas e atitudes. Para a avaliação do alcance da dimensão atitudinal dos conteúdos pelos estudantes, ou seja, do progresso dos estudantes quanto à aprendizagem de valores, normas e atitudes, Villa e Poblete (2007) e Coll e colaboradores (1992) organizam e recomendam indicadores, escalas de atitudes e níveis de progresso.

Para a avaliação do alcance das dimensões CPA dos conteúdos pelos estudantes, incluindo, obviamente, a dimensão atitudinal, e, ainda, com base nos quatro níveis de sofisticação do currículo, de Hodson $(2004,2011),{ }^{5}$ recomendamos ter como base a proposta de Conrado, Nunes-Neto e El-Hani (2016) de uma ferramenta para a análise do alcance de objetivos de aprendizagem pelo estudante durante a resolução de uma QSC (Quadro 2). A proposta consiste em adotar, para cada nível de sofisticação, quatro estágios de aprendizagem crescentes.

Quadro 2 - Instrumento para avaliação dos estágios de letramento científico crítico ${ }^{6}$

\begin{tabular}{|c|c|c|c|c|}
\hline Nível & Estágio o & Estágio 1 & Estágio 2 & Estágio 3 \\
\hline $\begin{array}{l}\text { 1. Reconhecimento } \\
\text { de relações CTSA }\end{array}$ & $\begin{array}{l}\text { Não percebe } \\
\text { conexões e } \\
\text { compartimentaliza } \\
\text { questões e } \\
\text { conhecimentos } \\
\text { entre C, T, S, A na } \\
\text { QSC }\end{array}$ & $\begin{array}{l}\text { Indica benefícios } \\
\text { da ciência e } \\
\text { da tecnologia } \\
\text { sobre sociedade } \\
\text { e ambiente } \\
\text { (perspectiva } \\
\text { salvacionista) }\end{array}$ & $\begin{array}{l}\text { Aponta } \\
\text { demandas da } \\
\text { sociedade sobre } \\
\text { a ciência e a } \\
\text { tecnologia ou } \\
\text { impactos da } \\
\text { ciência e da } \\
\text { tecnologia sobre } \\
\text { a sociedade e o } \\
\text { ambiente }\end{array}$ & $\begin{array}{l}\text { Reconhece que ciência e } \\
\text { tecnologia são, em certa } \\
\text { medida, culturalmente } \\
\text { determinadas, indicando } \\
\text { relações mútuas entre } \\
\text { conhecimentos de C, T, S, A }\end{array}$ \\
\hline $\begin{array}{l}\text { 2. Reconhecimento } \\
\text { da influência } \\
\text { de interesses } \\
\text { e do poder no } \\
\text { desenvolvimento } \\
\text { científico e } \\
\text { tecnológico }\end{array}$ & $\begin{array}{l}\text { Assume } \\
\text { neutralidade } \\
\text { da ciência e da } \\
\text { tecnologia ou não } \\
\text { explicita valores } \\
\text { e interesses } \\
\text { envolvidos na } \\
\text { atividade científica } \\
\text { e tecnológica }\end{array}$ & $\begin{array}{l}\text { Indica a } \\
\text { influência de } \\
\text { interesses de } \\
\text { determinados } \\
\text { grupos sociais no } \\
\text { desenvolvimento } \\
\text { científico e } \\
\text { tecnológico }\end{array}$ & \begin{tabular}{|l} 
Explicita que a \\
influência do \\
poder, na ciência \\
e na tecnologia, \\
pode gerar \\
consequências \\
negativas para \\
indivíduos, \\
sociedades e \\
ambientes
\end{tabular} & $\begin{array}{l}\text { Reconhece que as atividades } \\
\text { científica e tecnológica } \\
\text { ocorrem sob interesses de } \\
\text { particulares para benefícios } \\
\text { de alguns, às custas de outros, } \\
\text { encontrando exemplos na QSC }\end{array}$ \\
\hline
\end{tabular}

5 Para mais detalhes acerca dos quatro estágios de sofisticação do currículo para ações sociopolíticas relacionadas com a sustentabilidade ambiental, ver Hodson (2011) e Conrado e colaboradores. (2016).

6 Entendemos letramento científico crítico com base em Hodson (2011) e Zeidler e colaboradores (2005). Para nós, um estudante é letrado cientificamente, de um ponto de vista crítico, quando a sua aprendizagem das dimensões CPA dos conteúdos the permite o domínio de habilidades para utilizar adequadamente a linguagem científica (a partir da sua apropriação de modos de falar e argumentar em ciências), maior autonomia (com relação à adaptação de suas decisões com relação às condições naturais ou sociais do entorno), tomar decisões socioambientalmente responsáveis sobre QSC (considerando adequadamente as suas dimensões ético-políticas) e, por fim, executar ações sociopolíticas com relação às QSC, em direção a maiores justiça social e sustentabilidade ambiental. Para mais detalhes, ver Ferreira e colaboradores. (2016), Conrado (2017) e Conrado e colaboradores. (2016). 


\begin{tabular}{|l|l|l|l|l|}
\hline Nível & Estágio o & Estágio 1 & Estágio 2 & Estágio 3 \\
\hline $\begin{array}{l}\text { 3. Capacidade } \\
\text { para abordar } \\
\text { criticamente } \\
\text { controvérsias, para } \\
\text { explicitar valores } \\
\text { e para emitir juízo } \\
\text { ético }\end{array}$ & $\begin{array}{l}\text { Não aponta } \\
\text { controvérsias e } \\
\text { valores distintos } \\
\text { envolvidos nas } \\
\text { relações entre } \\
\text { CTSA e na QSC }\end{array}$ & $\begin{array}{l}\text { Menciona a } \\
\text { presença de } \\
\text { diferentes } \\
\text { valores e } \\
\text { pontos de vista } \\
\text { envolvidos na } \\
\text { QSC }\end{array}$ & $\begin{array}{l}\text { Questiona } \\
\text { juízos, valores e } \\
\text { decisões próprias } \\
\text { e dos outros }\end{array}$ & $\begin{array}{l}\text { Analisa criticamente } \\
\text { contradições e coerência } \\
\text { entre valores e condutas para } \\
\text { formular sua própria opinião } \\
\text { e juízo moral, justificados de } \\
\text { modo fundamentado }\end{array}$ \\
\hline $\begin{array}{l}\text { 4. Capacidade para } \\
\text { tomada de decisão } \\
\text { e para ações } \\
\text { sociopolíticas }\end{array}$ & $\begin{array}{l}\text { Não toma decisões } \\
\text { sobre a QSC }\end{array}$ & $\begin{array}{l}\text { Toma decisões } \\
\text { desconsiderando } \\
\text { consequências, } \\
\text { prós e contras } \\
\text { de ações e } \\
\text { propostas }\end{array}$ & $\begin{array}{l}\text { Toma decisões, } \\
\text { considerando } \\
\text { implicações, } \\
\text { prós e contras e } \\
\text { efeitos de ações } \\
\text { e propostas }\end{array}$ & $\begin{array}{l}\text { Toma decisões } \\
\text { socioambientalmente } \\
\text { responsáveis e parte para a buscando coerência } \\
\text { ação, conhecimentos, valores, } \\
\text { objetivos e condutas }\end{array}$ \\
\hline
\end{tabular}

Fonte: elaborado pelos autores com base em Conrado (2017).

Por fim, acreditamos que a capacitação para ações sociopolíticas e, a longo prazo, a formação de ativistas, que implica transformações de identidades pessoais dos estudantes, podem seguir da estrutura que propomos para a abordagem das QSC em salas de aula ou em comunidades de aprendizagem mais abrangentes. Muito embora não nos pareça necessário que ações sociopolíticas e iniciativas de ativismo estejam sempre presentes no alcance dos objetivos de aprendizagem de conteúdos nas dimensões CPA, nos parece que alcançar esses objetivos pode conduzir a ações sociopolíticas e ativismo, pois, de modo interessante, há uma certa progressão entre dimensões conceituais, procedimentais e atitudinais ao longo dos estágios e níveis da estrutura curricular para ações sociopolíticas, proposta por Hodson $(2004,2011)$ e operacionalizada aqui por nós. Em outras palavras, ao passo em que a aprendizagem de fatos, conceitos e princípios, assim como de procedimentos, técnicas e métodos é ponto de partida e meio, o alcance da aprendizagem de valores, normas e atitudes, culminando idealmente com a prática de ações sociopolíticas e iniciativas duradouras de ativismo, é - ou deveria ser - o ponto de chegada da estrutura curricular.

\section{Considerações finais}

Neste capítulo, apresentamos uma abordagem possível para o ensino de ciências que visa superar problemas da educação tradicional-tecnicista e, ainda, é alinhada com certas vertentes da educação CTSA, aquelas orientadas ao desenvolvimento moral e à explicitação de valores, além daquela voltada ao ativismo sociopolítico, descritas por Pedretti e Nazir (2011). Mais precisamente, propusemos, levando em conta contribuições destas duas vertentes da educação CTSA, uma estrutura de três elementos interconectados (casos que expõe QSC, questões norteadoras e objetivos CPA de aprendizagem) como uma heurística possível para o trabalho com QSC em salas de aula de ciências. 
Parece-nos muito importante que as aplicações de propostas de ensino baseadas em QSC, seguindo a abordagem que aqui expusemos, tenham como meta o fomento de ações sociopolíticas e a formação de ativistas sociopolíticos a longo prazo. Para isso, é importante que os professores de ciências - apesar de todos os contratempos que enfrentam em suas atividades profissionais (relacionados, por exemplo, a excesso de carga horária letiva, más condições de trabalho, baixo engajamento da comunidade escolar e do seu entorno) - estejam preparados para utilizar sua autonomia e as oportunidades de que dispõem para uma formação efetiva de estudantes capazes de se engajarem em causas sociais e ambientais relevantes. Para isto, pode ser muito positivo o estabelecimento de comunidades de prática, para trabalhos colaborativos, entre professores do ensino básico, pesquisadores em educação científica e tecnológica e estudantes de pós-graduação.

Num mundo que já se encontra hoje em crise, as novas gerações enfrentarão grandes desafios socioambientais e os jovens precisam estar preparados. Neste sentido, a educação científica - se realizada com a intenção de preparar nossos jovens para tais desafios, com os compromissos morais que isto exige por parte de todos os atores sociais envolvidos com a educação - pode ser um caminho com muitos frutos a oferecer.

\section{Referências}

ANDRADE, M. A. S. et al. Agrotóxicos como questão sociocientífica na Educação CTSA. REMEA - Revista Eletrônica do Mestrado de Educação Ambiental, Rio Grande, v. 33, n. 1, p. 171-191, 2016.

ARANHA, M. L. de A. Filosofia da Educação. 3. ed. rev. ampl. São Paulo: Moderna, 2006.

AULER, D.; BAZZO, W. A. Reflexões para a implementação do movimento CTS no contexto educacional brasileiro. Ciência \& Educação, Bauru, v. 7, n. 1, p. 1-13, 2001.

AULER, D.; DELIZOICOV, D. Ciência-tecnologia-sociedade: relações estabelecidas por professores de ciências. Revista Electrónica de Enseñanza de las Ciencias, Ourense, v. 5 , n. 2, p. 337-355, 2006 .

BARRETT, S.; PEDRETTI, E. Conflicting orientations to science - technology society - environment education. School Science and Mathematics, Menasha, v. 106, n. 5, p. 21-31, 2006.

BECKERT, C. Dilemas de Ética Ambiental: Estudo de um caso. Lisboa: Sociedade de Ética Ambiental \& Apenas Livros, 2004.

BECKERT, C. Ética. Lisboa: Centro de Filosofia da Faculdade de Lisboa, 2012.

BENCZE, L.; ALSOP, S. Ecojustice through responsibilist Science Education. In: ANNUAL CONFERENCE OF THE CANADIAN SOCIETY FOR THE STUDY OF EDUCATION, 2009, Ottawa. Proceedings... Ottawa: Carleton University, 2009. p. 1-28. 
BENCZE, J. L.; CARTER, L.; KRSTOVIC, M. Science \& technology education for personal, social \& environmental wellbeing: challenging capitalists' consumerist strategies. Revista Brasileira de Pesquisa em Educação em Ciências, Belo Horizonte, v. 14, n. 2, p. 39-56, 2014.

BERGANDI, D. The structural links between ecology, evolution and ethics: the virtuous epistemic circle. Dordrecht: Springer, 2013.

BERGANDI, D.; BLANDIN, P. From the protection of nature to sustainable development: the genesis of an ethical and political oxymoron. Revue d'histoire des sciences, Paris, v. 65, n. 1, jan./jun. 2012.

BERKOWITZ, M. W.; SIMMONS, P. Integrating science education and character education: the role of peer discussion. In: ZEIDLER, D. (Ed.). The role of moral reasoning on socioscientific issues and discourse in science education. Dordrecht, The Netherlands: Kluwer Academic Publishers, 2003. p. 117-138. (Science \& Technology Education Library, 19).

BONJOUR, L.; BAKER, A. Filosofia: textos fundamentais comentados. 2. ed. Porto Alegre: Artmed, 2010.

BORTOLETTO, A.; CARVALHO, W. L. P. Temas sociocientíficos: análise dos processos argumentativos no contexto escolar. In: CARVALHO, L. O. de; CARVALHO, W. L. P. de. (Org.). Formação de professores e questões sociocientíficas no ensino de ciências. São Paulo: Escrituras, 2012. p. 249-270.

BRASIL. Secretaria de Educação Fundamental. Parâmetros curriculares nacionais $\left(1^{a} a\right.$ $4^{a}$ séries). Brasília, DF, 1997.

BRASIL. Secretaria de Educação Fundamental. Parâmetros curriculares nacionais $\left(5^{a} a\right.$ $8^{a}$ séries). Brasília, DF, 1998.

BROWN-ACQUAYE, H. A. Each is necessary and none is redundant: the need for science in developing countries. Science Education, [S.l.], v. 85, n. 1, p. 68-70, 2001.

CARNEIRO, F. F. et al. (Org.). Dossiê ABRASCO: um alerta sobre os impactos dos agrotóxicos na saúde. Rio de Janeiro: EPSJV; São Paulo: Expressão Popular, 2015.

CARTER, L. Sociocultural influences on science education: innovation for contemporary times. Science Education, [S.1.], v. 92, n. 1, p. 165-181, 2008.

CARVALHO, I. N. Uma proposta de critérios para selecionar conteúdos conceituais para o ensino médio de biologia. 2016. 73 f. Dissertação (Mestrado em Ensino, Filosofia e História das Ciências) - Instituto de Física, Universidade Federal da Bahia, Salvador, 2016.

CARVALHO, I. N.; NUNES-NETO, N. F.; EL-HANI, C. N. Como selecionar conteúdos de biologia para o ensino médio? Revista de Educação, Ciências e Matemática, Duque de Caxias, v. 1, n. 1, p. 67-100, 2011.

CLÉMENT, P. Didactic transposition and KVP model: Cconceptions as interactions between Scientific knowledge, Values and Social Practices. In: CONFERENCE OF 
THE EUROPEAN SCIENCE EDUCATION RESEARCH ASSOCIATION, 2006, Braga. Atas... Braga: ESERA Summer School, 2006. p. 9-18.

COLL, C. et al. Los contenidos de la Reforma. Enseñanza y aprendizaje de conceptos, procedimientos y actitudes. Madrid: Santillana, 1992.

COLUCCI-GRAY, L. et al. From scientific literacy to sustainability literacy: an ecological framework for education. Science Education, New York, v. 90, n. 2, p. 227 252, 2006.

CONRADO, D. M. et al. Uso do conhecimento evolutivo na tomada de decisão de estudantes do ensino médio sobre questões socioambientais. Revista Contemporânea de Educação, Rio de janeiro, n. 14, p. 345-368, ago./dez. 2012.

CONRADO, D. M. et al. Evolução e ética na tomada de decisão em questões sociocientíficas. Revista Electrónica de Enseñanza de las Ciencias, Ourense, p. 803-807, 2013. Edição especial.

CONRADO, D. M. et al. Socioscientific issues about bees, pollination and food production in biology teaching. In: CONFERENCE OF THE EUROPEAN SCIENCE EDUCATION RESEARCH ASSOCIATION, 11., 2015, Helsinki. Proceedings... Helsinki, Finlândia: ESERA, 2015. p. 1-4.

CONRADO, D. M. et al. Ensino de biologia a partir de questões sociocientíficas: uma experiência com ingressantes em curso de licenciatura. Indagatio Didactica, Aveiro, v. 8, n. 1, p. 1132-1147, julho, 2016.

CONRADO, D. M. Questões Sociocientíficas na Educação CTSA: contribuições de um modelo teórico para o letramento científico crítico. 2017. 218 f. Tese (Doutorado em Ensino, Filosofia e História das Ciências) - Instituto de Física, Universidade Federal da Bahia, Salvador, 2017.

CONRADO, D. M. Uso de conhecimentos evolutivo e ético na tomada de decisão por estudantes de biologia. 2013. $220 \mathrm{f}$. Tese (Doutorado em Ecologia) - Instituto de Biologia, Universidade Federal da Bahia, Salvador, 2013.

CONRADO, D. M.; CONRADO, I. S. Cientificismo: uma análise crítica do discurso no ensino superior de biologia. In: CONGRESSO IBERO AMERICANO DE INVESTIGAÇÃO QUALITATIVA EM EDUCAÇÃO, 5., 2016, Porto. Atas... Porto: Universidade Lusófona do Porto, 2016a. p. 1054-1059.

CONRADO, D. M.; CONRADO, I. S. Análise crítica do discurso sobre imagens da ciência e da tecnologia em argumentos de estudantes de biologia. Revista de Pesquisa Qualitativa, São Paulo, v. 4, n. 5, p. 218-231, 2016 b.

CONRADO, D. M.; EL-HANI, C. N. Formação de cidadãos na perspectiva CTS: reflexões para o ensino de ciências. In: SIMPÓSIO NACIONAL DE ENSINO DE CIÊNCIA E TECNOlOGIA, 2., 2010, Ponta Grossa. Atas... Ponta Grossa: UTFPR, 2010. CONRADO, D. M.; EL-HANI, C. N.; NUNES-NETO, N. F. Sobre a ética ambiental na formação do biólogo. REMEA-Revista Eletrônica do Mestrado em Educação Ambiental, Rio Grande, v. 30, n. 1, p. 120-139, jan./jun. 2013. 
CONRADO, D. M.; NUNES-NETO, N. F.; EL-HANI, C. N. Análise de argumentos em uma questão sociocientífica no ensino de biologia. In: ENCONTRO NACIONAL DE ENSINO DE BIOLOGIA, 6.; ENCONTRO REGIONAL DE ENSINO DE BIOLOGIA DA REGIONAL 3, 8., 2016, Maringá. Anais... Maringá: Universidade Estadual de Maringá, 2016.

CONRADO, D. M.; NUNES-NETO, N. F. Dimensões do conteúdo em questões sociocientíficas no ensino de ecologia. In: ENCONTRO NACIONAL DE EDUCAÇÃO EM CIÊNCIAS, 16., 2015, Lisboa. Atas... Lisboa: Instituto de Letras, Universidade de Lisboa, 2016. p. 432-435, 2015.

COPI, I. Introdução à lógica. São Paulo: Mestre Jou, 1968.

DRIVER, R.; NEWTON, P.; OSBORNE, J. Establishing the norms of scientific argumentation in classrooms. Science Education, New York, v. 84, n. 3, p. 287-312, 2000 .

FELIPE, S. T. Antropocentrismo, sencientismo e biocentrismo: perspectivas éticas abolicionistas, bem-estaristas e conservadoras e o estatuto de animais não-humanos. Revista Páginas de Filosofia, São Bernardo do Campo, v. 1, n. 1, p. 2-30, jan./jul. 2009.

FERNANDES, C. S.; STUANI, G. M. Agrotóxicos no ensino de ciências: uma pesquisa na educação do campo. Educação \& Realidade, Porto Alegre, v. 40, n. 3, p. 745-762, 2015.

FERREIRA, T. A. S. et al. Ensino de análise do comportamento com o uso de questões sociocientíficas: um caso sobre a medicalização da vida. Indagatio Didactica, Aveiro, v. 8 , n. 1, p. 1481-1497, jul. 2016.

FOUREZ, G. A construção das ciências: introdução à filosofia e à ética das ciências. São Paulo: UNESP, 1995.

FOUREZ, G. Educar: docentes, alunos, escolas, éticas, sociedades. Aparecida, SP: Idéias e Letras, 2008.

FREIRE, P. Pedagogia da autonomia: saberes necessários à prática educativa. São Paulo: Paz e Terra, 1996.

FULLICK, P.; RATCLIFFE, M. (Ed.). Teaching ethical aspects of science. Totton: Bassett Press, 1996.

GIROUX, H. A. Theory and resistance in education. London: Bergin \& Garvey, 2001.

GOERGEN, P. Educação moral hoje: cenários, perspectivas e perplexidades. Educação \& Sociedade, Campinas, v. 28, n. 100, p. 737-762, 2007. Edição especial.

GUIMARÃES, A. G.; CARVALHO, W. L. P. de; OLIVEIRA, M. S. Raciocínio moral na tomada de decisões em relação a questões sociocientíficas: o exemplo do melhoramento genético humano. Ciência \& Educação, Bauru, v. 16, n. 2, p. 465-477, 2010. 
HEMPEL, M. Ecoalfabetización: el conocimiento no es suficiente. In: MASTNY, L. (Ed.). Gobernar para la sostenibilidad: la situación del mundo 2014. Barcelona: Icaria editorial, 2014. p. 79-93.

HODSON, D. Going Beyond STS: towards a curriculum for sociopolitical action. The Science Education Review, [S.1.], v. 3, v. 1, p. 2-7, 2004.

HODSON, D. Looking to the future: building a curriculum for social activism. Rotterdam: Sense Publishers, 2011.

HODSON, D. Don't be nervous, don't be flustered, don't be scared: be prepared. Canadian Journal of Science, Mathematics and Technology Education, Canadá, v. 13, n. 4, p. 313-331, 2013.

HURTSHOUSE, R. Normative Virtue Ethics. In: SHAFER-LANDAU, R. (Ed.). Ethical theory: an anthology. $2^{\text {nd }}$. Oxford: Wiley-Blackwell, 2013. p. 645-652.

JIMÉNEZ-ALEIXANDRE, M. P.; PEREIRO-MUÑOZ, C. Knowledge producers or knowledge consumers? Argumentation and decision making about environmental management. International Journal of Science Education, London, v. 24, n. 11, p. 11711190, 2002.

JIMÉNEZ-ALEIXANDRE, M. P.; FREDERICO-AGRASO, M. A argumentação sobre questões sociocientíficas: processos de construção e justificação do conhecimento em sala de aula. Educação em Revista, Belo Horizonte, v. 43, n. 1, p. 13-33, 2006.

KENTLY, F. D. Comparison of hidden curriculum theories. European Journal of Educational Studies, Bucharest, v. 1, n. 2, p. 83-88, 2009.

KERCKHOFF, A. S.; REIS, G. Responsible Stewards of the Earth: narratives of youth activism in high school (science). In: BENCZE, L.; ALSOP, S. (Ed.). Activist science and technology education. Dordrecht: Springer Netherlands, 2014. p. 465-476.

KNIGHT, J. K.; WOOD, W. B. Teaching more by lecturing less. The American Society for Cell Biology, Bethesda, v. 4, p. 298-310, 2005.

KRSTOVIC, M. Preparing students for self-directed research-informed actions on socioscientific issues. In: BENCZE, L.; ALSOP, S. (Ed.). Activist science and technology education. Dordrecht: Springer Netherlands, 2014. p. 399-417.

LACEY, H. Valores e atividade científica 2. São Paulo: Associação Filosófica Scientiae Studia: Ed. 34, 2010.

LAYTON, D. Revaluing the T in STS. International Journal of Science Education, London, v. 10, n. 4, p. 367-378, 1988.

LEOPOLD, A. The land ethic. In: LIGHT, A.; ROLSTON III, H. (Ed.). Environmental Ethics: an anthology. Malden-MA: Wiley-Blackwell, 2003. p. 38-46.

LEVINSON, R. Towards a theoretical framework for teaching controversial socioscientific Issues. International Journal of Science Education, London, v. 28, n. 10, p. 1201-1224, Aug. 2006. 
LIMA, G. Z. de; LINHARES, R. E. C. Escrever bons problemas. Revista Brasileira de Educação Médica, Rio de Janeiro, n. 32, v. 2, p. 197-201, 2008.

LODI, L. H.; ARAÚJO, U. F. Ética e cidadania e educação: escola, democracia e cidadania. In: Ética e cidadania: construindo valores na escola e na sociedade. Brasília, DF: Ministério da Educação, Secretaria de Educação Básica, 2007. p. 69-84.

LUCKESI, C. C. Filosofia da educação. 3. ed. São Paulo: Cortez, 2011.

SILVA, J. M. da. Ética prática: contributos para as Políticas da Água. Lisboa: Sociedade de Ética Ambiental / Apenas Livros, 2003. (Breviário de Ética Ambiental, n. 8).

MARTÍN, M. M. Conocer, manejar, valorar, participar: los fines de una educación para la ciudadanía. Revista Iberoamericana de Educación, Madrid, n. 42, p. 69-83, 2006.

MARTÍNEZ PÉREZ, L. F. M. Questões sociocientíficas na prática docente: ideologia, autonomia e formação de professores. São Paulo: UNESP, 2012.

MARTÍNEZ PÉREZ, L. F. M.; CARVALHO, W. L. P. Contribuições e dificuldades da abordagem de questões sociocientíficas à prática de professores de ciências. Educação e Pesquisa, São Paulo, v. 38, p. 728-742, 2012.

MARTÍNEZ PÉREZ, L. F.; PARGA LOZANO, D. L. La emergencia de las cuestiones sociocientíficas en el enfoque CTSA. Góndola, Enseñanza y Aprendizaje de las Ciencias, Bogotá, v. 8, n. 1, p. 23-35, 2013.

MARTÍNEZ PÉREZ, L. F.; VILLAMIZAR FÚQUENE, D. P. Unidades didácticas sobre cuestiones socio científicas: construcciones entre la escuela y la universidad. Bogotá: Colciencias; Alternaciencias: Universidad Pedagógica Nacional, 2014.

MATTHEWS, M. R. Science teaching: the role of History and Philosophy of Science. Routledge: London, 1994.

MEADOWS, D. H. The limits to growth. New York: Universe Books, 1972.

NORTON, B. Searching for sustainability: interdisciplinary essays in the Philosophy of Conservation Biology. Cambridge: Cambridge University Press, 2003.

NOSS, R. F. Values are a good thing in Conservation Biology. Conservation Biology, Boston, v. 21, n. 1, p. 18-20, 2007.

OLIVEIRA, R. J. O ensino das ciências e a ética na escola: interfaces possíveis. Química Nova na Escola, São Paulo, v. 32, n. 4, p. 227-232, 2010.

OSBORNE, J.; EDURAN, S.; SIMON, S. Enhancing the quality of argument in school science. Journal of Research in Science Teaching, New York, v. 41, n. 10, p. 994-1020, 2004.

PEDRETTI, E.; NAZIR, J. Currents in STSE education: mapping a complex field, 40 years on. Science Education, New York, v. 95, n. 4, p. 601-626, 2011.

PEDRETTI, E.; FORBES, J. STSE education: from curriculum rhetoric to classroom reality. Orbit, v. 31, n. 3, p. 39-41, 2000. 
PINZANI, A. Democracia versus tecnocracia: apatia e participação em sociedades complexas. Lua Nova, São Paulo, n. 89, p. 135-168, 2013.

RACHELS, J. Introducción a la filosofía moral. México: Fondo de Cultura Económica, 2006.

RACHELS, J. Problemas da filosofia. 2. ed. Lisboa: Gradiva, 2010. (Coleção Filosofia Aberta, 19).

RACHELS, J.; RACHELS, S. A coisa certa a fazer: leituras básicas sobre filosofia moral. 6. ed. Porto Alegre: AMGH, 2014.

RATCLIFFE, M.; GRACE, M. Science education for citizenship: teaching socio-scientific issues. Maidenhead: Open University Press, 2003.

REGAN, T. Animal Rights and Environmental Ethics. In: BERGANDI, D. (Ed.). The Structural Links between ecology, evolution and ethics: the virtuous epistemic circle. Dordrecht: Springer, 2013. p. 117-126.

REIS, P. Factors of success regarding classroom discussions of SSI: a cross-case study. Les Dossiers des Sciences de L'éducation, Toulouse, n. 29, p. 67-80, 2013.

REIS, P. Acción socio-política sobre cuestiones socio-científicas: reconstruyendo la formación docente y el currículo. Revista Uni-pluri/versidad, Lisboa, v. 14, n. 2, 2014.

REIS, G.; NG-A-FOOK, N.; GLITHERO, L. Provoking ecojustice-taking citizen science and youth activism beyond the school curriculum. In: MUELLER, M. P.; TIPPINS, D. J. (Ed.). EcoJustice, citizen science and youth activism: situated tensions for Science Education. Cham, Switzerland: Springer, 2015. p. 39-61.

SÁ, L. P.; QUEIROZ, S. L. Promovendo a argumentação no ensino superior de química. Química Nova, São Paulo, v. 30, n. 8, p. 2035-2042, 2007.

SÁ, L. P.; QUEIROZ, S. L. Estudo de casos no ensino de química. Campinas: Átomo, 2010.

SADLER, T. D. Moral and ethical dimensions of socioscientific decision-making as integral components of science literacy. Science Educator, Glastonbury, v. 13, p. 39-48, 2004a.

SADLER, T. D. Moral sensitivity and its contribution to the resolution of socioscientific issues. Journal of Moral Education, Abingdon, v. 33, n. 3, p. 339-358, 2004b.

SADLER, T. D.; BARAB, S. A.; SCOTT, B. What do students gain by engaging in socioscientific inquiry? Research in Science Education, Dordrecht, v. 37, n. 4, p. 371-391, 2007.

SADLER, T. D.; ZEIDLER, D. L. The morality of socioscientific issues: construal and resolution of genetic engineering dilemmas. Science Education, New York, v. 88, n. 1, p. 4-27, 2004. 
SANTOS, W. L. P. dos. Scientific literacy: a freirean perspective as a radical view of humanistic science education. Science Education, New York, v. 93, n. 2, p. 361-382, 2009.

SANTOS, W. L. P. Educação CTS e cidadania: confluências e diferenças. Amazônia, Belém, v. 9, n. 17, p. 49-62, 2012.

SANTOS, W. L. P. dos; MORTIMER, E. F. Uma análise de pressupostos teóricos da abordagem C-T-S (Ciência-Tecnologia-Sociedade) no contexto da educação brasileira. Ensaio Pesquisa em Educação em Ciências, Belo Horizonte, v. 2, n. 2, p. 133-162, 2002.

SARMENTO, A. C. de H. et al. Investigando princípios de design de uma sequência didática sobre metabolismo energético. Ciência \& Educação, Bauru, v. 19, n. 3, p. 573598, 2013.

SAVIANI, D. Política e educação no Brasil: o papel do congresso nacional na legislação do ensino. Campinas: Autores Associados, 1987.

SAVIN-BADEN, M.; MAJOR, C. H. Foundations of problem-based learning: Great Britain: MPG Books: Open University Press, 2004.

SILVA, S. M. B.; SANTOS, W. L. P. dos. Questões sociocientíficas e o lugar da moral nas pesquisas em ensino de ciências. Interacções, Lisboa, v. 10, n. 31, p. 124-148, 2014.

SINGER, P. (Ed.). Compendio de ética. Madrid: Alianza Editorial, 2004.

SINGER, P. Libertação Animal. Porto Alegre: Lugano, 2010.

SINGER, P. The Expanding circle: ethics, evolution, and moral progress. Princeton: Princeton University Press, 2011.

SOLBES, J. Contribución de las cuestiones sociocientíficas al desarrollo del pensamiento crítico (II): Ejemplos. Revista Eureka sobre Enseñanza y Divulgación de La Ciencias, Puerto Real, v. 10, n. 2, p. 148-158, 2013.

SOLOMON, J. Teaching science, technology and society. Buckingham: Open University Press, 1993.

TAN, M. Science teacher activism: the case of environmental education. Journal for Activist Science \& Technology Education, Toronto, v. 1, n. 1, p. 32-43, 2009.

TORRES-MERCHÁN, N. Y. El abordaje de situaciones contextuales para la solución de problemas y la toma de decisiones. Zona Próxima, Barranquilla, n. 14, p. 126-141, 2011.

VAZ, S. A. G.; DELFINO, Â. Manual de ética ambiental. Lisboa: Universidade Aberta, 2010 .

VELLOSO, A. M. S. et al. Argumentos elaborados sobre o tema "corrosão" por estudantes de um curso superior de química. Revista Electrónica de Enseñanza de las Ciencias, Ourense, v. 8, n. 2, p. 593-616, 2009. 
VILCHES, A.; GIL-PÉREZ, D.; PRAIA, J. De CTS a CTSA: educação por um futuro sustentável. In: SANTOS, W. L. P. dos; AULER, D. (Org.). CTS e educação científica: desafios, tendências e resultados de pesquisas. Brasília: UnB, 2011. p. 161-184.

VILLA, A.; POBLETE, M. Aprenizaje basado en competencias: una propuesta para la evaluación de las competencias genéricas. Bilbao: Universidad de Deusto, 2007.

VON LINSINGEN, I. Perspectiva educacional CTS: aspectos de um campo em consolidação na América Latina. Ciência \& Ensino, Campinas, v. 1, p. 1-19, nov. 2007. Edição especial.

VON LINSINGEN, I.; CASSIANI, S. Educação CTS em perspectiva discursiva: contribuições dos Estudos Sociais da Ciência e da Tecnologia. Redes, Buenos Aires, v. 16, n. 31, p. 163-182, 2010.

WORLD WILDLIFE FUND. WWF. Living Planet Report 2014: Summary. Gland, 2014. WARBURTON, N. Elementos básicos de filosofia. 2. ed. Lisboa: Gradiva, 2007. ZABALA, A. A prática educativa: como ensinar. Porto Alegre: Artes Médicas Sul, 1998. ZABALA, A.; ARNAU, L. Como aprender e ensinar competências. Porto Alegre: Artmed, 2010.

ZEIDLER, D. L.; KEEFER, M. The role of moral reasoning and the status of socioscientific issues in science education. In: ZEIDLER, D. L. (Ed.). The role of moral reasoning in socioscientific issues and discourse in science education. Dordrecht: Kluwer, 2003. p. 7-38.

ZEIDLER, D. et al. Beyond STS: A Research-based Framework for Socioscientific Issues Education. Science Education, New York, n. 89, p. 357-377, 2005.

ZIMAN, J. The rationale for STS is in the approach. In: SOLOMON, J.; AIKENHEAD, G. (Ed.). STS education: international perspectives on reform. New York: Teachers College Press, 1994. p. 21-31. 


\title{
USO DE AGROTÓXICOS UMA QUESTÃO SOCIOCIENTÍFICA PARA O ENSINO MÉDIO
}

\author{
Maria Aparecida da Silva Andrade \\ Nei Nunes-Neto \\ Rosiléia Oliveira de Almeida
}

\section{Introdução}

Embora a indústria de agrotóxicos tenha surgido após a Primeira Guerra Mundial, seu uso foi difundido, nos Estados Unidos e na Europa, após a Segunda Guerra Mundial e, no Brasil, durante o período que ficou conhecido como o de modernização da agricultura nacional, situado entre 1945 e 1985. (LONDRES, 2011) Essa modernização da agricultura, chamada de "Revolução Verde", trouxe uma série de mudanças no que se refere ao processo tradicional de trabalho na agricultura e no campo da produção. Diversas políticas foram implementadas em todo o mundo para expandir e assegurar este mercado. Segundo seus promotores, essa Revolução Verde seria fundamental para derrotar a fome que assolava boa parte da população mundial. Nesse processo, o que era produzido somente para a subsistência das famílias passou a ser produzido em larga escala para atender às necessidades de uma população crescente, assim como também a interesses comerciais de oligarquias político-econômicas. (LONDRES, 2011; PERES, 1999)

Segundo Londres (2011), várias medidas foram tomadas no cenário mundial, a fim de ajudar na modernização da agricultura, sendo que a Food and Agriculture Organiza- 
tion of the United Nations ${ }^{1}$ (FAO) e o Banco Mundial foram os maiores promotores da difusão do pacote tecnológico da Revolução Verde.

No Brasil, foram realizadas políticas de isenção fiscal e tributária às empresas multinacionais; houve também a criação, em 1965, do Sistema Nacional de Crédito Rural, que vinculava a obtenção de crédito agrícola à obrigatoriedade da compra de insumos químicos pelos agricultores. Outro elemento-chave foi a criação, em 1975, do Programa Nacional de Defensivos Agrícolas, no âmbito do Il Plano Nacional de Desenvolvimento (PND), que proporcionou recursos financeiros para a criação de empresas nacionais e a instalação de subsidiárias de empresas transnacionais de insumos agrícolas no país. Um outro fator ainda a colaborar de forma marcante para a enorme disseminação da utilização dos agrotóxicos no Brasil foi o marco regulatório defasado e pouco rigoroso que vigorou até 1989 (quando foi aprovada a Lei $n^{\circ} 7.802$ ), que facilitou, no país, o registro de centenas de substâncias tóxicas, muitas das quais já proibidas nos países desenvolvidos. (PELAEZ; TERRA; SILVA, 2009, p. 28)

Conforme Caporal e Azevedo (2011), o poder público brasileiro pouco incentiva ações contrárias ao uso dos agrotóxicos, uma vez que, ao aprovar o PND, estabeleceu-se a abertura do comércio brasileiro para o comércio internacional de agrotóxicos, o qual se mantém até os dias atuais. O crédito rural foi uma das ações da Revolução Verde efetivadas no Brasil, juntamente com a instalação de indústrias produtoras e importadoras de agrotóxicos, as quais buscavam, em conjunto, aumentar a produção agrícola através do uso de agroquímicos e da mecanização do campo. (LONDRES, 2011) Dessa forma, os impactos gerados pelo uso dos agrotóxicos seriam supostamente minimizados pela sua relevância para o crescimento da economia brasileira.

Os espaços escolar e acadêmico não são neutros, mas são locais em que se deve adotar um posicionamento crítico e político a favor da melhoria das condições de vida humana como um todo. (FOUREZ, 2008; FREIRE, 2001) Levando em conta os problemas socioambientais do uso dos agrotóxicos, consideramos relevante abordar esse tema no ensino de ciências, visando a melhoria da formação de cidadãos, no sentido de serem capazes de avaliar e tomar decisões sobre os agrotóxicos e suas consequências e de agir pelo que é certo, bom e justo para os seres humanos e a biosfera, além de pensar em alternativas que possam substituir esse modelo de produção de alimentos. (HODSON, 2011)

Aqui cabe notar a relevante contribuição da agroecologia, que, segundo diversos autores (ALTIERI; NICHOLLS, 2000; CAPORAL; AZEVEDO, 2012; CAPORAL; COSTABEBER, 2004), tem potencial para dar conta das necessidades alimentares em larga escala, sem prejudicar o meio ambiente. Assim, para Leff (2002) e Altieri e Nicholls (2000), a agroecologia poderá reverter a atual ordem mundial de produção através do manejo do solo pautado na valorização do saber tradicional, no cultivo sustentável, na

1 Órgão das Nações Unidas para a Alimentação e Agricultura. 
interdisciplinaridade e numa postura filosófica em que a finalidade não é o lucro, mas a reprodução ecológico-cultural do ecossistema, respeitando, portanto, as necessidades e os limites de cada sistema. Nesse sentido, o enfoque agroecológico incorpora aspectos ecológicos, econômicos, sociais, culturais, políticos e éticos, que são negligenciados ou não devidamente considerados no modelo do agronegócio, em consonância com o uso de agrotóxicos. (CAPORAL; COSTABEBER, 2004)

Concordando com Altieri (2000) e Lacey (2012), também criticamos a biotecnologia, pois, diferentemente da abordagem agroecológica, ela apresenta uma perspectiva unidimensional que não inclui as dimensões éticas, sociais, ecológicas e culturais. Altieri (2000) e Lacey (2012) concordam que a agroecologia tem a função de otimizar a dinâmica complexa do ecossistema, respeitando as condições ambientais e evitando a degradação. Ainda nesse sentido, Altieri (2000) concorda com Lacey (2011), ao defender que os cientistas envolvidos na pesquisa tecnológica devem se preocupar com quem se beneficiará com sua atividade e reconhecer os aspectos políticos, inevitavelmente presentes quando se discutem questões científicas básicas.

Com base nesse contexto, este capítulo tem como objetivo apresentar uma questão sociocientífica sobre agrotóxicos, organizada em uma proposta de ensino, discutindo aspectos científicos, políticos, socioambientais, econômicos e de saúde pertinentes ao tema, bem como bases para sua aplicação no ensino de ciências. A nossa perspectiva visa aproximar os conteúdos vistos em sala de aula da realidade dos estudantes, potencializando processos de ensino e aprendizagem que estejam relacionados à elaboração de pensamento crítico, a uma formação sobre e para valores éticos e morais e, por fim, a tomadas de decisão individual e coletiva.

O texto possui a seguinte estrutura: na próxima seção, faremos algumas exposições básicas acerca do nosso objeto, os agrotóxicos, especialmente no que se refere a seus impactos socioambientais. Na seção três, discutiremos o tema agrotóxicos no contexto do ensino de ciências sob a perspectiva da educação sobre as relações entre Ciência, Tecnologia, Sociedade e Ambiente (CTSA). Assim, com base nas seções prévias, na seção quatro, apresentamos uma proposta de ensino, baseada em uma Questão Sociocientífica (QSC) sobre o uso de agrotóxicos e seus efeitos socioambientais. Nessa seção, apresentaremos o caso, os conteúdos de aprendizagem, assim como uma sugestão de como aplicar a questão sociocientífica em sala de aula. Por fim, na seção cinco, lançaremos nossas considerações finais.

\section{Uso de agrotóxicos e consequentes problemas socioambientais}

O uso de agrotóxicos tem resultado em sérios problemas a indivíduos, sociedades e ambientes. Em particular, a ocorrência de doenças relacionadas ao uso dos agrotóxicos vem sendo apresentada como um problema de saúde pública, principalmente nos países em desenvolvimento que possuem a sua economia baseada no agronegócio, como é o 
caso do Brasil. (ARAÚJO et al., 2007) A mecanização do campo tem levado as pessoas para as cidades, causando inchaço dos grandes centros urbanos, além de desvalorização do campo e de quem nele trabalha. (SOUZA; ABRAHÃO, 2011) O agronegócio, modelo no qual a nossa agricultura está baseada, depende do monocultivo, de grandes latifúndios e de agrotóxicos, como afirma Camacho (2010), o que gera concentração de renda, dependência do uso do veneno, êxodo rural, insegurança alimentar e grandes lucros para as multinacionais produtoras de transgênicos e agrotóxicos.

Nesse sentido, ao saírem das suas comunidades ou ao aderirem a formas de produção baseadas no uso de agrotóxicos, trabalhadores rurais muitas vezes abandonam as suas raízes socioculturais para se adequar a este novo modelo de produção de alimentos no qual a ênfase está na produção em larga escala. (CAMACHO, 2010) Segundo Canclini (2004), a retirada de um indivíduo do seu espaço social é capaz de potencializar um estado de opressão e adversidade, por meio de mudanças nas formas de pertencimento e identificação, gerando ou amplificando situações de desigualdade e exclusão sociais. Ainda, quando é expropriado das suas terras, o agricultor se vê obrigado a ir para os grandes centros urbanos em busca de melhores condições de vida, o que pode causar inchaço populacional e condições de vulnerabilidade social (CAMACHO, 2010) Ainda, nesse sentido, ao longo dos anos, este processo poderá dar origem a um estado de homogeneização cultural. (HALL, 2000 apud FERIOTTI; CAMARGO, 2008)

A fim de superar as limitações do modelo do agronegócio, precisamos assumir um novo olhar sobre as tecnologias agrícolas. Segundo Altieri (2000), é necessário analisar o uso de tecnologias agrícolas de forma qualitativa, o que significa considerar não somente a produtividade ou o lucro, mas os desdobramentos socioambientais que o mesmo pode causar, tendo em vista aspectos éticos, sociais, políticos, ambientais e culturais.

Sob o modelo do agronegócio, a agricultura sofreu impactos diretos, pois o que era produzido somente para a subsistência das famílias passou a ser produzido em larga escala para atender às demandas comerciais da política capitalista e a um número de pessoas cada vez maior. (PERES, 1999) É notório o aumento da produtividade; todavia, a agricultura da perspectiva tecnocêntrica originada pela Revolução Verde foi concebida como um meio para reproduzir o capital, ao invés de colaborar para solucionar o problema da fome. (ANDRADES; GANIME, 2007) A Revolução Verde trouxe um conjunto de modificações que potencializaram a produção de alimentos para exportação e o surgimento de uma agricultura moderna ou capitalista, a qual envolve capital de várias origens, não só da agricultura, sustentando a atividade empresarial de grandes propriedades produtivas. A partir de 1980, estudiosos da área começaram a utilizar a expressão "agroindústria", mostrando a integração da indústria com a agricultura, dada pelo uso de insumos e produtos. O grande aumento de produção de alimentos dessa época levou a se adotar a expressão "agronegócio". (HEREDIA; PALMEIRA; LEITE, 2010) 
Para Altieri (2000), a agricultura, antes de tudo, é um processo social, que valoriza o conhecimento camponês e afirma que estes devem estar envolvidos desde o início, tanto no desenvolvimento quanto na aplicação das tecnologias. Ao negligenciar tais conhecimentos, corre-se o risco de provocar sérios danos à saúde humana, decorrentes da inserção de tecnologias na agricultura, considerando somente o ponto de vista técnico, o que frequentemente está associado também aos interesses de pequenos grupos. Assim, o uso de agrotóxicos constitui também um perigo para a saúde do trabalhador da agricultura familiar, que tem menos acesso às informações disponíveis sobre saúde e segurança relacionadas ao uso de agrotóxicos na agricultura. (GREGOLIS; PINTO; PERES, 2012) Segundo Matos, Santana e Nobre (2002) e Trapé (2011), o uso dos agrotóxicos pode causar alterações no sistema circulatório e respiratório, com destaque para hipertensão, bronquite e asma. Entre as manifestações de intoxicação por agrotóxicos observadas em trabalhadores rurais, estão a diminuição das defesas imunológicas, a anemia, a impotência sexual masculina, a cefaleia, a insônia, a alterações da pressão arterial, a alterações do humor e os distúrbios comportamentais, como surtos psicóticos. Segundo Soares e Porto (2012), as intoxicações por agrotóxicos podem ser agudas, quando os efeitos surgem até o prazo de 24 horas, ou crônicas, quando os danos resultam da exposição contínua ao produto.

Os impactos ao meio ambiente também são relatados na literatura, sendo que os maiores prejudicados são os rios, o ar, a água e os solos, causando impactos ambientais relevantes para a manutenção dos ecossistemas. (LONDRES, 2011) Segundo Soares e Porto (2012), os agrotóxicos agem no ambiente de duas formas: acumulam-se na biota e contaminam água e solo, causando impacto na interação natural entre duas ou mais espécies. Soares e Porto (2012) afirmam que, se o uso do produto ocorrer em áreas próximas a nascentes, há um comprometimento da qualidade destas águas, podendo contaminar alimentos, além de torná-las impróprias para consumo humano. Ainda segundo estes autores, a contaminação do solo pode causar perda da sua fertilidade, gerando um círculo vicioso formado pelo aumento do uso de fertilizantes. Segundo Martin-Laurent e colaboradores (2012), o uso de agrotóxicos tem sido uma ameaça para a biodiversidade do solo. A fertilização do solo por insumos agrícolas pode aumentar os níveis de nitrogênio e fósforo depositados sobre terras agrícolas, que são transportados para a atmosfera ou lixiviados para as águas subterrâneas. (GREGOIRE et al., 2009 apud MARTIN-LAURENT et al., 2012)

O ar também é contaminado pelo uso dos agrotóxicos, cuja toxicidade pode ameaçar diversas espécies. Nesse sentido, a polinização de abelhas tem sido apontada como um alvo de contaminação pela pulverização aérea de agrotóxicos, causando forte preocupação dos estudiosos na área, uma vez que as abelhas são essenciais na produção de alimentos, além de cumprir o importante papel de manter o equilíbrio ecológico do ecossistema. (STEFFAN-DEWENTER; POTTS; PACKER, 2005) 


\section{O tema agrotóxicos no ensino de ciências sob a abordagem CTSA}

Tradicionalmente, o ensino de ciências tem privilegiado o cientificismo, ao negar o papel e a importância da história e da filosofia, contribuindo para a construção de visões de ciência fragmentadas e acríticas. (GIL-PÉREZ et al., 2001; PRAIA; GIL-PÉREZ; VlLCHES, 2007) Segundo Muenchen e Auler (2007), atualmente existe a necessidade de construção de currículos que considerem temas sociais marcados pela componente científico-tecnológica, tendo em vista a influência cultural da tecnologia na sociedade e os perigos que essa influência pode trazer para o ambiente e para a vida em sociedade. Apoiados em trabalhos existentes na literatura, introduzimos no ensino de ciências o tema agrotóxicos, o qual é de importância social, envolve opiniões controversas e é capaz de explicitar as relações entre CTSA.

Pensamos que, ao se ver como parte dos processos que envolvem as relações entre CTSA, o cidadão passe a se considerar responsável pela sua prática, frente a situações que envolvem seu cotidiano, por meio de um posicionamento crítico, superando visões pautadas no cientificismo e no determinismo tecnológico. ${ }^{2}$ (CONRADO; EL-HANI, 2010)

Partir de um tema que favoreça uma abordagem que permita ao estudante desvendar estas nuances relacionadas a CTSA requer uma amplitude com relação à maneira com que o tema se relaciona com outros conhecimentos, por ter em sua própria natureza epistemológica relação com vários campos do saber.

O tema agrotóxicos, em nossa opinião, reflete estas características na medida que as premissas que explicam ou justificam seu uso apresentam as mais variadas raízes epistemológicas, já que envolve aspectos relacionados à sociedade, à economia, à política, ao ambiente, à ciência, à tecnologia, à ideologia, à ética e à moral. Ao introduzir esse tema no ensino de ciências, permite-se, em parte, superar a tendência predominante de enfocar a compreensão de conceitos, o que pode favorecer uma formação política, social e humana dos estudantes. (ANDRADE; RIBEIRO; TEIXEIRA, 2014; MENDES et al., 2013) Esse tema é constituído, em sua interdisciplinaridade, por aspectos éticos, morais, políticos, ideológicos, os quais permitem a formação de um espírito crítico por meio de uma QSC, permitindo a mobilização de atitudes e valores condizentes com a necessidade atual da sociedade de participação social e compreensão dos problemas trazidos pela ciência e pela tecnologia para a sociedade, contribuindo para a formação humanística e científica dos estudantes e professores. (HODSON, 2011; LACEY, 2010; SANTOS, 2009)

Em estudo realizado por Andrade, Ribeiro e Teixeira (2014), o tema agrotóxicos foi utilizado como gerador para o ensino sobre o corpo humano, relacionando-o com conteúdos socioambientais, políticos, econômicos, históricos e de saúde, permitindo uma abordagem crítica do corpo humano em seus aspectos socioambientais, em busca de

2 O mito do determinismo tecnológico tem como base a premissa de que o desenvolvimento tecnológico conduz ao desenvolvimento humano, acrescido da crença da autonomia da tecnologia sem a influência dos valores da sociedade. (SANTOS, 2007) 
uma leitura crítica da sociedade. Além disso, a abordagem do tema permitiu o envolvimento dos estudantes na disciplina, uma vez que os agrotóxicos são frequentemente tratados nos meios de comunicação de massa, possibilitando a contextualização com o cotidiano dos estudantes. Segundo Dumrauf e Cordero (2013), o uso da temática agrotóxicos, para a promoção da saúde em comunidades campesinas, possibilitou a problematização de aspectos sócio-históricos, econômicos, políticos, ambiental e de saúde, bem como a construção de processos reflexivos que permitissem a ação frente a problemáticas envolvendo o uso de agrotóxicos. Ainda nessa perspectiva, Ferraz e Brem (2007) utilizaram o tema agrotóxicos como gerador, buscando a construção de uma prática educativa contextualizada, por meio da abordagem dialógica de aspectos sócio-históricos, científicos, econômicos, argumentação e pensamento lógico matemático. Ainda nesse sentido, Broietti e colaboradores (2014), ao realizarem um trabalho no ensino de química, abordando o tema agrotóxicos, destacam a metodologia da horta orgânica como forma de incentivar os estudantes a buscar informações sobre o tema agrotóxicos e a agricultura orgânica, bem como a conscientização dos estudantes sobre os malefícios do consumo de agrotóxicos e os benefícios do consumo e cultivo orgânico. O tema agrotóxicos, ao ser colocado dentro de uma QSC, permite ao professor, do ponto de vista metodológico, inovar o seu ensino em uma perspectiva sociocultural, partir do cotidiano dos estudantes para permitir que eles se apropriem de forma crítica e significativa do conhecimento. Além disso, pode permitir aos estudantes compreender os problemas socioambientais e promover a participação ativa em sociedade, como sujeitos responsáveis e conscientes quanto ao seu papel de cidadão. (ANDRADE; ALMEIDA; NUNES-NETO, 2015) Segundo Lopes e Carvalho (2013), o uso de QSC, a partir do tema agrotóxicos na perspectiva CTSA, constituiu-se um meio para a formação dos professores que envolveu a leitura de textos acadêmicos e outros documentos de interesse dos participantes. A QSC construída pôde ser abordada em variadas disciplinas sob enfoques diferenciados, ajudando os professores na prática da interdisciplinaridade e da autonomia frente ao currículo escolar.

Ao dar voz aos estudantes, no trabalho com QSC, na perspectiva CTSA, gera-se uma mudança no que se diz respeito ao papel do aluno e do professor em sala de aula, havendo a alternância de determinados papéis que podem contribuir para a formação de jovens questionadores e participativos. Do ponto de vista epistemológico, pode permitir a construção de conhecimentos socialmente orientados e válidos no âmbito científico e tecnológico. (ANDRADE; ALMEIDA; NUNES-NETO, 2015)

Genovese e Pessoa (2013) afirmam que a utilização do tema agrotóxicos no ensino de ciências permitiu aos estudantes refletirem a respeito do papel da ciência e da tecnologia em nossa sociedade, corroborando com propostas curriculares para o ensino de ciências, sob a perspectiva do movimento/enfoque Ciência, Tecnologia e Sociedade (CTS), por meio do estudo de QSC. As QSC, nesse sentido, têm o potencial de fazer com que o ensino de ciências cumpra o seu papel de formar cidadãos críticos, ativos e par- 
ticipativos. A junção agrotóxicos, QSC e CTSA, além dos benefícios supracitados, pode aproximar os estudantes do conteúdo científico de maneira que o torne mais significativo e relevante. $O$ trabalho colaborativo entre professor e pesquisador a partir de uma QSC sobre agrotóxicos no contexto CTSA possibilitou a mobilização de conteúdos conceituais, procedimentais e atitudinais tanto pela professora colaboradora, quanto por professores que participaram da validação da pesquisa. (ANDRADE; ALMEIDA; NUNES-NETO, 2015) Observou-se que os professores encontraram benefícios em realizar um ensino que abarque conteúdos atitudinais e conceituais, mas também encontraram barreiras didáticas e burocráticas na escola. (ANDRADE; ALMEIDA; NUNES-NETO, 2015) Buffolo e Rodrigues (2015) apresentam as contribuições de uma sequência didática sobre agrotóxicos, afirmando que os resultados obtidos revelaram que o desenvolvimento da sequência didática ampliou a visão dos alunos a respeito das implicações sociais e ambientais provocadas pelo uso inadequado dos agrotóxicos, além de reflexões e maior compreensão sobre o tema, evidenciando a importância de introduzir questões socioambientais no ensino de química em uma perspectiva CTS.

Nesse contexto, acreditamos que a inserção do tema agrotóxicos no currículo de ciências pode permitir a formação de indivíduos com posicionamento crítico e responsabilidade social coletiva. Defendemos que, para que a sociedade chegue a este nível de entendimento sobre o tema, é imprescindível que a sala de aula seja um local onde estes problemas sejam tratados, sem dissociá-los da sua trama, levando em conta, portanto, seus aspectos científicos, socioambientais, políticos e humanísticos.

Assim, pretendemos que esta proposta de ensino com base em QSC possibilite a mobilização de conteúdos conceituais, procedimentais e atitudinais com vistas à formação para a ação sociopolítica dos estudantes. A união entre CTSA e QSC no ensino de ciências, a fim de abordar o tema agrotóxicos, em nossa visão, vem se constituindo como um meio promissor de se alcançar objetivos que dialoguem com um ensino que se pretenda científico, humanístico, crítico e socialmente responsável, uma vez que esse tema é atual, controverso e capaz de mobilizar conhecimentos distintos, permitindo a realização de um ensino de ciências contextualizado e sociopoliticamente engajado. (HODSON, 2004; ZEIDLER; NICHOLS, 2009)

\section{Uma QSC sobre o uso de agrotóxicos e seus efeitos socioambientais}

A QSC “aspectos socioambientais do uso de agrotóxicos" pode ser aplicada no ensino médio, regular ou profissionalizante, e no ensino fundamental, sendo necessário adaptá-la, tendo em vista os diferentes níveis de ensino e os objetivos estabelecidos pelo docente. Dentre as áreas de conhecimento que essa QSC mobiliza, destacamos: economia, política, ecologia, filosofia, história, biologia, química, sociologia, meio ambiente, geografia e saúde ambiental. 
Quadro 1 - Caso sobre o uso de agrotóxicos ${ }^{3}$

\section{Aspectos socioambientais do uso de agrotóxicos}

Esta semana, nas proximidades do município de Cruz das Almas, Bahia, na comunidade rural de Sapezinho do Bom Gosto, João Batista, após sair da sua plantação no quintal da casa, sentiu-se mal. João Batista foi encontrado desmaiado pela sua esposa, Maria, e pelo seu filho mais velho, Felipe. Maria percebeu que, ao lado do seu marido, havia embalagens de veneno que de vez em quando ele utilizava na plantação - o glifosato Roundup. Após passar dois meses em coma, o agricultor apresentou problemas associados à fala e à locomoção, impossibilitando-o de trabalhar na plantação. Segundo Felipe, seu pai desmatou uma grande área de terra onde planta somente laranja e, a cada ano, vê o solo ficando mais pobre e precisando de adubos e agrotóxicos. Maria, que se vê em uma situação difícil, uma vez que não sabe como vai trabalhar sozinha na plantação, desabafa:

- Maria: João vinha comprando os produtos na mão do vendedor desde 1990, porque se não comprasse não ganharia o dinheiro que o governo empresta para seguir com a lavoura e, em troca, ele ainda ganhava as sementes; além disso, os meninos ainda eram pequenos e não podiam ajudar João. Tem o Felipe, mas ele quer estudar na cidade.

- Felipe: meu pai aplicava o remédio sozinho. Não queria deixar de usar ele, porque conseguia dar conta da tarefa em pouco tempo. Além disso, não tem mais pessoas para fazer esse tipo de trabalho aqui na roça; os jovens estão indo procurar outras formas de viver na cidade.

- Maria: o homem do campo não tem mais valor. O trator e o remédio substituem nosso trabalho em dois tempos. Eu não sei o que fazer para continuar alimentando meus filhos. Cuidar da plantação é o único meio que a gente tinha para sobreviver.

- Felipe: mãe, o que vai ser de você e do meu irmão? Temos que voltar a produzir como antes, sem o veneno. Mas não se preocupa, estou entrando na faculdade e espero voltar com a solução para acabar com o uso desse tal de agrotóxico e saber por que ele é tão presente hoje na agricultura.

Ao entrar em um curso de Agroecologia, Felipe começa a buscar informações e decide montar um grupo de estudos na associação da comunidade para compreender melhor o assunto, juntamente com os moradores locais, bem como com os jovens da escola. E as primeiras perguntas a serem levantadas foram: que fatores têm contribuído para o uso intensivo de agrotóxicos? Existem formas alternativas de combater pragas e doenças? O que podemos fazer para eliminar os agrotóxicos das plantações?

Fonte: elaborado pelos autores, com base em Andrade e colaboradores (2016).

Tendo em vista os objetivos de aprendizagem (apresentados abaixo), elaboramos um conjunto de questões que poderão ser inseridas logo após a leitura do caso ou no decorrer da aplicação dessa QSC. Recomendamos que essas questões sejam discutidas em equipes, com elaboração de justificativas para cada resposta pelos estudantes. Outra maneira de discuti-las pode ser por meio do lançamento de questões para toda a classe, uma vez que o trabalho em grupo em todas as aulas pode causar desânimo entre os estudantes. ${ }^{4}$ Adicionalmente, questões como essas poderão orientar a construção de um pensamento crítico sobre o assunto e sobre as situações abordadas no caso, estimulando

3 O referido caso, bem como grande parte das questões sobre a QSC apresentados nesta seção, foram criados e desenvolvidos para a pesquisa de dissertação da primeira autora como parte de uma sequência didática para o ensino técnico profissionalizante. Resultados parciais dessa pesquisa podem ser encontrados em Andrade e colaboradores (2016). Para a dissertação da primeira autora, ver Andrade (2016).

4 Esta constatação foi realizada por Andrade, Almeida e Nunes-Neto (2015) em uma pesquisa com QSC, na qual a estratégia adotada de resolução de questões em grupo teve que ser substituída por outras estratégias que permitissem aos estudantes discutir coletivamente os problemas encontrados na resolução da QSC. Nesse sentido, a partir da segunda aula, alternamos a forma de resolução 
a formação de cidadãos capazes de ações sociopolíticas, conforme Hodson (2011). Seguem, abaixo, algumas dessas questões, cuja ordem de apresentação pode ser adaptada a cada situação de ensino. (ANDRADE, 2016; ANDRADE et al., 2016)

Q1. Esta situação é muito frequente onde você vive? Você já presenciou situações como essa?

Q2. Qual é o nome mais apropriado para se referir aos agrotóxicos: veneno ou remédio? Por quê?

Q3. Quais as razões para que agricultores como João Batista utilizem com frequência estes agrotóxicos?

Q4. Quais são os possíveis benefícios e malefícios trazidos pelo uso dos agrotóxicos (para os diferentes atores sociais, outros animais e o ambiente, em geral)?

Q5. Felipe, ingressando em um curso superior, conseguirá resolver o problema do seu pai João? Justifique.

Q6. E se você fosse vizinho de João Batista, você continuaria a aplicar os agrotóxicos? Justifique.

Q7. O uso de Equipamentos de Proteção Individual (EPI) poderia reduzir os prejuízos à saúde de João Batista? Há diferentes modos de exposição aos agrotóxicos?

Q8. Quem sofre mais com o uso do veneno? Quem são os principais afetados?

Q9. Você considera o uso indiscriminado de produtos que fazem mal ao ser humano, na produção de alimentos, um problema moral e ético?

Q10. Quais as consequências das tecnologias trazidas pela Revolução Verde para a agricultura, a saúde e o meio ambiente?

Q11. Qual é a classificação toxicológica do Roundup utilizado por João Batista e quais prejuízos ele pode causar para a saúde humana, a água e o solo?

Q12. Quais os agrotóxicos mais utilizados e como atuam nos sistemas vivos?

Q13. Como os agrotóxicos podem interferir nas cadeias alimentares?

Q14. Qual a relação entre a monocultura e o uso de agrotóxicos?

Q15. Quais as vantagens e desvantagens da monocultura?

Q16. Você concorda com a ideia de que o uso de agrotóxicos é necessário para suprir a necessidade de alimentos da humanidade?

Q17. Quais os responsáveis pela manutenção (e pelo aumento) do uso de agrotóxicos?

da QSC, lançando perguntas para toda a turma e discutindo-as em seguida, com formação de grupos, tendo em vista a manutenção do interesse dos estudantes pelo trabalho em sala de aula. 
Q18. Quais as políticas públicas no seu estado ou município sobre o uso de agrotóxicos?

Q19. Se o uso de agrotóxicos já é consagrado na história da agricultura brasileira, essa é uma razão suficiente para a continuidade de seu uso?

Q20. O que pode ser feito para a redução e a eliminação do uso destes produtos?

Q21. Existem tecnologias e estratégias alternativas ao cultivo de alimentos com agrotóxicos?

Q22. Quais as vantagens e desvantagens do cultivo sem agrotóxicos?

Q23. Quais as principais controvérsias relacionadas à substituição do modelo de produção baseado no uso intensivo de agrotóxicos pelo modelo da agroecologia?

Q24. O que sua equipe poderia fazer para ajudar famílias como a de João Batista para a redução ou a eliminação do uso de agrotóxicos em seu trabalho?

Q25. O que significa o valor do homem do campo, segundo Maria?

Q26. Poderíamos considerar o valor como sinônimo de valor econômico? Há valores não econômicos, como valores intrínsecos (por exemplo, da dignidade humana, dos outros animais etc.), sociais, culturais?

Q27. Que ações cotidianas realizadas pelos integrantes de sua equipe podem agravar ou melhorar situações como a da família de João e Maria?

Q28. O que você e seus colegas podem fazer para alertar sua família, sua comunidade e colegas da escola sobre os perigos do uso de agrotóxicos e seus desdobramentos socioambientais e ideológicos na sociedade e no meio ambiente?

Q29. Você considera que as ações sociopolíticas que você (e sua equipe) imaginou ou realizou de fato são eficazes para uma solução adequada do problema? Caso não seja, que obstáculos ou dificuldades você (e sua equipe) visualiza?

\section{Objetivos de aprendizagem}

\section{Conceituais}

- Conhecer as relações de poder que estão por trás do uso do agrotóxico, visando compreender os mecanismos políticos e econômicos envolvidos (Q2; Q4; Q8; Q10; Q14; Q16; Q17; Q18; Q19; Q23).

- Identificar relações entre CTSA, a partir da análise de tecnologias adotadas no dia a dia e da avaliação de sua contribuição para o bem-estar social (Q1; Q4; Q5; Q8; Q10; Q11; Q13; Q15; Q16; Q21; Q23; Q25; Q26; Q28). 
- Entender a interferência do uso dos agrotóxicos na teia alimentar, na qualidade da água e no solo, analisando os princípios ativos que causam contaminação, bem como as consequências para os ecossistemas (Q1; Q4; Q7; Q8; Q10; Q11; Q12; Q13; Q15; Q22).

- Apropriar-se de conceitos básicos em segurança do trabalho, a fim de conhecer meios de proteção que evitem a intoxicação aguda pelo produto e seus limites, tendo em vista a manutenção do veneno no ambiente (Q2; Q7; Q8; Q11; Q12; Q13; Q27; Q28).

- Construir conceitos básicos em agroecologia, como a definição de defensivos orgânicos, como eles funcionam e ainda quais as vantagens e desvantagens com relação aos defensivos sintéticos (Q2; Q4; Q8; Q12; Q14; Q18; Q20; Q21 a 25; Q27).

- Reconhecer mitos com relação a consumo versus produtividade com uso de agrotóxicos, visando promover alternativas de produção saudável de alimentos (Q1; Q2; Q3; Q15; Q16; Q17; Q19; Q23; Q22; Q27; Q28).

- Definir conceitos de praga, peste, erva-daninha, pesticida, herbicida, agrotóxico, toxina, biodiversidade e monocultura (Q1; Q2; Q11; Q13; Q14; Q20; Q21; Q22; Q23).

- Comparar significados atribuídos a sinônimos de agrotóxicos (Q1; Q2; Q4; Q7; Q9; Q10; Q11).

\section{Procedimentais}

- Identificar empresas que produzem agrotóxicos e ao mesmo tempo medicamentos, para que se consiga de maneira mais crítica visualizar as relações políticas e econômicas relacionadas ao uso do produto (Q9 a 12; Q17; Q14; Q28).

- Analisar o nível de toxicidade dos agrotóxicos mais utilizados na sua comunidade ou naquela mais próxima, avaliando os prejuízos que eles possam causar para a água, o solo e o ar, a fim de construir um panorama geral acerca do uso do produto e dos seus efeitos socioecológicos adversos (Q1; Q2; Q4; Q11; Q12; Q13; Q20; Q21; Q25).

- Desenvolver estratégias que possam dar visibilidade ao tema na comunidade (documento, carta, vídeo, manifesto etc.), chamando a atenção para o perigo do uso de agrotóxicos, o que permite traduzir suas aprendizagens conceituais sobre os impactos da ciência e da tecnologia na sociedade e no ambiente em ações de mobilização sociopolítica (Q22; Q24; Q25; Q27; Q28; Q29).

- Identificar EPI que são essenciais para diminuir a contaminação individual ou a intoxicação aguda, analisando até que ponto o uso do EPI pode proteger o indivíduo (Q7; Q8; Q11; Q12; Q13). 
- Discutir com agricultores possibilidades de utilizar defensivos orgânicos no combate às pragas, permitindo a produção saudável de alimentos (Q20; Q21; Q22; Q23).

- Apresentar resultados das pesquisas realizadas, discutindo e posicionando-se sobre as controvérsias, oportunidades e os desafios envolvidos na proposta de substituição do modelo de produção com uso intensivo de agrotóxicos pelo modelo da agroecologia (Q3; Q4; Q9; Q16; Q19; Q20; Q22 a 26; Q28; Q29).

\section{Atitudinais}

- Ser responsável na tomada de decisão sobre o uso de determinados aparatos tecnológicos como agrotóxicos, transgênicos, tendo em vista valores morais condizentes com o bem-estar social e a sustentabilidade ambiental (Q9; Q10; Q12; Q13; Q20; Q21; Q25; Q26; Q28).

- Respeitar normas estabelecidas em coletivo nas discussões realizadas em sala de aula, como o tempo estabelecido para cada grupo ou atividade (Q1 a 29).

- Colaborar na troca de conhecimentos com todos nos debates entre equipes, discutindo contra-argumentos acerca do uso dos agrotóxicos e do impacto desta tecnologia na sociedade e no ambiente (Q1 a 29).

- Mostrar interesse e participação pela execução das tarefas em sala de aula (Q1 a 29).

- Respeitar opiniões contrárias à que defende e buscar estabelecer pontos de consensos entre elas para que se identifiquem as controvérsias existentes nos discursos que envolvem a prática do uso intensivo dos agrotóxicos, bem como nos discursos que apontam a agroecologia como a melhor solução (Q1 a 29).

- Ser responsável com os compromissos estabelecidos de forma a garantir o cumprimento das atividades em sala e de atividades que envolvam participação e ações práticas, como realização de palestra, elaboração de panfletos, realização de manifesto, caminhadas em prol de uma agricultura que leve em conta a saúde da população (Q3 a 29).

- Estar disposto a aprender (Q1 a 29).

- Respeitar as diferentes formas de conhecimento, considerando a pertinência destes na resolução de problemas encontrados no seu cotidiano, sobretudo aos problemas relacionados ao uso de agrotóxicos (Q1 a 29).

- Adotar um posicionamento crítico frente ao uso de agrotóxicos e seus desdobramentos socioambientais, de saúde e econômicos, pautando-se em valores que levem em conta o bem-estar social, a segurança alimentar e a saúde ambiental (Q1 a 29). 
- Discutir e posicionar-se em relação aos valores econômicos e não econômicos, com ênfase nos valores morais e naqueles relativos à justiça social e à sustentabilidade ambiental (Q4; Q9; Q; 24; Q25; Q26; Q27; Q28).

- Realizar iniciativas de educação (fóruns de discussão, workshops, cartazes, panfletos informativos, blogs, campanhas em redes sociais), abordando aspectos socioambientais e políticos relacionados aos agrotóxicos, visando envolver outros cidadãos em ações sociopolíticas relacionadas ao tema (Q1 a 29).

\section{Meios de aplicação da QSC e orientações teórico-metodológicas da SD}

Esta Sequência Didática (SD), incluindo o caso sobre a QSC, envolve ou pode envolver diferentes áreas, como economia, política, ecologia, filosofia, história, biologia, química, sociologia, meio ambiente, matemática, geografia, saúde ambiental. De modo geral, caberá ao professor escolher os objetivos de aprendizagem conceituais, procedimentais e atitudinais condizentes com os objetivos da disciplina e dos conteúdos que pretende ensinar. A SD também poderá ser desenvolvida de modo transversal, envolvendo duas ou mais disciplinas, com a definição dos objetivos de aprendizagem que cada uma delas irá contemplar. De fato, é importante levar em conta a interdisciplinaridade do tema, o que é compatível com a perspectiva pedagógica CTSA. Por exemplo, essa SD pode ser aplicada por diferentes professores de ensino médio ou superior, em colaboração, na escola ou na universidade. Professores de filosofia e biologia, por exemplo, podem colaborar, realizando uma discussão conjunta sobre as bases ideológicas da atual crise ambiental; ou ainda, professores de ecologia e de ciências sociais podem colaborar em discussões sobre valores, serviços ecossistêmicos e relações entre economia e natureza na contemporaneidade.

Para auxiliar na aplicação da SD, sugerimos utilizar o modelo das tipologias do conteúdo de Zabala (1998). Segundo este modelo, existem três tipos de conteúdo, que podemos também entender como dimensões (CONRADO; NUNES-NETO, 2015), que seriam: a dimensão Conceitual (C), que visa a desenvolver as competências do educando nas suas relações com símbolos, expressões, ideias, imagens, representações e nexos, com os quais ele aprende e ressignifica o real; a dimensão Procedimental (P), que inclui regras, técnicas, métodos, destrezas ou habilidades, estratégias e ações ordenadas, dirigidas à realização de um objetivo; e a dimensão Atitudinal (A), que se refere à formação de atitudes, valores e normas, visando à intervenção do aluno em sua realidade.

5 A SD, sobre a QSC proposta foi aplicada e foram avaliados os resultados alcançados (ANDRADE, 2016), sendo possível observar a mobilização de conteúdos conceituais, procedimentais e atitudinais e ações sociopolíticas diretas e indiretas. Além disso, houve aproximação do conteúdo estudado em sala de aula à realidade dos estudantes, de modo a contribuir para o reconhecimento, pelos estudantes, de relações entre CTSA, e para a análise de valores morais envolvidos na temática. (ANDRADE; ALMEIDA; NUNES-NETO, 2015) 
Assim, as QSC podem se constituir como veículos para a abordagem das dimensões Conceitual, Procedimental e Atitudinal (CPA) do conteúdo, uma vez que são interdisciplinares, envolvendo aspectos éticos, políticos, econômicos e culturais do conteúdo científico. (CONRADO; NUNES-NETO, 2015) A partir dessa estratégia, dimensões CPA do conteúdo científico poderão ser exploradas, possibilitando uma formação mais integral do cidadão e, consequentemente, um melhor preparo para ações sociopolíticas. (ANDRADE; ALMEIDA; NUNES-NETO, 2015)

\section{Fases propostas para a aplicação da SD}

A apresentação desta sequência será realizada em etapas, sugerindo que cada etapa tenha a duração de duas horas-aula de 50 minutos cada. ${ }^{6} \mathrm{O}$ tempo total de aplicação dependerá do contexto no qual a QSC será aplicada, considerando os aspectos epistemológicos, psicocognitivos, didáticos, ético-políticos e socioculturais e os objetivos de aprendizagem propostos pelo professor.

Nesse sentido, para o primeiro encontro, o professor poderá apresentar a sequência de atividades programadas, estabelecendo, se possível, a priori o tempo determinado para cada atividade. Sugerimos que isto seja feito no início de todos os encontros, pois esse procedimento permite que os estudantes fiquem cientes das atividades que serão realizadas naquele encontro. Feito isto, o professor poderá iniciar a SD com a leitura do caso, juntamente com os alunos, a fim de aproximá-los do problema socioambiental. Após essa leitura, sugerimos reservar um momento para ouvir os estudantes, a fim de acessar as impressões suscitadas pelo caso. Em seguida, poderão ser lançadas algumas questões iniciais sobre o tema (como algumas das que listamos acima), a fim de que os estudantes façam reflexões sobre os efeitos socioambientais da utilização dos agrotóxicos, observando as reações dos estudantes frente ao caso, bem como os seus conhecimentos prévios sobre o tema. Em seguida, o professor poderá promover uma discussão sobre as relações de poder que envolvem o uso de agrotóxicos, para que os estudantes compreendam os mecanismos políticos e econômicos que estão por trás do uso do produto; trabalhar o uso inadequado do termo "remédio" para se referir aos agrotóxicos, bem como os possíveis benefícios e malefícios no uso dos agrotóxicos, analisando se as vantagens superam as desvantagens, o uso do EPI e a circularidade do produto no ambiente, princípios de injustiça ambiental, discutindo os afetados e quem mais sofre com o uso das substâncias; analisar os valores éticos e

6 Validamos esta SD em parceria com pesquisadores e professores de ensino médio técnico e superior. Deste modo, o trabalho colaborativo para a construção da SD possibilitou: a formação de pesquisadores a respeito dos processos educativos; o compartilhamento de conhecimentos e experiências entre professores e pesquisadores; a aplicação da SD como um produto da interação entre necessidades, habilidades e atividades diversas dos meios acadêmico e escolar; e, ainda, a aproximação entre pesquisa acadêmica e implementação pedagógica de inovações educacionais no ensino de ciências. (ANDRADE, 2016) 
morais por trás do uso do produto; e, ainda, solicitar que os estudantes se posicionem frente ao problema do uso, caso fossem agricultores. Para ajudar na discussão destes conteúdos, o professor poderá projetar reportagens ou levá-las impressas para que os alunos leiam e discutam, em atividades que podem ser desenvolvidas individualmente ou em grupos de discussão. Para que, no próximo encontro, a aula seja iniciada a partir do que os estudantes conhecem sobre o assunto, recomendamos que o professor solicite uma pesquisa individual sobre a importância dos agrotóxicos na produção de alimentos. Essa pesquisa poderá ser realizada também em pequenos grupos.

No segundo encontro, o professor poderá solicitar que os estudantes socializem os resultados da pesquisa, pedindo que se posicionem a favor ou contra os argumentos encontrados. Em seguida, ainda no segundo encontro, o professor poderá levar para a aula um texto ou matéria abordando a história do uso de agrotóxicos na agricultura, a fim de que os estudantes compreendam a partir de que argumentos os agrotóxicos se tornaram essenciais para a produção de alimentos, bem como os jogos de interesse envolvidos e em que momento sócio-histórico isto aconteceu. Espera-se que tal discussão permita aos estudantes compreender as contradições internas nos discursos que legitimam o uso de agrotóxicos como elemento necessário e inevitável, a fim de, supostamente, prover a humanidade com alimentos suficientes. Após a leitura do texto, os estudantes poderão responder algumas questões selecionadas sobre o caso e a QSC programadas para este encontro. Neste encontro, poderão ser discutidas as relações entre monocultura e uso de agrotóxicos, as vantagens e desvantagens da monocultura, entre outros assuntos. Vale ressaltar que esta atividade permitirá ainda aos estudantes o desenvolvimento de um pensamento crítico ao aprender a selecionar as informações, organizar, analisar, interpretar e defender argumentos e tomar atitudes frente situações complexas. Além disso, nesta atividade, os estudantes poderão pôr em prática a responsabilidade com os compromissos estabelecidos de forma a garantir o cumprimento das atividades em sala.

Para o terceiro encontro, o professor poderá solicitar aos estudantes que levem para a aula rótulos de embalagens de agrotóxicos para serem analisados, utilizando critérios como: níveis de toxicidade do agrotóxico, classificação toxicológica, EPI necessários para a aplicação, efeitos agudos e crônicos e as empresas que produzem estes agrotóxicos, intervalo de segurança para reentrada nas culturas, entre outros critérios possíveis. Em seguida, os estudantes resolverão questões da QSC pertinentes ao campo da saúde e poderão ler e discutir em sala uma ou mais reportagens sobre alguns efeitos dos agrotóxicos no corpo humano. Com estas atividades, o professor pode pôr em prática objetivos de ensino primordialmente procedimentais e atitudinais, a partir da classificação dos agrotóxicos e da leitura crítica das reportagens, percebendo a presença de incoerências entre a classificação dada pela Agência Nacional de Vigilância Sanitária (Anvisa) ${ }^{7}$

7 Para mais informações, consulte: <http://portal.anvisa.gov.br/wps/portal/anvisa/home>. 
e os efeitos efetivamente observados à saúde trazidos pelos agrotóxicos (a partir das pesquisas realizadas pelos estudantes). Além disso, os estudantes poderão identificar as empresas que produzem agrotóxicos e ao mesmo tempo medicamentos farmacêuticos, refletindo sobre interesses político-econômicos de tais empresas, em especial no que diz respeito a suas atuações nestes dois nichos de mercado (agricultura e fármacos para humanos). Ainda neste encontro, o professor poderá solicitar aos estudantes que pesquisem sobre casos de contaminação com agrotóxicos e procurem saber se em seu município existem políticas públicas contra o uso do produto e em que condições.

No quarto encontro, o professor poderá iniciar a aula com a socialização dos resultados da pesquisa solicitada na aula anterior. Em seguida, poderá realizar uma aula expositiva-dialogada sobre interferências do uso do agrotóxico na teia alimentar e os prejuízos à qualidade da água, analisando os princípios ativos que causam contaminação, as consequências desta para os seres vivos, além de discutir controvérsias, desafios e oportunidades para a substituição do modo de produção com uso de agrotóxicos por modos alternativos, como aqueles baseados na permacultura ou na agroecologia. Em paralelo, o professor poderá lançar outras questões da QSC relacionadas a estes conteúdos para ir discutindo ao longo da aula. Nesse sentido, neste encontro, poderão ser discutidos conceitos de teia alimentar e contaminação do solo e da água pelos agrotóxicos.

No quinto encontro, o professor poderá utilizar trechos do documentário de Silvio Tendler, O veneno está na mesa $11 .{ }^{8}$ Em seguida, o professor poderá organizar a classe em grupos para discutir os aspectos que mais lhe chamaram a atenção no filme, chamando a atenção para questões centrais como: a chamada Revolução Verde, formas alternativas de cultivo sem agrotóxicos e prejuízos que esta tecnologia pode causar para a sociedade e o meio ambiente. É importante discutir, de forma ponderada e crítica, os benefícios e malefícios da ciência e da tecnologia nas sociedades e nos ambientes, a partir do tema agrotóxicos, permitindo aos estudantes analisarem as tecnologias apresentadas pelo mundo contemporâneo. Com isso, pode-se chamar a atenção dos estudantes para a necessidade de serem responsáveis na tomada de decisão frente ao uso de aparatos tecnológicos, tendo em vista valores éticos e morais condizentes com o bem-estar socioambiental e coletivo, bem como o respeito por opiniões contrárias às que defendem, buscando estabelecer pontos de consenso ou pelo menos, quando o consenso não for possível, clareza sobre os pontos de dissenso. Essa atividade permitirá aos estudantes compreender o modelo hegemônico presente na agricultura que não leva em conta o bem-estar social, mostrando que nem sempre ciência e tecnologia produzem bem-estar social, além de possibilitar que os estudantes compreendam que, como cidadãos, têm o direito e o dever de participar de decisões envolvendo ciência e tecnologia. Ainda, cabe notar que um recurso que pode ajudar na reflexão dos estudantes sobre valores morais

8 Para mais informações, acesse: <https://www.youtube.com/watch?v=fyvoKljtvG4>. 
e éticos em sala de aula são as tirinhas, podendo ser utilizadas no decorrer das aulas, possibilitando que, de forma descontraída, lúdica, o professor discuta com os seus alunos os valores sobre o meio ambiente e a vida em sociedade. (LISBÔA, 2008; LISBÔA; JUNQUEIRA; DEL PINO, 2007)

Para o sexto encontro, o professor poderá iniciar a aula com a discussão de um texto ou história em quadrinhos sobre a história da agricultura, o surgimento da agroecologia, os jogos de interesses existentes no modelo baseado no uso intensivo de agrotóxicos, as vantagens de modelos sem agrotóxicos, como a agroecologia, ressaltando os aspectos políticos, econômicos, ideológicos e de saúde causados pelo modelo atual de produção de alimentos e comparando-o com o modelo de produção baseado no agronegócio. Histórias em quadrinhos têm sido utilizadas como ferramenta didática, à medida que contribuem para o tornar os textos mais acessíveis, facilitar a leitura, além de possibilitar o letramento científico no ensino de ciências. (MENDONÇA; OLIVEIRA; FRANCO, 2014) Os conteúdos atitudinais aqui desenvolvidos podem ser: a responsabilidade com a execução das atividades, o compromisso e a disposição para aprender, a construção de pensamento crítico referente aos conteúdos abordados, a mudança de posicionamento frente à temática agrotóxicos, a compreensão das relações de poder que envolvem a substituição do modelo baseado no agronegócio pela agroecologia e os jogos de interesse envolvidos no uso de agrotóxicos, bem como os aspectos éticos que envolvem a sua comercialização e utilização para a sociedade e o ambiente.

No próximo encontro, o professor poderá discutir conceitos básicos em agroecologia, como os de defensivos orgânicos, como eles funcionam e, ainda, qual é a sua vantagem com relação aos defensivos sintéticos, a partir de reportagens atuais sobre o tema, para que os estudantes conheçam alternativas de produção saudável de alimentos. Para realizar este objetivo, poderá ser realizado um dia de campo com agricultores locais, visando produzir defensivos orgânicos, com o objetivo de mostrar que existem formas alternativas de combater pragas, garantindo a produção saudável de alimentos. Nesta atividade, diversos conteúdos procedimentais podem ser desenvolvidos, como habilidades motoras para a produção dos defensivos orgânicos, assim como também de organização dos próprios estudantes em grupos. Ainda, diversos conteúdos atitudinais podem ser desenvolvidos, como, por exemplo, respeitar as diferentes formas de conhecimento, colaborar com os agricultores de uma perspectiva epistemológica multicultural, promovendo o diálogo entre conhecimentos científicos e tradicionais (isto significa, em grande medida, promover condições para - apesar das diferenças entre fundamentos epistemológicos distintos - um diálogo frutífero entre as diferentes formas de conhecimento, com vistas ao alcance de objetivos sociais compartilhados), valorizar o bem-estar de indivíduos, sociedades e ambiente, o que implica buscar maior justiça social e sustentabilidade ambiental, e por fim, gerar mu- 
dança de atitude frente à problemática discutida, o que, a longo prazo, pode conduzir à formação de ativistas socioambientais.

Com estas atividades, do ponto de vista valorativo, pode ser mostrada aos alunos a importância de respeitar normas estabelecidas para a execução das atividades em sala de aula, como o tempo para apresentação de cada grupo ou a realização de cada atividade, além da importância de atitude colaborativa na troca de conhecimentos com todos os envolvidos na atividade.

Para o sétimo encontro, o professor poderá envolver os estudantes na execução de ações como produção de documento, construção de petição, diálogo com agricultores da feira local, produção de vídeo ou manifesto contra o uso de agrotóxicos, chamando a atenção para os perigos de tais substâncias, para que os estudantes possam colocar em prática os conteúdos conceituais adquiridos com o estudo dos impactos da ciência e tecnologia na sociedade e no ambiente, questionando mitos com relação ao consumo versus produtividade. As atitudes que poderão ser desenvolvidas aqui seriam: a própria iniciativa em criar ações educacionais, abordando aspectos históricos, políticos, econômicos e sociais relacionados ao uso de agrotóxicos, bem como o envolvimento dos estudantes na realização das atividades e a mudança de seu comportamento frente à temática.

Pretendendo envolver toda a escola ou comunidade, pode ser realizado um dia de combate aos agrotóxicos, durante o qual podem ser realizadas iniciativas de educação (fóruns de discussão, workshops, construção de blogs, abordando aspectos socioambientais e políticos relacionados aos agrotóxicos; construção de cartazes e panfletos informativos; campanhas através de redes sociais como o Facebook ou o Twitter), envolvendo outros cidadãos com o objetivo de promover mudanças de comportamentos frente aos problemas socioambientais. Ainda, os estudantes podem ser orientados a apresentar as pesquisas realizadas em suas comunidades. A criação de petições em sites de ativismo pode ser um meio para a atuação sociopolítica dos estudantes.

A avaliação dos estudantes pode ser realizada qualitativamente, sobretudo para os conteúdos procedimentais e, mais ainda, para os atitudinais. Por exemplo, pode-se avaliar a participação e o envolvimento dos estudantes nas atividades e as discussões sobre as controvérsias sociocientíficas, entre outros aspectos. (REIS, 2014) Outra opção seria, ao final da aplicação da SD, solicitar aos estudantes que construam uma carta para agricultores, expondo os malefícios trazidos pelos agrotóxicos para a saúde e o meio ambiente.

Em suma, consideramos que esse tema tem extrema relevância para a formação de cidadãos, diante dos problemas socioambientais relacionados ao uso dos agrotóxicos e da necessidade de formar indivíduos capazes de participar ativamente da resolução desses problemas (ANDRADE; ALMEIDA; NUNES-NETO, 2015), no sentido de maior justiça social e sustentabilidade ambiental. (HODSON, 2013) 


\section{Considerações Finais}

Apresentamos neste capítulo uma proposta de ensino baseada em QSC sobre agrotóxicos, discutindo brevemente aspectos políticos, socioambientais, econômicos e de saúde pertinentes ao tema, bem como algumas bases para sua aplicação no ensino de ciências. Desse modo, esta proposta poderá possibilitar a aproximação do conteúdo abordado em sala de aula à realidade dos estudantes, contribuindo para o desenvolvimento de pensamento crítico sobre relações entre CTSA, análise de valores morais e éticos e ação sociopolítica.

A aplicação desta QSC pode ser realizada no contexto de uma SD, sendo que seu planejamento deve considerar a combinação mais precisa das questões acerca do caso com os objetivos de aprendizagem, de modo a potencializar o alcance dos objetivos de ensino e de aprendizagem. Nesse sentido, cabe também avaliar a aplicação da QSC numa perspectiva de currículo CTSA, como explicitado por Hodson (2011), considerando: o reconhecimento das relações entre CTSA a respeito dos agrotóxicos e suas consequências; a aplicação destas relações em exemplos concretos do cotidiano relacionados ao tema; a avaliação e a tomada de decisão sobre o uso de agrotóxicos e de outras técnicas na agricultura, considerando seus aspectos éticos; a organização de ações sociopolíticas, visando melhoria das condições humanas e ambientais associadas à produção de alimentos.

\section{Referências}

ALTIERI, M.; NICHOLS, C. I. Agricultura tradicional y conservación de la biodiversidad. In: ALTIERI, M.; NICHOLLS, C. I. Agroecología: teoría y práctica para una agricultura sustentable. México, D. F.: Programa de las Naciones Unidas para el Medio Ambiente. Red de Formación Ambiental para América Latina y el Caribe, 2000. p. 181-192.

ALTIERI, M. Agroecologia: a dinâmica produtiva da agricultura sustentável. 2. ed. Porto Alegre: Ed. UFRGS, 2000.

ANDRADE, M. A. S. et al. Agrotóxicos como questão sociocientífica na Educação CTSA. Revista Eletrônica Mestrado em Educação Ambiental, Rio Grande, v. 33, n. 1, p. 171-191, jan./abr., 2016.

ANDRADE, M. A. S. Construção e aplicação de uma sequência didática colaborativa a partir de uma questão sociocientífica sobre agrotóxicos na perspectiva CTSA. 2016. 230p. Dissertação (Mestrado em Ensino, Filosofia e História das Ciências) - Universidade Federal da Bahia e Universidade Estadual de Feira de Santana, Salvador, 2016.

ANDRADE, M, A, S.; ALMEIDA, R. O.; NUNES-NETO, N, F. Questão sociocientífica sobre agrotóxicos na educação ciência-tecnologia-sociedade-ambiente: uma proposta didática visando a ação sociopolítica. In: ENCONTRO REGIONAL DE EDUCAÇÃO, MARXISMO E EMANCIPAÇÃO HUMANA, 6., 2015, Feira de Santana. Anais... Feira de Santana: UEFS, 2015. p. 41-46. 
ANDRADE, M. A. S.; RIBEIRO, G.; TEIXEIRA, M. C. O uso de mapas conceituais em uma sequência didática sobre o corpo humano: contribuições ao processo de ensino e aprendizagem. Aprendizagem Significativa em Revista, Porto Alegre, v. 4, n. 2, p. 1-14, 2014.

ANDRADES, T. O.; GANIME, R. N. Revolução verde e a apropriação capitalista. CES Revista, Juiz de Fora, v. 21, p. 43-56, 2007.

ARAÚJO, A. J. et al. Exposição múltipla a agrotóxicos e efeitos à saúde: estudo transversal em amostra de 102 trabalhadores rurais, Nova Friburgo, Rio de Janeiro. Ciência \& Saúde Coletiva, Rio de Janeiro, v. 12, n. 1, p. 115-130, 2007.

BRASIL. Ministério da Agricultura, Pecuária e Abastecimento. Plano agrícola e pecuário Safra 2004/2005. Brasília, DF, 2004. Disponível em: <http://www.agricultura.gov.br/ arq_editor/file/Ministerio/planos\%20e\%20programas/pap\%202004\%202005.pdf>. Acesso em: 6 jun. 2016.

BROIETTI, F. C. D. et al. O uso de agrotóxicos versus o cultivo orgânico: uma proposta de ensino fundamentada na abordagem CTS. In: SIMPÓSIO NACIONAL DE ENSINO DE CIÊNCIA E TECNOlOGIA, 4., 2012, Ponta Grossa. Anais... Ponta Grossa: UFPR, 2014. p. 1-12.

BUFFOLO, A. C. C.; RODRIGUES, M. A. Agrotóxicos: uma proposta socioambiental reflexiva no ensino de química sob a perspectiva CTS. Investigações em Ensino de Ciências, Porto Alegre, v. 20, n. 1, p. 1-14, 2015.

CAMACHO, R. S. Barbárie moderna do agronegócio-latifundiário exportador e suas implicações socioambientais. Agrária, São Paulo, n. 13, p. 169-195, 2010.

CANCLINI, N. G. Diferentes, desiguales o desconectados. Revista CIDOB d'AfersInternacionals, Barcelona, n. 66-67, p. 113-133, 2004.

CAPORAL, F. R.; AZEVEDO, E. O. Princípios e perspectivas da agroecologia. Curitiba: Instituto Federal de Educação, Ciência e Tecnologia do Paraná - Educação à Distância, 2011.

CAPORAL, F. R.; COSTABEBER, J. A. Agroecologia e extensão rural: contribuições para a promoção do desenvolvimento rural sustentável. 2. ed. Porto Alegre: EMATER, 2004.

CONRADO, D. M.; EL-HANI, C. N. Formação de cidadãos na perspectiva CTS: reflexões para o ensino de ciências. In: SIMPÓSIO NACIONAL DE ENSINO DE CIÊNCIA E TECNOLOGIA, 2., 2010, Paraná. Anais... Paraná: UTFPR, 2010. p. 1-14.

CONRADO, D. M.; NUNES-NETO, N. F. Dimensões do conteúdo em questões sociocientíficas no ensino de ecologia. In: ENCONTRO NACIONAL DE EDUCAÇÃO EM CIÊNCIAS, 16., 2015, Lisboa. Anais... Lisboa: ENEC, 2015. p. 432-435.

DUMRAUF, A.; CORDERO, S. ¿Qué futuro nos espera? abordaje de la temática "agrotóxicos" en una propuesta de promoción de la salud con comunidades campesinas. In: ENCONTRO NACIONAL DE PESQUISA EM ENSINO DE CIÊNCIAS, 7., 2013, São Paulo. Anais... São Paulo: ABRAPEC, 2013. p. 1-8. 
FERIOTTI, M. L.; CAMARGO, D. M. P. Diversidade, educação, cultura e sustentabilidade: relacionando conceitos. O Mundo da Saúde, São Paulo, v. 32, n. 3, p. 359-366, jul./set. 2008.

FERRAZ, F, D.; BREMM, C. Tema gerador no ensino médio: agrotóxicos como possibilidade para uma prática educativa contextualizadora. In: ENCONTRO NACIONAL DE PESQUISA EM EDUCAÇÃO EM CIÊNCIAS 4., 2007, São Paulo. Anais... São Paulo: ABRAPEC, 2007. p. 123-131.

FOUREZ, G. Educar: docentes, alunos, escolas, éticas, sociedades. Aparecida, SP: Ideias \& Letras, 2008.

FREIRE, P. Política e educação: ensaios. 5. ed. São Paulo: Cortez, 2001.

GENOVESE, C. L. C. R.; PESSOA, J. M. Trabalhador rural, agrotóxicos e ensino de ciências: uma análise. In: ENCONTRO NACIONAL DE PESQUISA EM ENSINO DE CIÊNCIAS, 9., 2013, São Paulo. Anais... São Paulo: ABRAPEC, 2013. p. 1-8.

GIL-PÉREZ, D. et al. Para uma imagem não deformada do trabalho científico. Ciência \& Educação, Bauru, v. 7, n. 2, p. 125-153, 2001.

GREGOLIS, T. B. L.; PINTO, W. J.; PERES, F. Percepção de riscos do uso de agrotóxicos por trabalhadores da agricultura familiar do município de Rio Branco, AC. Revista Brasileira de Saúde Ocupacional, São Paulo, v. 37, n. 125, p. 99-113, 2012.

HEREDIA, B.; PALMEIRA, M.; LEITE, S. P. Sociedade e economia do "agronegócio" no Brasil. Revista Brasileira de Ciências Sociais, São Paulo, v. 11, n. 25, p. 159-196, 2010.

HODSON, D. Looking to the future: building a curriculum for social activism.

Rotterdam: Sense Publishers, 2011.

HODSON, D. Going beyond STS: towards a curriculum for sociopolitical action. The Science Education Review, Canadá, v. 3, n. 1, p. 2-7, 2004.

HODSON, D. Don't be nervous, don't be flustered, don't be scared. be prepared. Canadian Journal of Science, Mathematics and Technology Education, Canadá, v. 13, n. 4, p. 313-331, 2013.

LACEY, H. Valores e atividade científica 2. São Paulo: Associação Filosófica Scientiae Studia, São Paulo: Ed. 34, 2010.

LACEY, H. A imparcialidade da ciência e as responsabilidades dos cientistas. Scientiae Studia, São Paulo, v. 9, n. 3, p. 487-500, 2011.

LACEY, H. Pluralismo metodológico, incomensurabilidade e o status científico do conhecimento tradicional. Scientiae Studia, São Paulo, v. 10, n. 3, p. 425-53, 2012.

LEFF, H. Agroecologia e saber ambiental. Agroecologia e desenvolvimento rural sustentável, Porto Alegre, v. 3, n. 1, p. 36-51, 2002.

LISBÔA, L, L. História em quadrinhos como local de aprendizagem: saberes ambientais e a formação de sujeitos. 2008. 98 f. Dissertação (Mestrado em Educação em Ciências) Universidade Federal do Rio Grande do Sul, Porto Alegre, 2008. 
LISBÔA, L, L.; JUNQUEIRA, H.; DEL PINO, J, C. A temática ambiental e seu potencial educativo nas histórias em quadrinhos de Mauricio de Sousa. In: ENCONTRO NACIONAL DE PESQUISA EM ENSINO DE CIÊNCIAS, 6., 2007, Águas de Lindóia, SP. Anais... Águas de Lindóia: ABRAPEC, 2007. p. 208-218.

LONDRES, F. Agrotóxicos no Brasil: um guia para ação em defesa da vida. Rio de Janeiro: AS-PTA - Assessoria e Serviços a Projetos em Agricultura Alternativa, 2011.

LOPES, N. C.; CARVALHO, W. L. P. Agrotóxicos - toxidade versus custos: uma experiência de formação de professores com as questões sociocientíficas no ensino de ciências. In: ENCONTRO NACIONAL DE PESQUISA EM EDUCAÇÃO EM CIÊNCIAS- ENPEC, 9., 2013, Águas de Lindoia, SP. Anais... Águas de Líndóia: ABRAPEC, 2013. p. 123-133.

MARTIN-LAURENT, F. et al. Ecofun-Microbiodiv: An FP7 European project for developing and evaluating innovative tools for assessing the impact of pesticides on soil functional microbial diversity- towards new pesticide registration regulation? Environmental Science Pollution Research, [S.1.], v. 20, n. 3, p. 1203-1205, 2013.

MATOS, G. B.; SANTANA, O. A. M.; NOBRE, L. C. C. Intoxicação por agrotóxico. In: BAHIA. Superintendência de Vigilância e Proteção da Saúde. Secretaria da Saúde do Estado. Manual de normas e procedimentos técnicos para a vigilância da saúde do trabalhador. Salvador, 2002. p. 249-280.

MENDES, A. M. V. et al. Elaboração de uma sequência didática fundamentada na perspectiva CTS para o estudo dos benefícios e malefícios oriundos do uso de agrotóxicos. In: JORNADA DE ENSINO, PESQUISA E EXTENSÃO, 13., 2013, Recife. Anais... Recife: UFRPE, 2013. p. 1-4.

MENDONÇA, M. R. S.; OLIVEIRA, L. G.; FRANCO, M. A. M. O uso de histórias em quadrinhos no ensino de ciências: perspectivas de letramento científico. In: SIMPÓSIO NACIONAL DE CIÊNCIA E TECNOLOGIA, 4., 2014, Ponta Grossa. Anais... Ponta Grossa: UFOP, 2014. p. 234-254.

MUENCHEN, C.; AULER, D. Configurações curriculares mediante o enfoque CTS: desafios a serem enfrentados na educação de jovens e adultos. Ciência \& Educação, Bauru, v. 13, n. 3, p. 421-434, 2007.

(O) VENENO está na mesa Il. Direção: Sílvio Tendler. Intérpretes: Marcos Palmeira; Eduardo Tornaghi; Priscila Camargo; Augusto Madeira. Rio de Janeiro: Caliban, 2014. 1 DVD (70 min). son., color.

PELAEZ, V.; TERRA, F. H. B.; SILVA, L. R. A regulamentação dos agrotóxicos no Brasil: entre o poder de mercado e a defesa da saúde e do meio ambiente. In: ENCONTRO NACIONAL DE ECONOMIA POLÍTICA, 14., 2009, São Paulo. Anais... São Paulo: SBEP, 2009. p. 345-384.

PERES, F. É veneno ou é remédio? Os desafios da comunicação rural sobre agrotóxicos. 1999. 163 f. Dissertação (Mestrado em Saúde Pública) - Fundação Oswaldo Cruz, Rio de Janeiro, 1999. 
PRAIA, J.; GIL-PÉREZ, D.; VILCHES, A. O papel da natureza da ciência na educação para a cidadania. Ciência \& Educação, Bauru, v. 13, n. 2, p. 141-156, 2007.

REIS, P. Acción socio-política sobre cuestiones socio-científicas: reconstruyendo la formación docente y el currículo. Uni-pluri/versidad, Medellin, v. 14, n. 2, p. 16-26, 2014.

SANTOS, W. L. P. dos. Scientific literacy: A Freirean perspective as a radical view of humanistic science education. Science Education, Brasília, DF, v. 93, n. 2, p. 361-382, 2009.

SANTOS, W. Contextualização no ensino de ciências por meio de temas cts em uma perspectiva crítica. Ciência \& Ensino, Campinas, v. 1, p. 1-12, nov. 2007. Edição especial.

SOARES, W. L.; PORTO, M. F. S. Pesticide use and economic impactson health. Revista Saúde Pública, São Paulo, v. 46, n. 2, p. 209-217, 2012.

SOUZA, P. F.; ABRAHÃO, C. M. S. O êxodo rural e expectativa de permanência no campo: a educação do campo e a sustentabilidade. Revista Ruralidades, São Paulo, v. 2, n. 1, p. 1-17, 2011.

STEFFAN-DEWENTER, I.; POTTS, S, G.; PACKER, L. Pollinator diversity and crop pollination services are at risk. Trends in Ecology and Evolution, Amsterdam, v. 20, n. 12, p. 651-652, 2005.

TRAPÉ, D. Segurança no uso de agrotóxicos e efeitos na saúde de agricultores da região de Campinas. Revista Brasileira de Medicina do Trabalho, Rio de Janeiro, v. 9, n. 1, p. 10-14, 2011.

ZABALA, A. As sequências didáticas e as sequências de conteúdo. In: ZABALA, A. A prática educativa: como ensinar. São Paulo: Artmed, 1998. p. 233-314.

ZEIDLER, D. L.; NICHOLS, B. H. Socioscientific issues: theory and practice. Journal of Elementary Science Education, New York, v. 21, n. 2, p. 49-58, 2009. 


\title{
DECLÍNIO DE POLINIZADORES COMO QUESTÃO SOCIOCIENTÍFICA NO ENSINO DE BIOLOGIA
}

\author{
Dália Melissa Conrado \\ Nei Nunes-Neto \\ Blandina F. Viana \\ Charbel N. El-Hani
}

\section{Introdução}

Diante dos atuais e graves problemas socioambientais, ${ }^{1} \mathrm{o}$ cidadão ${ }^{2}$ deve ser capaz de atuar em contextos nos quais ele deverá mobilizar não só o conhecimento científico, mas também deverá ser capaz de argumentar e analisar argumentos, examinar e expli-

1 Problemas socioambientais são situações complexas das sociedades que envolvem prejuízos ao meio ambiente em diferentes escalas e amplitudes, que afetam a qualidade de vida humana e possuem natureza, causas, soluções e implicações multidimensionais, expressas em dimensões econômicas, tecnológicas, políticas e éticas. (JAMIESON, 2010)

2 Aqui, assumimos a noção de cidadão como um agente social responsável (GIROUX, 2004), capaz de: reconhecer e interpretar criticamente as relações de poder e opressão na sociedade; engajar-se de modo ativo e crítico em ações locais, nacionais e globais (GIROUX; GIROUX, 2006); e tomar decisões socialmente responsáveis, o que significa ter consciência de seu papel na sociedade, com compromisso de cooperação e corresponsabilidade social, na busca de melhor qualidade de vida em termos coletivos, e não apenas individuais. (CONRADO, 2013; SANTOS; MORTIMER, 2001) Para isso, a formação de cidadãos precisa ser condizente com uma preparação para participação 
citar valores, educar outros cidadãos e participar da tomada de decisão e de ações individuais e coletivas sobre esses problemas. (BETTENCOURT; VELHO; ALMEIDA, 2011; CONRADO; NUNES-NETO; EL-HANI, 2015; JAROSZ, 2004; MINTEER; COLLINS, 2005; PINZINO, 2012; TOMAS; RITCHIE; TONES, 2011) Nesse sentido, a educação científica tem um papel essencial na abordagem de questões complexas, com o intuito de preparar o cidadão para lidar com esses problemas. (FENSHAM, 2012)

Para alcançar isso, Noss (2007) enfatiza a importância de incluir, na educação científica e, particularmente, no ensino de biologia, uma maior ênfase nas dimensões não-conceituais dos conteúdos, assim como uma maior contextualização socioambiental dos temas abordados. (DILLON, 2012; SADLER; ZEIDLER, 2004) Assim, podemos dizer que uma formação mais ampla - isto é, que considere as dimensões Conceituais, Procedimentais e Atitudinais (CPA) dos conteúdos científicos - pode ser realizada a partir de estratégias de ensino que contextualizem social, filosófica ou historicamente temas relevantes no âmbito da educação científica. (CONRADO; NUNES-NETO, 2015) Esse tipo de abordagem contextualizada facilita a promoção do raciocínio crítico e sistemático (TORRES; MARTÍNEZ PÉREZ, 2011); melhora a compreensão e a aplicação dos conteúdos científicos no cotidiano (HODSON, 2013); e humaniza a ciência, por conectá-la às questões éticas e políticas. (BENCZE; ALSOP, 2009; CONRADO; EL-HANI; NUNES-NETO, 2013; MATTHEWS, 1994)

A formação de cidadãos informados, responsáveis, críticos e engajados ética e politicamente, capazes de atuar na busca de maior justiça social e sustentabilidade ambiental, tem sido assumida por diversos autores como um importante objetivo da educação científica. (BENCZE; CARTER; KRSTOVIC, 2014; HODSON, 2011; LEVINSON, 2010; PEDRETTI, 2003; REIS, 2013; SOLBES; VILCHES, 2004) Para alcançar esse objetivo, muitos autores têm defendido um currículo baseado em Questões Sociocientíficas (QSC), no contexto de uma abordagem pedagógica da educação Ciência, Tecnologia, Sociedade e Ambiente (CTSA). O ensino a partir de QSC tem sido apontado como uma estratégia eficiente para: melhorar a compreensão do conhecimento científico e da atividade científica, bem como de seu papel na sociedade; desenvolver habilidades argumentativas, atitudes de solidariedade e tolerância a diferentes pontos de vista; e empoderar os estudantes para ações sociopolíticas (CONRADO; NUNES-NETO; EL-HANI, 2015; REIS, 2013; HODSON, 2004) em relação aos problemas socioambientais atuais. (BENCZE; SPERLING; CARTER, 2012; CONRADO, 2013; HODSON, 2011; PEDRETTI; NAZIR, 2011; SANTOS, 2009)

As QSC são problemas controversos que, para sua solução, necessitam de conhecimentos científicos, mas envolvem não apenas estes, mas também outros tipos de conhecimentos, além de habilidades, valores e atitudes, como - possivelmente - aqueles provenientes de diferentes tradições culturais e religiosas, filosofias morais, entre

política, o que pode ser favorecida com uma educação baseada em questões sociocientíficas, no âmbito da educação CTSA. (SANTOS, 2009) 
outras fontes. (BERNARDO; VIANNA; SILVA, 2011; CONRADO, 2013; CONRADO et al., 2012; HODSON, 2013; SADLER; ZEIDLER, 2004) Compreender, relacionar e incorporar esses diferentes aspectos na tomada de decisão sobre uma QSC possibilita ao estudante uma aprendizagem mais integral do conteúdo (isto é, menos fragmentada ou parcial, em termos de disciplinas ou áreas do conhecimento ou campos da atuação humana). Isso significa que haverá, da perspectiva das QSC, uma conexão mais forte e explícita entre conteúdos científicos e não científicos. (CONRADO, 2013) Além disso, as QSC, geralmente, estão contextualizadas em temas e situações locais, o que contribui para o engajamento ou o interesse afetivo dos estudantes, condição importante para uma compreensão mais aprofundada e para uma capacitação para ações de melhoria e redução de problemas encontrados nos sistemas socioecológicos. ${ }^{3}$ (BARTHEL; FOLKE; COLDING, 2010; FEINSTEIN, KIRCHGASLER, 2015; PRETTY, 2011; TOMAS; RITCHIE; TONES, 2011)

Neste capítulo, enfocamos, em particular, um problema socioambiental relevante para o ensino de biologia, a saber, a diminuição das abelhas nativas, o déficit de polinização e suas consequências na produção de alimentos. O déficit de polinização tem acometido diversos sistemas socioecológicos ao redor do mundo. (AIZEN et al., 2009) Esse problema tem repercussões complexas, e, didaticamente, podemos analisá-lo, ao menos, em uma dimensão ambiental, bem como em uma dimensão social. A primeira é imediatamente percebida, quando notamos que a redução da taxa de polinização de plantas com flores é uma consequência direta, ao menos em parte, da extinção local de abelhas nativas. (GARIBALDI et al., 2013) As causas dessa extinção ainda são objeto de investigação pela ecologia; porém, vários fatores que contribuem para esse fenômeno têm sido levantados, como a intensificação da agricultura com agrotóxicos (LIMA; ROCHA, 2012; POTTS et al., 2010) e a propagação de doenças, tanto por microrganismos patógenos emergentes, quanto por espécies exóticas. (DOUBLET et al., 2014; VANBERGEN et al., 2013)

Por sua vez, a dimensão social aparece quando notamos, por exemplo, que o déficit de polinização, por reduzir a produção de alimentos, tanto em quantidade quanto em qualidade, tende a gerar consequências para as sociedades humanas, como, por exemplo, o déficit nutricional. (AIZEN et al., 2009; STEFFAN-DEWENTER; POTTS; PACKER, 2005)

Trata-se de um problema relevante no cenário mundial atual, sendo um tema de interesse público, interdisciplinar e com grandes oportunidades para propostas de ensino inovadoras e para uma aprendizagem bem-sucedida na educação científica. Com base no exposto, o objetivo deste capítulo é apresentar uma proposta de ensino para a educação

3 Sistemas socioecológicos são sistemas híbridos resultantes da forte interação entre os componentes humanos sociais e componentes estritamente ecológicos. Alguns exemplos são: fazendas, jardins, cidades, reservas extrativistas etc. (BERKES; COLDING; FOLKE, 2003; KREMEN; ILES; BACON, 2012; OSTROM, 2007) 
científica de nível médio ou superior, baseada em uma QSC sobre declínio de polinizadores e produção de alimentos, sob uma perspectiva de educação CTSA, com a concomitante discussão dos meios de aplicação em sala de aula.

A estrutura do capítulo é a seguinte: na seção 2, apresentamos algumas bases ecológicas do problema do déficit de polinização, causado pelo declínio de abelhas. Isso oferecerá um contexto para, na seção 3, apresentarmos uma QSC específica sobre o tema, na forma de um caso, na qual apontamos os níveis de ensino adequados, as áreas do conhecimento que podem ser mobilizadas, as questões específicas sobre o caso para motivar interações em sala, os objetivos de aprendizagem sugeridos em relação às questões propostas e, por fim, algumas sugestões de como aplicar a QSC no ensino. Finalmente, na seção 4, apresentamos nossas considerações finais.

\section{Causas e consequências do déficit de polinização por declínio de abelhas}

A polinização é um processo ecossistêmico essencial, necessário para a produção de frutos e/ou sementes. (ABROL, 2015; VANBERGEN et al., 2013; POTTS et al., 2010) Mais de 87\% das espécies de angiospermas do mundo (OLLERTON et al., 2011) e um terço das plantas cultivadas (KLEIN et al., 2007) necessitam de algum tipo de polinização animal para sua reprodução, sendo esse processo fundamental para a nutrição dos seres humanos. (EILERS et al., 2011; SAPIR; DORCHIN; MANDELIK, 2015) Particularmente, as abelhas se destacam como as principais polinizadoras da maior parte das plantas com flores, contribuindo tanto para a conservação da biodiversidade (ARENA; SGOLASTRA, 2014; PINKE, 2013), uma vez que a polinização por animais é crucial tanto para manter a variabilidade genética das plantas, quanto para a produção de alimentos para as populações humanas.

O declínio global das abelhas tem sido considerado uma questão crítica desde o final da década de 1980 e início dos anos 1990. (ABROL, 2015) Na Europa, uma infestação por ácaros levou ao declínio de abelhas melíferas (Apis mellifera) em meados da década de 1970. (IMPERATRIZ-FONSECA et al., 2012) Contudo, o maior alerta ocorreu após a divulgação mundial da perda de 30 a $90 \%$ das colmeias de apicultores norte-americanos ao final de 2006. (IMPERATRIZ-FONSECA et al., 2012; LIMA; ROCHA, 2012) No Brasil, um dos primeiros casos divulgados ocorreu em 2008. (IMPERATRIZ-FONSECA et al., 2012) Os múltiplos fatores que causam esse declínio muitas vezes confluem, amplificando seus efeitos deletérios nas populações de polinizadores. (POTTS et al., 2010; WAGONER; BONCRISTIANI; RUEPPELL, 2013) A principal causa do declínio de abelhas é a perda ou fragmentação de habitat (ABROL, 2015; POTTS et al., 2010; VANBERGEN et al., 2013), o que ocorre principalmente por causa de degradação ambiental (decorrente de desmatamento, criação de pastagens, queimadas, urbanização, agricultura intensiva, introdução de espécies não nativas), gerando perda de integridade da paisagem, 
de recursos florais e de locais de nidificação. (BOMMARCO; KLEIJN; POTTS, 2013; KENNEDY et al., 2013) Apesar da grande vagilidade/mobilidade das abelhas e da tolerância de muitos polinizadores em níveis moderados de perturbação ambiental, a fragmentação de habitats leva à redução tanto da riqueza quanto da abundância de abelhas. (POTTS et al., 2010)

Abelhas melíferas, por serem consideradas comercialmente mais vantajosas (principalmente devido à produção de mel) e facilmente adaptáveis a diversos ambientes, têm sido amplamente introduzidas como meio de aumentar a polinização dos cultivares, sendo responsável por até $90 \%$ da produção de algumas monoculturas. (ARENA; SGOLASTRA, 2014) Contudo, há evidências de que a Apis mellifera não substitui as abelhas silvestres na prestação desse serviço (GARIBALDI et al., 2013), apesar de haver alguma sobreposição de nicho. (GOULSON, 2003) Cabe notar que abelhas melíferas não são "funcionalmente equivalentes" às abelhas nativas, mas são, mais precisamente, "funcionalmente complementares" a estas, o que significa que, apesar de contribuírem para a polinização, as abelhas melíferas não substituem efetivamente as nativas, em caso de extinção destas. (GARIBALDI et al., 2013)

A intensificação da agricultura, principalmente após a Revolução Verde, tem aumentado o uso de agrotóxicos e a degradação ambiental. (LIMA; ROCHA, 2012) Os inseticidas causam morte por intoxicação direta, enquanto os herbicidas e fertilizantes alteram a disponibilidade de recurso floral para as abelhas. (POTTS et al., 2010) Além disso, a disseminação dos agrotóxicos pelo vento pode contaminar água, solo, plantas e animais. (PINHEIRO; FREITAS, 2010; SILVA et al., 2014)

Abelhas que estão expostas a doses subletais de agrotóxicos ficam mais suscetíveis à ação de agentes patogênicos que infectam suas colônias. (POTTS et al., 2010) Diante do uso inadequado dos agrotóxicos, há aumento da toxicidade e dos efeitos subletais, como alterações comportamentais, desorientação de voo, má formação de larvas e redução da prole. (CUTLER; SCOTT-DUPREE, 2014; GOULSON, 2003; 2013; LIMA; ROCHA, 2012) Como condições agravantes à exposição crônica a agrotóxicos, somam-se dois outros fatores: as mudanças climáticas, que podem aumentar a disseminação de vírus, ácaros e outros patógenos; e o enfraquecimento do sistema imunológico, associado à desnutrição das abelhas, que pode aumentar a vulnerabilidade delas a doenças. (LIMA; ROCHA, 2012; POTTS et al., 2010)

Em relação às consequências do declínio das abelhas, destacamos duas: influência na crise da biodiversidade e impactos na nutrição humana. (EILERS et al., 2011) Em primeiro lugar, é notável a influência do declínio das abelhas na crise da biodiversidade atual, que parece ser a sexta grande extinção em massa da vida na Terra. (BARNOSKY et al., 2011) Esta extinção em massa tem sido causada pelos impactos antrópicos sobre a biodiversidade, o que tem ocorrido através de diversos fatores, como introdução de espécies não nativas/exóticas, fragmentação ou redução de habitat, poluição (aquática, atmosférica e de solo) em diversas escalas temporais e espaciais, 
aquecimento global, intensificação do uso da terra para agricultura e pecuária, entre outros. (MILLENNIUM ECOSYSTEM ASSESSMENT, 2005) Em particular, podemos assumir que o declínio de abelhas é um, dentre vários fatores, que leva à crise da biodiversidade. Isso ocorre porque a redução das abelhas leva a déficit de polinização, o que, por afetar a reprodução das plantas com flores, reduz a variabilidade genética destas. Uma vez que as plantas apresentem reduzida variabilidade genética, serão mais suscetíveis a perturbações provenientes do ambiente, podendo ser extintas com maior probabilidade. De forma similar, muitos outros animais, dependentes de plantas, também podem ser afetados, o que pode levar a uma cascata de efeitos nos ecossistemas. (DUNNE; WILLIAMS, 2009)

Já em relação à nutrição humana, apesar de ser difícil estabelecer as complexas relações com os polinizadores animais, estes, de fato, possuem importante papel na disponibilidade de macro e micronutrientes (provenientes de frutos e sementes) essenciais para a saúde humana. (EILERS et al., 2011) Os polinizadores afetam, assim, não apenas o rendimento e o preço do alimento, mas também seu valor nutricional, principalmente em países em desenvolvimento, que estão mais vulneráveis à escassez de alimentos e nutrientes. (CHAPLIN-KRAMER et al., 2014; EILERS et al., 2011; ELLIS; MYERS; RICKETTS, 2015; NICOLE, 2015) Isso tem sido discutido amplamente nos estudos relacionados à segurança alimentar ou segurança nutricional dos alimentos. (ABROL, 2015; SAPIR; DORCHIN; MANDELIK, 2015)

Podemos mencionar alguns exemplos. Na investigação da qualidade nutricional de amêndoas com a contribuição de animais para a polinização cruzada, Brittain e colaboradores (2014) mostraram que o valor nutricional e a qualidade comercial aumentam na presença do polinizador animal, principalmente em relação à vitamina E. Eilers e colaboradores (2011) calcularam as proporções de nutrientes em diferentes culturas do mundo, dependentes e independentes de polinizadores. Seus resultados indicaram que plantas de cultivos (que dependem parcial ou totalmente de animais polinizadores) contêm grande parte das vitaminas A, C e E, e parte de minerais, como cálcio, fluoreto e ferro, além de antioxidantes, como b-criptoxantina e b-tocoferol, de lipídios e do ácido fólico, importantes para a nutrição humana. Já Chaplin-Kramer e colaboradores (2014) avaliaram a dependência do teor de micronutrientes em culturas de diferentes regiões do mundo em relação a polinizadores animais e mostraram haver sobreposições entre esta dependência e a gravidade da desnutrição em relação a alguns micronutrientes nas pessoas ao redor do mundo. Se considerarmos o problema global da desigualdade de acesso a nutrientes, o declínio de polinizadores poderá agravar dificuldades de nutrição da população humana global. (EILERS et al., 2011)

Em um estudo empírico sobre saúde nutricional, Ellis, Myers e Ricketts (2015) levantaram alimentos que contribuíam para a ingestão de cinco nutrientes (vitamina A, zinco, ferro, ácido fólico e cálcio) em situações com e sem polinizadores e o risco de 
deficiência desses nutrientes em quatro países em desenvolvimento. Seus resultados ${ }^{4}$ indicaram aumento de risco nutricional (devido à redução de ingesta de alimentos dependentes de polinizadores animais) em até $56 \%$ da população desses países, com destaque para a vitamina A (> 69\%).

Em suma, a polinização animal é um processo ecológico fundamental, traz contribuições importantes para a economia e saúde humanas e tem sido afetado por diversos fatores, assim como tem consequências socioambientais relevantes. Cabe, assim, considerar seriamente este tema em sala de aula; além disso, a construção de uma QSC a seu respeito fornece um recurso importante para uma educação focada nas relações CTSA.

\section{Uma QSC sobre declínio de polinizadores e produção de frutos}

Essa QSC pode ser aplicada tanto no ensino médio como no ensino superior, sendo apenas necessário adaptá-la de acordo com os objetivos de aprendizagem. Se possível, seria interessante se professores de várias áreas pudessem participar da aplicação da QSC. As áreas do conhecimento relacionadas e suas respectivas subáreas de maior interesse a considerar, são: biologia (ecologia, biologia evolutiva, botânica, zoologia, fisiologia humana, saúde), filosofia (filosofia moral, epistemologia da ecologia, ética ambiental), geografia (climatologia, geologia), química (bioquímica), matemática (estatística), física (biofísica), ciências sociais/sociologia (cultura, comportamento social, política), história (história ambiental).

Efetivamente, são muitas as áreas que apontamos acima como possíveis de serem abordadas. Caberá ao professor individualmente ou ao grupo de professores envolvidos determinar - de acordo com seus próprios contextos pessoais, contexto da escola, tempo disponível, interesses pedagógicos etc. - a melhor composição e articulação entre as diferentes áreas que oferecerão contexto, dentro do currículo, à aplicação desta QSC.

O Quadro 1 apresenta o caso (“O envenenamento das abelhas") que veicula a proposta de ensino baseada em QSC. Uma versão desse caso foi aplicada ao ensino superior de biologia, e resultados parciais de pesquisa envolvendo esse caso podem ser encontrados em Conrado (2017), Conrado e colaboradores $(2015,2016)$ e Conrado e Conrado (2016a, 2016b).

4 Cabe fazer a ressalva de que os resultados de risco dependem também dos hábitos alimentares e das condições locais, uma vez que muitos dos participantes consumiam alimentos locais, obtendo nutrientes de alimentos que não estão entre aqueles que o mercado analisa. Outra limitação do trabalho é que não foi considerada a interação de nutrientes no organismo, por exemplo, a dependência de absorção intestinal de um nutriente pela presença de outro. 
Quadro 1 - QSC sobre declínio de abelhas e produção de alimentos, apresentada na forma de um caso para o ensino de ciências

\section{O envenenamento das abelhas}

Imagine que seu tio é um apicultor e tem enfrentado problemas em relação ao seu vizinho que cultiva maçãs e usa um agrotóxico neonicotinoide. Seu tio lhe diz:

_ Minhas abelhas estão morrendo envenenadas! Meu vizinho diz que está usando o agrotóxico seguindo as instruções e que o SINDIVEG (Sindicato Nacional da Indústria de Produtos para Defesa Vegetal) afirma que não há estudos conclusivos sobre a influência dos agrotóxicos na saúde das abelhas. O que você sabe sobre isso?

Você, sabendo que as abelhas contribuem com o aumento da produtividade de mais $70 \%$ dos cultivos agrícolas, decide fazer uma investigação:

_. Eu e meus colegas vamos ver o que podemos fazer para lhe ajudar.

Seu tio lhe responde:

_ Muito obrigado! O que eu preciso saber é: se minhas abelhas estão, de fato, sendo prejudicadas pelo veneno do vizinho; se eu posso fazer algo para evitar a intoxicação de minhas abelhas; se eu posso dizer algo para que meu vizinho deixe de usar agrotóxicos em sua plantação. Além disso, os insetos e as flores estão trabalhando juntos há milênios e não é certo interferir com tanto veneno.

Quando você expõe o caso do seu tio ao seu grupo, seu amigo Paulo duvida da redução das abelhas:

_ Será que as abelhas estão mesmo desaparecendo? As lixeiras estão sempre cheias de abelhas! Sua amiga Júlia, que já conhecia alguns polinizadores de plantas produtoras de frutos de interesse comercial, diz:

_ Mesmo que não estivessem morrendo, temos que preservar as abelhas! Esse vizinho não sabe que as maçãs dele dependem dos polinizadores das redondezas?

Você responde:

_ Talvez ele esteja apostando em outras formas de polinização... Mas, até onde eu sei, com as abelhas, a qualidade do fruto é melhor, e aí o preço final pode ser maior.

Sua amiga Fernanda retruca:

_ Que o preço das frutas e dos legumes tem aumentado, isso tem. Mas será que as abelhas têm algo a ver com isso?

Finalmente, Paulo completa:

- Mas o mercado sempre está cheio de frutas e legumes (tanto em variedade quanto em quantidade). Os produtos chegam a estragar nas prateleiras! Como isso é possível?

Fonte: elaborado pelos autores com base em Conrado e colaboradores (2015).

Abaixo, propomos algumas questões orientadoras sobre o caso para serem discutidas em sala de aula e que podem direcionar sua resolução, pelos estudantes.

Q1. Sobre a dúvida de Paulo, há declínio nas populações de abelhas no mundo? Justifique.

Q2. Quais as formas de polinização? Classifique, com exemplos.

Q3. Sobre a dúvida de Fernanda, qual a relação entre o desaparecimento das abelhas e a queda na quantidade e na qualidade dos alimentos?

Q4. Quais as possíveis interações ecológicas que animais estabelecem com as plantas? Dê alguns exemplos, classificando-os. 
Q5. Sobre o comentário de Júlia, como a diversidade e a abundância de polinizadores podem afetar a produtividade em diversas culturas?

Q6. Como podemos explicar a afirmação do tio: "os insetos e as flores estão trabalhando juntos há milênios", a partir de conhecimentos da biologia evolutiva? Exemplifique, utilizando a abelha e a flor da macieira.

Q7. Quais as principais ações antrópicas sobre o ambiente que podem levar à redução de polinizadores? Justifique.

Q8. A polinização pode ser caracterizada como serviço ecossistêmico? Justifique.

Q9. Que (tipos de) valores podem ser atribuídos aos serviços de polinização?

Q10. Há relações entre a monocultura e o uso de agrotóxicos? Justifique.

Q11. Quais as vantagens e desvantagens da monocultura? Liste os diferentes argumentos.

Q12. Como os agrotóxicos podem afetar a sobrevivência das abelhas e a qualidade de vida humana?

Q13. O que o seu tio e o vizinho dele precisam saber sobre o uso de agrotóxicos e suas consequências para a biodiversidade? Liste, por ordem de prioridade, as informações e os conhecimentos relevantes.

Q14. Quais as alternativas para evitar o uso de agrotóxicos, como os neonicotinoides?

Q15. A biodiversidade (por exemplo, o número de espécies) está relacionada às propriedades ecossistêmicas (por exemplo, a ciclagem de matéria)? Como as abelhas e as plantas estão envolvidas nos fluxos de matéria dos ecossistemas?

Q16. Sobre o comentário "Mesmo que não estivessem morrendo, temos que preservar as abelhas!", quais os principais motivos (e com base em que valores) para ações de preservação ou conservação ambiental?

Q17. Quais os significados socioecológico e econômico da disponibilidade contínua e abundante de frutas e legumes nos grandes centros urbanos?

Q18. Descreva brevemente as normas legais do seu país para o uso de agrotóxicos.

Q19. Que estratégias sua equipe adotará para ajudar a resolver o problema de seu tio?

\section{Objetivos de aprendizagem}

A seguir, apresentamos alguns objetivos de aprendizagem para o ensino de ciências que poderão ser alcançados a partir desta proposta de ensino, com base neste caso e nas questões orientadoras acima. Para facilitar o reconhecimento da articulação entre esses 
objetivos e as questões orientadoras, inserimos estas últimas entre parênteses em cada objetivo.

\section{Conceituais}

- Compreender e relacionar fatos históricos e dados estatísticos sobre redução das populações de abelhas; sobre diversidade e abundância de polinizadores e sua relação com a produtividade agrícola; uso e efeitos de agrotóxicos e suas consequências ambientais; conservação ambiental e de polinizadores (Q1; Q5; Q7; Q10; Q11; Q12; Q13; Q15; Q16).

- Definir, compreender e aplicar nos contextos específicos conceitos e/ou princípios científicos, relativos à polinização, ao ecossistema, à fragmentação de habitat, às funções ecológicas, aos bens e serviços ecossistêmicos, à biodiversidade, ao mutualismo, à anatomia e à fisiologia de plantas, à produção de biomassa, à estabilidade ecossistêmica, aos agrotóxicos, às mudanças climáticas, aos ciclos biogeoquímicos, às interações ecológicas, à coevolução, à natureza, ao valor, à alimentação e ao especismo, à monocultura e à variabilidade genética, ao fechamento de restrições, ${ }^{5}$ à agroecologia, à bioacumulação, ao nicho ecológico, ao fluxo de matéria e energia e à ciclagem de nutrientes, à exclusão competitiva, à teoria da seleção natural (Q2 a Q16).

\section{Procedimentais}

- Realizar levantamento bibliográfico visando obter informações sobre os temas (Q1 a Q19).

- Elaborar e analisar argumentos sobre déficit de polinização e suas consequências socioambientais (Q1 a Q19).

- Classificar a polinização em diferentes tipos (Q2).

- Analisar e construir gráficos comparativos sobre eficiência de polinização entre diferentes espécies de polinizadores (Q3; Q5).

- Explicar a relação entre riqueza e abundância de espécies e taxas de polinização (Q1; Q3; Q5; Q11).

5 O conceito de fechamento de restrições é baseado na ideia de uma organização causal circular, introduzida por Kant (1802) e reinterpretada à luz da biologia teórica dos séculos XX e XXI (MORENO; MOSSIO, 2015; MOSSIO; SABORIDO; MORENO, 2009) e aplicada à ecologia. (COOPER; EL-HANI; NUNES-NETO, 2016; NUNES-NETO; MORENO; EL-HANI, 2014) Por exemplo, o conceito de função ecológica e o conceito (ou princípio teórico) de um fechamento organizacional que temos desenvolvido, em paralelo, em investigações sobre os fundamentos epistemológicos e éticos do entendimento sobre sistemas ecológicos e socioecológicos dos pontos de vista da epistemologia da ecologia e da ética ambiental, respectivamente, podem ser mobilizados para contextualizar o ensino de Ecologia quanto a estes assuntos. 
- Descrever técnicas de mensuração de processos ecológicos, como produção de biomassa, e de resíduos/níveis de agrotóxicos em organismos, como plantas e animais (Q3; Q10; Q11; Q12).

- Elaborar e analisar argumentos sobre ambientes sustentáveis (Q3; Q5; Q7; Q8; Q9; Q11; Q12; Q16; Q17; Q18; Q19).

\section{Atitudinais}

- Trabalhar em equipe e respeitar diferentes pontos de vista (Q1 a 19).

- Identificar e avaliar valores sociais nos discursos, na legislação e nas ações relacionadas à conservação ou à preservação de serviços ecossistêmicos, como a polinização (Q7; Q8; Q9; Q10; Q14; Q16; Q17; Q18).

- Discutir valores dos serviços ecossistêmicos e valores intrínsecos e instrumentais das espécies e dos ecossistemas (Q7; Q8; Q9; Q16; Q17).

- Planejar práticas para a manutenção de populações de polinizadores silvestres e seus habitats e para a redução dos problemas relacionados ao uso de agrotóxicos, como eventos de divulgação e de construção coletiva de jardins e ambientes atrativos para polinizadores como abelhas (Q7; Q8; Q9; Q11; Q12; Q14; Q16; Q19).

A depender de como e em que nível de ensino o caso for aplicado, sugerimos usar o caso sobre a QSC juntamente com atividades de argumentação ou de debate entre grupos na sala de aula, inserindo questões adicionais que possam promover condições para a aprendizagem dos conteúdos selecionados para a unidade didática. É importante estabelecer uma relação clara entre as questões feitas aos estudantes e os objetivos de aprendizagem, representados nas suas dimensões CPA. (COLL et al., 1992; ZABALA; ARNAU, 2010)

\section{Meios para aplicação e discussão da QSC no ensino}

A partir desse caso, os estudantes, em equipes, deverão investigar: as causas da morte das abelhas; suas consequências para a produção e a qualidade de alimentos dependentes de polinização; o significado socioecológico da disponibilidade de alimentos; as diferenças entre abelhas nativas e não nativas; as consequências socioambientais da monocultura; o uso de agrotóxicos e consequências para a biodiversidade, entre outros temas.

Podemos adotar diferentes técnicas para favorecer o processo de resolução da QSC em sala de aula. Aqui, apresentamos algumas sugestões. 


\section{Adoção de estratégias do método de Aprendizagem Baseada em Problemas}

Na medida em que a QSC se refere a um problema do mundo real, com implicações práticas, sugerimos a adoção do método (ou de alguns elementos do método, de acordo com os contextos do professor ou do grupo) de Aprendizagem Baseada em Problemas (ABP; ou PBL, do inglês Problem-Based Learning), para orientar a análise e a resolução do caso pelos estudantes, mas de modo a preservar a possibilidade de desenvolverem múltiplas abordagens e mobilizarem múltiplos conhecimentos e pensamentos para resolvê-la. ${ }^{6}$ Isso porque a ABP é centrada na aprendizagem de conteúdos e habilidades de maneira inter-relacionada e contextualizada em problemas reais, criando condições para uma maior aprendizagem de ambos, além de explicitar a dimensão atitudinal no planejamento dos conteúdos a serem ensinados. (BOROCHOVICIUS; TORTELLA, 2014; DEELMAN; HOEBERIGS, 2009)

Além disso, a ABP é uma abordagem centrada no estudante, que visa empoderá-lo para a condução de pesquisa, integração de teoria e prática e aplicação de conhecimentos e habilidades para desenvolver soluções viáveis para os problemas propostos, mostrando-se alinhada com o uso de QSC no ensino. (SAVERY, 2006) Na ABP, os estudantes assumem papel ativo e maior responsabilidade no processo de aprendizagem, analisando os problemas de modo a estabelecer seus pontos-chave e as lacunas de conhecimento que eles têm - e, assim, definindo o que precisam aprender. (BARROWS, 2002) Eles desenvolvem, assim, habilidades e valores para o trabalho em equipe e a resolução de problemas, como autonomia, criatividade, pensamento crítico e argumentação. (LEE; TAN, 2004) Para isso, eles utilizam ferramentas e técnicas para

6 Apesar da ABP ser amplamente usada em diferentes cursos, desde seu desenvolvimento na escola de medicina da Universidade McMaster, no Canadá, sua efetividade para atingir determinados objetivos de aprendizagem ainda continua em debate. Contudo, estudos empíricos têm apoiado a efetividade da $\mathrm{ABP}$, como mostram várias meta-análises que comparam o ensino via $A B P$ com o ensino baseado em exposições centradas no professor, por exemplo, ALBANESE; MITCHELL, 1993; DOCHY et al., 2003; GIJBELS et al., 2005. Uma metassíntese qualitativa de oito meta-análises, buscando estabelecer enunciados de valor generalizáveis sobre a efetividade da ABP, mostrou que essa abordagem é mais efetiva no que diz respeito à retenção de longo termo, ao desenvolvimento de habilidades e à satisfação de professores e estudantes, enquanto o ensino baseado em exposições é mais efetivo para a retenção de curto termo. (STROBEL; VAN BARNEVELD, 2009) Entre as razões pelas quais as disputas continuam quanto à efetividade da $A B P$ encontram-se: o fato de que os estudos empíricos sobre sua efetividade, usado nas meta-análises, em geral, têm limites importantes quanto às suas bases de dados e instrumentos, e as meta-análises disponíveis não são independentes, mas relacionadas umas com as outras (ALBANESE; DAST, 2014); a valorização da aprendizagem de conteúdos conceituais, frequentemente em detrimento dos procedimentais e atitudinais, e a contínua suspeita de que eles não são tão efetivamente aprendidos na $A B P$; e os limites da extensão da $A B P$ de cursos mais focados diretamente na ação prática (como Medicina ou Engenharia) para cursos de natureza mais básica (como Biologia ou Física). Contudo, nossa experiência com o uso de ABP, nos níveis de pós-graduação e graduação, nos últimos cinco anos, têm sido bastante positiva, em termos do engajamento, da motivação $\mathrm{e}$ da aprendizagem dos estudantes. 
organizar, planejar, avaliar e apresentar conteúdos relacionados ao caso. (SAVIN-BADEN; MAJOR, 2004)

Tanto para observar e avaliar o desenvolvimento das equipes quanto para auxiliá-los em suas atividades, o professor deverá acompanhar as equipes, se possível com a ajuda de tutores. Ao longo do processo de resolução do problema, os professores e tutores atuam como mediadores, colocando para os estudantes os tipos de questões metacognitivas que gostariam que os estudantes fizessem a si mesmos. (BARROWS, 2002)

Uma das técnicas mais comuns da ABP é o uso dos chamados "sete passos" (GIJSELAERS, 1995; MAURER; NEUHOLD, 2012), uma rotina organizacional para orientar as ações dos estudantes para a resolução do caso. Essa estratégia permite organizar ações e reuniões de trabalho em equipe, visando promover maior alcance dos objetivos de aprendizagem e desenvolver habilidades relacionadas à autoaprendizagem e à aprendizagem coletiva. (BRANDA, 2009; BUFREM; SAKAKIMA, 2003; DEELMAN; HOEBERIGS, 2009)

Essa rotina deve ser explicada aos estudantes logo no início da aplicação da QSC e, em seguida, integralmente, a cada reunião de grupo/equipe e também ao longo da resolução do caso. Os sete passos são (ARAÚJO; ARANTES, 2009; CONRADO, 2013; CONRADO; NUNES-NETO; EL-HANI, 2014):

- Esclarecer o problema e os termos e conceitos presentes em sua formulação: entender a relação do(s) problema(s) com a realidade e esclarecer frases e conceitos desconhecidos ou que pareçam confusos para o grupo. Para isso, é necessário realizar leitura atenciosa e interpretação do caso pela equipe para diminuir ao máximo as dúvidas sobre o(s) problema(s) contido(s) no mesmo, bem como esforçar-se para esclarecer conceitos, usando o repertório de conhecimentos e a capacidade de argumentação do grupo. Durante a resolução do caso, novos problemas poderão ser identificados e, por isso, é importante realizar este passo em todas as aulas, sendo que, nas primeiras reuniões, gastar-se-á mais tempo neste passo;

- Definir o problema: descrever exatamente que fenômenos devem ser explicados e entendidos, esclarecendo a situação e o tipo de decisão a tomar. Para isso, é importante que a equipe indique pontos considerados relevantes. $\mathrm{O}$ aumento de informações sobre o caso pode ampliar muito as áreas de conhecimento envolvidas e, por isso, a equipe deverá estabelecer prioridades de acordo com o tempo disponível para a resolução do caso;

- Chuva de ideias (brainstorming): usar conhecimentos prévios, o senso comum e a capacidade argumentativa do grupo para formular explicações e buscar respostas ao problema, sem preocupação com a exatidão das informações ou preconceitos sobre as ideias sugeridas. Neste passo, é realizada uma análise do(s) problema(s) definido(s) anteriormente, usando os conhecimentos acumulados 
até o momento. É importante que todos discutam e participem, sem medo da imprecisão das informações que surgirem;

- Detalhar explicações, sistematizando e estruturando resultados da chuva de ideias: a partir do que emergiu na chuva de ideias, construir hipóteses que explicam e possam fundamentar a resolução do problema, de forma coerente e detalhada, levantando as lacunas do conhecimento que precisam ser preenchidas por meio de estudo. Deve ser realizado um resumo dos aspectos considerados importantes que surgiram na chuva de ideias, o que auxiliará no estabelecimento, na próxima fase, do que deverá ser investigado sobre o problema;

- Propor objetivos de aprendizagem autodirigida: a partir da sistematização dos resultados da chuva de ideias e da construção de hipóteses, definir as lacunas de conhecimento no grupo, o que precisa ser estudado para avançar na resolução do problema, os meios e recursos para realizar a investigação e as ações necessárias para pesquisar a respeito de tais lacunas. Este é um passo em que a equipe formula seus objetivos de aprendizagem, diante da conclusão do passo anterior. Além disso, a equipe se organiza para o próximo passo, respeitando prazos e divisão de tarefas;

- Busca de informações e estudo individual: estudar conteúdos selecionados para preencher lacunas necessárias e relevantes do conhecimento. Neste passo, é comum realizar consultas sistemáticas à biblioteca, à internet ou a materiais disponíveis em sala de aula. Muitas vezes, um estudo complementar mais aprofundado poderá ser feito em horários extraclasse. É importante que as fontes de informações sejam diversificadas, mas, principalmente, confiáveis. A equipe deve estar atenta aos vieses ideológicos ou ao fornecimento de informações parciais (por exemplo, aquelas que deliberadamente negligenciam outras versões importantes da informação ou do dado apresentado, silenciando-as como parte da estratégia de convencer a audiência de uma certa tese);

- Avaliação: compartilhar conclusões do estudo individual com o grupo, integrar conhecimentos adquiridos e avaliar o processo de aquisição desses conhecimentos; a organização geral do grupo; e o avanço na resolução do problema. Deve-se propor novas hipóteses e soluções para o problema, bem como refletir sobre o processo de aprendizagem. Ao final desta etapa, a equipe deverá saber o que foi aprendido, o que ainda precisa ser aprendido, quais os principais resultados, qual o desempenho de cada componente da equipe, qual a proximidade que se encontram da resolução do caso e o que pode ser feito para melhorar as dificuldades encontradas. Caso uma resolução do caso que seja satisfatória para a equipe não tenha sido alcançada, deve-se retornar à chuva de ideias e dar andamento aos passos a partir disso (pode ser necessário retornar aos passos de esclarecimento e definição do 
problema, caso o grupo conclua não ter resolvido o problema por falta de clareza a seu respeito).

A fim de que se cumpra essa rotina em sala de aula, na organização do trabalho com a QSC, sugerimos o planejamento das aulas de forma que o professor possa acompanhar os momentos de: leitura e questionamentos sobre o caso; mobilização de conteúdos diversos para a resolução do caso; socialização de resultados encontrados; e trabalhos em equipe (TOLEDO JÚNIOR et al., 2008), pois isso facilitará o processo avaliativo do desempenho das equipes ao longo do processo da resolução do caso. Um último momento poderia ser reservado para a apresentação e o debate da resolução do caso pelas equipes, síntese dos conteúdos abordados e avaliações finais. Desse modo, a avaliação da aprendizagem poderá utilizar dados referentes ao início, durante o trabalho com a QSC e ao final dele. Uma vez que os objetivos de aprendizagem são amplos, a avaliação na ABP deve considerar, além dos conteúdos explorados e aprendidos, a avaliação do processo e dos produtos de aprendizagem, bem como a autoaprendizagem dos conteúdos pelo estudante; as interações em sala de aula; a organização da equipe; as dificuldades encontradas; as estratégias de aprendizagem adotadas. (SAVIN-BADEN; MAJOR, 2004) Duch e Groh (2001) acrescentam ainda que o método avaliativo deve considerar a capacidade do estudante de pensar criticamente, avaliar evidências e informações, justificar conclusões. Ademais, deve incluir habilidades além da realização mecânica de tarefas, durante as aulas e ao final do trabalho com a QSC. As ações dos professores e tutores também devem ser avaliadas pelos participantes.

\section{Elaboração de mapas conceituais}

Uma estratégia que também consideramos interessante é o uso de mapas conceituais para a organização dos conteúdos aprendidos pelos estudantes durante a sequência didática. O mapeamento conceitual é uma estratégia da teoria da aprendizagem significativa na qual são representadas espacialmente relações hierárquicas entre conceitos. (MOREIRA, 2013) Cabe destacar que o mapa conceitual permite conectar conhecimentos prévios com conhecimentos novos adquiridos e comparar diferentes modo de organização de conhecimentos sobre o mesmo tema ou questão. ${ }^{7}$ (MOREI-

7 Apesar de sua conexão com uma visão cognitivista da aprendizagem, consideramos que os mapas conceituais podem ser apropriados por perspectivas diferentes da aprendizagem, como, por exemplo, as sociointeracionistas, com as quais estamos comprometidos. Isso demanda, contudo, colocar de lado pressupostos da teoria da aprendizagem significativa que estão subjacentes aos mapas, como, por exemplo, o de que o cérebro armazenaria conceitos e proposições que constituiriam nossas estruturas de conhecimento, as quais seriam, então, representadas em mapas conceituais. (NOVAK; CAÑAS, 2008) Se esses pressupostos forem postos de lado, esses mapas passarão a ser vistos como estratégias representacionais que não capturam estruturas cognitivas internas dos sujeitos, mas construtos socialmente compartilhados que estão disponíveis num contexto social, como representações coletivas, as quais são aprendidas pelos sujeitos, mas de uma maneira na qual 
RA, 2013; NOVAK, 2010) Durante a resolução da QSC, estudantes podem beneficiar-se com a construção e a reconstrução de mapas à luz de novos conhecimentos, bem como com a comparação de mapas feitos por diferentes integrantes do grupo ou diferentes grupos.

Mapas conceituais podem ser usados para facilitar a aprendizagem ou como parte do processo avaliativo, pois indicam a organização do conhecimento e explicitam relações entre conceitos considerados importantes. (CARABETTA JÚNIOR, 2013; TAVARES, 2007) Além disso, podemos utilizar essa ferramenta para organizar argumentos a respeito de um tema.

Há várias formas de organizar um mapa conceitual, mas, basicamente, ele pode ser elaborado hierarquizando principais palavras-chave (conceitos) e conectando-as com linhas, rotuladas de modo a indicar as relações entre os conceitos, com verbos ou frases (termos de ligação). (AGUIAR; CORREIA, 2013; MOREIRA, 2010) Exemplos de conceitos e relações também podem ser representados num mapa conceitual.

Apesar de indicarmos o mapa conceitual como ferramenta útil para a organização de informações sobre um tema, é necessário esclarecer as limitações dessa estratégia para a aprendizagem de habilidades e valores. A razão disso é que o mapeamento conceitual é uma estratégia que visa facilitar a aprendizagem de conhecimentos (isto é, parte da dimensão conceitual do conteúdo). Por isso mesmo, se quisermos adotar estratégias capazes de capturar de modo mais preciso habilidades e valores (e, indo além, atitudes ou ações sociopolíticas), será necessário adotar métodos de representação mais complexos. Parece-nos que o uso de mapas baseados na Teoria Ator-Rede, de Bruno Latour (2005), conforme sugerido por Bencze, Sperling e Carter (2012), no contexto do ativismo WISE, ${ }^{8}$ é uma possibilidade a ser avaliada no futuro, como meio de seguir nessa direção.

\section{Organização e explicitação de relações entre Ciência, Tecnologia, Sociedade e Ambiente}

A mobilização de conteúdos relacionados à QSC poderá ser facilitada se houver o esclarecimento de elementos que compõem as relações entre CTSA associados ao caso. O Quadro 2 apresenta alguns elementos de CTSA encontrados na abordagem da QSC a partir desse caso.

não são jamais internalizadas completamente, sempre permanecendo como estruturas emergentes na relação entre cérebro, corpo e ambiente. (MORTIMER et al., 2014)

8 WISE é um acrônimo para Well-being of Individuals, Societies and Environment que tem sido apresentado como uma finalidade para o ativismo, na perspectiva do método STEPWISE. (BENCZE; CARTER, 2011; BENCZE; SPERLING; CARTER, 2012) 
Quadro 2 - Alguns exemplos de componentes CTSA na QSC sobre declínio de abelhas e produção de alimentos

\begin{tabular}{|c|c|c|}
\hline \multicolumn{3}{|c|}{ Exemplos } \\
\hline \multirow{4}{*}{ 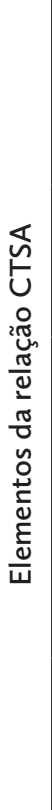 } & C & $\begin{array}{l}\text { Conhecimentos científicos sobre: a importância ecológica de abelhas, seu comportamento, } \\
\text { distribuição geográfica, fisiologia, imunologia, relações com outras espécies animais e } \\
\text { vegetais, funções ecológicas, dependência nutricional, susceptibilidade aos agrotóxicos e } \\
\text { poluição, condições de habitats, construção de nicho. Dados estatísticos comparativos e } \\
\text { previsão de flutuações e perda de resiliência em populações de polinizadores. }\end{array}$ \\
\hline & $\mathrm{T}$ & $\begin{array}{l}\text { Técnicas e tecnologias de: cultivo com e sem agrotóxicos; melhoramento genético para } \\
\text { maior resistência de plantas e animais a perturbações externas; hibridação; controle } \\
\text { biológico; manejo integrado de pragas; robótica para monitoramento ambiental e } \\
\text { polinização; mensuração de resíduos de agrotóxicos no ambiente e nos organismos. }\end{array}$ \\
\hline & $S$ & $\begin{array}{l}\text { Diálogos e açães sobre: hábitos alimentares; estrutura fundiária; modos socioeconômicos } \\
\text { de produção; política de incentivos à monocultura ou a formas alternativas de cultivo, a } \\
\text { exemplo dos agroecológicos; plantio de jardins com flores; saúde nutricional; fiscalização } \\
\text { no uso de toxinas nos cultivos; movimentos sociais para divulgar e exigir açães políticas } \\
\text { e legislação de proteção ambiental local e global; pressão popular para a promoção } \\
\text { de políticas públicas de preservação e conservação de polinizadores; valorização de } \\
\text { polinizadores por sua utilidade à espécie humana ou por seu valor intrínseco como seres } \\
\text { vivos; consideração moral antropocêntrica, biocêntrica, ecocêntrica; criação de ambientes e } \\
\text { paisagens amigáveis a polinizadores. }\end{array}$ \\
\hline & A & $\begin{array}{l}\text { Condições ambientais e fenômenos naturais/ecológicos: mudanças climáticas; dispersão } \\
\text { de toxinas pelo vento; proliferação de parasitas, vírus e outros patógenos; coevolução } \\
\text { entre plantas com flores e animais polinizadores; desertificação; resiliência e capacidade de } \\
\text { suporte do planeta. }\end{array}$ \\
\hline
\end{tabular}

Fonte: elaborado pelos autores com base em Conrado (2017).

Os estudantes poderão discutir as relações entre esses elementos, de modo a desenvolver conhecimentos, habilidades, valores e atitudes relacionados com os conteúdos CPA selecionados pelo professor.

\section{Adoção de textos e vídeos sobre o tema da QSC}

Outra sugestão para o trabalho com o caso em sala de aula é o uso de textos e vídeos de apoio para subsidiar a discussão sobre o tema da QSC. Vídeos e textos geralmente são recursos úteis para enriquecer e complementar discussões em sala de aula. (KRASILCHIK, 2004) Particularmente, no ensino de ciências, ambos os recursos poderão estimular momentos de reflexão e questionamento sobre a ciência, seus diferentes aspectos (como éticos, econômicos etc., que evidenciam controvérsias), além de auxiliar na compreensão do tema e suas implicações. (FEDERICO AGRASO; JIMÉNEZ ALEIXANDRE, 2006; LINHARES; REIS, 2013) Cabe ressaltar que os estudantes poderão buscar, em diversas fontes de informações e pontos de vista, fundamentos de várias áreas do conhecimento e dados específicos sobre o tema, o que estimula a realização de atividades relacionadas à pesquisa acadêmica. No Quadro 3, algumas indicações de textos e vídeos sobre o tema da QSC são fornecidas. 
Quadro 3 - Alguns recursos didáticos sobre abelhas, polinização e agrotóxicos

\begin{tabular}{|c|c|c|c|}
\hline Título & Autores & Ano & Fonte \\
\hline $\begin{array}{l}\text { Agrotóxicos e polinizadores: } \\
\text { isso combina? }\end{array}$ & $\begin{array}{l}\text { Fabiana Oliveira da } \\
\text { Silva e colaboradores }\end{array}$ & 2014 & $\begin{array}{l}\text { http://www.mma.gov.br/publicacoes/ } \\
\text { biodiversidade/category/57-poliniza } \\
\text { dores?download=1077:agrotoxicos- } \\
\text { polinizadores-isso-combina }\end{array}$ \\
\hline Agricultura e Polinizadores & $\begin{array}{l}\text { Associação } \\
\text { Brasileira de } \\
\text { Estudos das Abelhas } \\
\text { (A.B.E.L.H.A.) }\end{array}$ & 2015 & $\begin{array}{l}\text { http://www.abelha.org.br/publicacoes/ } \\
\text { ebooks/Agricultura-e-Polinizacao.pdf }\end{array}$ \\
\hline $\begin{array}{l}\text { Efeitos dos agrotóxicos sobre } \\
\text { as abelhas silvestres no Brasil: } \\
\text { proposta metodológica de } \\
\text { acompanhamento }\end{array}$ & $\begin{array}{l}\text { Maria Cecília de } \\
\text { Lima e Sá de Alencar } \\
\text { Rocha }\end{array}$ & 2012 & $\begin{array}{l}\text { http://www.ibama.gov.br/sophia/cnia/ } \\
\text { livros/ efeitosdosagrotoxicossobre } \\
\text { abelhassilvestresnobrasil.pdf }\end{array}$ \\
\hline $\begin{array}{l}\text { Polinizadores e pesticidas: } \\
\text { princípios e manejo para os } \\
\text { agroecossistemas brasileiros }\end{array}$ & $\begin{array}{l}\text { Breno Magalhães } \\
\text { Freitas e José Nunes } \\
\text { Pinheiro }\end{array}$ & 2012 & $\begin{array}{l}\text { http://www.semabelhasemalimento. } \\
\text { com.br/wp-content/uploads/2015/o2/ } \\
\text { polinizadores-e-pesticidas-final-.pdf }\end{array}$ \\
\hline $\begin{array}{l}\text { Água \& Polinização: qual a } \\
\text { importância dessa relação } \\
\text { para a vida na Terra? }\end{array}$ & $\begin{array}{l}\text { Walter Costa Neto e } \\
\text { colaboradores }\end{array}$ & 2014 & $\begin{array}{l}\text { http://www.semabelhasemalimento. } \\
\text { com.br/wp-content/uploads/2015/o2/ } \\
\text { CARTILHA_agua_polinizacao_BAIXA.pdf }\end{array}$ \\
\hline Biologia da Polinização & $\begin{array}{l}\text { André Rodrigo Rech } \\
\text { e colaboradores } \\
\text { (organizadores) }\end{array}$ & 2014 & $\begin{array}{l}\text { http://www.mma.gov.br/publicacoes/ } \\
\text { biodiversidade/category/57-polinizadores } \\
\text { ?download=1076:biologia-da-polinizacao }\end{array}$ \\
\hline $\begin{array}{l}\text { Guia llustrado de Abelhas } \\
\text { Polinizadoras no Brasil }\end{array}$ & $\begin{array}{l}\text { Cláudia Inês da Silva } \\
\text { e colaboradores }\end{array}$ & 2014 & $\begin{array}{l}\text { http://www.mma.gov.br/publicacoes/ } \\
\text { biodiversidade/category/57- } \\
\text { polinizadores?download=1042: guia- } \\
\text { ilustrado-de-abelhas- polinizadoras-no- } \\
\text { brasil }\end{array}$ \\
\hline $\begin{array}{l}\text { Why bees are disappearing } \\
\text { (legendado) }\end{array}$ & Marla Spivak & 2013 & $\begin{array}{l}\text { https://www.ted.com/talks/marla_ } \\
\text { spivak_why_bees_are_disappearing } \\
\text { https://www.youtube.com/ } \\
\text { watch?v=201FKBtYAwc }\end{array}$ \\
\hline Vanishing of the Bees & $\begin{array}{l}\text { George Langworthy; } \\
\text { Maryam Henein } \\
\text { (diretores) }\end{array}$ & 2009 & $\begin{array}{l}\text { https://www.youtube.com/watch?v=u- } \\
\text { JjQH_HUHQ }\end{array}$ \\
\hline Silence of the Bees & Doug Shultz (escritor) & 2007 & $\begin{array}{l}\text { https://www.youtube.com/ } \\
\text { watch?v=bqSIRhXcbqk }\end{array}$ \\
\hline $\begin{array}{l}\text { Every city needs healthy } \\
\text { honey bees (legendado) }\end{array}$ & Noah Wilson-Rich & 2012 & $\begin{array}{l}\text { https://www.ted.com/talks/noah_ } \\
\text { wilson_rich_every_city_needs_healthy_ } \\
\text { honey_bees }\end{array}$ \\
\hline $\begin{array}{l}\text { The hidden beauty of } \\
\text { pollination (legendado) }\end{array}$ & Louie Schwartzberg & 2011 & $\begin{array}{l}\text { https://www.ted.com/talks/louie__ } \\
\text { schwartzberg_the_hidden_beauty_of_- } \\
\text { pollination }\end{array}$ \\
\hline A plea for bees (legendado) & $\begin{array}{l}\text { Dennis van } \\
\text { Engelsdorp }\end{array}$ & 2008 & $\begin{array}{l}\text { https://www.ted.com/talks/dennis_ } \\
\text { vanengelsdorp_a_plea_for_bees }\end{array}$ \\
\hline $\begin{array}{l}\text { The first } 21 \text { days of a bee's life } \\
\text { (legendado) }\end{array}$ & AnandVarma & 2015 & $\begin{array}{l}\text { https://www.ted.com/talks/anand_ } \\
\text { varma_a_thrilling_look_at_the_first_21_ } \\
\text { days_of_a_bee_s_life }\end{array}$ \\
\hline A plant's-eye view (legendado) & Michael Pollan & 2007 & $\begin{array}{l}\text { https://www.ted.com/talks/michael_- } \\
\text { pollan_gives_a_plant_s_eye_view }\end{array}$ \\
\hline
\end{tabular}

Fonte: elaborado pelos autores com base em Conrado (2017). 


\section{Orientação a partir dos níveis de letramento científico}

Por fim, considerando um currículo para uma educação científica com a finalidade de formar indivíduos capazes de ações sociopolíticas, em direção a maiores: justiça social e sustentabilidade ambiental, conforme a recomendação de Hodson (2004b, p. 3), poderão ser implementadas atividades e discussões, envolvendo quatro estágios de letramento científico. Apontamos abaixo alguns aspectos, associados à QSC e ao caso que a representa em nossa proposta, que podem ser explicitados para cada um desses estágios:

- Reconhecer relações entre CTSA: por exemplo, nas relações entre as ciências envolvidas no estudo dos sistemas ecológicos e as tecnologias de produção de alimentos; no uso e no desenvolvimento de agrotóxicos, que são influenciados pela cultura capitalista desde a Revolução Verde; no desenvolvimento da monocultura e sua relação com a concentração de terras e de poder, além de questões relacionadas ao mercado e aos prejuízos ambientais; no desenvolvimento do conhecimento e das técnicas que baseiam modos alternativos de cultivo agrícola, a exemplo da agroecologia;

- Compreender que o desenvolvimento científico e tecnológico, por vezes, ocorre a partir de interesses particulares, com benefícios para alguns em detrimento de outros: por exemplo, nos interesses de multinacionais no desenvolvimento de novos agrotóxicos e transgênicos resistentes a eles. Ou, alternativamente, nos interesses políticos que podem favorecer ou não a divulgação de técnicas e pesquisas sobre agroecologia, também vinculados à ciência e tecnologia;

- Desenvolver o próprio ponto de vista e definir posições valorativas: por exemplo, na reflexão sobre as dimensões éticas e políticas de questões socioambientais relacionadas à agricultura com agrotóxicos ou à agroecologia; valores ambientais e consideração moral de sujeitos envolvidos nos serviços ecossistêmicos e na manutenção da biodiversidade;

- Tomar decisão e agir: por exemplo, na organização de abaixo-assinados ou cartas públicas destinadas ao executivo, legislativo e/ou judiciário; na organização de palestras e produção vídeos para divulgação em comunidades afetadas pelos problemas em pauta; em projetos de extensão universitária; na realização de campanhas virtuais de ativismo socioambiental (em sites como Avaaz, Change, ou Petição Pública), a fim de angariar apoio a causas específicas (como, por exemplo, políticas públicas para a proteção dos polinizadores), associadas ao problema maior; desenvolvimento de páginas de internet informativas e de troca de experiências; organização de eventos locais coletivos em que sejam convidados representantes de diversos grupos envolvidos com a questão em discussão (como ecólogos, agricultores, empresários, jornalistas científicos e ativistas); obtenção de conhecimento e ação em relação a projetos de lei em tramitação no legislativo que tenham relação com a questão. (CARVALHO et al., 2015) 


\section{Considerações finais}

Neste capítulo, apresentamos uma proposta de ensino baseada em QSC sobre o declínio de abelhas e a produção de alimentos, para uso na educação científica de nível médio ou superior, sob uma perspectiva de educação CTSA. Discutimos, além disso, meios para sua aplicação em sala de aula.

O uso de QSC na educação CTSA tem sido apontado como uma estratégia para uma formação mais integral e ampla de cidadãos para lidar com problemas socioambientais. Essa formação integral envolve a aprendizagem das dimensões CPA dos conteúdos científicos, que pode ser realizada a partir de casos contextualizados pela abordagem CTSA.

A partir das ideias desenvolvidas no presente trabalho, de futuras experiências em sala de aula e de interação com professores de ciências, esperamos aprimorar o uso dessa estratégia para preparar cidadãos para ações sociopolíticas sobre os problemas socioambientais, que, dessa forma, contribuam para a melhoria das condições sociais e ambientais.

\section{Referências}

ABROL, D. P. Pollination biology: pests and pollinators of fruit crops. Cham, Switzerland: Springer. 2015. v. 1.

AGUIAR, J. G.; CORREIA, P. R. M. Como fazer bons mapas conceituais? estabelecendo parâmetros de referências e propondo atividades de treinamento. Revista Brasileira de Pesquisa em Educação em Ciências, Belo Horizonte, v. 13, n. 2, p. 141-157, 2013.

AIZEN, M. A. et al. How much does agriculture depend on pollinators? lessons from long-term trends in crop production. Annals of Botany, London, v. 103, p. 1579-1588, 2009.

ALBANESE, M. A.; DAST, L. Problem-based learning: outcomes evidence from the health professions. Journal on Excellence in College Teaching, Oxford, v. 25, n. 3/4, p. 239-252, 2014

ALBANESE, M. A.; MITCHELL, S. Problem-based learning: a review of literature on its outcomes and implementation issues. Academic Medicine, Philadelphia, v. 68, p. 52-81, 1993.

ARAÚJO, U. F.; ARANTES, V. M. Comunidade, conhecimento e resolução de problemas: o projeto acadêmico da USP Leste. In: ARAÚJO, U. F.; SASTRE, G. (Org.). Aprendizagem baseada em problemas no ensino superior. São Paulo: Summus, 2009. p. 101-122.

ARENA, M.; SGOLASTRA, F. A meta-analysis comparing the sensitivity of bees to pesticides. Ecotoxicology, London, v. 23, n. 3, p. 324-334, 2014.

BARNOSKY, A. D. et al. Has the Earth's sixth mass extinction already arrived? Nature, London, v. 471, p. 51-57, 2011. 
BARROWS, H. S. Is it truly possible to have such a thing as dPBL? Distance Education, [S.1.], v. 23, n. 1, p. 119-122, 2002.

BARTHEL, S.; FOLKE, C.; COLDING, J. Social-ecological memory in urban gardens - Retaining the capacity for management of ecosystem services. Global Environmental Change, Oxford, v. 20, p. 255-265, 2010.

BENCZE, L.; ALSOP, S. Ecojustice through responsibilist Science Education. In: NNUAL CONFERENCE OF THE CANADIAN SOCIETY FOR THE STUDY OF EDUCATION, 2009. Ottawa. Proceeding... Otawa: Carleton University, 2009. p. 1-28.

BENCZE, J. L.; CARTER, L.; KRSTOVIC, M. Science \& technology education for personal, social \& environmental wellbeing: challenging capitalists' consumerist strategies. Revista Brasileira de Pesquisa em Educação em Ciências, Belo Horizonte, v. 14, n. 2, p. 39-56, 2014.

BENCZE, L.; CARTER, L. Globalizing Students Acting for the Common Good. Journal of Research in Science Teaching, New York, v. 48, n. 6, p. 648-669, 2011.

BENCZE, L.; SPERLING, E.; CARTER, L. Students' research informed socio-scientific activism: Re/vision for a sustainable future. Research in Science Education, Dordrecht, v. 42, n. 1, p. 129-148, 2012.

BERKES, F.; COLDING, J.; FOLKE, C. Navigating social-ecological systems: building resilience for complexity and change. Cambridge University Press, Cambridge, UK, 2003.

BERNARDO, J. R. da R.; VIANNA, D. M.; SILVA, V. H. D. da. A construção de propostas de ensino em Ciência-Tecnologia-Sociedade (CTS) para abordagem de temas sociocientíficos. In: SANTOS, W. L. P. dos; AULER, D. (Org.). CTS e educação científica: desafios, tendências e resultados de pesquisas. Brasília, DF: UnB, 2011. p. 373-393.

BETTENCOURT, C.; VELHO, J. L.; ALMEIDA, P. A. Biology teachers' perceptions about Science-Technology-Society (STS) education. Procedia Social and Behavioral Sciences, New York, v. 15, p. 3148-3152, 2011.

BOMMARCO, R.; KLEIJN, D.; POTTS, S. G. Ecological intensification: harnessing ecosystem services for food security. Trends in Ecology \& Evolution, Amsterdam, v. 28, n. 4, p. 230-238, 2013.

BOROCHOVICIUS, E.; TORTELLA, J. C. B. Aprendizagem Baseada em Problemas: um método de ensino-aprendizagem e suas práticas educativas. Revista Ensaio: Avaliação e Políticas Públicas em Educação, Rio de Janeiro, v. 22, n. 83, p. 263-294, 2014.

BRANDA, L. A. A aprendizagem baseada em problemas: o resplendor tão brilhante de outros tempos. In: ARAÚJO, U. F.; SASTRE, G. (Org.). Aprendizagem baseada em problemas no ensino superior. São Paulo: Summus, 2009. p. 236.

BRITTAIN, C. et al. Pollination and plant resources change the nutritional quality of almonds for human health. PLoS ONE, San Francisco, v. 9, n. 2, p. 1-7, 2014. 
BUFREM, L. S.; SAKAKIMA, A. M. O ensino, a pesquisa e a aprendizagem baseada em problemas. Transinformação, Campinas, v. 15, n. 3, p. 351-361, 2003.

CARABETTA JÚNIOR, V. A utilização de mapas conceituais como recurso didático para a construção e inter-relação de conceitos. Revista Brasileira de Educação Médica, Rio de Janeiro, v. 37, n. 3, p. 441-447, 2013.

CARVALHO, I. N. et al. Projetos de lei no ensino de ciências: possibilidades para modelagem de questões socio-científicas. In: ENCONTRO NACIONAL DE PESQUISA EM EDUCAÇÃO EM CIÊNCIAS, 10., 2015, Águas de Lindóia, SP. Anais... São Paulo: Associação Brasileira de Pesquisa em Educação em Ciências, 2015.

CHAPLIN-KRAMER, R. et al. Global malnutrition overlaps with pollinator-dependent micronutrient production. Proceedings of the Royal Society B, London, v. 281, n. 1794, p. 1-7, 2014.

COLL, C. et al. Los contenidos de la reforma: enseñanza y aprendizaje de conceptos, procedimientos y actitudes. Madrid: Santillana, 1992.

CONRADO, D. M. Uso de conhecimentos evolutivo e ético na tomada de decisão por estudantes de biologia. 2013. $220 \mathrm{f}$. Tese (Doutorado em Ecologia) - Instituto de Biologia, Universidade Federal da Bahia, Salvador, 2013.

CONRADO, D. M. Questões Sociocientíficas na Educação CTSA: contribuições de um modelo teórico para o letramento científico crítico. 2017. 239 f. Tese (Doutorado em Ensino, História e Filosofia das Ciências) - Instituto de Física, Universidade Federal da Bahia, Salvador, 2017.

CONRADO, D. M.; CONRADO, I. S. Cientificismo: uma análise crítica do discurso no ensino superior de biologia. In: CONGRESSO IBERO AMERICANO DE INVESTIGAÇÃO QUALITATIVA EM EDUCAÇÃO, 5., 2016, Porto. Atas... Porto: Universidade Lusófona do Porto, 2016a. p. 1054-1059.

CONRADO, D. M.; CONRADO, I. S. Análise crítica do discurso sobre imagens da ciência e da tecnologia em argumentos de estudantes de biologia. Revista de Pesquisa Qualitativa, São Paulo, v. 4, n. 5, p. 218-231, 2016 b.

CONRADO, D. M.; EL-HANI, C. N.; NUNES-NETO, N. F. Sobre a ética ambiental na formação do biólogo. Revista Eletrônica do Mestrado em Educação Ambiental, Rio Grande, v. 30, n. 1, p. 120-139, jan./ jun. 2013.

CONRADO, D. M. et al. Socioscientific issues about bees, pollination and food production in biology teaching. In: CONFERENCE OF THE EUROPEAN SCIENCE EDUCATION RESEARCH ASSOCIATION, 11., 2015. Proceeding... Helsinki: ESERA, 2015. p. 1-4.

CONRADO, D. M. et al. Uso do conhecimento evolutivo na tomada de decisão de estudantes do ensino médio sobre questões socioambientais. Revista Contemporânea de Educação, Rio de Janeiro, v. 7, n. 14, p. 345-368, 2012. 
CONRADO, D. M. et al. Ensino de biologia a partir de questões sociocientíficas: uma experiência com ingressantes em curso de licenciatura. Indagatio Didactica, Aveiro, v. 8, n. 1, p. 1132-1147, jul. 2016.

CONRADO, D. M.; NUNES-NETO, N. F. Dimensões do conteúdo em questões sociocientíficas no ensino de ecologia. In: ENCONTRO NACIONAL DE EDUCAÇÃO EM CIÊNCIAS, 16., 2015, Lisboa. Anais... Lisboa: ENEC, 2015. p. 432-435.

CONRADO, D. M.; NUNES-NETO, N. F.; EL-HANI, C. N. Argumentação sobre problemas socioambientais no ensino de biologia. Educação em Revista, Belo Horizonte, v. 31, p. 329-357, 2015.

CONRADO, D. M.; NUNES-NETO, N. F.; EL-HANI, C. N. Aprendizagem Baseada em Problemas (ABP) na Educação Científica como Estratégia para Formação do Cidadão Socioambientalmente Responsável. Revista Brasileira de Pesquisa em Educação em Ciências, Belo Horizonte, v. 14, p. 77-87, 2014.

COOPER, G. J.; EL-HANI, C. N.; NUNES-NETO, N. F. Three approaches to the teleological and normative aspects of ecological functions. In: ELDREDGE, N. et al. (Ed.). Evolutionary Theory: a hierarchical perspective. Chicago: University of Chicago Press, 2016.

CUTLER, G. C.; SCOTT-DUPREE, C. D. A field study examining the effects of exposure to neonicotinoid seed-treated corn on commercial bumble bee colonies. Ecotoxicology, [S.1.], v. 23, p. 1755-1763, 2014.

DEELMAN, A.; HOEBERIGS, B. A ABP no contexto da Universidade de Maastricht. In: ARAÚJO, U. F.; SASTRE, G. (Org.). Aprendizagem baseada em problemas no ensino superior. São Paulo: Summus, 2009. p. 79-100.

DILLON, J. Science, environment and health education: towards a reconceptualisation of their mutual interdependences. In: ZEYER, A.; KYBURZ-GRABER, R. (Ed.). Science, environment, health: towards a renewed pedagogy for science education. Dordrecht: Springer, 2012. p. 87-101.

DOCHY, F. et al. Effects of problem-based learning: a meta-analysis. Learning and Instruction, Oxford, v. 13, p. 533-568, 2003.

DOUBLET, V. et al. Bees under stress: sublethal doses of a neonicotinoid pesticide and pathogens interact to elevate honey bee mortality across the life cycle. Environmental Microbiology, Oxford, v. 17, n. 4, p. 969-983, 2014.

DUCH, B. J.; GROH, S. E. Assessment strategies in a problem-based learning course. In: DUCH, B. J.; GROH, S. E.; ALLEN, D. E. (Ed.). The power of problem-based learning: a practical "how to" for teaching undergraduate courses in any discipline. Sterling: Stylus Publishing, 2001. p. 95-108.

DUNNE, J. A.; WILLIAMS, R. J. Cascading extinctions and community collapse in model food webs. Philosophical Transactions of the Royal Society B, London, v. 364, p. 1711-1723, 2009. 
EILERS, E. J. et al. Contribution of pollinator-mediated crops to nutrients in the human food supply. PLoS ONE, San Francisco, v. 6, n. 6, p. 1-6, 2011.

ELLIS, A. M.; MYERS, S. S.; RICKETTS, T. H. Do Pollinators Contribute to Nutritional Health? PLoS ONE, San Francisco, v. 10, n. 1, p. 1-17, 2015.

FEDERICO AGRASO, M.; JIMÉNEZ ALEIXANDRE, M. P. ¿Clonación terapéutica?: decisiones sobre dilemas éticos en el aula. Alambique: Didáctica de las ciencias experimentales, Barcelona, n. 49, p. 43-50, 2006.

FEINSTEIN, N. W.; KIRCHGASLER, K. L. Sustainability in science education? how the next generation science standards approach sustainability, and why it matters. Science Education, [S.1.], v. 99, n. 1, p. 121-144, 2015.

FENSHAM, P. J. Preparing citizens for a complex world: the grand challenge of teaching socio-scientific issues in science education. In: ZEYER, A.; KYBURZGRABER, R. (Ed.). Science, environment, health: towards a renewed pedagogy for science education. Dordrecht: Springer, 2012. p. 7-29.

GARIBALDI, L. et al. Wild pollinators enhance fruit set of crops regardless of honey bee abundance. Science, Washington, v. 339, n. 6127, p. 1608-1611, 2013.

GIJBELS, D.; et al. Effects of problem-based learning: a meta-analysis from the angle of assessment. Review of Educational Research, Washington, v. 75, n. 1, p. 27-61, 2005.

GIJSELAERS, W. Perspectives on problem-based learning. In: GIJSELAERS, W. et al. (Ed.). Educational innovation in economics and business administration: the case of problem-based learning. Dordrecht: Kluwer, 1995. p. 39-52.

GIROUX, H. A. Cultural studies, public pedagogy, and the responsibility of intellectuals. Communication and Critical/Cultural Studies, Oxfordshire, v. 1, p. 59-79, 2004

GIROUX, H. A.; GIROUX, S. S. Challenging neoliberalism's new world order: the promise of critical pedagogy. Cultural Studies/Critical Methodologies, Thousand Oaks, v. 6, p. 21-32, 2006.

GOULSON, D. Review: an overview of the environmental risks posed by neonicotinoid insecticides. Journal of Applied Ecology, Oxford,v. 50, n. 4, p. 977-987, 2013.

GOULSON, D. Effects of introduced bees on native ecosystems. Annual Review of Ecology, Evolution, and Systematics, Palo Alto, Calif., v. 34. p. 1-26, 2003.

HAMPSON, G. P. Eco-logical education for the long emergency. Futures, Guildford, v. 44, p. 71-80, 2012.

HODSON, D. Challenging traditional views of the nature of science and scientific inquiry. In: ALSOP, S.; BENCZE, L.; PEDRETTI, E. (Ed.). Analysing exemplary science teaching: theoretical lenses and a spectrum of possibilities for practice. London: Open University Press, 2004a. p. 96-105. 
HODSON, D. Don't be nervous, don't be flustered, don't be scared. be prepared. Canadian Journal of Science, Mathematics and Technology Education, Toronto, v. 13, n. 4, p. 313-331, 2013.

HODSON, D. Going Beyond STS: towards a curriculum for sociopolitical. Science Education Review, Queensland, v. 3, n. 1, p. 2-7, 2004 b.

HODSON, D. Looking to the future: building a curriculum for social activism. Rotterdam: Sense Publishers, 2011.

IMPERATRIZ-FONSECA, V. L. et al. O desaparecimento das abelhas melíferas (Apismellifera) e as perspectivas do uso de abelhas não melíferas na polinização. In: SEMANA DOS POLINIZADORES, 3., 2012, Petrolina. Anais... Petrolina: Embrapa Semiárido, 2012. p. 213-226. Disponível em: <http://ainfo.cnptia.embrapa.br/digital/ bitstream/item/69296/1/Abelha.pdf>.

JAMIESON, D. Ética e meio ambiente: uma introdução. Tradução de André Luiz de Alvarenga. São Paulo: SENAC, 2010.

JAROSZ, L. Political ecology as ethical practice. Political Geography, [S.1.], v. 23, p. 917927, 2004.

KAHN, R. Critical pedagogy, ecoliteracy, and planetary crisis: the ecopedagogy movement. New York: Peter Lang, 2010. (Counterpoints: Studies in the Postmodern Theory of Education, v. 359).

KENNEDY, C. M. A global quantitative synthesis of local and landscape effects on wild bee pollinators in agroecosystems. Ecology Letters, Oxford, v. 16, n. 5, p. 584-599, 2013.

KLEIN, A. M. et al. Importance of pollinators in changing landscapes for world crops. Proceedings Biological Sciences, [S.1.], v. 274, n. 1608, p. 303-313, 2007.

KNIGHT, J. K.; WOOD, W. B. Teaching more by lecturing less. The American Society for Cell Biology, Bethesda, v. 4, n. 4, p. 298-310, 2005.

KRASILCHIK, M. Prática de ensino de biologia. São Paulo: EDUSP, 2004.

KREMEN, C.; ILES, A.; BACON, C. Diversified farming systems: an agroecological, systems-based alternative to modern industrial agriculture. Ecology and Society, Wolfville, v. 17, n. 4, p. 44-63, 2012.

LATOUR, B. Reassembling the social: an introduction to actor-network-theory. Oxford: Oxford University Press, 2005.

LEE, M. G. C.; TAN, O. S. Collaboration, dialogue, and critical openness through problem-based learning processes. In: TAN, O.-S. (Ed.). Enhancing thinking through problem-based learning approaches: international perspectives. Singapore: Cengage Learning, 2004. p. 133-144.

LEVINSON, R. Science education and democratic participation: an uneasy congruence? Studies in Science Education, Inglaterra, v. 46, n. 1, p. 69-119, 2010. 
LIMA, M. C.; ROCHA, S. A. Efeitos dos agrotóxicos sobre as abelhas silvestres no Brasil: proposta metodológica de acompanhamento. Brasília, DF: Ibama, 2012.

LINHARES, E.; REIS, P. A discussão de controvérsias sócio-científicas a partir de documentários em vídeo. In: MEMBIELA, P.; CASADO, N.; CEBREIROS, M. I. (Ed.). Retos y perspectivas en la enseñanza de las ciencias: retos e perspectivas no ensino das ciencias. Ourense: Edita Educación, 2013. p. 115-120.

MILLENNIUM ECOSYSTEM ASSESSMENT. Ecosystems and Human Well-Being: Synthesis. Washington: World Resources Institute, 2005.

MATTHEWS, M. R. Science teaching: the role of history and philosophy of science. London: Routledge, 1994.

MAURER, H.; NEUHOLD, C. Problems everywhere? strengths and challenges of a problem-based learning approach in european studies. Higher Education Academy Social Science Conference. Liverpool, May 2012. Disponível em: <http://papers.ssrn. com/sol3/papers.cfm?abstract_id=1997614>. Acesso em: 20 dez. 2015.

MINTEER, B. A.; COLLINS, J. P. Ecological ethics: building a new tool kit for ecologists and biodiversity managers. Conservation Biology, Boston, v. 19, n. 6, p. 1803 1812, 2005.

MOREIRA, M. A. Aprendizagem significativa em mapas conceituais. Porto Alegre: UFRGS, 2013.

MOREIRA, M. A. Mapas conceituais e aprendizagem significativa. São Paulo: Centauro, 2010 .

MORENO, A.; MOSSIO, M. Biological autonomy: a philosophical and theoretical enquiry. Dordrecht: Springer, 2015.

MORTIMER, E. F. et al. Conceptual profiles: theoretical-methodological bases of a research program. In: MORTIMER, E. F.; EL-HANI, C. N. (Ed.). Conceptual profiles: a theory of teaching and learning scientific concepts. Dordrecht: Springer, 2014. p. 3-33.

MOSSIO, M.; SABORIDO, C.; MORENO, A. An Organizational Account for Biological Functions. British Journal for the Philosophy of Science, Aberdeen, v. 60, p. 813-841, 2009.

NICOLE, W. Pollinator power: nutrition security benefits of an ecosystem service. Environmental Health Perspectives, Research Triangle ParK, v. 123, n. 8, p. A210-A215, 2015.

NOSS, R. F. Values are a good thing in conservation biology. Conservation Biology, Boston, v. 21, n. 1, p. 18-20, 2007.

NOVAK, J. D. Learning, creating, and using knowledge: concept maps as facilitative tools in schools and corporations. Journal of e-Learning and Knowledge Society, Research Triangle Park, v. 6, n. 3, p. 21-30, Sep. 2010. 
NOVAK, J. D.; CAÑAS, A. J. The theory underlying concept maps and how to construct and use them. Technical Report IHMC CmapTools, Florida, p. 1-36, 2008. Disponível em: <http://cmap.ihmc.us/Publications/ResearchPapers/ TheoryUnderlyingConceptMaps.pdf>. Acesso em: 20 dez. 2015.

NUNES-NETO, N.; MORENO, A.; EL-HANI, C. N. Function in ecology: an organizational approach. Biology and Philosophy, Dordrecht, v. 29, n. 1, p. 123-141, 2014.

OSTROM, E. Sustainable social-ecological systems: an impossibility? In: ANNUAL MEETINGS OF THE AMERICAN ASSOCIATION FOR THE ADVANCEMENT OF SCIENCE, “Science and Technology for Sustainable Well-Being”. San Francisco, 2007.

PEDRETTI, E. Teaching Science, Technology, Society and Environment (STSE) Education: preservice teachers' philosophical and pedagogical landscapes. In: ZEIDLER, D. (Ed.). The role of moral reasoning on socioscientific issues and discourse in science education. The Netherlands: Kluwer Academic Publishers, 2003. p. 219-239.

PEDRETTI, E.; NAZIR, J. Currents in STSE Education: Mapping a Complex Field, 40 Years On, Science Education, [S.1.], v. 95, n. 4, p. 601-626, 2011.

PINHEIRO, J. N.; FREITAS, B. M. Efeitos letais dos pesticidas agrícolas sobre polinizadores e perspectivas de manejo para os agroecossistemas brasileiros. Oecologia Australis, Rio de Janeiro, v. 14, n. 1, p. 266-281, 2010.

PINKE, M. How far is world agricultural production likely to be threatened by pollinator declines? Journal of Sustainability, [S.1.], v. 1, n. 1, p. 1-9, 2013.

PINZINO, D. W. Socioscientific Issues: A path towards advanced scientific literacy and improved conceptual understanding of socially controversial scientific theories. 2012. 35 f. Theses (Dissertations Education Specialist) - University of South Florida, 2012. Disponível em: <http://scholarcommons.usf.edu/etd/4387>. Acesso em: 12 jun. 2015.

POTTS, S. G. et al. Global pollinator declines: trends, impacts and drivers. Trends in Ecology and Evolution, Amsterdam, v. 25, n. 6, p. 345-353, 2010.

PRETTY, J. Interdisciplinary progress in approaches to address social-ecological and ecocultural systems. Environmental Conservation, Lausanne, v. 38, n. 2, p. 127-139, 2011.

REIS, P. Da discussão à ação sociopolítica sobre controvérsias sócio-científicas: uma questão de Cidadania. Ensino de Ciências e Tecnologia em Revista, Curitiba, v. 3, n. 1, p. 1-10, 2013.

SADLER, T.; ZEIDLER, D. The morality of socioscientific issues: construal and resolution of genetic engineering dilemmas. Science Education, [S.1.], v. 88, p. 4-27, 2004.

SANTOS, W. L. P. dos. Scientific literacy: a freirean perspective as a radical view of humanistic science education. Science Education, [S.1.], v. 93, n. 2, p. 361-382, 2009. 
SANTOS, W. L. P. dos; MORTIMER, E. F. Tomada de decisão para ação social responsável no ensino de ciências. Ciência e Educação, Bauru, v. 7, n. 1, p. 95-111, 2001.

SAPIR, Y.; DORCHIN, A.; MANDELIK, Y. Indicators of pollinator decline and pollen limitation. In: ARMON, R. H.; HANNINEN, O. (Ed.). Environmental Indicators. Dordrecht: Springer, 2015. p. 103-115.

SAVERY, J. R. Overview of problem-based learning: definitions and distinctions. The Interdisciplinary Journal of Problem-based Learning, [S.1.], v. 1, n. 1, p. 9-20, 2006.

SAVIN-BADEN, M.; MAJOR, C. H. Foundations of Problem-based Learning. Great Britain: MPG Books: Open University Press, 2004.

SILVA, F. O. et al. Agrotóxicos e polinizadores: isso combina? Rio de Janeiro: Funbio, 2014

SOLBES, J.; VILCHES, A. Papel de las relaciones entre Ciencia, Tecnología, Sociedad y Ambiente en la formación ciudadana. Ensenanza de las Ciencias, Barcelona, v. 22, n. 3, p. 337-48, 2004.

STEFFAN-DEWENTER, I.; POTTS, S. G.; PACKER L. Pollinator diversity and crop pollination services are at risk. Trends in Ecology and Evolution, Amsterdam, v. 20, n. 12, p. 651-652, Dec. 2005.

STROBEL, J.; VAN BARNEVELD, A. When is PBL more effective? A meta-synthesis of meta-analyses comparing PBL to conventional classrooms. The Interdisciplinary Journal of Problem-based Learning, [S.1.], v. 3, n. 1, p. 44-58, 2009.

TAVARES, R. Construindo mapas conceituais. Ciências \& Cognição, Rio de Janeiro, v. 12, p. 72-85, 2007.

TOLEDO JÚNIOR, A. C. de C. et al. Aprendizagem baseada em problemas: uma nova referência para a construção do currículo médico. Revista Médica de Minas Gerais, Belo Horizonte, v. 18, n. 2, p. 123-131, 2008.

TOMAS, L.; RITCHIE, S. M.; TONES, M. Attitudinal Impact of Hybridized Writing About a Socioscientific Issue. Journal of Research in Science Teaching, [S.1.], v. 48, n. 8, p. 878-900, 2011.

TORRES, N. Y.; MARTÍNEZ PÉREZ, L. F. Desarrollo de pensamiento crítico en estudiantes de Fisioterapia, a partir del estudio de las implicaciones sociocientíficas de los xenobióticos. Tecné, Episteme y Didaxis, [S.1.], n. 29, p. 65-84, 2011.

VANBERGEN, A. J. et al. Threats to an ecosystem service: pressures on pollinators. Frontiers in Ecology and the Environment, Washington, v. 11, p. 251-259, 2013.

WAGONER, K. M.; BONCRISTIANI, H. F.; RUEPPELL, O. Multifaceted responses to two major parasites in the honey bee (Apis mellifera). BMC Ecology, London, v. 13, n. 26, p. 1-3, 2013.

ZABALA, A.; ARNAU, L. Como aprender e ensinar competências. Porto Alegre: Artmed, 2010. 


\title{
PESCA DA LAGOSTA \\ QUESTÕES SOCIOCIENTÍFICAS NO CONTEXTO DE UMA INTERVENÇÃO DE EDUCAÇÃO AMBIENTAL MULTICULTURAL EM COMUNIDADE TRADICIONAL
}

\author{
Clívio Pimentel-Júnior \\ Wellington Bittencourt
}

\section{Introdução}

O capítulo em pauta apresenta uma proposta de intervenção pedagógica baseada em Questões Sociocientíficas (QSC) elaborada com base nos problemas socioambientais vivenciados pelos moradores do vilarejo de Garapuá, município de Cairú, Bahia. A QSC foi pensada para ser aplicada em uma mostra de cinema nacional, o Cine Garapuá (ver Figura 1); porém é importante ressaltar que pode ser utilizada, com adaptações, em outros contextos similares de educação formal e não-formal onde problemáticas socioambientais sejam evidentes. Será tratada, assim, como uma intervenção artístico-pedagógica de educação ambiental que já acontece no referido município, em um espaço educacional não-formal. ${ }^{1}$

1 De acordo com Gohn (2010), espaços educacionais não formais são marcados por ações de coletivos sociais que interagem segundo diretrizes do grupo com propósito de resolver problemas e questões comuns. Nesse contexto de negociações constantes, emergem condições e valores de pertencimento, consciência e organização em coletividade para o enfrentamento de problemáticas reais e criação de alternativas aos constrangimentos cotidianos. Neste trabalho, usamos o 
Figura 1 - Exibição do filme Tainá: a origem, para crianças da comunidade, no Cine Garapuá

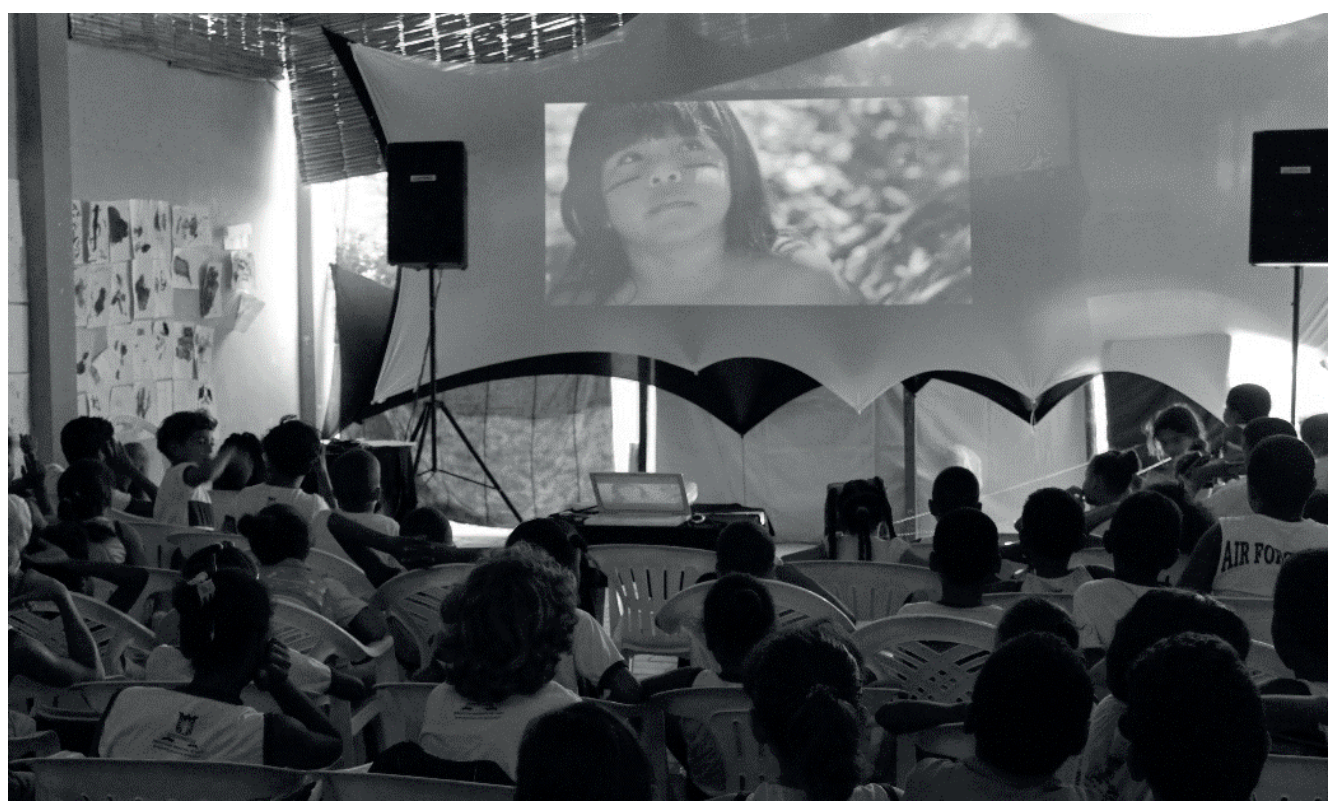

Fotógrafo: Lucas Viana.

O projeto Cine Garapuá teve sua primeira edição em 2014, sendo coordenado pela mesma equipe do Cine Capão, que já acontece há sete anos, no Vale do Capão, Chapada Diamantina, Bahia. Além da mostra de cinema brasileiro, o Cine Garapuá realizou em conjunto oficinas de audiovisual, stop motion e grafite, todos voltados à temática ambiental, para um público de crianças, adolescentes e adultos da comunidade de Garapuá. O projeto foi aprovado pelo Edital Setorial de Audiovisual do Fundo de Cultura do Estado da Bahia (Funceb) e contou com apoio da Prefeitura Municipal de Cairú, através da Secretaria de Educação, Secretaria de Assistência Social e Assessoria de Comunicação de Cairú, em que se estabeleceu o acordo de apoios e as autorizações para a realização do projeto, em benefício dos alunos da Escola Municipal José Gomes de Aragão - ensino médio e Educação de Jovens e Adultos (EJA) - e Escola Creche Dirce de Souza. O projeto teve como intento maior promover uma discussão a respeito das relações da comunidade de moradores da região com os seus ambientes naturais e, deste modo, sensibilizá-los para a necessidade de um desenvolvimento mais responsável na região. ${ }^{2}$ Devido

termo "não-formal" para se referir ao espaço educativo em questão por se tratar de um projeto de intervenção artístico-pedagógico de cunho socioambiental que visa fomentar ações sociopolíticas coletivas, para além do ambiente escolar, no enfrentamento de problemas reais comuns.

2 Informações mais detalhadas e fotos das ações do grupo podem ser visualizadas através de algumas redes sociais, como: Cine Garapuá. Facebook. 21 mar. 2014. Disponível em: <https://www.facebook. com/cinegarapua?fref=ts>. Acesso em 22 out. 2015; Cine Garapuá - making of. Youtube. Disponível em: <https://www.youtube.com/watch?v=LV3DKfy9RSo>. Acesso em: 22 out. 2015, Na trilha do 
às peculiaridades do contexto eleito para nossa intervenção, assumimos dois grandes desafios, os quais são, em certo sentido, inaugurais:

- $\quad$ o intento de elaborar uma QSC para a aplicação no âmbito educacional não-formal, visto que, até então, não encontramos referências na literatura do tratamento de QSC fora do espaço de educação escolar; e

- a particularidade de aplicar tal estratégia didática no contexto sociocultural de uma comunidade tradicional, o que evoca a questão do diálogo entre diferentes formas de saberes.

Apesar das dificuldades enfrentadas na recontextualização e na ampliação dos domínios de aplicação de uma ferramenta pedagógica, assumimos a ideia de que "acorrentar as concepções do professor a monolíticos estratagemas, propagados pelos programas pedagógicos, não é produtivo para sua praxe profissional criativa, assim como, limita, ou mesmo fossiliza a sua reflexão crítica, a sua imaginação". (LABURÚ; ARRUDA; NARDI, 2003, p. 254) Sob tal perspectiva, a QSC configura-se uma estratégia de intervenção pedagógica aplicável no contexto do projeto de educação socioambiental multicultural.

Do nosso ponto de vista, tornou-se fundamental compreender a singularidade cultural da comunidade para que pudéssemos desenvolver uma proposta de educação participativa que privilegiasse a diversidade de saberes. Através de um viés etnoecológico (DIEGUES, 2004), buscamos refletir a sustentabilidade no contexto das diferenças culturais. Partimos da compreensão de que, nas comunidades tradicionais, a degradação ambiental e a erosão de elementos da identidade cultural contribuem concomitantemente para a desagregação destes grupos sociais, conduzindo-os a consolidar posições de dependência e impotência frente à dominação da "monocultura do produtivismo capitalista”. (SANTOS, 2007, p. 31) Consideramos que muitas das questões socioambientais da comunidade tradicional de Garapuá poderiam ser criticamente apreendidas através do emprego da QSC. Deste modo, ela se configurou como estratégia didática para discutir as relações da comunidade com a manutenção dos seus ambientes, de modo a sensibilizá-la para um manejo socioambiental responsável na região.

Ainda que construída com base nestes aspectos, estamos atentos também às relações entre espaços não formais e formais de ensino. Defendemos que o campo da educação não-formal não apenas dialoga como reafirma a importância da educação formal via escolarização. Dessa forma, é importante nos precaver para que o espaço da educação não-formal não seja construído pela negação da escola. (AFONSO, 2001; GOHN, 2010) Em paralelo, trata-se de reconhecer que, para além do ambiente escolar - que, sozinho, não dá conta da formação dos indivíduos e dos coletivos sociais -, o processo de construção de conhecimento se dá em diversos contextos sociais, seja no seio familiar, nos

curta - Garapuá antes e depois. Youtube. Disponível em: <https://www.youtube.com/watch?v=S0jLcJamMll>. Acesso em: 22 out. 2015. 
ambientes de lazer, nos museus, em ambientes religiosos, centros culturais, Organizações Não Governamentais (ONG) etc. (BURNHAM, 2005) Assim, é importante destacar as ações educativas não formais como modo de ampliação de acesso da população à cultura científica bem como sua participação nela (GOHN, 2010) e a importância da apropriação deste referencial cultural na tomada de decisão para ação social responsável (SANTOS; MORTIMER, 2001), condizente com a ideia de cidadania ${ }^{3}$ (HODSON, 2004), para o enfrentamento coletivo de problemáticas socioambientais reais.

A problemática socioambiental, abordada neste trabalho por meio da QSC abaixo apresentada, diz respeito à relação entre a pesca e o consumo da lagosta na região de Garapuá. Nessa discussão, compreendemos que "[O] que deve ser considerado prioritariamente são as relações econômicas e culturais entre a humanidade e a natureza e entre os homens, possibilitando a ampliação da participação política dos cidadãos". (REIGOTA, 1994, p. 9) O critério de escolha deste tema para estruturar a QSC partiu da interpretação das relações simbólicas, econômicas, turísticas e gastronômicas que têm tradicionalmente girado em torno da pesca e do consumo da lagosta na região. Trata-se de uma aposta na ideia de que, ao interpretar essas relações e representá-las por meio de uma história fictícia, isto é, com potencial representativo dos conflitos vivenciados pelos moradores da região, despertaremos o interesse coletivo em participar das tomadas de decisões necessárias ao enfrentamento dos problemas expostos. A partir do reconhecimento de suas histórias de vida, simbolicamente representadas no enunciado da QSC, almejamos fomentar valores relativos ao sentido de pertencimento entre os membros da comunidade e seus ambientes, de modo a promover ações sociopolíticas viáveis para o manejo equilibrado na comunidade.

Convém, neste momento, apresentar alguns aspectos da comunidade de Garapuá que servem de contextualização do tema socioambiental trabalhado. Esperamos que, ao fazê-lo, torne-se explícita a importância da realização de práticas de observações interpretativas sistemáticas dos cotidianos vivenciados a fim de identificar conflitos socioambientais com forte potencial mobilizador de interesse na resolução dos mesmos pelos sujeitos envolvidos. Um olhar atento, tanto às questões culturais locais quanto aos propósitos de uma educação científica em uma perspectiva humanística e sociopolítica,

3 De acordo com Hodson (2004), faz parte da educação para a cidadania a ideia que o aluno consiga participar ativamente de tomadas de decisão através das experiências proporcionadas pelo currículo escolar, a fim de fomentar a participação sociopolítica em relação aos problemas da comunidade (em escala regional), e problemas globais (em escala planetária). Nesse sentido, o professor e a instituição escolar são responsáveis por fomentar nos alunos posturas contestadoras, construtivas, solidárias e comprometidas com o bem-estar individual e coletivo através do empoderamento, via currículo, convidando-os a tomar decisões referentes, por exemplo, ao contexto escolar, proporcionais ao seu nível de desenvolvimento. Por exemplo, pode-se mencionar projetos de controle da quantidade de energia gasta na escola, da quantidade de papel gasto nas atividades etc. Para ele, educar para a cidadania é manter em mente as consequências de nossas ações em contextos locais, passíveis de avaliação mais explícita, que oferecem ocasiões concretas para atuações responsáveis - e, por isso mesmo, empoderadoras -, articuladas com contextos globais. 
mostrou-se necessário a fim de aumentar o interesse do público nas questões científicas e no uso responsável da ciência. (AIKENHEAD, 2006; HODSON, 2004)

O vilarejo de Garapuá está localizado na ilha de Tinharé, possui economia baseada na pesca e no turismo e sua população não ultrapassa 800 habitantes. Sendo uma localidade de difícil acesso, a comunidade tem pouco contato com a produção cinematográfica nacional, não dispondo de cinema, vídeolocadora ou cineclube; a ilha já dispõe de conexão à internet ainda com uma utilização restrita pelas pousadas e para os turistas. Ou seja, a comunidade possui, de modo restrito, uma cultura audiovisual baseada quase que exclusivamente na televisão aberta.

Os municípios que fazem parte do Território de Identidade do Baixo Sul, em especial, o município de Cairú, possuem um potencial natural que abriga belíssimas áreas de preservação ambiental com ricos ecossistemas - a exemplo dos mangues, florestas tropicais e recifes de corais. Atualmente, Garapuá tem vivenciado um processo de forte especulação imobiliária, caracterizada pelo loteamento de grandes propriedades e subsequente venda dos lotes para imigrantes de outras regiões do país e estrangeiros. As dinâmicas econômicas decorrentes de tal processo especulativo podem ser e, de fato, têm sido prejudiciais à preservação e ao manejo dos ambientes da região. Na última década, o aumento expressivo da atividade turística vem exercendo fortes pressões na fisionomia ambiental da região, levando a agressões cuja extensão e velocidade não têm deixado oportunidade para a regeneração natural dos ecossistemas; além do impacto sociocultural que vem transformando a dinâmica da comunidade. (FRANCO, 2002)

Dentre as diversas atividades turísticas, que envolvem os ecossistemas naturais, praticadas na região, estão as visitações às piscinas naturais formadas periodicamente nos recifes, de acordo com os movimentos da maré e da dinâmica pluvial na região. As visitações são agendadas com guias turísticos ou diretamente com moradores e donos de barco na região, de acordo com estas informações. Atrelada a essa visitação, encontramos a atividade gastronômica voltada para o consumo da lagosta, amplamente ofertada e, segundo os moradores, por um preço que não se encontra facilmente nas áreas urbanas e regiões metropolitanas; de onde, aliás, provém a maioria dos turistas que visitam Garapuá. Acontece que, por um lado, a alta demanda de lagostas decorrentes do aumento do número de turistas tem movimentado significativamente a atividade econômica da região e garantido a subsistência de muitas famílias. Mas, por outro lado, técnicas ilegais de pescas aliadas a pescas em períodos de reprodução da lagosta têm se tornado práticas recorrentes na região com vistas a atender tal demanda. Esse consumo e pesca predatório e, em alguma medida, ilegal têm culminado numa maior dificuldade de encontro da lagosta na região, o que tem levado os pescadores a arriscarem frequentemente suas vidas, seja por meio de técnicas ilegais e arriscadas de pesca e mergulho, seja pela distância cada vez maior a percorrer mar adentro para a pesca da lagosta.

O problema, portanto, está colocado: como a educação científica pode contribuir no enfrentamento da problemática socioambiental, política e cultural em questão, por 
meio de práticas de educação não-formalmente estruturadas em QSC? Embora a QSC tenha sido elaborada com base na problemática vivida pelos moradores de Garapuá, reforçamos que esta pode ser aplicada em outras comunidades, tradicionais ou não, com problemas socioambientais semelhantes. Para tanto, adaptações demandadas pelo contexto ambiental, político e cultural local deverão ser feitas pelo educador no ambiente não-formal. Acreditamos, além disso, no seu potencial formativo em espaços formais de aprendizagem, ampliando o âmbito de aplicação desta QSC ou outras similares, contextualmente adaptadas pelo professor de ciências, para a sala de aula.

Apesar de este ser um problema socioambiental complexo, neste trabalho, ele será abordado prioritariamente do ponto de vista educacional; portanto, não pretendemos esgotá-lo por meio das discussões aqui apresentadas. Isto restringe o nosso objetivo em apresentar uma QSC elaborada, que envolve a problemática acima descrita, ao lado de conhecimentos específicos em biologia, ciências naturais, etnoecologia, ética ambiental, oceanografia e geografia, bem como meios para sua aplicação em espaços educacionais não formais com vistas a fomentar tomadas de decisões socialmente responsáveis e ações sociopolíticas.

A compreensão das relações simbólicas no Vilarejo de Garapuá bem como a busca por uma abordagem humanística da ciência, efetiva em termos comunicacionais, foram critérios determinantes para adentrarmos no campo dos estudos culturais como meio de superar uma possível abordagem cientificista. Além de limitante, de um ponto de vista pedagógico e comunicacional, essa abordagem expressa um colonialismo cultural catequizante. (BHABHA, 1998; GARCIA CANCLINI, 2008; SANTOS, 2006, 2007) Os estudos culturais têm apresentado forte potencial heurístico, quando se trata da compreensão de como se hibridizam ${ }^{4}$ conhecimentos científicos com saberes culturais cotidianamente forjados (CARVALHO et al., 2014) na formação de novas práticas culturais. Em termos pedagógicos e em consonância com as discussões de Bizzo (2009), apresentamos algumas orientações etnometodológicas e pedagógicas relevantes na aplicação desta QSC em espaços educacionais não formais de ensino, que traduzem a importância desses estudos no campo da educação não-formal e no ensino de ciências.

\section{Os estudos culturais e a aplicação de QSC em espaços educacionais não formais}

Pretendemos desenvolver, nesta seção, argumentos que apresentam noções provenientes da combinação de estudos culturais e sociológicos. Do nosso ponto de vista,

4 As dinâmicas de hibridismo cultural são entendidas como processos que "produzem misturando bens culturais e temporalidades históricas distintas que convivem num mesmo presente" (GARCIA CANCLINI, 2008, p. 56-83) e podem culminar na exigência e na negociação de novas formas de pensamento e ação. Esta forma de encarar a construção do conhecimento exige, por sua vez, nova forma de encarar os processos de aprendizagem, mediante ecologias intelectuais na construção de argumentos. (BIZZO, 2009; CARVALHO et al., 2014) 
tais argumentos são necessários para viabilizar a aplicação de QSC em espaços educacionais não formais. Recorremos às teorizações críticas pós-coloniais e culturais representadas nos estudos de Bhabha (1998), Santos (2006, 2007), Garcia Canclini (2008) e Certeau (2009) como forma de nos afastarmos do cientificismo, ${ }^{5}$ pois este tem sido impeditivo na construção de ambientes interativos em espaços educacionais não formais, com vistas a potencializar ações sociopolíticas coletivamente organizadas para o enfretamento de problemas reais. (GOHN, 2010) As perspectivas pós-coloniais, de acordo com Bhabha (1998, p. 239), formulam suas revisões críticas em torno de questões de diferença cultural, autoridade social e discriminação política, testemunhando as forças desiguais e irregulares de representação cultural envolvidas na competição pela autoridade política e social dentro da ordem do mundo moderno. Para o autor, toda a gama de teorias críticas contemporâneas sugere que é com aqueles que sofreram o sentenciamento da história - subjugação, dominação, deslocamento, invisibilidade - que aprendemos nossas lições mais duradouras de vida e pensamento. Isto é, segundo o autor, há uma convicção crescente de que a experiência afetiva da marginalidade social tem transformado as estratégias críticas, fazendo-as girar em torno da credibilidade de práticas simbólicas produzidas no ato da sobrevivência social dos que estão à margem. (BHABHA, 1998, p. 240)

Por sua vez, em Santos $(2006,2007)$, a sociologia crítica toma a forma de posicionamentos político-epistemológicos democráticos, operados por meio dos procedimentos sociológicos da tradução, da sociologia das ausências e das emergências. Para o autor, o trabalho de tradução aliado aos outros dois procedimentos sociológicos referidos constituem formas de combate à ocultação e ao descrédito sofrido pelas experiências sociais que transcendem a compreensão ocidental do mundo, sua tradição científica e/ou filosófica. Em suas palavras, "só assim, será possível criar o espaço-tempo para conhecer e valorizar a inesgotável experiência social que está em curso no mundo de hoje”. (SANTOS, 2006, p. 780) Ressaltamos, para os propósitos deste trabalho, a importância da tradução. Para Santos (2006, p. 804), a tradução pode criar interfaces dialógicas entre sistemas culturais e toma como ponto de partida a ideia de que todas as culturas são incompletas e, portanto, podem ser enriquecidas pelo diálogo e pelo confronto com outras culturas. As traduções ocorrem mediante as zonas de contato, que são "[...] campos sociais onde diferentes mundos-da-vida normativos, práticas e conhecimentos se encontram, chocam e interagem". (SANTOS, 2006, p. 808) Convém, nesse sentido, estar atento ao que surge a partir desses encontros e interações, em termos de saberes, no intuito de perceber potencialidades para

5 De acordo com Santos (2006), é possível caracterizar o cientificismo como uma ideologia totalitária que vê no conhecimento científico seu único ponto de ancoragem no que tange à confiabilidade e à credibilidade política e social, o que invariavelmente culmina numa ambiência propícia à emergência de uma "monocultura do saber e do rigor científico" (SANTOS, 2007, p. 29) impeditiva na criação de interfaces dialógicas entre saberes. 
tomadas de decisão socialmente referenciadas e coletivas, visando fomentar ações sociopolíticas viáveis para o enfrentamento coletivo de problemas reais.

Estes estudos socioculturais nos inspiraram a produzir algumas orientações etnometodológicas e pedagógicas combativas ao cientificismo e, a nosso ver, imprescindíveis como meio de viabilizar a aplicação de QSC em espaços educacionais não formais, neste caso, em comunidades tradicionais. Trata-se de orientações que se afastam de posturas soberbas e corretivas que impedem a construção coletiva de uma ambiência pedagógica respeitosa e produtiva, comprometida com as ações sociopolíticas necessárias ao enfrentamento das questões socioambientais e, ao mesmo tempo, atenta às diferenças culturais:

- nas dinâmicas socioculturais contemporâneas, marcadas pelo entrecruzamento de fronteiras e referenciais de leitura de mundo diversos, torna-se antidemocrático transformar a competência científica em autoridade, ao querer falar em nome do suposto "nativo" observado, tomado como objeto que nada tem, de útil e racional, a dizer, e que apenas deve seguir orientações;

- $\quad$ em consonância com Certeau (2009, p. 248), na investigação e nos estudos das "maneiras de viver" cotidianas de praticantes culturais, "é sempre bom lembrar que não se deve tomar os outros por idiotas”. Em outras palavras, é desfazer-se da ideia de que a relação dos praticantes com sua cultura é sempre inconsciente, irrefletida e alienada e o papel do investigador-intérprete, portador da competência técnico-científica, é esclarecer, decifrar, dominar e corrigir;

- evitar atribuições pejorativas de bens simbólicos à cultura popular/tradicional, sem esclarecer as diferenças entre senso comum e práticas cotidianas de uma cultura. Essa atribuição pejorativa, ao se desarticular de uma diferenciação entre os saberes, pode culminar em "limpezas culturais" de efeito homogeneizante ao se adotar a posição da "ciência correta", baseada em falsas oposições entre saberes.

Compartilhamos, com as perspectivas críticas e pós-coloniais, posicionamentos radicalmente opostos às abordagens cientificistas. $O$ processo de criação de interfaces dialógicas entre saberes é uma das ideias estruturantes das perspectivas educacionais pluralistas (AFONSO, 2001; BURNHAM, 2005; GOHN, 2010) que, dentre outros aspectos, reconhecem os espaços não formais como campos férteis na potencialização do interesse público nas questões científicas e no uso responsável e emancipatório da ciência. A criação de "pontes de diálogo" entre diferentes visões de mundo e saberes, por sua vez, exige abordagens pedagógicas combativas às abordagens de cunho homogeneizante, como o cientificismo. Consideramos, portanto, imprescindível para a viabilização da proposta desenvolvida que abordagens cientificistas sejam superadas como 
forma de criar uma "ambiência coletiva" pedagogicamente propícia à recepção, à apropriação e ao uso dos conhecimentos que aí se chocam e interagem, não sem conflitos, na fundamentação de ações coletivas socialmente referenciadas e reivindicatórias. Dessas atitudes reivindicatórias que se espera fomentar, decorre outro aspecto importante a destacar, no sentido de superar um tratamento que reduz a solução do problema à simples apropriação de conhecimentos. Ao lado da dimensão educativa, e tendo ela como alavanca propulsora, a análise e a resolução do problema observado requerem também uma ampla participação da comunidade local. Isto é, requerem uma mobilização coletiva no sentido de canalizar reivindicações acerca de investimentos que possibilitem a diversificação das atividades econômicas e de subsistência na região e direcioná-las às esferas políticas que a governam. Trata-se de reconhecer que o problema estudado está para além da relação entre o sujeito e o conhecimento e requer um olhar complexo a fim de evitar injustiças sociais sob a alegação de "ignorância”. Defendemos que o problema - ainda que tenha uma dimensão epistemológica - não é um problema puramente epistemológico, mas, sobretudo, social e político.

\section{QSC em espaços educacionais não formais e construtivismo contextual}

As orientações etnometodológicas desenvolvidas, na seção anterior, estão em consonância com a perspectiva do construtivismo contextual (COBERN, 1996, 2013) e do aprender ciência enquanto aquisição de cultura. (AIKENHEAD, 2006, 2009) São perspectivas que, de modo geral, se afastam da leitura colonialista de que as culturas e os saberes das comunidades tradicionais apresentam apenas "influências potencialmente adversas em relação aos interesses e avanços da ciência”. (COBERN, 1996, p. 6) De acordo com essas perspectivas, a aprendizagem em ciências envolve negociações e interpretações entre "visões de mundo" que engendram e são engendradas via processos socioculturais. Disto, decorre que aprender ciência significa "entrar numa nova cultura cruzando fronteiras". (AIKENHEAD, 2009, p. 90) Transitar entre diferentes culturas, no entanto, pode ser uma tarefa complexa e difícil para os interessados no mundo cultural da ciência, pois, muitas vezes, é vista como uma cultura estranha, alheia aos saberes úteis na resolução das necessidades cotidianas. (AIKENHEAD, 2009; CARVALHO et al., 2014; COBERN, 1996) Nesse sentido, o desafio de uma perspectiva de educação em ciências comprometida com as questões culturais e com os complexos "cruzamentos de fronteiras" pode ser traduzido por meio da ideia de "fornecer abrigo" (CARVALHO et al., 2014) àqueles que, na cultura científica, reivindicam o lugar de formas diferentes de uso da ciência em interação com outras visões de mundo. Como é possível "abrigar" as diferentes formas de "cruzamentos de fronteiras" entre a visão de mundo científica e outras visões de mundo que emergem no contato intercultural? Questionamentos desse tipo têm levado investigadores (AIKENHEAD, 2009; BIZZO, 2009; CARVALHO et al., 2014) 
a defender os "cruzamentos de fronteiras" como momentos marcados pela coexistência de preconcepções culturalmente forjadas com concepções científicas nas construções intelectuais. São momentos de construção de conhecimento caracterizados por "ecologias intelectuais" (BIZZO, 2009, p. 64) nas atividades de argumentação marcadas por hibridismos culturais.

Compreendendo a noção de hibridismo como estruturante das dinâmicas de "cruzamentos de fronteiras" entre visões de mundo, optamos, neste capítulo, por produzir algumas orientações pedagógicas, pensando tanto em espaços educacionais formais e, sobretudo, em não formais, como modo de viabilizar a aplicação da proposta de ensino baseada em QSC abaixo exposta de modo mais dialógico e propositivo, no que diz respeito à apropriação para a ação sociopolítica:

- nas conversações que se estabelecem nos espaços educacionais não formais, convém estar atento às argumentações construídas por meio de processos de hibridismo de referências, marcados por "ecologias intelectuais" na fundamentação de tomadas de decisão para a ação social responsável. Construções argumentativas marcadas por hibridismos se apresentam na forma de teias de relações entre os conhecimentos pré-existentes e os adquiridos, numa construção que mescla argumentos oriundos da percepção de mundo e do contato com conceitos científicos mais abstratos na fundamentação das ações. A aceitação e o reconhecimento desses argumentos, sobretudo em espaços educacionais não formais, podem não apenas potencializar o interesse para a visão de mundo científica, mas mobilizar para tomadas de decisão para ações responsáveis viáveis;

- sobretudo, mas não exclusivamente, em espaços educacionais não formais, cuja heterogeneidade dos grupos é algo evidente, convém estar atento aos "estados de cidadania"6 (BURNHAM, 2005) dos indivíduos, a fim de compreender a diversidade de "situações de cidadania" que, por sua vez, implicam em diversos níveis de participação sociopolítica. Trata-se de evitar injustiças sob a alegação de suposta "igualdade" de participação sociopolítica dos indivíduos nas sociedades complexas marcadas por vários níveis de exclusão social.

6 Segundo Burnham (2005), o termo "estado" é empregado como alternativa a "estrato", considerando que este último oferece uma ideia estática, de divisão permanente, separação sem interação, enquanto o primeiro permite a ideia de "estar sendo", num determinado momento, possibilitando mobilidade. O que se busca traduzir com o esquema referencial de "estados de cidadania" é o empenho de não aceitar dicotomias que escondem exploração, desrespeito e desigualdade na invisibilidade das diferentes formas e, sobretudo, condições de viver a cidadania e a democracia nas sociedades complexas, marcadas por desigualdades que vão desde a excludente privação ao acesso às condições mínimas de necessidades imediatas, até a participação instituinte nas esferas produtivas, políticas culturais e ambientais. 
Nas próximas seções, apresentamos a QSC desenvolvida por nós a partir do problema socioambiental observado no vilarejo de Garapuá, bem como algumas considerações finais em torno da defesa de uma educação científica para ação sociopolítica com aportes da socioantropologia crítica e pós-colonial.

\section{Uma QSC do mar}

Como dito, esta QSC e as orientações expostas acima foram produzidas a partir de um problema socioambiental vivenciado por moradores do Vilarejo de Garapuá. Trata-se de um contexto marcado por uma heterogeneidade evidente de pessoas com faixas etárias e níveis de escolaridade distintos, interesses pessoais e coletivos diferentes e, muitas vezes, divergentes, filiações políticas e ideológicas as mais diversas. Apesar de construída com base nestes aspectos, entendemos que este problema envolve questões educacionais, políticas e culturais que estão para além daquele contexto específico de ocorrência, sendo, portanto, possível encontrar outros espaços educacionais, formais e não formais, onde esta proposta seja aplicável. Pensando a educação científica no cenário brasileiro, que dispõe de uma costa marinha extensa, na qual os ecossistemas vêm sendo historicamente explorados, convém refletir as relações sociais, econômicas e ambientais envolvidas nestes processos predatórios. Esta QSC, por trabalhar com este tema, torna-se uma ferramenta útil para compreender tais problemas nos mais variados contextos.

No que diz respeito aos espaços educacionais formais, convém estar atento aos níveis de ensino a que serão destinados esta proposta: consideramos conveniente a aplicação desta QSC a partir dos anos finais - $8^{\circ}$ e $9^{\circ}$ anos - do ensino fundamental, bem como ensino médio, técnico e Educação de Jovens e Adultos (EJA), podendo ser abordado por diferentes disciplinas e até mesmo numa perspectiva interdisciplinar, dado seu caráter complexo e mobilizador de diferentes áreas do conhecimento, dentre as quais destacamos: ciências naturais, em aulas voltadas ao tema meio ambiente, dentre eles o marinho, podendo atrelar a discussão ao consumo de crustáceos e à conservação socioambiental; e/ou em etnoecologia, para refletir questões de configuração ambiental numa relação integrada às dinâmicas das comunidades; e/ou em ética ambiental, para problematizar questões de valores na educação, fomentando a conscientização socioambiental. No ensino superior, essa QSC também poderá ser aplicada, resguardando devidas adaptações para o contexto e os objetivos da disciplina.

O enunciado da QSC foi construído envolvendo personagens com potencial representativo das relações simbólicas que lá foram observadas e traduzidas por nós, por meio de um caso (Quadro 1). Logo após, apresentamos algumas questões relacionadas ao caso, seguidas dos objetivos de aprendizagem sugeridos. 
Quadro 1 - QSC sobre a pesca da lagosta, na forma de caso

Pesca da lagosta: uma QSC do mar

Rai, pescador e morador da região de Garapuá, com alto prestígio e respeito pelos demais membros da comunidade, devido à sua habilidade e competência em trazer "o barco cheio", foi comunicado pelos donos de restaurantes e agências de viagem que as piscinas e praias de Garapuá estão no roteiro de viagem de diversos pacotes turísticos fechados para o período de 5 de janeiro a 5 de março. Rai, sabendo da demanda, sobretudo da lagosta que está colocada nos folders turísticos da região, prontamente reuniu um grupo de pescadores e partiu pro mar; é época de barco cheio! O grupo de Rai, sabendo da dificuldade da alta demanda, optou por ir realizar a pesca em águas mais profundas, por meio do uso de compressores. Conversando com Rai, os pescadores falaram desta escolha, quando um deles disse:

- Mas você não ficou sabendo da história com o sobrinho de Zé Carlos, não? Essa história de pescar com compressor tá matando muita gente no mar... É perigoso...

Outro pescador do grupo replicou:

- Mas o que a gente vai fazer, se tá ficando cada vez mais difícil e, a cada ano que passa, a gente precisa ir mais longe pra conseguir pegar uma lagosta? Todo mundo sabe que o verão tá vindo aí e os turistas vão chegar querendo lagosta, é nossa oportunidade de ganhar um dinheirinho... Eu mesmo tô querendo aproveitar esse verão para dar um jeito no meu terreno, quero botar pra vender e precisa dar um trato nele... Tem sempre uns gringos querendo comprar...

Contudo, segundo regulamentação do Instituto Brasileiro do Meio Ambiente e dos Recursos Naturais Renováveis (Ibama), no que se refere à lagosta, a pesca é proibida no período de $1^{\circ}$ de dezembro até o dia 31 de maio. Rai sabe que o pescador que pegar lagosta nesta época pode pagar multa de até 100 mil reais e pode ficar preso por até 3 anos. Valmir, dono de um dos restaurantes da região, por sua vez, sabe que só pode vender a lagosta que estiver estocada, mediante apresentação do certificado de estocagem, garantindo que o animal tenha sido capturado antes do período de proibição, estando sujeito a multas e fechamento do estabelecimento. Jandira, esposa de Valmir, anda preocupada com a fiscalização e, junto com outras moradoras, começa a produzir doces artesanais, aproveitando a fartura das frutas típicas da região. Insiste em alertar seu marido:

- Val, essa pescaria de lagosta, nessa época, ainda vai dar problema!

Tentando convencê-lo, lembra-o do exemplo de Dona Ana, que tem ganhado um bom dinheiro todo verão, vendendo artesanato e roupas de renda que ela mesma faz em casa.

Ezequiel, guia turístico, responsável pelos pacotes fechados, é o tutor que acompanha os turistas na visitação às praias e piscinas naturais, locais onde tradicionalmente mais se consome a lagosta. Daniel integra o primeiro grupo de turistas a desembarcar na costa de Garapuá e desconhece as legislações ambientais de pesca da lagosta. Conversando entusiasmado com seus amigos, ele diz:

- Não vejo a hora da gente chegar nesse paraíso e se jogar na beira da praia pra ficar comendo lagosta na manteiga o dia inteiro! Ouvi falar que lá a gente pode comprar lagosta por um precinho bem barato, impossível de encontrar nos restaurantes de outros lugares.

Fonte: elaborado pelo autores com base em Pimentel-Júnior (2015).

\section{Questões do caso sobre a QSC}

Q1. Na posição de Rai, como você argumentaria com Valmir, dono do restaurante, e Ezequiel, guia turístico, em relação aos problemas da pesca da lagosta no período de alta estação indicado?

Q2. Na posição de Valmir, como você argumentaria com Rai e Ezequiel diante das demandas turísticas de consumo da lagosta? 
Q3. Na posição de Ezequiel, como você argumentaria com Daniel, turista passageiro em Garapuá, diante das relações de consumo da lagosta nesse período?

Q4. Na posição de Daniel, como você argumentaria com Valmir diante da oferta de lagosta nos cardápios dos restaurantes de Garapuá?

Q5. O que você acha do posicionamento de Dona Jandira? Quais outras alternativas socioeconômicas poderiam ser pensadas para substituir a pesca da lagosta durante o período de interdição?

Q6. Por que o trabalho dos pescadores pode ser perigoso? Quais são os riscos à saúde a que eles estão expostos? O que poderia ser feito para minimizar tais problemas?

Q7. Como você explica a observação do pescador que, a cada ano, fica mais difícil encontrar as lagostas? Quais seriam as consequências ambientais e socioeconômicas que podem ser geradas por esse fenômeno? O que poderia ser feito para reverter esse quadro de desaparecimento progressivo das lagostas?

Q8. Se você fosse um membro da comunidade de Garapuá, diante dos problemas ambientais envolvidos na relação de consumo da lagosta, como você argumentaria com os demais membros da comunidade para que, coletivamente, agissem frente às questões sociais e ambientais envolvidas nessa atividade turística/gastronômica? Quais atitudes você fomentaria na comunidade diante dessa situação?

Q9. De que forma a arte e a cultura podem contribuir para a resolução dos problemas socioecológicos da região?

Q10. O que poderia ser feito para o desenvolvimento de um turismo socioecológico responsável na comunidade?

Q11. Diante de pressões socioambientais que têm reduzido a quantidade de lagostas na região, que outras formas de garantir a renda da população poderiam ser exploradas?

Objetivos de aprendizagem (ZABALA, 1998), com base em Pimentel-Junior (2015):

\section{Conceituais}

- Compreender as relações ecológicas do ecossistema marinho da região;

- Compreender noções básicas de bioética e educação ambiental como fundamento para uma educação ambiental estruturada em propostas proativas de resolução de problemas ambientais comunitários articulados a uma ética global;

- Compreender conceitos básicos de bioenergética do habitat marinho: fluxo de energia, pirâmide, cadeia e teias alimentares; 
- Compreender conceitos básicos de equilíbrio dinâmico ecológico e resiliência ambiental;

- Compreender conceitos básicos de ciclo reprodutivo das principais espécies relacionadas à teia alimentar;

- Compreender conceitos e princípios sobre a fisiologia da respiração e outros associados à saúde humana;

- Apresentar conceitos de senciência relativos à fisiologia e à filogenia da dor nos animais.

\section{Procedimentais}

- Desenvolver capacidade de análise e revisão dos métodos e práticas de pesca empregados na região;

- Desenvolver capacidade de reconhecimento das imbricadas relações entre meio e social da comunidade de Garapuá e levantamento das problemáticas relativas ao consumo da lagosta;

- Desenvolver capacidade de produção de projetos de "gestão local", articulando história natural e social da comunidade de Garapuá;

- Desenvolver e elaborar um código de conduta para a pesca responsável;

- Aperfeiçoar técnicas e procedimentos de segurança durante o mergulho.

\section{Atitudinais}

- Fomentar valores relativos ao "sentido de pertencimento", à "parceria com a natureza" e às "atitudes responsáveis" que, simultaneamente, viabilizam as atividades turístico-gastronômicas e o respeito à dinâmica natural dos ciclos de vida envolvidos;

- Dicutir a identificação de um mosaico de áreas especialmente protegidas para implantação de áreas marinhas de proteção em zonas de berçários e criadouros;

- Promover a cogestão dos ambientes marinhos como uma atividade integrada na comunidade;

- Fomentar a articulação e a parceria entre os pescadores e o Ibama para que sejam otimizadas as práticas de fiscalização; coibir a pesca de compressor e do uso da rede de espera (caçoeira), assim como a captura de lagostas juvenis em fase de desova;

- Discutir o licenciamento das frotas artesanais da região como instrumento de inclusão socioeconômica;

- Refletir e discutir sobre a consideração moral humana de animais sencientes, sobretudo com relação aos interesses secundários humanos (de gosto gastronômico), além dos problemas socioambientais gerados e mantidos pela pesca 
de crustáceos, associados também com uma discussão sobre ética não-antropocêntrica;

- Discutir efeitos da manutenção de determinadas práticas de alimentação na saúde humana e ambiental e quais tradições e atitudes da comunidade deveriam ser estimuladas, visando a melhoria na qualidade de vida dessas comunidades e do meio natural;

- Discutir valores culturais e morais, dando maior ênfase aos aspectos éticos e políticos para o desenvolvimento de um pensamento crítico dos envolvidos;

- Compreender o código da legislação ambiental no que diz respeito à pesca das lagostas em território nacional.

\section{Considerações finais}

Neste capítulo, tomamos como objetivo descrever o contexto socioambiental e cultural de elaboração de uma QSC, discutindo meios de aplicação na educação formal e não-formal, visando aprendizagem de conteúdos conceituais, procedimentais e atitudinais implicados na formação de cidadãos para tomada de decisão para ação social responsável. Apresentamos argumentos, orientações etnometodológicas e pedagógicas com objetivo de orientar a aplicação desta ferramenta didática, tanto no espaço não-formal investigado, como em outros espaços educacionais formais e não formais. Defendemos que o modo culturalmente implicado de construção desta QSC pode apresentar forte potencial mobilizador de interesse e participação coletiva da comunidade, com vistas à estruturação de um espaço de debate deliberativo acerca das suas relações com seus ambientes. Os debates têm como objetivo buscar soluções socioeconômicas, culturais e ambientais viáveis para combater os problemas observados no vilarejo de Garapuá.

Desejamos que este trabalho auxilie no desenvolvimento de novas propostas comprometidas com a integração crítica das relações entre Ciência, Sociedade, Tecnologia e Ambiente (CTSA), principalmente no que concerne ao uso de alternativas criativas para a solução de problemas observados em contextos não formais. Permanecemos cônscios de que um dos grandes desafios educacionais na contemporaneidade diz respeito ao modo pelo qual o conhecimento científico possa dialogar com outras visões de mundo, garantindo-lhes espaço, ao passo que possa ser instrumentalmente útil e compreensível em variados contextos. A relevância destas questões esteve sempre em foco durante a elaboração da nossa proposta de ensino baseada em QSC e das orientações etnomedológicas e pedagógicas explicitadas. Ressaltamos que não foi nossa intenção descredibilizar os saberes tradicionais da comunidade. Ao contrário, introduzimos ideias alternativas para serem ressignificadas de acordo com as necessidades locais. Nesse sentido, o intuito passou também pela ampliação do repertório de possibilidades de ação efetiva no enfrentamento dos problemas socioambientais vivenciados pela comunidade. 
Finalmente, diante das inúmeras questões socioambientais e dos múltiplos extrativismos que se integram às cadeias produtivas da região, engendrando uma reestruturação sociocultural acelerada, almejamos o desenvolvimento de uma família de QSC. Tencionamos trabalhar a "QSC do mar" integrada com outras QSC, as quais seriam: a "QCS da terra", a "QSC do mangue" e a "QSC sociocultural". A ideia de produção de uma família de QSC surgiu a partir do reconhecimento dos diferentes níveis e áreas de conhecimentos envolvidos no problema observado que, por sua vez, exigem uma rede de QSC articuladas em torno dos conflitos socioambientais e culturais da comunidade. Esta pode ser uma oportunidade para refletir junto à comunidade nos processos de negociação que marcam as ações dos coletivos sociais e os processos de hibridismo cultural envolvidos na fundamentação dessas ações e na formação identitária.

\section{Referências}

AFONSO, A. J. Os lugares da educação. In: VON SIMSON, O. R. M.; PARK, M. B.; FERNANDES, R. S. (Org.). Educação não-formal: cenários da criação. Campinas: UNICAMP/Centro de Memória, 2001. p. 29-38.

AIKENHEAD, G. Educação científica para todos. Tradução de Maria Teresa Oliveira. Lisboa: Edições Pedago, 2009.

AIKENHEAD, G. Science education for everyday life: evidence-based practice. New York: Teachers college press, 2006.

BHABHA, H. K. O local da cultura. Belo Horizonte: Ed. UFMG, 1998.

BIZZO, N. Ciências: fácil ou difícil? São Paulo: Biruta, 2009.

BURNHAM, T. F. Da sociedade da informação à sociedade da aprendizagem:

Cidadania e participação sócio-política na (in)formação do trabalhador. In: ENCONTRO NACIONAL DE CIÊNCIA DA INFORMAÇ̃̃̃O, 6., 2005, Salvador. Anais... Salvador: ICI/UFBA, 2005.

CARVALHO, J. M. et al. Entrecruzando ciência e cultura nas práticas pedagógicas curriculares. Revista Teias, Rio de Janeiro, v. 14, n. 37, p. 130-142, 2014.

CERTEAU, M. de. A invenção do cotidiano: 1. Artes de fazer. 16. ed. Tradução de Ephraim Ferreira Alves. Petrópolis: Vozes, 2009.

COBERN, W. Constructivism and non-western science education research. International Journal of Science Education, London, v. 4, n. 3, p. 287-302, 1996.

COBERN, W.; MOLINA, A.; PEÑALOZA-J, G. Enseñanza de las ciencias y contextos culturales: um testemonio de vida. Revista Internacional de Investigación en Educación. Bogotá, v. 6, n. 12, p. 187-192, 2013.

DIEGUES, A. C. S. O mito moderno da natureza intocada. São Paulo: Hucitec, 2004. 
FRANCO, M. V. G. Partilhando saberes: educação ambiental na vila de Garapuá, município de Cairú-BA. 2012. 74 f. Trabalho de Conclusão de Curso (Graduação em Biologia) - Instituto de Biologia, Universidade Federal da Bahia, Salvador, 2002.

GARCIA CANCLINI, N. Culturas híbridas: estratégias para entrar e sair da modernidade. Tradução de Heloísa Pezza Cintrão, Regina Lessa. São Paulo: Edusp, 2008 .

GOHN, M. da G. Educação não-formal e o educador social. São Paulo: Cortez, 2010.

HODSON, D. Going beyond STS: towards a curriculum for sociopolitical action. The Science education review, [S.1.], v. 3, n. 1, p. 2-7, 2004.

LABURÚ, C. E.; ARRUDA, S. de M.; NARDI, R. Pluralismo metodológico no ensino de ciências. Ciência e Educação, Bauru, v. 9, n. 2, p. 247-260, 2003.

PIMENTEL-JÚNIOR, C. Educação científica para ação sociopolítica: elaboração e tratamento de questões sócio-científicas em espaços educacionais não formais. In: COLÓQUIO INTERNACIONAL DO MUSEU PEDAGÓGICO, 11, 2015, Vitória da Conquista. Anais... Vitória da Conquista: UESB, 2015. p. 3959-3972.

REIGOTA, O que é educação ambiental. São Paulo: Brasiliense, 1994.

SANTOS, B. de S. (Org.). Conhecimento prudente para uma vida decente: um discurso sobre as ciências revisitado. $2^{\text {a }}$ ed. São Paulo: Cortez, 2006.

SANTOS, B. de S. Renovar a teoria crítica e reinventar a emancipação social. São Paulo: Boitempo, 2007.

SANTOS, W. L. P. dos; MORTIMER, E. F. Tomada de decisão para ação social responsável no ensino de ciências. Ciência e Educação, Bauru, v. 7, n. 1, p. 95-111, 2001.

TAINÁ: a origem. Direção: Rosane Svartman. Produção: Pedro Rovai. Roteiro: Cláudia Levay. Intérpretes: Wiranu Tembé; Nuno Leal Maia; Mayara Bents e outros. [S.1.]: Sony Pictures, Telelmage, Quanta, Telecine Images, DownTown Images, 2013. (80 min.), son., color.

ZABALA, A. A prática educativa: como ensinar. Porto Alegre: Artmed, 1998. 


\title{
POLUIÇÃO HÍDRICA \\ UMA QUESTÃO SOCIOCIENTÍFICA PARA ABORDAR ÉTICA AMBIENTAL NO ENSINO FUNDAMENTAL DE CIÊNCIAS
}

\author{
Jéssica Santos \\ Dália Melissa Conrado \\ Nei Nunes-Neto
}

\section{Introdução}

A formação de cidadãos críticos e participativos deve ser a principal função da escola. A construção do indivíduo capaz de exercer seus direitos e deveres, de tomar decisões coletivas que permitam maiores justiça social, participação política e sustentabilidade ambiental reflete características da escola, assim como da própria sociedade que a envolve. (BRASIL, 1998; HODSON, 2004; TEIXEIRA, 2003; ZABALA, 1998; ZABALA; ARNAU, 2010) A cidadania não é apenas o exercício de direitos e deveres de um cidadão (como exercer o voto durante as eleições), mas deriva da escolha e da necessidade dos indivíduos para participar de uma organização política e social dinâmica e complexa. Inspirando-nos em convergências de diversos autores - Bencze e Alsop (2009), Conrado e colaboradores (2013), Gorczevski e Martin (2011), Henry Giroux e Susan Giroux (2006), Hodson (2004, 2011) e Santos e Mortimer (2001) -, para nós, a cidadania deve ser compreendida a partir de certas virtudes ou capacidades dos indivíduos para: 
- engajar-se em diálogos críticos com a sociedade e sua história;

- entender criticamente as relações de poder, assim como dos valores e interesses subjacentes aos diferentes grupos sociais;

- reconhecer as complexas inter-relações de forças que se estabelecem nas sociedades; e, por fim,

- participar politicamente das tomadas de decisões de sua sociedade e de ações sociopolíticas diretas e indiretas, visando o bem de indivíduos, sociedades e ambientes, e não apenas seu próprio bem.

A educação sempre está a serviço de um determinado tipo de cidadania. Por exemplo, ela pode atuar para uma formação crítica e reflexiva, fomentando a emancipação popular e as ações efetivas para uma determinada finalidade pactuada e explícita, rumo à maior justiça social e sustentabilidade ambiental; ou, diferentemente, pode ser responsável pela formação de indivíduos acríticos e obedientes, contribuindo para a manutenção de um quadro de imobilismo coletivo diante dos problemas socioambientais. (TEIXEIRA, 2003) Neste âmbito, a escola, como instituição capaz de oferecer contexto para educar e discutir criticamente a respeito dos valores presentes na sociedade, não pode fugir à sua responsabilidade de contribuir na formação de cidadãos críticos. Em particular, em países como o Brasil - que ainda não possui uma democracia madura, tal como as insistentes tentativas, por parte das oligarquias político-econômicas, de desmonte ou fragilização das instituições democráticas, reiteradamente nos lembram -, a discussão de cidadania e educação sobre valores deve estar atrelada às necessidades urgentes de transformação das relações sociais nas dimensões política e econômica, em seus diversos níveis, sempre atentando para a gravidade dos problemas ambientais e sociais, bastante concretos, que nos afligem.

Com o ensino de ciências, não deve ser diferente. Para contribuir com uma formação crítica do cidadão, da nossa perspectiva, pressupõe-se uma abordagem mais ampla e, por isso mesmo, integral do conteúdo nas aulas de ciências, isto é, superando uma abordagem tradicional e tecnicista da educação científica. (ARANHA, 2006; CONRADO; EL-HANI; NUNES-NETO, 2013; FOUREZ, 2008) Em outras palavras, o ensino de ciências deve abordar tanto as dimensões conceitual e procedimental quanto a atitudinal dos conteúdos (COLL et al., 1992; CONRADO; NUNES-NETO, 2015; ZABALA, 1998); o que pode fundamentar-se na perspectiva educacional Ciência, Tecnologia, Sociedade e Ambiente (CTSA).

Nesta linha, cabe notar que há diferentes vertentes na educação CTSA. De acordo com Pedretti e Nazir (2011), estas perspectivas e seus respectivos enfoques são:

- aplicação/design (resolução de problemas da ciência e da tecnologia);

- $\quad$ histórica (compreensão histórica e sociocultural da ciência); 
- raciocínio lógico e argumentativo (compreensão e tomada de decisão sobre Questões Sociocientíficas - QSC);

- raciocínio moral e ético (compreensão e tomada de decisão sobre QSC);

- sociocultural (compreensão da ciência e da tecnologia em um contexto sociocultural amplo);

- justiça social e ambiental (ação sociopolítica para a crítica e a resolução de problemas socioambientais).

Aqui, nos alinharemos mais com aquelas perspectivas que enfatizam a formação do caráter (ZEIDLER et al., 2005) e a educação moral e política como parte de uma educação científica escolar para melhor formação de cidadãos capazes de participação social, de modo responsável e valorizando a coletividade e a justiça socioambiental, o que podemos denominar de ação sociopolítica (HODSON, 2011); em suma, estamos mais alinhados com a quarta e a sexta abordagens, de acordo com a classificação de Pedretti e Nazir (2011). Segundo Hodson (2011), é a capacidade para ação sociopolítica como objetivo do ensino de ciências que levaria a um efetivo letramento científico funcional, também conhecido por letramento científico crítico.

Nesse contexto, enfatizar a dimensão atitudinal dos conteúdos - no âmbito de uma abordagem integral sobre o conteúdo (CONRADO; NUNES-NETO, 2015) - no currículo do ensino de ciências é um modo de preparar cidadãos para ações sociopolíticas (HODSON, 2004), conforme elaboraremos mais adiante. A inclusão de conteúdos atitudinais pode ocorrer na discussão sobre valores morais, interesses político-econômicos e limites da ciência, aproximando esta de uma abordagem humanitária. Assim, a partir de uma reflexão crítica sobre a dimensão moral dos problemas socioambientais, será possível entender que problemas socioambientais não serão resolvidos sem que haja uma necessária mudança de concepção e de hábitos dos próprios agentes sociais, informados e conscientes da responsabilidade de suas ações na sociedade. (HEMPEL, 2014; GRÜN, 2012; JAMIESON, 2010) Diante dos - graves e cada vez menos controlados - problemas socioambientais atuais (BENCZE; CARTER; KRSTOVIC, 2014; BERGANDI, 2013, 2014; WWF, 2014), ressaltamos a necessidade da formação de cidadãos críticos capazes de mobilizar conteúdos científicos no seu cotidiano, a fim de, num primeiro momento, contribuir para compreender criticamente as situações sociais e ambientais complexas que os envolvem; e, num segundo momento, a partir de uma preparação crítica, construir, coletivamente, ações sociopolíticas que contribuam para a solução destes problemas - mais à frente, esta ideia será melhor explicada com base na proposta de currículo em quatro níveis ou estágios de sofisticação, por Hodson (2004).

Neste capítulo, apresentamos uma proposta de ensino baseada em uma questão sociocientífica, como estratégia didática, que contemple conteúdos atitudinais (juntamente com outros conteúdos) para contribuir para um ensino de ciências respalda- 
do pela perspectiva da educação CTSA, visando a melhoria da formação de cidadãos capazes de ação sociopolítica. Nesta linha, discutimos a importância da ética ambiental no ensino de ciências e apresentamos um caso baseado em uma QSC sobre o tema "poluição hídrica", com algumas recomendações para sua aplicação no ensino fundamental de ciências, levando em conta a dimensão ética, proporcionada pela ética ambiental.

\section{Ética ambiental no ensino de ciências}

A ética ambiental nasce, no âmbito da filosofia ambiental, da necessidade de fundamentar filosoficamente o movimento ambientalista, que estava em crescimento acelerado, impulsionado pela crise ambiental, reconhecida na década de 1970. (SILVA, 2009) Além disso, a ética ambiental pode ser vista como uma perspectiva teórica para conceitualizar e sustentar uma política ambiental. (VAZ; DELFINO, 2010) Para isso, a ética ambiental oferece instrumentos e conceitos para reexaminar os conceitos de valor moral frente aos problemas ambientais e se desenvolveu em correntes éticas distintas, baseadas em diferentes noções de valor. Por exemplo, Jax e colaboradores (2013) sugerem uma divisão dos valores que atribuímos à natureza não-humana em: instrumental (que tem utilidade para alguém); eudaimonístico (relacionado ao bem-estar humano); fundamental (relacionado às condições básicas de existência de vida no planeta); e, por fim, inerente (relacionado à própria existência).

Figura 1 - Um mapa dos valores em ética ambiental

\begin{tabular}{|c|l|}
\hline $\begin{array}{l}\text { Valores da natureza } \\
\text { não-humana }\end{array}$ & $\begin{array}{l}\text { Valor inerente } \\
\text { consideração dos seres naturais não-humanos para seu próprio bem e por } \\
\text { sua própria existência }\end{array}$ \\
\hline $\begin{array}{l}\text { Valor fundamental } \\
\text { consideração de condições básicas para existência da vida (humana e } \\
\text { não-humana) na Terra }\end{array}$ \\
$\begin{array}{l}\text { Valor eudaimonístico } \\
\text { consideração de condições básicas para uma boa vida humana }\end{array}$ \\
$\begin{array}{l}\text { Valor instrumental } \\
\text { consideração de algo como meio para alguma outra finalidade (em } \\
\text { princípio, é substituível) }\end{array}$ \\
\hline
\end{tabular}

Fonte: adaptada de Vaz e Delfino (2010) e Jax e colaboradores (2013). ${ }^{1}$

1 O que Jax e colaboradores (2013) consideram valor inerente, Vaz e Delfino (2010) consideram valor intrínseco. O valor intrínseco é entendido como o valor que uma determinada coisa tem devido à sua própria natureza: "As coisas são intrinsecamente valiosas, mesmo na ausência de outros mo- 
A fim de esboçar uma primeira distinção, podemos dividi-la em ética antropocêntrica e ética não-antropocêntrica. (VAZ; DELFINO, 2010) Numa visão antropocêntrica, somente os seres humanos são considerados moralmente; deste modo, os seres vivos não-humanos, assim como o ambiente abiótico, são considerados apenas como instrumento para a obtenção de conforto e qualidade de vida humana e o exame moral recai somente sobre ações que afetam os seres humanos. (VAZ; DELFINO, 2010; NORTON, 2003) Em outras palavras, numa visão antropocêntrica em ética ambiental, os seres humanos são o centro da consideração moral e qualquer outro ser só é considerado moralmente de forma indireta, pelo benefício que gera para os humanos. Uma visão antropocêntrica mais fraca é a apresentada por Bryan Norton (1984). Ele considera que a ética não precisa recorrer ao valor intrínseco da natureza, mas a uma preocupação com a proteção da base dos recursos ao longo do tempo. (LIGHT; ROLSTON Ill, 2003; NORTON, 2013) O antropocentrismo é a principal tradição moral do Ocidente, tendo sido, sobretudo, fortalecido pelos pensamentos de Descartes e Bacon, entre outros, em meio ao projeto de articulação da ciência moderna, no século XVII.

As perspectivas éticas não-antropocêntricas consideram que a proteção da natureza deve acontecer em função dela mesma e não somente em razão dos seres humanos. (VAZ; DELFINO, 2010) Para fins didáticos, podemos dividir as correntes não-antropocêntricas em dois grandes grupos: biocentrismo e ecocentrismo.

O biocentrismo tem como centro da consideração moral a vida e surge como uma corrente divergente ao antropocentrismo (TELES, 2007), no sentido de, simplesmente, alterar a consideração moral, para ampliá-la na medida em que todos os seres vivos são considerados moralmente. Consideraremos três perspectivas biocêntricas. ${ }^{2}$ A primeira é aquela proposta por Paul Taylor (1981), em que o autor considera que o dever humano de preservar as espécies e de evitar a poluição e o desequilíbrio da natureza é a forma de manter a vida saudável de outras espécies, além da nossa. (BECKERT, 2004; VAZ; DELFINO, 2010) Seus princípios fundamentais são:

- Igualdade entre todos os membros da comunidade biótica, incluindo o homem;

- Interconexão entre todos os ecossistemas;

- Consideração de cada ser vivo como centro teleológico que tem um bem próprio a ser realizado;

tivos, quando há razões para promover, apreciar ou proteger por causa da sua própria natureza". (VAZ; DELFINO, 2010, p. 36)

2 Nossa caracterização das três abordagens como biocêntricas não é exata, mas apenas aproximada, pois, como veremos as perspectivas de Peter Singer e Tom Regan, cada uma, a seu modo, restringe a consideração moral a um conjunto menor do que aquele dos seres vivos como um todo. Contudo, apesar desta ligeira imprecisão, todas as três perspectivas coincidem em dois pontos: primeiro, obviamente, ampliam o escopo da consideração moral para além do antropocentrismo; e, segundo, tratam indivíduos - e não totalidades ecológicas - como os objetos de consideração moral. 
- Rejeição de todas as visões antropocêntricas. (BECKERT, 2004; TAYLOR, 1981)

Isto implica que não devemos julgar a natureza através dos padrões humanos, valorizando nela aquilo que está mais próximo de nós ou de nossas necessidades, mas através dos seus próprios padrões, daquilo que constitui o bem para cada ser vivo. (BECKERT, 2004)

A segunda perspectiva biocêntrica que consideramos aqui é aquela proposta por Peter Singer (2010), bem conhecida no campo da ética animal. Ela é baseada no utilitarismo (uma teoria ética consequencialista), e segundo ela, as ações humanas relacionadas aos animais não-humanos devem levar em conta os interesses destes, como parte dos interesses dos envolvidos com tais ações (ou seja, os interesses humanos não são os únicos relevantes). Isto leva Singer (2002) a defender o princípio segundo o qual os interesses de animais humanos e não-humanos devem ser igualmente considerados. Neste sentido, na perspectiva utilitarista de Singer, os interesses estão relacionados ao conceito de senciência, isto é, a capacidade de sentir prazer ou dor, que caracteriza o grupo com estatuto moral, ou seja, que deve ser considerado moralmente. Não sentir dor é um interesse dos animais, humanos ou não-humanos, assim como também continuar vivendo. Obviamente, o respeito a estes interesses por parte dos seres humanos - e assim, o princípio da igualdade de consideração de interesses - não se manifesta quando, a fim de satisfazer seus próprios interesses secundários (como se verifica, cotidianamente, no ato humano de comer outros animais), seres humanos privam os animais não-humanos de seus interesses primários (por exemplo, continuar vivendo, ao invés de ser morto para ser utilizado como alimento).

Por fim, como terceira perspectiva biocêntrica, consideramos a teoria de Tom Regan (2003, 2013). O autor assume, diferentemente de Singer, uma postura filosófica baseada na ideia de direitos. Para Regan (2013, p. 119), a ideia de direitos deve ser estendida a um grupo de animais que inclui os humanos. Assim, para a pergunta: "quem possui direitos morais?", Regan responde: os "sujeitos-de-uma-vida". O conceito de "sujeitos-de-uma-vida” ilumina, de acordo com Regan, a nossa igualdade moral, uma vez que ele aponta para as características que nós humanos temos em comum com outros animais (de modo similiar ao que ocorre com o conceito de senciência). Os "sujeitos-de-uma-vida" são animais que, entre outras características, experienciam o mundo, são capazes de sentir e possuem sua própria história, ao longo da vida. Como Regan (2013, p. 120) afirma: "do ponto de vista moral, cada um de nós é igual, porque cada um de nós é igualmente um alguém, não algo, o sujeito-de-uma-vida, não uma vida sem um sujeito”. O grupo de "sujeitos-de-uma-vida" inclui, segundo Regan (2013), todos os mamíferos, aves e, certamente, todos os peixes, muito provavelmente. ${ }^{3}$

3 Para mais explicações, ver Nunes-Neto (2015). 
Por sua vez, o ecocentrismo tem como principal objeto de consideração moral a coletividade natural, ou seja, todo o conjunto de relações entre os organismos e seu ambiente físico-químico. (BECKERT, 2004; VAZ; DELFINO, 2010) O ecocentrismo tem como respaldo científico a ecologia e um novo modo de enxergar a moralidade que reconhece a primazia moral dos totais ecológicos. (BLANDIN, 2013; JAMIESON, 2010; LARRERE, 2013) Neste sentido, ele é uma ética holista, diferentemente das éticas biocêntricas, que, por estarem focadas em indivíduos portadores de certas capacidades ou disposições, são conhecidas como individualistas. (NUNES-NETO, 2015)

Uma vez que a QSC que nos ocupa neste capítulo é a poluição hídrica, nossa preocupação deve estar focalizada sobre os corpos d'água, ao invés de estar focalizada sobre os indivíduos biológicos de forma direta; em consequência, nos parece mais apropriada a adoção de uma perspectiva ecocêntrica. Por sua vez, a ética ecocêntrica encontra respaldo científico na ciência da ecologia e, mais precisamente, em um conceito epistemologicamente central para a ecologia, o conceito de função. (CAPONI, 2010; NUNES-NETO, 2013; NUNES-NETO; CARMO; EL-HANI, 2013, 2016; NUNES-NETO; MORENO; EL-HANI, 2014) Por isso, é importante abordar o conceito de função aplicado aos sistemas ecológicos e, daí, derivar uma reflexão sobre o valor da água, como um componente relevante dos sistemas ecológicos.

Para De Groot, Wilson e Boumans (2002), as funções dos ecossistemas podem ser classificadas em:

- Funções de regulação - relacionadas à manutenção de todos os ciclos biogeoquímicos pelos organismos vivos e não vivos através de suas interações e processos;

- Funções de habitat - relacionadas ao provimento de abrigo de animais e plantas selvagens, por exemplo;

- Funções de produção - relacionadas à conversão de micronutrientes em macronutrientes através de processos biológicos como a fotossíntese; e

- Funções de informação - relacionadas às fontes de informação humana para aquisição de conhecimentos para a saúde humana, reflexão, desenvolvimento cognitivo, recreação, a partir da interação com os sistemas ecológicos. ${ }^{4}$

Quanto aos tipos de valor associados aos sistemas ecológicos, De Groot, Wilson e Boumans (2002) consideram três categorias:

4 Para mais detalhes sobre o conceito de função em ecologia, assim como suas extensões sociais, éticas e econômicas, recomendamos a consulta dos seguintes trabalhos: Millennium Ecosystem Assessment (2005); Jax (2005, 2010); Nunes-Neto (2013); Nunes-Neto e colaboradores, (2013, 2014); e Cooper; El-Hani e Nunes-Neto (2016). 
- Valor ecológico - determinado pela integridade da função de regulação e função de habitat dos ecossistemas e definidos por parâmetros ambientais, tais como a complexidade do ecossistema, diversidade e raridade;

- Valor econômico - é atribuído aos serviços de mercado que as funções ecossistêmicas fornecem à humanidade, principalmente as funções de produção, que servem de troca monetária no mercado;

- Valor sociocultural - determinado pela medida em que os ecossistemas naturais e suas funções podem contribuir para benefícios sociais, tais como saúde física e mental, educação, diversidade cultural, identidade e liberdade.

Nessa perspectiva, a ideia de que a natureza tem a função de ser fonte de bens e recursos ambientais para humanidade e que, portanto, deve ser dominada para usufruto humano tem nos colocado como principais protagonistas da crise ambiental atual. (SINGER, 2002) Em particular, o predomínio da noção de valor instrumental da natureza, em relação à noção de valor intrínseco da natureza, é uma das chaves para entender a - cada vez mais intermediada por atribuições de valor econômico - consideração moral da natureza pela humanidade. (GÓMEZ-BAGGHETUN et al., 2010; MCCAULEY, 2006)

Inúmeras são as tentativas humanas nos debates sobre mudanças ambientais de negar a sua contribuição para a atual crise ambiental. Isto indica que, enquanto a humanidade não entender que a principal fonte dos problemas ambientais é de natureza ética, acreditaremos no erro de que a ciência e a tecnologia poderão dar conta de solucionar todos os problemas ambientais, sem que sejam necessárias mudanças profundas de concepção, valores, normas e de hábitos (GRÜN, 2012), além de mudanças estruturais nas bases econômicas e de organização política de nossas sociedades. (BERGANDI, 2013, 2014)

Nos debates de ética ambiental, no entanto, não existe uma concordância óbvia na escolha ou na aprovação de uma teoria, devido ao grande número de valores ou perspectivas que se opõem entre si; como fica claro, por exemplo, nos dilemas entre uma teoria individualista e uma teoria holista: a consideração moral de totalidades ecológicas, por vezes, implica a negligência ou desconsideração de indivíduos (como em práticas de manejo baseadas em caça); porém, por outro lado, a consideração moral de indivíduos, se por um lado positiva, pode não implicar por si só a proteção das totalidades ecológicas. (NUNES-NETO, 2015) Ou ainda, outro exemplo, como na oposição entre valor intrínseco e valor instrumental da natureza, tal como eloquentemente expõe Patrick Blandin (2013, p. 93): "nós desejamos preservar a biosfera porque nós valorizamos a vida por si mesma ou por que a continuação dos processos ecológicos na Terra é necessária para a continuação da existência da nossa própria espécie?".

Como agentes morais, somos capazes de distinguir, sobretudo em casos mais simples, de uma forma ou de outra, as condutas eticamente recomendáveis das eticamente 
reprováveis. (SILVA, 2009) Contudo, perante casos complexos, surgem amplas divergências sobre qual conduta é a mais correta ou recomendável moralmente. Tais posicionamentos morais variam, desde uma postura mais consequencialista, a uma mais orientada por virtudes, ou ainda a uma postura mais deontológica (Kantiana), tal como expôs Jamieson (2010, p. 126):

Imaginemos um caso típico que poderia provocar reflexão moral. Suponhamos que John está trocando o óleo de seu carro e joga o óleo do motor usado no bueiro da rua. Um consequencialista irá focar na consequência do ato de John, a respeito do dano que essa ação irá causar ao meio ambiente. Um eticista da virtude irá pensar que tipo de caráter tem John para cometer tal ato. Um kantiano tentará entender o ato de John, o que achou que estava fazendo, quais eram seus motivos.

O posicionamento ético de uma pessoa está intimamente relacionado à sua formação pessoal, a qual será sempre influenciada por diferentes correntes éticas, mesmo que inconscientemente. Por isso, uma formação explícita em ética ambiental e valores é relevante para que os cidadãos tenham maior repertório de ideias e argumentos para compreender e lidar, nos contextos sociais e políticos em que vivem, com os problemas socioambientais. Além disso, uma formação que contextualize ideias abstratas - como as presentes nas teorias morais - em casos socioambientais concretos também será necessária.

Neste sentido, o ensino de ciências tem - na sua conexão ou nas suas intersecções com o ensino de filosofia ou com a própria filosofia moral - uma ótima oportunidade para abordar questões morais e assim ser mais capaz de conduzir a um processo de letramento científico crítico (HODSON, 2004), pois terá de incorporar explicitamente, nos conteúdos curriculares, os conteúdos (ou dimensões) atitudinais (ZABALA, 1998): os valores, atitudes e normas. Reconhecer conteúdos (ou dimensões) atitudinais significa reconduzir o ensino de ciências aos objetivos gerais que se propõe, efetivamente, nos documentos curriculares nacionais brasileiros - Parâmetros Curriculares Nacionais (PCN); Parâmetros Curriculares Nacionais para o Ensino Médio (PCNEM) - : ensinar para uma cidadania responsável, participativa e crítica sobre os problemas socioambientais atuais, de modo a transformar a sociedade, fundamentada em valores de justiça socioambiental. (HODSON, 2011)

Apesar de debruçar-se, como qualquer filosofia, sobre questões abstratas - como o significado de valor intrínseco ou a definição teórica de "sujeitos-de-uma-vida" -, não podemos esquecer que a ética ambiental é também uma ética aplicada. Assim, ela ocupa-se de questões concretas. Uma destas questões diz respeito à água, mais especificamente à poluição hídrica, a QSC abordada neste capítulo, que consideraremos na próxima seção. 


\section{Problemas socioambientais envolvendo a água e a poluição hídrica}

Cerca de $70 \%$ da cobertura do planeta é de água. De toda água existente no planeta, $97,5 \%$ é formado por água salgada. Por sua vez, a disponibilidade de água doce é irregular no planeta, pois $68,9 \%$ estão indisponíveis nas geleiras, calotas polares ou em regiões montanhosas, 29,9\% em águas subterrâneas, 0,9\% compõe a umidade do solo e dos pântanos e apenas $0,3 \%$ constitui a porção superficial de água doce presente em rios e lagos mais acessível ao consumo humano. (VICTORINO, 2007) Segundo o Programa Hidrológico Internacional da Organização das Nações Unidas para a Educação, a Ciência e a Cultura (Unesco), na América do Sul encontram-se 26\% do total de água disponível no planeta, ao passo que, nesta região, encontram-se apenas $6 \%$ da população mundial. (BRASIL, 2005)

Por sua vez, o Brasil abriga 13,7\% da água doce do planeta, que está distribuída no território de modo não uniforme. Cerca de 70\% do percentual de água doce do Brasil se encontra na bacia Amazônica, onde vive apenas $5 \%$ da população humana brasileira, enquanto que a região com maior população, o Sudeste, com $42,65 \%$ da população, detem $6 \%$ da água doce. Cabe notar que, no Brasil, o grande desafio do abastecimento das grandes metrópoles ou aglomerados urbanos está relacionado à frequente utilização de fontes hídricas comuns, o que resulta em conflitos pelo uso da água, de ordem quantitativa e qualitativa. Por exemplo, $61 \%$ do total de municípios brasileiros são abastecidos por mananciais superficiais; nos grandes centros urbanos, como São Paulo, Curitiba, Goiânia, Distrito Federal e Fortaleza, existe a necessidade de buscar mananciais cada vez mais distantes e de investimentos em obras de regularização, o que evidencia a forte pressão sobre a água no Brasil. (AGÊNCIA NACIONAL DE ÁGUAS, 2010)

Entre os principais problemas relacionados ao consumo da água, estão a poluição hídrica, os desperdícios, o consumo irresponsável e as elevadas demandas de água por certas atividades industriais e agrícolas. (BRASIL, 2005)

Consideremos, por ora, a poluição hídrica. A poluição hídrica é comumente consequência das atividades humanas desenvolvidas nas bacias hidrográficas, nos oceanos e mares ou no seu entorno. Entre as principais fontes poluidoras, estão o lançamento de esgotos domésticos, a recepção de água da chuva, que escoa das áreas agrícolas e do efeito de erosão do solo, recepção da água da chuva proveniente de regiões com poluição atmosférica, a exemplo da chuva ácida, percolação do chorume de lixões, compostos tóxicos oriundos de pesticidas utilizados na agricultura e no reflorestamento e águas contaminadas por xenobióticos, compostos orgânicos resistentes e traços de produtos farmacêuticos. (GALLI; ABE, 2010)

Por sua vez, quanto às altas demandas de água, é relevante examinar as contribuições da agricultura e da pecuária. (HOEKSTRA; MEKONNEN, 2012) A agricultura e a pecuária consomem cerca de dois terços da água doce do planeta, através da água da chuva, da água retida no solo e do uso indiscriminado da irrigação. No Brasil, a agricultura é a principal atividade humana responsável por consumir mais água, e somado 
com a pecuária e a siderúrgica é considerado o maior exportador de água. (DETONI; DONDONI; PADILHA, 2007)

Neste contexto, ao avaliar o consumo de água doce com base em seus usos diretos e indiretos, cabe fazer referência a uma ferramenta de gerenciamento de recursos hídricos denominada pegada hídrica (do inglês, water footprint). Tal ferramenta permite que empresas públicas e privadas, e também a população, em geral, entendam a quantidade de água necessária para a fabricação de produtos desde a sua produção até o consumidor final. Em dados publicados por Mekonnen e Hoekstra (2011) tendo como base o período de 1996 a 2005, a pegada hídrica da humanidade demonstra que o consumo de água está fortemente relacionado ao nível de desenvolvimento do país e com o nível de renda das pessoas. O consumidor médio nos Estados Unidos tem uma pegada hídrica de $2842 \mathrm{~m}^{3}$ /ano per capita, enquanto que um cidadão comum na China e na Índia tem pegadas hídricas de 1071 e $1089 \mathrm{~m}^{3}$ /ano per capita, respectivamente. O Brasil possui uma pegada hídrica de $2027 \mathrm{~m}^{3}$ /ano per capita, sendo que cerca de $9 \%$ da sua pegada hídrica total é água virtual, ou seja, está fora das fronteiras do país (ver Figura 2).

O estudo de Mekonnen e Hoekstra (2011) ilustra também a dimensão global do consumo e da poluição, mostrando que vários países dependem fortemente de recursos hídricos estrangeiros devido ao alto consumo de água virtual importada de cereais e carne; ${ }^{5}$ e que muitos países têm impactos significativos sobre o consumo de água e da poluição em outro lugar. (HOEKSTRA; MEKONNEN, 2012)

Figura 2 - Pegada hídrica do consumo nacional (em metros cúbicos por ano per capita, para o período 1996-2005) para alguns países com uma população maior do que 5 milhões

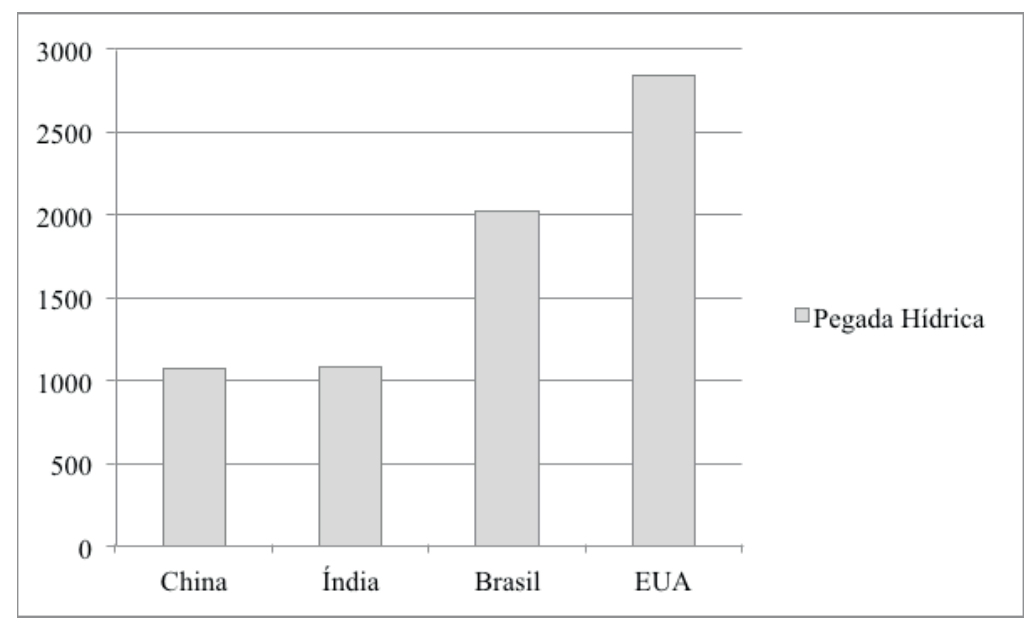

Fonte: adaptada de Hoekstra e Mekonnen (2011).

5 "Água virtual" é uma expressão utilizada para se referir à água presente na produção de alimentos e produtos industrializados. Assim, a exportação de certos bens da agropecuária consiste também numa exportação indireta de água. 
Os problemas descritos acima nos permitem perceber a gravidade da situação em que nos encontramos, com relação à água. Assim, não é surpreendente que, diante do quadro alarmante, tenha ocorrido uma preocupação geral com a água. A declaração ministerial em Haia, do mês de março de 2000, na Holanda, sobre a segurança da água no século XXI é o último marco dessa discussão que se inicia em Mar Del Plata, em 1977, continua em Dublin e foi consolidada no Capítulo 18 da Agenda 21, no Rio de Janeiro em 1992, reafirmada em Paris, em 1998, e no Segundo Fórum Mundial da Água, em Haia. Tais encontros internacionais contribuíram para que cada país elaborasse um plano e medidas em busca da preservação da água e do meio ambiente. No Brasil, desde 1930, existe o Código das Águas; tal código permitia ao poder público controlar e incentivar o aproveitamento industrial das águas. Em concordância com a Conferência das Nações Unidas sobre o Meio Ambiente e Desenvolvimento, também conhecida como ECO92 (a cúpula da Terra, realizada no Rio de Janeiro, em 1992), em 1997, é criada a Lei das Águas, que estabelece o Plano Nacional dos Recursos Hídricos, que tem como um de seus pilares o intenso envolvimento de entidades da sociedade civil na gestão das águas, na criação de comitês e conselhos.

As próprias características da água e do seu ciclo exigem que as problemáticas do seu uso aqui abordadas sejam analisadas e discutidas de forma integrada. Isso significa que questões políticas, econômicas, sociais, ambientais e éticas associadas à água devem ser discutidas de forma articulada nas diferentes escalas: regional, nacional e internacional.

Tendo em vista a relevância ética dos problemas socioambientais associados à água, como, por exemplo, a poluição hídrica, pensamos que esta é uma temática adequada para o ensino de ciências e pode, assim, ser caracterizada como uma QSC.

\section{Um caso a respeito da poluição hídrica}

A proposta de ensino baseada em QSC foi elaborada para o ensino fundamental, no formato de um caso. ${ }^{6}$ Entretanto, ela pode ser utilizada em outros níveis de ensino, como o ensino médio ou, ainda, no ensino superior, desde que devidamente adaptada para o contexto e os objetivos de aprendizagem específicos. Este caso busca mobilizar conteúdos da área da ecologia e da ética ambiental e poderá ser aplicado como parte de uma sequência didática ou, ainda, no ensino não-formal, como parte de um curso de extensão sobre o tema, por exemplo. Ainda, cabe notar que o professor interessado poderá desenvolver um caso, nos moldes do caso apresentado neste capítulo, para abordar a situação de um rio, uma lagoa ou parte da costa litorânea de seu próprio munícipio. Isso permite uma contextualização mais próxima à realidade sociocultural da comunidade escolar.

6 Ressaltamos que a proposta de ensino apresentada compôs parte de uma sequência didática sobre poluição hídrica, aplicada em sala de aula como parte da dissertação de mestrado da primeira autora deste capítulo. Resultados parciais podem ser consultados em trabalhos anteriores: Santos, Conrado e Nunes-Neto $(2015,2016)$. 
Quadro 1 - Caso baseado na QSC sobre poluição hídrica

\section{As águas do Parque São Bartolomeu}

Joana, de 8 anos, saiu acompanhada de sua mãe e outras coleguinhas em visita ao Parque São Bartolomeu. Sua mãe foi ao Parque porque precisava recolher algumas folhas para fazer um remédio com uma planta medicinal e sabia que no Parque poderia encontrar. No caminho, a mãe de Joana contou às meninas que costumava, quando criança, correr pelo parque, subir em árvores, enquanto sua mãe apanhava frutas e folhas.

- Hoje, é preciso muito cuidado, meninas, para andar aqui!

Quando chegou em casa, Joana correu para o colo de sua avó Teresa e the contou o passeio que fez no Parque São Bartolomeu. A menina disse que, apesar do verde, do barulho das águas e dos pássaros, tinha muita sujeira espalhada por todo canto, nas cachoeiras, na mata, que na cachoeira tinha até espuma. A menina ficou bastante assustada e perguntou:

- Vovó, no seu tempo era assim?

Dona Teresa contou à neta:

- No meu tempo, havia mais respeito com as áreas verdes, eram consideradas lugares santos. Nós cuidávamos desses lugares, não jogávamos lixo e esgoto. Não se podia fazer nenhum tipo de violência ali, nem contra os bichos, nem contra as pessoas; senão podíamos ser castigados. Hoje, as pessoas não têm mais respeito por nada, é uma tristeza só. Que pena que o parque não esteja mais bonito para você, minha netinha!

Joana perguntou para sua avó:

- O que podemos fazer para melhorar as condições do parque, vovó?

Fonte: elaborado pelos autores com base em Santos, Conrado e Nunes-Neto (2015, 2016).

Questões relacionadas ao caso sobre a QSC

Q1. Analisando a história vivenciada por Joana e o questionamento dela para com sua avó, quais reflexões podemos fazer?

Q2. Quais problemas estão presentes no Parque São Bartolomeu e de que forma podemos identificá-los?

Q3. Quais problemas presentes no Parque São Bartolomeu interferem em nossas vidas?

Q4. Qual a importância de reservas como a do parque São Bartolomeu para o meio ambiente?

Q5. Que atitudes devemos ter para evitar a poluição hídrica?

Q6. Sobre os problemas sinalizados por Joana, você considera que eles têm relação com a forma pela qual as pessoas se relacionam com o meio ambiente? Por quê?

Q7. Quais as semelhanças e diferenças entre bichos e pessoas, mencionados por Dona Teresa?

Q8. Você acha que a mãe de Joana deveria ir comprar um remédio pronto na farmácia, ao invés de ir coletar folhas e prepará-lo? Por quê? 
Q9. O que podemos fazer para respeitar o parque? O que se pode fazer para reverter a atual situação do Parque São Bartolomeu? Ajude Joana, propondo medidas que solucionariam tais problemas.

\section{Objetivos de aprendizagem}

Nesta seção, apresentamos os conteúdos de aprendizagem, divididos esquematicamente em três dimensões: conceituais, procedimentais e atitudinais. Os conteúdos relacionam-se aos temas de poluição hídrica, desde uma perspectiva da educação CTSA, e assim, constituem, de uma só vez, uma proposta de conteúdos a serem abordados nas áreas de ecologia e ética ambiental.

\section{Conceituais}

- Discutir e compreender: fatos históricos sobre o Parque São Bartolomeu, a partir de dados empíricos sobre ele; fatos relacionados à distribuição de água em todo o globo; fatos sobre pegadas hídricas em diversos países; fatos sobre poluição hídrica em todo o globo, com ênfase sobre contextos locais;

- Discutir e compreender o conceito de serviços ecossistêmicos (em geral e aplicado à água);

- Compreender os componentes sociais e ambientais, bem como suas relações, na constituição dos problemas socioambientais;

- Compreender e identificar os agentes da poluição ambiental e, especificamente, da poluição hídrica;

- Compreender como os resíduos sólidos podem ser reutilizados ou reciclados a fim de impedir ou reduzir a poluição ambiental;

- Compreender a importância da manutenção de parques e áreas verdes nas áreas urbanas;

- Compreender as relações entre meio ambiente e saúde;

- Compreender interações ecológicas (entre animais e plantas) e a relação entre fatores bióticos e abióticos no ecossistema;

- Compreender bases do ciclo da água e identificar seus aspectos interfronteiriços.

\section{Procedimentais}

- Analisar e construir argumentos acerca da poluição hídrica, das pegadas hídricas e de questões de valor, com ênfase sobre a dimensão ética, associadas ao uso da água;

- Identificar os possíveis responsáveis pela poluição em parques naturais;

- Relacionar a saúde do meio ambiente com o cuidado da nossa saúde; 
- Diferenciar as inúmeras atitudes humanas para com o meio ambiente;

- Esboçar mecanismos de como preservar o meio ambiente e os recursos naturais;

- Descrever, explicar e comparar fenômenos socioambientais relacionados ao uso da água e à poluição hídrica;

\section{Atitudinais}

- Discutir as ideias de valor instrumental e valor intrínseco das entidades e processos ecológicos (incluindo a água). Em particular, neste contexto, discutir e diferenciar valor econômico (monetário) e valor não econômico (respeito à vida, ao ambiente, à água, às identidades culturais locais) da natureza não-humana;

- Discutir a importância de se refletir sobre as razões para ações em que cabem juízo moral;

- Refletir criticamente de modo a diferenciar o que é considerado moralmente recomendável do que não é, na relação humana com o meio ambiente;

- Refletir criticamente sobre o consumo de bens materiais e os resíduos gerados, relacionando o tema com a poluição ambiental, sobretudo a poluição hídrica. Ainda, praticar hábitos relacionados a um consumo responsável;

- Compreender e praticar normas de boa convivência, de condutas adequadas em parques naturais etc. (por exemplo, não jogar lixo em ambientes naturais, mas sim, na lixeira; e, sempre que possível, separar lixo para reciclagem);

- Conhecer o sistema de gestão do parque, com base em leis ambientais;

- Compreender e respeitar o direito dos seres vivos à vida;

- Praticar o uso racional e adequado da água (em casa, na escola etc.);

- Praticar habilidades relacionadas ao trabalho coletivo (compreensão de diferentes pontos de vista, tolerância e trabalho colaborativo, solidariedade, respeito ao próximo etc.);

- Discutir com as comunidades sobre os problemas presentes em parques naturais, mobilizando-se para ações sociopolíticas;

- Promover a participação das decisões nos comitês de bacias hidrográficas da região, executando ações sociopolíticas.

\section{Meios para aplicação e discussão da QSC no ensino}

O caso proposto com base na QSC poderá ser aplicado como parte de uma sequência didática ou isoladamente. A contextualização do tema poluição hídrica deve ser realizada tomando como referência o local onde o estudante vive ou a localidade que melhor the sirva de referência. Isso deve ser considerado, uma vez que o problema socioambiental mais próximo pode lhes instigar mais o interesse e, assim, mais provavel- 
mente, isso pode ter papel positivo na tomada de decisão e no engajamento para ações com a comunidade do entorno.

O processo para tomada de decisão e ação responsável requer interesse e proximidade com o problema em questão. Santos e Mortimer (2001) propõem que a educação para a cidadania não seja aquela apresentada já com as soluções prontas para os estudantes; pois não se trata de fornecer a fórmula determinada da justiça, mas de apontar e refletir sobre os critérios para os juízos e suas dimensões éticas, permitindo ao indivíduo que determine, individual e coletivamente, os limites entre o aceitável e o inaceitável. Portanto, os professores não devem indicar precisamente quais as decisões certas ou adequadas, visto que o processo de tomada de decisão não implica apenas na capacidade de expressar ideias e argumentar, mas também na capacidade de avaliar as diferentes opiniões que surgem no debate e saber negociar uma solução de interesse comum. Dessa forma, os estudantes devem ser convidados a refletir sobre os problemas que lhes cercam, e buscar as soluções que são pertinentes.

Os valores discutidos e os conhecimentos (sobre o tema) devem subsidiar a melhor escolha das soluções apresentadas. A decisão escolhida deverá refletir a consciência e o compromisso com determinados valores explicitados e discutidos, além da capacidade de transformar atitudes, habilidades e valores em ações concretas (SANTOS; MORTIMER, 2001) para certos fins, que aqui defendemos. Para concretizar as ações sociopolíticas, por sua vez, sugerimos, por exemplo, o uso de ferramentas tecnológicas de mobilização sociopolítica, tais como: uso das redes sociais virtuais (no qual pode ser criado um grupo sobre o tema poluição hídrica ou pegada hídrica, em geral, ou sobre o problema específico relacionada à água no parque; a fim de informar e discutir o tema), produção de blogs, de vídeos, de entrevistas com moradores da comunidade local ou, por fim, a confecção de um jornal para divulgar dados e iniciativas junto à comunidade.

\section{Considerações finais}

A proposta de ensino baseada na QSC pode ser adotada como uma estratégia didática para possibilitar o diálogo e a ressignificação social da ciência, no ambiente escolar, ao possibilitar sua inserção no contexto das relações entre CTSA. Em particular, o caso proposto busca estabelecer uma relação de proximidade com a localidade onde o estudante vive, com os problemas ali enfrentados, com ênfase nos conteúdos atitudinais, fundamentados na ética ambiental.

Os conteúdos selecionados refletem os debates que ocorrem na ética ambiental e na sociedade, tais como: respeito à vida (perspectiva biocêntrica), conservação dos ecossistemas (perspectiva ecocêntrica), entendimento da posição dos seres humanos como parte do meio ambiente (perspectiva biocêntrica e ecocêntrica), atribuição de valor dado ao meio ambiente para análise dos serviços ecossistêmicos (perspectiva antropocêntrica), entre outros. 
Os conteúdos atitudinais debatidos podem indicar a importância de uma educação CTSA fundamentada em valores éticos para todos os cidadãos. Nesse sentido, é relevante adotar a educação CTSA logo no ensino fundamental, principalmente devido ao fato de ser uma fase de formação de caráter do indivíduo, que deve, portanto, ser rica em conteúdos atitudinais e que se estenda a outros níveis do ensino para a formação de cidadãos críticos, capazes de ações sociopolíticas que contribuam para maior justiça social e sustentabilidade ambiental.

\section{Referências}

AGÊNCIA NACIONAL DE ÁGUAS-ANA. Atlas Brasil: abastecimento urbano de água: resultados por estado. Brasília, DF, 2010.

ARANHA, M. L. de A. Filosofia da educação. 3. ed. São Paulo: Moderna, 2006.

BECKERT, C. Dilemas de ética ambiental: estudo de um caso. Lisboa: Apenas Livros, 2004.

BENCZE, L.; ALSOP, S. Ecojustice through responsibilist science education. In: ANNUAL CONFERENCE OF THE CANADIAN SOCIETY FOR THE STUDY OF EDUCATION, 2009. Ottawa. Proceeding... Otawa: Carleton University, 2009. p. 1-28.

BENCZE, J. L.; CARTER, L.; KRSTOVIC, M. Science \& technology education for personal, social \& environmental wellbeing: challenging capitalists' consumerist strategies. Revista Brasileira de Pesquisa em Educação em Ciências, Belo Horizonte, v. 14, n. 2, p. 39-56, 2014.

BERGANDI, D. Environnement, éthique et politique: les limites d'une démocratie inaboutie et leurs conséquences néfastes sur la protection de la nature. Éthique publique, Québec, v. 16, n. 1, 2014.

BERGANDI, D. The structural links between ecology, evolution and ethics: the virtuous epistemic circle. Dordrecht: Springer, 2013.

BERGANDI; D.; BLANDIN, P. From the protection of nature to sustainable development: the genesis of an ethical and political oxymoron. Revue D'histoire des Sciences, Evry, v. 65, n. 1, Jan./Jun., 2012.

BLANDIN, P. Towards EcoEvoEthics. In: BERGANDI, D. The structural links between ecology, evolution and ethics: the virtuous epistemic circle. Dordrecht: Springer, 2013. p. 83-100.

BRASIL. Manual de educação: consumo sustentável. Brasília, DF, 2005.

BRASIL. Ministério da Educação. Secretaria de Educação Fundamental. Parâmetros curriculares nacionais: terceiro e quarto ciclo, apresentação dos temas transversais. Brasília, 1998.

CAPONI, G. La ciencia de lo sustentable: razón de ser del discurso funcional en ecología. Principia, Florianópolis, v. 14, n. 3, p. 349-373, 2010. 
COLL, C. et al. Los contenidos en la reforma: enseñanza y aprendizaje de conceptos, procedimientos y actitudes. Madrid: Santillana, 1992.

CONRADO, D. M. et al. Evolução e ética na tomada de decisão em questões sociocientíficas. Revista Electrónica de Enseñanza de las Ciencias, Ourense, p. 803-807, 2013. Edição especial.

CONRADO, D. M.; EL-HANI, C. N.; NUNES-NETO, N. F. Sobre a ética ambiental na formação do biólogo. Revista Eletrônica do Mestrado em Educação Ambiental, Rio Grande, v. 30, n. 1, p. 120-139, jan./ jun. 2013.

CONRADO, D. M.; NUNES-NETO, N. F. Dimensões do conteúdo em questões sociocientíficas no ensino de ecologia. In: ENCONTRO NACIONAL DE EDUCAÇÃO EM CIÊNCIAS, 16., 2015, Lisboa. Anais... Lisboa: ENEC, 2015. p. 432-435.

COOPER, G. J.; EL-HANI, C. N.; NUNES-NETO, N. F. Three approaches to the teleological and normative aspects of ecological functions. In: ELDREDGE, N. et al. (Ed.). Evolutionary theory: a hierarchical perspective. Chicago: University of Chicago Press, 2016.

DE GROOT, R. S.; WILSON, M. A.; BOUMANS, R. M. J. A typology for the classification, description and valuation of ecosystem functions, goods and services. Ecological Economics, Amsterdam, v. 41, n. 2, p. 393-408, 2002.

DETONI, T. L.; DONDONI, P. C.; PADILHA, E. A. A escassez da água: um olhar global sobre a sustentabilidade e a consciência acadêmica. In: ENCONTRO NACIONAL DE ENGENHARIA DE PRODUÇÃO, 27., 2007, Iguaçu. Atas... Foz do Iguaçu: [S.n.], 2007.

FOUREZ, G. Educar: docentes, alunos, escolas, éticas, sociedades. Aparecida: Idéias e Letras, 2008.

GALLI, C. S.; ABE, D. S. Disponibilidade, poluição e eutrofização das águas. In: BICUDO, C. E. de M.; TUNDISI, J. G.; SCHEUENSTUHL, M. C. B. (Org.). Águas do Brasil: análises estratégicas. São Paulo: Instituto de Botânica, 2010. p. 165-174.

GIROUX, H. A.; GIROUX, S. S. Challenging neoliberalism's new world order: the promise of critical pedagogy. Cultural studies, critical methodologies, Thousand Oaks, v. 6, p. 21-32, 2006.

GÓMEZ-BAGGETHUN, E. et al. The history of ecosystem services in economic theory and practice: From early notions to markets and payment schemes. Ecological Economics, Amsterdam, v. 69, n. 1, p. 1209-1218, 2010.

GORCZEVSKI, C.; MARTIN, N. B. A necessária revisão do conceito de cidadania [recurso eletrônico]: movimentos sociais e novos protagonistas na esfera pública democrática. Santa Cruz do Sul: EDUNISC, 2011.

GRÜN, M. Ética e educação ambiental: a conexão necessária. 14. ed. Campinas: Papirus, 2012. 
HEMPEL, M. Ecoalfabetización: el conocimiento no es suficiente. In: GOBERNAR para la sostenibilidad: La situación del mundo 2014. Barcelona: Icaria editorial, 2014, p. 79-93.

HODSON, D. Going beyond STS: towards a curriculum for sociopolitical. Science Education Review, Queensland, v. 3, n. 1, p. 2-7, 2004.

HODSON, D. Looking to the future: building a curriculum for social activism.

Rotterdam: Sense Publishers, 2011.

HOEKSTRA, A.; MEKONNEN, M. M. The water footprint of humanity. Proceendings of the National Academy of Sciences of the Unites States of America, Washington, p. 32323237, v. 109, n. 9, 2012.

JAMIESON, D. Ética e meio ambiente: uma introdução. Tradução de André Luiz de Alvarenga. São Paulo: SENAC, 2010.

JAX, K. Ecosystem functioning. Cambridge: Cambridge University Press, 2010.

JAX, K. Function and "functioning" in ecology: what does it mean? Oikos, Oxford, v. 111, n. 3, p. 641-648, 2005.

JAX, K. et al. Ecosystem services and ethics. Ecological Economics, Amsterdam, v. 93, p. 260-268, 2013.

LARRERE C. Two philosophies of the environmental crises. In: BERGANDI, D. The structural links between ecology, evolution and ethics: the virtuous epistemic circle. Dordrecht: Springer, 2013. p. 141-149.

LIGHT, A.; ROLSTON III, H. Environmental ethics: an anthology. Oxford: WileyBlackwell, 2003.

MCCAULEY, D. J. Selling out on nature, Nature, London, v. 443, n. 7, p. 27-28, Sept. 2006.

MEKONNEN, M. M.; HOEKSTRA, A. Y. National water footprint accounts: the green, blue and grey water footprint of production and consumption. Delft: UNESCO, 2011. (Value of Water Research Report Series, n. 50).

MILLENNIUM ECOSYSTEM ASSESSMENT. Ecosystems and human well-being: desertification synthesis. Washington: World Resources Institute, 2005.

NORTON, B. Environmental ethics and weak anthropocentrism. Environmental Ethics, Denton, v. 6, n. 2, p. 131-148, 1984.

NORTON, B. Searching for sustainability: interdisciplinary essays in the philosophy of conservation biology. Cambridge: Cambridge University Press, 2003.

NORTON, B. Facts, values, and analogies: a Darwinian approach to environmental choice. In: BERGANDI, D. The structural links between ecology evolution and ethics: the virtuous epistemic circle. Dordrecht: Springer, 2013. p. 63-82. 
NUNES-NETO, N. F. The environmental crisis as a good case for an intellectual and practical integration between philosophy and science. Science \& Education, Dordrecht, p. 1285-1299, 2015.

NUNES-NETO, N. F. O discurso funcional na ecologia contemporânea. 2013. 95 f. Tese (Doutorado em Ecologia e Biomonitoramento) - Universidade Federal da Bahia, Salvador, 2013.

NUNES-NETO, N. F.; CARMO, R. S.; EL-HANI, C. N. O conceito de função na ecologia contemporânea. Revista de Filosofia Aurora, Curitiba, v. 25, n. 36, p. 43-73, 2013.

NUNES-NETO, N.; MORENO, A; EL-HANI, C. Function in ecology: an organizational approach. Biology and Philosophy, Dordrecht, v. 29, n. 1, p. 123-141, 2014.

NUNES-NETO, N.; CARMO, R.; EL-HANI, C. Biodiversity and ecosystem functioning: an analysis of the functional discourse in contemporary ecology. Filosofia e História da Biologia, São Paulo, v. 11, n. 2, p. 289-321, 2016.

PEDRETTI, E.; NAZIR, J. Currents in STSE Education: Mapping a Complex Field, 40 Years On, Science Education, Salem, v. 95, n. 4, p. 601-626, 2011.

REGAN, T. Empty cages: Facing the challenge of animal rights. Oxford: Rowman \& Littlefield Publishers. 2003.

REGAN, T. Animal Rights and Environmental Ethics. In: BERGANDI, D. (Ed.). The structural links between ecology, evolution and ethics: the virtuous epistemic circle. Dordrecht: Springer, 2013. p. 117-126.

SANTOS, J.; CONRADO, D. M.; NUNES-NETO, N. F. Ética ambiental a partir de questões sociocientíficas no ensino fundamental. In: ENCONTRO REGIONAL DE ENSINO DE BIOLOGIA DO NORDESTE, 6., 2015. Vitória da Conquista. Anais... Vitória da Conquista: Universidade Estadual do Sudoeste da Bahia. 2015. p. 1-10.

SANTOS, J.; CONRADO, D. M.; NUNES-NETO, N. F. Questões sociocientíficas no ensino fundamental de ciências: uma experiência com poluição de águas. Indagatio Didactica, Aveiro, v. 8, n. 1, p. 1051-1067, 2016.

SANTOS, W. L. P. dos; MORTIMER, E. F. Tomada de decisão para ação social responsável no ensino de ciências. Ciência e Educação, Bauru, v. 7, n. 1, p. 95-111, 2001. SILVA, J. M. da. Ética prática: contributos para as políticas da água. Lisboa: Sociedade de Ética Ambiental: Apenas Livros, 2009.

SINGER, P. Ética prática. 3. ed. São Paulo: Martin Fontes, 2002.

SINGER, P. Libertação Animal. Porto Alegre: Lugano, 2010.

TAYLOR, P. Respect for nature. Environmental Ethics, Denton, v. 3, n. 3, p. 197-218, 1981. 
TEIXEIRA, P. M. M. Educação científica e movimento C.T.S. no quadro das tendências pedagógicas no Brasil. Revista Brasileira de Pesquisa em Educação em Ciências, Porto Alegre, v. 3, n. 1, p. 88-102, 2003.

TELES, M. O valor moral da natureza: reflexões a partir da teoria axiológica de Tom Regan. Lisboa: Sociedade de Ética Ambiental: Apenas Livros, 2007. (Breviário de Ética Ambiental, n. 5).

VAZ, S. G.; DELFINO, A. Manual de ética ambiental. Lisboa: Universidade Aberta, 2010.

VICTORINO, C. J. A. Planeta água morrendo de sede: uma visão analítica na metodologia do uso e abuso dos recursos hídricos. Porto Alegre: EDIPUCRS, 2007.

WORLD WIDE FOUND FOR NATURE - WWF. Living Planet Report 2014: Summary. Gland, 2014.

ZABALA, A. A prática educativa: como ensinar. Porto Alegre: Artes Médicas Sul, 1998.

ZABALA, A.; ARNAU, L. Como aprender e ensinar competências. Porto Alegre: Artmed, 2010.

ZEIDLER, D. L. et al. Beyond STS: a research-based framework for socioscientific issues education. Science Education, Salem, v. 89, n. 3, p. 357-377, 2005. 


\title{
DOENÇA DE CHAGAS A PARTIR DE QUESTÕES SOCIOCIENTIIFICAS NA EDUCAÇÃO EM SAÚDE
}

\author{
Liziane Martins \\ Grégory Alves Dionor \\ Lucas Vinícius Ferraz \\ Helaine Silva Souza
}

\section{Introdução}

A Educação em Saúde (ES) surge da interlocução das pesquisas nos campos da saúde e da educação e vem despertando o interesse de muitos pesquisadores - Catalán, Sala e Beguer (1993), Daigle, Hebert e Humphries (2007) e Carvalho e colaboradores (2007, 2008, 2009, 2011). No Brasil, a ES é um direito que deve ser fornecido aos educandos pelo Estado. (BRASIL, 1996) Assim, tendo em vista a sua grande importância de contribuir para o bem público, ela deve ser tratada não como uma mera transmissão de informações, mas como ferramenta capaz de contribuir para empoderar os alunos para agirem de forma ativa na transformação da saúde daquelas esferas que lhes são acessíveis. (CARVALHO et al., 2008; DIONOR; FERREIRA; MARTINS, 2013) Este empoderamento possibilita aos discentes refletir sobre a realidade social na qual estão inseridos, percebendo os reflexos ambientais de suas decisões e como tais fatores podem influenciar não só sua própria saúde, mas de todo o coletivo. Isso porque, 
ao nosso ver, o empoderamento consiste em capacitar os indivíduos para a tomada de decisão consciente e justificada e esta ação possui estreita relação com ES, viabilizando a promoção de saúde na perspectiva socioecológica. (DIONOR; FERREIRA; MARTINS, 2013)

Apesar de tal importância, não é uma tarefa fácil a inclusão da ES na escola. Isso ocorre, em parte, porque há modos diferentes de entender o processo de saúde e doença, o que conduz a questões de natureza teórica e epistemológica (em medicina, ciências da saúde e filosofia da medicina). Assim, emerge a necessidade, primeiramente, de compreender que os processos educacionais relacionados à saúde devem considerar, de um modo ainda bastante geral, a existência de duas abordagens de saúde: a biomédica e a socioecológica. (CARVALHO et al., 2007; FERREIRA et al., 2014; WESTPHAL, 2006) Enquanto a primeira corresponde a ações que visam prevenir doenças e curar indivíduos doentes, utilizando estratégias que são, sobretudo, informativas e preocupando-se especialmente por fornecer, sem sensibilização dos indivíduos, prescrições sobre o que se deve (ou não) fazer para prevenir ou tratar doenças, a segunda, por sua vez, visa alcançar resultados de natureza coletiva, e não apenas individuais. (DIONOR; FERREIRA; MARTINS, 2014a)

$\mathrm{Na}$ abordagem socioecológica - a qual adotamos neste trabalho - pretendemos empoderar os indivíduos para que eles sejam agentes ativos de transformação não só de sua própria saúde, mas de todo o contexto ecológico e sociopolítico em que estão inseridos. Além disso, a abordagem socioecológica, por ter uma abrangência maior, permite com que se tracem interconexões entre saúde e certas abordagens teóricas em educação, como o campo da História e Filosofia da Ciência (HFC) e das relações entre Ciência, Tecnologia, Sociedade e Ambiente (CTSA). Assim, destacaremos, a seguir, as contribuições das abordagens HFC e CTSA, conjuntamente, para a ES.

A ausência de discussões históricas e filosóficas no ensino de ciências gera equívocos que repercutem diretamente na compreensão dos conteúdos científicos, pelos alunos. Assim, converge para o argumento a favor da contextualização histórico-filosófica dos conteúdos no ensino de ciências, o fato de que a HFC pode tornar as aulas de ciências mais desafiadoras e reflexivas, permitindo o desenvolvimento de um pensamento científico mais crítico, mais humanizado e com maior consideração de questões éticas. (MATTHEWS, 1995)

Desta maneira, percebe-se que a HFC pode servir como norteadora do processo de empoderamento dos indivíduos, ou seja, pode dar condições para que eles próprios tenham a capacidade de ponderar acerca de suas decisões e as consequências delas, baseando-se em argumentos melhor justificados. Assim, isso pode contribuir para que existam implicações do conhecimento teórico na prática cotidiana dos alunos (ATAÍDE; SILVA, 2011), na medida em que, pelo próprio empoderamento em HFC, eles terão condições de realizar escolhas conscientes e justificadas. 
Além disso, as atuais emergências sociais promovidas pela globalização, associadas ao contexto de formação cidadã e do desenvolvimento do ensino de ciências, desencadearam novas demandas para os processos de ensino e aprendizagem a partir da década de 1970. Nessa época, o movimento Ciência, Tecnologia e Sociedade (CTS) expande-se para o espaço do ensino de ciências (SANTOS; MORTIMER, 2002) e, em seguida, viria a ser complementado pela consideração do ambiente, compondo a abordagem CTSA na educação científica. (RICARDO, 2007)

Estas perspectivas, HFC e CTSA, nos processos de ensino e de aprendizagem de ciências, visam promover diálogos entre conteúdos científicos e a relação destes com o contexto social no qual os indivíduos estão inseridos, o que permite incluir nas aulas de ciências conteúdos de história, epistemologia e ética, por exemplo, relacionados aos conteúdos científicos. Assim, espera-se que o aluno possa desenvolver a capacidade de observar, a partir de várias ópticas, determinados contextos e situações, como os relativos à sua saúde e a de sua comunidade, analisando-os criticamente. Isto proporciona ao estudante a capacidade, inclusive, de perceber qual seu papel diante daquele cenário e como ele mesmo pode ser ali um agente transformador.

Entretanto, a conexão entre HFC e CTSA precisa encontrar bases mais concretas para sua efetiva implementação em sala de aula. (MARTINS et al., 2015) Tais bases podem ser adequadamente reconhecidas nas Questões Sociocientíficas (QSC).

As QSC podem viabilizar a inclusão de uma educação em saúde numa perspectiva socioecológica, visto que elas - as QSC - objetivam desenvolver a capacidade crítica dos educandos para que, dessa maneira, eles sejam capazes de tomar decisões responsáveis e engajadas acerca de determinadas questões sociais e ambientais urgentes (CASTRO et al., 2014; CONRADO; EL-HANI; NUNES-NETO, 2013), como as relativas à saúde. Sendo assim, os objetivos das QSC se assemelham aos de uma abordagem mais abrangente de saúde na busca pelo empoderamento dos alunos.

Assim, como as QSC ainda são pouco encontradas na ES (LEE, 2012), sobretudo como forma de promover uma formação mais ampla de cidadãos, este trabalho objetiva discutir a ES, numa abordagem socioecológica, a partir das perspectivas HFC e CTSA, por meio do uso de uma QSC sobre o tema Doença de Chagas, em uma Sequência Didática (SD) para o ensino médio. Por fim, cabe ressaltar que a escolha do tema se deu por ser esta uma temática presente não só nas salas de aula, mas, historicamente, estar presente no cotidiano de diversas comunidades que foram e ainda são acometidas por doenças tropicais.

\section{Doença de Chagas numa perspectiva abrangente}

Ao discutirmos as doenças tropicais nas aulas de ciências, é comum a apresentação de um discurso meramente biológico, enfatizando as formas evolutivas dos microrganismos, modos de transmissão das doenças e tecnologias necessárias para o seu tra- 
tamento. (MARTINS, 2010; MARTINS; SANTOS; EL-HANI, 2012) Algumas vezes, as discussões são sobre a importância do desenvolvimento de novas tecnologias para a fabricação de medicamentos e a busca da cura dessas doenças. (SANTOS; MEIRELES, 2013) Entretanto, apesar de haver ampla distribuição de medicamentos para verminoses, por exemplo, e o seu custo ser relativamente baixo, o problema não é resolvido, como podemos notar nos dados fornecidos pela World Health Organization (WHO) (PAHO; WHO, 2014), sobre a prevalência e a morbidade de doenças tropicais na região das Américas. Isso ocorre porque muitas doenças (parasitárias), por exemplo, envolvem tanto questões biológicas, quanto sociais, culturais e econômicas (DIONOR; FERREIRA; MARTINS, 2014b; MARTINS et al., 2014), como, por exemplo, a distribuição de renda ou os interesses e impacto da indústria farmacêutica. Não é suficiente conhecer causas e formas de tratamento de uma doença parasitária, quando se desconhecem os impactos das questões sanitárias e do desrespeito às culturas e aos saberes construídos ao longo da história de determinada comunidade, na propagação das doenças; as consequências da exclusão social, da miséria, da pobreza na manutenção e/ou na restauração da saúde; as implicações advindas do não acesso universal às práticas mercantis e rotineiras envolvidas no processo de saúde e doença etc. Trata-se, portanto, de valorizar uma ES que enfatize a importância dos fenômenos sociais na discussão dos fenômenos biológicos.

A seguir, consideraremos tais questões na abordagem de uma doença parasitária específica, a Doença de Chagas. Essa parasitose tropical, também chamada de tripanossomíase americana, é causada pelo protozoário Trypanosoma cruzi, que fica alojado no intestino do inseto da família Triatominae, conhecido popularmente como barbeiro. Quando o ser humano é contaminado pelas fezes do barbeiro portador do protozoário, nos primeiros anos da doença, pode não apresentar sintomas, sendo que, entre quatro a dez dias, a pessoa apenas manifesta febre, falta de apetite, mal-estar e uma leve inflamação no local da picada. Posteriormente, na fase crônica, com o coração muito comprometido, há a lesão do miocárdio e, de forma menos acentuada, do pericárdio, do endocárdio e das arteríolas coronárias. Ademais, pode haver manifestações clínicas como falta de ar, tonturas, inchaço das pernas e taquicardia. (ARGOLO et al., 2008)

O protozoário foi encontrado primeiramente no barbeiro - inseto hematófago após os estudos incessantes de Carlos Ribeiro Justiniano Chagas, um bacteriologista e médico sanitarista brasileiro, no período entre 1907 e 1909, que investigava formas de combate à malária em Minas Gerais, onde estava sendo construída a Estrada de Ferro Central do Brasil. (LANA; TAFURI, 2010) Isso porque estudos estavam sendo desenvolvidos para compreender os surtos endêmicos da malária nos locais desmatados para se construir as ferrovias que integrariam os territórios e promoveriam a expansão econômica da sociedade. (BENCHIMOL; SILVA, 2008) 
Essa parasitose pode ser transmitida ao homem pelas vias: vetorial (mais comum), transfusional (quando há uma deficiência no controle sanitário de hemoderivados e hemocomponentes), congênita (pela placenta, de mãe para filho), acidental (em laboratórios), oral (com ingestão de alimentos contaminados) e por transplantes (pela deficiência na avaliação dos órgãos e tecidos transplantados de doadores infectados). (AGÊNCIA NACIONAL DE VIGILÂNCIA SANITÁRIA, 2008)

A via vetorial tem se propagado devido ao desmatamento das florestas e também à precarização de saneamento básico nas comunidades, modificando o habitat de muitas espécies selvagens. Além disso, a distribuição desigual de renda também contribui para isso, pois promove um aumento da população de vetores em decorrência das instalações precárias de muitas famílias. Assim, o barbeiro, ao ser ameaçado, abriga-se em cafuas, galinheiros e chiqueiros. Ao mesmo tempo, com a destruição da fauna e da flora, tem ocorrido a interiorização, segundo Lana e Tafuri (2010), com a construção de habitações precárias de barro por indivíduos de baixa renda ou por fazendeiros, para seus funcionários. Desse modo, com alimento fácil (devido à presença dos moradores) e ambiente protegido (frestas do barro ressecado das casas), tem ocorrido a procriação exponencial dos barbeiros. Portanto, como medida profilática, é essencial melhorar as habitações rurais, principalmente para a população mais pobre. (BRASIL, 2004)

Já a transmissão por via oral é bastante comum no norte do país, principalmente na região amazônica, onde há contaminação frequente do açaí por barbeiros e pelos seus dejetos. (AGÊNCIA NACIONAL DE VIGILÂNCIA SANITÁRIA, 2007) Ainda há, na literatura, também casos de contaminação, pelo barbeiro, nos cultivos de cana-de-açúcar, na região Sul e Sudeste, provocando surtos na população que consumia o caldo de cana. (AGÊNCIA NACIONAL DE VIGILÂNCIA SANITÁRIA, 2008) Este fato evidencia a importância da vigilância sanitária no controle e no uso destes alimentos.

Diante disso, percebemos que não basta conhecer as formas de transmissão da doença para que a população fique protegida. É preciso entender as causas que favoreceram a emergência da Doença de Chagas e os contextos sociais e históricos que propiciam a disseminação e a manutenção dessa condição nos dias atuais.

Frente a isso, podemos afirmar que, quando os conteúdos são trabalhados numa perspectiva de HFC e CTSA, por exemplo, na qual aspectos mais amplos, como: sociais (discussão da relação estreita entre desigualdade econômica, distribuição de renda e acesso igualitário à educação e aos serviços médico-hospitalares com a Doença de Chagas), tecnológicos (padronização das práticas de saúde, novas pesquisas para o controle desta parasitose, surgimento de fármacos), ambientais (controle dos vetores, manutenção da fauna e flora das florestas), entre outros, também são levados em consideração. Desse modo, a ES torna-se mais significativa, capaz de empoderar os alunos para serem agentes ativos na mudança do panorama atual da Doença de Chagas. 


\section{Sequência didática para a abordagem da Doença de Chagas, com o uso de QSC}

A seguir, propomos uma SD aplicável ao ensino médio e que pode mobilizar conteúdos de diversas áreas, como: educação, saúde, biologia, sociologia, geografia, história, filosofia e matemática, pois as discussões sobre Doença de Chagas suscitam reflexões sobre diversas questões, como: epidemiológicas e socioeconômicas, como o papel das desigualdades socioeconômicas na incidência da doença (sociologia); distribuição espacial da doença em áreas rurais periféricas e nos diversos países, incluindo o efeito de migrações (geografia); a história da ciência e dos personagens associados à descoberta e caracterização da doença, como o impacto dos conhecimentos produzidos por Carlos Chagas, Osvaldo Cruz, Adolfo Lutz etc. na sociedade (história); os conceitos de saúde e doença, função e malfunção, assim como questões éticas da prática médica (filosofia); aspectos médico-hospitalares e farmacológicos (saúde); aspectos ambientais e anatômico-fisiológicos das doenças (biologia); modelagem matemática para a compreensão da dinâmica de disseminação da doença nos indivíduos e o comportamento da população do vetor (matemática); educação popular e educação no campo (educação).

Apesar da relevância desses múltiplos olhares, este trabalho se restringe a duas das áreas mencionadas acima: saúde e biologia. Para tanto, estabelecemos alguns objetivos de aprendizagem para esta SD, categorizando-os em conceituais, procedimentais e atitudinais. (ZABALA, 1998; ZABALA; ARNAU, 2010)

\section{Conceituais}

- Discutir dados numéricos da incidência e da prevalência da doença no mundo;

- Reconhecer a influência histórica e ambiental no surgimento e na disseminação da doença;

- Caracterizar a Doença de Chagas, para identificar os sinais e sintomas e as características anatômicas e fisiológicas relacionadas à patologia, bem como formas de tratamento e controle da doença;

- Compreender a abordagem socioecológica da saúde e seus princípios teóricos, por meio da percepção da variedade de condicionantes que influenciam a saúde individual e coletiva;

- Compreender, a partir de conceitos e princípios teóricos da ecologia, como fatores ecológicos influenciam a saúde individual e coletiva.

\section{Procedimentais}

- Levantar bibliografia que aborda a temática Doença de Chagas; 
- Traçar um perfil dos indivíduos e regiões que são acometidos pela Doença de Chagas;

- Comparar índices de desmatamento com incidência da doença no Brasil;

- Analisar a influência do contexto sociocultural para a manutenção de práticas de prevenção de doenças parasitárias;

- Avaliar dados epidemiológicos, a partir da análise de gráficos, para discutir se há (ou não) um controle da doença atualmente;

- Listar ações colaborativas para reduzir o risco de contaminação e disseminação da doença.

\section{Atitudinais}

- Sensibilizar-se sobre a importância de preservar/conservar o meio ambiente, de modo a reduzir ao máximo as alterações dos ciclos biológicos dos animais, principalmente, silvestres;

- Refletir sobre as causas da falta de investimento no campo, as consequências do êxodo rural e o valor do meio rural para a sobrevivência do meio urbano, de modo a promover ações para auxiliar essa população desatendida a se prevenir contra a Doença de Chagas;

- Discutir criticamente os valores subjacentes à prática científica, às práticas dos profissionais de saúde e da indústria farmacêutica, com ênfase sobre tecnociência, neutralidade científica e salvacionismo tecnológico;

- Conhecer e avaliar criticamente as legislações relacionadas com o tema (ver, por exemplo, Lei $n^{\circ} 8.080 / 1990$, que dispõe sobre as condições para a promoção, a proteção e a recuperação da saúde etc.; Lei $n^{\circ}$ 9.605/1998, que trata sobre as sanções penais e administrativas derivadas de condutas e atividades lesivas ao meio ambiente; Lei $\mathrm{n}^{\circ} 12.651 / 2012$, que estabelece normas gerais sobre a proteção da vegetação, a exploração florestal etc.);

- Empoderar-se para exigir o controle sanitário adequado, tanto no preparo como no armazenamento de alimentos, assim como na análise criteriosa dos hemoderivados usados em transfusões sanguíneas, quando for o caso.

A fim de alcançar os objetivos pretendidos, apresentamos, no Quadro 1, uma QSC, em formato de caso, para potencializar as discussões sobre a Doença de Chagas. 
Quadro 1 - Caso sobre Doença de Chagas

\section{Chagas: uma doença de diversas causas}

Minha tia Helena, que hoje mora comigo, está em tratamento médico para a Doença de Chagas e em recuperação de uma recente cirurgia no esôfago. Eu presencio diariamente a luta dela e, pensando na situação, lembro que minha tia foi criada no interior da Bahia, em uma zona rural. Naquela época, as casas eram feitas de taipa e pouco concreto, e o desmatamento na região era outro fator presente...

Eu me lembro bem dos relatos da tia Helena sobre as condições em que vivia na "roça", na qual as adversidades encontradas no dia a dia, a exemplo da deficitária rede de esgoto e ausência de energia elétrica, aconteciam, principalmente, na época de estiagem prolongada, quando a colheita diminuía e os recursos também. Apesar destas dificuldades, ocorriam, às vezes, visitas de agentes de saúde para promoverem a vermifugação e a pesagem das crianças.

Nesta região, não existia escola próxima e o acesso à educação era precário para os moradores. Diante das condições relatadas, da redução de oferta de trabalho, do desmatamento e de uma promessa por uma vida mais digna na cidade, houve aumento da migração para os grandes centros urbanos, principalmente pela nova geração, que ansiava por acesso à educação e ao emprego. Tia Helena saiu do interior e foi para Salvador, estabelecendo-se no subúrbio ferroviário por volta de 1980.

Depois desta mudança para a capital, contudo, a situação dela piorou ainda mais, pois, além de não ter qualidade de vida e não ter como plantar seu alimento, vivia com muita poluição, sem acesso a saneamento, moradia digna e trabalho. Agrega-se a isto o fato de que as condições de estresse (violência, medo, trânsito etc.), somadas a uma alimentação não saudável e uma vida em que o lazer é a televisão, fragilizaram o sistema imunológico dela, aumentando a probabilidade de manifestar várias doenças.

Ademais, o sistema de saúde público de uma capital tende a ser precário pela maior demanda, levando a uma piora no atendimento e recuperação do indivíduo doente. Em consequência, ela começou a sentir-se mal constantemente e a situação piorou de forma significativa, a partir de 2002. Após alguns exames, a Doença de Chagas foi confirmada, juntamente com a informação de que o seu estado estava avançado, com o comprometimento de vários órgãos. Atualmente, ela está se recuperando da cirurgia de dilatação do esôfago, numa tentativa de driblar a desnutrição, além da companhia de inúmeros medicamentos para o controle dos sinais e sintomas que se agravam, diariamente, roubando-lhe a oportunidade de uma vida plena aos 50 anos de idade.

Não contente com a situação atual de minha tia, resolvi estudar a doença de modo mais aprofundado e, por isso, encaminho esse relato a vocês, amigos, para que possamos pensar e pesquisar nas seguintes questões:

Fonte: elaborado pelos autores.

Questões do caso relacionadas à QSC:

Q1. Com tanto desenvolvimento científico, por que a Doença de Chagas ainda não tem cura e os efeitos e a toxicidade do seu tratamento promovem tanto sofrimento a estas pessoas?

Q2. Qual a origem da doença? Será genética ou resultante de alguma malformação biológica da minha tia?

Q3. Sabendo que a doença tem manifestações agudas (de alguns dias até semanas) ou tardias (após décadas), como a mudança de minha tia para o subúr- 
bio de Salvador, a cerca de 20 anos atrás, influenciou o desenvolvimento da doença?

Q4. Será que as ações do homem na natureza influenciaram de alguma forma a propagação desta doença, visto que, assim como minha tia Helena, temos vários conhecidos na mesma situação?

Q5. O que podemos fazer para ajudar minha tia nesta luta? E como contribuir com o controle desta doença, de modo a não termos mais infectados?

Q6. Quais ações sociais podem ser implementadas, para prevenir essa doença e que estão ao nosso alcance, enquanto estudantes?

A seguir, discutimos uma forma de aplicar esta QSC no ensino médio de biologia, a partir de elementos da SD e do uso do modelo de argumentação de Toulmin (2006). Vale destacar que as SD são entendidas como conjuntos de atividades sistematizadas, organizadas e planejadas de modo a auxiliar os processos de ensino e de aprendizagem (DOLZ; NOVERRAZ; SCHNEUWLY, 2004), por meio de ferramentas variadas, como diálogos, discussões, resoluções de problemas, atividades de argumentação etc.

Desta forma, de modo geral, propomos seis encontros assim organizados:

- discussão da ES numa perspectiva socioecológica, a partir da contextualização do tema da QSC e com a identificação dos condicionantes de saúde presentes na história de tia Helena;

- discussão do enunciado da QSC (caso de tia Helena) e das suas questões norteadoras;

- aplicação do modelo de argumentação de Toulmin, para socializar informações sobre a Doença de Chagas;

- socializações dos argumentos construídos;

- proposição de ações viáveis para solucionar problemas relacionados às doenças parasitárias; e

- síntese e socialização dos resultados encontrados na resolução do caso (QSC) e para a avaliação final das atividades da SD.

Detalhamos, a seguir, características de cada encontro que poderão orientar a prática do docente. Também sugerimos estratégias que poderão ser utilizadas em conjunto com a QSC, justificando e fundamentando-as como formas de promover uma melhor compreensão das diferentes dimensões envolvidas no processo de saúde e doença, bem como para viabilizar uma abordagem socioecológica da Doença de Chagas nesta SD. 


\section{ENCONTRO: 2 horas/aula}

- Identificação de conhecimentos prévios sobre "condicionantes de saúde", a partir de questionamentos sobre saúde, doença, qualidade de vida, saúde individual, coletiva e ambiental. O professor pode anotar no quadro as principais ideias dos estudantes;

- Explanação sobre a abordagem socioecológica de saúde em aula expositiva-dialogada, mostrando a abrangência dos condicionantes de saúde, segundo essa perspectiva, a saber: condicionantes ambientais, religiosos, sociais, culturais, políticos, psicológicos, entre outros. Isso significa que, para essa abordagem, a saúde é o resultado da melhoria das condições sociais e ambientais que afetam a saúde individual e coletiva. Em contrapartida, no modelo biomédico de saúde, os condicionantes de saúde são aqueles relacionados ao uso de medicamentos e tratamentos médicos e hospitalares para o controle ou a supressão de doenças;

- Apresentação e discussão dos seguintes questionamentos: "Que pontos devem ser considerados ao tratarmos de uma doença parasitária específica, a exemplo da Doença de Chagas? Que conhecimentos são relevantes sobre o tema?”;

- Leitura do caso (QSC) “Chagas: uma doença de diversas causas”, de modo individual ou em conjunto com a turma, com discussões iniciais sobre as questões do caso;

- Identificação dos condicionantes de saúde/doença apresentados no caso. O professor deve nortear os alunos durante esse processo e poderá escrever os principais pontos apresentados por eles no quadro ou inserir questões como: quais os fatores e condicionantes envolvidos na situação que afetaram a saúde de tia Helena?;

- Solicitação de pesquisa em livros/revista/internet sobre "Doença de Chagas". O professor deve esclarecer que é para buscar dados/informações ligados especificamente a essa temática. Essa pesquisa é uma oportunidade para os alunos aprimorarem as respostas dadas às perguntas acima realizadas. A pesquisa deverá ser feita em casa.

\section{ENCONTRO: 2 horas/aula}

- Socialização e discussão da pesquisa solicitada no encontro anterior, podendo ser anotado no quadro os principais pontos encontrados na pesquisa dos alunos;

- Exibição do vídeo “Doença de Chagas”. (FIOCRUZ, 2012) Explique que é preciso que se atentem aos dados epidemiológicos e geográficos no que diz respeito à Doença de Chagas, apresentados no vídeo, pois, juntamente com a pesquisa, terão condições de realizar a atividade seguinte;

- Releitura do caso "Chagas: uma doença de diversas causas", de modo individual ou em conjunto com a turma, com reflexões sobre as questões do caso, considerando informações do vídeo e da pesquisa realizada em casa; 
- Discussão do caso a partir das questões norteadoras apresentadas abaixo e com base em informações do vídeo. O professor deve, neste momento, mediar a discussão, dadas as possíveis divergências entre os pontos de vistas dos alunos sobre a temática:

- Cronologicamente, como você identifica, no texto, elementos que enquadrem a Doença de Chagas na fase aguda e na crônica?

- Tendo em vista a terapêutica parcialmente ineficaz e a inexistência de cura da tripanossomíase americana, pela ciência, o que pode ser realizado nesta comunidade que, atualmente, ainda vive com esta endemia no seu cotidiano?

- De acordo com Lana e Tafuri (2010), 300 mil novos casos por ano são identificados no mundo e há cerca de 6 milhões de habitantes infectados no Brasil. A maioria dos infectados é por via vetorial e concentra-se na região Norte e Nordeste do país. Por que há predominância nestas regiões? No entanto, há dados mostrando uma crescente incidência nas regiões Sul e Sudeste. O que pode justificar o desenvolvimento da Doença de Chagas nestas regiões?

- Observe o mapa abaixo (Figura 1) sobre a distribuição do grau de risco para a contaminação por barbeiros nos municípios da Bahia e justifique por que há alto risco nas regiões mais escuras?

Figura 1 - Distribuição do grau de risco para Doença de Chagas no estado da Bahia

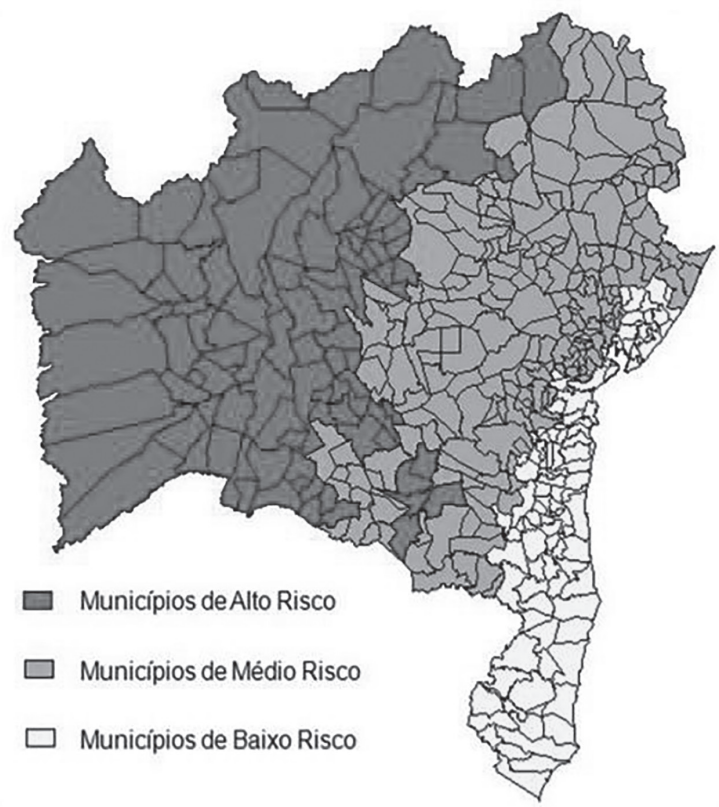

Fonte: Bahia (2013). 


\section{ENCONTRO: 2 horas/aula}

- Revisão dos pontos de discussão do encontro anterior;

- Apresentação de atividade de argumentação sobre a temática "Doença de Chagas" utilizando o modelo de Toulmin. (NUNES; ALMOULOUD, 2013; RELVAS; ANTUNES, 2006) O professor pode apresentar alguns aspectos básicos da argumentação para que, de modo didático, fique evidente aos alunos a importância de construir argumentos sólidos;

- Explanação sobre como argumentar, a partir de aula expositiva. Durante esta etapa, deve ser apresentado o modelo de Toulmin (2006) como ferramenta para análise e elaboração de argumentos (O que é? Para que serve? Como usar?);

- Identificação das partes componentes do modelo de Toulmin, a partir de um exemplo, para verificar se houve a apropriação, por parte dos alunos, deste modelo de argumento. Pode ser solicitado aos alunos que identifiquem, no caso, os componentes do modelo de Toulmin estudados em sala.

\section{ENCONTRO: 2 horas/aula}

- Continuação do desenvolvimento da atividade (argumentação) iniciada no encontro anterior;

- Socialização e discussão da atividade realizada;

- Discussão e resolução das seguintes questões:

- Que dados estatísticos e epidemiológicos podem favorecer a compreensão da Doença de Chagas na Bahia?

- Quais ações podemos implementar no nosso dia a dia para reduzir o risco de disseminação da Doença de Chagas?

- Que ações podemos sugerir no cotidiano dos habitantes do meio rural para reduzir a contaminação pelo barbeiro?

- Qual a relação entre a redução das espécies nativas provocadas pelo desmatamento e o aumento do vetor (o barbeiro)?

- Quais os principais fatores que influenciam o desmatamento no Brasil?

- Como as demandas de consumo por bens e serviços, nos centros urbanos, podem reforçar e manter práticas que aumentam a degradação ambiental, principalmente nas áreas rurais?

\section{ENCONTRO: 2 horas/aula}

- Releitura do caso "Chagas: uma doença de diversas causas". Pedir aos alunos que identifiquem, a partir do caso, a influência do contexto sociocultural envolvido no processo de prevenção e tratamento da doença parasitária. Solicitar 
que os alunos, individualmente ou em grupos, respondam aos questionamentos do caso;

- Diante das indagações apresentadas no caso, dividir a sala em dois grandes grupos para um debate, no qual:

- Um grupo defenderá a importância de se permanecer no meio rural, buscando uma convivência harmoniosa com os sistemas ecológicos e solidária entre os habitantes da região, com distribuição igualitária de renda e acesso comum a todos da comunidade às práticas de saúde, de modo a controlar e prevenir a Doença de Chagas.

- O outro irá defender a importância de aumentar a urbanização do meio rural como forma de contribuir efetivamente para a prevenção e o controle da Doença de Chagas, com incentivos para se levar ao campo tecnologias e investimentos em infraestrutura e industrialização, aumentando, assim, a qualidade de vida.

- Proposição - pelos alunos - de ações sociopolíticas, voltadas à Doenças de Chagas, viáveis para a sua comunidade. Um dos grupos deverá elaborar cartazes divulgando essas ações e atribuindo as responsabilidades para as esferas envolvidas (indivíduo, comunidade, governo) perante tal situação. O outro grupo confeccionará panfletos para serem entregues em uma passeata a ser organizada pela turma.

\section{ENCONTRO: 2 horas/aula}

- Socialização, discussão e síntese das soluções encontradas para os questionamentos no caso "Chagas: uma doença de diversas causas";

- Socialização, discussão e síntese dos resultados do debate dos dois grupos a respeito de ações no meio rural para prevenir e controlar a Doença de Chagas;

- Exposição de cartazes e panfletos elaborados pelos grupos e organização de cronograma para divulgar na comunidade local os conhecimentos, habilidades e valores desenvolvidos durante as atividades;

- Avaliação da SD pelos estudantes, autoavaliação e avaliação mútua.

\section{Avaliação}

Em todas as aulas, recomendamos avaliar a participação dos estudantes durante as discussões, a partir de critérios como: coerência do argumento apresentado com a temática tratada; capacidade de estabelecer conexões entre o caso e o vídeo utilizados; identificação dos reflexos da situação apresentada e sua própria realidade; participação dos estudantes em todas as atividades, sempre levando em consideração o alcance individual e coletivo dos objetivos de aprendizagem conceituais, procedimentais e atitudinais. 


\section{Considerações finais}

A partir das discussões levantadas, podemos perceber que é importante que se trate a ES numa perspectiva socioecológica, considerando, assim, aspectos socioeconômicos, ambientais, culturais, educacionais e políticos da saúde, seja individual ou coletivamente. Para isso, conta-se com contribuições das perspectivas HFC e da educação CTSA, que podem auxiliar na inclusão de questões sociais e ambientais, como a Doença de Chagas. Isso é possível, por exemplo, por meio de várias estratégias de ensino, como as encontradas na SD apresentada.

Essa SD pode ser aplicada a todas as modalidades de ensino, desde que adequações sejam realizadas pelo professor, de acordo com o perfil do seu público e objetivos de ensino e aprendizagem. Por exemplo, tal SD poderia ser adaptada para o ensino superior em cursos como biologia, ciências naturais, geografia, medicina, entre outros.

Outra sugestão é utilizar, como estratégia complementar, a construção de jogos e cenários para o levantamento dos conhecimentos, habilidades e valores prévios dos alunos, a partir da discussão dos elementos que compõem as abordagens biomédica (exemplo: asfalto; instituições; autoridade médica; controle de animais; indústria farmacêutica; natureza como fonte de recursos e depósito de resíduos) e socioecológica (exemplo: parque com plantas, pássaros, cães, insetos, pessoas fazendo exercício físico; feira de produtos orgânicos; locais de compostagem e preservação ambiental). A partir desse levantamento, os alunos poderiam construir, com a orientação do professor, um ou mais jogos, como, por exemplo, um quebra-cabeça, e apresentar esse jogo à comunidade do bairro ou a turmas de alunos do ensino fundamental, numa atividade extraclasse.

Essas ações podem, além de estimular a criatividade, o trabalho coletivo e o raciocínio crítico, colocar os estudantes na posição de agentes capazes de melhorar a consciência, a sensibilização e a informação de outros integrantes da comunidade, como pais, outros professores e jovens.

\section{Referências}

AGÊNCIA NACIONAL DE VIGILÂNCIA SANITÁRIA (Brasil). Nota técnica Doença de Chagas Aguda por transmissão oral. Brasília, DF, 2007. Disponível em: <http://www. anvisa.gov.br/divulga/noticias/2005/240305_nota.pdf>. Acesso em: 28 out. 2014.

AGÊNCIA NACIONAL DE VIGILÂNCIA SANITÁRIA (Brasil). Gerenciamento do risco sanitário na transmissão de Doença de Chagas Aguda por alimentos. Brasília, DF, 2008. Informe técnico.

ARGOLO, A. M. et al. Doença de Chagas e seus principais vetores no Brasil. Rio de Janeiro: Imperial Novo Milênio, 2008.

ATAÍDE, M. C. E. S.; SILVA, B. V. C. As metodologias de ensino de ciências: contribuições da experimentação e da história e filosofia da ciência. Holos, Natal, v. 4, p. 171-181, 2011. 
BAHIA. Secretaria de Saúde. Superintendência de Vigilância e proteção da Saúde. Diretoria de Vigilância Epidemiológica. Situação epidemiológica da Doença de Chagas - Bahia. Boletim, Salvador, n. 2, jan. 2013. Disponível em: <http://www.suvisa.ba.gov. br/sites/default/files/2\%20boletim_epidemiologico\%20Chagas\%20\%5B1\%5D.pdf>. Acesso em: 29 maio 2016.

BENCHIMOL, J. L.; SILVA, A. F. C. Ferrovias, doenças e medicina tropical no Brasil da Primeira República. História, Ciências, Saúde - Manguinhos, Rio de Janeiro, v. 15, n. 3 , p. 719-762, 2008.

BRASIL. Lei no 9.394, de 20 de dezembro de 1996. Lei de Diretrizes e Bases da Educação Nacional. Diário oficial da República Federativa do Brasil. Brasília, DF, 23 dez. 1996.

BRASIL. Ministério da Saúde. Secretaria de Vigilância em Saúde. Manual de Doença de Chagas Aguda. Brasília, DF, 2004. Disponível em: <http://bvsms.saude.gov.br/bvs/ publicacoes/manual_chagas.pdf>. Acesso em: 28 out. 2014.

CARVALHO, G. S. et al. Health education approaches in school textbooks of 16 countries: biomedical model versus health promotion. In: IOSTE INTERNATIONAL MEETING ON CRITICAL ANALYSIS OF SCHOOL SCIENCE TEXTBOOK, 14., Hammamet, 2007. Proceedings... Tunis: University of Tunis, 2007. p. 380-392.

CARVALHO, G. S. et al. Comparing health education approaches in textbooks of sixteen countries. Science Education International, [S.1.], v. 19, n. 2, p. 133-146, jun. 2008 .

CARVALHO, G. S. et al. Addictive substances: textbook approaches from 16 countries. Journal of Biological Education, New York, v. 44, n. 1, p. 26-30, 2009.

CARVALHO, G. S. et al. Trends in environmental education images of textbooks from Western and Eastern European countries and Non-European countries. International Journal of Science Education, London, v. 33, n. 18, p. 2587-2610, 2011.

CASTRO, L. V. F. S. et al. Educação em saúde: do tradicional ao inovador. Revista da SBEnBio, Campinas, n. 7, p. 4919-4931, out. 2014.

CATALÁN, V. G.; SALA, R. M. J.; BEGUER, C. A. La educación para la salud: una propuesta fundamentada desde el campo de la docencia. Enseñanza de las ciencias: Revista de Investigacion y Experiencias Didacticas, Barcelona, v. 11, n. 3, p. 289-296, 1993.

CONRADO, D. M.; EL-HANI, C. N.; NUNES-NETO, N. F. Sobre a ética ambiental naformação do biólogo. Revista Eletrônica do Mestrado em Educação Ambiental, Rio Grande, v. 30, n. 1, p. 120-139, jan./jun. 2013.

DAIGLE, K.; HEBERT, E.; HUMPHRIES, C. Children's understanding of health and health-related behavior. Education, [S.1.], v. 128, n. 2, p. 237-247, 2007.

DIONOR, G. A.; FERREIRA, R. L.; MARTINS, L. Abordagens de saúde em livro didático de biologia: construção de ferramenta analítica. Revista da SBEnBio, Campinas, n. 7, p. 2796-2808, out. 2014a. 
DIONOR, G. A.; FERREIRA, R. L.; MARTINS, L. Análise da temática educação em saúde em atas de evento sobre educação em Ciências. Candombá: Revista virtual, Salvador, v. 9, n. 1, p. 22-34, jan./dez. 2013.

DIONOR, G. A.; FERREIRA, R. L.; MARTINS, L. Estado da arte em atas de evento sobre educação em ciências acerca da temática educação em saúde. Revista da SBEnBio, Campinas, n. 7, p. 2784-2795, out. 2014b.

DOENÇA de Chagas: ontem e hoje. Produção: Fiocruz e SESPA. Youtube, [S.1.], 2012. Disponível em: <https://www.youtube.com/watch?v=Prpe7CvYvnU>. Acesso em: 19 jan. 2015.

DOLZ, J.; NOVERRAZ, M.; SCHNEUWLY, B. Sequências didáticas para o oral e a escrita: apresentação de um procedimento. In: DOLZ, J.; SCHNEUWLY, B. Gêneros orais e escritos na escola. Campinas: Mercado de Letras, 2004. p. 95-128.

FERREIRA, R. L. et al. Educação em saúde numa perspectiva socioecológica: uma proposta para o Ensino Médio compatível com o tempo presente. Revista da SBEnBio, Campinas, n. 7, p. 6576-6587, 2014.

LANA, M.; TAFURI, W. L. Trypanosoma cruzi e Doença de Chagas. In: NEVES, D. P. Parasitologia humana. 11. ed. São Paulo: Atheneu, 2010. p. 85-108.

LEE, Y. C. Socio-scientific issues in health contexts: treading a rugged terrain. International Journal of Science Education, London, v. 34, n. 3, p. 459-483, 2012.

MARTINS, L. Saúde no contexto educacional: as abordagens de saúde em um livro didático de biologia do ensino médio largamente usado. 2010. 172 f. Dissertação (Mestrado em Ensino, Filosofia e História das Ciências) - Instituto de Biologia, Universidade Federal da Bahia, Salvador, 2010.

MARTINS, L. et al. Health education with socioscientific issues. In: BIANNUAL CONFERENCE OF THE EUROPEAN SCIENCE EDUCATION RESEARCH ASSOCIATION, 11., 2015, Helsinki. Proceedings... Helsinki: ESERA, 2015. p. 1-4.

MARTINS, L. et al. Educação em Saúde: breves reflexões sobre o Reducionismo e o Holismo. In: AUDI, L. C. C.; OLIVEIRA, J. M. de; REIS, M. J. E. (Org.). Educação e desenvolvimento: debates contemporâneos. Campinas: Pontes, 2014. v. 1, p. 165-177.

MARTINS, L.; SANTOS, G. S.; EL-HANI, C. N. Abordagens de saúde em um livro didático de biologia largamente utilizado no ensino médio brasileiro. Investigações em Ensino de Ciências, Porto Alegre, v. 17, n. 1, p. 249-283, 2012.

MATTHEWS, M. R. História, filosofia e ensino de ciências: a tendência atual de reaproximação. Caderno Catarinense de Ensino de Física, Florianópolis, v. 12, n. 3, 1995.

NUNES, J. M. V.; ALMOULOUD, S. A. O modelo de Toulmin e a análise da prática da argumentação em matemática. Educação Matemática Pesquisa, São Paulo, v. 15, n. 2, p. $487-512,2013$. 
PAN AMERICAN HEALTH ORGANIZATION - PAHO; WORLD HEALTH

ORGANIZATION-WHO. 20 years basic indicators: health situation in the Americas, Washington, 2014.

RELVAS, S.; ANTUNES, P. Análise da aplicabilidade dos modelos de argumentação na resolução alternativa de conflitos. Apresentado CONFERÊNCIA IBÉRICA DE SISTEMAS E TECNOLOGIAS DE INFORMAÇÃO, 1., Esposende, 2006. Actas... Esposende: [s.n.], 2006.

RICARDO, E. C. Educação CTSA: obstáculos e possibilidades para sua implementação no contexto escolar. Ciência \& Ensino, Campinas, v. 1, p. 1-12, nov. 2007. Edição especial.

SANTOS, T. T. dos; MEIRELLES, R. S. M. de. A abordagem das doenças negligenciadas na Educação em Saúde: análise das atas dos ENPECs entre 2009 e 2011. In: ENCONTRO DE PESQUISA EM EDUCAÇÃO EM CIÊNCIAS, 9., 2013, Águas de Lindóia. Anais... Belo Horizonte: ABRAPEC, 2013.

SANTOS, W. P. dos; MORTIMER, E. F. Uma Análise de Pressupostos Teóricos da Abordagem CTS (Ciência - Tecnologia - Sociedade) no Contexto da Educação Brasileira. Ensaio: Pesquisa em Educação em Ciências, Belo Horizonte, v. 2, n. 2, dez. 2002.

TOUlMiN, S. E. Os usos do argumento. 2. ed. São Paulo: Martins Fontes, 2006.

WESTPHAL, M. F. Promoção da saúde e prevenção de doenças. In: CAMPOS, G. W. et al. (Org.). Tratado de saúde coletiva. São Paulo: HUCITEC; Rio de Janeiro: FIOCRUZ, 2006. p. 635-667.

ZABALA, A. A prática educativa: como ensinar. Porto Alegre: Artmed, 1998.

ZABALA, A.; ARNAU, L. Como aprender e ensinar competências. Porto Alegre: Artmed, 2010. 


\title{
TIPOS DE PRÓTESES COMO TEMA SOCIOCIENTÍFICO PARA A PROMOÇÃO DA ARGUMENTAÇÃO NO ENSINO DE QUÍMICA
}

\author{
Luciana Passos Sá \\ Salete Linhares Queiroz
}

\section{Introdução}

A Questão Sociocientífica (QSC) discutida neste capítulo e apresentada no formato do caso, denominado Caso das Próteses, trata de uma situação fictícia, porém baseada em histórias reais de pessoas, normalmente vítimas de acidentes, que necessitam recorrer ao uso de próteses para substituir partes do corpo. O caso se mostrou bastante favorável na promoção de argumentos pelos estudantes por exigir, na sua análise e resolução, a consideração de aspectos que vão além daqueles de natureza científica. Questões políticas e éticas ligadas, por exemplo, à investigação de novas tecnologias mais acessíveis à população ou questões de cunho social e/ou econômico, como o custo envolvido nos diferentes tipos de próteses existentes e às diferentes oportunidades de acesso da sociedade a tecnologias que visam à melhoria da qualidade de vida do indivíduo, são aspectos mencionados na argumentação acerca do tema. Também são pontos fortemente enfatizados na análise da QSC envolvida neste caso aspectos mais específicos relacionados aos diferentes tipos de próteses, tais como leveza e maleabilidade dos materiais, biocompatibilidade e recuperação pós-operatória. 
Nesse contexto, o objetivo deste capítulo é apresentar uma QSC, elaborada no formato de um caso, tendo em vista a promoção da argumentação no ensino superior de química. Assim, discutiremos a potencialidade das QSC para a promoção da argumentação no ensino de ciências. Também apresentaremos informações acerca da elaboração de casos e, particularmente, detalharemos características do caso denominado Caso das Próteses e formas de sua aplicação no ensino superior de química.

\section{QSC na promoção da argumentação no ensino de ciências}

A inserção de QSC em ações desenvolvidas, tanto no ensino básico (KOLSTO, 2006; SADLER; DONNELLY, 2006) quanto no superior (SÁ; KASSEBOEHMER; QUEIROZ, 2013; CONRADO; NUNES-NETO; EL-HANI, 2015), tem sido fortemente incentivada, dentre outras razões, pela potencialidade que a discussão a respeito das mesmas apresenta em promover habilidades argumentativas entre os estudantes. Segundo Simonneaux (2008), as QSC, frequentemente referenciadas pela sigla SSI (oriunda da sigla inglesa Socioscientific Issues), são questões controversas em que competem diferentes visões e que têm implicações em um ou mais campos do conhecimento, como a biologia, a sociologia, a ética, a política, a economia, dentre outras.

Campaner e De Longhi (2007) reconhecem o caráter transversal e interdisciplinar envolvido em tais questões e destacam que o propósito fundamental da sua abordagem está relacionado à formação de cidadãos comprometidos socioambientalmente, com capacidade crítica e reflexiva. Nessa perspectiva, estes se tornam aptos a avaliar as informações recebidas, a refletir sobre as atuações próprias e alheias e hábeis para argumentar adequadamente diante das decisões a serem tomadas.

Dentre as estratégias comumente empregadas em propostas com abordagem SSI, algumas têm se destacado nos trabalhos reportados na literatura, como o debate, o role-play e o estudo de caso. O debate está centrado na prática da argumentação (ALTARUGIO; DINIZ; LOCATELLI, 2010) como uma "[...] atividade social discursiva que se realiza pela justificação de pontos de vista e consideração de perspectivas contrárias [contra-argumento] com o objetivo último de promover mudanças nas representações dos participantes sobre o tema discutido". (DE CHIARO; LEITÃO, 2005, p. 350) O role-play consiste em uma atividade que inclui a atribuição de papéis a um ou mais membros de um pequeno grupo, de modo que uma determinada questão seja analisada em diferentes perspectivas. (SIMONNEAUX, 2001) O estudo de caso, por sua vez, é um método que oferece aos estudantes a oportunidade de direcionar a própria aprendizagem e investigar aspectos sociocientíficos presentes em situações reais ou simuladas. São narrativas sobre dilemas vivenciados por indivíduos que necessitam tomar importantes decisões acerca de determinadas questões. A tomada de decisão é normalmente acompanhada de argumentação por aqueles que a tomaram. (SÁ; QUEIROZ, 2009) 
A argumentação pode ser entendida como uma atividade social, intelectual e verbal, empregada quando se pretende justificar ou refutar uma opinião, que consiste em fazer declarações, levando em consideração o receptor e a finalidade com a qual se emitem. Para que haja argumentação, são necessárias a escolha entre diferentes opções ou explicações e a análise dos critérios que permitam avaliar como mais adequada a opção escolhida. (SANMARTÍ, 2003) Segundo Leitão e Almeida (2000), a argumentação não implica necessariamente presença mínima de dois interlocutores. É possível haver argumentação em situações de monólogos, como palestras e textos escritos que, mesmo nessas condições, é ainda o diálogo que estrutura a forma que a argumentação assume. Em tais situações, o diálogo se realiza pela presença de um interlocutor imaginário a quem a argumentação se dirige. O convencimento de outro sujeito é sempre o fim último da argumentação.

Nessa perspectiva, a apresentação de QSC em forma de estudo de caso pode possibilitar o desenvolvimento de habilidades argumentativas no ensino de ciências, além de aumentar o interesse dos estudantes pela aula, a compreensão dos conteúdos envolvidos e a capacidade de comunicação a partir do uso de conhecimentos científicos, aliados a outros tipos de conhecimentos, como aqueles de natureza social, ética, política e econômica.

\section{Elaboração de casos de caráter sociocientífico}

O caso que apresentamos neste capítulo foi elaborado para aplicação no ensino superior de química. Contudo, como se fundamenta na discussão de aspectos sociocientíficos e não apenas de caráter científico, é também conveniente para estudo em outros níveis e cursos. Para tanto, é necessário que sejam estabelecidas relações entre o cenário apresentado no caso e o contexto educacional, de modo a que se fomente o desenvolvimento de habilidades de comunicação oral dos alunos e de busca nas diversas fontes de informação, por exemplo.

Além do Caso das Próteses, mais cinco casos $^{1}$ de mesma natureza foram elaborados de acordo com as recomendações de Herreid (1998) sobre os aspectos a serem considerados na elaboração de um "bom caso", dentre os quais destacamos:

- $\quad$ utilidade pedagógica: deve ser útil para o curso e para os estudantes;

- relevância ao leitor: deve envolver situações que possivelmente os estudantes estejam aptos a compreender e enfrentar;

1 Os casos Praga do Coqueiro, Caso das Próteses, Ameaça nos Laranjais, Poluição em Rondônia e Doença de Granja foram elaborados em conjunto e podem ser encontrados na íntegra, na página do Grupo de Pesquisa em Ensino de Química do Instituto de Química de São Carlos da Universidade de São Paulo (GPEQSC). Disponível em: <http://www.gpeqsc.com.br/casos/arquivos/colecao/ colcaso01.pdf>. 
- interesse pela questão/conflito: para que pareça real, deve descrever um drama, um suspense, uma questão a ser resolvida.

A maioria dos casos é fundamentada sobre um assunto controverso:

- atualidade: deve tratar de questões atuais, que levem o aluno a compreender a importância do assunto;

- extensão: devem ser curtos, suficientes para introduzir os fatos, sem que cause uma análise tediosa;

- empatia com os personagens centrais: as características escolhidas para os personagens devem influenciar na tomada de decisões;

- necessidade de decisão: deve haver urgência e seriedade na resolução dos casos;

- generalizações: deve ter aplicabilidade geral, e não ser específico para uma curiosidade apenas;

- narrativa/diálogos: deve narrar uma história em que o final não exista ainda e incluir diálogos que promovam a empatia dos estudantes com os personagens da história.

Nesse sentido, recomendamos adicionar vida e drama nos diálogos. (SÁ, 2010)

Pesquisas recentes publicadas na revista Pesquisa Fundação de Amparo à Pesquisa do Estado de São Paulo (Fapesp) serviram como fonte de inspiração para a elaboração dos casos. Os casos foram estruturados de modo que apresentassem em seu contexto questões sociais, ambientais, econômicas e/ou éticas, com o intuito de estimular no aluno a capacidade de tomar decisões diante de problemas da vida real e de argumentar a favor das mesmas.

A seguir, discutiremos a argumentação a partir da aplicação do caso denominado Caso das Próteses (Quadro 1), que aborda a situação do jovem João Carlos, vítima de grave acidente de moto, que provocou uma grande fratura no seu maxilar. As sequelas causadas pelo acidente fizeram com que ele ficasse desmotivado e com dificuldades de relacionamento com as outras pessoas. Além disso, o jovem ficou com limitações na realização das funções de falar e mastigar comidas sólidas. A família de João Carlos não possuía recursos financeiros suficientes para busca de tratamento particular e necessitava recorrer ao Sistema Único de Saúde (SUS). Como futuros químicos, cabia aos grupos responsáveis pela resolução do caso ajudar a equipe de médicos a escolher o tipo de prótese mais adequado para João Carlos. 
Quadro 1 - Caso das Próteses

\section{Caso das Próteses}

João Carlos, 23 anos, há dois anos evita sair de casa para ir ao mercado, jogar com os amigos e até procurar emprego. Foi exatamente há dois anos que João foi vítima de um terrível acidente de moto, que acabou resultando em uma grande fratura no seu maxilar. A perda da antiga forma de seu rosto o tornou uma pessoa triste, com baixa autoestima e sem vontade de se relacionar com as outras pessoas. Além disso, João sente dificuldades para falar e mastigar comidas sólidas.

João sempre morou em São Carlos, cursava Física na Universidade de São Paulo (USP), mas abandonou o curso e outras atividades logo após o acidente.

Mariana nunca desistiu de buscar uma solução para o problema de seu único irmão. Foi a hospitais, clínicas, falou com vários médicos, mas a situação era difícil, pois não tinham muitos recursos financeiros. No entanto, depois de várias tentativas frustradas, Mariana conversa com um médico que se mostra disposto a ajudá-la.

Mariana chega em casa eufórica e conversa com os familiares:

- Mamãe, João, venham aqui. Tenho ótimas notícias para vocês.

- O que aconteceu? Pergunta João, sem mostrar muito entusiasmo.

- Dr. Alberto se mostrou muito interessado em nos ajudar. Ele me falou sobre vários tipos de próteses que estão sendo utilizadas em pessoas vítimas de acidentes com armas e carros. Essas próteses substituem ossos da mandíbula, crânio ou face. sua mãe.

- Mas, como iremos pagar uma cirurgia como essa? Deve custar muito caro, comenta Dona Lourdes,

- Dr. Alberto me falou que cirurgias como essas estão sendo feitas pelo SUS, me prometeu falar com alguns amigos seus, especialistas na área, e, junto com eles, pensar em um tipo de prótese adequada para João, explica Mariana.

- Obrigado, minha irmã. Meu maior sonho é ter de volta a antiga forma do meu rosto, fala João.

Dois dias depois, Dr. Alberto liga para Mariana:

- Como vai, Dr. Alberto? Fala Mariana.

- Olá Mariana, tenho ótimas notícias. Conversei com alguns colegas e eles me falaram sobre excelentes próteses utilizadas atualmente, e que irão decidir sobre o tipo mais adequado a ser usado para o caso de João. Falei da situação de seu irmão e eles estão dispostos a operá-lo o mais breve possível. É preciso que ele compareça a uma consulta amanhã, às dez horas, para acertarem tudo, explica Dr. Alberto.

- Muito obrigada, Dr. Alberto. Amanhã estaremos lá.

No dia seguinte, tudo foi acertado e a cirurgia marcada para uma semana depois.

Vocês, como estudantes de Química, ajudarão a equipe de médicos a escolher o tipo de prótese mais adequado para o caso de João Carlos.

Fonte: adaptado de Ereno (2003). 
A partir desse caso, outras questões poderão ser exploradas por professores de outras disciplinas, de acordo com seu contexto. Abaixo, inserimos alguns exemplos, com indicação de algumas áreas correlatas, entre parênteses:

Q1. Onde, quando e em que contexto surgem as próteses? (história e geografia)

Q2. Quais os diferentes tipos de materiais para próteses, seus diferentes usos, suas vantagens e desvantagens? (química e física)

Q3. Há relações entre a implantação de próteses e o aumento da sensação do "membro fantasma" em pacientes? (biologia e psicologia)

Q4. Como acidentes que levam à perda de partes do corpo podem afetar a qualidade de vida de um indivíduo e sua família? (sociologia e psicologia)

Q5. Como a implantação de próteses pode melhorar a autoestima e a qualidade de vida de pacientes? (sociologia e psicologia)

Q6. Quais as políticas públicas do Brasil e os desafios para o acesso a tecnologias como próteses para a população de baixa renda? (sociologia e política)

Q7. Quais as estimativas de oferta e demanda de próteses para a população brasileira? (matemática)

Q8. Os benefícios sociais do desenvolvimento de novas tecnologias para substituição de partes do corpo humano superam os custos socioambientais? (biologia e filosofia)

Q9. As próteses artificiais podem substituir perfeitamente elementos naturais/biológicos humanos? Haveriam implicações morais nessa substituição? (biologia e filosofia)

Q10. Quais as controvérsias envolvidas no uso de tecnologias como próteses para a melhoria ou a recuperação de habilidades humanas, como, por exemplo, no caso da formação de soldados biônicos? (filosofia e política)

\section{Objetivos de aprendizagem (conceituais, procedimentais e atitudinais)}

Com base nos resultados da aplicação deste caso (SÁ, 2010), podemos organizar alguns objetivos de aprendizagem (ZABALA; ARNAU, 2010) para orientar professores de diversas áreas na abordagem do Caso das Próteses:

\section{Conceituais}

- Compreensão de fatos, conceitos e dados associados aos impactos ambientais, sociais e econômicos, como viabilidade, segurança, conforto, qualidade de vida 
do paciente e outras vantagens e desvantagens, relacionados aos diferentes tipos de prótese; histórico de evolução das próteses e seu uso em diferentes contextos, como para vítimas da guerra.

\section{Procedimentais}

- Comparação de diferentes tipos de próteses para o paciente, considerando materiais, custos e resultados; organização e apresentação de argumentos, considerando aspectos científicos, éticos, históricos, políticos, sociais, ambientais, entre outros.

\section{Atitudinais}

- Reflexão sobre problemas burocráticos, de natureza ética e política, relacionados ao SUS brasileiro; questões de negligência médica e irregularidades na prescrição de dispositivos médicos como próteses; dificuldades de acesso a tratamentos médicos de maior qualidade por indivíduos com menores condições financeiras; exclusão social vivenciada por portadores de alguma deficiência física; comportamentos de risco para acidentes, como de trânsito; interesses, custos e benefícios envolvidos no desenvolvimento de tecnologias relacionadas à saúde humana; formas de divulgar informações para a população dos resultados/argumentos encontrados na resolução do caso.

\section{Meios para aplicação e discussão da QSC no ensino}

Para a resolução do caso pelos alunos, recomendamos a formação de grupos, constituídos de três a cinco participantes. Antes do início do trabalho com o caso, os alunos deverão ser orientados sobre as possíveis maneiras de proceder para a sua resolução e tomar conhecimento do Guia para a Análise e Resolução dos Casos (Quadro 2). Este tem o objetivo de auxiliá-los na discussão e na análise dos problemas apresentados no caso. É recomendável também solicitar aos alunos que pesquisem individualmente, nas diversas fontes, informações sobre os assuntos envolvidos no caso e que tragam os resultados das pesquisas para os próximos encontros. Nos encontros, para os quais sugerimos uma duração planejada para duas horas cada, os alunos poderão responder, por escrito, questões relacionadas ao caso, elaboradas tomando por base o Modelo Normativo de Tomada de Decisão de Kortland (1996), que evidencia etapas capazes de: organizar as informações coletadas a respeito do problema; refletir e comparar alternativas de solução do problema; e facilitar a tomada de decisão pelos alunos e posterior argumentação (Figura 1). 
Quadro 2 - Guia para a análise e resolução dos casos

\section{Os estudantes devem considerar os seguintes itens após a leitura:}

1- Reconhecer assuntos em potencial. Listar termos ou frases que pareçam ser importantes para compreensão do assunto que o caso aborda.

2- Fazer levantamento de conexões por meio de tempestade mental. Discutir sucintamente com seu grupo o seguinte:

- Sobre o que é o caso?

- Quais são os temas principais do caso?

Para organizar melhor o seu trabalho, tome nota dos assuntos e perguntas pricipais que surgirem na tabela abaixo:

\begin{tabular}{|l|l|}
\hline O que nós sabemos sobre o caso? & O que nós ainda precisamos saber para solucionar o caso? \\
\hline & \\
& \\
\hline
\end{tabular}

3- Obter fontes ou referências adicionais para ajudar a responder ou explorar as perguntas. Estas podem conter materiais impressos, artigos, banco de dados, resultados de simulações, mapas etc. Sejam criativos na procura de informações.

4- Projetar e conduzir investigações científicas relevantes para as perguntas. Estas podem utilizar métodos laboratoriais, pesquisa de campo apropriada (entrevista com especialistas da área), computadores com módulos de software, gráficos etc.)

5- Produzir material que demonstre o entendimento das conclusões. Fazer uma apresentação em Power Point ou Open Office e escrever um artigo nos moldes apresentados na revista Eletrônica do CDCC (revista@cdcc.sc.usp.br). Esses materiais devem servir para persuadir os colegas de suas ideias e evidenciar a compreensão das suas conclusões.

Fonte: Sá (2010, p. 274).

Figura 1 - Modelo normativo de tomada de decisão de Kortland (1996)

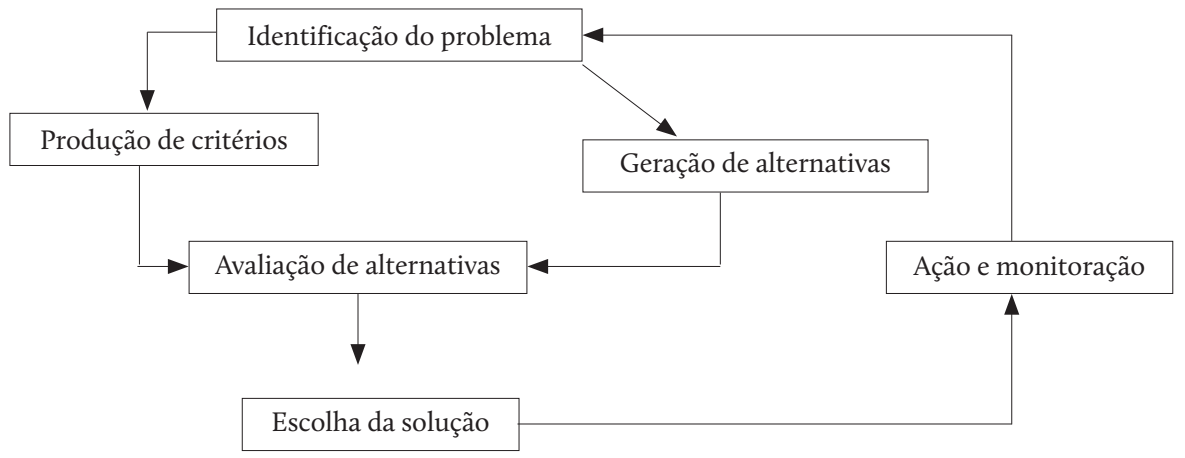

Fonte: Sá (2010, p. 76). 
Também sugerimos a produção de um diário do caso, que deverá deixar claro ao leitor o processo que conduzirá o grupo à resolução do caso, incluindo informações obtidas no processo e reflexões sobre o seu andamento. Um texto sobre a situação envolvida no caso estudado, com formato de linguagem voltada para o ensino médio ou para a comunidade não acadêmica, também poderá ser produzido pelos alunos. A resolução dos casos deverá ser apresentada por cada grupo, em um período de aproximadamente 20 minutos. Após a realização das exposições orais, um debate pode ser promovido entre os grupos. Experiências reportadas na literatura indicam que a argumentação é mais profícua quando o debate é promovido entre grupos que se dedicaram à resolução de um mesmo caso. (SÁ, 2010)

A segunda perspectiva que consideramos para a aplicação da QSC consiste na explicitação das fontes de evidências empregadas pelos grupos como forma de garantir confiabilidade às informações fornecidas. Desse modo, os enunciados podem ser classificados como evidências pessoais ou de autoridade, de acordo com as suas fontes. (KIM; SONG, 2005) Algumas fontes de evidências poderão ser identificadas nas apresentações orais dos grupos, como evidências de autoridade por especialistas e instituições, evidências pessoais, entre outras. O professor pode orientar os estudantes quanto à avaliação da confiabilidade das fontes de informação, durante o processo investigativo realizado pelos estudantes.

Por fim, para a análise dos argumentos dos alunos, recomendamos o uso do modelo de Toulmin (2001), com posterior aplicação de metodologia proposta por Erduran, Simon e Osborne (2004).

O primeiro, ilustrado na Figura 2, permite a análise dos argumentos elaborados pelos estudantes do ponto de vista estrutural, ou seja, pela distinção entre os diferentes componentes que constituem um argumento, assim como as relações existentes entre eles. O modelo, além de mostrar o papel das evidências na elaboração de afirmações, relacionando aos dados e conclusões por meio de justificativas, também realça as limitações de uma dada teoria, bem como sua sustentação em outras teorias. (SÁ, 2010)

Figura 2 - Modelo de Toulmin.

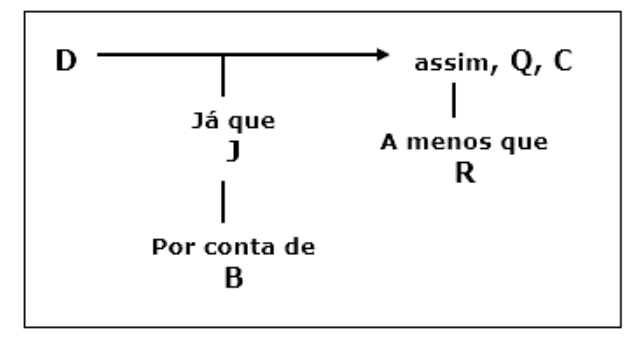

Fonte: Toulmin (2001, p. 150). 
Segundo Toulmin (2001), os elementos fundamentais de um argumento são: o dado (D), a conclusão (C) e a justificativa (J). É possível apresentar um argumento contando apenas com esses elementos. Porém, para que um argumento seja completo, pode-se especificar em que condições a justificativa apresentada é válida ou não, indicando um peso para tal justificativa. Desta forma, podem ser acrescentados ao argumento qualificadores modais $(\mathrm{Q})$, ou seja, especificações das condições necessárias para que uma dada justificativa seja válida. Da mesma forma, é possível especificar em que condições a justificativa não é válida ou suficiente para dar suporte à conclusão. Neste caso, é apresentada uma refutação (R) da justificativa. Além dos elementos já citados, a justificativa, que apresenta um caráter hipotético, pode ser apoiada em uma alegação categórica baseada em uma lei, por exemplo. Trata-se de uma alegação que dá suporte à justificativa, denominada backing (B) ou conhecimento básico. Uma descrição detalhada de cada um desses componentes, assim como uma visão geral a respeito do respectivo modelo, pode ser encontrada no livro Os usos do argumento. (TOULMIN, 2001)

A metodologia proposta por Erduran, Simon e Osborne (2004) sugere que a qualidade dos argumentos é avaliada a partir da observação da combinação dos componentes do argumento, segundo Toulmin (2001), nas falas/textos escritos produzidos pelos estudantes. Ou seja, as combinações que possuem um maior número de componentes são típicas de um argumento mais bem elaborado. Assim, um argumento que apresenta "conclusão, dado e justificativa" é menos sofisticado do que outro que tem apenas "conclusão, dado, justificativa e refutação".

\section{Estratégias de aprendizagem}

A psicologia cognitiva baseada na Teoria do Processamento da Informação tem concentrado seus esforços em esclarecer como os seres humanos adquirem, armazenam e utilizam as informações. Adeptos dessa visão destacam a importância de se transcender o ensino dos fatos e de se assegurar a apropriação, por parte dos estudantes, dos processos psicológicos pelos quais se aprendem os fatos. Neste contexto, eles acreditam no ensino de estratégias de aprendizagem como um caminho frutífero em direção à autorregulação da aprendizagem. (BORUCHOVITCH, 2007)

Nesse sentido, recomendamos analisar as estratégias de aprendizagem empregadas pelos alunos no processo de resolução do caso e verificar em que medida o caso proposto estimula determinados tipos de estratégias pelos estudantes. Para tanto, quatro tipos de estratégias podem ser consideradas: cognitivas, metacognitivas, sociais e afetivas. De acordo com Dembo (1994), as estratégias cognitivas operam diretamente sobre o material a ser aprendido, auxiliando o estudante a melhor processar a informação, enquanto que as metacognitivas são procedimentos que o indivíduo emprega para planejar, monitorar e regular o seu próprio pensamento e ação. Paiva (1998) define as estratégias sociais como aquelas que promovem a interação e a cooperação de uns com os outros, e 
as afetivas como aquelas que envolvem o controle das emoções, das atitudes, dos valores e da motivação.

\section{Considerações finais}

Neste capítulo, discutimos acerca de uma proposta de ensino baseada no emprego de casos de caráter sociocientífico e como esta pode favorecer o desenvolvimento de habilidades argumentativas. Casos, como o aqui apresentado, não são produzidos de forma aleatória, mas com base em orientações sobre os aspectos desejáveis em uma narrativa sociocientífica, quando se pretende trabalhar conteúdos específicos ou estimular determinados tipos de habilidades. Simonneaux (2008), por exemplo, sinaliza que o conhecimento envolvido nas QSC não deve ser simplesmente controverso, mas deve também abarcar uma pluralidade de disciplinas. O contexto do problema e os campos das disciplinas envolvidas devem ser definidos de modo a construir uma situação propícia ao debate, em que a argumentação sobre a questão não envolva somente o conteúdo, mas também dimensões sociais e valores pessoais. Nesse sentido, o caso proposto contempla as recomendações supracitadas e pode ser adaptado em situações nas quais o professor deseje estimular o pensamento crítico dos estudantes acerca de questões dessa natureza.

Também vale destacar que, embora o foco da proposta tenha sido o desenvolvimento da argumentação, esta também se mostra favorável à aprendizagem de conceitos científicos e à melhor compreensão acerca da natureza da construção do conhecimento científico. Adaptações à proposta se mostram pertinentes, de acordo com os objetivos do professor e o nível de ensino, sendo plausível a inserção de ações como esta no ensino fundamental e médio. Tais ações contemplam aspectos importantes na formação do estudante, como o desenvolvimento do pensamento crítico e da expressão oral e escrita, assim como da capacidade de trabalhar em grupo. Nessa perspectiva, é considerável a potencialidade das mesmas para a formação de um cidadão capaz de organizar seus conhecimentos para a resolução de problemas sociais e ambientais.

\section{Referências}

ALTARUGIO, M. H.; DINIZ, M. H.; LOCATELlI, S. W. O debate como estratégia em aulas de química. Química Nova na Escola, São Paulo, v. 32, n. 1, p. 26-30, 2010.

BORUCHOVITCH, E. Aprender a aprender: propostas de intervenção em estratégias de aprendizagem. Educação Temática Digital, Campinas, v. 8, n. 2, p. 156-167, 2007.

CAMPANER, G.; DE LONGHI, A. L. La argumentación en educación ambiental. Una estrategia didáctica para la escuela media. Revista Electrónica de Enseñanza de las Ciencias, Ourense, v. 6, n. 2, p. 442-456, 2007. 
CONRADO, D. M.; NUNES-NETO, N. F.; EL-HANI, C. N. Argumentação sobre problemas socioambientais no ensino de biologia. Educação em Revista, Belo Horizonte, v. 31, n. 1, p. 329-357, 2015.

DE CHIARO, S.; LEITÃO, S. O papel do professor na construção discursiva da argumentação em sala de aula. Psicologia: Reflexão e Crítica, Porto Alegre, v. 18, n. 3, p. 350-357, 2005.

DEMBO, M. H. Applying educational psychology. New York: Longman, 1994.

ERENO, D. Próteses de mamona. Pesquisa Fapesp, São Paulo, n. 91, p. 66-71, 2003.

ERDURAN, S.; SIMON, S.; OSBORNE, J. Tapping into argumentation: developments in the application of Toulmin's argument pattern for studying science discourse.

Science Education, New York, v. 88, n. 6, p. 915-933, 2004.

HERREID, C. F. What makes a good case? Journal of College Science Teaching, [S.1.], v. 27, n. 3, p. 163-169, 1998.

KIM, H.; SONG, J. The features of peer argumentation in middle school students' scientific inquiry. Research in Science Education, Amsterdam, v. 36, n. 3, p. 211-233, 2005.

KOLSTO, S. D. Patterns in student's argumentation confronted with a risk-focused socio-scientific issue. International Journal of Science Education, London, v. 28, n. 14, p. 1689-1716, 2006.

KORTLAND, K. An STS case study about students' decision making on the waste issue. Science Education, New York, v. 80, n. 6, p. 673-689, 1996.

LEITÃO, S.; ALMEIDA, E. G. S. A produção de contra-argumentos na escrita infantil. Psicologia: Reflexão e Crítica, Porto Alegre, v. 13, n. 3, p. 351-361, 2000.

PAIVA, V. L. M. O. Estratégias individuais de aprendizagem de língua inglesa. Letras e Letras, Uberlândia, v. 14, n. 1, p. 73-88, 1998.

SADLER, T. D.; DONNELLY, L. A. Socioscientific argumentation: the effects of content knowledge and morality. International Journal of Science Education, London, v. 28, n. 12, p. 1463-1488, 2006.

SÁ, L. P. Argumentação no ensino superior de química: investigando uma atividade fundamentada em estudo de casos. 2006. 152 f. Dissertação (Mestrado em Química) Instituto de Química São Carlos, Universidade de São Paulo, São Paulo, 2006.

SÁ, L. P. Estudo de casos na promoção da argumentação sobre questões sócio-científicas no ensino superior de química. 2010. 278f. Tese (Doutorado em Química) - Universidade Federal de São Carlos, São Carlos, 2010.

SÁ, L. P.; QUEIROZ, S. L. Estudo de casos no ensino de química. Campinas: Átomo, 2009. 
SÁ, L. P.; KASSEBOEHMER, A. C.; QUEIROZ, S. L. Casos investigativos de caráter sociocientífico: aplicação no ensino superior de química. Educación Química, México, v. 24, n. 2, p. 522-528, 2013. Suplemento.

SANMARTí, N. Aprende ciéncies tot aprenent a escriture ciéncie. Barcelona: Centres de recuros pedagògics de laciutat de Barcelona, 2003.

SIMONNEAUX, L. Argumentation in socio-scientific contexts. In: ERDURAN, S., JIMENEZ-ALEIXANDRE, M. P. (Ed.). Argumentation in Science Education: Perspectives from classroom-based research. Dordrecht: Springer, 2008. p. 179-199.

SIMONNEAUX, L. Role-play or debate to promote students' argumentation and justification on an issue in animal transgenesis. International Journal of Science Education, London, v. 23, n. 9, p. 903-927, 2001.

TOULMIN, S. Os usos do argumento. Tradução de Reinaldo Guarany. São Paulo: Martins Fontes, 2001.

ZABALA, A.; ARNAU, L. Como aprender e ensinar competências. Porto Alegre: Artmed, 2010. 


\title{
MEDICALIZAÇÃO DA VIDA E ANÁLISE DO COMPORTAMENTO A PARTIR DE QUESTÕES SOCIOCIENTIIFICAS
}

\author{
Felipe Melo Souza Santos \\ Mateus de Mattos Souza \\ Maurício Cardoso Borges Lacerda Moura \\ Tiago Alfredo da Silva Ferreira
}

\section{Introdução}

Este capítulo tem por objetivo apresentar uma Questão Sociocientífica (QSC) sobre a medicalização da vida (ou seja, o "Caso Fernando"), discutindo meios para a sua aplicação no ensino de ciências e, em específico, no ensino de Análise do Comportamento (AC). A medicalização ${ }^{1}$ da vida, enquanto um fenômeno moderno, ${ }^{2}$ é caracterizado por

1 Segundo Faraone e colaboradores (2010), há uma diferença entre medicalização, que é a transformação de experiências subjetivas comuns em problemas médicos, e medicamentalização, que envolve fabricação, dispensação e marketing de remédios. Para os fins deste artigo, será utilizada apenas medicalização, porque é o termo mais utilizado no Brasil, como exemplificado pela cartilha do Conselho Federal de Psicologia (2012).

2 Alguns autores apontam o início das práticas medicalizantes desde pelo menos 1890, através de intervenções médicas na educação, nos negócios e em outras esferas de vida. Para uma análise histórica mais aprofundada da história do termo e das práticas, sugerimos Petrina (2006) e Figueira e Caliman (2014). 
um processo de transformação de experiências humanas (por exemplo, luto, desatenção e ansiedade), em transtornos ou doenças (por exemplo, depressão, transtorno do déficit de atenção com hiperatividade e transtorno de ansiedade generalizada). (BRZOZOWSKI; CAPONI, 2013) Esse processo é consonante com a expansão do poder biomédico (LEMOS, 2014), com a medicina e a indústria farmacêutica como agências de controle social, influenciando o desenvolvimento da vida dos sujeitos em diversos ambientes com os quais interagem, como a escola, a família e o trabalho. Essa transformação vem causando uma epidemia de diagnósticos (MEIRA, 2012) que transforma qualitativamente a experiência dos sujeitos com suas próprias sensações fisiológicas.

A medicalização faz parte de um fenômeno social maior, que envolve atribuir aos sujeitos individuais as causas e soluções de problemas sociais complexos, retirando-os do contexto no qual estão inseridos. (BRZOZOWSKI; CAPONI, 2013; CALADO, 2014) Nesta lógica, a intervenção também se dará no próprio indivíduo, justificando a utilização de medicamentos que alteram o organismo de modo a agir num provável ou suposto agente etiológico.

A medicalização envolve a tentativa de categorizar condutas como normais (isto é, normatização) e a subsequente criação de categorias como desviantes, numa lógica que acaba por expandir a quantidade de transtornos. As categorias de ansiedade, por exemplo, aumentaram de 9 (AMERICAN PSYCHIATRIC ASSOCIATION, 1987) para 12 (AMERICAN PSYCHIATRIC ASSOCIATION, 1994) nos Manuais Diagnósticos e Estatísticos de Saúde Mental (DSM). O diagnóstico de Transtorno do Déficit de Atenção com Hiperatividade (TDAH), de modo semelhante, tem sido amplamente utilizado, apesar da crítica à ausência de evidências científicas em sua etiologia. (TIMIMI et al., 2004)

Além do aumento do número de categorias, expandem-se, também, o número de diagnósticos dados às pessoas e a subsequente receita de medicamentos. Dados da Organização para a Cooperação e Desenvolvimento Econômico (OCDE) apontam que a prescrição de medicamentos, como metilfenidato (comumente utilizado para o TDAH), ansiolíticos, hipnóticos e antidepressivos, aumentou entre os anos de 2000 a 2012. (OLIVA, 2014) Enquanto o consumo de ansiolíticos, hipnóticos e antidepressivos teve um aumento de quase 100\%, na Espanha, em outros países da Europa, o metilfenidato teve um aumento de quase $1000 \%$. Indo na mesma direção, o consumo de metilfenidato no Brasil aumentou o suficiente para colocá-lo como "[...] o segundo maior consumidor mundial de metilfenidato [...]" (CONSELHO FEDERAL DE PSICOLOGIA, 2012, p. 7), situação que tem mobilizado entidades civis, acadêmicas e políticas.

A gravidade da situação mobilizou o Conselho Federal de Psicologia, que elaborou uma cartilha sobre a "Não medicalização da vida", na qual é defendido que o lobby da indústria farmacêutica acaba por influenciar o que é considerado comportamento desviante (isto é, qualquer comportamento enquadrado em manuais classificatórios como 
o DSM), pressionando financeiramente (por exemplo, através de incentivos como viagens pagas para congressos internacionais e bônus em dinheiro) e cientificamente (por exemplo, apresentando resultados de testes químicos realizados pelo próprio laboratório) os médicos para a elaboração de diagnósticos e subsequente receita de medicamentos, que servem para o tratamento de algumas condições. O incentivo para a utilização desses remédios pode aumentar a probabilidade de os médicos virem a fechar diagnósticos e, consequentemente, receitar os medicamentos que lhes sirvam de tratamento, tornando os "comportamentos desviantes" muito mais prováveis de se tornarem partes de diagnósticos já conhecidos. Essa é uma visão semelhante ao ponto de vista de Silvia Faraone e colaboradores (2010), que apontam que, além dos médicos, a indústria farmacêutica influencia formadores de opinião (por exemplo, blogueiros, artistas); organizações de usuários (por exemplo, associações de pais de filhos com TDAH) e organizações educativas, nas quais incluem-se tanto psicopedagogos como os próprios professores. Este fenômeno da medicalização parece ocorrer em diferentes culturas ocidentais, onde a utilização de explicações médicas e psiquiátricas legitimam as crenças e práticas comunitárias envolvidas. (TIMIMI, 2010, p. 702)

Nesse contexto, parece possível dizer que há influência das práticas de medicalização no modo como os estudantes das áreas de saúde aprendem a tratar de questões relativas à experiência de sofrimento subjetivo e no modo como propõem resolver estes problemas. Segundo Timimi (2010, p. 701-702), apesar de a cultura ocidental dispor de métodos psicoterápicos (por exemplo, terapia familiar; terapia cognitivo-comportamental; terapia psicodinâmica) e farmacêuticos para lidar com tais questões, o ensino desses métodos se apresenta por uma abordagem que enfatiza a reprodutibilidade técnica de acordo com manuais de classificação, isto é, enfatiza-se o aprimoramento de técnicas para elaboração de diagnósticos muito mais do que reflexões (como as éticas) sobre a sua necessidade e das subsequentes receitas de medicamentos. Além disso, esse tipo de abordagem frequentemente não traz à tona, nas propostas de ensino, considerações sobre os valores pessoais dos professores acerca do assunto, o que pode acabar fazendo com que tais valores sejam transmitidos sem a devida reflexão, guiando as decisões principais dos educadores, conforme evidenciado por um estudo de Bell e Lederman (2003, p. 367). Nele, os autores indicaram que professores universitários têm padrões de argumentação com ênfase maior no que os autores denominam filosofia pessoal e compromissos subjetivos (isto é, valores pessoais, fatores relacionados à moralidade e considerações sociais) em detrimento de raciocínio baseado em evidências científicas. Se esse é um processo que ocorre com professores, seus alunos estariam tão ou mais sujeitos a ele, tendo em vista o papel do professor na educação científica. Não que a transmissão de valores seja um problema para o ensino de ciências, mas a perspectiva da reprodutibilidade técnica pode acabar fazendo com que os valores sejam subaproveitados e ocultados na educação científica. Por isso, faz-se mister repensar como valores vêm a ser aprendidos num contexto de ensino. 
Congruentes com a perspectiva de evidenciar os valores no ensino de ciências, o uso de QSC é uma estratégia pedagógica que busca conectar ciência, tecnologia, sociedade e ambiente para promover letramento ${ }^{3}$ científico. As QSC sugerem mudanças no panorama do objetivo do ensino das ciências, que passa a abranger mais do que o ensino de conteúdo conceitual (por exemplo, aprender conceitos de psicologia) como objetivo final para mudanças conceituais, procedimentais e atitudinais do estudante de ciências. Essas mudanças atitudinais visam, em última instância, promover o desenvolvimento cognitivo e moral do aluno (ZEIDLER et al., 2005, p. 361), e isto envolve não só o aprendizado de conteúdos conceituais, mas também a capacidade de pensar criticamente, avaliar impactos para a tomada de decisão e construir valores pessoais congruentes com o contexto do aluno. Esses objetivos podem ser alcançados através da discussão de problemas dilemáticos socialmente relevantes, mas que não tenham que atender a um padrão único de respostas corretas. Com isso, é possível haver, também, "[...] o crescimento psicológico, social e emocional [...]” (ZEIDLER; KEEFER, 2003, p. 12) do aluno.

Existem várias formas de se propor uma QSC; entretanto, propõe-se aqui uma QSC baseada em uma formulação de caso, conforme proposto por Keefer (2003, p. 253), que envolve:

- identificar os dilemas morais;

- identificar o conhecimento relevante e fatos desconhecidos num problema;

- oferecer uma resolução;

- prover uma justificativa;

- considerar cenários alternativos que argumentem conclusões diferentes;

- identificar e avaliar consequências morais;

- oferecer uma resolução alternativa.

O caso em questão se chama o "Caso Fernando", que é uma história sobre um pai que pede ajuda a seu filho, estudante do curso de Psicologia numa disciplina de AC, para tratar de sua dificuldade em parar de tomar seus medicamentos psiquiátricos (isto é, antidepressivo, tranquilizante e hipnótico). A partir da discussão e da análise do caso na disciplina, espera-se que os alunos alcancem os objetivos da aprendizagem (ZABALA, 1998): conceituais (neste caso, conceitos específicos de AC); procedimentais (isto é, habilidades e competências do aluno) e, por último, atitudinais, que en-

3 Para os propósitos deste capítulo, será utilizado o termo "letramento" ao invés de "alfabetização". Enquanto alfabetização envolve mudanças no repertório de conhecimentos do sujeito, letramento envolve, além disso, a capacidade de utilizar socialmente esse conhecimento, isto é, compreendê-lo conceitualmente a fim de produzir explicações úteis de fenômenos. Para maiores informações sobre essa distinção, consultar Santos (2007). 
volvem ser crítico em relação à ciência (neste caso, AC e psicologia) e ser proativo na identificação de problemas sociais, bem como possuir autonomia no levantamento de ferramentas para resolvê-los.

\section{Análise do Comportamento}

A AC é uma disciplina científica que estuda o comportamento humano complexo a partir de uma perspectiva contextualista. Nesta perspectiva, o comportamento humano só pode ser compreendido a partir da interação entre o sujeito que se comporta e o ambiente físico e social com o qual ele interage. Os analistas do comportamento compreendem que uma caracterização correta das causas do comportamento humano deve considerar três níveis de seleção, a saber: a) filogenético; b) ontogenético; c) cultural. (SKINNER, 1981) O primeiro nível de seleção, a filogênese, remonta à história evolutiva da espécie e responde pela seleção natural, através da qual repertórios comportamentais compartilhados pela espécie, que evoluíram em interação com o ambiente ao longo de milhares de anos, foram selecionados. Um segundo nível de seleção é a ontogênese. Aqui, as consequências do comportamento operam sobre o sujeito do comportamento através de processos como o condicionamento operante e o condicionamento reflexo. Estes processos são centrais na investigação sobre as causas do comportamento, pois descrevem de que maneira um sujeito vem a adquirir repertório comportamental, podendo, assim, agir sobre o seu ambiente atual ao longo de sua história de vida. Finalmente, um terceiro nível de seleção, discutido pela análise do comportamento, é o cultural. O comportamento humano está inserido em um contexto verbal que permite a organização de contingências especiais destinadas a ensinar os indivíduos, ao longo de uma vida, comportamentos que ele não poderia aprender somente a partir da sua experiência direta. $\mathrm{O}$ ensino de ciências constitui um bom exemplo de como uma cultura pode ensinar indivíduos através da linguagem a operar com sucesso sobre o ambiente. Neste ambiente de ensino formal, o típico aluno de ciências adquire um conjunto de competências em sala de aula, a partir de interações verbais e não verbais, sem que, necessariamente, aprenda em contato direto com o contexto sobre o qual está sendo ensinado.

Quando perguntado sobre as causas do comportamento, o analista do comportamento deve considerar estes três níveis de seleção, irredutíveis um ao outro e interativos entre si. Os analistas do comportamento argumentam que uma investigação causal sobre o comportamento humano complexo que aponte somente para um destes três níveis de seleção constitui um reducionismo. (CARVALHO NETO et al., 2003)

Enquanto ciência, a AC dirigiu importantes críticas às psicologias mentalistas,

que apontam para entidades e processos internos na investigação sobre as causas do comportamento. (SKINNER, 2009) Há relativo consenso na AC de que o mentalismo consiste numa estratégia problemática em uma análise científica do comportamen- 
to, uma vez que os processos e entidades referidos como causa do comportamento em perspectivas mentalistas não podem ser claramente explicados e investigados. (MATOS, 1993) Uma segunda objeção, levantada a explicações mentalistas sobre o comportamento humano, é de que perspectivas mentalistas, ao encerrarem no indivíduo as causas de seu comportamento, obscurecem as variáveis contextuais das quais o comportamento é função, reforçando uma imagem sem história e descontextualizada de indivíduo. (SKINNER, 2003) Na análise de problemas sociais complexos, como a medicalização, especificar as causas de um diagnóstico como o déficit de atenção somente observando sintomas individuais, por um lado, encerra o debate sobre o contexto mais amplo em que o diagnóstico foi formulado, tal como o referido na introdução deste texto, e, por outro, reforça a ideia de que a terapêutica deve ser dirigida ao indivíduo, particularmente à supressão dos sintomas, o que fortalece o uso de estratégias farmacológicas.

\section{Medicalização no ensino de psicologia e questões sociais}

O fenômeno da medicalização mobiliza diversas áreas do conhecimento, tais como medicina, biologia, sociologia e psicologia. Enquanto fenômeno social, está para além do aumento quantitativo de diagnósticos e uso de psicofármacos. Como argumentado neste capítulo, a medicalização é um fenômeno que reflete uma cultura que busca no indivíduo as causas de seu comportamento. O estudante de psicologia será desafiado em sua formação a compreender a medicalização como um fenômeno complexo com o qual o profissional de saúde frequentemente lidará. Partindo desta premissa, consideramos que o ensino de AC deve estar comprometido com uma compreensão ampla da medicalização, contemplando as dimensões éticas e políticas deste fenômeno social.

Até a década de 1990, a psicoterapia analítico-comportamental estava mais explicitamente centrada nos modelos de comportamento operante e de comportamento respondente. $\mathrm{O}$ aluno de $\mathrm{AC}$ que conhecesse o contexto experimental no qual esses modelos foram desenvolvidos, os princípios filosóficos subjacentes a uma ciência do comportamento humano e o uso dos modelos operante e respondente para a compreensão de fenômenos humanos, como a cognição e a subjetividade, teria completado a sua formação em AC no nível de graduação. Nas duas últimas décadas, tanto alguns aspectos da teoria quanto a prática das psicoterapias de orientação analítico comportamental passaram por profundas mudanças. (HAYES et al., 2003) As investigações sobre cognição ensejaram o desenvolvimento de uma nova teoria sobre a linguagem, ${ }^{4}$ o que por sua vez, resultou no surgimento de modelos terapêuticos que,

4 A Teoria das Molduras Relacionais (RFT) é uma abordagem analítico comportamental sobre a cognição e a linguagem. As pesquisas em RFT permitiram uma melhor definição do comportamento 
vieram a ser reunidos sob o nome de terceira onda de terapias comportamentais. Estes novos modelos de psicoterapia apontam para áreas de trabalho que até então estavam fora da tradição psicoterápica de orientação comportamental, tais como valores, aceitação e cidadania. As psicoterapias da terceira onda apresentam métodos que são mais experienciais do que baseados em regras verbais (HAYES et al., 2003), ganhando relevo no ensino de AC por permitirem um entendimento mais profundo e contextual de fenômenos humanos que precisam ser evidenciados em problemas como a medicalização da vida.

Dado este recente pluralismo metodológico que se apresenta nas ciências do comportamento e a complexidade dos fenômenos contemporâneos que são apresentados para o analista do comportamento, o aluno de AC precisa ir além da mera aquisição de informações científicas, construindo um entendimento autônomo da realidade que o cerca. ${ }^{5}$ Isto quer dizer que objetivos conceituais propostos a partir da análise do comportamento enquanto teoria, ainda que sejam necessários, são insuficientes para a atuação diante de problemas como a medicalização. O aluno deve não só entender, mas também ser capaz de refletir criticamente e se posicionar a respeito dos dilemas e problemas que se colocam quando o comportamento humano é pensado no contexto de fenômenos como a medicalização. O modelo de seleção pelas consequências, proposto por Skinner (1981), já assume que a investigação sobre as causas do comportamento empreendida pela $\mathrm{AC}$ não pode ser reduzida à causalidade biológica, e este é um princípio que deve orientar o aluno de $\mathrm{AC}$ a entender o fenômeno da medicalização em um contexto mais amplo. A AC enfrenta, portanto, desafios sociais, tais como a discussão acerca da diversidade de fenômenos como a medicalização a partir de uma perspectiva não reducionista. Em consistência com esse desafio, a didática de ensino dessa disciplina científica deve ser repensada.

\section{Uma QSC sobre a medicalização da vida}

O "Caso Fernando" foi elaborado para servir de mobilização dos conteúdos da disciplina Teorias e Sistemas: Comportamental, para o quarto semestre do curso de Psicologia de uma faculdade do ensino privado. Essa disciplina apresenta a análise do comportamento, enquanto disciplina científica, e o behaviorismo radical, enquanto

verbal e um avanço na compreensão científica sobre os efeitos da cognição e linguagem sobre a experiência humana. (HAYES et al., 2003)

5 A expressão "entendimento autônomo" se refere a um valor epistêmico que habilita o indivíduo a integrar as diversas partes de um sistema cognitivo examinado a partir de um posicionamento pessoal crítico. Neste sentido, opõe-se à disposição pessoal de examinar apenas objetos discretos, desvinculados de seu contexto mais amplo, e de reproduzir acriticamente os objetos examinados. (FERREIRA, 2015) 
sistema filosófico que a fundamenta. ${ }^{6}$ Para essa disciplina, a QSC foi planejada como mobilizadora e organizadora dos conteúdos conceituais, procedimentais e atitudinais que foram considerados objetivos de aprendizagem. Para além dessa dupla função, a QSC também originou conteúdos que não são tradicionalmente ensinados nessa disciplina, como reflexões sociais mais amplas e sua relação com a análise do comportamento em geral.

Não obstante sua construção original ter sido realizada no contexto do ensino de psicologia, a QSC apresentada neste capítulo pode ser utilizada em salas de aula de cursos de saúde (exemplo, biologia, medicina, farmácia) ou de outras áreas que possuam uma interface com a temática (exemplo, sociologia). As questões que envolvem a medicalização da vida são amplas o bastante para permitir que áreas distintas possam interagir em uma interdisciplinaridade produtiva para o ensino e aprendizagem. Neste sentido, o "Caso Fernando" (ver Quadro 1) foi construído de tal maneira que a interdisciplinaridade se faz necessária para ampla compreensão da situação descrita. (FERREIRA et al., 2016)

Este caso é inspirado no artigo "Você consegue viver sem drogas legais?", da jornalista Eliane Brum (2014). ${ }^{7}$ O "Caso Fernando" apresenta algumas características importantes para seu uso como uma QSC no ensino de ciências:

- Trata de uma questão que envolve tecnologia científica (ao menos, farmacêutica e psicoterapêutica) e uma questão social relevante;

- Envolve um dilema e, portanto, não apresenta uma resposta fechada para o aluno, permitindo sua reflexão crítica e produção de perspectiva autônoma;

- É amplo o bastante para que não se resuma à história de vida de um personagem, podendo ser pensado como um exemplo de histórias diversas que se organizam na cultura contemporânea.

6 O behaviorismo radical é a filosofia da ciência do comportamento, sistematizada por B. F. Skinner (1904-1990), que fundamenta a AC. O behaviorismo radical é considerado um dos três grandes sistemas (os outros dois grandes sistemas são a psicanálise e a gestalt) que, historicamente, nortearam a construção da psicologia. (MARX; HILLIX, 1978)

7 Como é característico de textos jornalísticos, o artigo de Brum (2014) apresenta posicionamentos acerca da medicalização da vida que representam a posição pessoal da autora. Na elaboração do "Caso Fernando", procuramos não inserir tais posicionamentos pessoais para que o aluno possa ter uma situação aberta para construir sua própria perspectiva acerca do caso. 
Quadro 1 - Caso sobre medicalização da vida

\section{Caso Fernando}

Leandro é um aluno do $3^{\circ}$ semestre de Psicologia da Faculdade Ruy Barbosa e procurou um grupo de alunos do $4^{\circ}$ semestre para que pudessem orientá-lo na resolução de um problema familiar. Este grupo de alunos da disciplina Teorias e Sistemas ouviu com atenção quando Leandro começou a relatar que o seu pai, Fernando, estava passando por algumas dificuldades. O que se segue é um resumo com as principais informações a respeito do pai de Leandro.

Fernando é casado com Maria, mãe do Leandro, há 15 anos. Hoje, com 40 anos de idade, Fernando é bem-sucedido financeiramente, muito reconhecido em seu meio profissional e sempre tem uma programação diferente no final de semana, porque possui uma boa rede de amigos que prezam muito por sua companhia. Fernando, aparentemente, é um homem realizado.

Mas, mesmo com tudo isso, Fernando toma Lexapro ${ }^{\mathrm{TM}}$ (um antidepressivo), Rivotri| ${ }^{\mathrm{TM}}$ (um ansiolítico, tranquilizante) e Stilnox ${ }^{\mathrm{TM}}$ (um hipnótico, indutor de sono).* A primeira vez que ele tomou um antidepressivo foi quando perdeu o seu pai (avô de Leandro) há 5 anos. Fernando foi acompanhado por um bom psiquiatra nesse período porque não conseguia sair de casa, o trabalho estava se acumulando e ele estava se isolando até mesmo da família. Como o psiquiatra entendeu que se tratava de um luto muito doloroso, receitou um antidepressivo para que essa fase pudesse ser superada e Fernando pudesse voltar a trabalhar. Com a ajuda do antidepressivo, depois de algumas semanas, ele voltou a produzir com a mesma qualidade de antes. Três meses depois da morte de quem amava, ele já voltara a ser o profissional produtivo de antes.

Enquanto tomava o medicamento, Fernando conseguiu produzir ainda mais do que antes no trabalho. Ele relata que se aprofundou ainda mais no trabalho como uma forma de não se concentrar tanto em sua perda e acabou por tornar-se ainda mais produtivo e reconhecido. Começou a ser ainda mais solicitado do que antes e ter uma agenda ainda mais agitada. Mas quando tentou - após um ano de uso da medicação - reduzir o antidepressivo, começou a experimentar algo que não conhecia: uma angústia muito forte, crises de ansiedade e uma dificuldade muito grande para dormir.

Fernando retornou ao psiquiatra e começou a tomar os medicamentos que hoje ainda utiliza: uma dosagem mais alta do antidepressivo, o ansiolítico e o indutor do sono. Ele voltou a ser produtivo, mas agora sofre de uma ansiedade controlada, perene e perturbadora. Ele percebe que está com um estilo de vida altamente produtivo - no trabalho -, mas escasso de momentos de tranquilidade e prazer subjetivo. Fernando teme a possibilidade de ter que aumentar a dose dos medicamentos daqui a algum tempo. Nesse ponto, começou a perguntar a seu filho, Leandro, se na faculdade de psicologia ele havia aprendido algo que pudesse ajudá-lo.

É nesse contexto que Leandro pede ajuda para o grupo do $4^{\circ}$ semestre, solicitando principalmente que o ajudem a entender o que está acontecendo com seu pai e como ajudá-lo a decidir se deve ou não tentar retirar os medicamentos.

Fonte: adaptado de Ferreira e colaboradores (2016).

* Assim como Brum (2014, p. 254), citamos os nomes dos remédios porque tais psicofármacos (bem como uma grande quantidade de outros) se tornaram comuns o bastante para se tornarem populares. Citando diretamente a autora: "[...] o fato de nomes tão esquisitos estarem na boca de todos quer dizer alguma coisa sobre o nosso tempo".

A partir da leitura do caso, são apresentados 11 questionamentos iniciais. Esses questionamentos são gerais, como se espera de uma disciplina de quarto semestre, mas podem ser modificados pelo interesse dos alunos ao longo das discussões, assim como pelo contexto de aplicação (a depender de se está no ensino médio, superior ou pós-graduação, em que curso etc.). Os principais questionamentos que emergem do "Caso Fernando" e que guiam a disciplina são: 
Q1. A causa dos sentimentos e pensamentos é fisiológica? Ou de outra natureza (psicológica, ambiental etc.)?

Q2. Quais os efeitos de uma medicação psiquiátrica? Quais os efeitos que a população média espera para o uso do medicamento?

Q3. Qual o papel da genética nos transtornos psicopatológicos?

Q4. Como a AC lida com os eventos privados que Fernando descreve?

Q5. Qual o papel psicológico que o diagnóstico exerce sobre o sujeito? Como o entendimento do comportamento verbal é importante nesta questão?

Q6. Como o modelo de seleção pelas consequências pode explicar os efeitos da retirada e consequente retomada da medicação em Fernando?

Q7. Como orientar Fernando, a partir da AC, para evitar a dependência da medicação?

Q8. Quais as possibilidades de intervenção que a AC pode desenvolver na situação de Fernando?

Q9. Como os analistas do comportamento podem atuar na promoção de uma qualidade de vida que não dependa da indústria farmacêutica?

Q10. Que dimensões éticas e políticas (incluindo valores e interesses) se podem reconhecer nas relações complexas estabelecidas entre: a) as ciências da saúde e do comportamento; b) as indústrias farmacêuticas, os medicamentos e as tecnologias que os produzem; c) a sociedade como um todo, incluindo as condições que influenciam o consumo de medicamentos; d) o ambiente natural?

Q11. Em particular, em que condições os benefícios de tratamentos medicamentosos, como o relatado no caso, superam os seus custos sociais e ambientais, como, por exemplo, as consequências do aumento de produtos dispostos em ambientes naturais (advindos de medicamentos não utilizados ou utilizados e excretados por humanos)?

A partir da discussão inicial com os alunos sobre o caso e sobre os questionamentos, os objetivos de aprendizagem podem ser apresentados e discutidos. Aqui, apresentamos alguns objetivos de aprendizagem, construídos especificamente no contexto da disciplina de Teorias e Sistemas: Comportamental (Quadro 2). 
Quadro 2 - Objetivos de aprendizagem relacionados ao caso
Conceituais
1. Causalidade e análise do comportamento humano;
2. Eventos privados e ciência do comportamento;
3. Genética, fisiologia e comportamento;
4. Modelo de seleção pelas consequências;
5. Comportamento operante e comportamento respondente;
6. Comportamento verbal e controle por regras.

"Ao final da disciplina, o aluno será capaz de descrever e discutir criticamente sobre..."

\section{Procedimentais}

"Ao final da disciplina, o aluno será capaz de..."

1. Identificar e descrever variáveis significativas para uma análise funcional do comportamento em estudos de caso;

2. Analisar comportamento humano de maneira contextualizada a partir de uma perspectiva analítico-comportamental;

3. Pesquisar literatura adequada para a resolução de questões comportamentais a partir da utilização de bancos de dados científicos;

4. Discriminar entre explicações analítico-funcionais e explicações mentalistas.

\section{Atitudinais}

"Ao final da disciplina, o aluno será capaz de..."

1. Possuir atitude crítica em relação às demandas psicológicas, a partir de um exame do contexto social e político em que ocorrem;

2. Ser autônomo para avaliar os limites e as possibilidades da empreitada científica na resolução de problemas humanos;

3. Possuir e agir conforme valores que envolvam trabalho em equipe, promovendo uma atuação em uníssono;

4. Refletir criticamente em relação à indústria, em geral, e sua influência na subjetividade humana;

5. Analisar criticamente, em uma perspectiva ética, as relações de poder existentes entre medicina e psicologia;

6. Possuir atitude crítica em relação aos valores de produtividade capitalista na construção da subjetividade humana;

7. Promover ações para a discussão com a comunidade que envolvam a temática da disciplina e soluções alternativas para o dilema.

Fonte: adaptado de Ferreira e colaboradores (2016).

Sugerimos algumas estratégias para a resolução da QSC, visando a consecução de tais objetivos de aprendizagem: 
a. Discussão de textos: a partir do tema da aula, ${ }^{8}$ dois grupos de alunos ficam responsáveis por localizar textos nos bancos de dados científicos apropriados, enviando previamente para os outros alunos, e guiar a discussão da aula. A escolha dos textos é mediada a partir de conversas com os monitores da disciplina e através do fórum online com o professor;

b. Workshop sobre construção de argumentação científica: a partir de textos e de exercícios de lógica básica, a construção de argumentos é discutida em sala de aula, contextualizada em exemplos sociais (por exemplo, debates políticos) ou conceituais (por exemplo, críticas à análise do comportamento feitas por autores de outras abordagens teóricas);

c. Estudo de caso: dois profissionais analistas do comportamento são convidados para apresentar estudos de caso clínico para os alunos, e o "Caso Fernando" é problematizado a partir das análises e intervenções propostas pelos apresentadores;

d. Entrevistas: os alunos, em grupos separados, realizam entrevistas com profissionais envolvidos na QSC (psicólogo, psiquiatra, farmacêutico etc.) e discutem os resultados da entrevista na disciplina.

Com essas estratégias pedagógicas, são discutidos os questionamentos relativos ao Caso Fernando. As estratégias a, b, d são parte da avaliação processual dos alunos (enquanto, na c, os alunos são avaliados em relação a sua participação na aula). A avaliação final ocorre como conclusão da disciplina: os grupos de alunos devem formular respostas para cada um dos questionamentos e apresentá-las para a turma oralmente. Com isto, espera-se que os conteúdos conceituais, procedimentais e atitudinais sejam integrados no enfrentamento crítico de questões que envolvem o aluno, a tecnologia científica, o ambiente e a sociedade.

\section{Considerações finais}

A utilização da QSC (a medicalização da vida, abordada aqui no "Caso Fernando") para o ensino introdutório de AC e behaviorismo radical cumpre algumas exigências bastante significativas para o momento atual de ensino. Primeiro, em se tratando de ensino de Psicologia em semestres iniciais, este método envolve a construção do pensamento crítico e autônomo do aluno para refletir sobre a sua própria realidade, inclusive a realidade de ensino de Psicologia em que ele está inserido diretamente. Ensinar a AC, a partir do exame crítico da relação entre ciência, tecnologia, ambiente e sociedade, implica empoderar o aluno de Psicologia para ser autônomo em relação à sua própria formação. Em segundo lugar, tratando-se de um contexto em que a AC está se tornando

8 Apesar de existir uma proposta inicial oferecida pelo professor para os temas das aulas, esta proposta pode ser modificada à medida em que os alunos percebam a necessidade de um novo tema para o entendimento do "Caso Fernando". 
cada vez mais plural em suas perspectivas, muitas delas concorrentes entre si, enfatizar a construção de uma perspectiva crítica pessoal do aluno em situações dilemáticas é uma necessidade para evitar a doutrinação do aluno e para a formação de um analista do comportamento reflexivo e produtivo no cenário brasileiro do comportamentalismo radical.

Por fim, mas não menos importante, estas estratégias têm por objetivo a produção de um ensino significativo para o aluno. A educação científica necessita ser realizada de tal forma que o aluno possa atribuir um sentido existencial para tudo aquilo que permeia a sua formação acadêmica. Ao mesmo tempo, parte importante do que atrai um professor de ciências para a carreira de sala de aula é a possibilidade de fazer diferença na vida dos alunos. Enclausurar aluno e professor em um processo educacional destituído de sentido para a vida comunitária é uma violência contra as motivações mais importantes para que a educação formal seja levada a bom termo. Em outras palavras, a utilização de QSC no ensino de AC parece dar um novo significado à expressão de Skinner (1978, p. 3): "Os homens agem sobre o mundo, modificam-no e, por sua vez, são modificados pelas consequências de sua ação".

Neste capítulo, apresentamos uma proposta para o ensino de ciências sobre o tema medicalização da vida, na forma de caso (Caso Fernando). Até o presente momento, foi realizada apenas uma pesquisa qualitativa acerca da utilização dessa proposta. Tal pesquisa indicou resultados promissores acerca do aprendizado de conteúdos conceituais, procedimentais e atitudinais em alunos de Psicologia a partir da sequência didática proposta no presente capítulo. (FERREIRA et al., 2016) Neste sentido, sugerimos que outras pesquisas empíricas sejam realizadas para verificação da efetividade dos procedimentos utilizados em relação aos objetivos de aprendizagem em outros contextos de ensino de ciências. Esta QSC não se aplica apenas ao ensino de AC, mas pode ser, com adaptações, utilizada em outros contextos de ensino de disciplinas da saúde em geral (psicologia, farmácia, medicina etc.) ou de áreas afins (por exemplo, sociologia). Apesar da necessidade de novas investigações, aplicações (sempre críticas) da QSC, aqui formulada na forma de caso, devem ser estimuladas. A medicalização da vida é um problema a ser enfrentado por toda sociedade e, mais especificamente, pelo ensino contextualizado de ciências. Que este capítulo sirva, então, como estímulo para novas experiências de ensino que sejam relevantes para alunos, professores e para a comunidade que os cerca.

\section{Referências}

AMERICAN PSYCHIATRIC ASSOCIATION. Diagnostic And Statistical Manual Of Mental Disorders. $3^{\text {rd }}$. Washington: Arlington, 1987.

AMERICAN PSYCHIATRIC ASSOCIATION. Diagnostic And Statistical Manual of Mental Disorders. $4^{\text {th }}$. Washington: Arlington, 1994. 
BELL, R. L.; LEDERMAN, N. G. Understandings of the nature of science and decision making on science and technology based issues. Science Education, New York, v. 87, n. 3, p. 352-377, 2003.

BRUM, E. A menina quebrada. Porto Alegre: Arquipélago Editorial, 2014.

BRZOZOWSKI, F. S.; CAPONI, S. N. C. Medicalização dos desvios de comportamento na infância: aspectos positivos e negativos. Psicologia: Ciência e Profissão, Brasília, DF, v. 33, n. 1, p. 208-221, 2013.

CALADO, V. A. Estágio em psicologia escolar e educacional: ruptura com a medicalização da educação. Psicologia Escolar e Educacional, Campinas, v. 18, n. 3, p. 567-569, dez. 2014.

CARVALHO NETO, M. B. et al. O projeto Genoma Humano e os perigos do determinismo reducionista biológico na explicação do comportamento: uma análise Behaviorista Radical. Revista Brasileira de Terapia Comportamental e Cognitiva, São Paulo, v. 5, n. 1, p. 41-56, jun. 2003.

CONSELHO FEDERAL DE PSICOLOGIA - CFP. Subsídios para a campanha: não à medicalização da vida - medicalização da educação. Brasília, DF, 2012. Disponível em: <http://site.cfp.org.br/wp-content/uploads/2012/07/Caderno_AF.pdf>. Acesso em: 16 jan. 2015.

FARAONE, S. et al. Discurso médico y estrategias de marketing de la industria farmacéutica en los procesos de medicación de la infancia en Argentina. Interface, Botucatu, v. 14, n. 34, set. 2010. Disponível em: <http://www.redalyc.org/home.oa>. Acesso em: 18 mar. 2015.

FERREIRA, T. A. S. Entendimento, conhecimento e autonomia: virtudes intelectuais e o objetivo do ensino de ciências. 2015. 126 f. Tese (Doutorado em Ensino, História e Filosofia das Ciências) - Instituto de Física, Universidade Federal da Bahia, Salvador 2015.

FERREIRA, T. A. S. et al. Ensino de Análise do Comportamento com o uso de Questões Sociocientíficas: um caso sobre a medicalização da vida. Indagatio Didactica, Aveiro, v. 8, n. 1, p. 1481-1497, jul. 2016.

FIGUEIRA, P. L.; CALIMAN, L. V. Considerações sobre os movimentos de medicalização da vida. Psicologia Clínica, Rio de Janeiro, v. 26, n. 2, p. 17-32, 2014.

HAYES, S. et al. Acceptance and commitment therapy: een derde-generatie drags therapie. Gedragstherapie, [S.1.], v. 2, p. 69-96, 2003.

KEEFER, M. W. Moral reasoning and case-based approaches to ethical instruction in science. In: ZEIDLER, D. L. (Org.). The role of moral reasoning on socioscientific issues and discourse in science education. Dordrecht: Kluwer Academic Press, 2003. p. 241259.

LEMOS, F. C. S. A medicalização da educação e da resistência no presente: disciplina, biopolítica e segurança. Psicologia Escolar e Educacional, Campinas, v. 18, n. 3, p. 485492, dez. 2014. 
MARX, M.; HILLIX, W. Sistemas e teorias em psicologia. São Paulo: Cultrix, 1978.

MATOS, M. A. O behaviorismo metodológico e suas relações com o mentalismo e o behaviorismo radical. Apresentado no II Encontro Brasileiro de Psicoterapia e Medicina Comportamental, Campinas, out. 1993. Disponível em: <http://www.itcrcampinas. com.br/txt/behaviorismometodologico.pdf>. Acesso em: 21 jun. 2015.

MEIRA, M. E. M. Para uma crítica da medicalização na educação. Psicologia Escolar e Educacional, Campinas, v. 16, n. 1, p. 135-142, 2012.

OLIVA, M. P. Colgados de los ansiolíticos. El País, Madrid, set. 2014. Seção Sociedad. Disponível em: <http://elpais.com/tag/sociedad/a/>. Acesso em: 18 mar. 2015.

PETRINA, S. The medicalization of education: a historiographic synthesis. History of Education Quarterly, Bloomington, v. 46, n. 4, p. 503-531, 2006.

SANTOS, W. L. P. dos. Educação científica na perspectiva de letramento como prática social: funções, princípios e desafios. Revista Brasileira de Educação, Rio de Janeiro, v. 12, n. 36, p. 474-492, 2007. Disponível em: <http://dx.doi.org/10.1590/S141324782007000300007>. Acesso em: 12 jun. 2015.

SKINNER, B. F. Ciência e comportamento humano. São Paulo: Martins Fontes, 2003.

SKINNER, B. F. O comportamento verbal. São Paulo: Cultrix, 1978.

SKINNER, B. F. Sobre o behaviorismo. São Paulo: Cultrix, 2009.

SKINNER, B. F. Selection by consequences. Science, Washington, v. 213, n. 4507, p. 501-504, jul. 1981.

TIMIMI, S. et al. A critique of the international consensus statement on ADHD. Clinical Child and Family Psychology Review, [S.1.], v. 7, n. 1, p. 59-63, 2004.

TIMIMI, S. The McDonaldization of childhood: children's mental health in neoliberal market cultures. Transcultural Psychiatry, London, v. 47, n. 5, p. 686-706, 2010. Disponível em: <http://www.ncbi.nlm.nih.gov/>. Acesso em: 31 mar. 2015.

ZABALA, A. A prática educativa: como ensinar. Porto Alegre: Artmed, 1998.

ZEIDLER, D. L. et al. Beyond STS: A research-based framework for socioscientific issues education. Science education, New York, v. 89, n. 3, p. 357-377, maio 2005.

ZEIDLER, D. L.; KEEFER, M. The role of moral reasoning and the status of socioscientific issues in science education: philosophical, psychological and pedagogical considerations. In: ZEIDLER, D. L. (Ed.). The role of moral reasoning on socioscientific issues and discourse in science education. Dordrecht: Kluwer Academic Press, 2003. p. 7-38. 


\title{
DOPING GENÉTICO UMA QUESTÃO SOCIOCIENTÍFICA PARA O ENSINO SUPERIOR
}

\author{
Shirley Margareth Buffon da Silva
}

\section{Introdução}

Em pouco mais de meio século, o conhecimento genético passou por grandes avanços, como o sequenciamento do genoma humano e de diversas outras espécies; a produção de insulina e hormônio de crescimento, utilizando a técnica do DNA (ácido desoxirribonucleico) recombinante; a caracterização de diversas enfermidades hereditárias e a detecção de suscetibilidades genéticas para o desenvolvimento de enfermidades comuns não transmissíveis, como o câncer, as doenças cardiovasculares, o diabetes e as enfermidades mentais. (PENCHASZADEH, 2012)

Como um dos resultados desse avanço, foi desenvolvida a técnica de terapia gênica, que consiste na transferência de material genético para células-alvo com o objetivo de suprir os produtos de um gene estruturalmente anormal no genoma ${ }^{1}$ de uma pessoa. (SANTAMARIA et al., 2013)

Vale ressaltar que esse tipo de terapia ainda se encontra em fase experimental e requer uma regulamentação pautada por critérios éticos presentes em outras terapias

1 Genoma é toda a informação hereditária de um organismo que está codificada em seu DNA (ou, em alguns vírus, no RNA). 
médicas, além de uma avaliação de riscos e benefícios suficientemente positiva para que possa ser aplicada.

Devido às perspectivas de tratamento de doenças para as quais não existem melhores alternativas (como, por exemplo, câncer, amaurose congênita de Leber, $\beta$-talassemia, imunodeficiência combinada grave ligada ao $\mathrm{X}$, hemofilia $\mathrm{B}$, síndrome de Wiskott-Aldrich, deficiência de lipoproteína lipase grave, doenças cardiovasculares, doenças infecciosas, neurológicas, oculares, inflamatórias), a terapia gênica não encontra dificuldade para ser considerada legítima. Ressalve-se, entretanto, que essa técnica pode ser utilizada não apenas com finalidade terapêutica, mas também com objetivo de melhoramento ou aprimoramento genético que se baseia apenas na modificação e no aperfeiçoamento de fenótipos ${ }^{2}$ normais. (BENTO, 2008; COELHO, 2012; WIRTH; PARKER; YLÄ-HERTTUALA, 2013)

O uso da terapia gênica com esse objetivo suscita questões de ordem moral e ética. Bento (2008, p. 188) afirma que "[...] uma terapia que tentasse um caminho de melhoramento da genética humana deixaria de ser uma terapia, [...] mas tratar-se-ia de um eugenismo, ${ }^{3}$ com riscos incontroláveis para as gerações futuras”.

Recentemente, o potencial para uso indevido da terapia gênica entre atletas tem despertado a atenção de cientistas e de órgãos reguladores de esporte. A transferência de genes que poderiam melhorar o desempenho esportivo de atletas saudáveis, técnica proibida em 2003, pela Agência Mundial Antidoping (AMA), ${ }^{4}$ foi denominada doping genético. (HAISMA; HON, 2006)

Uma vez inserido no genoma do atleta, o gene de interesse poderia expressar um produto endógeno capaz de melhorar o desempenho atlético que os métodos atuais de detecção de doping não são capazes de identificar, o que poderia estimular seu uso indevido entre atletas. (QUEIROZ; ALVES, 2012)

Com essa QSC, é possível discutir conteúdos sobre hereditariedade, DNA, transcrição, tradução, melhoramento genético, fisiologia do esporte, bem como suscitar um debate sobre as dimensões éticas de tais conteúdos aplicados a esse contexto. Nesse sentido, nosso propósito é apresentar um dilema sobre terapia gênica, discutindo meios para sua aplicação no ensino de ciências.

Este capítulo encontra-se dividido em quatro partes: a primeira apresenta um breve panorama sobre a terapia gênica, o doping genético e as questões de ordem moral e ética; a segunda trata das QSC como ferramenta para o desenvolvimento moral; a terceira

2 Fenótipo representa as características observáveis ou caracteres de um organismo ou população, como, por exemplo: morfologia, desenvolvimento, propriedades bioquímicas ou fisiológicas e comportamento.

3 Eugenismo: sistema de ideias ou doutrina que tem como base a eugenia, o aprimoramento genético do ser humano. O movimento eugenista esteve presente na Europa e nas Américas, inclusive no Brasil, no início do século XIX.

4 World Anti-Doping Agency (Wada). 
traz uma proposta de ensino baseada em QSC sobre o doping genético, objetivos e meios para discussão; e a quarta trata das considerações finais e implicações deste trabalho.

\section{Terapia gênica, doping genético e suas relações}

A terapia gênica pode ser caracterizada como a transferência de material genético para células-alvo com o objetivo de tratamento ou prevenção de uma doença. Os materiais genéticos podem ser DNA, RNA (ácido ribonucleico) ou células geneticamente alteradas. O material genético inserido nas células de um indivíduo pode gerar a forma funcional de uma proteína que, devido a alterações estruturais no seu gene, é produzida em pequenas quantidades ou sem atividade biológica. Com essa técnica, também é possível regular a expressão de outros genes, ativá-los ou inativá-los. (HAISMA; HON, 2006)

Wirth, Parker e Ylä-Herttuala (2013) relatam que teriam sido realizados mais de 1.800 ensaios clínicos de terapia gênica em todo o mundo. Dos ensaios clínicos em curso no mundo, o câncer é a doença mais tratada, alcançando porcentagem superior a $60 \%$; ele é seguido por doenças cardiovasculares e doenças monogênicas. ${ }^{5}$

O gene de interesse pode ser introduzido na célula-alvo das seguintes maneiras:

- in vivo: envolve a introdução direta do gene alvo no interior do corpo por via biológica (vetores virais), químicas (lipossomas) e/ou métodos físicos (injeção direta utilizando uma seringa ou pistola de genes); e

- ex vivo: no qual células do próprio paciente são retiradas por meio de biópsia, modificadas geneticamente e reintroduzidas no paciente. (SANTAMARIA et al., 2013)

Vetores virais derivados de retrovírus, adenovírus e lentivírus são os mais comuns, e para serem utilizados são submetidos a várias alterações genéticas, com a retirada ou inativação dos genes que lhes conferem virulência. Assim, ao se ligarem e entrarem na célula-alvo, os vetores virais injetam seu material genético contendo o gene terapêutico no DNA do paciente, possibilitando a transcrição e a tradução do gene para sua proteína funcional correspondente, ou então, utilizam a maquinaria molecular da célula hospedeira para expressar seus genes. (AZZAZY; MANSOUR; CHRISTENSON, 2009)

Segundo Haisma e Hon (2006), a expressão da proteína de interesse depende da natureza do promotor e do vetor utilizado na introdução do gene, podendo ser de curta duração (dias/semanas) ou de longa duração (semanas/anos). A proteína expressa pode ficar confinada à célula-alvo ou, se for uma proteína segregada, pode migrar a partir da célula para o tecido circundante ou para a circulação.

5 Doenças monogênicas são doenças hereditárias causadas por uma mutação ou alteração na sequência de DNA de um único gene. 
A terapia gênica pode ser classificada em duas categorias: terapia gênica somática e terapia gênica germinal. A diferença entre essas duas abordagens é que, na terapia gênica somática, o material genético é introduzido em células somáticas (todas as células do corpo, exceto as sexuais) e a alteração não é passada para as próximas gerações, afetando apenas o indivíduo em tratamento. Entretanto, caso a terapia gênica seja realizada em células da linhagem germinal (células sexuais e as que constituem a base da sua formação), o gene terapêutico será transmitido aos descendentes do paciente. (WIRTH; PARKER; YLÄ-HERTTUALA, 2013)

A Lista de Substâncias e Métodos Proibidos da AMA (2004, p. 6) já definia doping genético como "uso não terapêutico de genes, elementos genéticos e/ou células que têm a capacidade de melhorar o desempenho atlético". Em 2015, após revisão, a denominação doping genético ficou definida pela mesma agência como "a transferência de ácidos nucleicos ou seus análogos nas células e a utilização de células geneticamente modificadas". (WADA/AMA, 2015, p. 7)

Os produtos gênicos mais importantes para doping genético são: eritropoietina (aumenta a produção de hemácias, de modo que a capacidade de transporte de $\mathrm{O}_{2}$ para os tecidos fica aumentada), bloqueadores da miostatina (regulador negativo da hipertrofia muscular), fator de crescimento endotelial vascular (VEFG) (crescimento do endotélio vascular, na angiogênese e na vasculogênese), fator de crescimento semelhante a insulina (IGF-1) e hormônio de crescimento $(\mathrm{GH})$ (aumento da síntese proteica na musculatura esquelética), leptina (controle da sensação de fome e saciedade, redução do consumo alimentar e, consequente, perda de peso), endorfinas e encefalinas (diminuição da sensação de dor) e receptor ativado por proliferador de peroxissomo delta (PPAR $\Delta$ ) (diminui a quantidade de tecido adiposo, reduz o peso corporal e aumenta a termogênese). (ARTIOLI; HIRATA; LANCHA JUNIOR, 2007) Na Figura 1, podemos visualizar os principais alvos do doping genético.

A terapia gênica pode apresentar problemas conhecidos, por exemplo, a inserção do material transgênico em células não alvo ou de modificação genética em células da linhagem germinal com a possibilidade de transmissão do transgene aos descendentes, resposta inflamatória e falta de controle da ativação do gene de interesse. Em pessoas saudáveis, é provável que tais problemas sejam ainda mais importantes, já que haveria excesso do produto do gene transferido. (AZZAZY; MANSOUR; CHRISTENSON, 2009; FISCHETTO; BERMON, 2013)

Fischetto e Bermon (2013) relatam que, no caso do gene precursor da eritropoietina (EPO), a produção incontrolada de células vermelhas pode levar ao desenvolvimento de hipertensão, acidentes vasculares cerebrais ou cardíacos por policitemia secundária, anemia autoimune e aumento da vascularização de tumores não detectados. No caso dos genes GH e IGF-1, podem ocorrer acromegalia e desenvolvimento incontrolado do tecido conectivo em órgãos como fígado, coração e pulmão; também existe a possibilidade de valvulopatias, insuficiência cardíaca, apneia do sono, espessamento dos tecidos 
moles, espessamento da pele, Doença de Raynaud, hipertrofia muscular com os consequentes problemas osteoarticulares, além do potencial oncogênico desses hormônios.

Figura 1 - Tecidos e órgãos-alvo para o doping genético

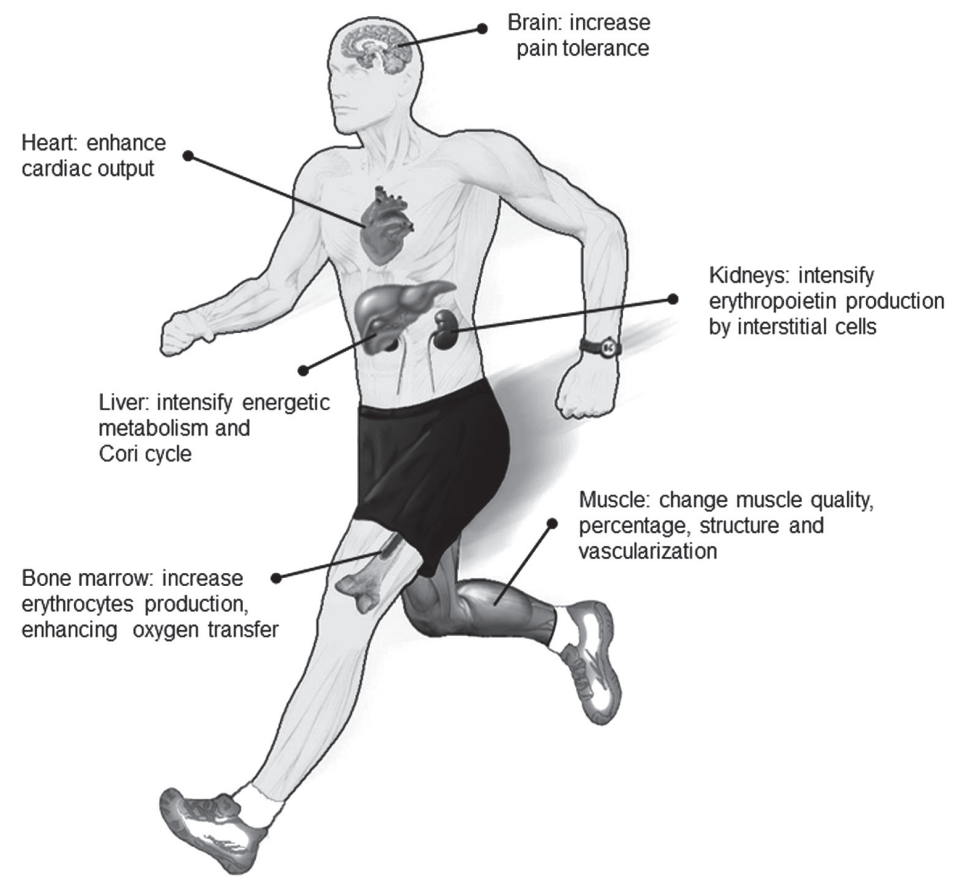

Em sentido anti-horário, são apresentados: (1) coração: aumento no débito cardíaco; (2) fígado: intensificação do metabolismo energético e do ciclo de Cori; (3) medula óssea: aumento da produção de eritrócitos e da transferência de oxigênio; (4) músculo: alteração da qualidade, estrutura e vascularização; (5) rins: aumento da síntese de eritropoietina pelas células intersticiais e (6) cérebro: aumento da tolerância à dor (tradução nossa, com alteração de esquema de cores).

Fonte: Oliveira e colaboradores (2011, p. 1195).

Segundo Artioli, Hirata e Lancha Junior (2007), apesar dos rigorosos controles em todas as etapas de preparação dos vírus geneticamente modificados, há possibilidade de contaminação com produtos químicos provenientes do processo de produção e purificação dos vírus. Existe o risco dos vírus provocarem respostas inflamatórias importantes no paciente. Outro problema relacionado ao vetor viral decorre da capacidade de mutação e replicação que ele poderia ter, principalmente se houver falhas em sua preparação. O autor também relata a possibilidade, embora pequena, de o gene ser introduzido erroneamente em células germinativas como um risco inerente ao procedimento.

A dificuldade de detecção do doping genético está associada ao fato de a proteína produzida pelo gene de interesse ou as células geneticamente manipuladas ser estrutu- 
ral e funcionalmente muito semelhante às proteínas endógenas. A maioria das proteínas transgênicas, especialmente as relacionadas ao aumento da força muscular, são produzidas localmente no músculo e podem ser indetectáveis no sangue ou na urina. Um dos métodos apontados como confiável seria uma biópsia do músculo, que dificilmente seria aceito pelos atletas por ser um método invasivo. (BRZEZIAŃSKA; DOMAŃSKA; JEGIER, 2014)

Quando tratamos das diversas finalidades ligadas à engenharia genética, a primeira e fundamental seria o tratamento de doenças graves utilizando a manipulação genética. No esporte, a terapia gênica constitui, ainda, uma possibilidade na recuperação de tecidos de baixa capacidade regenerativa, tais como tendões, cartilagens e músculos esqueléticos, facilitando a recuperação de rompimentos de ligamentos cruzados, meniscos, lesões em cartilagens e calcificação óssea tardia pela inserção de fatores de crescimento para estimular a cicatrização. (COELHO, 2012)

Entretanto, é possível que atletas saudáveis utilizem esse mesmo método em busca de um incremento do desempenho atlético, sendo difícil a distinção entre a terapia para a cura de doenças ou para o aprimoramento genético, o que exige uma reflexão acerca do significado moral da manipulação genética. (BENTO, 2008)

A história da genética humana está distante de ter sido harmoniosa e livre de conflitos. Assim como o conhecimento científico interfere na sociedade, as forças sociais externas também interferem no desenvolvimento da ciência, de forma que a genética não está isenta de conflitos com a sociedade, a política e as ideologias. (PENCHASZADEH, 2012)

Nesse contexto, afloram o determinismo e o reducionismo genético que Penchaszadeh (2004) aponta como ideologias prejudiciais. O determinismo genético se caracteriza pela ideia de que os traços humanos, determinados pelos genes, são pouco afetados por mudanças no ambiente físico e social. O reducionismo também considera que as variações nas características humanas são decorrentes, principalmente, dos genes e que estes são a explicação final para muitas características dos seres vivos. Dessa forma, essas ideologias têm produzido visões do ser humano que privilegiam o individual sobre o coletivo, o biológico sobre o sociocultural. Penchaszadeh (2012) ainda explica que, com o conhecimento genético disponível atualmente, chegamos à compreensão de que todas as características humanas não dependem unicamente da constituição genética, mas são o resultado das interações entre as circunstâncias físicas, biológicas, sociais, culturais e psicológicas as quais o indivíduo é exposto ao longo da vida. Portanto, esse contexto, influenciado pelo reducionismo genético em que se exagera o papel dos genes e as indústrias biotecnológica e farmacêutica são enaltecidas, constitui uma ameaça à equidade e ao direito à saúde.

Apesar da relevância, o tema em questão tem sido pouco explorado na educação científica/ensino de ciências. Esse fato pode ser observado em levantamento realizado 
na base de dados de referências e citações de literatura científica SCOPUS, utilizando os descritores gene doping e education, em que foram identificadas 11 referências, sendo que nenhuma na área de ensino de ciências e na pesquisa nessa área. Nesse sentido, percebemos que as discussões sobre o doping genético e suas implicações do ponto de vista da saúde, legal e ético adquirem grande importância.

\section{As Questões Sociocientíficas no ensino e o desenvolvimento moral}

Pesquisas da área de ensino de ciências têm apresentado evidências de que os processos de tomada de decisões envolvendo Questões Sociocientíficas (QSC) são guiados, além do conhecimento científico, por fatores sociais, morais e afetivos. ${ }^{6}$ De acordo com Sadler e Zeidler (2004), apoiados em Blair (1997), Nucci (2001), Tisak (1995), Turiel (1983) e Turiel e Smetana (1984), o conhecimento social e a tomada de decisão residem em um dos três domínios universais:

- convencional: está relacionado às questões que são resolvidas mais adequadamente com a aplicação de normas sociais previamente estabelecidas;

- pessoal: representa as decisões que estão sujeitas à escolha pessoal e de preferência de um indivíduo, por exemplo, o fato de determinados indivíduos optarem por adotar comportamentos veganos, a despeito da maioria da população adotar comportamentos especistas, evidenciando o domínio pessoal sobre uma ideologia ainda hegemônica;

- moral: é definido por prescrições universalmente reconhecidas com base em concepções do bem-estar humano, justiça e direitos. A ética é o campo da filosofia que fundamenta este último domínio.

Zeidler e Keefer (2003) apontam que as QSC, devido à sua natureza controversa, requerem a consideração de questões éticas e a elaboração de julgamentos morais sobre temas sociocientíficos. Para isso, é necessário aprender sobre ética. Mueller e Zeidler (2010) apoiam essa ideia, salientando que as decisões éticas são fundamentalmente necessárias para a participação mais efetiva em ações que afetam comunidades.

Com isso, constata-se que o conhecimento científico não representa o todo das questões. De acordo com Garvey (2010), a ciência explica os fatos, e não tudo o que se deve fazer a respeito dos problemas, isto, é tomar uma decisão e agir em concordância. É neste ponto que recorremos também aos nossos valores, inescapavelmente.

6 Ver, por exemplo, Bell e Lederman (2003), Sadler e Fowler (2006) e Walker e Zeidler (2007). 
Segundo Callado Moreno (2012), todas as ações humanas são orientadas consciente ou inconscientemente por valores, que são projetos ideais que supõem a eleição de determinadas opções como desejáveis e apreciáveis.

Nesse contexto, compreendemos que a tomada de decisão em QSC implica o ato de escolher entre uma ou mais alternativas muitas vezes conflitantes, emergindo aí o elemento valorativo presente nos juízos de valor, estes que, por sua vez, se apoiam nos princípios morais do indivíduo e da sociedade.

Consideramos, neste capítulo, a apresentação de um dilema sociocientífico que envolve tomada de decisão e, portanto, que inclui o raciocínio moral.

Uma QSC sobre o tema doping genético envolve a análise de custo-benefício, a qual remete à consideração dos riscos que interagem com os valores, e estes se apoiam no raciocínio moral. Tais aspectos devem ser levados em conta por aqueles que desejam alcançar um desempenho superior no esporte, além de realizar considerações sobre o uso da engenharia genética para o aperfeiçoamento de características fenotípicas normais.

Estudos têm demonstrado que os valores morais não são inatos nem hereditários, eles se formam e se desenvolvem em função de um complexo sistema de atividades, influências e interações no transcorrer da vida do indivíduo. (REY, 1983; REY; MARTíNEZ, 1989)

Neste sentido, Rey e Martínez (1989) afirmam que o desenvolvimento da esfera moral humana não pode ser atingido somente pelas normas e informações sobre as quais atuam as organizações e instituições sociais. A moralidade é um processo racional, cognoscitivo e afetivo em que seus determinantes atuam por múltiplos canais sobre a individualidade. Dessa forma, a educação moral possui um caráter ativo, cujos conteúdos não podem ser impostos ao indivíduo, mas podem auxiliá-lo na reflexão sobre os valores morais; e sistêmico, no qual todas as organizações e instituições da sociedade são agentes da educação moral.

A educação moral tem sido apontada como imprescindível à formação do cidadão, pois muitos são os problemas derivados das rápidas mudanças que as sociedades estão sofrendo (a exemplo dos problemas sociais e ambientais atuais). Muitas dessas mudanças requerem de nós a capacidade de interpretar situações com base em raciocínio moral, pois nelas estão envolvidos conflitos de valores que nos obrigam a optar por aqueles que deem um sentido mais justo às nossas ações.

Considerando o caráter ativo da educação moral, o educador deve ser um orientador que promova a organização de atividades que estimulem a participação ativa dos estudantes. Falar de moralidade significa enfrentar fatos e acontecimentos que preocupam, inquietam e questionam, fatos que provocam conflitos de valores. Os conflitos de valores são oportunidades para trabalhar questões morais e valorativas, dentro de uma 
educação moral. Sendo assim, a educação moral deverá transmitir e discutir criticamente conteúdos que possam ser de utilidade na resolução dos conflitos de valor e, desta forma, deverá ajudar a desenvolver as capacidades morais que permitirão a cada sujeito enfrentar crítica e reflexivamente tais conflitos. (PUIG, 1998)

Então, pergunta-se: como o ensino de ciências e as discussões de QSC podem contribuir com o desenvolvimento da esfera moral dos estudantes? Tendo como pressuposto que as QSC estão relacionadas ao conhecimento científico, são controversas por natureza, envolvem conflitos de valor que requerem uma análise crítica e reflexiva, nos deparamos com a necessidade de um ensino de ciências que prepare os estudantes para avaliar responsavelmente os problemas científicos e tecnológicos produzidos pela sociedade atual, para lidar com questões de valor, para aprender a fazer julgamentos e assumir a responsabilidade por suas próprias vidas e pela vida dos outros.

Rachels (2006, p. 15), ao expressar a concepção mínima sobre moralidade como o "esforço em guiar a conduta do indivíduo por meio da razão", ou seja, ser guiado pelas melhores razões para fazer algo, chega à caracterização do que deve ser um agente moral consciente: aquele que se preocupa de forma imparcial com os interesses de cada um que possam ser afetados por aquilo que ele faça; que analisa o fato e suas implicações; que aceita princípios de conduta depois de examiná-los para verificar sua consistência e, mais ainda, que esteja disposto a agir de acordo com o resultado de suas deliberações. Logo, percebemos que o papel do indivíduo como agente moral está diretamente relacionado ao pensamento crítico e reflexivo que é capaz de chegar a tomadas de decisão e, a partir disso, fomentar as ações pertinentes (o que exige protagonismo social).

Portanto, consideramos que o ensino de ciências e as discussões em QSC podem contribuir com o desenvolvimento moral dos estudantes e capacitá-los para agir com responsabilidade na tomada de decisões. (SILVA; SANTOS, 2014)

\section{Uma QSC sobre o doping genético}

Essa QSC se aplica ao ensino superior, nos cursos de Biologia, Educação FÍsica, Medicina, Química, Fisioterapia, em disciplinas como Biologia Molecular e Genética, Fisiologia do Esporte e, com adaptações, ao ensino médio. Apresenta-se, inicialmente, o caso (Quadro 1) com questões relacionadas e, em seguida, principais objetivos de aprendizagem, segundo Zabala (1998). 
Quadro 1 - Caso sobre doping genético

Imagine que $\underline{X}$,* um atleta de alta performance, ganhador de vários prêmios em competições e medalha de ouro nas Olimpíadas de 2016, apesar dos treinamentos incessantes, começou a ter uma queda no desempenho em algumas provas. Com a aproximação de novas competições e das Olimpíadas de 2020, $\underline{X}$ expõe sua preocupação a seu primo, $\underline{Y}$ :

- Y, estou preocupado, pois tenho sofrido pressão por parte do meu treinador. Quero dar o melhor de mim nos treinos e nas competições e ser motivo de orgulho para minha família e para meu país, mas está difícil. Sinto que estou já no limite do meu corpo, mas acho que não é suficiente.

- Primo, tenho ouvido falar que tem muita gente fazendo um procedimento para melhora do desempenho. Parece que se chama doping genético. Você já ouviu falar?

- Não sei, mas não haveria problemas nisso? Parece estranho.

Pesquisando sobre o assunto, $\underline{X}$ chegou ao conhecimento da terapia gênica e do doping genético o que despertou seu interesse. Suponha que você é amigo(a) de $\underline{X}$. O que você faria para ajudá-lo a decidir?

Fonte: elaborado pela autora.

* Sugere-se que X e Y sejam substituídos por nomes fictícios.

A seguir, algumas questões para nortear a discussão sobre o caso (envolvendo a ciência e a moralidade da manipulação genética) e alguns objetivos de aprendizagem relacionados a essas questões:

Q1. O que é o doping genético? Explique em consiste, do ponto de vista biológico e técnico.

Q2. Quais poderão ser os impactos dessa alteração genética sobre o indivíduo?

Q3. Que escolha você acha que X deve realizar? Justifique.

Q4. Qual seria o critério para justificar, do ponto de vista científico, sua resposta?

Q5. Qual seria o critério para justificar, do ponto de vista moral, sua resposta?

Q6. Como apreciador e espectador do esporte, o que é um limite aceitável para as atitudes dos atletas, com relação ao uso de substâncias e procedimentos que auxiliem o desempenho dos atletas?

Q7. Que critérios podem ser adotados com vistas à detecção, à desaprovação e à punição desse tipo de doping?

Q8. Quais outras formas de intervenção genética de seres humanos?

Q9. Você concorda com a manipulação genética de seres humanos com vistas a um aprimoramento genético, considerando não só o caso do doping genético, mas outras formas de intervenção genética? Justifique sua resposta.

Q10. Com que objetivo devem-se aplicar técnicas de intervenção genética em adultos? Como distinguir entre terapia e melhoramento? 
Q11. Como deveria acontecer a participação das empresas privadas no patenteamento das biotecnologias genéticas, gênicas e genômicas?

Q12. Quem seria responsabilizado moral e legalmente pelo insucesso de uma alteração irreversível na estrutura genética de um ser humano?

Q13. Como a informação genética pessoal pode afetar a percepção social e individual das pessoas? E das minorias? Sua liberação pode aumentar a desigualdade social?

Q14. Como valores pessoais estão ligados aos valores do esporte e que impacto isso tem sobre a tomada de decisão?

Q15. Por que as regras são importantes para o desporto e para a sociedade?

Q16. Por que alguns atletas se colocam em risco por doping?

Q17. Como a sociedade combate o doping no esporte?

\section{Objetivos de aprendizagem do tipo conceitual}

- Identificação de genes envolvidos em processos como a síntese de eritropoetina, entre outros;

- Descrição do histórico da manipulação genética e do doping genético;

- Caracterização do desenvolvimento da técnica de terapia gênica, que pode conduzir ao doping genético;

- Definição de DNA, RNA, gene, cromossomo, doping genético;

- Discussão dos princípios de biologia celular e genética, como replicação do DNA, transcrição, tradução, expressão gênica, fisiologia celular;

\section{Objetivos de aprendizagem do tipo procedimental}

- Descrição e comparação de técnicas de extração de DNA, amplificação de genes, análise do DNA por eletroforese, Reação em Cadeia da Polimerase (PCR), eletroforese em gel de agarose;

- Argumentação utilizando conhecimentos envolvidos no caso;

- Explicação e classificação de vantagens e desvantagens associadas ao uso de doping genético e outras técnicas de intervenção genética.

\section{Objetivos de aprendizagem do tipo atitudinal}

- Conhecimento e discussão acerca das implicações morais e éticas dos avanços tecnológicos e científicos na área da engenharia genética;

- Conhecimento da legislação acerca da manipulação genética na espécie humana e em outros organismos; e de normas de bioética; 
- Planejamento de ações para fomentar a prática esportiva livre do consumo de produtos e intervenções que potencializem a performance dos atletas, de forma a promover a saúde, justiça e igualdade entre os atletas.

Para alcançar os objetivos de aprendizagem, podem ser utilizados diferentes formatos de ensino. Reis (2007) apresenta algumas possibilidades, como:

- discussão: nesse formato, os estudantes analisam o dilema proposto, apresentando e discutindo suas diferentes opiniões, e o professor pode fazer intervenções a fim de orientar a discussão;

- debate: esse formato envolve a discussão de posições opostas;

- tribunal: apresentam-se diferentes argumentos de indivíduos ou grupos em conflitos de interesse, visando uma decisão final por um júri;

- resolução de problema: requer o envolvimento dos estudantes na elaboração e na discussão de possíveis soluções para situações controversas;

- individual: os estudantes são convidados a expor suas posições individualmente.

De acordo Reis e Pereira (1998), o sucesso das atividades depende de alguns fatores, dentre eles, a atuação do professor, que, durante a realização das atividades, deve criar um ambiente de respeito pelas opiniões individuais, valorizando diferentes contribuições e ideias, motivar e sensibilizar os estudantes para o assunto em análise; incentivar a participação de todos nas sessões de discussão e envolver a turma no esclarecimento das dúvidas apresentadas, procurar manter o interesse da discussão nos diferentes pontos de vista sem expor as suas opiniões pessoais sobre o assunto, evitando influenciar as respostas dos estudantes, que podem interpretá-las como corretas ou desejáveis.

\section{Considerações finais}

Pesquisas têm levado à compreensão de que os processos de tomada de decisão suscitados pelas QSC envolvem diferentes fatores, tais como: científicos, sociais, morais e afetivos.

Considerando que um dos objetivos fundamentais do letramento científico é a formação integral do cidadão, para tanto, faz-se necessária a capacidade de considerar e reconhecer a dimensão moral das mudanças produzidas pelo rápido avanço do desenvolvimento científico e tecnológico. Essa proposição fundamenta a importância das QSC no desenvolvimento moral.

Nesse sentido, consideramos que as QSC podem contribuir com o desenvolvimento moral dos estudantes, uma vez que consideramos ser a formação moral de uma pessoa 
caracterizada como um processo de construção pessoal e coletiva a partir de reflexão, do diálogo e da ação da pessoa.

Concluímos que, a partir da proposta de ensino baseada em QSC aqui apresentada, o professor pode contribuir para que os estudantes mobilizem diversos conteúdos, no sentido de desenvolver competências e habilidades para analisar criticamente os impactos que podem ser produzidos pelo conhecimento da engenharia genética para o futuro da humanidade.

\section{Referências}

AGENCIA MUNDIAL ANTIDOPAJE- AMA. La lista de prohibiciones 2015 estándar internacional. 2014. Disponível em: <https://www.wada-ama.org/sites/default/files/ resources/files/wada-2015-prohibited-list-esp.pdf >. Acesso em: 29 out. 2015.

ARTIOLI, G. G.; HIRATA, R. D. C.; LANCHA JUNIOR, A. H. Terapia gênica, doping genético e esporte: fundamentação e implicações para o futuro. Revista Brasileira Medicina do Esporte, Rio de Janeiro, v. 13, n. 5, p. 349-354, 2007.

AZZAZY, H. M. E.; MANSOUR, M. M. H.; CHRISTENSON, R. H. Gene doping: of mice and men. Clinical Biochemistry, Toronto, v. 42, n. 6, p. 435-441, 2009.

BELL, R. L.; LEDERMAN, N. G. Understandings of the nature of science and decision making on science and technology based issues. Science Education, New York, v. 87, n. 3, p. 352-377, 2003.

BENTO, L. A. Bioética: desafios éticos no debate contemporâneo. São Paulo: Paulinas, 2008 .

BLAIR, R. J. R. Affect and the moral-conventional distinction. Journal of Moral Education, Abingdon, v. 26, n. 2, p. 187-196, 1997.

BRZEZIAŃSKA, E.; DOMAŃSKA, D.; JEGIER, A. Gene doping in sport: perspectives and risks. Biology of Sport, [S.1.], v. 31, n. 4, p. 251-259, 2014.

CALLADO MORENO, J. A. Relación entre el nível de desarrollo del juicio moral del professorado de tercer ciclo de educación primaria y su disposición a la transmisión de valores sociales a su alunado. 2012. 50 f. Tese (Doutorado em Educação) - Faculdade de Humanidades y Ciencias de la Educación, Universidad de Jaén, Jaén, 2012.

COELHO, M. M. Doping genético, o atleta superior e bioética. Revista Bioétikos, São Paulo, v. 6, n. 2, p. 171-180, 2012.

FISCHETTO, G.; BERMON, S. From Gene Engineering to Gene Modulation and Manipulation: Can We Prevent or Detect Gene Doping in Sports? Sports Medicine, Auckland, v. 43, n. 10, p. 965-977, 2013.

GARVEY, J. Mudanças climáticas: considerações éticas o certo e o errado no aquecimento global. Tradução de Rogério Bettoni. São Paulo: Rosari, 2010. 
HAISMA, H. J.; HON, O. Gene doping. International Journal of Sports Medicine, Stuttgart, v. 27, n. 4, p. 257-266, 2006.

MUELLER, M. P.; ZEIDLER, D. L. Moral-ethical character and science education: Ecojustice ethics through socioscientific issues (SSI). In: TIPPINS, M. D. et al. (Ed.). Cultural studies and environmentalism: the confluence of ecojustice, place-based (science) education, and indigenous knowledge systems. New York: Springer, 2010. p. 105-128.

NUCCI, L.; TURIEL, E. God's word, religious rules, and their relation to Christian and Jewish children's concepts of morality. Child Development, Chicago, v. 64, n. 5, p. 1475 1491, 1993.

NUCCI, L. P. Education in the moral domain. Cambridge: Cambridge University Press, 2001.

OLIVEIRA, R. S. et al. The use of genes for performance enhancement: doping or therapy? Brazilian Journal of Medical and Biological Research, Ribeirão Preto, n. 44, v. 12, p. 1194-1201, 2011.

PENCHASZADEH, V. B. Problemas éticos do determinismo genético. Revista Bioética, Brasília, DF, v. 12, n. 1, p. 61-68, 2004.

PENCHASZADEH, V. B. Reduccionismo genético: un obstáculo para la vigencia del derecho a la salud. In: PORTO, D. et al. (Org.). Bioéticas, poderes e injustiças: 10 anos depois. Brasília, DF: Conselho Federal de Medicina, 2012. p. 237-246.

PUIG, J. M. A construção da personalidade moral. São Paulo: Ática, 1998.

QUEIROZ, P. R. M.; ALVES, L. S. Doping genético. Principais genes alvo, riscos associados e possíveis métodos de detecção. Ensaios e Ciência: Ciências Biológicas, Agrárias e da Saúde, Andradina, v. 16, n. 1, p. 177-193, 2012.

RACHELS, J. Os elementos da filosofia moral. Tradução de Roberto Cavallari Filho. Barueri. São Paulo: Manole, 2006.

REY, F. L. G. Motivación moral en adolescentes y jóvenes. La Habana: Científico-Técnica, 1983.

REY, F. L. G.; MARTÍNEZ, A. M. La personalidad, su educación y desarrollo. La Habana: Pueblo y Educación, 1989.

REIS, P.; PEREIRA, M. Discutindo o “admirável mundo novo”. Inovação, [S.l.], n. 3, p. 45-59, 1998.

REIS, P. O ensino de ética nas aulas de ciências através do estudo de casos. Interacções, Lisboa, n. 5, p. 36-45, 2007.

RICHARDSON, H. S. Moral reasoning. In: ZALTA, E. N. (Ed.). The Stanford encyclopedia of philosophy. Stanford: Stanford University, 2014. [online]. Disponível em: <http://plato.stanford.edu/archives/win2014/entries/reasoning-moral/>. Acesso em: 28 out. 2015. 
SADLER, T. D. Moral sensitivity and its contribution to the resolution of socioscientific issues. Journal of Moral Education, New York, v. 33, n. 3, p. 339-358, 2004.

SADLER, T. D.; FOWLER, S. R. A threshold model of content knowledge transfer for socioscientific argumentation. Science Education, New York, v. 90, n. 6, p. 986-1004, 2006.

SADLER, T. D.; ZEIDLER, D. L. The morality of socioscientific issues construal and resolution of genetic engineering dilemmas. Science Education, New York, v. 8, n. 1, p. 4-27, 2004.

SANTAMARIA, S. et al. Gene doping: biomedical and laws aspects of genetic modification of athletes. Medicina Sportiva, Roma, v. 17, n. 4, p. 193-199, 2013.

SILVA, S. M. B.; SANTOS, W. L. P. Questões sociocientíficas e o lugar da moral nas pesquisas em ensino de ciências. Interaç̧ões, v. 10, n. 31, p. 124-148, 2014.

TISAK, M. Domains of social reasoning and beyond. In: VASTA, R. Annals of Child Development. London: Jessica Kingsley Publishers, 1995. v. 11, p. 95-130.

TURIEL, E. The development of social knowledge: Morality and convention. Cambridge: Cambridge University Press, 1983.

TURIEL, E.; SMETANA, J. Social knowledge and social action: the coordination of domains. In: KURTINES, W. M.; GEWIRTZ, J. L. (Ed.). Morality, moral behavior, and moral development: Basic issues in theory and research. New York: Wiley, 1984. p. 261282.

WALKER, K. A.; ZEIDLER, D. L. Promoting discourse about socioscientific issues through scaffolded inquiry. International Journal of Science Education, London, v. 29, n. 11, p. 1387-1410, 2007.

WIRTH, T.; PARKER, N.; YLÄ-HERTTUALA, S. History of gene therapy. Gene, [S.1.], v. 525, p. 162-169, 2013.

WORLD ANTI- DOPING AGENCY -WADA. The 2004 prohibited list international standard. 2004. Disponível em: <https://wada-main-prod.s3.amazonaws.com/ resources/files/WADA_Prohibited_List_2004_EN.pdf>. Acesso em: 29 out. 2015.

ZEIDLER, D. L.; KEEFER, M. The role of moral reasoning and the status of socioscientific issues in science education: philosophical, psychological and pedagogical considerations. In: ZEIDLER, D. L. (Ed.). The role of moral reasoning on socioscientific issues and discourse in science education. Dordrecht: Kluwer Academic Publishers, 2003. p. 7-38.

ZABALA, A. A prática educativa: como ensinar. Porto Alegre: Artes Médicas, 1998. 


\title{
TRANSGÊNICOS, LEIS E A CIÊNCIA TRAZENDO A LEGISLAÇÃO PARA A SALA DE AULA DE BIOLOGIA
}

\author{
Ítalo Nascimento de Carvalho \\ Dália Melissa Conrado \\ Charbel N. El-Hani \\ Nei Nunes-Neto
}

\section{Introdução}

As tecnologias de DNA (ácido desoxirribonucleico) recombinante são, indubitavelmente, uma grande realização humana, não apenas enquanto feito intelectual, mas também enquanto recurso. Isso porque permitiram quebrar as barreiras genéticas entre as espécies com muito mais facilidade do que se acredita ocorrer na natureza (por meio da transferência horizontal de DNA) e de forma direcionada, pelo menos em princípio, a favor dos humanos. Essa tecnologia é comumente utilizada em aplicações que afetam o dia a dia de uma considerável parcela da população em questões pouco controversas, como a produção de insulina para tratamento do diabetes melito, desde a década de 1990 (GUALANDI-SIGNORINI; GIORGI, 2001), e de hormônios de crescimento, desde a década de 1980. (AYYAR, 2011) Porém, como toda criação humana, essa tecnologia não trouxe apenas benefícios (ou, ao menos, a perspectiva de futuros benefícios) sem eventuais prejuízos em diversos âmbitos. Entre os usos dessa tecnologia que mais 
levantam preocupações está a produção de Organismos Transgênicos (OT), visando a produção de alimentos. No que se refere à agricultura, a aprovação do primeiro vegetal transgênico para consumo humano ocorreu em 1994: o tomate Flavr Savr, corruptela de Flavor Saver (que pode ser traduzido para algo como "protetor de sabor"), aprovado pela Food and Drugs Administration, dos Estados Unidos da América. Desde então, as plantações comerciais de variedades transgênicas de diversas espécies estão em constante crescimento: saltaram de uma área de 1,7 milhão de hectares, em 1996, para 175,3 milhões de hectares em 2013 em todo o mundo (um aumento de mais de 10.000 \%). (ISAAA, 2013) Em termos da área destinada a plantações comerciais com transgênicos, o Brasil fica atrás apenas dos Estados Unidos, com uma área de 40,3 milhões de hectares, sendo há cinco anos o país com maior crescimento de utilização de transgênicos no mundo (10\% ao ano em média). (ISAAA, 2013)

Apesar dessa ampla utilização, os vegetais transgênicos ainda geram muitas discussões quanto a seus benefícios e efeitos deletérios para a saúde humana e o meio ambiente e, nestas discussões, com frequência predominam a dúvida e a desconfiança. Vinte anos após o início das plantações comerciais, a maior parte dessas dúvidas não foi sanada por conta da falta de estudos específicos, sendo que muitos dos estudos existentes são questionados ou publicados com uma nota de cautela dos autores, afirmando-se que "mais estudos são necessários”. (DANIELSEN et al., 2012; PILON-SMITS, 2013; WANG et al., 2014)

A fim de examinar esse problema, podemos focalizar nossa análise sobre três grandes grupos sociais. Num primeiro momento, consideremos o âmbito da produção, no qual se pode evidenciar uma diferença existente entre, pelo menos, dois grupos sociais: o das grandes corporações, que utilizam o conhecimento científico primariamente para a produção de tecnologias que visam a obtenção de lucros no menor intervalo de tempo possível, muitas vezes sem considerar profundamente todos os riscos envolvidos; e o meio acadêmico, tradicionalmente visto como mais cauteloso e disposto a empregar mais tempo para compreender melhor os possíveis problemas de uma nova tecnologia. Apesar de esta representação ser bastante esquemática e dicotômica, ela serve como uma aproximação inicial para compreender as polêmicas geradas pelos transgênicos. Afinal, um olhar mais atento ao modo como a ciência tem estabelecido vínculos (por vezes, questionáveis) com os interesses econômicos (BENCZE; CARTER; KRSTOVIC, 2014) pode levar-nos a questionar essa distinção. Contudo, ela é útil ao menos didaticamente, para fins do argumento.

Por fim, há um terceiro grupo, central em todas estas discussões, que não pode ser negligenciado: o dos cidadãos, potenciais afetados por estes produtos, seja diretamente (pelo consumo de alimentos por eles compostos), seja indiretamente (pelos efeitos ambientais causados pelas plantações). Este é o grupo que, em última instância, deve ser convencido dos benefícios ou prejuízos dos alimentos transgênicos. Da nossa perspectiva, é ele que deve ser informado pelos outros dois grupos para que possa decidir se é favor ou não da produção desse tipo de alimento e, então, pressionar o governo para ser ouvido. 
Tentando convencer esse terceiro grupo, quem advoga a favor dos transgênicos argumenta que eles permitiriam o aumento da produção de alimentos, o que supostamente ajudaria a acabar com a fome no planeta. Este argumento é contestado pelos que afirmam que a produção mundial atual de alimentos é suficiente para todos os humanos, mas a fome persiste por causa de sua má distribuição, gerando pobreza crônica em diversos locais. (SINGER, 2002) Por sua vez, outros dizem que as estimativas de crescimento populacional indicam que, antes do fim deste século, a demanda superará a oferta de alimentos e os transgênicos serão, então, um importante recurso para que a fome não cresça. (CONWAY, 2000)

Entre outros vários argumentos, é possível perceber que os transgênicos são uma ferramenta importante para a humanidade, com uma boa dose de polêmica a seu respeito e, por isso, não podem simplesmente ser desconsiderados na educação científica. Tendo em vista toda a desconfiança que ainda se encontra na literatura acadêmica (como veremos adiante), é possível afirmarmos que, no nosso atual nível de conhecimento, sabemos o suficiente para entender que seus riscos não devem ser negligenciados, nem subestimados, o que aumenta a importância de criar condições para que os cidadãos os compreendam melhor, assim como suas implicações. Uma saída (fácil de dizer, mas difícil de fazer) está na realização de mais estudos científicos feitos por diferentes perspectivas teóricas, preferencialmente com financiamento público, a fim de compreender mais a fundo o assunto; e, em consequência, sermos capazes de maximizar as vantagens e resolver ou minimizar ao máximo os riscos.

Ao considerarmos as discussões sobre transgênicos, não devemos perder de vista, ainda, o risco de se utilizar o mesmo termo, "transgênicos", para referir-se de maneira agregada a uma grande variedade de produtos, o que implica uma falsa ideia de homogeneidade. De fato, existem diversos tipos de transgênicos que envolvem diversas estratégias de manipulação genética, afetando diferentes traços fenotípicos. Pretty (2001) chama a atenção para algumas destas estratégias: inserção de um novo gene para melhorar características já presentes na espécie ou conferir melhoras nutricionais ou farmacêuticas; introduzir novos genes para melhorar a resistência a herbicidas, pragas, patógenos e estresse ambiental; aumentar a produção de híbridos ou modificar a produção de sementes para induzir a apomixia. ${ }^{1}$ Muito embora diversas dúvidas dizem respeito a todas estas estratégias e os consequentes tipos de transgênicos, cada uma delas pode levantar preocupações que não se aplicam a outras.

Pretty (2001) também destaca que a estratégia mais utilizada é a de inserção de sequências nucleotídicas que confiram às plantas maior resistência a herbicidas ou uma capacidade de sintetizar moléculas inseticidas (a bactéria Bacillus thuringiensis, por exemplo, é a espécie mais utilizada como doadora de sequências codificadoras destas últimas), além da tecnologia terminator (que faz com que as sementes da planta sejam

1 Forma de reprodução vegetal em que sementes são produzidas sem fecundação e, portanto, gera uma prole geneticamente idêntica ao parental. 
estéreis, não podendo ser reutilizadas para uma nova colheita. Por este motivo, também é popularmente conhecida com tecnologia da semente suicida).

Tendo em vista sua importância, seu impacto na vida das pessoas e sua natureza controversa, o tema dos transgênicos é um excelente candidato para um ensino de ciências baseado em Questões Sociocientíficas (QSC). Decisões sobre a adoção de tecnologias de manipulação genética para gerar produtos utilizados em contextos cotidianos do cidadão deveriam ter maior participação popular, o que também fornece um argumento a favor da necessidade de sua inclusão no ensino, já que essa participação depende da capacidade das pessoas de compreender os assuntos em pauta. (KLINTMAN, 2002; VICTORINO, 2004) Se levarmos em consideração que a polêmica em torno dos transgênicos levou à criação de legislações específicas e mudanças na legislação já existente em diversos países, o tema ganha uma dimensão ainda maior.

Com base no contexto exposto nesta primeira seção, o objetivo deste capítulo é apresentar uma série de ideias que podem ser utilizadas para a construção de diversas QSC que tratem, inicialmente, da temática dos transgênicos e da legislação referente à rotulagem de produtos alimentícios que contenham organismos transgênicos em sua composição. Este tema pode ser utilizado, ainda, como porta de entrada para a discussão de diversos outros (como, por exemplo, terapia gênica, relação entre ciência, valores e participação democrática), que, por sua vez, podem ser abordados à escolha do professor.

O capítulo está estruturado da seguinte maneira: na segunda seção, fazemos algumas reflexões sobre o uso de Projetos de Lei (PL) como ponto de partida para a construção de QSC, com o objetivo de mostrar algumas possibilidades e limitações dessa estratégia. Nas duas seções seguintes, discorremos sobre algumas ideias para a construção de QSC que tratem da temática dos transgênicos e da legislação de rotulagem de produtos alimentícios com transgênicos, incluindo algumas orientações a respeito da construção e do uso das QSC. Na quinta seção, trazemos as considerações finais.

\section{O uso de Projetos de Lei como temas para Questões Sociocientíficas}

Utilizar PL como temas para QSC é uma estratégia que abre um enorme leque de possibilidades para iniciativas educacionais. Além da grande quantidade de PL que estão sempre sendo discutidos ou até mesmo arquivados, ${ }^{2}$ um único PL pode motivar debates sobre uma miríade de assuntos pertencentes a diversas áreas do conhecimento.

2 Segundo a ferramenta de busca do site da Câmara dos Deputados (http://www2.camara.leg.br/ busca/?o=relevance\&v=legislacao\&colecao=S\&conteudolegin $=\&$ numero=\&ano=2014\&tiponor$\mathrm{maF}=$ Emenda+Constitucional\&tiponormaF=Lei+Complementar\&tiponormaF=Lei+Ordin\%C3\%Alria\&tiponormaF=Medida+Provis\%C3\%B3ria\&tiponormaF=Decreto+Legislativo\&tiponormaF=Decreto\&tiponormaF=Decreto-Lei, acesso em: 20 de abril de 2015), só em 2014 foram protocoladas 377 propostas, entre emendas constitucionais, leis ordinárias, decretos/lei, leis complementares, medidas provisórias e decretos. Se levarmos em conta os outros órgãos do Legislativo, haverá a 
Devido à amplitude de temas possíveis de se abordar na sala de aula a partir de um PL e aos escassos trabalhos encontrados na literatura sobre o assunto (LEE, 2007; WILKERSON; FRULAND, 2006), terá grande importância a reflexão docente sobre as relações dos temas com os objetivos de aprendizagem e o contexto em que tem lugar o trabalho pedagógico. Contudo, é possível identificar, em termos gerais, alguns princípios úteis (CARVALHO et al., 2015):

- parece importante que o professor não perca de vista, no trabalho em sala de aula, os objetivos para os quais está usando a QSC construída em torno do PL, de modo a minimizar o desvio da atenção dos estudantes para tópicos que têm menor conexão com aqueles objetivos (por mais interessantes que sejam), mas sem prejudicar a dinâmica de trabalho dos estudantes. Será tanto mais fácil alcançar esse propósito quanto melhor for o planejamento dos objetivos de aprendizagem;

- é recomendável que estes objetivos não sejam nem excessivamente amplos e gerais, nem demasiado específicos;

- não é aconselhável estabelecer um número muito grande de objetivos, o que poderá dificultar o trabalho dos estudantes, tornar mais fácil perder de vista o foco do trabalho e levar a iniciativa a ser incompatível com o tempo escolar.

O uso de QSC baseadas em PL informa os estudantes sobre iniciativas parlamentares que, muitas vezes, não são divulgadas pelos meios de comunicação de massa. Nesse sentido, podem ser trabalhadas em sala discussões sobre os interesses da mídia e a ilusão de sua neutralidade, lançando-se um olhar crítico sobre sua influência na sociedade brasileira (GUARESCHI, 2006; LIMA, 2004), tendo-se o cuidado, contudo, de não perder de vista o tema central da QSC.

Além disso, é importante que o professor estimule a compreensão dos estudantes acerca de seu papel como cidadãos, entendendo-se que cidadania requer participação política, ativismo e engajamento cultural. (GIROUX, 2004) Eles poderão ter melhores condições, assim, de compreender suas possibilidades de participação na busca de mudanças sociais por meio de busca de um entendimento informado e crítico dos problemas sociais e ambientais e de ativismo político. Será mais provável, assim, que abandonem a ideia bastante comum em nosso país de que a democracia se resume a votar uma vez a cada dois anos. (PINZANI, 2013) A redação de cartas abertas à comunidade, $e$-mails e abaixo-assinados destinados aos representantes dos poderes Executivos e Legislativo, confecção de cartazes, faixas e panfletos e organização de passeatas, palestras e debates públicos são alguns exemplos de ações práticas diretas que poderão ser estimuladas por meio do trabalho com QSC estruturadas em torno de PL. (CARVALHO et al., 2015)

cada ano grande quantidade de propostas que poderão ser analisadas quanto ao seu potencial na construção de QSC. 
Outra vantagem de tais QSC é a possibilidade de os estudantes se engajarem em argumentação e investigação a partir da análise dos PL. Isso porque, na discussão dos PL em sala, suas habilidades argumentativas serão postas em ação e desenvolvidas; além disso, será necessário que eles investiguem fontes variadas de informação para a compreensão dos textos e de suas consequências, em caso de aprovação, veto ou arquivamento.

O professor também pode determinar algum tempo para que os estudantes (em grupos ou individualmente) tracem um plano de trabalho, identificando que tipos de informações buscarão e onde imaginam encontrá-las. Em seguida, ele pode avaliar os planos dos estudantes e fazer ajustes e sugestões que achar necessários. Durante toda a fase de pesquisa, os grupos podem fazer breves relatórios ao professor, indicando progressos e necessidades. Estes também são modos de estabelecer avaliações processuais, o que auxiliará na avaliação final da atividade pelo professor.

Uma possível desvantagem do uso de QSC baseadas em PL reside no fato da desatualização de um cenário, por conta da votação ou do arquivamento de um PL relacionado à QSC. Nesse contexto, o professor poderia utilizar o cenário para estimular discussões sobre repercussões da aprovação, da reprovação ou do arquivamento do PL, para que os estudantes possam assumir posturas informadas sobre a situação do PL, além de conhecerem mais profundamente os mecanismos de criação e mudanças da legislação. (CARVALHO et al., 2015) Adicionalmente, se considerarmos o tempo de tramitação dos PL, os estudantes poderão agir, após tomada de decisão sobre o assunto, para participar no desarquivamento ou na modificação do texto da lei aprovada ou revogada.

O professor também poderá, em decorrência da discussão com os estudantes acerca de PL relacionados a uma QSC específica, organizar um PL de iniciativa popular, para ser proposto ao Legislativo (claro, considerando as dificuldades, inclusive, logísticas de uma empreitada deste tipo). ${ }^{3}$ Em caso de provável apatia dos estudantes para se engajarem em ações desse tipo, devido a um descrédito em sua efetividade, sugerimos que o professor exponha alguns casos em que a participação popular tenha gerado bons resultados. Por exemplo, há atualmente quatro casos de projetos de iniciativa popular que se tornaram lei ${ }^{4}$ (BONIN, 2010): a Lei ${ }^{\circ} 8.930$, de 7 de setembro de 1994 (que caracterizou a chacina realizada por esquadrão da morte como crime hediondo); a Lei $n^{\circ} 9.840$, de 28 de setembro de 1999 (que tornou a compra de votos crime punível com cassação); a Lei $n^{\circ} 11.124$, de 16 de junho de 2005 (que criou o Fundo Nacional de Habitação de Interesse Social); e a Lei Complementar $n^{\circ}$ 135, de 4 de junho de 2010 (Lei da Ficha Limpa).

3 Para um guia sobre PL de iniciativa popular, ver o site da Câmara dos Deputados: <http://www2. camara.leg.br/participe/sua-proposta-pode-virar-lei>.

4 É válido ressaltar que a possibilidade de PL de iniciativa popular só foi garantida pela Constituição de 1988, o que aconteceu 26 anos antes da publicação deste trabalho. Deixamos para o leitor julgar se a média de uma lei desse tipo a cada oito anos é satisfatória ou não. De qualquer modo, está clara, pensamos, a importância do incentivo à participação popular por meio de tais $\mathrm{PL}$, podendo a escola ter papel relevante neste incentivo. 
Por fim, os PL podem destacar para o estudante a relevância de conhecimentos científicos relacionados a uma QSC que se está propondo que se aprendam. Ao mesmo tempo, os vários fatores sociopolíticos associados a qualquer PL mostram que o conhecimento científico, a despeito de sua importância, não é suficiente para englobar todas as complexas dimensões do problema relacionado ao PL e da tomada de decisão a seu respeito. Nas aulas de ciências, a consideração de interesses, valores e consequências sociais e ambientais de um PL relacionado a uma QSC poderá evidenciar que todos os atores sociais envolvidos na resolução de uma QSC (sejam parlamentares, cientistas ou outros cidadãos) não são neutros. Trata-se também de uma forma de questionar a visão popular da neutralidade científica, despertando o senso crítico sobre o fazer científico e seus resultados, reconhecendo uma influência mútua entre sociedade e ciência.

\section{Questões Sociocientíficas sobre transgênicos para os ensinos médio e superior}

Apesar de ser possível criar diversas QSC relacionadas entre si pelo tema (transgênicos), que serviriam como ponto de entrada, apresentamos aqui um cenário único, em forma de um caso/cenário (Quadro 1). Esse repertório inclui as características propostas por Lima e Linhares (2008), possuindo: apresentação de um cenário em um enunciado; questões que guiam o trabalho de pesquisa dos estudantes e os colocam na posição de tomar decisões; objetivos de aprendizagem a serem atingidos pelos estudantes (relacionados aos conteúdos conceituais, procedimentais e atitudinais) (COLL et al., 1992; ZABALA, 1998); e um resumo da discussão que se espera que os estudantes realizem em sala. Essa QSC poderá mobilizar conteúdos de ecologia, genética, evolução, legislação, cidadania, ética e política ambiental, de acordo com a ênfase e os objetivos de aprendizagem estabelecidos pelo professor.

A partir desse cenário, listamos diversas questões e objetivos que podem ser selecionados pelo professor conforme o campo da biologia ao qual ele quer destacar (evolução, ecologia, genética, saúde humana) e o nível educacional em que a QSC será trabalhada (ensino médio, graduação ou pós-graduação). Algumas perguntas podem ser utilizadas em todos os níveis sem alterações, sendo a exigência maior, quanto à profundidade das resposta, quanto mais avançados forem os estudantes.

As perguntas de Q1 a Q6 constituem um núcleo básico, no qual cada pergunta constitui um passo para que o estudante progrida do conhecimento de conceitos e procedimentos necessários para entender a questão em direção aos procedimentos e atitudes necessários para a ação social. As questões de Q7 a Q9 podem ser utilizadas para abordar tópicos mais específicos dentro do tema ou de outros relacionados a ele. A questão Q10 é mais adequada para aplicação com estudantes do ensino superior, de acordo com seu objetivo correspondente. 
Cabe ressaltar que os transgênicos de que tratam os objetivos e perguntas abaixo são aqueles em que foram inseridas sequências nucleotídicas relacionadas à resistência a pesticidas e pragas, pois são os mais disponíveis comercialmente até o momento. (SCHNEIDER; SCHNEIDER; RICHARDSON, [2014]) Muitas das críticas feitas a eles também são aplicáveis a outros tipos de transgênicos, mas estes levantam novas preocupações que não serão abordadas aqui por questão de espaço, embora também suscitem discussões importantes.

Quadro 1 - QSC sobre transgênicos usando PL em tramitação no Legislativo brasileiro

O que os olhos não veem: rotular ou não rotular produtos que contêm transgênicos?

Rafael estava com vontade de comer um cuscuz no jantar e decidiu ir ao mercado comprar a massa de milho para fazê-lo. Ao procurar na prateleira pela sua marca preferida, percebeu que a embalagem havia sido modificada: agora possuía estampado em um canto um triângulo amarelo com um "T" preto (semelhante ao reproduzido na imagem abaixo), acompanhado do texto "contém milho transgênico".

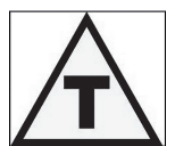

Como achou estranho aquele símbolo, Rafael decidiu olhar em outras seções do supermercado, para ver se o símbolo ocorria também em outros produtos ou se apenas o seu desejado cuscuz parecia estar mudando sua natureza. Assim, ele foi verificando, pouco a pouco, que o símbolo aparecia em diversos outros produtos, como pães, biscoitos e até mesmo ração para cães e gatos.

Ao voltar para casa, ele mostrou a embalagem da massa de milho para sua mãe e apontou para o símbolo:

- Mãe, o que é isso aqui?

- Não sei. Nunca reparei nisso em nada que comprei. Veja na internet e depois me diga o que é.

Seguindo a sugestão de sua mãe, Rafael pesquisou rapidamente e descobriu que o símbolo é colocado no rótulo dos alimentos que possuem organismos transgênicos em sua composição, seguindo a Lei Federal $n^{\circ} 11.105$, de 2005, e o Decreto $n^{\circ} 4.680$, de 2003. No dia seguinte, ele comentou o que havia descoberto com Poliana, uma colega da escola. Ela então mostrou que estava um pouco mais bem informada sobre o assunto:

- É, isso já tem tempo! Vi em algum site que tem gente que quer tirar esse símbolo, tem um monte de projetos de lei no congresso propondo que não seja obrigatório. Parece que o que está em destaque agora é o PL $n^{\circ}$ 4148, de 2008, do deputado federal Luis Carlos Heinze, do Rio Grande do Sul. Pelo que entendi, tem gente que defende o lado dos produtores e diz que eles ficam prejudicados pelo símbolo no rótulo. Quem é a favor do símbolo diz que é por causa dos riscos dos transgênicos para a saúde e para o meio ambiente. Tem quem fale também em direitos do consumidor.

Desconfiados e querendo saber mais sobre o porquê de um simples símbolo levar à proposição de não apenas um, mas de diversos projetos de lei contra ele, Rafael e Poliana resolveram pedir ajuda a mais um amigo para pesquisar sobre o assunto. Como eles sabiam que você tem mais experiência com pesquisas, vieram falar com você. Eles também querem ajuda para entender o ponto de vista de todos os lados envolvidos.

Fonte: elaborado pelos autores. 


\section{Questões relacionadas ao caso sobre a QSC}

Aqui apresentamos uma série de questões relacionadas aos objetivos de aprendizagem propostos. A relação das questões com os objetivos de aprendizagem a que elas se direcionam podem ser visualizadas ao final de cada objetivo de aprendizagem proposto abaixo, entre parênteses.

Q1. Observe os rótulos dos alimentos em sua casa (como, por exemplo, aqueles produzidos a partir de milho e soja). Eles possuem a sinalização que indica a presença de organismos transgênicos em sua composição? Se possuírem, ela está de acordo com a legislação pertinente no Brasil?

Q2. O uso de organismos transgênicos na produção de alimentos pode causar impactos ambientais? O consumo de alimentos transgênicos pode ser prejudicial à saúde humana? Justifique.

Q3. Procure as razões apontadas pelo deputado em seu PL. Você concorda com os argumentos que o deputado utilizou para defender a ideia de que a legislação atual prejudica economicamente os produtores e fabricantes de alimento? Por quê?

Q4. Levando em conta possíveis impactos dos OT sobre o meio ambiente e a saúde humana, o direito de informação do consumidor e as consequências do aviso nos rótulos para os produtores, que decisão você acha que Rafael e Poliana deveriam tomar: ser a favor ou contra a aprovação de PL como o exemplificado acima? ${ }^{5}$ Justifique.

Q5. Você acha que Rafael, Poliana e você deveriam informar suas famílias sobre tudo que descobriram, sobre a decisão que vocês tomaram e sobre os motivos que os levaram a se decidir para, em seguida, tentar convencê-las a consumir alimentos de acordo com essa decisão? Vocês também deveriam informar a outras pessoas? Justifique.

Q6. O que vocês poderiam fazer para mostrar seu ponto de vista aos senadores e deputados que votarão o PL, tentando convencê-los de que este seria o melhor ponto de vista?

Q7. Analise se o cultivo de OT em plantações pode levar a um maior uso de agroquímicos por parte dos produtores e os impactos que isso poderia gerar. Você

5 A questão que propomos aqui não pressupõe apenas duas respostas, ser a favor ou contra, na medida em que esperamos um argumento justificado, acompanhando e suportando a posição de ser a favor ou contra. $\mathrm{O}$ argumento também deve ponderar, qualificar e, se for o caso, superar refutações ao argumento, como requisitos de uma boa argumentação, num contínuo de possíveis respostas ou soluções. Cabe notar que a pressuposição de que somente duas respostas possíveis (sim ou não; a favor ou contra), para questões complexas como estas, consiste na falácia da pergunta complexa. Para mais detalhes sobre o assunto, ver Copi (1978). 
consegue identificar possíveis limitações dessa estratégia? Se sim, que alternativas você sugeriria?

Q8. Analise a estratégia de inserir em plantas sequências nucleotídicas que codificam proteínas pesticidas, como aquelas extraídas da bactéria Bacillus thuringiensis. Isso poderia trazer riscos à saúde humana?

Q9. Se você fosse um técnico consultado por um parlamentar sobre este PL, você recomendaria que ele votasse a favor ou contra? Justifique.

Q10. Você acha que é tecnicamente viável adotar o critério de detectabilidade (detectar no produto final, através de procedimentos químicos e/ou bioquímicos, compostos que estão ali presentes devido ao uso de técnicas de transgenia) em vez da rastreabilidade (localizar o uso de organismos e/ou compostos sabidamente transgênicos ao longo de toda a cadeia de produção de um item, incluindo suas matérias primas), como sugerido pelo Heinze? E economicamente, seria viável?

\section{Objetivos de aprendizagem}

Quanto aos objetivos de aprendizagem, para criar condições convenientes (considerando o tempo escolar e o nível cognitivo dos estudantes) para a aplicação da QSC, da perspectiva aqui esboçada, ressaltamos que deve haver um equilíbrio entre os três tipos ou dimensões dos conteúdos (conceitual, procedimental, atitudinal), evitando a tendência comum de enfatizar os conteúdos ou dimensões conceituais em detrimento dos outros, ou até mesmo de negligenciar os conteúdos ou dimensões atitudinais. (CONRADO; NUNES-NETO, 2015; FOUREZ, 2008; ZABALA, 1998) Quanto ao nível de especificidade, o professor poderá realizar ajustes conforme seu entendimento das condições objetivas em que desenvolve seu trabalho pedagógico, considerando a complexidade do tema tratado, o tempo escolar disponível e as necessidades, as capacidades e os interesses dos estudantes.

\section{Conceituais}

- Compreender, a partir de leituras sobre genética e ecologia de populações, como os OT podem levar à perda de variabilidade genética em populações naturais, por meio da competição entre indivíduos, o que afeta a evolução das populações naturais (relação com Q2 e Q7);

- Compreender como os OT podem afetar a evolução de populações naturais, diferenciando populações com maior e menor variabilidade genética (relação com Q2 e Q7);

- Entender como os OT podem potencializar a contaminação ambiental por pesticidas, explicando a estratégia de incluir nas plantas sequências nucleotídicas 
de resistência a estes agroquímicos para que estes possam ser aplicados em maior quantidade contra ervas não desejadas na lavoura ${ }^{6}$ e que já apresentam alguma resistência (relação com Q2 e Q7);

- Entender como os OT podem levar a problemas na saúde humana, exemplificando casos em que a inserção de sequências nucleotídicas em um organismo o leva a produzir substâncias pesticidas ou outros compostos com potencial alergênico (relação com Q2 e Q8);

- Analisar, a partir da literatura, os efeitos dos pesticidas no solo e nos corpos d'água, atribuindo às suas características potencialmente tóxicas os danos às formas de vida presentes nestes ambientes (relação com Q2);

- Conhecer e entender o processo pelo qual os PL passam até sua aprovação ou sanção pelo presidente da República (relação com Q6);

- Conhecer e compreender as limitações impostas à estratégia de aumentar o uso de agrotóxicos, explicando como ocorre a seleção de indivíduos resistentes aos mesmos e o consequente aumento na frequência da resistência nas populações de pragas (relação com Q7);

- Compreender os conceitos de organismos transgênicos (aqueles que receberam trechos de DNA de organismos de outras espécies) e de organismos geneticamente modificados (que tiveram seu genoma alterado de alguma forma, mas não obrigatoriamente envolvendo a transgenia) e suas relações (relação com Q1 e Q2).

\section{Procedimentais}

- Identificar e reconhecer as informações presentes em rótulos de produtos alimentícios, interpretando imagens, tabelas e textos escritos (relação com Q1);

- Aplicar procedimentos de pesquisa online, executando buscas por textos originais de dispositivos legais, como leis, decretos e portarias (relação com Q3);

- Discutir e colocar em prática formas de participação democrática além do voto, exemplificando ações que o cidadão comum pode realizar como forma de influenciar os representantes do poder Legislativo, como opinar em enquetes no site do Congresso, enviar e-mails aos parlamentares, realizar abaixo-assinados e articular ações enquanto participantes de movimentos civis organizados (relação com Q6).

6 Neste trabalho, tomamos a decisão de utilizar a expressão "ervas não desejadas" em lugar de "ervas daninhas" ou "pragas", por considerarmos que estes termos estão impregnados dos valores dominantes no grande agronegócio surgido após a Revolução Verde, na primeira metade do século XX. Estes valores figuram como parte de um processo de mecanização e industrialização crescente da agricultura, favorecendo as monoculturas em detrimento da consideração de variáveis socioambientais. Na verdade, a maioria das espécies conhecidas como pragas são benéficas num sistema agroecológico de produção, por exemplo. 
- Criar ações de participação democrática enquanto cidadão, produzindo textos e documentos ou planejando manifestações adequadas às mesmas (relação com Q6);

- Desenvolver habilidades argumentativas, como, por exemplo, aplicar o modelo argumentativo de Toulmin (2006), implementando-o na construção de diagramas que representem a defesa de um ponto de vista (relação com Q3).

- Avaliar e aplicar a hierarquia das formas de discordar proposta por Paul Graham (2008), implementando-a na análise de argumentos presentes em um PL (relação com Q3);

- Listar, analisar e discutir as limitações dos métodos bioquímicos de detecção de sequências nucleotídicas transgênicas (e proteínas por elas codificadas) em alimentos, inferindo como as técnicas de processamento e preparo destes, antes de chegarem ao consumidor final, levam à destruição de sequências nucleotídicas e proteínas (relação com Q10);

- Organizar esquemas comparativos de formas de cultivo que permitem mitigar o problema das pragas agrícolas e do aumento de resistência dessas pragas às formas de combate tradicionais, comparando a monocultura com suas alternativas, como, por exemplo, a agroecologia ou a permacultura (relação com Q7);

- Avaliar fontes de informação online quanto a sua confiabilidade, verificando aspectos como autoridade, atualidade e precisão das informações fornecidas (relação com Q3);

- Avaliar se os produtos presentes em seu cotidiano atendem à legislação relativa aos produtos que contêm organismos transgênicos em sua composição, analisando rótulos e dispositivos legais pertinentes, conforme a legislação referente à rotulagem de produtos alimentícios (relação com Q1).

\section{Atitudinais}

- Reconhecer a importância e adotar o hábito de acompanhar na mídia (de diversas modalidades) iniciativas de PL e votações destes projetos, verificando informações acerca deles (relação com Q3 e Q4);

- Reconhecer a importância e adotar o hábito de analisar criticamente PL, identificando valores éticos subjacentes aos mesmos e avaliando seus graus de prioridade (relação com Q4);

- Reconhecer a importância do engajamento político para um exercício efetivo da cidadania em uma sociedade democrática (relação com Q4 e Q6);

- Reconhecer e apropriar-se do poder do cidadão enquanto consumidor, adotando o hábito de se informar sobre o que consome (relação com Q4 e Q5);

- Analisar a própria maneira de pensar, identificando e explicitando os valores éticos defendidos por si mesmo e, desenvolvendo a autocrítica como passo inicial para uma possível mudança de comportamento (relação com Q4); 
- Discutir o direito do consumidor à informação, interpretando os textos do Código de Defesa do Consumidor (CDC) e da Lei da Transparência, que o asseguram legalmente (relação com Q4);

- Analisar o papel social de sua profissão atual ou futura, conferindo as respectivas implicações sociais a suas atribuições e reconhecendo a responsabilidade ética sobre suas próprias decisões (relação com Q9);

- Comparar, discutir e avaliar vantagens e desvantagens das diversas formas de produção agrícola, analisando criticamente suas consequências quanto aos aspectos sociais, econômicos, ambientais e éticos (relação com Q7);

- Reconhecer a importância de estar bem informado para a tomada de decisões e da adoção da postura de divulgar tais informações para outras pessoas de seu convívio (relação com Q5);

- Adotar o hábito de avaliar fontes de informação online (relação com Q3);

- Organizar propostas de divulgação dos resultados encontrados sobre o tema para a comunidade escolar ou para um público mais amplo, como em vídeos e páginas de internet (relação com Q1, Q2, Q5 e Q7);

\section{Resumo da discussão da QSC e subsídios para a abordagem em sala de aula pelo professor}

No Brasil, o direito do consumidor à informação sobre o produto, presente no rótulo, é assegurado pelas Leis Federais $n^{\circ}$ 8.078/90 (CDC) e Lei $n^{0} 12.741 / 12$ (Lei da Transparência). Segundo essas leis, o rótulo deve permitir que o consumidor saiba as características do produto que lhe é vendido, incluindo potenciais riscos advindos de seu consumo, além de outras informações pertinentes (vale ressaltar que, atualmente, apenas os potenciais riscos à saúde humana são informados). Mediante a consulta ao rótulo, o consumidor poderá decidir, de acordo com seus critérios pessoais e os valores éticos que os embasam (fundamentados, por sua vez, em teorias morais), se irá adquirir o produto oferecido.

Ainda que no PL no 4.148/2008 o deputado Luis Heinze afirme que defende o direito à informação, ele argumenta, baseado na experiência diária com o consumidor (embora ele não tenha deixado explícita a fonte de tal experiência), que a atual sinalização induz ao erro, ao falso entendimento ou que é simplesmente inútil, levando a uma situação contrária àquela objetivada pelo CDC. Sobre este ponto, duas questões devem ser discutidas.

Primeiramente, o deputado argumenta que o formato e as cores do símbolo determinado pela portaria do Ministério da Justiça são normalmente utilizados "[...] em placas de advertência, atenção e existência de risco, afixadas em locais de perigo, radiação, eletricidade, explosão, entre outros”. (BRASIL, 2008, p. 6) Desse modo, ele promoveria uma identificação do produto a situações de perigo, nocividade, alerta e cuidado, afe- 
tando a percepção do consumidor quanto à sua qualidade. Heinze, inclusive, sugere que o uso desse símbolo permitiria inferir que a competitividade do produto brasileiro no mercado externo seria reduzida, já que os consumidores de outros países não estariam familiarizados com a legislação brasileira, e evitariam comprar estes produtos por temores desinformados. (BRASIL, 2008)

Contudo, a apresentação gráfica do símbolo tem razão de ser, por ser facilmente identificável por suas características chamativas (a combinação das cores amarela e preta são usadas em diversas ocasiões em que uma mensagem importante dever ser transmitida e rapidamente assimilada, o que é observado, aliás, na natureza, em colorações aposemáticas exibidas por animais que oferecem algum risco de toxicidade, como ocorre com os sapos coloridos da família Dendrobatidae). A simples colocação da frase "Contém transgênicos", desacompanhada do símbolo, pode, por sua vez, escapar à vista dos consumidores menos atentos.

Em segundo lugar, o deputado afirma que incluir no rótulo o nome da espécie doadora do gene transplantado (outra exigência do Decreto $n^{\circ} 4.680$ ) também contrariaria o CDC, porque nomes científicos são de difícil compreensão para a população leiga. Entretanto, não fica claro por que isso confundiria o consumidor. Pelo contrário, isso poderia facilitar a busca de informações adicionais em outras fontes sobre o produto que tem em mãos.

O deputado também argumenta que se deve modificar os critérios para a obrigatoriedade do aviso, baseando-se principalmente na dificuldade e no custo econômico (para os produtores) de rastrear a origem das matérias primas e insumos e, quando não houver OT entre eles, conseguir a certificação por algum órgão competente e ser então isentado de assinalar o rótulo como a notificação. Porém, ao sugerir a substituição do critério de rastreabilidade para o critério de detectabilidade, o deputado transfere a responsabilidade da realização de testes para os órgãos governamentais (e, por consequência, transfere o custo para os contribuintes), aos quais compete a fiscalização dos produtos.

Além de transferir o ônus econômico do produtor para a sociedade em geral, isso dificultaria ainda mais a fiscalização, por motivos técnicos: não há protocolos universais e nem facilmente aplicáveis para identificar a presença de DNA ou proteínas transgênicas nos diversos tipos de produtos que podem conter OT em sua composição, uma vez que eles podem ser degradados durante processamentos tanto químicos, quanto físicos (aquecimento, por exemplo). Além disso, há produtos (como o óleo vegetal) que não mantêm o conteúdo proteico de sua matéria prima.

Além disso, outro argumento de ordem econômica mobilizado no PL diz respeito à afirmativa de que a utilização da cor amarela encarece a embalagem. Entretanto, isso não procede, uma vez que, primeiramente, tal aumento de custo é irrisório frente ao custo total das embalagens, nas quais o uso de muitas cores e outros artifícios para atrair a atenção do consumidor é bastante comum. (CREPALDI, 2006; VIANA et al., 2013) 
Para chegar a esta conclusão, basta examinarmos algumas embalagens ou correspondências e propagandas de diversos produtos na mídia ou impressos, os quais parecem desnecessariamente onerosos ou coloridos. E, em segundo lugar, como já comentado, o símbolo de um triângulo preto preenchido de amarelo é universalmente reconhecido como representação de perigo.

Assim, há um conflito de valores estabelecido: por um lado, diversas empresas não querem seus produtos associados a uma possível má imagem pública agregada aos transgênicos, o que, supostamente, reduziria suas vendas. Por isso, eliminar a sinalização ou torná-la menos visível lhes seria vantajoso. Por outro lado, os consumidores têm o direito à informação sobre o que estão consumindo, sendo que as informações relevantes devem estar presentes no rótulo da maneira mais clara possível. A partir disso, eles devem decidir que valores orientarão sua decisão: se prezam mais pelos lucros dos donos dos meios de produção (mercado financeiro) com benefícios a oligarquias político/econômicas, frequentemente localizadas fora dos países produtores, ou se prezam pela conservação ambiental, por tomar precauções visando resguardar a própria saúde e de sua família etc..

Ao pensar em conservação ambiental, o cidadão deve ter em mente que, mesmo que a sequência nucleotídica transferida para um OT seja mínima frente ao genoma completo da planta, a alteração fenotípica (inclusive as não intencionais) pode produzir um organismo que é novo perante a rede já existente de relações ecológicas. (WOLFENBARGER; PHIFER, 2000) Essa novidade pode até mesmo romper a resiliência de um sistema ecológico, uma vez que os outros integrantes desse sistema não possuem características próprias para lidar com a novidade.

Pode-se argumentar, certamente, que novidades surgem o tempo todo nas espécies, mesmo sem interferência humana. Todavia, deve-se considerar que dificilmente essas novidades se espalham nas populações e no espaço de forma tão rápida quanto aquelas produzidas pelos humanos. (FUTUYMA, 2005) Futuyma, por exemplo, qualifica como "rápido" um evento em que algumas espécies levaram oito mil anos para se espalharem por áreas continentais após um período de glaciação. Uma mutação que confere uma vantagem evolutiva a uma espécie de planta em geral surge em um único indivíduo e pode levar gerações para se fixar na população. Poderá demorar mais tempo ainda para se espalhar por todo um continente, o que permite que surjam ou sejam selecionadas em outras espécies mudanças que possibilitem que elas lidem com a nova forma de relação. Isso não acontece no caso dos transgênicos, em que uma população inteira com indivíduos modificados é inserida abruptamente no sistema.

Estas preocupações se tornam relevantes se considerarmos a possibilidade de que indivíduos transgênicos, suas sementes e/ou seu pólen não fiquem restritos à área da lavoura e acabem atingindo áreas de vegetação natural, gerando efeitos que examinaremos abaixo. Porém, diversas estratégias para evitar que isso ocorra já foram e continuam sendo consideradas. Podemos citar, como exemplo, a indução da apomixia e da cleis- 
togamia ${ }^{7}$ (técnicas ainda em fases iniciais de desenvolvimento), inclusão do novo gene no DNA do cloroplasto ou mitocôndria (organelas que apresentam herança, a princípio, exclusivamente materna), ou ainda a utilização de mecanismos que produzam sementes "suicidas", embora todas apresentem limitações. ${ }^{8}$ (CHAPMAN; BURKE, 2006)

Uma vez que não é possível evitar que os organismos transgênicos (ou suas sementes e seu pólen) escapem das lavouras, passamos a considerar os diversos mecanismos pelos quais eles podem afetar o ambiente. (DALE et al., 2002; PRETTY, 2001; WOLFENBARGER; PHIFER, 2000) A primeira preocupação diz respeito ao fluxo gênico entre as variedades transgênicas e as populações selvagens. Há diversos fatores que influenciam a possibilidade de este fluxo ocorrer, dentre os quais quatro são básicos: a distância que o pólen pode percorrer a partir da plantação, a sincronia das florações da plantação e das espécies que podem receber o pólen, a compatibilidade sexual entre as espécies e a ecologia da espécie recipiente.

Sabe-se que o pólen pode viajar vários quilômetros, dependendo de como ele se dispersa (por meio do vento, de insetos, de aves etc.) inclusive, e a possibilidade de a polinização se efetivar depende da longevidade do grão. Em linhas gerais, a probabilidade da polinização diminui com a distância. Ainda assim, há registros de casos em que ocorreu polinização de populações selvagens por variantes cultivadas, resultando inclusive em surgimento de híbridos entre espécies aparentadas. O risco de o fluxo gênico ocorrer será maior para certas espécies, a depender da flora nativa de cada local, caso ocorrido no Reino Unido, por exemplo, onde há alto risco de hibridização entre variedades de beterraba. (RAYBOULD; GRAY, 1993)

Porém, o fluxo gênico só desperta preocupações nos casos em que o fenótipo influenciado pela sequência nucleotídica transplantada pode dotar os indivíduos transgênicos de vantagem seletiva (caso contrário, os indivíduos que a possuem não causarão problemas ou deixarão poucos ou nenhum descendente, e a frequência do traço reduzirá até chegar a zero na população). Os casos mais estudados têm sido aqueles em que o traço afetado é a tolerância a herbicidas e as evidências apontam que, em ambientes naturais livres da aplicação desses agroquímicos, os organismos transgênicos não prosperam mais do que as variantes não transgênicas. (CRAWLEY et al., 1993, 2001)

No caso da resistência a predadores, entretanto, a situação é outra: há evidências de que uma variedade de couve transgênica tem melhor resultado do que a variedade tradicional quanto à predação por mariposas em um experimento dentro de uma estufa (RAMACHANDRAN et al., 2000), o que fundamenta a preocupação de que o mesmo

7 Situação em que uma flor que possui androceu e gineceu se autofecunda antes mesmo de se abrir, - que acaba evitando que seu pólen seja dispersado.

8 Para mais detalhes sobre as estratégias aqui citadas e suas limitações, além de outras, consultar o trabalho original de Chapman e Burke (2006). 
possa ocorrer em ambiente natural e com outras espécies (embora trabalhos que investiguem essa possibilidade ainda não estejam disponíveis). ${ }^{?}$

Outro risco está na transferência horizontal de DNA, que pode levar sequências nucleotídicas introduzidas em OT a serem incorporadas a genomas de bactérias e vírus, com efeitos inesperados e potencialmente danosos. (UETANABARO; GÓES-NETO, 2006) Embora isso seja teoricamente possível, não há, contudo, evidências de que já tenha acontecido.

Um terceiro problema seria a aceleração do aumento da resistência de insetos e ervas indesejadas na lavoura aos agroquímicos. A estratégia de inserir, nos vegetais, sequências nucleotídicas que lhes permitam tolerar maiores doses dessas substâncias se justifica na possibilidade de aplicar quantidades cada vez maiores de agroquímicos nas lavouras. Assim, seria possível combater com mais eficiência espécies indesejadas que já apresentem algum grau de resistência às doses normalmente utilizadas, sem que as plantas cultivadas fossem afetadas.

Porém, é possível que, em populações das referidas espécies, existam indivíduos que resistam até mesmo às doses aumentadas dos defensivos e, ao se reproduzirem, transmitam a seus descendentes essa característica. Dessa forma, em algumas gerações, a população (que inicialmente estaria reduzida em número a alguns poucos indivíduos resistentes) poderia retornar a um tamanho próximo ao inicial, mas composta, em sua maioria, por indivíduos resistentes, inutilizando os agrotóxicos anteriormente utilizados e dificultando o combate aos ataques. (GLIESSMAN, 2000)

Além disso, pensando em curto prazo, é possível que, num primeiro momento, o aumento do uso dos pesticidas cause uma drástica redução nas populações das espécies indesejadas, causando um impacto ecológico, por reduzir os recursos disponíveis para espécies animais que as predavam. Isso contribuiria para a redução da diversidade de espécies no local.

O aumento da quantidade de agrotóxicos utilizados nas lavouras também pode provocar o aumento de contaminações, causando impactos ambientais diversos. (ZAMBERLAM; FRONCHETI, 2012) Os agrotóxicos podem permanecer no solo, potencialmente afetando as propriedades químicas do mesmo e afetando a biota ali existente. As proteínas transgênicas originárias do Bacillus thuringiensis, por exemplo, podem ser produzidas pelas raízes das plantas e se misturar ao solo (além de serem liberadas por outras partes da planta que sejam decompostas após a colheita), onde permanecem por centenas de dias estabilizadas e ativas, quando ligadas à argila, aos ácidos húmicos, entre outros. Ali, podem ser ingeridas, juntamente com a terra, por diversas

9 A resistência a predadores é uma preocupação importante no modelo de cultivo em monocultura, atualmente hegemônico como meio de produção de alimentos, justificando a produção de organismos transgênicos cada vez mais resistentes. Porém, em modelos de cultivo em policultura, este problema possui menor relevância, uma vez que a presença do predador será diminuída por uma série de fatores ecológicos, sendo reduzidas, assim, as pressões seletivas sobre as variedades cultivadas. 
espécies. Entretanto, testes feitos com várias espécies de vertebrados e invertebrados têm produzido resultados negativos para efeitos prejudiciais dessas proteínas. (DALE et al., 2002) Outra possibilidade seria dos agrotóxicos se infiltrarem e atingirem lençóis freáticos, afetando a potabilidade da água, ou serem carregados pela chuva ou pela água excedente da irrigação artificial, podendo contaminar rios, lagos e até mesmo mares. (BROWN; VAN BEINUM, 2009; GOMES; BARIZON, 2014; MOURA; FRANCO; MATALLO, 2008) Essa contaminação pode matar ou debilitar diversas espécies, reduzindo suas populações e prejudicando as redes tróficas.

Por motivos de espaço, não exploraremos estes temas em maior profundidade aqui. Entretanto, há farta literatura disponível sobre o assunto. Como exemplos, podemos citar Silva e Fay (2004), Peres e Moreira (2003) e Paschoal (1979).

Outra possibilidade é que as próprias espécies cultivadas prejudiquem cultivos subsequentes, caso suas sementes germinem espontaneamente nos campos quando outra espécie estiver sendo plantada, sendo necessário, desse modo, combatê-las com algum agrotóxico ao qual não sejam tolerantes. Neste caso, há um risco que não deve ser negligenciado: o de que variantes transgênicas de uma mesma espécie, cada uma tolerante a um tipo de agrotóxico, intercruzem e gerem variantes com múltiplas tolerâncias.

Quanto aos transgênicos que sintetizam substâncias inseticidas, uma das preocupações é que essas substâncias atinjam espécies animais que não são indesejadas nas lavouras, mas que, ao ter contato com elas, promovem benefícios (como a polinização). (LIMA; ROCHA, 2012; POTTS et al., 2010) Espécies que não interagem diretamente com as plantas transgênicas também poderiam ser afetadas, caso se alimentem de insetos que as ingeriram (se a substância for passível de bioacumulação).

Um exemplo é o caso da mariposa monarca, cujas larvas se mostraram sensíveis à alimentação, contendo pólen de milho que expressava uma proteína inseticida direcionada ao combate de outras espécies de insetos. Esse estudo, porém, é questionado por ter sido realizado em condições diferentes daquelas em que as larvas se encontram na natureza. (ANDOW; ZWAHLEN, 2006; DALE; CLARK; FONTES, 2002; PRETTY, 2001; WOLFENBARGER; PHIFER, 2000) De fato, tal questionamento é esperado, uma vez que estudos em laboratório (muitas vezes realizados em pequena escala) dificilmente reproduzem tais condições, incluindo os níveis de exposição à substância, que são influenciados não só pelas condições abióticas, mas também pelas relações ecológicas (como a presença de outras fontes de alimento e de competidores), ausentes no ambiente artificial. Porém, é razoável esperar o mesmo tipo de questionamentos a estudos que não evidenciem efeitos sobre espécies que não aquelas intencionadas.

Caso o consumidor considere sua saúde, ele poderá decidir por não comprar produtos contendo transgênicos com base em diversos motivos. Abordaremos aqui três tipos de possíveis efeitos: nutricionais, tóxicos e alergênicos. É possível, em teoria, haver diferenças nutricionais entre variedades transgênicas e convencionais, uma vez que a sequência nucleotídica inserida em um novo genoma pode ser traduzida em produtos 
com potencial de interferir na regulação da rede metabólica do organismo receptor, impedindo ou reduzindo a transcrição ou tradução de sequências nativas. É possível também que o produto da sequência inserida inicie ou potencialize cascatas de reações que causem a degradação de produtos nativos.

Entretanto, diversos estudos realizados até o momento não encontraram tais diferenças, o que tem contribuído para a aceitação do princípio da "equivalência substancial". (BAKSHI, 2003) Segundo este princípio, "se um novo alimento for substancialmente equivalente em composição e características nutricionais a um alimento que já existia, ele pode ser considerado tão seguro quanto os alimentos convencionais [...] e não requer extensivos testes de segurança”. (HOLLINGWORTH, 2003, p. 3) Todavia, Domingo e Bordonaba (2011) questionam a ideia de que duas plantas com as mesmas características nutricionais trariam riscos iguais (ou a falta de riscos) à saúde humana e defendem que testes toxicológicos precisam ser feitos para que seus efeitos sejam avaliados. Algumas pesquisas sobre os transgênicos na alimentação de animais não-humanos têm apresentado diferentes resultados (DOMINGO, 2007; DOMINGO; BORDONABA, 2011; VENDÔMOIS et al., 2009), sendo que uma pequena porção desses estudos tem sido realizada por empresas que desenvolvem ou produzem organismos transgênicos.

No que se refere às alergias, diversas questões são levantadas. Uma publicação da Society of Toxicology lista três delas: se as proteínas transgênicas produzirão efeitos alergênicos em pessoas que já são sensíveis a elas ou a proteínas estruturalmente similares; se as técnicas de transgenia aumentarão os níveis de expressão de proteínas nativas com conhecido papel alergênico; e se os produtos de sequências inseridas em vegetais causarão novas alergias em quem já apresenta reações a outras substâncias. Nenhuma dessas questões apresenta fácil resposta, cada caso devendo ser analisado isoladamente. (HOLLINGWORTH, 2003)

Pode-se perceber, em suma, que diversos riscos dos transgênicos são previstos em teoria, mas há uma escassez de estudos que os avaliem, prevalecendo a dúvida. Em casos como este, acreditamos que a melhor estratégia seria se valer do "princípio da precaução": se não sabemos se determinada estratégia ou tecnologia tem consequências negativas (ou consequências negativas aceitáveis), mas temos bases científicas plausíveis que justifiquem uma desconfiança de que tais consequências são possíveis, o melhor é não utilizar tal estratégia ou tecnologia - até que a lacuna no conhecimento seja preenchida. ${ }^{10}$ (LACEY, 2006) Na prática, porém, este princípio não vem sendo aplicado aos transgênicos.

Ao decidir não comprar produtos com OT em sua composição, o consumidor mostra que não deseja contribuir, ainda que de maneira indireta, para possíveis e diversos impactos ambientais e na saúde humana que os fabricantes geram em nome do lucro. Caso o número de consumidores insatisfeitos aumente, os fabricantes se verão, então,

10 Para uma discussão mais aprofundada sobre o princípio da precaução e a legitimidade de sua aplicação à ciência, recomendamos, por exemplo, consultar Lacey (2006). 
na posição de rever seus métodos de produção, para recuperarem a competitividade no mercado. Mas, para isso, é importante que a população seja informada e sensibilizada, para, então, modificar seus hábitos de consumo e sua forma de participação política. É interessante notar aqui como transformações sociais no sistema produtivo e no próprio sistema socioecológico como um todo são possíveis por transformações realizadas nos sistemas de valores aceitos pelos cidadãos.

Além disso, é importante dizer que pensar (e repensar) os hábitos de consumo não é a única forma de participação democrática em que o cidadão pode se engajar. É possível pressionar os governantes por meio de abaixo-assinados, cartas abertas, manifestações como passeatas e protestos, além de articulações entre movimentos civis organizados e órgãos como o Ministério Público, e até mesmo órgãos representativos de categorias profissionais, como a Ordem dos Advogados do Brasil.

\section{Considerações finais}

No ensino de ciências, é essencial abordar o tema "transgênicos" de um modo amplo, visando melhor preparar o estudante para tomar decisões informadas, assumir uma postura crítica e participar dos debates e ações sobre o assunto. Nesse sentido, o ensino baseado em QSC, como estratégias didáticas pode facilitar a organização e a mobilização de conteúdos conceituais, procedimentais e atitudinais na abordagem dos transgênicos em sala de aula.

Além de QSC baseadas em PL, aquelas que envolvem o papel do consumidor também podem ser usadas com proveito, uma vez que mostram como atos simples do cotidiano podem (e devem) ser considerados como atos políticos. Os estudantes devem ser alertados e chamados a fazerem uso de seu poder enquanto consumidores, sendo que uma forma de o exercerem é evitando o consumo de produtos vendidos por empresas que defendem valores que eles não apoiam. Evidentemente, para que isso seja possível, eles devem ser capazes de identificar, de modo geral, os valores defendidos pelos diversos grupos sociais no que concerne às questões sociais e/ou ambientais específicas e, a partir disso, identificar seus próprios valores.

O professor pode estimular os estudantes a observarem rótulos de alimentos e interpretarem outras informações neles contidas (além da presença de organismos transgênicos), analisando-as criticamente. Eles podem ser também estimulados a pesquisar a legislação pertinente, propondo-se sua leitura e a avaliação acerca de seu cumprimento. Pode-se ensinar a eles acerca de como denunciar, caso as leis não estejam sendo cumpridas. Todas estas são formas de empoderamento para o exercício da cidadania.

É pouco provável, porém, que os objetivos atitudinais referentes aos hábitos de consumo e de participação política sejam efetivamente alcançados apenas com uma intervenção didática, embora ela seja um passo importante. Após a sensibilização inicial, é importante que o professor ou o grupo colaborativo de professores, sempre que 
possível, traga estas reflexões à tona. Discussões mais profundas também devem ser suscitadas, abordando inclusive questões como as razões pelas quais os produtos que agridem menos o ambiente muitas vezes custarem mais, em termos financeiros.

A QSC discutida neste capítulo estabelece pontos de contato entre diversas disciplinas escolares, podendo servir de base para trabalhos interdisciplinares: português e redação (gêneros textuais, produção textual etc.); filosofia (ética no consumo, cidadania, política); biologia (genética, biologia da conservação, evolução), química (química orgânica); ciências sociais (economia, cultura); e história.

Nos casos em que esta proposta de ensino baseada em QSC for adaptada para utilização no ensino superior, o professor pode modificar os objetivos e as questões para sejam aprofundadas as discussões de assuntos como a genética de populações; os métodos bioquímicos de detecção de proteínas e ácidos nucleicos, incluindo suas limitações técnicas, custos econômicos etc.; possíveis formas de realizar a fiscalização dos produtos sujeitos à lei; possíveis mudanças legislativas que compatibilizassem os interesses dos produtores, consumidores e a possibilidade de fiscalização, entre outras várias questões. Caso seja utilizada em um curso de pós-graduação, é importante não se limitar ao tema específico do curso (por exemplo, apenas à genética, ou apenas à ecologia), mas abordar também outros temas, de maneira a favorecer uma visão mais integrada das áreas da biologia, assim como de diversas ciências e das relações ciência, tecnologia, sociedade e ambiente, uma vez que a pesquisa ou a atividade profissional dos estudantes envolverá o mundo real, não um fragmento dele.

Gostaríamos de ressaltar que esta proposta de ensino baseada em QSC pode e deve ser adaptada aos interesses locais de cada comunidade, sendo que a discussão pode dar maior enfoque a um ou mais aspectos particulares que representem problemas encontrados num contexto social específico.

Encerramos informando que, até a data de finalização deste capítulo, o projeto de Lei $\mathrm{n}^{\circ} 4.148$, trabalhado na QSC, tendo sido encaminhado ao Senado Federal em 30 de maio de 2015, encontrava-se em apreciação pela Comissão de Agricultura e Reforma Agrária, sendo que sua última tramitação datava de 23 de março de 2016. O trajeto completo do PL, incluindo os textos dos pareceres emitidos pelas comissões que o apreciaram, pode ser consultado online no site da Câmara dos Deputados, ${ }^{11}$ e no site do Senado Federal. ${ }^{12}$ Um exemplo da repercussão que a aprovação do PL pela Câmara gerou na mídia pode ser encontrado no site da Revista Carta Capital (datando de 4 de maio de 2015). ${ }^{13}$

11 Ver em: <http://www2.camara.leg.br/proposicoesWeb/fichadetramitacao?idProposicao=412728>.

12 Ver em: <http://www25.senado.leg.br/web/atividade/materias/-/materia/120996>.

13 Ver em: <http://www.cartacapital.com.br/blogs/parlatorio/veja-a-lista-de-deputados-que-derrubaram-a-rotulagem-de-alimentos-transgenicos-4519.html $>$. 


\section{Referências}

ANDOW, D. A.; ZWAHLEN, C. Assessing environmental risks of transgenic plants. Ecology Letters, Oxford, v. 9, n. 2, p. 196-214, 2006.

AYYAR, V. S. History of growth hormone therapy. Indian Journal of Endocrinology and Metabolism, [Mumbai], v. 15, n. 3, p. 162-165, 2011. Suplemento.

BAKSHI, A. Potential adverse health effects of genetically modified crops. Journal of Toxicology and Environmental Health, Washington, v. 6, n. 3, p. 211-226, 2003. Part B: Critical Reviews.

BENCZE, J. L.; CARTER, L.; KRSTOVIC, M. Science \& technology education for personal, social \& environmental wellbeing: challenging capitalists' consumerist strategies. Revista Brasileira de Pesquisa em Educação em Ciências, Belo Horizonte, n. 14, n. 2, p. 39-56, 2014.

BONIN, R. Ficha Limpa é o quarto projeto de iniciativa popular a se tornar lei. G1, Rio de Janeiro, 20 maio 2010. Disponível em: <http://g1.globo.com/especiais/ eleicoes-2010/noticia/2010/05/ficha-limpa-e-o-quarto-projeto-de-iniciativa-popularse-tornar-lei.html>. Acesso em: 9 out. 2014.

BRASIL. Congresso Nacional Câmara dos Deputados. Projeto de lei 4.148/2008. Altera e acresce dispositivos à Lei n. ${ }^{\circ} 11.105$, de 24 de março de 2005. Brasília, DF, 2008. Disponível em: <http://www.camara.gov.br/proposicoesWeb/ fichadetramitacao?idProposicao=412728> . Acesso em: 7 maio 2014.

BRASIL. Decreto n. ${ }^{\circ} 4.680$, de 24 de abril de 2003. Regulamenta o direito à informação, assegurado pela Lei n. ${ }^{\circ} 8.078$, de 11 de setembro de 1990, quanto aos alimentos e ingredientes alimentares destinados ao consumo humano ou animal que contenham ou sejam produzidos a partir de organismos geneticamente modificados, sem prejuízo do cumprimento das demais normas aplicáveis. Diário Oficial [da] República Federativa do Brasil, Brasília, DF, 28 abr. 2003. Disponível em: <http://www. planalto.gov.br/ccivil_03/decreto/2003/d4680.htm>. Acesso em: 23 jul. 2014.

BRASIL. Lei n. ${ }^{\circ} 8.078 / 90$, de 11 de setembro de 1990. Dispõe sobre a proteção do consumidor e dá outras providências. Diário Oficial [da] República Federativa do Brasil, Brasília, DF, 12 set. 1990. Disponível em: <http://www.planalto.gov.br/ccivil_03/leis/ 18078.htm>. Acesso em: 23 jul. 2014.

BRASIL. Lei n. ${ }^{\circ} 11.105$, de 24 de março de 2005. Regulamenta os incisos II, IV e V do IJ $1^{\circ}$ do art. 225 da Constituição Federal, estabelece normas de segurança e mecanismos de fiscalização de atividades que envolvam organismos geneticamente modificados - OGM e seus derivados, cria o Conselho Nacional de Biossegurança - CNBS, reestrutura a Comissão Técnica Nacional de Biossegurança - CTNBio, dispõe sobre a Política Nacional de Biossegurança - PNB, revoga a Lei n. ${ }^{\circ}$ 8.974, de 5 de janeiro de 1995, e a Medida Provisória n. ${ }^{\circ}$ 2.191-9, de 23 de agosto de 2001, e os arts. 5o 6oㅜ 7을

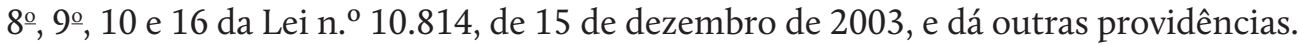
Diário Oficial [da] República Federativa do Brasil, Brasília, DF, 28 mar. 2005. Disponível 
em: <http://www.planalto.gov.br/ccivil_03/_ato2004-2006/2005/lei/111105.htm>. Acesso em: 7 maio 2014.

BRASIL. Lei n. ${ }^{\circ}$ 12.741, de 8 de dezembro de 2012. Dispõe sobre as medidas de esclarecimento ao consumidor, de que trata o $\int 5^{\circ}$ do artigo 150 da Constituição Federal; altera o inciso III do art. $6^{\circ}$ e o inciso IV do art. 106 da Lei ${ }^{\circ} 8.078$, de 11 de setembro de 1990 - Código de Defesa do Consumidor. Diário Oficial [da] República Federativa do Brasil, Brasília, DF, 10 dez. 2012. Disponível em: <http://www.planalto. gov.br/ccivil_03/_ato2011-2014/2012/lei/112741.htm>. Acesso em: 7 maio 2014.

BROWN, C. D.; VAN BEINUM, W. Pesticide transport via sub-surface drains in Europe. Environmental Pollution, Barking, GB, v. 157, n. 12, p. 3314-3324, 2009.

CARVALHO, I. N. et al. Projetos de lei no ensino de ciências: possibilidades para modelagem de questões socio-científicas. In: ENCONTRO NACIONAL DE PESQUISA EM EDUCAÇÃO EM CIÊNCIAS, 10., 2015. Águas de Lindóia. Anais... Águas de Lindóia: Associação Brasileira de Pesquisa em Educação Ciências, 2015.

CHAPMAN, M. A.; BURKE, J. M. Letting the gene out of the bottle: the population genetics of genetically modified crops. New Phytologist, Oxford, v. 170, n. 3, p. 429-443, 2006.

COLL, C. et al. Los contenidos de la reforma: enseñanza y aprendizaje de conceptos, procedimientos y actitudes. Madrid: Santillana, 1992.

CONRADO, D. M.; NUNES-NETO, N. F. Dimensões do conteúdo em questões sociocientíficas no ensino de ecologia. In: ENCONTRO NACIONAL DE EDUCAÇÃO EM CIÊNCIAS, 16., 2015, Lisboa. Atas... Lisboa: Instituto de Letras, Universidade de Lisboa, 2015. p. 432-435.

CONWAY, G. Genetically modified crops: risks and promise. Conservation Ecology, [S.1.], v. 4, n. 1, 2000. Disponível em: <http://www.consecol.org/vol4/iss1/art2/>. Acesso em: 29 set. 2014.

COPI, I. M. Introdução à lógica. 2. ed. São Paulo: Mestre Jou, 1978.

CRAWLEY, M. J. et al. Ecology of transgenic oilseed rape in natural habitats. Nature, [S.l.], v. 363, p. 620-623, 1993.

CRAWLEY, M. J. et al. Biotechnology: transgenic crops in natural habitats. Nature, [S.1.], v. 409, p. 682-683, 2001.

CREPALDI, L. A influência das cores na decisão de compras: um estudo do comportamento do consumidor no ABC paulista. In: CONGRESSO BRASILEIRO DE CIÊNCIAS DA COMUNICAÇÃO, 29., 2006, Brasília, DF. Anais... Brasília, DF: UnB, 2006. p. 1-13.

DALE, P. J.; CLARK, B.; FONTES, E. M. G. Potential for the environmental impact of transgenic crops. Nature Biotechnology, New York, v. 20, n. 6, p. 567-574, 2002. 
DANIELSEN, L. et al. Fungal soil communities in a young transgenic poplar plantation form a rich reservoir for fungal root communities. Ecology and Evolution, Oxford, v. 2, n. 8, p. 1935-1948, 2012.

DOMINGO, J. L. Toxicity studies of genetically modified plants: a review of the published literature. Critical Reviews in Food Science and Nutrition, Boca Raton, Fla., v. 47, n. 8 , p. $721-733,2007$.

DOMINGO, J. L.; BORDONABA, J. G. A literature review on the safety assessment of genetically modified plants. Environmental International, New York, v. 37, n. 4, p. 734$742,2011$.

FOUREZ, G. Educar: docentes, alunos, escolas, éticas, sociedades. Aparecida, SP: Ideias \& Letras, 2008.

FUTUYMA, D. J. Evolution. Sunderland: Sinauer Associates, 2005.

GIROUX, H. A. Cultural studies, public pedagogy, and the responsibility of intellectuals. Communication and Critical/Cultural Studies, Oxfordshire, v. 1, n. 1, p. 59-79, 2004.

GLIESSMAN, S. R. Agroecologia: processos ecológicos em agricultura sustentável. Porto Alegre: UFRGS, 2000.

GOMES, M. A. F.; BARIZON, R. R. M. Panorama da contaminação ambiental por agrotóxicos e nitrato de origem agrícola no Brasil: cenário 1992/2001. Jagruariúna: Embrapa Meio Ambiente, 2014.

GRAHAM, P. How to disagree. 2008. Disponível em: <http://www.paulgraham.com/ disagree.html>. Acesso em: 28 set. 2014.

GUALANDI-SIGNORINI, A. M.; GIORGI, G. Insulin formulations - a review. European Review for Medical and Pharmacological Sciences, [Roma] v. 5, p. 73-83, 2001.

GUARESCHI, P.A. Mídia e cidadania. Conexão - Comunicação e Cultura (UCS), Caxias do Sul, v. 5, n. 9, p. 27-40, 2006.

HOLLINGWORTH, R. M. et al. The safety of genetically modified foods produced through biotechnology. Toxicological Sciences, Orlando, v. 71, n. 1, p. 2-8, 2003.

ISAAA. ISAAA Brief 46-2013: executive summary. global status of commercialized Biotech/GM Crops. 2013. Disponível em: <http://www.isaaa.org/resources/ publications/ briefs/46/executivesummary/>. Acesso em: 22 set. 2014.

KLINTMAN, M. The genetically modified (gm) food labelling controversy: ideological and epistemic crossovers. Social Studies of Science, London, v. 32, n. 1, p. 71-91, 2002.

LACEY, H. O princípio de precaução e a autonomia da ciência. Scientiae Studia, São Paulo, v. 4, n. 3, p. 373-392, 2006.

LEE, Y. C. Developing decision-making skills for socio-scientific issues. Journal of Biological Education, v. 41, n. 4, p. 170-177, 2007. 
LIMA, G. Z.; LINHARES, R. E. C. Escrever bons problemas. Revista Brasileira de Educação Médica, Rio de Janeiro, v. 32, n. 2, p. 197-201, 2008.

LIMA, M. C.; ROCHA, S. A. Efeitos dos agrotóxicos sobre as abelhas silvestres no Brasil: proposta metodológica de acompanhamento. Brasília, DF: Ibama, 2012.

LIMA, V. A. Sete teses sobre mídia e política no Brasil. Revista USP, São Paulo, n. 61, p. 48-57, 2004.

MOURA, M. A. M.; FRANCO, D. A. S.; MATALLO, M. B. Impacto de herbicidas sobre os recursos hídricos. Revista de tecnologia \& inovação agropecuária, São Paulo, v. 1, n. 1, p. $142-151,2008$.

PASCHOAL A. Pragas, praguicidas e a crise ambiental: problemas e soluções. Rio de Janeiro: FGV, 1979.

PERES, F.; MOREIRA, J. C. É veneno ou é remédio? agrotóxicos, saúde e ambiente. Rio de Janeiro: FIOCRUZ, 2003.

PILON-SMITS, E. A. H. Engineering plant selenium accumulation: potential uses and ecological impacts. In: BANUELOS, G. S.; LIN, Z.; YIN, X. Selenium in the environment and human health. Boca Raton: CRC Press, 2013. p. 217-218.

PINZANI, A. Democracia versus tecnocracia: apatia e participação em sociedades complexas. Lua Nova, São Paulo, v. 89, p. 135-168, 2013.

POTTS, S. et al. Global pollinator declines: trends, impacts and drivers. Trends in Ecology \& Evolution, Amsterdam, n. 25, v. 6, p. 345-353, 2010.

PRETTY, J. The rapid emergence of genetic modification in world agriculture: contested risks and benefits. Environmental Conservation, Lausanne, v. 28, n. 3, p. 248 $262,2001$.

RAMACHANDRAN, S. et al. N. Intraspecific competition of an insect-resistant transgenic canola in seed mixtures. Agronomy Journal, Madison, v. 92, n. 2, p. 368-374, 2000 .

RAYBOULD, A. F.; GRAY, A. J. Genetically modified crops and hybridisation with wild relatives: a UK perspective. Journal of Applied Ecology, London, v. 30, p. 199-219, 1993.

SCHNEIDER, K. R.; SCHNEIDER, R. G.; RICHARDSON, S. Genetically modified food. [2014]. Disponível em: <https://edis.ifas.ufl.edu/fs084>. Acesso em: 24 dez. 2015.

SILVA, C. M. M. S.; FAY, E. F. Agrotóxico e ambiente. Brasília, DF: Embrapa Informação Tecnológica, 2004.

SINGER, P. Ética prática. 3. ed. São Paulo: Martins Fontes, 2002.

TOULMIN, S. E. Os usos do argumento. 2. ed. São Paulo: Martins Fontes, 2006.

UETANABARO, A. P. T.; GÓES-NETO, A. Segurança alimentar: transferência horizontal de genes e alimentos transgênicos. Scientibus, Feira de Santana, n. 35, p. 111-124, jul./dez. 2006. 
VENDÔMOIS, J. S. et al. A comparison of the effects of three GM corn varieties on mammalian health. International Journey of Biological Sciences, [S.1.], v. 5, n. 7, p. 706726, 2009.

VIANA, C. A. et al. A cor e a embalagem na decisão de compra: reflexões sobre estratégias persuasivas no PDV. In: SEMINÁRIO INTERNACIONAL DE PESQUISA EM COMUNICAÇÃO: EPISTEMOLOGIA E DESAFIOS DA PESQUISA NO CAMPO DA comunicação, 5., 2013, Santa Maria. Anais... Santa Maria: UFSM, 2013. p. 1-13.

VICTORINO, V. I. Participação pública na construção institucional da biossegurança no Brasil: a questão dos transgênicos. Convergencia: Revista de Ciencias Sociales, Toluca, v. 11, n. 35, p. 107-127, 2004.

WANG, Y. et al. Expression of crylab protein in a marker-free transgenic bt rice line and its efficacy in controlling a target pest, chilosuppressalis (lepidoptera: crambidae). Environmental Entomology, Oxford, v. 43, n. 2, p. 528-536, 2014.

WILKERSON, J.; FRULAND, R. Simulating a federal legislature. Academic Exchange Quarterly, [S.1.], v. 10, n. 4, p. 38-44, 2006.

WOLFENBARGER, L. L.; PHIFER, P. R. The ecological risks and benefits of genetically engineered plants. Science, [S.1.], v. 290, p. 2088-2093, 2000.

ZABALA, A. A função social do ensino e a concepção sobre os processos de aprendizagem: instrumentos de análise. In: ZABALA, A. A prática educativa. Porto Alegre: Artmed, 1998. p. 27-52.

ZAMBERLAM, J.; FRONCHETI, A. Agroecologia: caminho de preservação do agricultor e do ambiente. Petrópolis: Vozes, 2012. 


\title{
COTAS RACIAIS, GENES E POLÍTICA UMA QUESTÃO SOCIOCIENTÍFICA PARA O ENSINO DE CIÊNCIAS
}

\author{
Thiago Leandro da Silva Dias \\ Kelly Meneses Fernandes \\ Juanma Sánchez Arteaga \\ Claudia Sepúlveda
}

\section{Introdução}

A ciência não é uma atividade neutra e o seu desenvolvimento está diretamente imbricado com os aspectos sociais, políticos, econômicos, culturais e ambientais, um empreendimento que não diz respeito exclusivamente aos cientistas e possui fortes implicações para a sociedade. (GIL-PERÉZ et al., 2001; SANTOS; MORTIMER, 2001, 2002) Ao longo da história, por exemplo, é possível verificar como discursos científicos e práticas das tecnociências estiveram comprometidos com processos sociais de dominação entre povos, compondo complexas relações de poder.

Em todo o século XIX - um período marcado pelo imperialismo e guerras coloniais -, os conceitos relativos ao pensamento darwinista contribuíram para mistificar cientificamente determinadas hierarquias raciais no imaginário coletivo do mundo ocidental. (SÁNCHEZ-ARTEAGA, 2007) Existem relatos de outros casos históricos de marginalização de determinados grupos humanos fundamentada na naturalização de categorias 
de normalidade, inferioridade e superioridade em sistemas hierárquicos de indivíduos, como, por exemplo, as numerosas tentativas históricas de demonstrar a superioridade intelectual dos homens sobre as mulheres. (FEDIGAN, 1986; HARAWAY, 1991; QUEROL, 2001; SCHIEBINGER, 2000) Esses exemplos históricos de alterização ${ }^{1}$ científica mostram que a marginalização de diferentes comunidades humanas sobre bases científicas tem sido uma prática recorrente na história das ciências biomédicas. (SÁNCHEZ-ARTEAGA, SEPÚLVEDA; EL-HANI, 2013)

Os conhecimentos derivados das ciências naturais que contribuíram para criação e legitimação do conceito de raça ao longo da história, com objetivos explícitos de inferiorização, marginalização e dominação étnicas - seja na política expansionista das potências europeias do século XIX, pautada nos discursos darwinistas sobre competição inter-racial e extinção racial, ou nas políticas eugênicas do século XX - atualmente põem em questão a própria existência de raças dentro da espécie humana, a partir da investigação genética contemporânea. (PENA; BORTOLINE, 2004; SÁNCHEZ ARTEAGA; SEPÚLVEDA; EL-HANI, 2013) No entanto, essa tendência de desconstrução do conceito biológico de raça não necessariamente permite negar a existência dessa categoria como construção e realidade social e pode vincular-se a diversas perspectivas ideológicas, políticas e econômicas em torno da questão racial, como no caso da implementação de políticas de ações afirmativas em universidades brasileiras.

O debate em torno dos resultados de um conjunto de estudos da genética humana com marcadores de ancestralidade sobre a composição étnica da população brasileira, tornado público sob o título "Retrato molecular do Brasil", mostra-se relevante para as reflexões sobre o papel que o conhecimento científico-tecnológico pode exercer na conformação das relações sociais e políticas na sociedade ocidental moderna. (SANTOS; MAIO, 2004)

O estudo de autoria de Sérgio Pena e colaboradores (2000), geneticistas ligados à Universidade Federal de Minas Gerais, utiliza ferramentas da moderna genética molecular, visando reconstituir as "origens genéticas do brasileiro". ${ }^{2}$ Os resultados da pesquisa indicam, entre outros aspectos, que a amostra de indivíduos, autoclassificados como brancos, que participou do estudo, apresentava uma maior frequência de marcadores genéticos de origem africana e/ou ameríndia do que de origem europeia. Entre as impli-

1 Usamos o termo "alterização" com o significado atribuído por Sanchez-Arteaga, Sepúlveda e El-Hani (2013, p. 61), para fazer referência aos processos simbólicos de geração e construção de categorias com as quais passamos a compreender os "outros". Entendidos desta forma, esses processos podem ser considerados como intrínsecos a todo processo social, envolvidos na construção de identidade. Mas, neste caso específico da alterização científica, estamos nos referindo aos processos de nomear e etiquetar aqueles que são considerados como diferentes, "outros", desde o ponto de vista de uma comunidade hegemônica constituída por "nós", processos esses que, na maioria das vezes, implicam inferiorizar e discriminar aqueles tidos como diferentes.

2 Esses estudos buscaram, através do sequenciamento de porções do DNA mitocondrial e do cromossomo $Y$, identificar padrões de ancestralidade das matrilinhagens e patrilinhagens da população brasileira. 
cações destes resultados, encontram-se as conclusões de que os afrodescendentes são em número bem maior do que aqueles que aparentam ser por suas características físicas e, de outro lado, que muitos dos indivíduos que se identificam como negros apresentam uma proporção significativa de ancestralidade europeia. (PENA et al., 2000; SANTOS; MAIO, 2005a) Segundo Santos e Maio (2005a), o que emerge das pesquisas genéticas é a corroboração quanto à natureza mestiça da amostra de brasileiros (autoclassificados) brancos, já que a maioria (aproximadamente $60 \%$ ) apresenta marcadores genéticos indicadores de matrilinhagem de origem ameríndia ou africana.

Tais resultados desestabilizam discursos racialistas, que afirmam a existência de raça, baseados em um conjunto específico e limitado de características fenotípicas, e relativizam diversas questões sociais e políticas em torno dos parâmetros raciais de classificação e processos identitários no Brasil. Nessa conjuntura, conforme Santos e Maio (2004, p. 4), "[...] há uma forte tensão entre perspectivas, cujos ingredientes incluem raça, genes, construção de identidades coletivas, história e modalidades de interpretação do Brasil, bem como ativismo e estratégias de combate ao racismo".

O debate sobre implementação de políticas de ações afirmativas ${ }^{3}$ é um exemplo que pode indicar como conhecimentos científicos da nova genômica são apropriados ideologicamente por alguns grupos sociais e geram tensões entre demandas sociais diversas. A polêmica se dá, principalmente, no que diz respeito à definição de critérios indicados para definir quem deve ser beneficiado por tais políticas, levando em consideração a relativização e a negação do conceito de raça como categoria de distinção biológica. Por esta razão, consideramos que este tema pode dar origem a uma Questão Sociocientífica (QSC) a ser tratada no contexto do ensino de biologia.

A utilização de QSC no ensino de ciência e biologia, a partir da abordagem educacional Ciência, Tecnologia, Sociedade e Ambiente (CTSA), baseia-se no uso de conhecimentos científicos sobre temas sociais controversos, que geralmente exigem dos educandos diálogos, discussões e debates, além de um grau de raciocínio moral ou avaliação de questões éticas e posicionamento crítico no processo de tomada de decisões. (MARTÍNEZ PÉREZ; CARVALHO, 2012; ZEIDLER; NICHOLS, 2009)

As QSC apresentam, para o ensino de ciências, importantes possibilidades para trabalhar aspectos políticos, ideológicos, culturais e éticos relacionados à ciência contemporânea (MARTÍNEZ PÉREZ, 2010) e podem, ainda, promover a capacidade de posicionamento na esfera social que subsidie alguma ação sociopolítica. (HODSON, 2004) Um viés de trabalho com estes aspectos pode ser planejado a partir de controvérsias, envolvendo temáticas sobre raça, ciência e sociedade.

A abordagem de tais temáticas, a partir dessa perspectiva, relaciona-se ainda com a possibilidade de implementação de uma educação das relações étnico-raciais (BRASIL,

3 Trata-se de conjuntos de ações políticas dirigidas à correção de desigualdades raciais e sociais, orientadas para oferta de tratamento diferenciado com vistas a corrigir desvantagens e marginalização criadas e mantidas por estrutura social excludente e discriminatória. (BRASIL, 2004) 
2004, 2009) no ensino de ciências e biologia. Verrangia e Silva (2010) descrevem algumas temáticas e questões prioritárias do ponto de vista dessa diretriz educacional, como abordagens que visem analisar criticamente a utilização dos conhecimentos científicos pela mídia na discussão, por exemplo, sobre políticas públicas, como as ações afirmativas. Para realizar a crítica sugerida, podem ser promovidas atividades que identifiquem e avaliem a veiculação de conhecimentos do campo da genética molecular e de populações a respeito da variabilidade genética humana e, especificamente, os estudos sobre padrões de ancestralidade da população brasileira, baseados em marcadores gênicos, no contexto de discussões sobre as chamadas cotas raciais. (VERRANGIA, 2014; VERRANGIA; SILVA, 2010)

Diante do exposto, levantamos a seguinte questão: quais as possibilidades e os desafios em promover compreensão crítica das relações CTSA e das relações étnico-raciais, por meio da abordagem de uma QSC baseada no uso do conhecimento sobre variabilidade genética e ancestralidade genômica da população brasileira e suas implicações sociais e políticas no debate sobre cotas raciais nas universidades brasileiras? Tal necessidade de problematização sustenta o objetivo deste capítulo, o qual pretende apresentar uma QSC sobre os discursos em torno das origens genéticas da população brasileira e as políticas de ações afirmativas, discutindo meios para sua aplicação no ensino de ciências e biologia.

Para dar conta de tal objetivo, aprofundaremos algumas questões sobre a temática proposta e, em seguida, apresentaremos um caso de QSC, elencando os objetivos estruturantes e as formas de aplicação e discussão dessa estratégia de ensino em contexto de salas de aula. Assinalamos algumas considerações sobre a educação das relações étnico-raciais, bem como algumas possibilidades futuras de aplicabilidade e pesquisa em salas de aula e espaços não formais de educação científica, como em exposições museais.

\section{"Retrato molecular do Brasil" e cotas raciais: alicerces para o debate}

É recente a adoção de ações afirmativas no Brasil, marcando sobremaneira o início do século XXI. Vistas como medidas para criar igualdade de oportunidades para grupos e populações socialmente excluídas, essas ações preveem um tratamento diferenciado na sua execução, objetivando uma maior inserção na educação, no sistema de saúde e no mercado de trabalho. (SANTOS, 2012) O sistema de cotas, um exemplo de política de ações afirmativas, representa ação dirigida à correção de desigualdades raciais e sociais na educação através da reserva de vagas para negros e indígenas nas universidades públicas.

Essa temática complexa e controversa tem suscitado diversos posicionamentos, constituindo-se em questão que tem gerado apreciações divergentes no plano jurídico e acadêmico como também discussões acaloradas no plano social. (BAYMA, 2012) Como 
salienta Oliveira Filho (2009, p. 2), “[...] a adoção de ações afirmativas como estratégia de combate às diferenças socioeconômicas entre grupos racializados, uma tendência das políticas públicas governamentais nos últimos anos, é bastante suscetível a uma rejeição fundamentada em argumentos universalistas [...]".

Um exemplo destes argumentos universalistas pode ser verificado nos discursos que se baseiam na perspectiva de que no Brasil, por conta do elevado grau de miscigenação e da ausência de uma fronteira biológica entre raças, exista uma suposta igualdade racial que limita qualquer tomada de ação política com vistas a reparos socioeconômicos, como as cotas raciais. Segundo Oliveira Filho (2009, p. 2), "os racismos universalistas procuram assimilar as diferenças, mas preservam mecanismos que perpetuam a desigualdade, a dominação e a exploração", tais como os mobilizados pelo discurso "mitológico" da democracia racial, que considera a existência de relações culturais e sociais entre negros e brancos no Brasil como harmoniosas, democráticas e diluídas nas questões socioeconômicas. (MUNANGA, 2004)

O discurso da democracia racial é adversário de qualquer discurso que afirme diferenças étnicas na sociedade brasileira. (OLIVEIRA FILHO, 2009) Sobre esse processo, Joaze Bernardino (2002) afirma que a democracia racial e o ideal de embranquecimento $^{4}$ conformam grandes desafios para a implementação de ações afirmativas no Brasil. No bojo desse discurso, a miscigenação é um argumento muito utilizado para mascarar as relações de discriminação racial e impedir a implementação de políticas direcionadas aos negros. (MATTA, 2007; OLIVEIRA FILHO, 2009) Diante de tal conjuntura, os dados de Pena e colaboradores (2000) sobre a composição étnica da população brasileira podem endossar tal argumento, já que era o intuito da pesquisa destrinchar, do ponto de vista biológico, a história de formação do povo brasileiro, enfatizando a realidade sociodemográfica do país no tocante à mestiçagem. (PENA et al., 2000)

Ao longo da história, o discurso da miscigenação tem sido utilizado na defesa de uma ideia sobre inexistência de fronteiras raciais no Brasil. (BERNARDINO, 2002) Nesse contexto, os resultados de Pena e colaboradores (2000) podem ser utilizados como um modo de comprovação, de ordem científica, da inexistência de tais fronteiras raciais da população brasileira, reiterando tal discurso.

Sobre esse paralelo, Santos e Maio (2004) discutem como narrativas sobre a história da formação do povo brasileiro produzidas pela genômica, nos moldes de Pena e colaboradores (2000), vão ao encontro de um imaginário social amplamente arraigado que vê na miscigenação um elemento positivo e definidor da identidade do Brasil enquanto nação. Tal perspectiva, que se depreende da pesquisa genômica, pode se tornar peça relevante em jogos retóricos de grande relevância sociopolítica, graças à autoridade e

4 Explica o autor que, ao lado do mito da democracia racial, arquitetou-se no Brasil o ideal do branqueamento, que pressupunha uma solução para o problema racial brasileiro, em fins do século XIX e início do século $X X$, através da gradual eliminação do negro, que seria assimilado pela população branca. (BERNARDINO, 2002) 
à legitimidade de que a pesquisa científica desfruta na sociedade ocidental nos tempos atuais. (SANTOS; MAIO, 2004)

Santos e Maio (2004, 2005a) nos oferecem suportes necessários para debater tais questões relacionadas aos referidos estudos genéticos. Os autores analisaram de forma contextualizada um conjunto de debates em curso sobre a repercussão dos resultados do retrato molecular no contexto social brasileiro, examinando como a nova genética, para além de uma dimensão biológica, torna-se uma arena de disputa na qual estão presentes elementos históricos, sociais e políticos.

Os autores analisam a recepção aos estudos genômicos a partir da narrativa de diversos atores sociais. ${ }^{5}$ Entre estes, destaca-se um ativista do movimento negro, Athayde Motta, que analisa a divulgação dos resultados dos estudos de Pena e colaboradores do ponto de vista das possíveis implicações para as políticas públicas de combate ao racismo no Brasil. Para Athayde Motta, a pesquisa de Pena e colaboradores (2000) fornece um "simulacro de suporte científico" para o "mito da democracia racial", solapando as bases que fundamentam possibilidades de identidades coletivas necessárias para organizar resistências a opressões.

Uma opinião, pode-se dizer, antagônica à de Motta é representada pelo comentário entusiasta de um articulista da Folha de S. Paulo que se referiu ao trabalho como "um artigo fenomenal", "uma verdadeira aula, motivo de orgulho para a ciência brasileira". Para Elio Gaspari, o estudo "é a comprovação científica daquilo que Gilberto Freyre ${ }^{6}$ formulou em termos sociológicos", o que no seu julgamento demonstra que a genética tem grande potencialidade de reconstruir a história do povo brasileiro.

Nessa arena dos debates sobre a composição étnico-racial do Brasil, é possível encontrarmos cientistas e geneticistas tecendo comentários e fazendo julgamentos a respeito de direitos humanos e cotas raciais, com base no conhecimento científico. Um geneticista contemporâneo proeminente, Francisco Salzano (2005, p. 2, grifo nosso), questiona a validade do estabelecimento de cotas raciais em universidades avaliando tal sistema como inconstitucional, por meio do seguinte argumento:

[...] a Constituição Brasileira de 1988 , em seu artigo $5^{\circ}$, afirma que 'todos são iguais perante a lei, sem distinção de qualquer natureza', e no seu parágrafo XLII estabelece que 'a prática do racismo constitui crime inafiançável e imprescritível, sujeito à pena de reclusão, nos termos da lei'. E o que está ocorrendo, justamente, é um racismo às avessas, inclusive

5 Os argumentos mobilizados por estes atores são vinculados ideologicamente a determinadas posições políticas e compromissos sociais. O uso de narrativas objetiva apresentar o debate e chamar a atenção para a multiplicidade de opiniões e valores envolvidos na interpretação de determinados resultados de pesquisa, e não necessariamente tecer e apontar limites na construção argumentativa de cada posição, embora estejamos conscientes de que estes existam.

6 Atribui-se a Gilberto Freyre o legado de profusão da "democracia racial", convivência harmônica entre as raças, no qual o Brasil se apresenta ao mundo como um "paraíso tropical". (MATTA, 2007) 
com a instituição (vergonhosa) do apartheid: há vestibular para brancos e vestibular para negros e índios separados, incomunicáveis [...].

Para justificar sua opinião, o geneticista mobiliza dados da pesquisa de Pena e colaboradores (2000) afirmando que se $86 \%$ da população brasileira possui mais de $10 \%$ de ancestralidade africana, essa fração poderia solicitar o benefício das cotas com legitimidade. Salzano (2005) relata ainda que o fato amplamente demonstrado que a África foi o berço de toda a humanidade é suficiente para que todos os brasileiros exijam direito ao benefício.

A posição de Francisco Salzano vai de encontro às proposições do próprio Sérgio Pena, em artigo com Maria Bortolini, que questiona se a genética pode definir quem deve se beneficiar das cotas universitárias e demais ações afirmativas. Pena e Bartolini (2004, p. 16) são enfáticos em afirmar que "[...] a informação genética sobre a estrutura da população brasileira deve ser considerada apenas como um subsídio para o processo de tomada de decisões [...]". Nesse sentido, cabe destacar que o conhecimento científico, por si só, não é suficiente para apoiar a tomada de decisões sobre questões sociais.

Desse modo, na interpretação dos autores, não compete à genética fazer prescrições sociais e a definição sobre quem deve se beneficiar das cotas universitárias e das ações afirmativas no Brasil deverá ser resolvida na esfera política, levando em conta múltiplos fatores e conhecimentos, como a história do país, o sofrimento de seus vários segmentos, as análises de custo e benefício e as bases éticas da consideração moral humana. (PENA; BARTOLINI, 2004) Embora a postura dos autores seja de tentar restringir ou apresentar uma ponderação ao papel a ser exercido pelos conhecimentos genéticos nos processos de tomada de decisão política, Sérgio Pena, em entrevista à revista Ciência Hoje, avalia as ações afirmativas como um contrassenso e reforça a defesa à abolição do conceito de raça, pois:

[...] em prol de ações reparadoras, as próprias vítimas do racismo no passado queiram agora usá-lo como base para suas políticas de ação afirmativa. A única opção é eliminar o conceito de raça completamente e criar uma sociedade 'desracializada', onde as diferenças individuais sejam valorizadas [...]. (QUAL..., 2013)

Como discutido e exemplificado, no caso do debate sobre as cotas, é frequente a mobilização de argumentos universalistas e antirracialistas, reiterados pela afirmação da miscigenação. Como esclarece Oliveira Filho (2009), o tema da miscigenação e os outros temas, que constituem o que se poderia chamar de discurso da democracia racial, têm sido usados repetidamente pelos brasileiros com o objetivo de obliterar o caráter opressivo das relações raciais no Brasil e impedir a adoção de medidas estatais que diminuam a desigualdade entre negros e brancos, como a política de reserva de vagas para acessar o ensino superior. Conforme Santos e Maio (2004), percebe-se a 
emergência de associações (como "nossa mestiçagem tem um teste de DNA") que colocam os resultados da pesquisa com marcadores genéticos de ancestralidade como elementos questionadores da própria ideia de implementação de cotas raciais no Brasil.

\section{Uma QSC sobre cotas raciais}

Esta QSC foi planejada para compor intervenção em salas de aula de licenciatura em Biologia, em disciplinas como Ensino de Genética ou Ensino de Ciências, mobilizando as seguintes áreas do conhecimento: genética, história da ciência, ética, sociologia e políticas públicas. Pode ser também abordada para discutir interdisciplinarmente a pluralidade cultural e a educação das relações étnico-raciais, sendo possível utilizar também em outros cursos ou espaços não formais, desde que se faça uma adaptação da abordagem conforme análise e seleção de certos objetivos educacionais.

Quadro 1 - Caso $^{7}$ sobre genética, raça e políticas de ações afirmativas

\section{O impasse sobre implementação de cotas raciais na universidade}

Suponha que, na universidade em que você estuda, esteja ocorrendo um debate sobre a necessidade e a validade do sistema de cotas raciais. Nesta universidade, não existe um sistema de cotas e nenhuma política de reservas de vagas para negros e indígenas, como a adotada em muitas universidades federais e estaduais do Brasil e assumida como constitucional pelo Supremo Tribunal Federal (STF) em 2012.

A maioria dos professores, estudantes e funcionários da universidade está inclinada a defender que não existe necessidade de um sistema de acesso ao ensino superior que selecione as pessoas pelos critérios raciais, já que no Brasil as fronteiras raciais se diluíram diante do alto grau de miscigenação. Dentre outros argumentos contra as cotas, é recorrente a mobilização do discurso científico de que raças humanas não existem.

Diante de tal impasse, a Administração Central da Universidade decidiu convocar um plebiscito para permitir que a comunidade acadêmica decida, através do voto, sobre a implementação ou não de um sistema de cotas raciais para acesso ao ensino superior. A proposta é que esse plebiscito seja precedido por um ciclo de palestras e debates que ocorrerão durante uma semana na universidade.

Nesta conjuntura, durante uma aula em que você assistia, um grupo de estudantes negros solicita à professora alguns minutos para realizar um convite para um seminário que está próximo. $\mathrm{A}$ professora cede espaço. Durante a explanação, o grupo tece alguns comentários sobre a conjuntura racialmente desigual da sociedade e relatam as dificuldades e impossibilidades do povo negro de acessar e cursar o nível superior. Nesse momento, a professora intervém:

- Vocês poderiam expor, então, o convite? Eu preciso retomar minha aula, logo em seguida.

7 O cenário do caso nos remete a uma sala de aula com estudantes de cursos heterogêneos e de maioria racial branca. O caso apresenta uma situação hipotética de uma universidade que está discutindo cotas raciais; porém, tem como referência um conflito recente ocorrido em sala de aula da Universidade de São Paulo (USP) e divulgado na mídia eletrônica em 10 de março de 2015: <http://www.jornaldocampus.usp.br/index.php/2015/04/movimento-negro-promove-acoes-para-discutir-relacoes-raciais-na-universidade/>. Acesso em: 23 maio 2015. Para mais informações sobre o caso, ver: <https://www.youtube.com/watch?v=hG9UTnAZI6Y >. Acesso em: 22 de nov. 2015. 
Rodrigo, um dos estudantes negros do grupo, expõe enfaticamente:

- Estamos convidando todas e todos para um debate que há anos vem sendo silenciado nesta universidade, expondo a luta do nosso povo contra as infinitas desigualdades e discriminações raciais! As cotas raciais.

Nesse momento, muitos estudantes começam a emitir opinião ao mesmo tempo. Paulo, seu amigo, logo expõe em voz alta:

- Se o problema é entrar na universidade, estuda, faz um cursinho e entra!

Rafaela aproveita o momento e complementa:

- Nós sabemos que não existem raças humanas, já estudamos isso aqui na disciplina de genética. Para que uma política que privilegia uma raça? Isso é racismo da parte de vocês!

Com muita euforia na sala, Dandara, uma estudante negra da turma, tenta se posicionar:

- É só vocês olharem para o lado pra perceberem que a maioria dessa sala é branca! Isso sim é expressão do racismo, na sociedade brasileira, de maioria negra e parda. A dificuldade de acesso ao estudo pelos negros é questão histórica.

Alguns estudantes aplaudem Dandara e fazem falas de denúncia de racismo dentro da universidade. Na tentativa de acabar com a confusão instaurada, a professora solicita que o grupo realize o tal convite e finalize a explanação. Os estudantes do grupo reiteram as denúncias, dão informações sobre as palestras e debates e se retiram.

Carlos, um estudante branco, tenta mediar a discussão que continua:

- Eu não acho que nós devemos racializar, o que devemos fazer é dar oportunidades iguais a todos. Somos todos iguais, da mesma raça, humana!

A professora tenta estimular uma discussão mais qualificada, utilizando a sua própria aula para iniciar um debate sobre o tema.

Fonte: adaptado de Dias e colaboradores (2015).

\section{Questões sobre o caso}

Q1. Você, enquanto sujeito que acompanhou a discussão, com legítima oportunidade de fala no momento ou após o ocorrido, como se expressaria, na sala de aula?

Q2. Com relação à fala de Rodrigo, você reconhece a necessidade de debater tais temas na universidade? Por quê?

Q3. Levando em consideração as falas de Paulo e Dandara, os argumentos apresentados por um e por outro são suficientes para você emitir um juízo adequado a respeito deste tema? Caso não sejam, quais informações você julga necessárias para fazê-lo?

Q4. Sobre a fala de Rafaela, você concorda que não há razão para se falar de políticas públicas racialmente definidas já que a genética comprovou a inexistência de raças humanas? Por quê?

Q5. Com relação à fala de Carlos, quais ações seriam viáveis para promover oportunidades iguais para todos? Será que é possível realizar algo dessa natureza sem considerar a existência de desigualdades sociais e raciais? Justifique suas respostas. 
Q6. Você conhece outro fato, na história do Brasil, em que o discurso científico influenciou decisões sociais sobre questões raciais no país? Se sim, qual?

Q7. Como o discurso favorável ou contra as cotas poderia ser respaldado por uma ética? Quais os valores podem sustentar cada posicionamento ético relacionado ao tema?

Q8. Como os discursos referentes às cotas poderiam ser comparados a discursos de defesa da ampliação da consideração moral com relação aos seres humanos?

Levando em consideração que você e seus colegas têm o dever de emitir um voto em consonância ou não com a política de cotas nesta universidade, como você se posicionaria? A decisão deve ser justificada com base em um argumento central, elaborado com conhecimentos e referenciado com materiais necessários e relevantes para a discussão. De preferência, proponha formas de ações coletivas para contribuir com o debate que vai ocorrer na universidade, levando em consideração as consequências de diferentes interpretações dos conhecimentos sobre genética e raça para a definição de políticas públicas.

\section{Objetivos de aprendizagem da QSC segundo características tipológicas dos conteúdos}

Os objetivos educacionais desta QSC foram elaborados a partir da tipologia dos conteúdos proposta por Zabala (1998). Conforme o autor, “[...] a determinação das finalidades ou dos objetivos da educação, sejam explícitos ou não, é o ponto de partida de qualquer análise da prática [educativa]" (ZABALA, 1998, p. 29), e esse modo de determinar consiste em fazê-lo em relação às capacidades que se pretende desenvolver nos alunos.

Os propósitos estabelecidos nos objetivos educacionais são imprescindíveis para realizar a análise global do processo educacional; porém, quando nos situamos no âmbito da aula e, concretamente, numa unidade de análise válida para entender a prática que nela acontece, temos que buscar alguns instrumentos mais definidos. (ZABALA, 1998)

Nesse caso, o autor propõe os conteúdos de aprendizagem ${ }^{8}$ como instrumentos de explicitação das intenções educativas. Decidimos adotar a tipologia de Zabala (1998), para explicitar os conteúdos de aprendizagem que propomos para a aplicação da QSC apresentada na seção anterior.

8 Entendidos como tudo quanto se tem que aprender para alcançar determinados objetivos que não abrangem apenas as capacidades cognitivas, como também as motoras, afetivas, de relações interpessoais e inserção social. (ZABALA, 1998) 


\section{Conceituais}

- Fatos: a implantação de um sistema de cotas raciais, a qual tem sido debatida socialmente no Brasil com mais intensidade no século XXI; o discurso científico que tem sido empregado no âmbito de debates sociais, a exemplo daqueles a respeito da implantação de políticas públicas de ações afirmativas; os discursos racistas comuns na história das ciências naturais e biomédicas; o mito da democracia racial como discurso obliterador de conquista de direitos raciais no Brasil; os mitos relacionados ao cientificismo;

- Conceitos: raça biológica e raça como construção social; espécie; populações; alterização; racismo; evolução; polimorfismo; marcadores genéticos; cientificismo;

- Princípios: frequências regionais de haplogrupos mitocondriais e do cromossomo Y como indicativo de ancestralidade; direito a um acesso qualificado aos bens sociais e políticos; ampliação do direito à diferença como um dos pilares dos direitos sociais.

\section{Procedimentais}

- Procedimentos: desenvolver a capacidade argumentativa; interpretar os resultados de estudo de identificação das proporções genéticas de ancestralidade africana, europeia e ameríndia;

- Técnicas: compreender como são empregadas as análises do DNA mitocondrial, do cromossomo Y e do DNA nuclear; realizar análise de discurso científico sobre relações raciais;

- Métodos: comparar diferentes discursos e vínculos ideológicos e políticos.

\section{Atitudinais}

- Valores: consideração moral das diferentes raças, etnias e gêneros; valor intrínseco e extrínseco de sujeitos; convivência democrática e igualitária entre diferentes grupos com consciência dos mecanismos de poder que permeiam as relações sociais;

- Normas: comunicação intersubjetiva entre sujeitos como aspecto central da elaboração e constante transformação dos princípios ético-morais que regem os conflitos (MARQUES, 2010); consideração sobre a Lei $n^{\circ}$ 12.711/2012 e o Decreto $\mathrm{n}^{0} 7.824 / 2012$, que definem as condições gerais de reservas de vagas para negros e indígenas em universidade públicas brasileiras, além da legislação que criminaliza os atos de discriminação ou preconceito de raça, cor, etnia, religião ou procedência nacional (Lei $\left.{ }^{0} 7.716 / 1989\right)$;

- Atitudes: respeito às diferentes raças e etnias socialmente construídas e solidariedade com as minorias sociais, políticas e econômicas e suas formas de resistência; conduzir debate qualificado sobre política de ações afirmativas; criticar, em um debate público, a função ideológica do discurso científico sobre raças na 
geração de processos de alterização e exclusão; e atuar na superação das desigualdades sociais e raciais.

\section{Meios para aplicação e discussão da QSC no ensino}

Os fatores que influenciam as relações entre os processos sociais de alterização, exclusão e marginalização de grupos humanos e os discursos ou práticas tecnocientíficas aparecem submersos dentro de uma matriz complexa de relações culturais profundamente influenciadas por forças históricas, socioeconômicas, políticas e ideológicas (SÁNCHEZ-ARTEAGA; SEPÚLVEDA; EL-HANI, 2013), como é o caso que se propõe discutir com esta QSC.

É perceptível como o debate sobre políticas de ações afirmativas está imerso numa conjuntura de conflitos, nos quais conhecimentos científicos são frequentemente utilizados para interpretar desigualdades sociais e culturais e meios para reparação das mesmas. Sendo assim, a condução dessa QSC deve levar em consideração essa teia de complexas relações de poder e estimular sua compreensão e crítica a partir da análise de valores e ideologias envolvidos na situação problema.

Uma forma viável para problematizar esse conjunto de fatores é esclarecer as formas possíveis de relação entre os resultados de Pena e colaboradores (2000) com temas e ideologias que constituem o discurso da democracia racial, como a miscigenação, a mestiçagem e o branqueamento, através das reações e análises de pesquisadores e atores sociais sobre a questão das políticas de ações afirmativas. Para tal intento, podem ser utilizados como subsídio para o debate em sala alguns trabalhos e textos que analisam e/ou representam essas reações, a exemplo de Bernardino (2002), Santos e Maio (2004, 2005a, 2005b), Pena e Bortolini (2004), entre outros. ${ }^{9}$

Podem ser utilizados ainda outros recursos que mobilizam diversos argumentos nesse sentido, como vídeos disponíveis na internet, a exemplo da audiência pública sobre cotas raciais nas universidades brasileiras, realizada em $2010 ;{ }^{10}$ do debate no Superior Tribunal Federal sobre constitucionalidade das cotas raciais em 2012;11 do documentário Raça humana, que revela os bastidores das cotas raciais na Universidade de Brasília (UnB), ${ }^{12}$ e de fragmento do documentário USP 7\% que mostra a mobilização em favor da cotas raciais na maior universidade do Brasil. ${ }^{13}$ Além de vídeos, outros veícu-

9 Outra referência que pode ser utilizada é a seção Espaço Aberto do número 23 da revista Horizontes Antropológicos, a qual aborda discussão sobre cotas raciais a partir da enunciação de intelectuais sobre um artigo de Marcos Chor Maio e Ricardo Ventura Santos. Conforme proposta dos editores, esse debate promove a relação entre reflexões acadêmicas e a ação política, expandindo o seu interesse para além do tema propriamente dito. (TEIXEIRA; STEIL, 2005)

10 Ver em: <https://www.youtube.com/watch?v=|BfsV3tH0T0 $>$.

11 Ver em: <https://www.youtube.com/watch?v=D_6JXx1_Coc>.

12 Ver em: <https://www.youtube.com/watch?v=y_dbLLBPXLo>.

13 Ver em: <https://www.youtube.com/watch?v=WAWkE2bU0QM>. 
los importantes, como sites, jornais e revistas virtuais, reúnem informações pertinentes para o debate sobre cotas raciais. ${ }^{14}$

Essas referências devem balizar as discussões em sala sobre o uso de conhecimentos científicos na orientação de decisões políticas e sociais, assim como para gerar exclusão e desigualdade. Nesse percurso discursivo, podem ser explorados também alguns fatos emblemáticos de alterização e racismo ao longo da história da ciência, além da construção do próprio conceito de raças humanas pelas ciências naturais. Para subsidiar tal abordagem, propomos utilizar alguns princípios elaborados por Sánchez Arteaga e El-Hani (2012) para intervenções educativas sobre racismo científico e relações CTSA. ${ }^{15}$ Para os autores, a abordagem do racismo científico do século XIX, na Europa e no Brasil, pode desenvolver uma forma de análise de como os discursos da biologia desempenharam uma função ideológica sobre as relações inter-raciais no passado e, nesse sentido servem como base para professores e estudantes analisarem as funções ideológicas do conhecimento biológico contemporâneo.

Essa perspectiva de desenvolvimento da QSC em sala de aula corrobora a proposta de Hodson (2004) que estabelece quatro níveis de sofisticação de um currículo voltado para ação sociopolítica, baseado na abordagem da educação CTSA. Diante deste primeiro cenário de discussão, acreditamos que a QSC tem potencialidades de estimular os seguintes níveis:

- $\quad$ percepção da dependência cultural da ciência e da tecnologia; e

- percepção que o desenvolvimento científico e tecnológico ocorre a partir de interesses particulares, com benefícios para alguns em detrimento de outros diante de relações da distribuição de riquezas e poder. (HODSON, 2004)

No percurso de aplicação da QSC, pode-se pensar em dois momentos específicos para intervenção, conforme objetivos educacionais pretendidos. $\mathrm{O}$ primeiro momento, composto de leitura do caso e resposta às primeiras seis questões, com posterior debate ampliado sobre as temáticas e conceitos identificados. Durante esta etapa, pode ser estimulada a prática de pesquisa bibliográfica pelos estudantes para melhor fundamentar a discussão, além de permitir maior contato e apropriação das temáticas relacionadas.

14 Ver em: Jornal do Campus da USP <http://www.jornaldocampus.usp.br/>; Portal Geledés <http:// www.geledes.org.br/\#gs.U=W6kpA>; Revista Äfrica e Africanidades <http://www.africaeafricanidades.com.br/>; Revista da Associação Brasileira de Pesquisadores(as) Negros(as) <http://www. abpn.org.br/Revista/index.php/edicoes/search/results>; Blog do Negro Belchior na Carta Capital $<$ http://negrobelchior.cartacapital.com.br/>; Anistia Internacional Brasil: <https://anistia.org.br/?no-high>; Carta Educação <http://www.cartaeducacao.com.br/>. Acesso em: 22 nov. 2015.

15 Os autores ressaltam a necessidade e importância de trabalhar em intervenções educativas os discursos biológicos sobre raças, incluindo as implicações da pesquisa genética contemporânea que põe em questão a própria existência de raças na espécie humana. 
Já indicamos algumas fontes e referências para estimular a compreensão sobre os vínculos políticos e ideológicos de determinados discursos científicos; porém, se faz necessário mediar outras reflexões pertinentes à situação-problema, tais como referentes aos dados sobre desigualdades raciais no Brasil e à dificuldade de acesso da população negra e indígena a direitos sociais mínimos.

Sobre este tema, sugerimos utilizar, por exemplo, pesquisa de Henriques (2001) e o Relatório anual das desigualdades raciais no Brasil 2009-2010 ${ }^{16}$ o que permitirá um diálogo a respeito dos mecanismos sociais e razões históricas que obstruem, no Brasil, a mobilidade socioeconômica ascendente das pessoas negras e etnicamente distintas do padrão eurocêntrico. Nessa questão, é importante ainda debater sobre o acesso desigual ao espaço geográfico, disponibilizando para análise as próprias condições de mobilidade urbana da população menos favorecida em termos socioeconômicos, de maioria negra, e a territorialidade periférica destas. Além disso, pode-se trazer à tona as diversas formas de cerceamento dos diretos sociais básicos para esta parcela da população que perduram desde o pós-abolição ${ }^{17}$ e, dessa maneira, dialogar sobre a ideia de colonialidade no padrão de poder hoje hegemônico, ${ }^{18}$ como forma de conjeturar processos de dominação e relações de poder ao longo da história. Outro recurso que pode ser utilizado para aprofundar facetas da desigualdade racial no Brasil é o conjunto de dados sobre violência contra juventude negra dispostos em Brasil (2015), que agrega dados relativos às dimensões consideradas centrais na determinação da vulnerabilidade dos jovens à violência, tais como: taxa de frequência à escola, escolaridade, inserção no mercado de trabalho, taxa de mortalidade por causas internas, taxa de mortalidade por causas violentas, valor do rendimento familiar médio mensal, entre outros. Em termos gerais, são destaques nesse material as elevadas taxas de violência observadas no país contra adolescentes e jovens entre 12 e 29 anos de idade, em especial jovens negros, que, em 2013, foram 18,4\% mais encarcerados e 30,5\% mais vítimas de homicídios dos que os jovens brancos.

A prevalência de jovens negros serem mais vítimas de assassinatos do que jovens brancos é uma tendência nacional: em média, jovens negros têm 2,5 mais chances de morrer do que jovens brancos no país. (BRASIL, 2015) Estimular a crítica sobre essa conjuntura homicida sobre a juventude negra ${ }^{19}$ e os fatores sociais, econômicos

16 Disponível em: <http://www.palmares.gov.br/wp-content/uploads/2011/09/desigualdades_raciais_2009-2010.pdf>. Acesso em: 20 ago. 2017.

17 Para mais informações sobre, ver o livro As políticas públicas e a desigualdade racial no Brasil: 120 anos após a abolição, publicado pelo Instituto de Pesquisa Econômica Aplicada. Disponível em: <http://www.ipea.gov.br/portal/images/stories/Livro_desigualdadesraciais.pdf>. Acesso em: 20 ago. 2017.

18 Para Quijano (2005), um dos eixos fundamentais do padrão de poder mundial é a classificação social da população mundial de acordo com a ideia de "raça", uma construção mental que expressa a experiência básica da dominação colonial e que desde então permeia as dimensões mais importantes do poder mundial, incluindo sua racionalidade específica, o eurocentrismo.

$19 \mathrm{Na}$ interpretação de muitos atores políticos e do movimento negro, vivemos efetivamente um genocídio da juventude negra, que envolve todas as políticas estatais que sistematicamente têm 
e políticos em voga é extremamente necessário por dimensionar em última análise as consequências nefastas e inadmissíveis do racismo institucionalizado e das diversas políticas estatais no gerenciamento de mortes de uma parcela significativa da juventude brasileira.

Um outro aspecto para condução da QSC é esclarecer sobre questões metodológicas e procedimentais da pesquisa de Pena e colaboradores (2000), para incentivar a compreensão sobre os dados e conhecimentos teóricos que a genética se baseia para definir a composição étnico-racial da população brasileira a partir de marcadores moleculares de ancestralidades e concluir sobre a inexistência de raças do ponto de vista biológico. Propõe-se, sobre esse aspecto, o uso do trabalho original de Pena e colaboradores (2000), além de trabalhos originais da equipe de pesquisa com apresentação dos resultados em pormenores para a comunidade científica. (ALVES-SILVA et al., 2000; CARVALHO-SILVA et al., 2001; PARRA et al., 2003)

Num segundo momento de aplicação da QSC, grupos de estudantes deverão levantar possíveis argumentos para sustentar a escolha de decisão diante da questão sete, que aponta uma problemática a ser resolvida. Podem ser promovidos espaços para diálogo com o(a) professor(a) da disciplina culminando em um momento ampliado de apresentação pública das propostas desenvolvidas e dos argumentos que as sustentam. Dependendo do contexto didático e da disponibilidade de tempo hábil para o desenvolvimento da estratégia pedagógica, pode-se incluir como demanda de pesquisa para qualificar as respostas, a fundamentação teórica de estratégias de argumentação nas discussões em grupos. ${ }^{20}$

Estas etapas fundamentarão o nível três, do currículo proposto por Hodson (2004): desenvolvimento de próprio ponto de vista dos estudantes e de posições valorativas, que iniciam com o fomento da autoestima e do bem-estar pessoal, e estende-se ao respeito dos direitos de outros indivíduos, à confiança mútua, à busca de justiça, à tomada de decisão cooperativa e criativa e à resolução de conflitos entre indivíduos, dentro e entre comunidades. A proposição desse nível de educação dialoga profundamente com as diretrizes pedagógicas e princípios políticos de uma educação das relações étnico-raciais:

[...] atividades curriculares ou não, em que: - promovam-se oportunidades de diálogo em que se conheçam, se ponham em comunicação diferentes sistemas simbólicos e estruturas conceituais, bem como se busquem formas de convivência respeitosa, além da construção de projeto de sociedade em que todos se sintam encorajados a expor, defender sua especificidade étnico-racial e a buscar garantias para que todos o façam; - sejam incen-

impacto negativo na qualidade de vida da população negra. O genocídio diz respeito a todo ato que visa destruir, matar, limitar a reprodução física, cultural e social de um determinado grupo em desvantagem social em relação aos outros grupos em determinada sociedade. (FEFFERMANN, 2013)

Por exemplo, Toulmin (2006). 
tivadas atividades em que pessoas de diferentes culturas interatuem e se interpretem reciprocamente, respeitando os valores, visões de mundo, raciocínios e pensamentos de cada um [...]. (BRASIL, 2004, p. 11)

Além desta diretriz, o caso em questão pode fomentar outros princípios e demandas de uma educação das relações étnico-raciais, como os processos de construção de identidades raciais, as estratégias de combate a preconceitos e discriminações e o fomento de consciências dos direitos raciais e sociais.

A tônica do racismo no debate sobre cotas raciais e a mobilização de discursos científicos antirracialistas no combate às políticas de ações afirmativas são, talvez, aspectos da proposta geral desta QSC que mais dialoguem com demandas de uma educação das relações étnico-raciais no sentido de potencializar estratégias e ações educativas de combate ao racismo e às discriminações; tais demandas estão expressas nos documentos legais e nas diversas proposições políticas do movimento negro para a educação brasileira. $^{21}$

Ao dimensionar os alicerces e componentes do racismo nesse debate, incluindo seus discursos, ideologias e consequências sociais, o(a) professor(a) pode facilmente estabelecer relações com expressões e ações racistas no cotidiano dos(a)s estudantes e traçar metas e propostas para superação destas, implicando, segundo as propostas de Gomes (2012), na formação de subjetividades inconformistas diante das práticas racistas e no conhecimento teórico-conceitual mais aprofundado sobre as questões afro-brasileiras.

Outra forma de trabalhar relações étnico-raciais a partir do caso em questão é discutir sobre o sentido dos testes de ancestralidade na construção de identidades, ou ainda sobre a influência do discurso de desinvenção das raças do ponto de vista biológico em processos identitários coletivos que se forjam na luta antirracista e na defesa de políticas de ações afirmativas. Um aspecto importante a ser discutido, nesse sentido, é problematizar se marcadores moleculares podem definir quem deve ser assistido(a) por políticas com recorte racial (PENA; BORTOLINE, 2004; SANTOS; BORTOLINE; MAIO, 2005/2006; SANTOS; MAIO, 2005a) ou ainda se dados genéticos contribuem para reforçar identidades minoritárias ou para negação e relativização destas. Nesse debate é importante ressaltar a contribuição das políticas afirmativas como mecanismos capazes de corrigir o reconhecimento distorcido e a estigmatização que têm sido projetados so-

21 Os principais dispositivos legais que fundamentam tal perspectiva educacional são: Lei 9.394, de 9 de dezembro de 1996, relacionada às alterações recentes: Lei 10.639, de 9 de janeiro de 2003 e Lei 11.645, de 10 de março de 2008; a Resolução do Conselho Nacional de Educação - CNE/ CP- 01/2004, que aprovou as Diretrizes Curriculares Nacionais para a Educação das Relações Étnico-raciais e para o Ensino de História e Cultura Afro-Brasileira e Africana (BRASIL, 2004), e o Parecer CNE/CP 03/2004, que fundamenta tais diretrizes; Plano Nacional de Implementação das Diretrizes Curriculares Nacionais para a Educação das Relações Étnico-raciais e para o Ensino de História e Cultura Afro-brasileira e Africana. (BRASIL, 2009) 
bre a população negra, provocando, assim, uma reviravolta identitária ao permitir uma atribuição de um valor positivo à classificação social do negro e do indígena. ${ }^{22}$

Nesse quesito, é pertinente problematizar a polêmica entre a desconstrução do conceito biológico de raça e a permanência desse conceito enquanto categoria de distinção, classificação e discriminação social, fato central na argumentação sobre a defesa e o combate às políticas de ações afirmativas e em todo debate sobre a questão racial no Brasil. É importante explicitar que a categoria de raça que opera no imaginário da população e produz discursos racistas é ainda a ideia de raça produzida pela ciência moderna nos séculos XIX e XX. Essa perspectiva de discussão pode ser trabalhada a partir da proposição das diretrizes para educação das relações étnico-raciais, as quais entendem o conceito de raça como construção social forjada nas tensas relações entre brancos e negros, muitas vezes simuladas como harmoniosas, nada tendo a ver com o conceito biológico de raça cunhado no século XVIII e hoje sobejamente superado. (BRASIL, 2004) Essa ideia reitera os escritos de Guimarães (1999, p. 153) sobre a necessidade de teorizar as "raças" como o que elas são, ou seja, "[...] construtos sociais, formas de identidade baseadas numa ideia biológica errônea, mas eficaz, socialmente, para construir, manter e reproduzir diferenças e privilégios”. Nessa discussão, é também importante entender a relação do ideário antirracialista com uma política de negação do racismo como fenômeno social, buscando compreender como a redução do antirracismo ao antirracialismo sustentou a necessidade de retomada do conceito social de raça na história. (GUIMARÃES, 1999; PENA; BIRCHAL, 2006; SCHUCMAN, 2010)

Por fim, com a apresentação das propostas e dos argumentos, deve ser encaminhada uma discussão que mobilize os conhecimentos trabalhados e desenvolvidos para o nível quatro, do currículo proposto por Hodson (2004): preparo e realização da ação sociopolítica. Nesse sentido, pode-se iniciar uma avaliação ampliada sobre as ações coletivas que cada grupo elencou como forma de contribuição para o debate que está ocorrendo na universidade, encaminhada no sentido de caracterizar as ações que conseguem responder às demandas sociais/raciais em estreita relação com projetos de sociedade, formas de dominação e propostas de transformação social.

A depender do contexto que essa estratégia de ensino seja desenvolvida, para refletir sobre a realidade social local e avaliar a pertinência de atuação no sentido de promoção de espaços para discussão sobre políticas de ações afirmativas, podemos propor uma plataforma de debates com representantes políticos, institucionais e movimentos sociais, que tenha como diretriz a promoção de discussão e encaminhamentos como forma de refletir e transformar tais políticas, impactando, assim, a realidade de cada universidade.

Como resolução desta QSC, pode-se pensar ainda numa atividade pública e didática como produto, na qual seja divulgada e problematizada, de forma mais abrangente e contextualizada, a interrelação que se estabelece entre conhecimentos científicos e va-

22 Para essa discussão, ver Bernardino (2002). 
riadas demandas sociais e políticas em torno da questão racial. Uma forma para colocar em prática tal proposta pode ser baseada em experiências de ensino do nosso grupo de pesquisa realizadas desde 2011 sobre ciência e raça, ${ }^{23}$ cujas motivações iniciais estão relacionadas à reflexão sobre os riscos potenciais que discursos teóricos e práticas das tecnociências podem apresentar para promover alterização, exclusão e marginalização de determinados grupos sociais e culturais. (DIAS et al., 2014)

\section{Considerações e perspectivas}

Problematizar a questão étnico-racial no âmbito do ensino de ciências e biologia a partir das controvérsias sociocientíficas é colaborar com a reflexão em salas de aula, e fora delas, sobre a compreensão da natureza do conhecimento científico, entendendo a ciência como uma atividade social e cultural imersa em contextos históricos nos quais permeiam valores, crenças e ideologias que repercutem na construção e no consequente uso dos seus aportes teóricos.

Neste caso, em especial, trata-se de contribuir com o debate sobre o papel que a mobilização do conhecimento científico pode exercer em processos de decisões políticas contemporâneas que fundamentam alterização, racismo e marginalização de determinados grupos humanos. Dessa forma, tal perspectiva reitera a necessidade de superar visões de ciência descontextualizada, a problemática e linear, tão frequentemente abordadas entre professores e estudantes nas escolas.

Em vista disso, assumimos que a QSC apresentada pode contribuir com a formatação de propostas para trabalhar com tais alicerces teórico-metodológicos em intervenções didáticas de ciências e biologia, colaborando com a formação de professores nesse sentido e reduzindo, assim, uma lacuna existente na literatura sobre construção de práticas educativas voltadas para a questão étnico-racial (GOMES, 2003; VERRANGIA; SILVA, 2010) e sobre formulação de estratégias de ensino com enfoque CTSA. (ZEIDLER; NICHOLS, 2009)

O processo de implementação desta proposta didática pode encontrar algumas limitações e dificuldades, ao exigir do(a) professor(a) uma apropriação teórica e discursiva ampla e diversa, sobre temáticas e conceitos normalmente ausentes e/ou silenciados nos currículos de licenciatura em Biologia, por exemplo. Vale ressaltar, ainda, a dificuldade em realizar um tratamento adequado da questão racial brasileira, tão múltipla e polêmica, e por envolver questões notadamente subjetivas e identitárias.

23 Fruto de uma construção coletiva que envolve pesquisadores do Laboratório de Ensino, Filosofia e História da Biologia (Instituto de Biologia da Universidade Federal da Bahia) e do Grupo Colaborativo de Pesquisa em Ensino de Ciências (Departamento de Educação da Universidade Estadual de Feira de Santana), juntamente com estudantes de graduação em Ciências Biológicas e do Programa de Pós-graduação em Ensino, Filosofia e História das Ciências (PPGEFHC). Essa articulação permitiu a construção de oito edições de uma exposição itinerante que aborda de forma interativa temáticas que versam sobre ciência, raça, literatura e sociedade. 
A proposição desta QSC só terá sua potencialidade explorada quando concretizar-se como prática educativa em salas de aula ou outros espaços educativos, podendo ser devidamente investigada a partir da colaboração com pesquisadores do tema e da abordagem curricular CTSA a partir de QSC. Diante do que defendemos e tentamos argumentar neste capítulo, o esforço de substanciar práticas educativas com tal perspectiva é derivado de diversas contribuições teóricas, políticas e institucionais nas quais reside responsabilidade conjunta de pesquisadores, professores e gestores públicos na consolidação de uma educação que questione as relações de dominação e poder, promova o exercício de cidadania de caráter emancipatório, com base numa agenda política.

\section{Referências}

ALVES-SILVA, J. et al. The ancestry of brazilian mt DNA lineages. American Journal of Human Genetics, Chicago, v. 67, n. 2, p. 444-461, 2000.

BAYMA, F. Reflexões sobre a constitucionalidade das cotas raciais em universidades públicas no Brasil: referências internacionais e os desafios pós-julgamento das cotas. Ensaio: Avaliação e Políticas Públicas em Educação, Rio de Janeiro, v. 20, n. 75, p. 325346, 2012.

BERNARDINO, J. Ação afirmativa e a rediscussão do mito da democracia racial no Brasil. Estudos Afro-Asiáticos, Rio de Janeiro, ano 24, n. 2, p. 247-273, 2002.

BRASIL. Índice de vulnerabilidade juvenil à violência e desigualdade racial 2014. Brasília, DF, 2015. Série Juventude Viva. Disponível em: <http://unesdoc.unesco.org/ images/0023/002329/232972POR.pdf>. Acesso em: 3 dez. 2015.

BRASIL. Ministério da Educação. Conselho Nacional de Educação. Diretrizes Curriculares Nacionais para a educação das relações étnico-raciais e para o ensino de história e cultura afro-brasileira e africana. Brasília, DF, 2004. Disponível em: <http:// portal.mec.gov.br/cne/arquivos/pdf/003.pdf>. Acesso em: 14 nov. 2014.

BRASIL. Ministério da Educação. Plano nacional das diretrizes curriculares nacionais para a educações das relações étnico-raciais e para o ensino de história e cultura afrobrasileira e africana. Brasília, DF, 2009.

CARVALHO-SILVA, D. R. et al. The phylogeography of Brazilian Y-chromosome lineages. American Journal of Human Genetics, Chicago, v. 68, n. 1, p. 281-286, 2001.

DIAS, T. L. S. et al. As contribuições da exposição ciência, raça e literatura para a educação das relações étnico-raciais. Revista da SBEnBio, Campinas, v. 7, p. 7226-7238, 2014.

DIAS, T. L. S. et al. Genética, raça e políticas de ações afirmativas a partir de questões sociocientíficas. In: SIMPÓSIO NACIONAL DE TECNOLOGIA E SOCIEDADE, 6., 2015, Rio de Janeiro. Anais... Rio de Janeiro: CCMN/UFRJ, 2015. p. 1-17.

FEDIGAN, L. M. The changing role of women in models of human evolution. Annual Review of Anthropology, [S.1.], v. 15, p. 25-66, 1986. 
FEFFERMANN, M. A luta contra o genocídio da juventude negra: reflexões sobre a realidade brasileira. In: CONGRESO DE LA ASOCIACIÓN LATINOAMERICANA DE SOCIOLOGÍA, 29., 2013, Santiago. Anais... Santiago: Asociación Latinoamericana de Sociología, 2013. Disponível em: <http://actacientifica.servicioit/biblioteca/pn/ PN33/P_Fefferman.pdf>. Acesso em: 12 dez. 2015.

GIL-PÉREZ, D. et al. Para uma imagem não deformada do trabalho científico. Ciência \& Educação, Bauru. v. 7, n. 2, p. 125-153, 2001.

GOMES, N. L. Cultura negra e educação. Revista Brasileira de Educação, Belo Horizonte, n. 23, p. 75-85, 2003.

GOMES, N. L. Práticas pedagógicas de trabalho com relações étnico-raciais na escola na perspectiva da Lei $n^{o}$ 10.639/03. Brasília: MEC: Unesco, 2012.

GUIMARÃES, A. S. A. Raça e os estudos de relações raciais no Brasil. Novos Estudos CEBRAP, São Paulo, n. 54, p. 147-156, 1999.

HARAWAY, D. J. Ciencia, cyborgs y mujeres: la reinvención de la naturaleza. Madrid: Cátedra, 1991.

HENRIQUES, R. Desigualdade racial no Brasil: evolução das condições de vida na década de 90. Rio de Janeiro: IPEA, 2001. (Texto para Discussão, 807).

HODSON, D. Going beyond STS: towards a curriculum for sociopolitical action. The Science Education Review, Warwick, v. 3, n. 1, p. 2-7, 2004.

MARQUES, A. C. S. Ética do discurso e deliberação mediada sobre a questão das cotas raciais. Líbero, São Paulo, v. 13, n. 26, p. 75-90, 2010.

MARTÍNEZ PÉREZ, L. F. A abordagem de questões sociocientíficas na formação continuada de professores de Ciências: contribuições e dificuldades. 2010. 351 f. Tese (Doutorado em Educação para a Ciência) - Faculdade de Ciências, Universidade Estadual Paulista, Bauru, 2010.

MARTÍNEZ PÉREZ, L. F.; CARVALHO, W. L. P. Contribuições e dificuldades da abordagem de questões sociocientíficas à prática de professores de ciências. Educação e Pesquisa, São Paulo, v. 38, n. 3, p. 728-742, 2012.

MATTA, L. G. da. Da democracia racial à ação afirmativa: a política de cotas para negros. Revista Jurídica da Faminas, Muriaé, v. 3, n. 1, p. 59- 72, 2007.

MUNANGA, K. Uma abordagem conceitual das noções de raça, racismo, identidade e etnia. In: BRANDÃO, A. A. P. (Org.). Cadernos Penesb. Niterói: Ed. UFF, 2004. p. 15-34.

OLIVEIRA FILHO, P. A mobilização do discurso da democracia racial no combate às cotas para afrodescendentes. Estudos de Psicologia, Campinas, v. 26, n. 4, p. 429-436, 2009.

PARRA, F. C. et al. Color and genomic ancestry in Brazilians. Proceedings of the National Academy of Sciences, New York, v. 100, n. 1, p. 177-82, 2003. 
PENA, S. D. J. et al. Retrato molecular do Brasil. Ciência Hoje, São Paulo, v. 27, n. 159, p. 16-25, 2000.

PENA, S. D. J.; BORTOLINI, M. C. Pode a genética definir quem deve se beneficiar das cotas universitárias e demais ações afirmativas? Estudos Avançados, São Paulo, v. 18, n. 50, p. 31-50, 2004.

PENA, S. D. J.; BIRCHAL, T. S. A inexistência biológica versus a existência social de raças humanas: pode a ciência instruir o etos social? Revista USP, São Paulo, n. 68, p. 10-21, 2005-2006.

QUAL a sua raça/cor? Ciência Hoje, Rio de Janeiro, 13 maio 2013. Disponível em: <http://www.cienciahoje.org.br/noticia/v/ler/id/1934/n/qual_a_sua_raca_cor/Post_ page/1166>. Acesso em: 10 jun. 2015.

QUEROL, M. A. Adán y Darwin. Madrid: Síntesis, 2001.

QUIJANO, A. Colonialidade do poder, eurocentrismo e América Latina. In: LANDER, E. (Org.). A colonialidade do saber: eurocentrismo e ciências sociais - perspectivas latino-americanas. Buenos Aires: CLACSO, 2005. p. 227-278.

SALZANO, F. M. Raça, racismo e direitos humanos. Horizontes Antropológicos, Porto Alegre, v. 11, n. 23, p. 225-227, 2005.

SANTOS, J. T. dos. Ações afirmativas e educação superior no Brasil: um balanço crítico da produção. Revista brasileira de estudos pedagógicos, Brasília, DF, v. 93, n. 234, p. 401422, 2012.

SANTOS, R. V.; MAIO, M. C. Qual "retrato do Brasil"? Raça, biologia, identidades e política na era da genômica. Mana, Rio de Janeiro, v. 10, n. 1, p. 61-95, 2004.

SANTOS, R. V.; MAIO, M. C. Antropologia, raça e os dilemas das identidades na era da genômica. História, Ciências, Saúde - Manguinhos, Rio de Janeiro, v. 12, n. 2, p. 447 468, 2005a.

SANTOS, R. V.; MAIO, M. C. Política de Cotas Raciais, os "olhos da sociedade" e os usos da antropologia: o caso do vestibular da Universidade de Brasília (UNB). Horizontes Antropológicos, Porto Alegre, v. 11, n. 23, p. 181-214, 2005b.

SANTOS, R. V.; BORTOLINE, M. C.; MAIO, M. C. No fio da navalha: raça, genética e identidades. Revista USP, São Paulo, n. 68, p. 22-35, 2005/2006.

SANTOS, W. L. P. dos; MORTIMER, E. F. Tomada de decisão para ação social responsável no ensino de ciências. Ciência e Educação, Bauru, v. 7, n. 1, p. 95-111, 2001.

SANTOS, W. L. P. dos; MORTIMER, E. F. Uma análise de pressupostos teóricos da abordagem C-T-S (Ciência - Tecnologia - Sociedade) no contexto da educação brasileira. Ensaio - Pesquisa em Educação em Ciências, Belo Horizonte, v. 2, n. 2, p. 1-23, 2002.

SÁNCHEZ-ARTEAGA, J. M. S. La razón salvaje. La lógica del dominio: tecnociencia, racismo y racionalidad. Madrid: Lengua de Trapo, 2007. 
SÁNCHEZ-ARTEAGA, J. M.; EL-HANI, C. N. Othering processes and STS curricula: From nineteenth century scientific discourse on interracial competition and racial extinction to othering in biomedical technosciences. Science \& Education, Dordrecht, v. 21, n. 5, p. 607-629. 2012.

SÁNCHEZ-ARTEAGA, J. M.; SEPÚLVEDA, C.; EL-HANI, C. N. Racismo científico, procesos de alterización y enseñanza de ciencias. Magis, Revista Internacional de Investigación en Educación, Rio de Janeiro, v. 6, n. 12, p. 55-67, 2013.

SCHIEBINGER, L. Has feminism changed science? Signs: journal of women in culture and society, Chicago, v. 25, n. 4, p. 1171-1175, 2000.

SCHUCMAN, L. V. Racismo e antirracismo: a categoria raça em questão. Psicologia Política, São Paulo, v. 10, n. 19, p. 41-55, 2010.

TEIXEIRA, S. A.; STEIL, C. A. Introdução ao debate sobre cotas. Horizontes Antropológicos, Porto Alegre, v. 11, n. 23, p. 179-180, 2005.

TOUlMiN, S. E. Os usos do argumento. 2. ed. São Paulo: Martins Fontes, 2006.

VERRANGIA, D.; SILVA, P. B. G. Cidadania, relações étnico-raciais e educação. Educação \& Pesquisa, São Paulo, v. 36, n. 3, p. 705-718, 2010.

VERRANGIA, D. Educação e diversidade étnico-racial: o ensino e a pesquisa em caso. Interacções, Lisboa, v. 10, n. 31, p. 2-27, 2014.

ZABALA, A. A prática educativa: como ensinar. Porto Alegre: Artmed, 1998.

ZEIDLER, D. L.; NICHOLS, B. H. Socioscientific issues: theory and practice. Journal of Elementary Science Education, New York, v. 21, n. 2, p. 49-58, 2009. 


\title{
UNIVERSALIZAÇÃO DE ENERGIA ELÉTRICA EM UMA QUESTÃO SOCIOCIENTÍFICA PARA O ENSINO TÉCNICO
}

\author{
Regina Palácio \\ Mônica Silveira \\ Dália Melissa Conrado
}

\section{Introdução}

De acordo com a Constituição Federal Brasileira, o Estado tem a obrigatoriedade de promover o acesso à energia elétrica para todos os cidadãos, ou seja, o acesso à energia elétrica deve ser universalizado. (BRASIL, 1988) Assim, de acordo com a Constituição, mesmo aquelas pessoas que residem em locais remotos e distantes da rede elétrica devem ter seus direitos de acesso garantidos. (BRASIL, 1988) Entretanto, apesar de dados apontarem que quase $98 \%$ da população brasileira possuem acesso à energia elétrica (IBGE, 2010), a forma como a universalização tem sido feita não determina que o acesso à energia elétrica tem a efetividade desejada, especialmente a longo prazo. A tecnologia empregada e sua manutenção, os impactos ambientais, sociais e econômicos e os diferentes interesses e valores são questões que estão fortemente envolvidas nesse tema.

$\mathrm{Na}$ educação científica e tecnológica, o tema "universalização do acesso à energia elétrica” é abordado em cursos técnico, graduação e pós-graduação voltados para a área de energia, como eletromecânica, eletrotécnica, algumas engenharias, entre outros. 
Particularmente, esse tema é parte do conteúdo da disciplina Regulação da Indústria de Energia, ministrada pelas duas primeiras autoras deste capítulo.

Além disso, o tema possibilita não apenas abordar a importância da energia elétrica na vida cotidiana e os impactos econômicos, sociais e ambientais da universalização do acesso à energia elétrica, mas também desenvolver uma reflexão crítica sobre os modos de consumo e de distribuição de energia elétrica. Para isso, deverão ser adotadas estratégias e técnicas de ensino que abordam de modo mais amplo e interdisciplinar esse tema em sala de aula. O uso de Questões Sociocientíficas (QSC), no contexto da educação Ciência, Tecnologia, Sociedade e Ambiente (CTSA), permite contextualizar o tema e torná-lo mais atraente e próximo da realidade do estudante, além de possibilitar a mobilização de conteúdos de diversas áreas do conhecimento e o engajamento do estudante para participar da solução de problemas socioambientais com ações sociopolíticas. (HODSON, 2011, 2013; SADLER, 2011)

Assim, o presente capítulo apresenta uma QSC sobre os problemas associados à falta de acesso à energia elétrica no meio rural, visando discutir o direito ao acesso à energia elétrica, as opções que têm sido adotadas para tal, as relações CTSA e as ações para mitigar essa situação de falta de acesso.

O capítulo foi estruturado para apresentar a contextualização do problema com foco no bem-estar social e na integridade dos sistemas ecológicos. (LOUREIRO, 2014) Além disso, de que a legislação deve ser cumprida de acordo com os valores de justiça e equidade social. (RACHELS, 2003) Em seguida, discutimos aspectos relevantes relacionados à eletrificação rural; apresentamos um caso como elemento central da QSC; e algumas sugestões de sua aplicação para o ensino médio. Por fim, nas considerações finais, indicamos a importância da QSC como método de ensino para a aprendizagem de temas técnicos controversos.

\section{Universalização de energia elétrica como direito do cidadão}

Nas sociedades ocidentais, o Estado moderno, composto pelos três poderes (Legislativo, Executivo, Judiciário) independentes, detém o poder, que emana do povo, e que lhe atribui o papel de organizar a sociedade, através de diretrizes básicas para a convivência social. O cidadão, enquanto parte do Estado, deve fiscalizar o governo e os seus representantes a fim de que não se distanciem da vontade geral. ${ }^{1}$ Para isso, a cidadania pressupõe participação política na elaboração da vontade geral, mas também na fiscalização sobre o alcance das diretrizes estabelecidas por esta vontade geral. (ROUSSEAU,

$1 \quad$ A vontade geral é "aquela que dá voz aos interesses que cada pessoa tem em comum com todas as demais, de modo que, ao ser atendido um interesse seu, também estarão sendo atendidos os interesses de todas as pessoas". (PINTO, 2005, p. 85) Em outras palavras, a vontade geral representa a soberania política da vontade coletiva como um todo, ao invés dos interesses de um indivíduo ou um grupo particular. (ROUSSEAU, 1999) 
1762 apud PIEROBON, 2012) A consideração sobre a cidadania ${ }^{2}$ é ponto de fundamental importância dentro de um Estado democrático; por isso, a Constituição Brasileira apresenta estes conceitos em seu primeiro capítulo.

No Título II, Capítulo I, Dos Direitos e Garantias Fundamentais Individuais e Coletivos, da Constituição Federal Brasileira (BRASIL, 1988), os direitos dos indivíduos foram previstos. $\mathrm{O}$ texto evidencia que as pessoas devem receber um tratamento respeitável, baseado na dignidade humana. Esta, por sua vez, pode ser entendida como um conjunto de coisas ou atos que uma pessoa ou grupo social considera básico para se ter um mínimo grau de liberdade na realização de suas escolhas e no convívio em sociedade. (ANDRADE; LEMOS, 2008) Entretanto, em algum sentido, tais direitos, com base na dignidade humana, ainda não foram implementados na prática.

Do ponto de vista esboçado acima, a promoção do acesso à energia elétrica para todos os habitantes do país torna-se uma obrigação do Estado. Isto porque a energia elétrica é entendida pela Constituição como algo imprescindível ${ }^{3}$ para se ter qualidade de vida, uma vez que, deste ponto de vista, ela contribui para a promoção do bem-estar social e o desenvolvimento econômico de uma sociedade. (FOURNIER; PENTEADO, 2014; FUGIMOTO, 2005) Além disso, em muitos contextos, o acesso à rede elétrica é fundamental para a realização de atividades essenciais à vida moderna, como cozinhar, estudar e trabalhar. (ANDRADE, 2009; RIBEIRO; SANTOS, 1994)

O acesso à eletricidade é um direito social, que contribui para garantir a liberdade do cidadão de fazer escolhas responsáveis a respeito do seu uso. Não significa de modo algum que a falta de energia elétrica leve à redução da qualidade de vida ou da dignidade humana, porém cabe a cada cidadão o direito de escolher em que situações prioriza o uso da eletricidade para suas necessidades e ao Estado de promover políticas públicas para garantir a educação adequada para que - junto com a universalização do acesso à energia elétrica - seja feito um uso socioambientalmente responsável da energia. Adicionalmente, cabe não só aos indivíduos, mas a toda a sociedade refletir sobre o uso, o desperdício e as consequências socioambientais da geração e da distribuição da energia elétrica.

2 "Cidadania" é um termo polissêmico que pode ser compreendido como uma qualidade (disposição ou capacidade) do cidadão que participa da vida coletiva, com consciência crítica de seu papel nas interações sociais, sendo capaz de engajar em diálogos críticos com a sociedade, considerando sua história; e participar politicamente de tomadas de decisões e ações sociopolíticas, visando o bem de indivíduos, sociedades e ambientes. Para mais detalhes, ver: Ferreira, (1993); Santos e Mortimer (2001); Hodson, (2004, 2011); H. Giroux e S. Giroux (2006); Bencze e Alsop (2009); Gorczevski e Martin (2011) e Conrado, El-Hani e Nunes-Neto (2013).

3 Vale ressaltar que, apesar da importância do acesso à energia elétrica para a maior parte dos indivíduos, a satisfação da dignidade humana não está necessariamente ligada ao acesso à energia elétrica. Como exemplo, podemos considerar pequenos agrupamentos humanos que não dependem e não utilizam essa tecnologia para viverem. Do mesmo modo, o acesso à energia elétrica pode não ser suficiente para a qualidade de vida, como, por exemplo, grupos humanos com acesso à energia elétrica, mas com falta de acesso ao saneamento básico. 
A obrigatoriedade constitucional de universalizar o acesso à energia elétrica inclui locais remotos e distantes da rede elétrica que devem também ter seus direitos garantidos. A Lei $n^{\circ} 10.438$ definiu que a universalização dos serviços públicos de energia elétrica deve ser realizada sem ônus de qualquer espécie ao cidadão, nos horizontes temporais estabelecidos pela Agência Nacional de Energia Elétrica (Aneel). (BRASIL, 2002)

A regulamentação inicial ocorreu por meio da Resolução Aneel no 223, de 29 de abril de 2003, que estabeleceu as regras para que as distribuidoras do país elaborassem os Planos de Universalização e definiu o ano limite (que ia até 2014 e, atualmente, até 2018) para o alcance da universalização em cada área de concessão. (AGÊNCIA NACIONAL DE ENERGIA ELÉTRICA, 2003)

Apesar de todo o arcabouço legal existente no Brasil, muitas famílias permanecem ainda sem energia elétrica. De acordo com o Censo, cerca de 2,7 bilhões de domicílios não são atendidos por energia elétrica, sendo que o levantamento ainda considerou como atendida a unidade que tivesse energia fornecida por fonte própria, como geradores a diesel. (IBGE, 2010)

Diante dessa situação, para viabilizar a universalização do acesso à energia elétrica, dentro dos prazos e metas definidos na legislação, foram criados diversos programas, como Luz da Terra (1995), Luz no Campo (1999) e Luz para Todos (2003). Neles, a eletrificação em áreas rurais é realizada por meio de eletricidade independente da rede (isolada), devido à inviabilidade técnico-econômica de levar o sistema de rede elétrica (poste e fio) até áreas remotas.

Neste contexto, tecnologias de energia renovável são utilizadas mais frequentemente para a geração isolada, substituindo o uso de geradores à diesel, o que reduz impactos ambientais negativos. Contudo, a escolha das diferentes tecnologias para fornecer eletricidade rural depende, primeiro, das condições climáticas e geográficas (especialmente no caso das energias renováveis) do local. Além disso, deve-se promover a capacitação da comunidade, na ocasião da introdução da tecnologia da energia alternativa, para garantir uma manutenção adequada dos equipamentos. A manutenção é, muitas vezes, um assunto crítico: é necessária para garantir a sustentabilidade técnica do sistema isolado. Com relação a estas questões, ainda existe uma deficiência de informação e comunicação entre a população rural e as possíveis prestadoras de serviços sobre os potenciais e as implicações das tecnologias alternativas. (CAMARGO; RIBEIRO, 2003) Assim, os usuários devem ser informados sobre as cargas compatíveis com o sistema, os procedimentos necessários de manutenção, como também os custos relacionados. Por sua vez, os provedores, além de capacitar a comunidade para o uso adequado da tecnologia, devem ser treinados e providenciar componentes, instalação e serviços de manutenção de boa qualidade.

Apesar de ser considerado um bem comum e haver leis que garantam o acesso à energia elétrica para todos os cidadãos, a falta de cumprimento da legislação e as consequências para a vida dos cidadãos sem o acesso são assuntos relevantes nos ambien- 
tes acadêmico e escolar. Discussões sobre o tema podem capacitar cidadãos para lidar com as formas, necessidades e consequências do uso da energia elétrica no contexto social cotidiano, diante dos problemas socioambientais atuais, como crise energética, degradação ambiental e desigualdade social. Para isso, esses assuntos deverão ser colocados em evidência, a fim de desenvolver no estudante um pensamento crítico (SOLBES, 2013), uma reflexão moral (ZEIDLER, 2005), praticar habilidades argumentativas (CONRADO; NUNES-NETO; EL-HANI, 2015) e preparar-se para ações sociopolíticas (HODSON, 2004, 2011, 2013) relacionadas a este tema.

Devido à grande complexidade do tema da energia elétrica, assim como da sua universalização, trataremos, a seguir, apenas das questões associadas à universalização da eletrificação no meio rural.

\section{Benefícios, discussões e desafios a respeito da eletrificação rural}

Segundo Camargo, Ribeiro e Guerra (2008), a eletricidade, em geral, contribui para melhorar as condições de saúde, segurança, educação e qualidade de vida. No meio rural, ainda é comum a falta de energia elétrica (IBGE, 2010), o que gera problemas na execução de atividades noturnas, muitas vezes essenciais, como funcionamento de escolas e hospitais, tarefas laborais, ações culturais e de lazer. Além disso, muitos trabalhos diurnos podem ser facilitados, quando se dispõe de eletricidade, pois existe a possibilidade de utilizar máquinas, como no manejo do solo e no auxílio à colheita, para o funcionamento de bombas d'água, o manuseio de eletrodomésticos, entre outros. Não menos importante, a energia elétrica também facilita e dá acessibilidade a determinados meios de comunicação e acesso às informações disponíveis nesses veículos. (ANDRADE, 2009; REIS; SILVEIRA, 2000)

No meio rural, o acesso à eletricidade pode ser visto como um artifício inibidor da migração campo-cidade. Conforme Camargo, Ribeiro e Guerra (2008), os programas de eletrificação rural ajudaram a reter no meio rural aquelas pessoas que teriam abandonado essas áreas em busca de melhores condições de vida, ao mesmo tempo em que ajudou a trazer de volta alguns que já haviam abandonado a vida no campo. A energia elétrica pode ser considerada uma condição para reduzir os movimentos migratórios para as cidades, evitando, assim, o agravamento ou o aumento de problemas socioambientais, como o crescimento de favelas e regiões de pobreza; a desvalorização de áreas verdes; e a redução de indivíduos envolvidos com a produção de alimentos, decorrentes do êxodo rural. (LISBOA, 2013)

É de consenso geral que o acesso à energia elétrica, associado à disponibilidade de renda, permite o uso de equipamentos como televisão, geladeira e equipamento de som, que, de modo geral, melhoram a qualidade de vida e o acesso à informação. Segundo Lisboa (2013), a Pesquisa Quantitativa Domiciliar de Avaliação da Satisfação e de Impacto do Programa Luz para Todos, realizada em 2009, pelo Ministério das Minas e Energia, identificou que $79 \%$ dos domicílios atendidos pelo programa adquiriram te- 
levisores e 73\% desses domicílios compraram geladeiras. Esses dados podem indicar a importância atribuída pelas pessoas a esses aparelhos no meio rural.

Apesar de ser considerada como condição para melhorar o bem-estar social, o uso da energia elétrica, ao menos em parte, depende do indivíduo e seus valores. A avaliação do que, de fato, é uma necessidade e o que se torna desperdício relaciona-se com a habilidade para pensar criticamente sobre o tema. Apesar de o acesso a determinados equipamentos tender a melhorar a qualidade de vida do indivíduo no meio rural, o uso de aparelhos, como televisão, pode aumentar: o desejo de consumo, associado à insatisfação por não ter uma vida urbana satisfatória em termos de certos padrões de consumo (que podem ser veiculados nos meios de comunicação como um objetivo a ser alcançado por todos); e, ainda, estimular a falta de criticidade, ao receber informações prontas e influenciadas por estruturas hegemônicas de poder, que visam promover a massificação apolítica e acrítica da população. (CORTEZ, 2009) Outra desvantagem, é que o uso de determinados eletrodomésticos pode levar à alimentação menos saudável, ao sedentarismo, além de problemas como o aumento da geração de resíduos, lixo eletrônico, no meio rural. (MARQUES, 2007; WHO, 2002; WIDMER, 2005) Nesse caso, se o consumidor é alienado e induzido ao consumo de necessidades artificialmente criadas e não sabe refletir criticamente sobre sua situação, torna-se preso em um ciclo consumista e, portanto, não é livre para decidir sobre suas necessidades e refletir de modo mais aprofundado sobre as consequências de suas ações, perdendo, assim, em alguma medida, sua autonomia. (ARANHA, 1993; ZATTI, 2007)

Por isso, no contexto do uso da energia elétrica, de acordo com Valois Coelho, Cartaxo (2006), tanto no meio rural, quanto urbano, devemos refletir sobre:

- o aumento da aquisição de determinados bens de consumo, em face dos problemas socioambientais decorrentes do consumismo;

- a escassez de políticas públicas e ações dedicadas a combater o desperdício de energia elétrica;

- $\quad$ as contradições referentes à geração e ao uso de energia elétrica de modo sustentável.

Corroborando com este pensamento, Gusmão e colaboradores (2002) e Cavalcante e Cartaxo (2008) acrescentam ainda:

- os interesses adjacentes às decisões políticas de investimento público em regiões ligadas à indústria;

- $\quad$ as questões de justiça social e distribuição da energia elétrica.

Adicionalmente, apesar de ser comumente considerado benéfico, o acesso à energia elétrica não é por si suficiente para se ter qualidade de vida. Há muitos fatores que 
influenciam na qualidade de vida dos indivíduos e da sociedade e que podem ser independentes do acesso à energia elétrica, como distribuição de renda, condições de saneamento, saúde e alimentação, estado emocional do indivíduo, entre outros, o que pode estar associado, por exemplo, à implementação social de um modelo de saúde socioecológico em detrimento de um modelo biomédico. (MARTINS et al., 2015) Em relação à necessidade, podemos refletir sobre a existência de contextos em que se pode ter uma boa qualidade de vida sem nenhum acesso à energia elétrica.

Ainda, o acesso à energia elétrica no meio rural pode não garantir a melhoria da qualidade de vida da população de menor renda. (COOK, 2013) Khandker e colaboradores (2012) discutem como o acesso e a distribuição de energia elétrica podem ser desiguais nos diferentes estratos sociais do meio rural. Eles argumentam que os mais beneficiados pela distribuição da energia no meio rural na Índia são os cidadãos com maior poder aquisitivo para pagar pelas taxas de uso da energia, ao passo que a população com menor poder aquisitivo não é capaz de usufruir do mesmo modo dos benefícios de uma eletrificação, pois, além das taxas de uso, teriam que adquirir equipamentos elétricos compatíveis, que, por sua vez, poderiam ser danificados, uma vez que bairros mais pobres geralmente possuem usos limitados por restrição da oferta ou quedas de energia. Contudo, os impactos e custos sociais e ambientais para a eletrificação de uma região são igualmente distribuídos entre os cidadãos. Em suma, os benefícios são internalizados para um pequeno grupo, e os prejuízos são externalizados e distribuídos para todos, sobretudo para uma maioria que não pode se proteger desses prejuízos, por estar em desvantagem socioeconômica. (HARDIN, 1968)

Deste modo, faz parte de uma educação crítica refletir sobre a equidade da distribuição da energia elétrica em dado contexto, como no meio rural, e sobre as mudanças no estilo de vida da população como um todo (tanto no meio rural como no meio urbana), considerando os diferentes valores e interesses dos envolvidos.

Com relação aos desafios da eletrificação rural, cabe considerar alguns fatores. Camargo e Ribeiro (2003) apresentam alguns aspectos, como: custo da extensão da rede para atendimento rural, custo de manutenção dessas redes, baixo consumo dos moradores das áreas rurais, pouco poder político e baixa influência dos moradores para defender seus direitos. Estes fatores foram apontados como relevantes na dificuldade em universalização do acesso à energia elétrica. Além disso, os autores mencionam questões técnicas, como o uso de tecnologias de menor custo (fogão solar, aquecimento de água com garrafa PET - Polietileno Tereftalat -, entre outras), e questões políticas, como a negação da existência de determinados problemas, como a exclusão de parte da sociedade ao acesso à energia elétrica.

Gusmão e colaboradores (2002), além de enfatizarem dificuldades resultantes de projetos mal executados, incluem a necessidade de aliar a universalização do acesso à energia elétrica com outros programas educativos, culturais e ambientais para garantir a redução das desigualdades sociais e da degradação ambiental, uma vez que apenas o 
acesso à energia pode não garantir condições para seu uso adequado em longo prazo em uma comunidade. Em concordância com isso, Cook (2013) também recomenda investimentos em infraestrutura educacional para assegurar a efetividade de programas de eletrificação rural para comunidades de baixa renda.

Nesse sentido, a discussão sobre o direito de acesso à energia no meio rural, juntamente com a reflexão sobre a necessidade de enfrentamento dos problemas socioambientais atuais por todos os seres humanos, mas sobretudo daqueles envolvidos com o excessivo consumo de energia, devem contribuir para uma reflexão crítica sobre direito, geração, distribuição, consumo e consequências socioambientais. Uma vez que esse debate é essencial para a formação de cidadãos críticos, responsáveis e participativos na construção de uma sociedade mais justa socialmente e ambientalmente sustentável, principalmente no contexto do ensino técnico, defendemos o uso deste tema no ensino de ciências, com base na educação CTSA, de modo a melhor preparar cidadãos para ações sociopolíticas.

\section{Uma QSC sobre a universalização do acesso à energia elétrica}

Nas últimas décadas, pesquisas desenvolvidas sobre as concepções de professores quanto à educação com enfoque em CTSA mostraram que ainda existem limitações no entendimento e na aplicação desta perspectiva na educação científica. (MARTíNEZ PÉREZ; LOZANO; AGUILAR, 2012) Alguns autores têm defendido o ensino de ciências focado em QSC como uma maneira de abordar as interações CTSA em sala de aula, possibilitando, além do aprendizado de conteúdos conceituais, compreender e aplicar o conteúdo científico e desenvolver o pensamento crítico, a argumentação, a criatividade, a reflexão moral e o engajamento na tomada de decisão. (CONRADO, 2013; CONRADO et al., 2015; EASTWOOD et al., 2012; HODSON, 2013; MARTÍNEZ PÉREZ; LOZANO; AGUILAR, 2012)

As QSC envolvem situações sociais significativas, controversas, geralmente discutidas na mídia, que abarcam aspectos éticos e morais, bem como riscos e impactos globais. (EASTWOOD et al., 2012; CONRADO; EL-HANI; NUNES-NETO, 2013; HODSON, 2013) Em sala de aula, as QSC se referem a discussões que se desenvolvem na sociedade atual e que suscitam opiniões diversas e influenciam a tomada de decisão dos cidadãos. (CONRADO et al., 2012) Nesse contexto, a análise e a tomada de decisão a partir das QSC exigem capacidade de mobilizar conteúdos científicos aliados a outros conteúdos. (CONRADO, 2013; MARTÍNEZ PÉREZ et al., 2011)

O enunciado da proposta abaixo, no Quadro 1 (SILVEIRA; PALÁCIO; CONRADO, 2016), foi elaborado a partir de artigos publicados em jornais e revistas, visando apresentar um caso associado a um contexto real do Brasil, que estimule no grupo de estudantes a investigação sobre o tema "universalização da energia, suas tecnologias e seus impactos", bem como que leve ao desenvolvimento de argumentos para resolver as 
questões colocadas. Essa proposta de ensino com base em QSC se aplica principalmente ao ensino médio, podendo ser adaptada para aplicação em outros níveis de ensino.

Quadro 1 - Caso para discussão da $\mathrm{QSC}^{4}$

\section{Qualidade de vida e energia elétrica}

Reginaldo trabalhava como operário em uma indústria têxtil em São Paulo. Em 2011, viajou de férias para Saboeiro, no interior do Ceará, para visitar parentes da esposa Joana. Ele se encantou com a paisagem, com a cordialidade da população e com a produção de algodão da região.

Assim, o casal resolveu adquirir uma faixa de terras, planejando o plantio de pequenas lavouras de subsistência e a produção de tecido artesanal de algodão. Eles sabiam que passariam por uma fase de adaptação, mas compensaria, pois trocariam a correria e o estresse do trânsito da capital paulista pela vida tranquila do meio rural. Empolgado, o ex-operário e a mulher se mudaram "de mala e cuia".

No entanto, o sonho virou pesadelo. O painel de energia solar, que era o único meio de obtenção de energia elétrica do município, funcionou somente por dois anos e meio. Sem energia, acabou a garantia de conforto e o sonho de Reginaldo ter seu próprio negócio. Desolado, o casal resolveu procurar a ajuda do vereador Manoel.

Manoel: então, como começaram os problemas com o sistema solar de energia elétrica?

Reginaldo: a bateria descarregou de vez. A nossa vida mudou pra pior.

Joana: êita, bota pior nisso, Reginho! Estamos isolados agora. A gente vive aqui como se estivesse em outro mundo. Trouxe, de São Paulo, TV, rádio, celular, geladeira, micro-ondas. Nem posso ver minha novela! Tudo inútil agora! E o conforto? Coisinha boba, como beber água gelada ou se refrescar no ventilador. Tem não, senhor.

Reginaldo: isso não é o pior, Joana! Ruim é não poder ganhar o próprio sustento. Depois de comprar as máquinas... Sorte que parte do trabalho ainda posso fazer na mão, mas no passo que vou... O senhor tem que pensar agora no que fazer pra resolver essa situação, Seu Manoel!

Manoel: calma! Calma, pessoal! Vocês estão certos; em pleno século XXI, isso não poderia mais acontecer. Esse é um serviço básico para a sobrevivência humana. Entretanto, às vezes, vemos os problemas maiores do que eles realmente são. Várias famílias me procuraram relatando essa mesma situação. Vamos analisar bem.

Joana: mas, Seu Manoel, até a comida da gente muda por causa da falta de luz. Agora, a gente tem que comer o alimento rapidinho pra não perder, pois não tem mais a geladeira. E a higiene? A comida, que não tem onde guardar, acaba trazendo mosquito pra dentro de casa! Desse jeito, já estamos pensando em ir embora.

Reginaldo: na verdade, a gente ficaria feliz com muito menos, como ligar a bomba pra puxar água da cisterna e ligar o motor da máquina de tecer. O que o senhor pode fazer pela gente? Eu tô frustrado, pois pensei que minha vida iria melhorar, que eu ia melhorar os negócios, mas tudo foi ilusão. O senhor tem que trazer a luz de volta, senão nós vamos embora pra São Paulo!

Manoel: pensem bem, meus amigos! Estamos pensando em nossas necessidades, mas precisamos ver as opções que existem para trazer novamente a energia elétrica para nossa comunidade. Além disso, temos que pensar nos impactos sociais, financeiros e ambientais. Outra coisa: vocês só estão vendo o lado negativo. Lembrem-se da vida tranquila de nosso município, sem os problemas de uma grande cidade. Vão desistir de tudo que investiram aqui sem lutar?

Fonte: adaptado de Silveira, Palácio e Conrado (2016).

4 O presente caso foi aplicado a duas turmas do ensino técnico do Instituto Federal de Educação, Ciência e Tecnologia, Bahia, Brasil. Uma análise sobre a mobilização de conteúdos conceituais, procedimentais e atitudinais, referente a uma pesquisa piloto sobre a aplicação desta proposta de ensino baseada em QSC (em uma sequência didática) pode ser encontrada em Silveira, Palácio e Conrado (2016). 
O caso apresentado na QSC permite que sejam colocadas diferentes perspectivas sobre os problemas, possibilitando discussões diversas e interdisciplinares em sala de aula. Por um lado, um personagem preocupa-se com o seu dia a dia doméstico em que os aparelhos elétricos lhe trarão mais conforto e mais tempo para se dedicar a outras atividades. Por outro, outro personagem preocupa-se com o sustento da família a partir do uso de determinados equipamentos, percebendo dificuldades pela falta de energia elétrica. E, por fim, o argumento de um político da região que visualiza o problema de maneira mais ampla, relacionando brevemente problemas ambientais e econômicos de se trazer eletricidade para comunidades isoladas.

Para nortear as discussões sobre o caso e orientar a aplicação da QSC, na perspectiva da educação CTSA, sugerimos utilizar alguns questionamentos tendo como critério os níveis de sofisticação de uma proposta de currículo, envolvendo relações CTSA e ativismo sociopolítico apresentados por Hodson (2004). São quatro níveis que conduzem à abordagem de temas científicos de maneira contextualizada, indo desde o entendimento das relações entre CTSA (nível 1), compreensão dos diversos aspectos considerados na tomada de decisão (nível 2), formação de opinião e juízo moral sobre os temas envolvidos (nível 3) e atuação sociopolítica responsável (nível 4).

Com base nessa fundamentação, propomos algumas questões para nortear a discussão com os estudantes. O professor poderá selecionar algumas e elaborar outras, de acordo com seus objetivos de ensino e aprendizagem. Entre parênteses, apontamos o nível de sofisticação do currículo que sugerimos para cada questão:

Q1. Quais são as diferentes tecnologias que podem ser utilizadas para garantir o acesso à energia elétrica no meio rural? (níveis 1 e 2).

Q2. Quais as vantagens e desvantagens das tecnologias usadas nos programas de universalização ao acesso à energia elétrica? (níveis 1 e 2).

Q3. Que tecnologias relacionadas à geração da energia elétrica não estão contempladas nos programas de universalização e por quais motivos? (níveis 1 e 2).

Q4. Quais os impactos sociais, ambientais e econômicos na universalização do acesso à energia elétrica? (níveis 1 e 2).

Q5. Ao considerarmos a demanda humana atual por energia elétrica e a capacidade de suporte do planeta para suprir as necessidades humanas, qual o quadro atual de degradação ambiental versus consumo humano (incluindo de energia elétrica) em que nos encontramos? Considere diferentes pegadas ecológicas e índices de desenvolvimento humano pelo mundo. (níveis 1 e 2).

Q6. As inovações tecnológicas (incluindo aquelas utilizadas para a produção de energia elétrica) será capaz de resolver os problemas socioambientais? Explique com base na ideia do salvacionismo tecnológico. 
Q7. Somente o acesso à energia elétrica é garantia de conforto? Quais seriam os requisitos para se ter conforto no meio rural? E no meio urbano? Qual a relação desses requisitos para conforto, tanto no meio rural quanto no meio urbano, com a energia elétrica? (níveis 1 e 2).

Q8. O acesso à energia elétrica, pela presença de rede elétrica ou placas solares, por exemplo, no meio rural, garante o uso da energia pela população de baixa renda? Justifique. (níveis 1 e 2).

Q9. Seria possível conciliar o direito social a ter acesso à energia elétrica com os limites ambientais impostos pela escassez de recursos naturais? Justifique. (níveis 1 e 2 ).

Q10. Há interesses envolvidos na manutenção e na promoção de determinadas tecnologias de geração e distribuição de energia elétrica, em detrimento de outras? Elabore sobre isso. (níveis 2 e 3 ).

Q11. O acesso à energia elétrica, no meio rural ou nas periferias, é diferente do acesso no meio urbano ou nos grandes centros? Esse acesso deveria ser diferente? Justifique. (níveis 2 e 3).

Q12. O seu grupo concorda com a reivindicação de Reginaldo, dirigida a Manoel? Justifique. (níveis 2 e 3).

Q13. Qual a opinião do seu grupo sobre os argumentos de Manoel? Justifique. (níveis 2 e 3$)$.

Q14. Sobre as necessidades de Joana, quais delas seu grupo considera importantes e quais seriam desnecessárias para a vida no meio rural? Justifique. (níveis 2 e 3).

Q15. Quais são os critérios para eleger as prioridades de localidades a serem atendidas pelo acesso à energia elétrica? Justifique. (níveis 2 e 3).

Q16. Num contexto de escassez de recursos naturais e financeiros, seria possível negociar para que ocorra a universalização equitativa do atendimento de necessidades humanas prioritárias que requerem energia elétrica? Como seria possível? Justifique. (níveis 2 e 3).

Q17. O vereador tem poder político para modificar essa situação de Saboeiro? O que seu grupo faria se estivesse no lugar dele? Justifique. (níveis 2 e 3).

Q18. Diante dessa situação, se seu grupo estivesse no lugar do casal, o que vocês fariam para evitar a decisão de retornar para São Paulo? (níveis 2 e 3).

Q19. Se seu grupo fosse profissionalmente contratado para auxiliar na resolução do problema de Reginaldo e Joana, o que vocês fariam? (níveis 2 e 3).

Q20. Vocês, na situação de cidadãos urbanizados e com acesso à energia elétrica, que atitudes tomariam para ajudar pessoas como Joana e Reginaldo? (níveis 3 e 4). 
Q21. O que a comunidade escolar pode fazer para reduzir o consumo de energia no meio urbano e divulgar a importância desta ação para a população local? Organizem ações favoráveis que possam beneficiar o bairro, a cidade ou o estado. (níveis 3 e 4).

Para melhor orientar a aplicação da QSC, é relevante definir alguns objetivos de aprendizagem. Conforme Zabala (1998) e Coll e colaboradores (1992), podemos definir conteúdos de aprendizagem que contemplem uma formação ampla do cidadão, explicitando-os, didaticamente, em ao menos, três tipos: Conceituais, Procedimentais e Atitudinais (CPA).

Os conteúdos conceituais são aqueles que respondem à pergunta "o que saber?", correspondendo a uma dimensão mais epistemológica do conteúdo. Os conteúdos procedimentais visam responder à questão "o que saber fazer?", caracterizando uma dimensão mais metodológica do conteúdo. Já os conteúdos atitudinais trabalham a percepção de "como se deve ser?", aprofundando mais na dimensão axiológica (sobretudo, a ética) do conteúdo. (ZABALA, 1998; ZABALA; ARNAU, 2010; CONRADO; NUNES NETO, 2015) Nesse sentido, enquanto os conteúdos conceituais priorizam fatos e definições, os procedimentais organizam métodos e técnicas para a execução das ações, e os atitudinais enfatizam a avaliação de condições e razões morais para as ações, a partir de normas (como legislação), valores morais e atitudes que orientam o funcionamento da sociedade. (COLL et al., 1992; CONRADO; NUNES-NETO 2015; ZABALA; ARNAU, 2010) Os objetivos de aprendizagem podem ser abordados em dimensões CPA, a partir do uso de QSC. (CONRADO; NUNES-NETO, 2015)

$\mathrm{Na}$ presente proposta de ensino com base em QSC, os conteúdos conceituais propostos abordam aspectos e fatos associados a pelo menos duas disciplinas ministradas em cursos técnicos e de ensino médio: Regulação do Setor Elétrico e Desenvolvimento Sustentável. Na primeira disciplina, poderão ser abordados os seguintes assuntos:

- direitos do cidadão em relação ao fornecimento de energia elétrica;

- programas de eletrificação;

- fontes alternativas de energia elétrica;

- papel dos agentes do setor elétrico.

Na segunda disciplina, poderão ser abordados:

- impactos socioeconômicos da eletrificação rural;

- vantagens e desvantagens das tecnologias alternativas de geração de energia elétrica;

- impactos ambientais da eletrificação rural; 
- o uso da tecnologia para resolver problemas socioambientais e o mito do salvacionismo tecnológico.

Ainda, poderão ser abordados conceitos relacionados à sociologia e à história, discutindo os processos que levaram à reestruturação do setor elétrico e seus impactos na sociedade como um todo.

Os conteúdos procedimentais podem ser abordados, visando:

- desenvolver habilidades para pesquisa bibliográfica;

- ampliar a capacidade de organização do discurso e da argumentação oral e escrita;

- aprimorar a habilidade de trabalhar em grupo;

- estruturar a capacidade de resolver problemas sociais, mobilizando o conhecimento científico;

- aprimorar a capacidade de relacionar o conhecimento acadêmico-escolar com o cotidiano;

- realizar visita técnica a uma comunidade isolada;

- redigir relatório da situação de uma comunidade isolada;

- melhorar o entendimento de documentos legais relativos ao setor elétrico; e

- avaliar dados estatísticos e mapas, em relação à produção, distribuição e consumo de energia elétrica no Brasil e no mundo.

Por fim, os conteúdos atitudinais envolvem:

- o aprendizado sobre aspectos de legislação acerca da energia elétrica no Brasil;

- a prática de solidariedade e respeito ao próximo durante execução das atividades;

- o exercício da responsabilidade socioambiental;

- a reflexão sobre valores e ideologias da cultura hegemônica do consumismo e suas consequências socioambientais;

- o desenvolvimento de pensamento crítico sobre os impactos do processo de universalização do acesso à energia elétrica na vida dos cidadãos das comunidades rurais;

- a elaboração de materiais com informações aprendidas para socialização com a comunidade do entorno; $\mathrm{e}$

- a organização coletiva para promover ações que contribuam para a resolução de problemas semelhantes no cotidiano, além de aperfeiçoar comportamentos críticos, de engajamento e de liderança; 
- a conscientização em relação ao valor da energia elétrica na nossa vida; e

- a mudança de atitudes relacionadas ao uso desnecessário ou exagerado da energia elétrica.

Considerando a relevância de se explicitar alguns direcionamentos sobre a aplicação desta proposta de ensino baseada em QSC, inserimos algumas sugestões que poderão auxiliar o professor, nas seguintes etapas:

- Planejamento e levantamento de concepções prévias: explicação do tipo de atividade que será desenvolvida e questionamentos gerais sobre o tema para discussão com os estudantes. Solicitação aos estudantes que pesquisem, para a aula seguinte, sobre o acesso à energia elétrica: situação, tecnologias, legislação e impactos. O resultado da pesquisa pode ser sintetizado em uma página. Poderá ser incluído um momento para apresentar e discutir brevemente o que cada estudante (ou equipe) encontrou, numa próxima aula;

- Apresentação da QSC: exposição do caso, conforme descrito, incluindo as questões sugeridas. A turma deve se dividir em equipes com três ou quatro componentes cada. Nessa etapa, serão apresentadas dicas sobre a formulação dos argumentos baseados no modelo de argumentação de Toulmin. (SÁ; QUEIROZ, 2007; TOULMIN, 2006;) e na análise de argumentos e falácias (COPI, 1968), visando preparar o estudante na elaboração das atividades para a aula seguinte. As pesquisas prévias dos estudantes poderão auxiliar na resolução do caso;

- Discussão das questões: apresentação dos argumentos de cada equipe para responder às questões, discutindo com a turma as opiniões individuais e os contra-argumentos;

- Sintetização dos conteúdos conceituais, procedimentais e atitudinais: explanação do professor sobre os conteúdos envolvidos na QSC, com discussão geral em sala;

- Organização de propostas para a identificação e a resolução coletiva de situações semelhantes no cotidiano, principalmente em relação ao auxílio à população rural, sem acesso à energia elétrica, e às ações de divulgação e mobilização da população urbana em relação à necessidade de reduzir o consumo de energia elétrica, com planejamento de ações locais nos diversos setores da sociedade;

- Avaliação de aprendizagem: sugestão de avaliação individual de aprendizagem a partir da criação de portfólio virtual, no qual cada estudante alerte para os problemas e aponte soluções, expondo suas criações sobre a temática, seja por meio de poema, música, vídeo, texto, desenho etc. Adicionalmente, recomendamos a adoção de avaliação mútua (em que o grupo avalia a si, os outros colegas e as atividades) e avaliação processual (a partir de observação docente sobre o comportamento dos estudantes e a mobilização de conteúdos durante 
as aulas), para uma análise mais completa dos diversos conteúdos mobilizados ou aprendidos. Todo o processo avaliativo deverá ser explicitado inicialmente aos estudantes, o que permitirá identificar a evolução deles com relação aos conteúdos CPA planejados para serem alcançados a partir da QSC.

\section{Considerações finais}

Devido ao tema "universalização de energia elétrica" ser bastante técnico e específico de cursos voltados para a área técnica, apresentá-lo aos discentes de uma maneira contextualizada com os problemas socioambientais estimula uma reflexão crítica sobre os impactos de seus conhecimentos, habilidades, valores e atitudes como profissionais e como cidadãos na sociedade como um todo. Além disso, amplia o pensamento crítico a respeito das necessidades básicas do indivíduo, bem como dos impactos ambientais decorrentes de suas escolhas.

Ainda, o tema "universalização de energia elétrica", abordado numa proposta de ensino com base em QSC, contribui para aprimorar a capacidade de argumentação, quando o estudante compreende as opiniões, as razões e os valores que diferentes atores sociais podem sustentar sobre o mesmo problema. O modo em que foi elaborada a QSC permite uma discussão interdisciplinar dentro de disciplinas técnicas da área de engenharia, como Regulação da Indústria de Energia, podendo também ser ampliada para contemplar mais precisamente conteúdos das áreas técnicas, como equipamentos, manutenção e instalações. Além disso, essa proposta pode ser adequada e aplicada em outros contextos do ensino médio nas disciplinas de Biologia, Geografia, Sociologia, Filosofia, Informática, uma vez que aborda questões sobre meio ambiente, planejamento ambiental e urbano, migrações, distribuição e organização social, desigualdades sociais, ideologias e valores morais, entre outros. Os estudantes também poderiam se envolver na elaboração de produtos que podem ser divulgados online, como, por exemplo, um "índice de pegada elétrica”, com base na pegada ecológica. Portanto, a proposta de ensino por QSC apresentada pode ser adaptada para outros níveis de ensino com relativa facilidade.

Além das questões trazidas pelos próprios personagens do texto, outros problemas poderão ser levantados pelos discentes. Entretanto, sugerimos que o professor oriente as discussões para o impacto que a energia elétrica (ou sua falta) tem na vida das pessoas e qual o valor e a importância da energia e sua relação com as tecnologias no cotidiano do cidadão. Deste modo, os processos de ensino poderão capacitar o estudante não apenas para compreender os conhecimentos científicos, técnicos e filosóficos, mas também para desenvolver um pensamento crítico sobre as situações que envolvem relações CTSA, mobilizar esses conhecimentos no seu cotidiano e, sobretudo, para integrar esses conhecimentos com ações para a melhoria da qualidade de vida individual, social e ambiental. 
Por fim, esperamos que este capítulo contribua nos processos de ensino e de aprendizagem relacionados ao acesso à energia elétrica e às relações CTSA desse tema e que possa estimular o desenvolvimento de novas propostas de ensino baseadas em QSC sobre outros temas nas áreas de engenharia e tecnologias, a fim de aperfeiçoar e tornar mais ampla a formação de cidadãos participativos e capazes de agir de forma responsável para a melhoria de nossa sociedade, para que ela possa ser tanto socialmente mais justa quanto ambientalmente mais sustentável.

\section{Referências}

AGÊNCIA NACIONAL DE ENERGIA ELÉTRICA (Brasil). Resolução nº 223, de 2003. Diário Oficial [da] República Federativa do Brasil, Brasília, DF, 30 abr. 2003. Disponível em: <http://www.aneel.gov.br/cedoc/ bres2003223.pdf>. Acesso em: 2 jun. 2015.

ANDRADE, M. M. P. O direito social fundamental de acesso à energia elétrica e a atuação Estatal. 2009. 140 f. Dissertação (Mestrado em Direito) - Centro de Ciências Sociais Aplicadas, Universidade Federal do Rio Grande do Norte, Natal, 2009. Disponível em: $<$ http://repositorio.ufrn.br:8080/jspui/handle/123456789/13902>. Acesso em: 19 out. 2014.

ANDRADE, M. M. P.; LEMOS, A. M. R. O direito social fundamental de acesso à energia e sua relação com o desenvolvimento. In: CONGRESSO NACIONAL DO CONPEDI, 17., 2008, Brasília, DF. Anais... Brasília, DF: CONPEDI, 2008. p. 944-956.

ARANHA, M. L. de. Filosofando: introdução à filosofia. 2. ed. São Paulo: Moderna, 1993.

BENCZE, L; ALSOP, S. Ecojustice through responsibilist Science Education. In: ANNUAL CONFERENCE OF THE CANADIAN SOCIETY FOR THE STUDY OF EDUCATION, 2009. Ottawa. Proceeding... Otawa: Carleton University, 2009. p. 1-28.

BRASIL. Constituição (1988). Constituição da República Federativa do Brasil. Brasília, DF: Senado, 1988.

BRASIL. Lei ${ }^{\circ} 10.438$, de 2002. Dispõe sobre a expansão da oferta de energia elétrica emergencial, recomposição tarifária extraordinária, cria o Programa de Incentivo às Fontes Alternativas de Energia Elétrica (Proinfa), a Conta de Desenvolvimento Energético (CDE), dispõe sobre a universalização do serviço público de energia elétrica, dá nova redação às Leis $\mathrm{n}^{\circ} 9.427$, de 26 de dezembro de 1996, $\mathrm{n}^{\circ} 9.648$, de 27 de maio de $1998, \mathrm{n}^{\circ} 3.890$-A, de 25 de abril de 1961, $\mathrm{n}^{\circ}$ 5.655, de 20 de maio de 1971, $\mathrm{n}^{\circ} 5.899$, de 5 de julho de 1973, n ${ }^{\circ} 9.991$, de 24 de julho de 2000, e dá outras providências. Diário Oficial [da] República Federativa do Brasil, Brasília, DF, 29 abr. 2002. Disponível em: <http://www.planalto.gov.br/ccivil_03/Leis/2002/L10438.htm>. Acesso em: 2 jun. 2015.

CAMARGO, E.; RIBEIRO, F. Eletrificação rural direito à energia elétrica: a experiência do programa Luz para Todos e o futuro que se apresenta. In: ELETRÔNICOS DO BRAZIL-JAPAN INTERNATIONAL WORKSHOP: SOCIETY, ENERGY AND 
ENVIRONMENT, 10., 2003, São Paulo, Anais... São Paulo: UNICAMP, 2003.

Disponível em: <http://www.nipeunicamp.org.br/brasiljapao/admin/resources/ uploads/ednaldo_camargo.pdf $>$. Acesso em: 13 out. 2014.

CAMARGO, E.; RIBEIRO, F.; GUERRA, S. O Programa Luz para Todos: metas e resultados. Espaço Energia, Paraná, n. 9, p. 21-24, out. 2008. Disponível em: <http:// www.espacoenergia.com.br/edicoes/9/EE009-04.pdf>. Acesso em: 13 out. 2014.

CAVALCANTE, A. S.; CARTAXO, E. F. A inclusão elétrica e o desafio da sustentabilidade nas áreas remotas do interior da Amazônia. In: CONGRESSO INTERNACIONAL SOBRE GERAÇÃO DISTRIBUÍDA E ENERGIA NO MEIO RURAL, 7, 2008, Fortaleza. Anais... Fortaleza: Universidade de Fortaleza, 2008. p. 1-11.

CARTAXO, E. F.; COELHO, I. M. H. V.; PAIXÃO, V. Sustentabilidade do programa "Luz para Todos" no estado do Amazonas. Revista Brasileira de Energia, Brasília, DF, v. 12, n. 1, p. 1-8, 2006.

COLL, C. et al. Los contenidos de la reforma: enseñanza y aprendizaje de conceptos, procedimientos y actitudes. Madrid: Santillana, 1992.

CONRADO, D. M. Uso de conhecimentos evolutivo e ético na tomada de decisão por estudantes de biologia. 2013. 220 f. Tese (Doutorado em Ecologia e Biomonitoramento) - Instituto de Biologia, Universidade Federal da Bahia, Salvador, 2013.

CONRADO, D. M. et al. Socioscientific issues about bees, pollination and food production in biology teaching. In: CONFERENCE OF THE EUROPEAN SCIENCE EDUCATION RESEARCH ASSOCIATION, 11., 2015, Helsink. Proceeding... Helsinki: ESERA, 2015. p. 1-4.

CONRADO, D. M. et al. Uso do conhecimento evolutivo na tomada de decisão de estudantes do ensino médio sobre questões socioambientais. Revista Contemporânea de Educação, Rio de Janeiro, v. 7, n. 14, p. 345-368, 2012.

CONRADO, D. M.; NUNES-NETO, N. F. Dimensões do conteúdo em questões sociocientíficas no ensino de ecologia. In: ENCONTRO NACIONAL DE EDUCAÇÃO EM CIÊNCIAS, 16., 2015, Lisboa. Anais... Lisboa: ENEC, 2015. p. 432-435.

CONRADO, D. M.; NUNES-NETO, N. F.; EL-HANI, C. N. Argumentação sobre problemas socioambientais no ensino de biologia. Educação em Revista, Belo Horizonte, v. 31, p. 329-357, 2015.

CONRADO, D. M.; EL-HANI, C. N.; NUNES-NETO, N. F. Sobre a ética ambiental na formação do biólogo. REMEA - Revista Eletrônica do Mestrado em Educação Ambiental, Rio Grande, v. 30, n. 1, p. 120-139, jan./ jun. 2013.

COOK, P. Rural Electrification and Rural Development. In: BHATTACHARYYA, S. (Ed.). Rural electrification through decentralised off-grid systems in developing countries. Green Energy and Technology. London: Springer-Verlag, 2013. p. 13-38.

COPI, I. Introdução à lógica. São Paulo: Mestre Jou, 1968. 
CORTEZ, A. T. C. Consumo e desperdício: as duas faces das desigualdades. In: CORTEZ, A. T. C.; ORTIGOZA, S. A. G. (Org.). Da produção ao consumo: impactos socioambientais no espaço urbano. São Paulo: UNESP: Cultura Acadêmica, 2009. p. 35-62.

EASTWOOD, J. L. et al. Contextualizing nature of science instruction in socioscientific issues. International Journal of Science Education, London, v. 34, n. 15, p. 2289-2315, 2012.

FERREIRA, N. T. Cidadania: uma questão para a educação. Rio de Janeiro: Nova Fronteira, 1993.

FOURNIER, A.; PENTEADO, C. Eletrificação rural: desafios para a universalização da energia. In: CONGRESSO BRASILEIRO DE ENERGIA, 12., 2008, Rio de Janeiro. Anais... Rio de Janeiro: COPPE/UFRJ, 2008. v. 1, p. 373-387. Disponível em: <http:// www.aneel.gov.br/biblioteca/downloads/livros/eletrificacao_rural_XII.pdf >. Acesso em: 13 out. 2014.

FUGIMOTO, S. K. A Universalização do serviço de energia elétrica- acesso e uso contínuo. 2005. 264 f. Dissertação (Mestrado em Engenharia) - Escola Politécnica da Universidade de São Paulo, São Paulo, 2005. Disponível em: <http://www.aneel.gov. br/biblioteca/trabalhos/trabalhos/Dissertacao_Sergio_Fugimoto.pdf >. Acesso em: 13 out. 2014.

GIROUX, H. A.; GIROUX, S. S. Challenging neoliberalism's new world order: the promise of critical pedagogy. Cultural Studies, Critical Methodologies, Thousand Oaks, v. 6, p. 21-32, 2006.

GORCZEVSKI, C.; MARTIN, N. B. A necessária revisão do conceito de cidadania: movimentos sociais e novos protagonistas na esfera pública democrática. Santa Cruz do Sul: EDUNISC, 2011.

GUSMÃO, M. V. et al. O programa de eletrificação rural "Luz no Campo": resultados iniciais. In: ENCONTRO DE ENERGIA NO MEIO RURAL., 4., 2002, Campinas. Anais... Campinas: Unicamp, 2002.

HARDIN, G. The tragedy of the commons. Science, [S.1.], v. 162, p. 1243-1248, 1968. HODSON, D. Going beyond STS: towards a curriculum for sociopolitical. Science Education Review, Queensland, v. 3, n. 1, p. 2-7, 2004.

HODSON, D. Looking to the future: building a curriculum for social activism. Rotterdam: Sense Publishers, 2011.

HODSON, D. Don't be nervous, don't be flustered, don't be scared: be prepared. Canadian Journal of Science, Mathematics and Technology Education, Toronto, v. 13, n. 4, p. 313-331, 2013.

IBGE. Censo demográfico 2010. Rio de Janeiro, 2010. Disponível em: <http://www. censo2010.ibge.gov.br>. Acesso em: 10 jan. 2015. 
KHANDKER, S. R. et al. Who benefits most from rural electrification? evidence in India. Policy Research working paper, Washington, n. WPS 6095, p. 1-40, 2012. Disponível em: <http://documents.worldbank.org/curated/en/374171468331748897/ Who-benefits-most-from-rural-electrification-evidence-in-India>. Acesso em: 2 jun. 2015.

LISBOA, M. T. O policy cycle e o programa "Luz para Todos". In: ENCONTRO INTERNACIONAL PARTICIPAÇÃO, DEMOCRACIA E POLÍTICAS PÚBLICAS: APROXIMANDO AGENDAS E AGENTES, 2013, Araraquara. Anais Eletrônicos... Araraquara: UFRGS, 2013. p. 1-26. Disponível em: <http://www.encontropdpp. sinteseeventos.com.br/>. Acesso em: 4 dez. 2014.

LOUREIRO, C. F. B. Sustentabilidade e educação ambiental: controvérsias e caminhos do caso brasileiro. Sinais Sociais, Rio de Janeiro, v. 9, n. 26, p. 39-71, 2014.

MARQUES, R. F. R. Influência da tecnologia sobre a prática cotidiana de atividade física. In: VILARTA, R. et al. (Org.). Qualidade de vida e novas tecnologias. Campinas: IPES Editorial, 2007. p. 139-148.

MARTINS, L. et al. Health education with socioscientific issues. In: BIANNUAL CONFERENCE OF THE EUROPEAN SCIENCE EDUCATION RESEARCH ASSOCIATION, 11., 2015, Helsinki. Proceeding... Helsinki: ESERA, 2015. p. 1-4.

MARTÍNEZ PÉREZ, L. F. et al. A Abordagem de questões sociocientíficas no Ensino de Ciências: contribuições à pesquisa da área. In: ENCONTRO NACIONAL DE PESQUISA EM EDUCAÇÃO EM CIÊNCIAS, 8., 2011, Campinas. Anais Eletrônicos... Campinas: UNICAMP, 2011. Disponível em: <http://www.nutes.ufrj.br/abrapec/ viiienpec/resumos/R1606-1.pdf>. Acesso em: 27 mar. 2015.

MARTÍNEZ PÉREZ, L. F.; LOZANO, D. L. P.; AGUILAR, D. L. G. Cuestiones sociocientíficas en la formación de profesores de ciencias. Educyt, Cali, p. 139-151, dez. 2012. Disponível em: <http://revistaprospectiva.univalle.edu.co/index.php/educyt/ issue/archive >. Acesso em: 30 mar. 2015.

PIEROBON, F. A cidadania e o cidadão no contrato social de Rosseau. Argumenta, Jacarezinho, PR, n. 17, p. 267-282, 2012.

PINTO, M. M. A noção de vontade geral e seu papel no pensamento político de JeanJacques Rousseau. Cadernos de Ética e Filosofia Política, São Paulo, n. 72, p. 83-97, 2005.

RACHELS, J. The elements of moral philosophy. New York: McGraw-Hill, 2003.

REIS, L. B.; SILVEIRA, S. Energia elétrica para o desenvolvimento sustentável: introdução de uma visão multidisciplinar. São Paulo: Universidade de São Paulo, 2000.

RIBEIRO, F. S.; SANTOS, J. F. M. Política de eletrificação rural: superando dilemas institucionais. Revista do BNDES, Rio de Janeiro, v. 1, n. 2, p. 131-152, dez. 1994. Disponível em: <http://www.bndes.gov.br/SiteBNDES/bndes/bndes_pt/Institucional/ Publicacoes/Consulta_Expressa/Tipo/Revista_do_BNDES/199412_7.html>. Acesso em: 14 maio 2015.

ROUSSEAU, J. Do contrato social. São Paulo: Nova Cultural, 1999. 
SÁ, L. P.; QUEIROZ, S. L. Promovendo a argumentação no ensino superior de química. Revista Química Nova, São Paulo, v. 30, n. 8, p. 2035-2042, 2007.

SADLER, T. D. Socio-scientific issues in the classroom: teaching, learning and research, Gainesville: Springer, 2011.

SANTOS, W. L. P. dos; MORTIMER, E. F. Tomada de decisão para ação social responsável no ensino de ciências. Ciência e Educação, Bauru, v. 7, n. 1, p. 95-111, 2001.

SILVEIRA, M.; PALÁCIO, R.; CONRADO, D. M. Aplicação de questões sociocientíficas como estratégia para o ensino sobre energia elétrica. Indagatio Didactica, Aveiro, v. 8, p. 1033-1050, 2016. Edição Especial.

SOLBES, J. Contribución de las cuestiones sociocientíficas al desarrollo del pensamiento crítico (II): Ejemplos. Revista Eureka sobre Enseñanza y Divulgación de La Ciencias, Barcelona, v. 10, n. 2, p. 148-158, 2013.

TOUlMiN, S. E. Os usos do argumento. 2. ed. São Paulo: Martins Fontes, 2006.

WIDMER, R. et al. Global perspectives on e-waste. Environmental Impact Assessment Review, New York, v. 25, n. 5, p. 436-458, 2005.

WORLD HEALTH ORGANIZATION-WHO. WHO handbook on establishing a dialogue on risks from electromagnetic fields. Geneva, 2002. Disponível em: <http://www.who. int/peh-emf/publications/en/>. Acesso em: 21 mar. 2011.

ZABALA, A. A prática educativa: como ensinar. Porto Alegre: Artmed, 1998.

ZABALA, A.; ARNAU, L. O termo competência surge como resposta às limitações do ensino tradicional. In: ZABALA, A.; ARNAU, L. Como aprender a ensinar competências. Porto Alegre: Artmed, 2010. p. 17-26.

ZATTI, V. Autonomia e educação em Immanuel Kant e Paulo Freire. Porto Alegre: EDIPUCRS, 2007.

ZEIDLER, D. et al. Beyond STS: a research-based framework for socioscientific issues education. Science Education, New York, v. 89, n. 3, p. 357-377, may 2005. 


\title{
GEOENGENHARIA DO CLIMA UMA CONTROVÉRSIA SOCIOCIENTÍFICA SOBRE A RESPONSABILIDADE NA MANIPULAÇÃO DO CLIMA
}

\author{
Ana Rita Marques \\ Pedro Reis
}

\section{Introdução}

As alterações climáticas antropogénicas são uma realidade atual, global e, nos últimos anos, cada vez mais consensual, impactando os equilíbrios naturais e a segurança de uma grande parte da população. As principais causas das alterações climáticas antropogénicas centram-se no aumento das concentrações de um conjunto de gases emitidos pelas atividades humanas e que interferem com os padrões normais de troca de energia por radiação da Terra com o espaço exterior, fenômeno este designado efeito de estufa. (BORREGO et al., 2010)

O fenômeno do aquecimento global, outrora controverso e sujeito a questionamentos relativamente às suas origens e causas, evoluiu para um consenso mundial, sendo que o trabalho de órgãos como o Painel Intergovernamental sobre Mudanças Climáticas (IPCC) muito tem contribuído para que este tópico seja tratado com gravidade e preocupação nas mais diferentes esferas de decisão. (MARTINS, 2009) Com efeito, foram já diversos os países cujos governos reconheceram a gravidade da situação e a necessidade de se tomarem medidas efetivas para contorná-la, existindo três possibilidades de responder ao aquecimento global: adaptação e mitigação (ambas reconhecidas e 
consideradas amplamente necessárias) e a Geoengenharia do Clima (GC). A GC pode ser descrita como a manipulação intencional e em larga escala do clima, com a finalidade de combater e reduzir as alterações climáticas antropogénicas indesejadas, mais especificamente o aquecimento global causado pelas emissões de gases com efeito de estufa. (MARTINS, 2009) Diversos métodos têm vindo a ser contemplados para esse fim, com resultados, objetivos, tecnologias e custos bastante distintos entre si. No entanto, todas as medidas de GC apresentam uma série de riscos e incertezas que eliminam a possibilidade de serem utilizadas de imediato; carecem, por isso, de mais estudos que permitam esclarecer ao máximo as dúvidas relativamente aos seus custos, efeitos diretos sobre o clima e efeitos colaterais sobre o meio ambiente. (BALA, 2009; CORNER; PIDGEON, 2010; GARVEY, 2008; MARTINS, 2009; MCNEILL, 2000; WEART, 2006)

A investigação científica e a inovação tecnológica estão constantemente a transformar o mundo. Dos telemóveis à internet, passando pelos mais recentes tratamentos contra o cancro, a ciência e a tecnologia têm o potencial de mudar as nossas vidas. Estes desenvolvimentos também criam novos riscos e novos dilemas éticos. Entretanto, os desafios que a sociedade enfrenta também são imensos - do envelhecimento saudável à sustentabilidade, da saúde global à segurança ambiental. Alguns afirmam que a investigação e a inovação poderão dar conta destes desafios, mas nada garante o seu sucesso à partida. A investigação e a inovação são sempre um pouco imprevisíveis, mas tal não pode servir de desculpa para a irresponsabilidade. Por outro lado, compreender e responsabilizar-se por desenvolvimentos que afetam profundamente a vida de todos não diz respeito só à ciência e aos cientistas. (SUTCLIFFE, 2011) O rumo e os objetivos da investigação e da inovação, a distribuição dos seus resultados (tanto positivos como negativos), os usos de novas tecnologias e o foco na resolução de problemas prementes são questões que os cidadãos têm que discutir e decidir em conjunto. (RRI TOOLS, [200-]; SUTCLIFFE, 2011)

A GC é um tema que pode ser abordado do ponto de vista da Investigação e Inovação Responsáveis (IIR). Tal significa que um ou mais compromissos (com foco na responsabilidade) orientariam as considerações sobre o processo de investigação em GC e suas aplicações, a fim de resolver problemas ambientais.

É nesse sentido que abordar a GC enquanto estratégia de combate, por exemplo, ao aquecimento global, através da lente da IIR, afigura-se como algo extremamente pertinente e necessário. Contudo, o desafio reside precisamente no modo como concretizar essa abordagem, garantindo que faça sentido para os cidadãos e não seja sentida como descontextualizada. Faz igualmente parte do desafio a capacitação dos alunos - cidadãos do presente - para a ação socioambiental e para a ação sociopolítica acerca da GC, de modo que esta tecnologia possa ser desenvolvida de um modo responsável.

Com base no contexto acima, este capítulo pretende apresentar uma sequência possível de atividades, organizadas segundo o modelo dos 5E de Rodger Bybee, no âmbito da estratégia de ensino Inquiry-Based Science Education (IBSE) que, incidindo na IIR no âmbito da GC, permitam perspetivar a manipulação intencional do clima como um do- 
mínio de investigação científica controverso que exige, por isso, responsabilidade. Em virtude da necessidade de sensibilizar os cidadãos para: as questões que o tema envolve; a compreensão dos papéis dos diferentes agentes e grupos envolvidos na problemática; o entendimento das interações entre a Ciência, a Tecnologia, a Sociedade e o Ambiente (CTSA), a sequência de atividades propõe o desenvolvimento, a construção e a apresentação de uma exposição pelos alunos - processo entendido e explicitamente abordado enquanto estratégia de ativismo coletivo fundamentado em investigação.

A secção seguinte apresenta a controvérsia sociocientífica, indicando-se os níveis de ensino a que se aplica e das áreas do conhecimento que mobiliza, as questões de investigação que suscita aos alunos, os objetivos de aprendizagem que visa atingir e os meios para que a sua aplicação se concretize. Por último, apresentam-se as considerações finais.

\section{Fundamentação teórica das opções metodológicas e didáticas}

O processo de investigação científica e inovação tecnológica em GC deve pautar-se por princípios de responsabilidade que, de acordo com a Comissão Europeia, deverá respeitar seis dimensões fundamentais:

- envolvimento;

- $\quad$ igualdade de gênero;

- $\quad$ educação em ciências;

- livre acesso;

- ética; e

- governação. (SUTCLIFFE, 2011)

A ideia de IIR procura trazer a debate diferentes questões relacionadas a cada uma dessas dimensões, antecipar consequências e rumos da investigação e da inovação e implicar a sociedade na discussão sobre como a ciência e a tecnologia podem contribuir para um mundo e um futuro melhores. (RRI TOOLS, [200-])

\section{A Investigação e a Inovação Responsáveis}

O plano de ação da União Europeia, Science in Society, desenvolvido com a finalidade de serem definidas as estratégias comuns para uma melhor ligação entre ciência e os cidadãos europeus, tem vindo a focar a sua atenção no tema IIR. A participação conjunta e inclusiva de todos os atores sociais é condição fundamental para que os processos e os produtos da investigação e da inovação se compatibilizem com os valores, necessidades e expectativas da sociedade. (SUTCLIFFE, 2011)

O envolvimento pressupõe a participação conjunta de todos os atores sociais - investigadores, indústria, decisores políticos e sociedade civil - no processo de investi- 
gação e inovação. Uma estrutura sólida de excelência em IIR implica que os desafios sociais sejam enquadrados em função das grandes preocupações sociais, éticas e econômicas. É igualmente importante que, para o desenvolvimento de uma IIR, ocorra uma aprendizagem conjunta e que as práticas adotadas sejam comuns - os atores sociais devem estar em sintonia -, de modo que se desenvolvam as melhores soluções para os problemas e oportunidades sociais e de modo a prevenir possíveis falhas das inovações futuras. (SUTCLIFFE, 2011)

A igualdade de gênero diz respeito ao envolvimento igual e equilibrado tanto dos homens como das mulheres. É fundamental combater a baixa representatividade das mulheres nas instituições de investigação e nos processos decisórios sobre questões científicas e tecnológicas. (SUTCLIFFE, 2011)

A Europa precisa de mais investigadores; precisa também aperfeiçoar o atual ensino das ciências de modo a melhor munir os futuros investigadores e demais atores sociais de conhecimento e competências necessários a uma plena participação responsável no processo de investigação e inovação. A dimensão educação em ciências surge assim, como fundamental. (SUTCLIFFE, 2011) Essa educação é imprescindível para a promoção da alfabetização científica dos cidadãos, condição necessária para uma efetiva cidadania ativa.

A responsabilidade requer uma investigação e uma inovação transparentes e acessíveis; tal pressupõe permitir, aos atores sociais, o livre acesso aos resultados - publicações e dados - da investigação científica financiada pelo dinheiro público. Tal medida estimulará não só a inovação como também a utilização dos resultados científicos por todos os atores sociais, o que contribui para a tomada de decisão fundamentada na investigação científica. (SUTCLIFFE, 2011)

A sociedade europeia assenta em valores comuns e partilhados, qual sejam o respeito pelos direitos humanos, a aplicação do Estado de direito, a proteção ambiental e a manutenção dos padrões sociais na economia social de mercado. (FONTAINE, 2010) De modo a responder adequadamente aos desafios sociais, a investigação e a inovação devem respeitar os direitos fundamentais e os mais altos padrões éticos. Para além dos aspetos legais obrigatórios, esta medida visa assegurar uma maior relevância e aceitação social dos resultados da investigação e da inovação. A dimensão ética não deve ser entendida como um constrangimento à investigação e à inovação responsáveis, mas antes como garantia da qualidade dos resultados. (SUTCLIFFE, 2011)

A última dimensão - governação - engloba todas as outras. Os cidadãos devem ser capacitados e envolvidos na governação, avaliando e controlando as propostas científicas e tecnológicas de modo a prevenir os desenvolvimentos em investigação e inovação que não tenham em conta a dimensão ética, podendo ser prejudiciais à sociedade e ao ambiente. Pretende-se o desenvolvimento de modelos harmoniosos para uma investigação e uma inovação responsáveis que integrem o envolvimento público, a igualdade de gênero, a educação em ciências, o livre acesso e a ética. (SUTCLIFFE, 2011) 


\section{Ampliação do modelo dos $5 \mathrm{E}$ de Rodger Bybee: o modelo dos $7 \mathrm{E}$}

O modo como a ciência é ensinada revelou ser determinante para o sucesso das aprendizagens dos alunos e para a sua motivação para as áreas científicas. (ROCARD et al., 2007) Aquele sucesso e motivação podem ser alcançados através de uma estratégia de Ensino das Ciências Baseado em Investigação IBSE. No contexto das atividades investigativas, o aluno assume e reconhece o problema a investigar como sendo real e pertinente e, consequentemente, envolve-se em planejamento, execução, interpretação e avaliação dos resultados e das soluções, comunicando aos outros a sua investigação. (BYBEE, 2000) Um ensino baseado em atividades investigativas proporciona aos alunos ambientes propícios à reflexão e ao pensamento crítico e lógico sobre fatos ou evidências, conduzindo à apropriação dos conceitos científicos e a um melhor entendimento do mundo ao seu redor. (BYBEE, 2000) No contexto das atividades investigativas IBSE, o modelo de aprendizagem dos 5E, desenvolvido por Bybee e colaboradores (2006), contempla cinco etapas: engage (envolvimento), explore (exploração), explain (explicação), extend (ampliação) e evaluate (avaliação). O modelo ampliado contempla também as etapas exchange (partilha) e empowerment (empoderamento/ativismo). A inclusão dessas duas etapas surgiu na sequência do Projeto We Act - Promoting Collective Activism on Socio-Scientific Issues, enquadrado pela Universidade de Lisboa, o qual tem por objetivo principal o desenvolvimento, a implementação e o estudo de materiais, metodologias e abordagens que apoiem professores e alunos na realização de ações informadas e negociadas sobre QSC. (REIS, 2014) O Quadro 1 evidencia os principais aspetos de cada etapa no contexto das atividades propostas neste artigo.

Quadro 1 - O modelo dos 7E

\section{Engage/Envolvimento}

Tem como objetivo despertar o interesse dos alunos - motivando-os para as tarefas subsequentes - e identificar os seus conhecimentos prévios sobre o(s) tópico(s) em estudo.

\section{Explore/Exploração}

Tem como objetivo permitir que os alunos se envolvam no(s) tópico(s) e construam conhecimento acerca do(s) mesmo(s) - realizando atividades de pesquisa, atividades experimentais, ou outras, em que formulam hipóteses, planeiam e executam investigações preliminares. Nesta fase, os alunos têm a oportunidade de se envolver diretamente com os fenômenos e materiais relacionados com o(s) tópico(s) de investigação - questionando, analisando dados e refletindo sobre os resultados.

\section{Explain/Explicação}

Tem como objetivo criar a oportunidade para os alunos partilharem com os pares e/ou com o professor o que aprenderam até então - fazendo uso de uma linguagem científica adequada. Pretende-se que, durante este processo, os alunos reflitam sobre as suas conceções cientificamente incorretas e sejam capazes de construir novas conceções, cientificamente corretas. 


\section{Extend/Ampliação}

Tem como objetivo permitir que os alunos mobilizem o novo conhecimento (adquirido nas fases anteriores), aplicando-o a novas situações problema - as quais incluem os aspetos da investigação e da inovação responsáveis. Através deste processo, pretende-se que os alunos desenvolvam uma compreensão mais abrangente e aprofundada dos conceitos, relacionando as novas experiências com as experiências anteriores.

\section{Exchange/Partilha}

Pressupõe o planeamento e a conceção de uma exposição interativa dos produtos da investigação desenvolvida. Pretende-se que os alunos partilhem com a comunidade os resultados das suas investigações - os produtos podem assumir diferentes formatos (pôster, jogo, vídeo, entre outros). Trata-se de uma oportunidade para os alunos comunicarem, para um público mais alargado, o novo conhecimento construído. Esta fase está em estreita relação com a fase de empowerment (ativismo), já que se pretende, através da exposição, consciencializar e sensibilizar os demais para as questões alvo da investigação.

\section{Empowerment/Ativismo}

Desenvolve-se em simultâneo com as restantes etapas; pretende-se envolver os alunos numa ação coletiva, fundamentada em pesquisa e investigação, tendo em vista a resolução de problemas sociocientíficos relacionados aos temas científicos atuais. Desde cedo, devem ser criadas oportunidades para que os alunos sintam valorizada a sua participação em todas as fases do processo.

\section{Evaluate/Avaliação}

Os alunos têm a oportunidade de avaliar os seus conhecimentos e capacidades; o professor tem a possibilidade de avaliar o progresso dos seus alunos relativamente aos objetivos de aprendizagem estabelecidos. O processo avaliativo foca-se, sobretudo, nos alunos e na criação de oportunidades para que estes reflitam sobre o seu desempenho - fazendo uso da autoavaliação -, mas também sobre as próprias tarefas realizadas. Esta fase está presente ao longo da concretização das restantes fases - é importante que os alunos tenham várias oportunidades para refletir sobre o seu desempenho, dificuldades e resultados.

Fonte: adaptado de Bybee e colaboradores (2006).

\section{As exposições como estratégia de ativismo coletivo fundamentado em investigação}

A educação para o empoderamento - sendo participativa, afetiva, com recurso a problemas, situada, multicultural, dialógica, democrática, investigativa, interdisciplinar e ativista - permite que os alunos se tornem trabalhadores capazes, cidadãos pensantes e, assim, críticos sociais e agentes da mudança. (SHOR, 1992) A probabilidade dos alunos se tornarem cidadãos ativos no futuro é substancialmente aumentada se os encorajarmos a agir agora, no presente, fornecendo-lhes oportunidades para que o façam e exemplos detalhados de ações bem-sucedidas e de intervenções levadas a cabo por outros. (HODSON, 2014) Urge empoderar os cidadãos para que sejam capazes de enfrentar os diferentes problemas que permeiam as sociedades atuais, muitos deles altamente controversos e que representam ameaças ao bem estar dos indivíduos, sociedades e ambientes. Enfrentar esses problemas implica compreendê-los, tomar decisões e agir. (REIS, 2013, 2014) 
Os alunos podem e devem ser encarados como podendo fazer parte da solução para problemas atuais (JENSEN, 2002), e a educação em ciência que eles tiverem será decisiva para que os próprios assim se consigam assumir. Seja qual for o critério de seleção subjacente à escolha do tema problematizador que norteará a ação dos alunos, estes necessitam de conhecimento científico, se deles se espera um envolvimento para além do nível meramente superficial. O conhecimento substantivo, orientado para a ação, é determinante para compreender os aspetos subjacentes aos problemas, avaliar diferentes posições, decidir de modo informado e argumentar. (HODSON, 2014; JENSEN, 2002) É este conhecimento científico, fruto da investigação levada a cabo pelos alunos, que distingue o ativismo coletivo, defendido por autores como Derek Hodson, daquele que é movido apenas pelo senso comum.

O desenvolvimento de uma exposição científica constitui um pretexto e um contexto para os alunos investigarem sobre os seus próprios interesses: questionando, colaborando e observando (SLEEPER; STERLING, 2004), recorrendo à lógica e à evidência no processo de formulação e revisão das explicações científicas, reconhecendo e analisando explicações alternativas e comunicando argumentos científicos. Através da construção e da apresentação de exposições sobre a IIR de temas científicos controversos e atuais, alunos e professores têm a oportunidade de contatar com temas que realçam uma ciência de fronteira, controversa, incerta e sob debate. A discussão inerente à conceção das exposições pode ser particularmente útil, promovendo:

- a aprendizagem sobre os conteúdos, processos e a Natureza da Ciência e da tecnologia; e

- o desenvolvimento cognitivo, social, político, moral e ético. (KOLSTØ, 2001; MILLAR, 1997; SADLER, 2004)

Entendida como uma iniciativa de educação junto de outros cidadãos, a concretização da exposição possibilita aos alunos participar numa ação comunitária sobre temas sociocientíficos controversos e motivar outros a envolver-se nela. A ação comunitária fundamentada em investigação pode ser considerada uma importante dimensão da literacia científica (HODSON, 1998), possibilitando aos alunos aumentar o seu conhecimento acerca dos problemas em causa e desenvolver competências de investigação e cidadania participativa e fundamentada, desenvolvendo também o sentimento de poder de intervenção na evolução da sociedade. (MARQUES, 2013; MARQUES; REIS, 2017; REIS, 2013)

\section{Uma controvérsia sociocientífica sobre geoengenharia responsável do clima}

As atividades sugeridas destinam-se a alunos do $8^{\circ}$ ano ao $12^{\circ}$ ano (idades compreendidas entre os 12 e os 18 anos). Como ponto de partida, os alunos devem já ter 
abordado a problemática das alterações climáticas e do aquecimento global - causas e consequências -, de modo a melhor compreenderem o potencial da GC, assim como os riscos associados a esta área de investigação científica, e da aplicação tecnológica, nas sociedades e no ambiente, e, deste modo, a importância de uma IIR neste domínio.

As áreas do conhecimento mobilizáveis relacionam-se com as diferentes estratégias de GC que os alunos terão que pesquisar, compreender e, relativamente às quais, identificar vantagens e desvantagens. As estratégias existentes podem organizar-se em dois grandes grupos: as que visam a remoção do $\mathrm{CO}_{2}$ da atmosfera - Carbon Dioxide Removal, CDR - e as que visam gerir a radiação solar que atinge o nosso planeta Solar Radiation Management (SRM). Como estratégias CDR que os alunos terão que pesquisar, temos:

- fertilização dos oceanos com Fe e N;

- $\quad$ florestação;

- sequestro de carbono por biochar e/ou biomassa;

- captura direta e industrial de $\mathrm{CO}_{2}$ do ar ambiente;

- aumento dos processos naturais de extração do $\mathrm{CO}_{2}$ da atmosfera (dissolução de silicatos e formação de carbonatos).

Como estratégias Solar Radiation Management (SRM), os alunos terão que realizar pesquisa sobre:

- aumento do albedo de superfície (estimulando a reflexão da radiação solar através de superfícies mais brilhantes, por exemplo, telhados brancos, culturas de determinadas espécies vegetais; e através de refletores colocados nos desertos);

- aumento do albedo estratosférico (através da formação de nuvens mais brilhantes por via da dispersão de aerossóis);

- refletores colocados no espaço.

Assim, no domínio da biologia, mobilizam-se, entre outros, conhecimentos relativos ao processo fotossintético e ao impacto da proliferação de fitoplâncton nas teias alimentares dos ecossistemas marinhos. No domínio da química, mobilizam-se conhecimentos relativos à acidificação dos oceanos e ao impacto da mesma nos ecossistemas. No domínio da física, mobilizam-se conhecimentos relacionados à radiação, à reflexão e ao albedo. Nos domínios da geografia e da história, mobilizam-se conhecimentos acerca das questões geopolíticas, como, por exemplo, as associações entre o militarismo, as tecnologias espaciais e o controle do clima, especialmente desde a Guerra Fria. Nos domínios da sociologia e da filosofia, mobilizam-se conhecimentos relativos aos valores sociais e culturais, às desigualdades sociais no acesso aos benefícios da GC, além de debates éticos, como a relação complexa entre técnica, ideologia e moralidade, possivelmente a partir das elaborações teóricas da Escola de Frankfurt. De modo transversal, 
e a partir das atividades que promovem a reflexão acerca da IIR na GC, mobilizam-se conhecimentos acerca das relações CTSA.

A controvérsia sociocientífica é apresentada aos alunos através do diálogo entre dois irmãos e outros intervenientes (Quadro 2); através desse diálogo, são lançadas questões às quais os alunos têm que dar resposta a partir de uma pesquisa orientada.

Quadro 2 - Controvérsia sociocientífica sobre GC

\section{Um diálogo sobre o controle do clima}

Finalmente, o primeiro dia de férias de verão. Os irmãos Gonçalo e Inês estavam ansiosos por poderem ir à praia: as previsões meteorológicas davam bom tempo!

Acordaram cedo, céu cinzento. Pode ser que mude... Pensaram. Arranjaram tudo e foram para a paragem do autocarro.

Mas eis senão quando caem uns pequenos pingos de chuva, que vão ficando cada vez mais pesados, até que finalmente cai uma chuvada monumental.

Os irmãos, visivelmente aborrecidos, abrigados na paragem, juntamente com outras pessoas que lá estavam à espera do autocarro, começam o seguinte diálogo:

_Mas que azar! Já viste isto, Gonçalo? Semanas e semanas à espera do bom tempo, as previsões eram fantásticas, primeiro dia de férias e cai esta chuvada? Esquece lá a praia.

_Pois, é mesmo para esquecer. E ainda bem que podemos nos abrigar na paragem, já viste a molha que íamos apanhar?

_Que irritação! Juro... Quem me dera poder controlar o tempo! Já imaginaste se isso fosse possível? Olha, em primeiro lugar tinha garantido que hoje não chovia e estaria calor.

_Era bom era. E imagina naqueles dias de exame: um mega nevão, escola fechada! Isso é que era.

_Sim, controlar o tempo era fantástico. Dava imenso jeito! Qual seria a receita para fazer nuvens e chuva? - a Inês lançou a questão a sorrir.

_Olhe, menina, sem me querer intrometer, isso já foi feito - respondeu um senhor que estava na paragem.

_Foi feito? O quê? Alguém já fez nuvens e chuva?

_Já ouviu falar da Guerra do Vietname, suponho. Pois, olhe que os Estados Unidos da América, entre 1967 e 1972, gastaram mais de 3 milhões de dólares por ano numa operação secreta no sudeste asiático. O objetivo era fazerem nuvens artificiais de modo a atrapalhar o sistema de rotas utilizado pelas tropas vietnamitas.

_A sério? Os norte-americanos também já fazem nuvens? - perguntou Gonçalo, incrédulo.

_Acredite, meu rapaz. Sabe por que nome ficou conhecida essa operação secreta? Operação Popeye! Se tiver dúvidas, procure na internet e vai ver que tenho razão.

Nisto, uma senhora que muito atentamente ouvia a conversa, interpelou os irmãos:

_E existem provas de que isso acontece!

_Provas? - perguntou a Inês.

- Sim, provas. Todos os dias, basta olharem para o céu.

A senhora retira do bolso o seu telemóvel:

_Olhem, esta foto tirei há uns dias quando estava a sair de casa. Estão a ver isto no céu, estes rastos?

_Sim, de aviões?

_Não, isto não são rastos normais de um avião. Isto são rastos químicos, são chemtrails! Eles pulverizam substâncias químicas no céu, de forma deliberada e a grandes altitudes, com o objetivo de controlarem o clima! E acreditem, isto não nos faz nada bem.

_O quê? Controlarem o clima? Mas como?

_Olhem, o meu autocarro vem aí. Não tenho mais tempo, mas pesquisem pelo programa Haarp. Não se esqueçam, Haarp, com dois A's! - e entrou no autocarro.

Os dois irmãos olharam um para o outro, intrigados.

_Pulverizar produtos químicos para fazer nuvens? Controlar o clima? Será que isto é mesmo verdade? Eu vi a foto dela, já vi aqueles rastos no céu tantas vezes!

Uma outra senhora que acabara de chegar à paragem interveio:

_Peço desculpa, mas não posso evitar. Ouvi-vos falar em fazer nuvens e em rastos. Sou climatóloga e acreditem que sei do que falo, isso dos chemtrails não é verdade. É verdade que é possível manipular o clima, mas isso é feito com as melhores das intenções: combater o aquecimento global! E tem um nome: geoengenharia do clima.

_Hmmm... geoengenharia do clima. Nunca ouvi falar...!

- Basicamente, pretende-se reduzir os níveis de $\mathrm{CO}_{2}$ na atmosfera através das estratégias de remoção de dióxido de carbono (carbon dioxide removal), ou então evitar que a radiação Infravermelha do sol atinja a superfície do planeta ou, ainda, estimular a sua reflexão, através das estratégias de gestão da radiação solar (solar radiation management). Há várias estratégias de geoengenharia e baseadas em princípios biológicos, físicos e químicos. sável!

Não acreditem nestas coisas das "teorias da conspiração", o importante é que a geoengenharia seja respon- 
_Bem, obrigada pelo esclarecimento... Acho. Já estou baralhada que chegue! E entretanto já não chove. Gonçalo, vamos embora?

_Sim, vamos para casa. Já vi que hoje não há praia para ninguém...

Os irmãos voltaram para casa e resolveram escrever algumas notas soltas daquilo que tinham ouvido. Estes dois adoravam aprender, e este assunto era demasiado intrigante e misterioso para que o pudessem esquecer.

Fonte: elaborado pelos autores.

Aqui ficam as notas deles. Questões relacionadas à QSC:

Q1. O clima já foi manipulado no passado? Em que consistiu a Operação Popeye? O que são os chemtrails? O que defendem as "teorias da conspiração" a este respeito? O que é a Haarp?

Q2. Qual a relação entre a GC e o aquecimento global?

Q3. Em que consistem as estratégias de remoção do dióxido de carbono (CDR) e gestão da radiação solar (Solar Radiation Management, SRM)? Quais os princípios biológicos, químicos e físicos que estão subjacentes às várias opções metodológicas de cada uma dessas estratégias? Que vantagens e desvantagens apresentam cada uma delas?

Q4. Sobre o que disse a cientista, será mesmo que, sempre, as intervenções tecnológicas baseadas na ciência são feitas "com as melhores das intenções”? O que ela quis dizer, exatamente, com responsabilidade, especificamente na criação e no uso da tecnologia? Haveria outro modo de resolver os problemas do clima, que não fossem (somente) baseados em GC?

Q5. De que modo se pode assegurar uma GC mais responsável?

Q6. Haveria problemas ecológicos e técnicos da implementação de mecanismos de GC? O que a literatura científica tem dito sobre isto?

As diferentes atividades e as situações de aprendizagem que as questões do caso acima proporcionam têm como objetivo estimular o desenvolvimento, nos alunos, de diversas competências. Estas podem ser organizadas a partir dos objetivos de aprendizagem Conceituais (C), Procedimentais (P), e Atitudinais (A), seguindo a caracterização de Zabala (1998) e Coll e colaboradores (1992). Por exemplo, pretende-se que os alunos sejam capazes de:

- Definir e explicar o conceito de GC, associando-o às alterações climáticas (C);

- Com base na história desde a Guerra Fria, examinar criticamente os valores e interesses dos diferentes atores sociais (stakeholders) subjacentes às suas posições e decisões com relação a mecanismos de GC (C); 
- Estudar o alcance e os limites das intervenções técnicas humanas sobre os ecossistemas (C);

- Identificar diferentes opções de ações (incluindo intervenções técnicas, transformações em sistemas de valores, políticas públicas etc.) para resolver problemas ambientais como os problemas da mudança climática (C, P);

- Identificar diferentes opções metodológicas de GC no âmbito da estratégia $C D R$ e da estratégia $S R M(\mathrm{P})$;

- Selecionar informação que permita caracterizar cada opção metodológica de GC, atendendo aos princípios biológicos, físicos e químicos subjacentes, e avaliar as suas vantagens e desvantagens (P);

- Desenvolver competências de comunicação (verbais e não verbais) (P);

- Utilizar diferentes ferramentas das Tecnologias de Informação e Comunicação (TIC) (P);

- Planear e construir um manifesto que contemple um conjunto de orientações e boas práticas no campo da GC, atendendo às seis dimensões da IIR (P, A);

- Planear e desenvolver uma ação coletiva fundamentada em investigação, na forma de uma exposição, que sensibilize e alerte para as questões da IIR na GC $(\mathrm{P}, \mathrm{A})$;

- Gerir o trabalho de grupo e trabalhar de forma colaborativa no desenvolvimento das atividades (A);

- Avaliar e refletir acerca do seu desempenho, fazendo uso da autoavaliação (A).

\section{Meios para aplicação e discussão da QSC}

A abordagem ao conjunto de atividades que propomos segue o modelo dos 7E: envolvimento, exploração, explicação, ampliação, partilha, ativismo e avaliação.

\section{Envolvimento}

O envolvimento dos alunos é estimulado através da associação entre a GC e as teorias da conspiração. Para o efeito, são colocadas à disposição dos alunos fontes de informação como vídeos, documentários e notícias (Quadro 3). Os alunos têm que consultar essas fontes de modo a responderem às questões: o clima já foi manipulado no passado? Em que consistiu a Operação Popeye? O que são os chemtrails? O que defendem as teorias da conspiração a este respeito? O que é a Haarp? As respostas às questões são concretizadas através de um mapa de conceitos que os alunos terão que construir fazendo uso da ferramenta Popplet $^{1}$ ou outros recursos para produção de mapas conceituais

1 Ver em: <https://popplet.com/>. 
virtuais. Esse mapa será, depois, partilhado com os colegas através de uma plataforma construída para o efeito (por exemplo, um blogue).

Quadro 3 - Fontes de informação para a etapa envolvimento

\begin{tabular}{|l|}
\hline Em inglês \\
\hline $\begin{array}{l}\text { James Fleming with A Brief History of Weather and Climate Control (12:33): https://www.youtube. } \\
\text { com/watch?v=v7TBqqll6y4 }\end{array}$ \\
\hline Weather Warfare (44:19; History Channel): https://www.youtube.com/watch?v=ACaXYxCQhvY \\
\hline $\begin{array}{l}\text { Can We Control the Weather?: http://www.weather.com/news/science/can-we-control- } \\
\text { weather-20130616 }\end{array}$ \\
\hline Em português \\
\hline $\begin{array}{l}\text { Domingo Espetacular 11/o9/2011 - Haarp (oo:20:29): https://www.youtube.com/watch?v=_Pfij8- } \\
\text { BIZc }\end{array}$ \\
\hline $\begin{array}{l}\text { Os riscos de a china "semear" nuvens de neve (DN ciência): http://www.dn.pt/inicio/ciencia/ } \\
\text { interior.aspx?content_id=1421141\&seccao=Biosfera }\end{array}$ \\
\hline $\begin{array}{l}\text { Arquivos Confidenciais, Controle Climático (Haarp) - 1 temporada, ep. } 6 \text { (oo:18:28) (pt_br): } \\
\text { https://www.youtube.com/watch?v=69ZCJOVHKCE }\end{array}$ \\
\hline
\end{tabular}

Fonte: elaborado pelos autores.

\section{Exploração}

De modo a responder às questões seguintes: qual a relação entre a GC e o aquecimento global? Em que consistem as estratégias CDR e SRM? Quais os princípios biológicos, químicos e físicos que estão subjacentes às várias opções metodológicas de cada uma dessas estratégias? Que vantagens e desvantagens apresentam cada uma delas? Sobre o que disse a cientista, será mesmo que, sempre, as intervenções tecnológicas baseadas na ciência são feitas "com as melhores das intenções"? O que ela quis dizer, exatamente, com responsabilidade, especificamente na criação e no uso da tecnologia? Haveria outro modo de resolver os problemas do clima, que não fossem (somente) baseados em GC? Haveria problemas ecológicos e técnicos da implementação de mecanismos de GC? O que a literatura científica tem dito sobre isto? - sugere-se que a turma seja dividida em dois grupos - CDR e SRM - e estes, em subgrupos. Cada subgrupo pesquisa sobre uma ou mais opções/tecnologias no âmbito da CDR ou da SRM. Sugere-se que os alunos coloquem as suas anotações num mural digital (por exemplo, Padlet) ${ }^{2}$ a que todos podem ter acesso. São fornecidas fontes de informação que os alunos podem consultar (Quadro 4).

2 Ver em: <https://pt-br.padlet.com>. 
Quadro 4 - Algumas fontes de informação para a etapa exploração

\begin{tabular}{|l|}
\hline Em inglês \\
\hline $\begin{array}{l}\text { Oxford Geoengineering Programme: http://www.geoengineering.ox.ac.uk/what-is-geoengineering/ } \\
\text { what-is-geoengineering/ }\end{array}$ \\
\hline $\begin{array}{l}\text { IPCC Report (2007) - Mitigation of Climate Change: http://www.ipcc.ch/publications_and_data/ } \\
\text { ar4/wg3/en/ch11s11-2-2.html }\end{array}$ \\
\hline $\begin{array}{l}\text { Royal Society Report (2009): https://royalsociety.org/ /media/Royal_Society_Content/policy/ } \\
\text { publications/2009/8693.pdf }\end{array}$ \\
\hline Em português \\
\hline $\begin{array}{l}\text { A Sustentabilidade - ainda é possível?: http://www.akatu.org.br/Content/Akatu/Arquivos/file/ } \\
\text { EstadodoMundo2013web.pdf }\end{array}$ \\
\hline $\begin{array}{l}\text { Estudo sobre geoengenharia: http://www2.camara.leg.br/documentos-e-pesquisa/publicacoes/ } \\
\text { estnottec/tema14/2010_3958.pdf }\end{array}$ \\
\hline $\begin{array}{l}\text { Tese: Respostas à mudança climática: http://www.lume.ufrgs.br/bitstream/ } \\
\text { handle/10183/21464/o00736342.pdf?sequence=1 }\end{array}$ \\
\hline
\end{tabular}

Fonte: elaborado pelos autores.

Uma outra sugestão de atividade, que deveria acontecer previamente à atividade de pesquisa acima descrita, pode consistir num debate entre dois grupos, sendo que um deles seria a favor da GC e outro, contra. Assim, a turma poderia ser dividida nestes dois grandes grupos. Este debate, sendo anterior ao debate entre CDR e SRM, pode abarcar posições que não estariam contempladas naquele, sendo um debate mais amplo e aberto, no qual se reconhece que o problema socioambiental da mudança climática não tem uma dimensão apenas tecnológica. Caberia, na discussão, inclusive, reconhecer que dificilmente apenas uma posição (contra ou a favor da GC) estaria correta. Com efeito, para se chegar a uma solução geral para todos, os alunos teriam que levar em conta argumentos dos dois lados, pois ambos apresentariam vantagens frente à sua alternativa. Esta atividade, inicialmente de debate, mas que se pretende que convirja para uma discussão, através da qual é preciso chegar a um consenso, permitiria aos alunos compreender que a dicotomia rígida entre ser a favor ou do contra pode e deve, afinal, ser relativizada, abrindo portas para um entendimento mais sofisticado do assunto. Através desta atividade, a argumentação poderia ser muito bem explorada.

\section{Explicação}

Em seguida, cada grupo, através do contributo dos subgrupos correspondentes, constrói um documento conjunto sobre os resultados da etapa anterior na forma de uma apresentação virtual, como em Prezi, ${ }^{3}$ que é mais tarde partilhado com a turma.

3 Ver em: <https://prezi.com>. 
Aquando da apresentação, cada aluno deve ter a oportunidade de fazer questões e tirar notas de modo a cumprir a tarefa de construção de um novo mapa de conceito, desta feita, que integre todo o conhecimento construído através das apresentações.

\section{Ampliação, partilha e ativismo}

Este é o momento em que é feita a ligação entre a GC e a IIR. Para o efeito, os alunos devem ler o texto sobre a IIR e realizar a atividade sobre as suas seis dimensões, estabelecendo a correspondência entre cada dimensão e algumas afirmações. Os alunos têm que justificar as suas opções e o professor deve estimular a participação dos alunos e a discussão. Segue-se a introdução da tarefa propriamente dita: pede-se aos alunos que, sendo já conhecedores da temática GC, construam uma exposição com a finalidade de dar a conhecer o tema e alertar os cidadãos para as questões da GC e da IIR. Tendo em conta a etapa prévia de debate, em que se discute se a GC deve ou não ser realizada, é possível que os alunos utilizem a IIR como meio para contestar a GC. Tal é tão válido como recorrer à IIR em GC como meio de a tornar uma área de investigação científica mais responsável. A turma é dividida em grupos, cada grupo contemplando preferencialmente seis elementos, dado que são seis as dimensões da IIR. Cada elemento fica responsável por uma destas seis dimensões. Pretende-se que cada grupo construa um manifesto, o qual representa um conjunto de orientações/diretrizes sobre a investigação e a inovação responsáveis na área da GC. Os manifestos podem assumir o formato que os alunos desejarem (por exemplo, um vídeo - MovieMaker, uma banda desenhada - Pixton, um cartaz digital - Glogster, um jogo, um livro, entre outros). Após a decisão acerca do formato que o manifesto deverá ter, cada elemento do grupo estabelece a relação entre a GC e a sua dimensão da IIR, contribuindo assim para o objeto final a ser exposto - cada objeto a ser construído (um por grupo) tem que contemplar as seis dimensões da IIR.

\section{Avaliação}

A auto e a heteroavaliação estão presentes em vários momentos. Para cada momento de avaliação, concebem-se grelhas de avaliação, com descritores e níveis de desempenho, que são utilizadas pelos professores e pelos alunos. Os alunos devem ter acesso aos critérios no início de cada atividade. Assim, como principais momentos avaliativos, temos:

- Avaliação em conjunto dos resultados do muro digital (etapa exploração);

- Comunicação dos resultados da pesquisa a partir de uma apresentação virtual (etapa explicação);

- Construção de um mapa de conceitos que integre todo o conhecimento construído a partir das comunicações dos colegas (etapa explicação);

- Construção de um objeto que contemple as dimensões da IIR e que seja capaz de alertar para: 
- a gravidade dos problemas socioambientais atuais, com ênfase na mudança climática;

- a necessidade de refletir cuidadosa e criticamente sobre os possíveis alcances e limites da GC como forma de contribuir para a adaptação e a mitigação das mudanças climáticas, numa discussão que contemple ainda outras possibilidades (por exemplo, a de não usar GC, de usar parcialmente GC em integração com outros modos de enfrentar o problema, como transformação de hábitos de consumo, influência sobre grupos políticos a fim de reformular leis sobre clima etc.);

- a necessidade de uma GC responsável, caso a opção de utilização de GC seja considerada pelos alunos que concebam o objeto (etapas ampliação, partilha e ativismo).

Apresenta-se, no Quadro 5 e a título ilustrativo, uma possível grelha de avaliação do objeto a construir pelos alunos.

Quadro 5 - Grelha de avaliação do objeto final a ser exposto

\begin{tabular}{|c|c|c|c|c|c|}
\hline & 4 & 3 & 2 & 1 & \\
\hline $\begin{array}{l}\text { 1. Correção } \\
\text { científica }\end{array}$ & $\begin{array}{l}\text { Objeto revelador } \\
\text { de um excelente } \\
\text { domínio de } \\
\text { conceitos e } \\
\text { informações }\end{array}$ & $\begin{array}{l}\text { Objeto sem qualquer } \\
\text { incorrecção ao nível } \\
\text { dos conceitos ou das } \\
\text { informações }\end{array}$ & $\begin{array}{l}\text { Objeto com algumas } \\
\text { incorrecções ao nível } \\
\text { dos conceitos ou das } \\
\text { informações }\end{array}$ & $\begin{array}{l}\text { Objeto com várias } \\
\text { incorrecções } \\
\text { ao nível dos } \\
\text { conceitos ou das } \\
\text { informações }\end{array}$ & $---/ 4$ \\
\hline 2. Mensagem & $\begin{array}{l}\text { Mensagem clara, } \\
\text { objectiva e com } \\
\text { evidenciação } \\
\text { dos aspectos } \\
\text { fundamentais }\end{array}$ & $\begin{array}{l}\text { Mensagem clara, } \\
\text { mas com alguns } \\
\text { aspectos supérfluos }\end{array}$ & $\begin{array}{l}\text { Mensagem clara, } \\
\text { mas pouco objectiva; } \\
\text { foram apresentados } \\
\text { muitos aspectos } \\
\text { supérfluos }\end{array}$ & $\begin{array}{l}\text { Mensagem pouco } \\
\text { clara, pouco } \\
\text { objectiva, sem } \\
\text { evidenciação } \\
\text { dos aspectos } \\
\text { fundamentais }\end{array}$ & $---/ 4$ \\
\hline $\begin{array}{l}\text { 3. Ligação com } \\
\text { a IIR }\end{array}$ & $\begin{array}{l}\text { Existe uma ligação } \\
\text { muito explícita } \\
\text { entre o tema e a IIR }\end{array}$ & $\begin{array}{l}\text { Existe uma ligação } \\
\text { explícita entre o tema } \\
\text { e a IIR }\end{array}$ & $\begin{array}{l}\text { Existe uma ligação } \\
\text { pouco explícita entre } \\
\text { o tema e a IIR }\end{array}$ & A IIR está ausente & $-\_/ 4$ \\
\hline $\begin{array}{l}\text { 4. Dimensões } \\
\text { da IIR }\end{array}$ & $\begin{array}{l}\text { Estão presentes as } \\
6 \text { dimensões da IIR }\end{array}$ & $\begin{array}{l}\text { Estão presentes } 4 \text { ou } 5 \\
\text { dimensões da IIR }\end{array}$ & $\begin{array}{l}\text { Estão presentes } 2 \text { ou } 3 \\
\text { dimensões da IIR }\end{array}$ & $\begin{array}{l}\text { Apenas está } \\
\text { presente uma } \\
\text { dimensão da IIR }\end{array}$ & $-\_/ 4$ \\
\hline 5. Interatividade* & $\begin{array}{l}\text { O objeto é muito } \\
\text { interativo }\end{array}$ & $\begin{array}{l}\text { O objetivo é } \\
\text { moderadamente } \\
\text { interativo }\end{array}$ & $\begin{array}{l}\text { O objeto é pouco } \\
\text { interativo }\end{array}$ & $\begin{array}{l}\text { O objeto não é } \\
\text { interativo }\end{array}$ & -_-_/4 \\
\hline 6. Ativismo*** & Muito explícito & $\begin{array}{l}\text { Moderadamente } \\
\text { explícito }\end{array}$ & Pouco explícito & Ausente & $-\_/ 4$ \\
\hline 7. Aspeto gráfico & $\begin{array}{l}\text { Objeto muito } \\
\text { apelativo do ponto } \\
\text { de vista gráfico }\end{array}$ & $\begin{array}{l}\text { Objeto } \\
\text { moderadamente } \\
\text { apelativo do ponto de } \\
\text { vista gráfico }\end{array}$ & $\begin{array}{l}\text { Objeto pouco } \\
\text { apelativo do ponto de } \\
\text { vista gráfico }\end{array}$ & $\begin{array}{l}\text { Objeto nada } \\
\text { apelativo do ponto } \\
\text { de vista gráfico }\end{array}$ & -_-_/4 \\
\hline & & Total & & & $\ldots-1 / 28$ \\
\hline
\end{tabular}

* Corresponde à capacidade de levantar questões, promover a reflexão individual e coletiva, promover a interação entre visitantes, permitir que o visitante deixe a sua marca.

** Compreende a capacidade do objeto alertar o visitante e motivá-lo para a ação.

Fonte: elaborado pelos autores. 


\section{Considerações finais}

Abordar o tema da GC na forma de uma QSC permite, tanto a alunos como a professores, perspetivar este tópico científico atendendo às suas diferentes facetas. Se, por um lado, possibilita o desenvolvimento de uma consciência acerca dos problemas socioambientais atuais relacionados com as alterações climáticas, por outro, permite a reflexão acerca das potencialidades e limites da GC enquanto estratégia de mitigação do aquecimento global.

A estrutura de atividades apresentada, que tem sido utilizada com sucesso no âmbito do Projeto Including Responsible Research and Innovation in cutting Edge Science and Inquiry-based Science Education to improve Teacher's Ability of Bridging Learning Environments (IRRESISTIBLE) ${ }^{4}$ e do Projeto We Act (REIS, 2014), poderá ser utilizada para a abordagem de outras controvérsias sociocientíficas. Este tipo de atividade - cruzando a metodologia IBSE com a abordagem de tópicos científicos controversos através da lente da IIR e promovendo a capacitação dos cidadãos para a ação coletiva fundamentada em investigação - é extremamente importante, contribuindo para a promoção do envolvimento de todos os cidadãos na implementação e na exigência de uma investigação e uma inovação pautadas pela responsabilidade.

\section{Referências}

BALA, G. Problems with geoengineering schemes to combat climate change. Current Science, Bangalore, v. 96, n. 1, p. 41-48, 2009.

BORREGO, C. et al. As alterações climáticas: uma realidade transformada em desafio. Captar: Ciência e Ambiente para Todos, Aveiro, v. 2, n. 2, p. 1-16, 2010.

BYBEE, R. Teaching science as inquiry. In: MINSTRELL, J.; VAN ZEE, H. (Ed.). Inquiry into inquiry: learning and teaching in science. Washington: American Association for the Advancement of Science, 2000. p. 20-46.

BYBEE, R. W. et al. The BSCS 5E Instructional model: origins and effectiveness. Colorado Springs: BSCS, 2006.

COLL C. et al. Los contenidos en la reforma: enseñanza y aprendizaje de conceptos, procedimientos y actitudes. Buenos Aires: Santillana, 1992.

CORNER, A.; PIDGEON, N. Geoengineering the climate: the social and ethical implications. Environment Magazine, London, v. 52, n. 1, p. 26-37, 2010.

FONTAINE, P. A Europa em 12 lições. Luxemburgo: Serviço das Publicações Oficiais das Comunidades Europeias, 2010.

GARVEY, J. The ethics of climate change: right and wrong in a warming world. London: Continuum, 2008.

4 Ver em: <http://www.irresistible-project.eu/index.php/pt/>. 
HODSON, D. Becoming part of the solution: learning about activism, learning through activism, learning from activism. In: ALSOP, S.; BENCZE, L. (Ed.). Activism in science and technology education. London: Springer, 2014. p. 67-98.

HODSON, D. Teaching and learning science: towards a personalized approach. Buckingham: Open University Press, 1998.

JENSEN, B. B. Knowledge, action and pro-environmental behaviour. Environmental Education Research, Abingdon, v. 8, n. 3, p. 325-334, 2002.

KOLSTØ, S. Scientific literacy for citizenship: tools for dealing with the science dimension of controversial socioscientific issues. Science Education, New York, v. 85, n. 3, p. 291-310, 2001.

MARQUES, A. R. As potencialidades de uma abordagem interdisciplinar entre as ciências naturais e as tecnologias de informação e comunicação no desenvolvimento de um projeto de ativismo ambiental. 2013. Dissertação (Mestrado em Ensino de Biologia e de Geologia) - Universidade de Lisboa, Lisboa, 2013. Disponível em: <http://repositorio. ul.pt/handle/10451/10206>. Acesso em: 23 jun. 2015.

MARQUES, A. R.; REIS, P. Producción y difusión de vídeos digitales sobre contaminación ambiental. Estudio de caso: Activismo colectivo basado en la investigación. Revista Eureka sobre Enseñanza y Divulgación de las Ciencias, v. 14, n. 1, p. 215-226, 2017.

MARTINS, A. Respostas à mudança climática: cooperação internacional e os esforços de mitigação, adaptação e geoengenharia. 2009. 110 f. Dissertação (Mestrado em Relações Internacionais) - Faculdade de Ciências Econômicas, Universidade Federal do Rio Grande do Sul, Porto Alegre, 2009.

MCNEILL, J. R. Something new under the Sun: an environmental history of the twentieth-century world. London: W. W. Norton \& Company, 2000.

MILLAR, R. Science education for democracy: what can the school curriculum achieve? In: LEVINSON, R.; THOMAS, J. (Ed.). Science today: problem or crisis? London: Routledge, 1997. p. 87-101.

REIS, P. Da discussão à ação sociopolítica sobre controvérsias sociocientíficas: uma questão de cidadania. Ensino de Ciências e Tecnologia em Revista, Ponta Grossa, PR, v. 3, n. 1, p. 1-10, 2013.

REIS. P. Promoting students' collective socio-scientific activism: teacher's perspectives. In: ALSOP, S.; BENCZE, L. (Ed.). Activism in science and technology education. London: Springer, 2014. p. 547-574.

ROCARD, M. et al. A renewed pedagogy for the future of Europe. Bruxelas: Comissão Europeia, 2007.

RRI TOOLS. RRI Information Sheet. [S.l.], [200-]. Disponível em: <http://www. rri-tools.eu/documents/10182/16050/RRI+One+Pager/e8e658bc-4a34-4627-8de49379f58acb40>. Acesso em: 23 jun. 2015. 
SADLER, T. D. Informal reasoning regarding socioscientific issues: a critical review of research. Journal of Research in Science Teaching, New York, v. 41, n. 5, p. 513-536, 2004.

SHOR, l. Empowering education: critical teaching for social change. Chicago: The University of Chicago Press, 1992.

SLEEPER, M.; STERLING, R. The in-class science exhibition. Science Scope, Washington, v. 27, n. 6, p. 49-52, 2004.

SUTCLIFFE, H. A report on Responsible Research \& Innovation. [S.1.]: MATTER, 2011.

WEART, S. R. (Dir.). El calentamiento global: historia de un descubrimiento científico. Pamplona: Laetoli, 2006.

ZABALA, A. A prática educativa: como ensinar. Porto Alegre: Artmed, 1998. 


\title{
LA EXPLOTACIÓN DEL COLTÁN UNA CUESTIÓN SOCIOCIENTÍFICA PARA EL DESARROLLO DE COMPETENCIAS
}

\author{
Martha Nury Bonilla Castañeda \\ Leonardo Fabio Martínez Pérez
}

\section{Introducción}

El Coltán es una mezcla de dos minerales: la columbita, que se compone de óxido de niobio, hierro y magnesio, y la tantalita que se compone de óxidos de tántalo, hierro y magnesio. Se caracteriza por ser una roca brillante, color gris oscuro y que se identifica fácilmente en terrenos rocosos y laderas de los ríos. Ha pasado de ser una curiosidad mineralógica a un material clave para la industria tecnológica, ya que es un componente para dispositivos electrónicos móviles, ordenadores, pantallas planas, cámaras digitales y equipos de alta tecnología como los satélites artificiales. Es esencial para la fabricación de condensadores electrolíticos de Tantalio. Esto se debe a que el Tantalio posee dos características de gran importancia: capacidad eléctrica de altísima exactitud y un peso 20 veces menor que el de otros materiales utilizados en la fabricación de capacitadores. (SEGUNDO, 2013)

Por sus propiedades, el Coltán se ubica como un material de vital importancia para el avance tecnológico, especialmente la nanotecnología que produce múltiples dispositivos móviles, convirtiéndose en un elemento de gran importancia para países como Estados Unidos, Alemania, Bélgica, Países bajos y Kazajistán, entre otros, que han iniciado 
la extracción indiscriminada del mineral, impactando el medio ambiente, ecosistemas y hábitats. También ha desatado guerras patrocinadas por las multinacionales en países pobres del África y América Latina, territorios que tienen importantes yacimientos de este mineral. Estos conflictos traen como consecuencia pobreza, desigualdad y especialmente un fuerte desastre ambiental y cultural en los países del tercer mundo. (SEGUNDO, 2013) Infortunadamente las situaciones conflictivas de los países poseedores del Coltán son desconocidas por la mayoría de consumidores del material, es decir, ciudadanos que transitan diariamente por el mundo llevando consigo celulares, equipos portátiles, cámaras digitales y otros artefatos que se han convertido en elementos indispensables en el diario vivir de la mayoría de los seres humanos.

El desconocimiento de los desastres socioambientales, asociados con el consumo indiscriminado de productos tecnológicos, terminan patrocinando la destrucción de comunidades culturales y ambientales sin ningún tipo de control, ni esperanza de un rumbo nuevo para los países productores de Coltán. Las manipulaciones de empresas multinacionales, asociadas con gobiernos corruptos y el obscurantismo en el cual viven la mayoría de los ciudadanos del mundo que se mantienen ajenos al tema, no favorece que estos países aspiren a un cambio que dignifique su situación como seres humanos con derechos concebidos internacionalmente. Las circunstancias, expuestas anteriormente, traen a colación las relaciones entre la Ciencia, Tecnología, Sociedad y Ambiente (CTSA), expuestas a través de una Cuestión Sociocientífica (CSC), que contribuyen con la formación de ciudadanos participativos y capaces de argumentación en la sociedad. (MARTÍNEZ; PARGA, 2013a) Además incita a los docentes a buscar estrategias didácticas que le permitan al estudiante construir un punto de vista a partir de una CSC planteada en aula como la explotación del Coltán.

Esto hace más interesante el aprendizaje de las ciencias, pues permite evidenciar la utilidad del conocimiento para los diferentes actores involucrados. Además de que permite: "desarrollar capacidades para participar en una sociedad democrática... para lo cual es necesario la construcción de ambientes de discusión en las clases de ciencias que favorezcan vivir y ejercer la ciudadanía”. (MARTíNEZ; PARGA, 2013b, p. 27) Teniendo en cuenta las anteriores consideraciones, en este capítulo se realiza una aproximación didáctica a la siguiente pregunta ¿Cómo desarrollar competencias que permitan la formación ciudadana a través de una CSC sobre la explotación del Coltán, en clase de Enseñanza de las Ciencias Naturales? Así, se busca dar una respuesta pertinente a este cuestionamiento, teniendo como objetivo analizar la explotación del Coltán como una CSC, para desarrollar competencias en estudiantes de grado séptimo de Educación Básica Secundaria, ${ }^{1}$ de tal manera que se propenda por la formación ciudadana, a través de una serie de actividades que permitan integrar los contenidos conceptuales, procedimenta-

1 Este grado equivale a la séptima serie do Ensino Fundamental da educação brasileira. 
les y actitudinales, dando relevancia a la adquisición de conocimientos integrados que puedan ser utilizados por los estudiantes.

A continuación se presenta una visión general del capítulo, que pretende mostrar la aplicación de una CSC definida por las implicaciones sociales y ambientales de la explotación del Coltán. Inicialmente, se describe el Cóltan, explicando su composición Química y propiedades, estableciendo las razones por las que este material es considerado estratégico para el avance tecnológico y a su vez ocasiona la explotación masiva en diferentes regiones del mundo, patrocinada por multinacionales a la cabeza del avance tecnológico, en contraste con las consecuencias socioambientales que ha traído, especialmente a la Republica del Congo que posee las mayores reservas en el continente africano. Las relaciones establecidas entre la explotación del Coltán en pro del avance tecnológico y sus consecuencias socioambientales permiten tratar la extracción del Cóltan, como una CSC, con finalidades educativas como el desarrollo de competencias para el ejercicio de una ciudadanía responsable.

El capítulo pretende ejemplificar como se puede utilizar una CSC con el fin de desarrollar capacidades en los educandos, a través de la aplicación de una secuencia didáctica, organizada en cuatro fases, de acuerdo con la propuesta de Zabala y Arnau (2007). Las fases son: el análisis de una situación; identificación de posibles esquemas de actuación; selección de esquemas de actuación y conocimiento; dominio y trasferencia de los componentes de una competencia. Finalmente se plantean las conclusiones.

\section{El coltán: un mineral estratégico para el avance tecnológico y científico}

El Coltán es una mezcla que debe su nombre a la abreviatura de los minerales que lo componen Tantalita y Columbita. En la Columbita (Fe.Mn) $\mathrm{Nb}_{2} \mathrm{O}_{6}$ predomina el Niobio, mientras que en la Tantalita (Fe.Mn) $\mathrm{Ta}_{2} \mathrm{O}_{6}$ predomina el Tantalio. Son minerales de aspecto oscuro y veteados, de estos se pueden extraer elementos químicos como el Niobio y el Tantalio.

Uno de los grandes intereses de la explotación del Coltán es extraer el Tantalio cuyo símbolo químico es Ta, siendo un metal de transición que presenta propiedades como su alta resistencia a la corrosión, lo cual lo hace un buen sustituto para el platino en la elaboración de la instrumentación. No obstante, se hace de gran valor en la telefonía móvil, teniendo en cuenta que a partir del Tantalio se pueden construir condensadores electrolíticos de menor tamaño, pero mayor capacidad de almacenamiento de carga eléctrica superando ampliamente el Aluminio. Considerando que los condensadores son vitales en cualquier dispositivo electrónico, el Tantalio es un elemento de gran valor para los dispositivos portátiles. También se utiliza para la fabricación de resistencias de alta potencia, superaleaciones usadas en turbinas de aviones o reactores nucleares y en prótesis 
humanas, siendo un metal imprescindible para la tecnología moderna, conduciendo a la explotación masiva del Coltán.

El Niobio se descubre a partir del análisis de los restos de la producción del Tantalio. Es un elemento de transición que se usa en superaleaciones con aplicaciones en la aeronáutica, siendo su propiedad más interesante la superconductividad. Cuando el material se enfría por debajo de su temperatura crítica que es bajo de $-264^{\circ} \mathrm{C}$, su resistencia eléctrica es nula y se puede mantener una corriente eléctrica indefinida a través de este. Esta propiedad permite la fabricación de electroimanes utilizados en aparatos de resonancia magnética y en los aceleradores de partículas. También se usan compuestos como Niobato de litio $\left(\mathrm{LiNbO}_{3}\right)$, material clave para elaborar fibras ópticas. La gran relevancia que ha tomado el uso del Coltán en el avance tecnológico, ha provocado una explotación sin límites, que desemboca en el deterioro acelerado del medioambiente y la cultura de países poseedores de Coltán.

\section{Las CSC como un medio para formación de ciudadanía en el aula}

De otra parte, hablando de la educación de la ciudadanía en términos de desarrollo de competencias, la explotación excesiva del Cóltan y las consecuencias socioambientales lo postulan como una CSC ubicada en el enfoque CTSA, que tiene como objetivo fundamental el estudio de las ciencias en cuanto a sus condiciones y consecuencias sociales y ambientales, permitiendo a los educandos ver la utilidad de los conocimientos, convirtiéndose en una estrategia para diversos temas en el área de ciencias naturales.

La educación CTSA posibilita la preparación de los estudiantes para enfrentar problemáticas actuales, las causas y las medidas a tomar. Además de buscar la comprensión de la influencia de la sociedad en las metas que persigue la ciencia y la tecnología. (MARTÍNEZ; PARGA, 2013a) Sin embargo, son pocos los docentes que manejan este enfoque y otros no lo conocen, haciéndose importante dar a conocer diferentes herramientas que permitan llevar al aula el estudio de CSC que oriente la integración de contenidos o competencias científicas, definidas por Pedrinaci (2012, p. 31) como: "Un conjunto integrado de capacidades para utilizar el conocimiento científico a fin de describir, explicar y predecir fenômenos naturales”. Ahora bien, la competencia en el sentido educativo amplio de la palabra es definida por Zabala y Arnau (2007, p. 40) como "la intervención eficaz en los diferentes ámbitos de la vida mediante acciones en las que se movilizan, al mismo tiempo y de manera interrelacionada, componentes actitudinales, procedimentales y conceptuales". Estas capacidades o conocimientos son clasificadas por los dos autores en conceptuales; procedimentales, metodológicas $\mathrm{y}$ actitudinales. 
Las capacidades conceptuales se hacen evidentes cuando el estudiante utiliza conocimientos científicos para describir, explicar o predecir fenômenos naturales (CAÑAL, 2012, p. 222) o utiliza conceptos y modelos para reflexionar sobre problemas que se plantean en su contexto. Una pregunta que podría direccionar el desarrollo de capacidades científicas a través del análisis de la CSC sobre el Coltán podría ser ¿Cómo se puede explicar la disminución del peso y tamaño de los celulares en el tiempo? A partir de esta pregunta, se invita a los estudiantes a indagación, por medio del uso de diferentes capacidades como: la formulación de hipótesis, a partir de sus conocimientos previos, la recolección y selección de información, el uso de Tecnologías de la Información y la Comunicación (TIC) etc. Las capacidades van siendo usadas en el proceso de resolución de la pegunta y van apareciendo sin ningún orden jerárquico de acuerdo a su clasificación (conceptuales, metodológicas y actitudinales) que Pedrinaci (2012) define para efectos de análisis de la siguiente manera:

- Conceptuales: implican el uso de conceptos, modelos o teorías en el análisis de problemas y soluciones planteadas en diferentes contextos vivenciales de los estudiantes;

- Metodológicas o procedimentales: tendrían que ver con las habilidades de procesar la información obtenida, obtener información relevante, diferenciar la ciencia de otras interpretaciones no científicas, diseñar estrategias de investigación;

- Actitudinales: incluyen valorar la calidad de la información en función de su procedencia, observar el interés de los educandos por resolver problemáticas socioambientales a partir del conocimiento y la indagación, y ser capaz de adoptar decisiones autónomas y críticas en contextos personales y sociales.

\section{El coltán: una CSC para el desarrollo de competencias en aula}

El nivel educativo en el que se aplica la CSC en relación al Coltán es séptimo grado de educación básica secundaria. Las áreas de conocimientos implicadas son: química, (composición de la materia, propiedades de la materia), física (conductibilidad eléctrica, capacidad de almacenamiento de electricidad), biología (polución ambiental, perdida de biodiversidad, contaminación del agua y suelo, biomagnificación, resiliencia ecológica, salud humana); sociología (desigualdades sociales, políticas públicas, consumismo, economía y comportamiento social).

La CSC, en forma de un caso (Cuadro 1), expresa que la explotación del Coltán trae desastres socioambientales al planeta. 
Cuadro 1 - Caso para la discusión sobre la cuestión sociocientífica

\section{La explotación del Coltán}

Diana es una estudiante de educación media y en el descanso conversa con sus compañeros Carlos y Camilo, los cuales están sorprendidos porque ella tiene un celular que no es de última generación, pues usa uno que recibió de su hermano mayor después de que él lo utilizó por muchos años.

Carlos le dice a Diana, - ¿Cómo puedes andar con un celular tan viejo? Hay nuevos modelos que poseen muchas aplicaciones y se puede comprar en un precio no muy alto, ¿por qué no compras uno de estos?

Camilo interviene y complementa diciendo: - yo creo que requieres ese aparato, este te permitirá hablar con tu familia y amigos en cualquier momento, además con este celular viejo está fuera de moda. No sigas en la época arcaica, estamos en el siglo XXI.

Frente a las sugerencias de sus compañeros Diana responde: - amigos, no me había dado cuenta que ese celular de última gama fuera tan necesario, pero como ustedes lo dicen con tanta convicción voy a pensar sobre ello.

Ella vuelve a su casa y después de su clase, piensa con cuidado sobre lo que sus amigos le dijeron y decide leer sobre los celulares, sobre cómo son producidos y comercializados. Diana consulta en internet y rápidamente descubre que la producción de estos aparatos, actualmente, está íntimamente vinculada a ciertos minerales y a la República Democrática del Congo. Diana percata que el Coltán, extraído sobre todo de este país es un mineral esencial para la producción de celulares, además, encuentra información general sobre la extracción de Coltán que la asocia a importantes problemas sociales y ambientales que resultan alarmantes.

A partir de lo anterior Diana formula algunos cuestionamientos para decidir si debe o no comprar un celular y también sobre el resultado de su investigación para compartirlo con sus amigos en términos de planear en cuáles acciones podrían planearse y ejecutarse para reducir los problemas socioambientales relacionados con la explotación masiva de Coltán, ¿usted podría ayudarla?

Fuente: elaboración de los autores.

En este contexto, se proponen los siguientes cuestionamientos y objetivos a ser desarrollados en el aula.

C1. ¿Cuáles son las causas de la explotación masiva del Coltán?

C2. ¿Qué procedimientos son utilizados para la explotación masiva del Coltán?

C3. ¿Cuáles son las condiciones sociales, políticas, ambientales y econômicas, de los países dueños de yacimientos de Coltán?

\section{Objetivos de aprendizaje}

\section{Factuales}

- Identificar los símbolos químicos del Tantalio y el Niobio y las fórmulas químicas de la tantalita y la columbita;

- Identificar los acontecimientos sociales y económicos de gran relevancia en la República del Congo.

\section{Conceptuales}

- Comprender el funcionamiento de un capacitador;

- Explicar la diferencia entre mezcla, compuesto y elemento. 
- Comprender los diferentes métodos de separación de la materia;

- Explicar los métodos de extracción minera y su efecto en el medio ambiente;

- Comprender la situación socioambiental que viven los ciudadanos de la República del Congo.

\section{Procedimentales}

- Recolectar información relacionada con la explotación del Coltán;

- Seleccionar información relevante, teniendo en cuenta la fuente en relación con la explotación del Coltán;

- Elaborar el modelo de la botella de Leyden y explicar su funcionamiento.

\section{Actitudinales}

- Reflexionar críticamente acerca de los avances tecnológicos en contraste con el efecto que estos producen, a partir de los espacios creados en el aula por el profesor;

- Reflexionar acerca de la actuación de cada estudiante, en relación con la explotación masiva de los recursos naturales;

- Planear y proponer acciones para contribuir a la reducción de problemas socioambientales caracterizados a partir de la explotación del Coltán;

- De manera grupal crear y publicar un Blog, a través del cual se presenten reflexiones sobre los aspectos científicos y tecnológicos de la explotación del Coltán, así como las implicaciones sociales y ambientales, de tal manera que sensibilice a la comunidad de la compra exagerada de celulares.

\section{Mecanismos que permiten aplicar y discutir la CSC}

Para aplicar y discutir la CSC en la educación con el fin de alcanzar los objetivos de aprendizaje, se sugieren el empleo de secuencias didácticas que permiten encadenar y articular diferentes actividades a lo largo de una unidad didáctica, para esto Zabala y Arnau (2013) proponen fases para establecer una secuencia didáctica, y estas son ejemplificadas de la siguiente manera, por medio de la aplicación en aula de la CSC denominada la explotación del Coltán:

\section{Análisis de una situación compleja}

La explotación masiva del Coltán trae desastres ambientales y culturales en conformidad con la estructura propuesta en la Figura 1. A partir de esta, se puede discutir y desarrollar sobre los siguientes aspectos:

Identificación de cuestiones que permitirán enfrentar la situación:

C4. ¿Cuáles son las causas de la explotación masiva del Coltán? 


\section{C5. ¿Qué procesos se utilizan para la extracción del Coltán?}

C6. ¿Cuáles son las condiciones sociales, ambientales, políticas y econômicas de los territorios, poseedores de yacimientos de Coltán, especialmente la República del Congo?

Identificación de información relevante para la interpretación y la resolución de los cuestionamientos:

Figura 1 - Desarrollo de competencias a partir de la CSC: la explotación masiva del Coltán

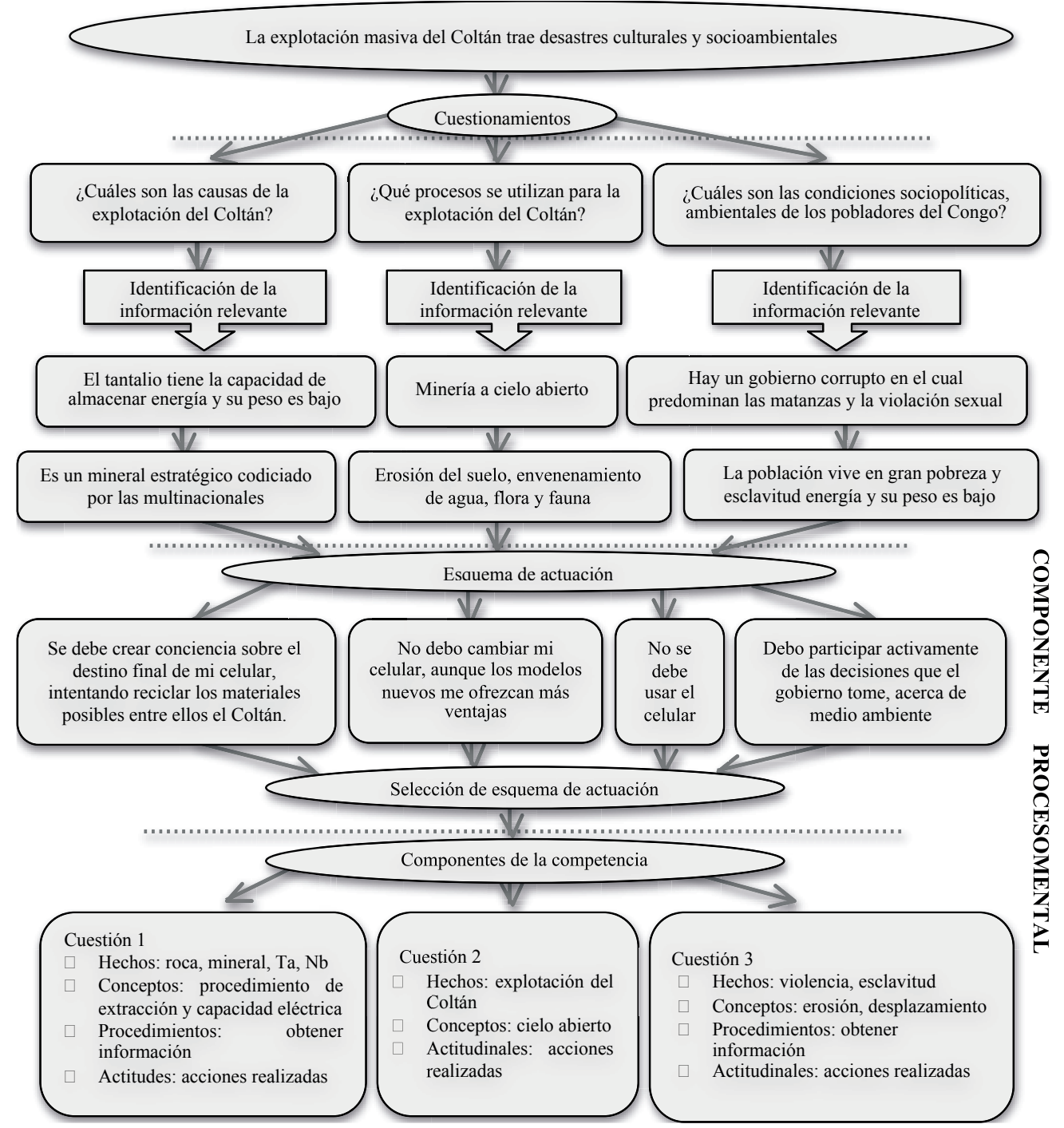

Fuente: elaboración de los autores. 
Comentarios al cuestionamiento 1:

- El Cóltan es una roca que contiene Tantalio;

- El Tantalio es un elemento que tiene importantes propiedades químicas, ya que puede almacenar grandes cantidades de electricidad y su peso es muy bajo, siendo utilizado en la fabricación de condensadores, usados en artefatos electrónicos como los celulares;

- El Coltán es un material estratégico, así las grandes multinacionales pueden patrocinar su explotación masiva.

Comentarios al cuestionamiento 2:

- Se practica la minería a cielo abierto;

- La minería a cielo abierto erosiona los suelos, afectando las poblaciones que habitan en la región, ya que contaminan las fuentes de agua y arrasan con la fauna y la flora, produciendo desplazamientos y con ellos pobreza.

Comentarios al cuestionamiento 3:

- A partir de los siguientes videos favorezca la reflexión sobre los siguientes cuestionamientos: presentan un gobierno corrupto y sus pobladores se encuentran en una guerra sangrienta en donde se destacan las matanzas continuas, la violencia sexual y la esclavitud (como en el caso del Congo en África). ¿Qué relación tiene esta problemática con la explotación del Coltán?;

- A pesar de ser una nación inmensamente rica en cuanto a recursos naturales, prevalece la pobreza y la violencia. ¿Qué acciones sociales emprender?

Se puede completar la actividad utilizando algunos videos.

\section{Identificación de los posibles esquemas que pueden dar respuesta a los problemas de la situación}

Por ejemplo:

- No se debería seguir usando celulares;

- Debo usar mi celular con cuidado y responsabilidad, cambiándolo únicamente si fuera estrictamente necesario. A pesar de que los nuevos modelos podrían facilitar la comunicación, debido a sus nuevas aplicaciones, puedo invertir en la calidad de la comunicación con los medios que ya existen, y, así, no estimular el consumismo y las tecnologías que lucran a partir de la degradación ambiental y humana; 
- Cada vez que abandone un celular, debo decidir consciente de su destino final, haciendo provecho de los materiales que podrían reutilizar, de tal forma, que se evita la contaminación y se contribuye bajando la tasa de explotación del Coltán;

- Se debe participar políticamente involucrándose en las decisiones que toma el gobierno en relación a la explotación de los recursos naturales. Se puede también buscar campañas relativas al uso del Coltán (más detalle).

\section{Selección de los esquemas y disposición para aplicarlos de forma estratégica}

Los tres últimos esquemas, expuestos en la Figura 1, constituyen algunas posibilidades de actuación que deben analizarse con detenimiento, pues lo importante es establecer las problemáticas asociadas al uso del celular, de tal manera que la actuación de los ciudadanos contribuya a una reflexión profunda sobre la explotación masiva del Coltán.

\section{Conocimiento, dominio y transferencia de cada uno de los componentes de las competencias}

Se observa que para trabajar alrededor de la Figura 1 es necesario integrar los componentes de hecho, concepto y procedimiento que permitan interpretar la situación llevando a cada sujeto a un actuar colectivo que podría mitigarlo o solucionarlo a partir la problemática de la situación planteada.

Adicionalmente, Zabala y Arnau (2013) indican la importancia de establecer en el aula una organización social y sugieren:

- El grupo completo para la presentación del problema real, la identificación de los problemas que esta situación lleva y en la finalización para llegar a conclusiones;

- Formación de pequeños grupos heterogéneos en los cuales se fomente el diálogo, el debate, la cooperación, la responsabilidad, la autonomía y la resolución de conflictos;

- El trabajo individual para estudiantes que tengan cierto grado de autonomía.

\section{Referencias}

CAÑAL, P. Saber ciencias no equivale a tener competencia profesional para enseñar ciencias. En: PEDRINACl, E. (Coord.). El desarrollo de la competencia científica. Barcelona: Graó, 2012. p. 217-239.

MARTÍNEZ, L.; PARGA, D. La emergencia de las cuestiones sociocientíficas en el enfoque CTSA. Revista Góndola, Bogotá, v. 8, n. 1, p. 22-33, 2013 a. 
MARTÍNEZ, L.; PARGA, D. Discurso ético y ambiental sobre cuestiones sociocientíficas: aportes para la formación del profesorado. Bogotá: Universidad Pedagógica Nacional, $2013 b$.

PEDRINACI, E. El ejercicio de una ciudadanía responsable exige disponer de cierta competencia científica. En: PEDRINACI, E. (Coord.). El desarrollo de la competencia científica. Barcelona: Graó, 2012. p. 15-37.

SEGUNDO, J. Oro azul, quimera y rapiña: Documental El Coltan de la Orinoquia.

Colombia: Universidad Nacional de Colombia, 2013. Disponible en: <http://docplayer. es/12840548-Oro-azul-quimera-y-rapina-documental-el-coltan-de-la-orinoquia. html>. Acceso en: 5 ago. 2015.

ZABALA, A.; ARNAU, L. La enseñanza de las competencias. Aula de innovación Educativa, Barcelona, n. 161, p. 40-46, 2007. Disponible en: <http://srvcnpbs.xtec.cat/ inslle/docs/2008_Competencias_Zabala.pdf>. Acceso en: 20 Julio 2014. 


\section{ENERGÍA NUCLEAR \\ UNA CUESTIÓN SOCIOCIENTÍFICA PARA \\ EL DESARROLLO DEL PENSAMIENTO CRÍTICO}

Jordi Solbes

Nidia Torres

\section{Introducción}

Es difícil encontrar un tema científico que haya tenido tanto impacto en la historia mundial en varios niveles o aspectos, como la energía nuclear. Podemos apuntar impactos de este tema a nivel tecnológico (bombas atómicas y de hidrógeno, centrales nucleares), económico (el coste de los armamentos, la consolidación del complejo militar-industrial, las empresas nucleares), político (las relaciones entre países, la guerra fría), social y ambiental (la contaminación radiactiva fruto de las pruebas y los accidentes nucleares) y cultural (surge el tema de la responsabilidad del científico, que se refleja en la literatura y en libros de divulgación de los propios científicos). Por todo esto, es un tema que nos muestra las relaciones Ciencia, Tecnología y Sociedad (CTS) en su integridad. (SOLBES; VILCHES, 1997)

Así, en este trabajo, se trata de comprobar si el alumnado es capaz de interpretar los procesos energéticos vinculados con las reacciones nucleares. Y, yendo más allá para incluir sobre todo los contextos de la Sociedad y del Ambiente, si es capaz de utilizar estos conocimientos para la comprensión y valoración de cuestiones socio-científicas como el armamento y reactores nucleares, siendo conscientes de sus riesgos y repercusiones. 
En base a esto, nuestro objetivo en este capítulo es plantear junto a unos conceptos básicos (isótopo, curva de energía de enlace, reacción de fisión y fusión) un caso en formato de Cuestión Sociocientífica (CSC), que incluye los tópicos principales: las consecuencias de las bombas atómicas, el papel de los científicos en su construcción pero también en su rechazo y el precio que pagaron por este último y, por último, aplicar el pensamiento crítico a los argumentos acerca de las centrales nucleares.

\section{Una CSC acerca de la energía nuclear}

Esta CSC, presentada en la forma de un caso, se aplica a los últimos cursos de secundaria o primeros universitarios y las áreas de conocimiento implicadas son la física y química nuclear, la historia de la ciencia y la historia universal. El caso se visualiza en el Cuadro 1, con algunos objetivos de aprendizaje en Cuadro 2. Es posible abordar los tópicos apuntados arriba en 4 momentos distintos de una Secuencia Didáctica (SD) (con la CSC en formato de caso) sobre el tema energía nuclear.

Cuadro 1 - CSC sobre energía nuclear

Una consulta pública es realizada en un determinado Estado brasileño* sobre la necesidad de la instalación de una central nuclear para generar más energía. A los estudiantes, se pide para posicionarse en contra o en favor de la propuesta y cada estudiante o grupo de estudiantes debe formular sus argumentos para soportar sus conclusiones.

Fuente: elaboración de los autores.

En la próxima sección, para la resolución del caso, se proponen a las y los estudiantes cuatro actividades/momentos, compuestos de textos, en letra normal (y señalizados por la letra T), y preguntas, en letra cursiva (y precedidas por una letra P); luego, en seguida, ponemos comentarios de suporte al profesor están sangrados (y precedidas por una letra C).

* En la aplicación, el profesor/maestro puede tener en cuenta que Estados brasileños, como Sergipe y Pernambuco, han sido candidatos a la instalación de centrales de energía nuclear (http:// www.eletronuclear.gov.br/). Además, en el Estado de Bahia, específicamente en la ciudad de Caetité, ya existen importantes minas de uranio, en que se planea reanudar el suministro de uranio para las centrales Angra 1, 2 y 3 en el Estado de Rio de Janeiro, Brasil (http://www.ebc.com.br/ noticias/2015/06/producao-de-uranio-da-mina-de-caetite-na-bahia-sera-retomada-em-2016). La central Angra 3 está en proceso de instalación (http://agenciabrasil.ebc.com.br/geral/noticia/2016-04/investigacoes-sobre-irregularidades-em-angra-3-serao-concluidas-ate-julho). 
Cuadro 2 - Algunos objetivos de aprendizaje para la CSC

\begin{tabular}{|c|c|c|}
\hline \multicolumn{3}{|c|}{ Objetivos de aprendizaje } \\
\hline Conceptuales & Procedimentales & Actitudinales \\
\hline $\begin{array}{l}\text { Comprender los principales } \\
\text { conceptos, su vinculación } \\
\text { a problemas de interés y } \\
\text { su articulación en cuerpos } \\
\text { coherentes de conocimientos. } \\
\text { En concreto, el } \\
\text { descubrimiento del núcleo, su } \\
\text { composición y el concepto de } \\
\text { isótopo, la energía de enlace, } \\
\text { y las reacciones nucleares: } \\
\text { estudio de las reacciones } \\
\text { de fisión y fusión, sus } \\
\text { aplicaciones en armamentos } \\
\text { y producción de energía } \\
\text { y riesgos y repercusiones } \\
\text { (residuos de alta actividad, } \\
\text { problemas de seguridad etc.) } \\
\text { de las mismas. }\end{array}$ & $\begin{array}{l}\text { Estar informado sobre el } \\
\text { tema, no limitarse a los } \\
\text { discursos dominantes, } \\
\text { conocer posturas } \\
\text { alternativas, cuestionar la } \\
\text { validez de los argumentos } \\
\text { rechazando conclusiones no } \\
\text { basadas en pruebas, detectar } \\
\text { falacias argumentativas, } \\
\text { evaluar la credibilidad de las } \\
\text { fuentes teniendo en cuenta } \\
\text { los intereses subyacentes } \\
\text { y crear argumentaciones } \\
\text { sólidas. Aplicar los } \\
\text { conocimientos físicos } \\
\text { pertinentes a la resolución } \\
\text { de problemas de la vida } \\
\text { cotidiana. }\end{array}$ & $\begin{array}{l}\text { Valorar la necesidad de trabajar } \\
\text { para lograr un futuro sostenible } \\
\text { y satisfactorio para el conjunto } \\
\text { de la humanidad, una vez que } \\
\text { ya han sido comprendidas las } \\
\text { complejas interacciones actuales } \\
\text { de la física con la tecnología, } \\
\text { la sociedad y el ambiente. } \\
\text { Posicionarse críticamente con } \\
\text { respecto al uso de la energía } \\
\text { nuclear. Organizarse en grupos } \\
\text { para divulgar informaciones a la } \\
\text { comunidad sobre las ventajas y } \\
\text { los riesgos del uso de la energía } \\
\text { nuclear, así como las respectivas } \\
\text { consecuencias sociales y } \\
\text { ambientales }\end{array}$ \\
\hline
\end{tabular}

Fuente: elaboración de los autores.

\section{Mecanismos que permitan aplicar y discutir la CSC}

Esta actividad se puede plantear como un debate, pero hay que tener presente que se puede generar un debate siempre que se pone a gente a defender posturas diferentes (solo hay que ver algunos programas televisivos). El tema es que en los debates socio-científicos, es decir, en controversias sociales que tienen su base en temas científicos, muchas veces la comunidad científica tiene un fuerte consenso respecto a una de las posturas, con lo cual generar un debate es darle alas a una postura que no las tiene o favorecerla, porque el alumnado que participa en los debates piensa que en los mismos se tiene que llegar a un equilibrio de las posturas enfrentadas. Un ejemplo típico de ello es el debate sobre la validez científica o no de la astrología, ya que en el fondo, la confrontación con científicos da más autoridad a los astrólogos. Igualmente sucede con el debate sobre el cambio climático y su origen antrópico. De hecho, estos debates nunca se cierran porque hay detrás intereses de grupos poderosos que quieren mantenerlos. (SOLBES, 2013b)

Podemos encontrar información sobre la energía nuclear y sus implicaciones sociales y ambientales en múltiples libros y artículos de historia y sociología de la ciencia (BOWLER; MORUS, 2005; JEROME, 2002; KRAGH, 2007; SÁNCHEZ RON, 2006, 2014; SOLBES, 2013a, 2013b); libros de literatura (FRAYN, 2000; KIPPHARDT, 1966; VOLPI, 1999), reflexiones de científicos conscientes de su responsabilidad (BORN, 1968; RAMÌREZ MARTÍN; FERNANDEZ-RAÑADA, 1996; SALAM, 1986; WEISSKOPF, 1990) e incluso algunos libros de texto de física. (HEWITT, 2004; TIPLER, 2003) 
A continuación, se presentan los tópicos que se pueden abordar en el aula alrededor de la CSC relacionada con la energía nuclear: descubrimiento del núcleo y los isótopos; reacciones nucleares; las bombas atómicas y sus consecuencias; las centrales nucleares: sus repercusiones y riesgos.

\section{Descubrimiento del núcleo y los isótopos}

T: El estudio de la dispersión de partículas alfa por finas láminas de oro en 1911 sorprendió a Rutherford, que dijo: "Lo que pasaba era tan increíble como si alguien hubiese disparado un proyectil hacia un papel de seda y el proyectil volviese hacia el cañón”. Y le llevó a la idea de un átomo formado por un núcleo central (masivo y cargado positivamente), alrededor del cual se movían los electrones. También se pudo determinar el radio del átomo y el núcleo de $\mathrm{Au}$, encontrándose respectivamente $\mathrm{r}_{\text {átomo Au }}=1,3 \cdot 10^{-10} \mathrm{~m}$ y el $\mathrm{r}_{\text {núcleo Au }}$ es $7,3 \cdot 10^{-15} \mathrm{~m}$.

P: ¿Qué relación hay entre dichos radios? Si se toma como diámetro del átomo de Au la longitud de un campo de futbol grande $(120 \mathrm{~m})$, ¿cuál sería el tamaño del núcleo?

C: El radio del átomo es 18000 veces mayor que el del núcleo, lo que implica que la mayor parte del volumen ocupado por un átomo es espacio vacío. Pero como es tan difícil asimilar las magnitudes muy grandes o muy pequeñas, tan alejadas de la escala humana, proponemos la escala de un campo de futbol para el diámetro atómico. Se obtiene para el núcleo:

$$
14,6 \cdot 10^{-15} \mathrm{~m} \cdot \frac{120 \mathrm{~m}}{2,6 \cdot 10^{-10} \mathrm{~m}}=0,007 \mathrm{~m}=7 \mathrm{~mm}
$$

El tamaño de una pequeña bola de acero, prácticamente invisible desde la corteza del átomo.

T: Mediante los resultados obtenidos, se pudo determinar la carga del núcleo de una serie de elementos y se constató que coincidía con el número de orden del elemento en el Sistema Periódico, o sea, con su número atómico Z. Cuando Chadwick descubrió en 1932 el neutrón - una partícula neutra con masa ligeramente superior a la del protón se admitió que el núcleo contienen $\mathrm{Z}$ protones y $\mathrm{N}$ neutrones, es decir, un total de $\mathrm{A}=\mathrm{Z}$ $+\mathrm{N}$ nucleones. Se pudo así explicar la existencia de nuevos elementos con propiedades químicas idénticas a las de los elementos ya conocidos, aunque difieran en propiedades físicas. Son los isótopos, núcleos con el mismo número atómico $\mathrm{Z}$ y distinto número másico A y, por tanto, con las mismas propiedades químicas (es el mismo elemento) y distintas propiedades físicas.

P: El hidrógeno presenta tres isótopos de masas 1, 2 y 3 que reciben, respectivamente, los nombres de hidrógeno, deuterio y tritio. Indica el número de protones, neutrones y electrones de que constan sus átomos. 
P: Justifica que la masa atómica del hidrógeno sea 1,008 en lugar de 1,000. ¿Cuál de los isótopos del hidrógeno debe ser el más abundante?

P: Cuántos protones, neutrones y electrones tienen los isótopos del Neón: ${ }_{10}^{20} \mathrm{Ne},{ }_{10}^{21} \mathrm{Ne} y$ ${ }_{10}^{22} \mathrm{Ne}$ ?

C: Como es $\mathrm{H}$, en todos el $\mathrm{n}^{\mathrm{o}}$ atómico es $\mathrm{Z}=1$, pero el $\mathrm{n}^{\mathrm{o}}$ de neutrones es $\mathrm{N}=0,1$ y 2 , respectivamente. El isótopo más abundante es $\mathrm{H}-1$. El n ${ }^{\circ}$ de p y e- es $\mathrm{Z}$, por tanto, todos tienen $10 . \mathrm{N}=10,11$ y 12 respectivamente.

P: Si se representa la energía de enlace por nucleón para los isótopos naturales en función del número másico $\left(E_{b} / A=f(A)\right)$ se obtiene la siguiente curva (Figura 1). Señalar cuáles son los aspectos más significativos que se aprecian en la misma.

Figura 1 - Energía de enlace por nucleón

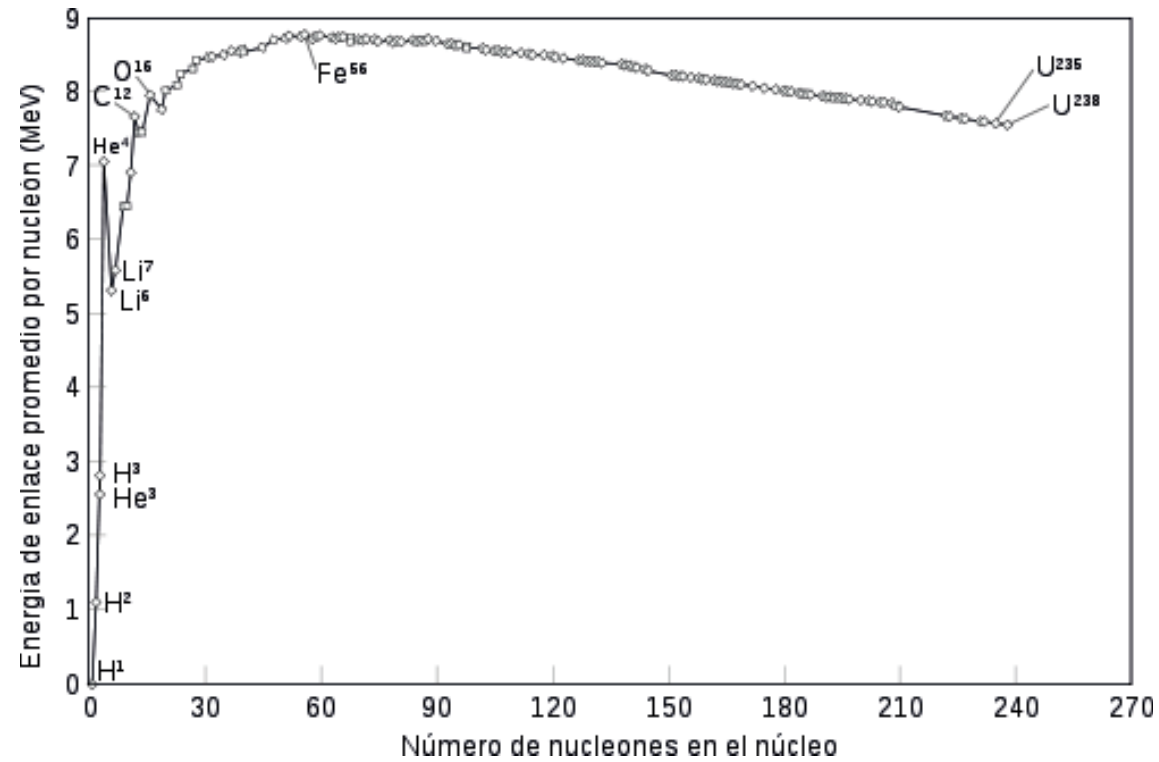

Fuente: Wikipedia ([2015]).

C: Se representa en Mega electronvoltio (MeV), siendo el eV una unidad de energía que da la variación de energía potencial que experimenta un electrón al moverse en una diferencia de potencial de 1 voltio. Equivale a 1,6 $\times 10^{-19} \mathrm{~J}$, obteniéndose este valor de multiplicar la carga del electrón $\left(1,6 \times 10^{-19} \mathrm{C}\right)$ por la unidad de potencial eléctrico $(\mathrm{V})$. Se obtienen una curva como una colina en la que el valor de la energía de enlace por nucleón crece rápidamente al aumentar el número másico $\mathrm{A}$, alcanzando un valor prácticamente constante, de unos $8 \mathrm{MeV}$, a partir de $\mathrm{A}>16$. Alcanza su cima para $A=56$ (Hierro) y, por encima de $A=60$, aproximadamente, la curva disminuye lentamente, lo que indica que los núcleos más pesados y más ligeros se 
mantienen unidos menos firmemente que los de la zona central ( $\mathrm{Fe}, \mathrm{Co}, \mathrm{Ni}$ ). Más adelante veremos que este hecho permite la liberación de energía en los procesos de fisión y fusión. En segundo lugar, se presentan una serie de picos para los núcleos $\mathrm{He}-4, \mathrm{C}-12$, O-16, que indican una estabilidad superior de dichos isótopos con respecto a los más próximos. Todo parece indicar que los núcleos que tienen 2, 8, 20, $28,50,82$ y 126 protones y/o neutrones son más estables y los elementos correspondientes, mucho más abundantes en la naturaleza, por lo que son denominados números mágicos. Es una situación similar a lo que ocurría con los átomos con 2, $10,18,36,54$ y 86 electrones en la corteza (los gases nobles) cuya estabilidad es la mayor de todos los elementos. Este hecho pone de manifiesto la existencia de niveles energéticos en el núcleo, lo que llevó en 1949 a Johannes H. D. Jensen y a Maria Goeppert Mayer a proponer un modelo de capas para el núcleo.

\section{Reacciones nucleares}

T: Se dice que se produce una reacción nuclear cuando un núcleo se ve alcanzado por otro o por una partícula más simple.

P: Aplicando las leyes de conservación de $A$ ( $n^{o}$ de nucleones) y $Z$ (carga), escribe las siguientes reacciones: la transmutación del N-14 al bombardearlo con partículas alfa (He-4), en la que se observa la emisión de protones; el bombardeo de Be-9 o Al-27 con He-4, en las que se emiten neutrones. Señalar su importancia.

C: Se trata de reacciones históricamente importantes. En la primera tenemos la primera transmutación artificial, la del Nitrógeno-14 al bombardearlo con Helio-4 (partículas alfa), en la que se produce $\mathrm{O}-17$ y permitió a Rutherford observar la emisión de protones en 1919. En la $2^{\mathrm{a}}$ el bombardeo de Berilio-9 con Helio-4, que produce Carbono-12 y condujo a Chadwick al descubrimiento del neutrón en 1932. En 1934 el matrimonio Frédéric Joliot e Irene Curie descubren la radiactividad artificial al bombardear Aluminio-27 con partículas alfa, que producen un neutrón y Fósforo-30 que emite radiación. En 1934 Enrico Fermi inicia experimentos sistemáticos para producir isótopos radiactivos por absorción de neutrones.

T: De hecho, incluso aunque la partícula incidente tenga energía suficiente, hay que tener en cuenta que para provocar dicha reacción, es preciso acelerar haces de partículas (núcleos, protones) en número muy superior a los que llegan a colisionar, con lo que en realidad se consume más energía que se libera en una transmutación nuclear. Para que la energía liberada en una reacción nuclear pueda aprovecharse, es necesario que, una vez iniciada, pueda automantenerse, como ocurre, por ejemplo, en una reacción química exotérmica.

P: Otto Hahn y su ayudante Fritz Strassman descubren en 1938 que al bombardear Uranio-235 con neutrones lentos se produce Bario-144. ¿Puedes explicar lo que se ha producido? 
A partir de la curva de E de enlace por nucleón, ¿puedes explicar la energía producida a partir la curva de energía de enlace por nucleón $E_{b} / A$ ?

C: Aunque Hahn no fue capaz de explicarlo, le comunicó los resultados a Lise Meitner, que por su origen judío había tenido que abandonar Alemania. Ella y su sobrino Otto Frisch, fueron capaces de explicarlo al sugerir que el núcleo se había partido en dos, se había fisionado. Por otra parte, la curva $\mathrm{E}_{\mathrm{b}} / \mathrm{A}$ muestra que los isótopos más estables son los de masas atómicas próximas al nucleido Hierro-56. Por ello, los elementos pesados como el Uranio-235 o el Plutonio-239, sometidos a bombardeo de neutrones, que no son repelidos por el núcleo al carecer de carga, se pueden romper en dos o más núcleos de masa intermedia. La $\mathrm{E}_{\mathrm{b}} / \mathrm{A}$ de estos isótopos es de unos 8,5 MeV/nucleón y la del U-235, menos estable, es de 7,6 MeV/nucleón. Se libera una energía de 0,9 MeV/nucleón. Se puede determinar el valor exacto calculando el defecto de masa de la reacción, pero esto sólo se realizaría con alumnado de los primeros cursos universitarios.

P: El deuterio al interactuar con el tritio da helio y un neutrón ¿Qué tipo de reacción es y cuál es aproximadamente la energía liberada?

C: Se trata de una reacción de fusión: ${ }^{3} \mathrm{H}+{ }^{2} \mathrm{H} \rightarrow{ }^{4} \mathrm{He}+\mathrm{n}$. Dado que el He-4 es muy estable, con $7 \mathrm{MeV} /$ nucleón y que los reactivos $\mathrm{H}-3$ con $3 \mathrm{MeV} /$ nucleón y H-2 con 1 $\mathrm{MeV} /$ nucleón, esto nos indica que se puede liberar unos $5 \mathrm{MeV} /$ nucleón, mayor que en las reacciones de fisión.

\section{Las bombas atómicas y sus consecuencias}

P: ¿Qué conoces sobre las aplicaciones militares de la ciencia? ¿Cuándo comienzan a realizarse de una forma sistemática?

C: En todas las épocas se ha aplicado la ciencia fines militares: desde Arquímedes al cálculo de la trayectoria de una bala de cañón pasando por la formación de ingenieros y artilleros militares. Sin embargo, hasta el siglo XX la ciencia desempeñó sólo un papel subordinado en la guerra.

Por ello la aportación de los científicos fue poco valorada por los aliados en los inicios de la Gran Guerra y se enviaron algunos científicos jóvenes en la frente, como por ejemplo Moseley en Gallipoli, donde murió en el año 1915. Posteriormente, la carencia de productos químicos importados de Alemania (tintes, acetona, fenol) y la necesidad de detectar los submarinos $U$ alemanes (primero con micrófonos y luego mediante el eco de ultrasonidos), obligaron a utilizar la ciencia en esa guerra, que ha sido denominada con frecuencia la guerra de la química. Esta pudo desempeñar un papel muy importante porque la industria química (más desarrollada que la industria relacionada con la física) fue capaz de aportar productos como los explosivos, los gases tóxicos o los tintes. Un ejemplo característico es el problema que se le 
plantea en Alemania cuando el bloqueo naval, impide sus importaciones de abonos (nitrato de Chile). La síntesis del amoníaco de Haber y Bosch, realizada en 1913 en la empresa BASF, permitió a Alemania abastecerse del producto y producir las municiones y fertilizantes que necesitaba. Esta síntesis del amoníaco, por la que en 1918 se concedió el premio Nobel de Química a Haber, pone a su vez de manifiesto cómo la ciencia puede ser utilizada tanto para el desarrollo de la agricultura y el bienestar de la humanidad como para la guerra. (SÁNCHEZ RON, 2006; SOLBES, 2002) En cambio, en la Il Guerra Mundial, era evidente para todos los estados implicados, que la ciencia iba a desempeñar un papel decisivo, como veremos a continuación.

T: Un problema de la fisión es si se puede originar una reacción en cadena. Esto se comprobó experimentalmente por Fermi y Joliot en 1939. Cuando Szilard conoce este hecho promueve, junto con Wigner y Teller, que Einstein, que estaba en los Estados Unidos (EEUU) desde 1933, escribiese una carta al presidente F.D. Roosevelt en 1939 en la que sugería el desarrollo de armas nucleares, para adelantarse al proyecto de los alemanes. Se inicia así proyecto Manhattan, dirigido por el general Groves, en el que se invirtieron 2191 millones de dólares y participaron físicos de Europa huidos del nazismo como Bethe, Teller, Wigner, Peierls, Szilard, Weisskopf, Franck, Fermi, Segré o Bohr y estadounidenses como Oppenheimer (director científico), Feynman, Lawrence, Compton, Seaborg, Condon, Urey, Álvarez o Wheler.

P: ¿Cuál era el objetivo de dicho proyecto? ¿Cuáles fueron sus consecuencias?

C: El objetivo era la construcción de las primeras bombas atómicas que se lanzaron en 1945 en Hiroshima (Little boy, con 12 kilotones (kt), es decir, 12.000 toneladas de TNT) donde en un radio de $500 \mathrm{~m}$ de la explosión todo fue incinerado, a $3 \mathrm{~km}$ todos los edificios fueron destruidos y se produjo un hongo de polvo que ascendió 12 km, murieron 145.000 personas; y en Nagasaki (Fat man, de 22 kt), produjo 70.000 víctimas. La primera era de Uranio enriquecido y la segunda de Plutonio (elemento inexistente en la Tierra y producido en el primer reactor nuclear). Sobre el mismo se puede visionar la excelente película de Roland Joffé, Fat Man and Little Boy que se exhibió en España con el título de Creadores de sombras y en Latinoamérica con los títulos de Arma secreta y Proyecto Manhattan, en la que participan actores tan conocidos como P. Newman o J. Cusak (se pueden ver fragmentos de la misma donde se presentan dichos problemas, así como los conflictos morales y políticos que tuvieron los científicos, que se plantearan en otra actividad). Sus principales consecuencias, además de 210.000 víctimas, fueron el final de la Il Guerra mundial en el Pacífico, el inicio de la carrera nuclear y la guerra fría, el aumento de dinero destinado por los gobiernos a Investigación y Desarrollo $(\mathrm{I}+\mathrm{D})$ y el nacimiento de la gran ciencia y del complejo militar-industrial. Eisenhower, presidente de los EEUU y general de la Il Guerra mundial, advertía en 1960 del enorme poder que había acumulado este último. 
P: Las investigaciones del proyecto plantearon problemas, de los que surgieron conceptos como enriquecimiento del uranio, reacción en cadena y su control o masa crítica, que ahora forman parte del lenguaje ordinario. ¿Puedes explicar lo que significan?

C: Hubo difíciles problemas que fue necesario resolver para producir la fisión. En primer lugar, la escasez $(0,7 \%)$ del isótopo U-235 en el uranio natural y por eso hay que enriquecerlo mediante complejos procesos de difusión o ultracentrifugación. Una reacción en cadena es una serie de reacciones, para las que es necesario que en cada fisión se emitan dos o tres nuevos neutrones, que puedan colisionar con otros átomos de uranio. Además, los neutrones que se producen en la fisión son rápidos y la probabilidad de que el núcleo de U-235 absorba un neutrón sólo es elevada para neutrones lentos. Y hay que eliminar neutrones si se quiere controlar la reacción (en un reactor). Por ello, hay que utilizar una sustancia, denominada moderador (agua pesada, grafito) para que absorba neutrones y los frene. Por último, si la masa de uranio es pequeña, la mayoría de los neutrones escaparán antes de que puedan originar otra fisión. Se necesita una cantidad de materia superior a una masa denominada "crítica" para que la reacción se automantenga. Para la producción de bombas atómicas es necesario emplear dos masas subcríticas durante el transporte, que se unían dando una masa superior a la crítica en el momento de la detonación.

P: ¿Qué es la carrera nuclear? Busca información de los principales acontecimientos de la misma.

C: El desarrollo de la bomba atómica por EEUU supone el inicio de la guerra fría y de la carrera nuclear, que prosigue al ser producido la bomba atómica en la Unión de Repúblicas Socialistas Soviéticas (URSS) en 1949. Aunque disponían de un notable grupo de físicos, encabezados por Kurchatov, tardaron 4 años, porque su capacidad industrial era menor que la de EEUU. En el Reino Unido la consiguieron en 1952. La réplica norteamericana a la bomba atómica soviética fue la autorización en 1950 por el presidente Truman de un nuevo programa de investigación para desarrollar la bomba de hidrógeno. Los EEUU ensayaron la bomba H o termonuclear en 1952. Esto lleva a los soviéticos, en un proyecto dirigido por Andrei Sajarov, a producir su bomba H en 1953. En 1957 lo conseguían bombas atómicas los ingleses, en 1960 Francia y en 1964 China. En 1962 se produce la crisis de los misiles en Cuba que lleva a EEUU y a la Unión Soviética al borde de la guerra nuclear. En 1963, después de más de 500 explosiones nucleares, de 10 toneladas de Plutonio en la atmosfera y de muchas manifestaciones en contra de las mismas se firma el Tratado Parcial para la Prohibición de Pruebas, que las prohíbe en la atmósfera, el espacio exterior y bajo el agua, pero no las subterráneas. Ni Francia ni China lo suscribieron y continuaron su experimentación al aire libre. Las pruebas francesas cesaron en 1974, después de las protestas de los países del Pacífico Sur, los más directamente afectados por la radiactividad. En 1968 se firma Tratado de no Proliferación de armas nucleares, que 
sólo autoriza a la posesión de las mismas a los países que habían realizado pruebas antes de 1967 (EEUU, URSS, Reino Unido [RU], Francia y China). Entre los no firmantes se encuentran Brasil, España, Argentina, Pakistán, India, Israel y Sudáfrica, todos ellos con capacidad de desarrollo de bombas, al disponer de centrales nucleares. En 1988 se firmó el Tratado de Fuerzas Nucleares de Alcance intermedio, por los presidentes R. Reagan y M. Gorbachov en las que accedían a destruir los misiles tácticos. En 1991, los presidentes Gorbachov y G. Bush firman el primer Tratado de Reducción de Armas Estratégicas, START. Por este acuerdo se destruirían un tercio de las armas estratégicas. En 1996 se firma el Tratado de Prohibición Completa de Pruebas Nucleares, salvo India, después de más de más de 2000 detonaciones, de las cuales 1054 correspondían a Estados Unidos, unas 800 a la Unión Soviética, 210 a Francia, 45 a RU, 45 a China, 5 o 6 a India, entre 3 y 6 a Pakistán y 2 a Corea del Norte. Estos acuerdos han permitido pasar de unas 50.000 cabezas nucleares en el mundo en 1985 (con 20.000 Mt), a 17.300 cabezas, 7.700 de EEUU, 8.500 de Rusia y el resto de Francia (300), China (250), Reino Unido (225), India (100), Pakistán (110) Israel $(80)$ y Corea del Norte $(<10)$. Pero siguen siendo suficientes para provocar la desaparición de la civilización humana y, más, si se tienen en cuenta que el polvo y el humo provocarían un invierno nuclear.

P: Busca información sobre los cobayas del plutonio. ¿Qué cuestiones éticas están involucradas en el uso de personas en experimentos científicos?

C: Además de las pruebas, que tuvieron importantes consecuencias ambientales y en la salud, otra práctica poco conocida y evidentemente poco democrática, es la utilización en EEUU, entre 1945 y 55 de 23.000 personas, sin su conocimiento, para estudiar los efectos de las radiaciones. Se realizaron experimentos del tipo de inyecciones de plutonio 238 y 239 o de uranio enriquecido, de exposición a nubes radiactivas, de irradiación masiva con rayos X etc. similares a los realizados por los médicos nazis. El seguimiento de estos casos perduró hasta los años 1970. Estos experimentos de utilización de seres humanos como "cobayas del plutonio" sólo se han conocido 20 años después de que finalizasen los controles y se realizaron porque los científicos implicados pensaban que no deberían responder nunca de ellos. (BELL, 1995) Se trata así a las personas como medios, sin tener en cuenta su dignidad.

T: La unanimidad de los científicos ante la bomba se rompe cuando en 1944 se sabe que los nazis no van a conseguir la bomba y, sobre todo, poco después de los lanzamientos de las bombas sobre Japón.

P: Por grupos de trabajo, buscad información de los siguientes científicos para ver sus contribuciones a los proyectos nucleares y su apoyo o rechazo a los mismos, con los poderes y concepciones establecidos se vieron involucrados: Hahn, Lise Meitner, Heisenberg, Bohr, 
Linus Pauling, Einstein, Fermi, Rotblat, Frederic e Irene Joliot-Curie, Max Born, David Bohm, Leo Szilard, Robert Oppenheimer, Victor Weisskopf, Teller, Harold Urey, Leite Lopes, Sajarov.

C: Cuando Hitler sube al poder en 1933 se inicia su política belicista, nacionalista y antisemita, promulgándose la ley de restauración de la carrera del funcionariado, según la cual "los funcionarios que no sean de linaje ario han de ser jubilados o pasar a la situación de excedencia”. Más de 500.000 personas tuvieron que exiliarse de Alemania entre ellos unos 2.500 científicos. Uno de los primeros en ser perseguido fue Einstein. Reunía alguna de las características que más odiaban los nazis: era judío, pacifista y progresista. Schrödinger, por discrepancias ideológicas, abandonó Berlín en 1933, pasando a Austria, de donde tuvo que exiliarse al ser anexionada por Alemania en 1938. Otros físicos que tuvieron que exiliarse fueron Lise Meitner, Max Born, Stern, Bloch, Wigner, Bethe, Gabor, Heitler, London, Nordheim, Peierls, Teller, Szilard, Weisskopf, Fermi, Segre etc. Muchos de ellos colaboraron en los EEUU con el proyecto Manhattan y el proyecto radar, para localizar aviones o blancos con ondas de radio, por temor a que los nazis desarrollaran una bomba atómica. En el proyecto nazi de bomba atómica (Urain-Verein) participaron activamente científicos como Heisenberg, Hahn, Gerlach, von Weizsäcker, Wirtz, Harteck etc. Aunque los físicos alemanes no llegaron a producir la bomba posiblemente por falta de recursos económicos, consiguieron un reactor nuclear, producir agua pesada, separar los isótopos del uranio etc. Para trasladar los institutos de Hahn y Heisenberg desde Berlín al sur de Alemania en Oranienburg los nazis utilizaron prisioneros de guerra y ciudadanos deportados así como para trabajar en la industria militar alemana (Krupp, IG Farben, Tyssen). También se puede tratar este tema mediante la lectura de fragmentos de obras literarias antes mencionadas. (FRAYN, 2000; VOLPI, 1999)

La unanimidad empieza a romperse cuando en 1944 se sabe que los nazis no van a conseguir la bomba y Rotblat abandona el proyecto. Fue acusado de espionaje y se le mantuvo bajo vigilancia durante años. Fue secretario de Pugwash entre 1957 y 1973 y presidente de la misma a partir de 1988, recibiendo el Premio Nobel de la Paz en 1995. Otros científicos, como Bohr, Szilard, Franck, redactan informes y recogen firmas contra el lanzamiento de las bombas en Japón, en tanto que Lawrence, Compton y Oppenheimer, director científico del proyecto Manhattan, apoyaron públicamente el bombardeo. Esto evidencia que no es tan sencillo pasarles la responsabilidad sólo a políticos y militares. Pero una vez lanzadas y a la vista de que el propósito era intimidar a los soviéticos los efectos y se producen muchas iniciativas contra la producción de bombas y las pruebas de las mismas. En 1946 se constituye el Comité de emergencia de científicos atómicos, destinado a recaudar fondos para causas antinucleares, constituido por Einstein, Urey, Bethe, Morse, Pauling, Seitz, Weisskopf, Szilard etc. Cuando los soviéticos hicieron explotar su propia bomba en 1949 Teller y Lawrence apoyaron ante el gobierno la idea de producir una bomba 
más poderosa, la de hidrógeno. También hubo científicos, como Oppenheimer, director científico del proyecto Manhattan, se opusieron a su producción.

En estos años, la oposición sigue a cargo de científicos importantes, que denuncian los peligros de la proliferación nuclear y señalan que esas armas amenazan la existencia de la humanidad: manifiesto de Einstein y Russell de 1955, apoyado, entre otros, por Pauling, Born y Bridgman; el manifiesto del grupo de Götinga de 1958 promovido por Born; las conferencias Pugwahs convocadas por iniciativa de Russell (que las presidió entre 1957 y 1970), Einstein y Frederic Joliot-Curie a partir de 1958; Pauling, Bethe y otros denuncian la radiación en la atmósfera producida por las pruebas.

En consecuencia, el FBI (Federal Bureau of Investigation) abrió dossiers a Einstein, Urey (Nobel de Química en 1934), Weisskopf (fundador de la Union of concerned scientists y director del CERN), Szilard y muchos otros. A Edward Condon se le negó el pasaporte en 1945 y tuvo que testificar ante el Comité de Actividades Antiamericanas. Oppenheimer se opuso, como hemos dicho, a la producción de una bomba $\mathrm{H}$ y, por eso, la Atomic Energy Commission, tras un proceso que recordó el de Galileo y en el que testificó Teller en su contra, lo apartó en 1954 de sus cargos e investigaciones al declararlo un riesgo para la seguridad nacional (se pueden leer fragmentos en Kipphardt, 1966). A Pauling, Premio Nobel de Química de 1954, se le retiró el pasaporte en 1952 por su participación en campañas contra las armas nucleares y por su libro No more war. Esto le convirtió en una de las pocas personas que han vuelto a recibir un segundo Premio Nobel, el de la Paz de 1963. Frédéric Joliot-Curie fue nombrado por De Gaulle en 1945, Alto Comisionado para la Energía Atómica. En el 1948 supervisó la construcción del primer reactor atómico francés. En 1950, en pleno auge de la guerra fría, el Primer Ministro Bidault le destituyó como Alto Comisionado y unos meses más tarde (1951) también fue destituida Irène Joliot-Curie de la Comisión. Andrei Sajarov, en la década de los 1960 jugó un activo papel contra la proliferación de armas nucleares y de las pruebas nucleares en atmósfera. En 1968 se le prohibió investigar en los centros y laboratorios de la URSS y se le desposeyó de los honores adquiridos. En 1975 le fue otorgado el Premio Nobel de la Paz, no se le permitió salir de la URSS, y fue su mujer la encargada de recogerlo. David Bohm, autor de una investigación sobre protones y deuterones útil para el Proyecto Manhattan, por lo que no le permitieron defender su tesis, aunque se le concedió el doctorado en 1943. Hubo de comparecer en 1949 ante el Comité. Al negarse a declarar fue acusado de desacato al Congreso. No se le renovó su contrato en la Universidad de Princeton y no encontrando trabajo en ninguna otra, tuvo que ir en 1951 a São Paulo. Leite Lopes, físico y autor de La ciencia y el dilema de América Latina: dependencia o liberación, fue despedido por la Dictadura Militar en 1969 del Centro Brasileiro de Pesquisas Físicas (CBPF) que él había fundado y exiliado en EEUU hasta 1974, pero 
cuando queda en evidencia la colaboración de Estados Unidos con el golpe militar se muda a Francia al Centre National de la Recherche Scientifique (CNRS) hasta 1989. En la medida en que estos científicos aplicaron el pensamiento crítico a las concepciones establecidas sobre los armamentos se vieron involucrados en problemas con el poder, en este caso el estado. Otros simplemente por sus ideas de izquierdas, como Bohm o por ser críticos con la situación de la ciencia en su país como Leite Lopes. Esto nos muestra que la ciencia es metodológicamente crítica, pero para que se pueda considerar como pensamiento crítico tiene que salir de las "paredes del laboratorio" e incidir en cuestiones sociales, lo que puede implicar enfrentamientos con el poder dominante en cada época: religioso, político, económico. (SOLBES, 2013a; SOLBES; TORRES, 2013)

P: En vista de la oposición de los científicos, se trataba de convencer a la opinión pública, mediante campañas como la de "átomos para la paz", iniciada en 1954 por Eisenhower, que la investigación nuclear realizaba contribuciones no bélicas. Busca información sobre cuándo se pone en marcha la primera central nuclear productora de electricidad ¿Qué nos indica este dato sobre la campaña?

C: El primer reactor nuclear lo inventa Fermi, en el marco del proyecto Manhattan. Los primeros reactores, fueron el estadounidense de Hanford (1944) y el anglo-francés de Chalk River (Canadá) de 1947. Su finalidad básica era la producción de material fisionable (plutonio), que se usó en la bomba de Nagasaki (1945). Era una alternativa por si fallaba el enriquecimiento de uranio, que se usó en la bomba de Hiroshima. De ahí, la gran preocupación actual de que algunos países, como Irán, puedan tener una central nuclear. En 1955 entró en servicio el primero de una serie de submarinos de propulsión nuclear, el Nautilus. Pero hasta 1956, once años después de Hiroshima y dos años después del inicio de la campaña propagandística, no se pone en marcha la primera central nuclear productora de electricidad en Calder Hall (Gran Bretaña) y en 1957 la de Shippingport (EEUU). Hasta 1966 RU era el mayor productor de energía nuclear mundial. Incluso Walt Disney colaboro activamente en la campaña con el film "Nuestro amigo el átomo", muy didáctico, con la brillante metáfora entre el genio y el núcleo atómico, pero con un evidente carácter propagandístico, pues afirma que cualquier problema se puede solucionar con la energía nuclear, dentro del enfoque tecnocrático de que cualquier problema humano puede resolverse con tecnología.

\section{Las centrales nucleares: sus repercusiones y riesgos}

$P$ : ¿Cuál es el esquema de funcionamiento de una central nuclear?

C: Una central nuclear es básicamente una máquina térmica. Consta de una caldera, el reactor nuclear, en el que se controla la reacción utilizando barras de control que 
absorben neutrones y mantienen su producción muy próxima a un neutrón por fisión. Esta calienta un fluido, normalmente agua, que hace girar una turbina, que a su vez hace girar bobinas entre imanes, lo que genera, según la ley de Faraday, una corriente eléctrica. Por último, el líquido se refrigera con torres de evaporación y con el agua de ríos o mares (por eso las centrales se construyen al lado de los mismos). El medio utilizado para hacer girar las bobinas sirve para denominar las centrales eléctricas existentes, tanto las más usuales (térmica, hidroeléctrica, nuclear) como las alternativas (eólicas, geotérmicas, mareomotrices, solares térmicas etc.). Como en todas las máquinas térmicas su rendimiento, el cociente entre el trabajo producido y el calor suministrado es bajo: en las máquinas más eficientes es menor del $30 \%$.

T: Conviene señalar que con el olvido de Chernobil y el problema del calentamiento global, había ido calando en la opinión, particularmente entre los estudiantes de físicas, químicas etc. e incluso en ecólogos como Lovelock, la necesidad de construir nuevas centrales nucleares. Por eso, les presentamos a los estudiantes los argumentos que aparecen usualmente en los medios de comunicación y les pedimos que los pongan en cuestión. (SOLBES, 2013b)

P: Algunos señalan que las centrales nucleares pueden ayudar a frenar la producción mundial de $\mathrm{CO}_{2}$. Otros que es una energía muy difundida, con más de 430 reactores en funcionamiento que producen ya alrededor del 17\% del total de la electricidad en el mundo, tanta como la que proviene de la energía hidroeléctrica. Frente a esto, el número de accidentes es bajo y, en consecuencia, se puede afirmar que es una energía segura. Además, afirman que es barata y que la dosis de radiación anual en las proximidades de una central es inferior a la ambiental. ¿Puedes cuestionar con pruebas científicas estos argumentos?

C: La afirmación de que las centrales evitan la producción de $\mathrm{CO}_{2}$ es falsa, porque se centra sólo en la etapa de funcionamiento de la central, olvidando que su construcción, y sobre todo el enriquecimiento y transporte del Uranio consume mucha energía eléctrica y combustibles, por tanto, produce $\mathrm{CO}_{2}$. También lo produce en abundancia el desmantelamiento de la central y el transporte de los residuos. Y, por otra parte, el uranio es un recurso no renovable. Según cual sea el consumo, se barajan escenarios de agotamiento entre 2030 y 2070.

Sostener que el coste del kw-h nuclear es muy barato también es una falsedad que olvida el apoyo gubernamental a esta energía y que se basa en la misma falacia que el punto anterior, considerar sólo la fase de funcionamiento. Pero si se incluyen todos los costes del proceso, incluyendo enriquecimiento del uranio, construcción y desmantelamiento de la central (que es toda ella un residuo radiactivo) y el almacenamiento de los residuos, que es financiado por los contribuyentes, ya no resulta tan barata. 
La idea de que los adelantos tecnológicos y la experiencia en el uso de las centrales nucleares hacen que la seguridad sea cada vez mayor, olvida la gravedad de los tristemente famosos accidentes de Three Mile Island en EEUU (1979), de nivel 5, Chernóbil (1986) y de Fukushima (2011), ambos de nivel 7 (el máximo). El primero sin víctimas mortales, pero con una nube radiactiva de unos $30 \mathrm{~km}^{2}$ que obligo a desplazar a unas 25.000 personas y a un costoso proceso de limpieza que duró diez años. En el de Chernóbil fueron arrojadas a la atmósfera unas 200 toneladas de material radiactivo (equivalente al de 500 bombas atómicas como la de Hiroshima), causó directamente la muerte de 31 personas, forzó al gobierno de la Unión Soviética a la evacuación de unas 135.000 personas y provocó una alarma internacional al detectarse radiactividad en diversos países de Europa septentrional y central. El gobierno ocultó la catástrofe las primeras dos semanas y mintió informando que había sucedido un accidente nada alarmante en la central. 1.000 personas recibieron $0,5 \mathrm{~Sv}^{1}$, 20.000 cerca de $0,25 \mathrm{~Sv}, 200.000$ personas recibieron alrededor de 0,1 Sv. En total, 600.000 personas recibieron dosis de radiación por los trabajos de descontaminación posteriores al accidente. 5.000.000 de personas vivieron en áreas contaminadas y 400.000 en áreas gravemente contaminadas.

Pero se han producido muchos otros accidentes no tan conocidos por el público. Así, Wikipedia menciona muchos accidentes nucleares civiles graves, algunos de los cuales han obligado a cerrar centrales nucleares, como Vandellós I (España) en 1989, de nivel 3, el de Windscale (RU), un reactor para producir plutonio en 1957, de nivel 5, o el accidente de Goiânia (Brasil) en 1987, que causa 4 muertos y 249 heridos, por envenenamiento por radiación de una fuente radiactiva médica de cesio-137 en desuso robada de un hospital abandonado, de nivel 5.

Tampoco se contabilizan los accidentes nucleares militares en tiempos de paz como la colisión de dos aviones B-52 y KC-135 de los Estados Unidos, que perdieron cuatro bombas nucleares frente a las costas de la ciudad española de Palomares en 1966, cuyas secuelas aún están sin resolver o los submarinos soviéticos K-8 (en el golfo de Vizcaya), K-431 (explosión del reactor y dispersión de los productos radiactivos por las corrientes oceánicas) y K-219 (una explosión produjo su hundimiento en el Atlántico). En total, hay 8 submarinos nucleares hundidos en el mundo (2 de EEUU, 4 de la antigua URSS y 2 de Rusia).

Hay todavía otros accidentes que regímenes dictatoriales consiguieron mantener en secreto. La explosión en la central secreta de Mayak, (URSS), de nivel 6, causa 200 muertos y contamina $90 \mathrm{~km}^{2}$ con estroncio. Un total de 10.000 personas fueron evacuadas y decenas de miles quedaron expuestas a la radiación. También la fuga de unos 7001 de desechos de alta radiactividad del Centro de Energía Nuclear de Madrid (España) en 1970 al Río Manzanares, afluente del Río Tajo, que desemboca

1 Sievert (Sv) es una unidad que mide la dosis de radiación absorbida por la materia viva, corregida por los efectos biológicos producidos. 1 Sv es un Jkg-l. 
en Lisboa (Portugal), produciéndose la más grave contaminación radiactiva de la historia de España, oculta por la dictadura de Franco y sólo desvelada más de 20 años después, con lo cual no ha podido ser evaluada. (YARNOZ; YOLDI, 1994)

Los problemas son tan graves que no hay empresa aseguradora (ni consorcio de las mismas) que quiera hacer pólizas a las centrales. Aún más, si se tienen en cuenta que éstas pueden ser objeto de atentados terroristas, como el que obligó a cerrar y desmantelar Lemóniz I y Il en el País Vasco, cuando habían finalizado las obras y tan sólo faltaba la introducción del combustible nuclear, costando ese proceso unos 6.000 millones de euros.

También se dice que las centrales son poco contaminantes o que producen menos contaminación radiactiva que la propia naturaleza. Esto se basa en el funcionamiento normal, olvidando los accidentes de distinta gravedad que producen emisiones y que los productos radiactivos naturales tienen masas elevadas y, por tanto, son difícilmente asimilables, salvo el radón que se inhala. Pero los elementos radiactivos fruto de las reacciones de fisión, como el estroncio 90, el cesio 137 o el yodo 131, tienen masas intermedias, con lo cual son asimilados con facilidad por los seres vivos, entrando en la cadena alimentaria. (ROTHMAN, 1980) Así, el I-131 se concentra en la tiroides y, para evitarlo, se suministró yodo a la población después de Fukushima. En cuanto a los residuos y la seguridad de los almacenamientos es un tema no resuelto, por eso nunca se menciona. Entre 1963 y 1983 se vertieron más de 140.000 toneladas de residuos radiactivos en la fosa atlántica, a $700 \mathrm{~km}$ de Galicia. Cuando Cousteau mostró fotografías de los "seguros" bidones abiertos, se prohibió esta actividad. Ahora se ha optado por el Almacén Temporal Centralizado (ATC) en Francia y Reino Unido y, recientemente, en España, concebidos para unos 100 años. Solo EEUU dispone de un Almacén Geológico Profundo (AGP) destinado a residuos militares. Conviene recordar que en el combustible gastado de los reactores se encuentran sustancias como el plutonio 239 (vida media de 24.400 años), el neptunio 237 (vida media de 2.130 .000 años) y el plutonio 240 (vida media de 6.600 años). Se supone que el almacenamiento de estos residuos debe ser garantizado por decenas de miles de años hasta que la radiactividad baje lo suficiente como para que dejen de ser peligrosos, pero la obra humana más duradera (las pirámides) no excede de los 4.500 años.

P: ¿Qué está pasando en Fukushima? ¿Por qué está siendo silenciado por los medios de comunicación?

C: Fukushima tiene poca resonancia porque tanto Tokyo Electric Power Company (TEPCO) (la empresa propietaria) como el gobierno como los defensores de las centrales nucleares, trataron de minimizar su gravedad. Pero se trata de una catástrofe absoluta: entre 300 y 400 toneladas de agua radiactiva son vertidas diariamente al Pacífico. Esto ha estado ocurriendo desde hace casi cuatro años. Según ha reconoci- 
do TEPCO, en el periodo entre mayo de 2011 y agosto de 2013 se han derramado al océano Pacífico sustancias que representan un total de 20 billones de Bq (becquerel, medida de actividad equivalente a una desintegración por segundo) de cesio 137, 10 billones de Bq de estroncio 90 y 40 billones de Bq de tritio". ${ }^{2}$

Mycle Schneider, consultor independiente en energía nuclear, señalaba en una reciente entrevista en Rio de Janeiro que "La cantidad de radiactividad que se filtró al agua y a los sótanos se estima en el triple de la que se liberó tras el accidente de Chernóbil”, es decir el equivalente a 1.500 bombas como la de Hiroshima. ${ }^{3}$

P: Se puede decir que como Brasil sigue creciendo la demanda por energía, tiene la sexta mayor reserva de uranio en el mundo y también la tecnología necesaria para la fabricación de combustible nuclear, y como sólo tiene una Central nuclear Almirante Álvaro Alberto, en Angra dos Reis, Río de Janeiro, con dos Reactores de Agua Presurizada (PWR): Angra I, con $626 \mathrm{MW}$, se conectó a la red en 1982 y Angra II, con $1275 \mathrm{MW}$, conectado en 2000, esto asegura un papel importante de las plantas nucleares.

C: Aunque en Latinoamérica haya pocas centrales nucleares: los 2 reactores mencionados en Brasil, 3 Argentina (Atucha I y Il, en Lima, a 100 km de Buenos Aires, y Embalse, en la provincia de Córdoba), y 2 en México (Laguna Verde l y ll en Punta Limón, Veracruz), eso no quiere decir que sean necesarias más.

Hacerlo sería olvidar los problemas que conlleva la fisión nuclear (producción de residuos radiactivos de gran duración y, en consecuencia, de difícil almacenamiento, así como de materiales fisibles reutilizables en armamento nuclear y la posibilidad de accidentes nucleares de gran magnitud) vistos en las actividades anteriores. Se olvida así mismo que la casi totalidad de la energía de nuestro planeta procede del Sol. Por tanto, parece que las únicas soluciones pasan por el ahorro y la eficacia en el uso de la energía y por el aprovechamiento de la energía del Sol, es decir, por las energías renovables. Son energías que agotan menos recursos y que tienen un impacto ambiental más bajo que las convencionales. Las más utilizadas en la actualidad son la biomasa y la hidroeléctrica. Pero también está la energía eólica o la solar. La energía solar es un término confuso porque incluye gran cantidad de dispositivos que sólo tienen en común la utilización directa de la luz del Sol. Podemos mencionar los paneles solares (que suministran agua caliente para uso doméstico), la arquitectura solar, que permite reducir considerablemente los gastos en calefacción, refrigeración e iluminación de las casas simplemente mediante el diseño adecuado de las mismas, los hornos solares (que concentran los rayos solares con espejos para producir elevadas temperaturas), las centrales electrosolares (grandes hornos solares, que calientan un fluido que acciona turbinas y generadores) y las células solares

2 Ver em: <http://www.rebelion.org/noticia.php?id=196316>.

3 Ver em: <http://www.ipsnoticias.net/2014/06/fukushima-es-un-desastre-que-no-termino/>. 
fotovoltaicas, construidas a partir de semiconductores, como el silicio, que transforman directamente la luz en electricidad. (SAPIÑA, 2006; SOLBES, 2002)

En la tecnología algunos autores distinguen entre tecnologías autoritarias y democráticas (MUNFORD, 1992) o de tecnologías pesadas e ingobernables y livianas y flexibles. (WINNER, 1987) Y esto sucede a un nivel muy amplio, en la producción, en la energía, el transporte etc. Así, en la producción de energía se opta por unidades complejas y centralizadas (nucleares, térmicas) frente a las reducidas y descentralizadas (solares, eólicas). Incluso en el caso de la solar se financian proyectos faraónicos (mediante satélites o grandes superficies de heliostatos) cuando se trata de la energía más fácil de adaptar al consumo inmediato: a través de placas solares, células fotovoltaicas etc. En transporte también se opta por unidades de alto consumo energético (por persona o tonelada de mercancía transportada) frente a las de bajo, por lo privado frente a lo público. Es decir, para el transporte de personas se opta por el automóvil, el autobús, el avión (que sólo es rentable para grandes distancias) en vez del tren, el tranvía, el metro. Para el de mercancías se opta por el camión en lugar del tren o el barco. (SAPIÑA, 2006; SOLBES, 2002)

Esto no quiere decir que haya que cerrarlas todas inmediatamente, porque pueden facilitar una transición hacia las renovables, pero cuestiona la construcción de otras nuevas. Tampoco plantea el abandono de los isótopos radiactivos en sus múltiples aplicaciones médicas, industriales etc.

\section{Consideraciones finales}

Este tema con el enfoque usual de la enseñanza de la física se limitaría a unos conceptos básicos como isótopo, curva de energía de enlace, reacción de fisión y fusión, entre otros. Sin embargo, un enfoque de pensamiento crítico mediante cuestiones socio-científicas nos permite abordar temas como:

- Los armamentos nucleares y sus consecuencias (el complejo militar-industrial, las tratados entre países durante la Guerra Fría, la contaminación radiactiva fruto de las pruebas, los accidentes nucleares);

- La responsabilidad de los científicos en la construcción de las bombas pero también en su rechazo y el precio que pagaron por este último;

- Los reactores nucleares, siendo conscientes de sus riesgos y repercusiones.

En resumen, el uso de las CSC de modo interdisciplinar por los profesores de física contribuye a la educación CTS y al reto de una educación científica crítica que implica dar sentido al aprendizaje de los contenidos científicos inmersos en cuestiones sociales, ambientales, econômicas y políticas, dejando de lado nociones ingenuas y lineales en el aprendizaje de la física. 
Finalmente señalamos que dado su carácter multidimensional la CSC relatada puede dar lugar al estudio de cuestiones éticas, no solo con respecto a los seres humanos, en que importan mucho las implicaciones en la salud, pero también acerca de la utilización de o la implicación sobre otros organismos vivos. Así esto daría apertura a otro enfoque sobre la CSC, por ejemplo, incluyendo la manipulación de animales con experimentos de radiación, las implicaciones ecológicas, la pérdida de biodiversidad. (IAEA, 2002) Así mismo, es conveniente dar apertura al uso de objetos virtuales como lo señalan Chang, $\mathrm{Wu}$ e Hsu (2013) para simular escenarios reales de las CSC estudiando como esto contribuye a efectuar experiencias de aprendizaje del contenido de la ciencia y la toma de decisiones informadas.

\section{Referencias}

BELL, R. Los cobayas humanos del plutonio. Mundo científico, Barcelona, n. 15, p. 510520, 1995.

BORN, M. La responsabilidad del científico. Barcelona: Labor, 1968.

BOWLER, P. J.; MORUS, I. R. Panorama general de la ciencia moderna. Barcelona: Crítica, 2005.

CHANG, H.-Y.; WU, H.-K.; HSU, Y.-S. Integrating a mobile augmented reality activity to contextualize student learning of a socioscientific issue. British Journal of Educational Technology, v. 44, n. 3, p. e95-e99, 2013. Disponible en: <http://dx.doi. org/10.1111/j.1467-8535.2012.01379.x>. Acceso en: 23 oct. 2015.

FRAYN, M. Copenhagen. Londres: Methuen, 2000.

HEWITT, P. Física conceptual. México: Pearson Education, 2004.

IAEA. Ethical considerations in protecting the environment from the effects of ionizing radiation. Vienna: International Atomic Energy Agency, 2002.

JEROME, F. El expediente Einstein. Barcelona: Planeta, 2002.

JIMÉNEZ-ALEIXANDRE, M. P. 10 ideas clave: competencias en argumentación y uso de pruebas. Barcelona: Graó, 2010.

KIPPHARDT, H. El caso oppenheimer. Barcelona: Ayma, 1966.

KRAGH, H. Generaciones cuánticas. Madrid: Akal, 2007.

RAMÌREZ MARTÍN, J.; FERNANDEZ-RAÑADA, A. De la agresión a la guerra nuclear: Rotblat, Pugwash y la Paz. Oviedo: Nobel, 1996.

MUNFORD, L. Técnica y civilización. Madrid: Alianza, 1992.

ROTHMAN, H. La barbarie ecológica: estudio sobre la polución en la sociedad industrial. Barcelona: Fontamara, 1980.

SALAM, A. Defensa nuclear, desarme y desarrollo. Revista de Enseñanza de la Física, Córdoba, v. 2, n. 1, p. 25-35, 1986. 
SÁNCHEZ RON, J. M. El mundo después de la revolución. Barcelona: Pasado y Presente, 2014.

SÁNCHEZ RON, J. M. El poder de la ciencia. Madrid: Crítica, 2006.

SAPIÑA, F. El reto energético. València: Publicacions Universitat de València, 2006.

SOLBES, J. Contribución de las cuestiones socio-científicas al desarrollo del pensamiento crítico (I): introducción. Revista Eureka sobre Enseñanza y Divulgación de las Ciencias, Puerto Real, v. 10, n. 1, p. 1-10, 2013a. Disponible en: <http://roderic. uv.es/handle/10550/34997>. Acceso en: 23 out. 2015.

SOLBES, J. Contribución de las cuestiones socio-científicas al desarrollo del pensamiento crítico (II): ejemplos. Revista Eureka sobre Enseñanza y Divulgación de las Ciencias, Puerto Real, v. 10, n. 2, p. 171-181, 2013b. Disponible en: <http://roderic. uv.es/handle/10550/34992>. Acceso en: 23 out. 2015.

SOLBES, J. Les empremtes de la ciència. Ciència, tecnologia, societat: unes relacions controvertides. Alzira: Germania, 2002.

SOLBES, J.; TORRES, N. Y. Analisis de las competencias de pensamiento crítico desde el aborde de las cuestiones sociocientíficas: un estudio en el ámbito universitario.

Didáctica de las Ciencias Experimentales y Sociales, Valencia, n. 26, p. 247-269, 2012. Disponible en: <http://roderic.uv.es/handle/10550/25687>. Acceso en: 23 oct. 2015.

SOLBES, J.; TORRES, N. Y. ¿Cuáles son las concepciones de los docentes de ciencias en formación y en ejercicio sobre el pensamiento crítico? Tecné, Episteme y Didaxis, Bogotá, n. 33, p. 61-85, 2013. Disponible en: <http://roderic.uv.es/ handle/10550/35214>. Acceso en: 23 oct. 2015.

SOLBES, J.; VILCHES, A. STS interactions and the teaching of physics and chemistry, Science Education, New York, v. 81, n. 4, p. 377-386, 1997. Disponible en: <http:// roderic.uv.es/handle/10550/36290>. Acceso en: 23 out. 2015.

TIPLER, P. A. Física moderna. Barcelona: Reverté, 2003.

VOLPI, J. En busca de Klingsor. Barcelona: Seix Barral, 1999.

YARNOZ, C.; YOLDI, J. Los informes secretos del accidente nuclear de Madrid. El País, Madrid, 24 oct. 1994. Disponible en: <http://elpais.com/diario/1994/10/24/ sociedad/782953223_850215.html>. Acceso en: 23 oct. 2015.

WALKER, M. La Física bajo el tercer Reich. Mundo científico, Barcelona, n. 145, p. 324-332, 1994.

WEISSKOPF, V. F. La física en el siglo XX. Madrid: Alianza, 1990.

WIKIPEDIA: La enciclopedia libre. Energía de enlace nuclear, [S.1.], [2015]. Disponible en: <https://es.wikipedia.org/wiki/Energ\%C3\%ADa_de_enlace_nuclear >. Acceso en: 23 oct. 2015.

WINNER, L. La ballena y el reactor. Barcelona: Gedisa, 1987. 


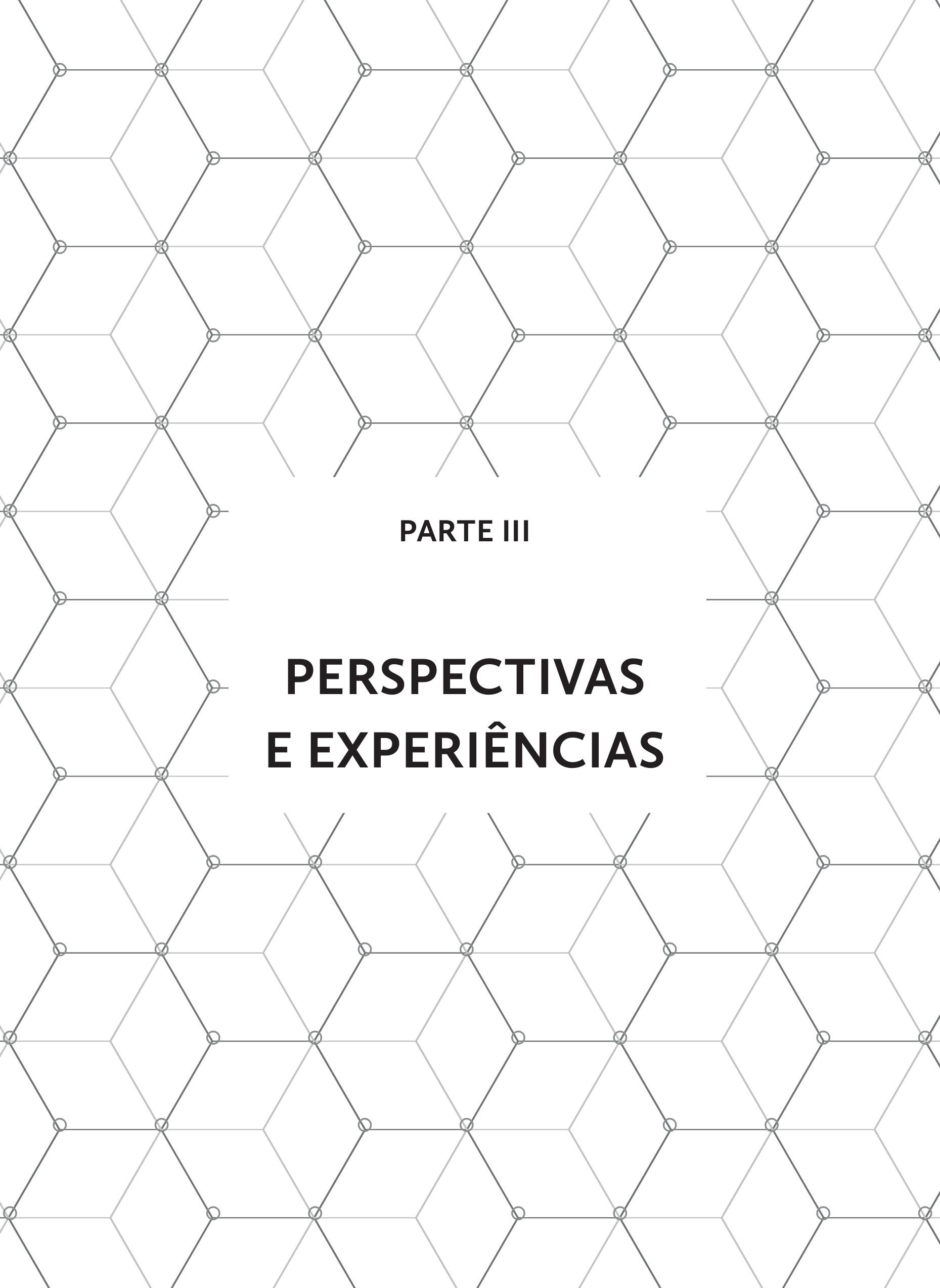




\title{
GRUPOS COLABORATIVOS PARA CONSTRUÇÃO E APLICAÇÃO DE QUESTÕES SOCIOCIENTIIFICAS NA EDUCAÇÃO BÁSICA POSSIBILIDADES E DESAFIOS
}

\author{
Ana Paula Miranda Guimarães \\ Anna Cássia Sarmento \\ Cássia Regina Reis Muniz \\ Charbel N. El-Hani
}

\section{Introdução}

O modo predominante de ensinar ciências na educação básica não tem acompanhado a dinâmica social contemporânea, fortemente influenciada pelo desenvolvimento científico e tecnológico. (MUENCHEN; AULER, 2007) Os assuntos relativos à ciência e à tecnologia ainda têm sido abordados de modo fragmentado, em disciplinas separadas e mesmo no interior da mesma disciplina. A ênfase ainda tem recaído, em termos gerais, sobre a memorização de conceitos científicos desarticulados dos contextos sociais e políticos de sua produção e da realidade na qual os estudantes vivem e desenvolvem suas atividades cotidianas. Quando o ensino de ciências é conduzido desse modo, os assuntos de ciência e tecnologia terminam por não se constituírem num campo fértil para a promoção de questionamentos que possibilitem, ao estudante, desenvolver uma visão 
da ciência como uma construção social, cultural e histórica e tampouco uma capacidade de atuar como cidadão crítico, capaz de realizar ações sociopolíticas.

Ao assumir que um processo educativo deve ter como um de seus objetivos a formação de cidadãos, é importante explicitar o que se entende por "cidadão". Estamos assumindo aqui uma visão de que a cidadania requer participação política, ativismo e engajamento cultural. Trata-se de ser um cidadão global e, ao mesmo tempo, um agente social responsável. (GIROUX, 2004) Nesses termos, ser um cidadão implica ser capaz de engajar-se em diálogo crítico com o passado; entender as relações de poder na sociedade e interpretá-las criticamente; ser ativo e crítico nas esferas locais, nacionais e globais, entendendo as relações entre elas; ser capaz de reconhecer forças que minam a justiça social, econômica e política tanto local quanto globalmente (GIROUX; GIROUX, 2006); e tomar decisões visando não somente o bem individual, mas também coletivo. (SANTOS; MORTIMER, 2001)

Entre as alternativas para a construção de uma educação capaz de promover o desenvolvimento da cidadania para realizar ação sociopolítica (HODSON, 2004), temos os currículos centrados nas relações Ciência, Tecnologia, Sociedade e Ambiente (CTSA), que apresentam o potencial de promover uma melhor compreensão da ciência e da tecnologia, de seus aspectos históricos e sociais e de suas relações com a sociedade e o ambiente. Outra alternativa é o uso de Questões Sociocientíficas (QSC), as quais, embora entendidas por autores, como Zeidler e colaboradores (2005), como se situando para além dos currículos Ciência, Tecnologia e Sociedade (CTS), podem ser entendidas, no contexto latino-americano, como intimamente relacionadas a estes currículos. ${ }^{1}$ Propostas curriculares de ciências têm sido desenvolvidas na perspectiva de fomentar entre os estudantes a compreensão das relações CTSA, introduzindo QSC com o objetivo de orientá-los na construção de conhecimentos que possam ser usados na tomada de decisão socialmente responsável acerca de problemas do cotidiano. (SANTOS; MORTIMER, 2001)

É importante direcionar tais práticas de ensino para a aprendizagem de conteúdos conceituais, procedimentais e atitudinais. De acordo com Zabala (1998), esses três tipos de conteúdos estão relacionados às seguintes perguntas:

1 Zeidler e colaboradores (2005) argumentam que a educação CTS não está, como "tipicamente" concebida e praticada, inserida num quadro sociológico ou desenvolvimental coerente, capaz de considerar o desenvolvimento psicológico, epistemológico e do caráter e da virtude do estudante de modo explícito. Os objetivos dos currículos CTS são, em sua visão, aumentar o interesse dos estudantes ao colocar conteúdos científicos dentro de um contexto social. Em contraste, a abordagem das QSC tem objetivos mais amplos, uma vez que, mais do que prover um contexto para a aprendizagem de ciências, busca estimular e promover o desenvolvimento intelectual do estudante no que tange à sua moralidade e ética, bem como à compreensão da interdependência entre ciência e sociedade. Estes autores estão se referindo ao movimento CTS no contexto dos países anglo-saxões e seus comentários críticos, bem como a contraposição com as QSC, não se aplicam a vários desenvolvimentos dos currículos CTSA no contexto latino-americano, no qual muitas propostas não se limitam a prover contexto para a aprendizagem de ciências, mas se ocupam de dimensões não somente éticas e morais, mas também sociopolíticas das relações CTSA, com ênfase, inclusive, sobre a natureza de tais relações no Brasil e na América Latina. (LINSINGEN, 2007; SANTOS, 2012; SANTOS; MORTIMER, 2002) 
- o que se deve saber?

- o que se deve saber fazer?

- $\quad$ o que se deve ser?

A primeira pergunta se relaciona aos conceitos e princípios, ambos abstratos. A segunda tem relação com regras, técnicas, métodos, destrezas ou habilidades, estratégias, procedimentos do fazer ciência. A última está relacionada ao desenvolvimento de valores e atitudes, assim como à aprendizagem de normas.

A integração de QSC na educação tem o potencial de criar condições para o desenvolvimento da cidadania dos estudantes, entendida como exposto acima, porque favorece o estabelecimento de uma relação mais estreita entre ciência escolar, vida cotidiana e contexto social em que eles vivem, bem como o compartilhamento de suas ideias, experiências, exploração de valores e atitudes. Possibilita, também, que eles avaliem os avanços da ciência, em termos de vantagens e desvantagens para suas vidas individuais e da coletividade, além de favorecer o desenvolvimento de habilidades de tomada de decisão, mobilizando conhecimentos sobre ética. (GUTIEREZ, 2015) Nessa perspectiva, podem ser criadas condições para que os estudantes desenvolvam o potencial de serem participantes responsáveis nas mudanças da sociedade. (BOSSÉR et al., 2015)

Neste capítulo, discutimos o papel do trabalho colaborativo de professores-investigadores da educação básica e pesquisadores universitários na construção e na aplicação de QSC na educação básica, assim como características de inovações educacionais, utilizando QSC, além de apontar possibilidades para superação dos desafios que a aplicação delas traz para professores deste nível de escolaridade. Na próxima seção, faremos uma discussão acerca da importância do trabalho educacional em grupos colaborativos para o desenvolvimento de inovações educacionais e como forma de diminuir a lacuna pesquisa-prática. Em seguida, trataremos de possibilidades de superação dos desafios enfrentados pelos professores para a implementação de inovações educacionais, utilizando QSC. Posteriormente, apresentaremos argumentos presentes na literatura que apontam formas de escolher boas QSC. Apresentaremos, então, o referencial teórico-metodológico que tem apoiado as nossas pesquisas sobre construção e investigação de inovações educacionais, na forma de Sequências Didáticas (SD), a pesquisa de design educacional (design research). Por fim, sugerimos alguns princípios de design que acreditamos ser fundamentais para a construção de uma SD baseada em QSC.

\section{Grupos colaborativos e lacuna pesquisa-prática}

Em nosso entendimento, as inovações educacionais que utilizam QSC podem ser melhor desenvolvidas e investigadas em grupos colaborativos que reúnam professores-pesquisadores da educação básica e pesquisadores universitários. Esta heterogeneidade de sujeitos e saberes traz contribuições importantes para a construção da prática peda- 
gógica e para a pesquisa educacional, proporcionando suporte teórico, metodológico e afetivo para a construção de uma prática inovadora dentro do sistema educacional.

Almeida, Sepúlveda e El-Hani (2013) identificaram as condições necessárias para a constituição de um grupo colaborativo:

- ausência de hierarquia das posições dos sujeitos dentro do grupo;

- formação heterogênea e diversidade de opiniões;

- $\quad$ posse de metas compartilhadas;

- apoio mútuo;

- sentimento de pertencimento a um todo comum;

- relações significativas e afetivas entre seus membros.

Numa perspectiva de colaboração na construção e na investigação de práticas educacionais, objetiva-se compartilhar saberes e experiências entre os diferentes sujeitos, visando o desenvolvimento de inovações educacionais e a pesquisa educacional. Todos estes processos envolvem a integração de saberes tácitos e saberes teóricos e metodológicos de professores-pesquisadores e pesquisadores universitários, buscando-se a construção de inovações e o desenvolvimento de pesquisa educacional com rigor e legitimidade, tanto da perspectiva da pesquisa, quanto da prática, tendo na devida consideração o saber docente e o contexto de sala de aula.

Numa pesquisa colaborativa, deve ocorrer ampla interação entre pesquisadores universitários e professores-pesquisadores da educação básica, com possíveis posições hierárquicas desses atores se encontrando sempre sob uma atenção crítica. O pesquisador universitário não atua nessa pesquisa como um orientador e os professores da escola não são meros executores. É imprescindível que ocorra um trabalho coletivo e interativo, no qual todos sejam importantes e possuam direito à fala e à influência nas decisões. Este modelo de pesquisa é defendido por muitos autores que ressaltam a escola como produtora de conhecimento e participante ativa da pesquisa educacional, na qual deve atuar de uma perspectiva crítica. (ANDRÉ, 2001; HARGREAVES, 1999; EL-HANI; GRECA, 2011; ZEICHNER, 1998)

É claro que a participação em grupos colaborativos não implica necessariamente o engajamento dos professores da educação básica no processo de pesquisa. Eles podem participar, auxiliando no processo de construção e implementação da intervenção, o que contribui para a melhoria da sua prática pedagógica e seu desenvolvimento profissional, ao mesmo tempo em que contribui para a pesquisa. Contudo, na nossa visão e experiência, um dos caminhos para o sucesso e a melhoria do ensino é a participação desses professores em grupos colaborativos no processo de pesquisa, como professores-pesquisadores.

A pesquisa colaborativa traz grandes vantagens para os professores da educação básica, como temos constatado em nossa experiência, incluindo a experiência das três 
primeiras autoras do presente artigo que são professoras-pesquisadoras. Entre estas vantagens, temos o estímulo para a prática pedagógica, o empoderamento, o desenvolvimento profissional, a melhora da autoestima, a diversificação das atividades, a melhoria da infraestrutura material da escola a partir da obtenção de financiamentos, entre muitas outras. A existência de vantagens pode parecer estranha e até controversa, pois pesquisar é um processo complexo, que demanda tempo, bastante esforço e até gera, algumas vezes, gastos monetários. Contudo, mesmo com estes aparentes fatores negativos, pesquisar é uma ação extremamente vantajosa e promissora para os professores da educação básica. Para além de nossa experiência com o trabalho colaborativo de pesquisa, outros trabalhos dão suporte a tais afirmações, como mostra o caso Rosa, analisado por Villani, Freitas e Brasilis (2009). Nesse trabalho, apresenta-se como a professora Rosa desenvolve pesquisa e reflexão das suas aulas de biologia, com rigor teórico e metodológico, juntamente com um grupo colaborativo, discutindo-se vantagens para sua prática docente, como aquelas mencionadas acima.

No estado da Bahia, existem três grupos colaborativos em que os autores deste artigo estão envolvidos, sendo também exemplos bem-sucedidos, em pesquisa em ensino de ciências e biologia. Estes grupos integram professores-pesquisadores da educação básica e pesquisadores universitários e buscam alcançar as condições necessárias para que se constituam efetivamente como grupos colaborativos. Entre estes grupos, temos:

- Grupo Colaboração em Pesquisa e Prática em Educação Científica (CoPPEC) ${ }^{2}$ (ALMEIDA; SEPÚLVEDA; EL-HANI, 2013; SEPÚLVEDA et al., 2012);

- Grupo Colaborativo de Pesquisa em Ensino de Ciências (GCPEC); ${ }^{3}$

- Grupo de Pesquisa em Ensino de Ciências e Inovações Educacionais (Encine). ${ }^{4}$ (FIGUEIREDO et al., 2016) ${ }^{5}$

Foi a partir das experiências, convivências e pesquisas realizadas nesses grupos que identificamos as vantagens citadas acima, proporcionadas pela realização de pesquisa colaborativa por professores da educação básica.

2 O CoPPEC é um grupo colaborativo que desenvolve uma prática social de pesquisa colaborativa por meio da investigação de inovações educacionais, construídas como SD implementadas no contexto real de ensino. (ALMEIDA, 2014)

3 O GCPEC é um grupo colaborativo que tem como objetivo desenvolver e investigar inovações educacionais para o ensino fundamental e médio de ciências, por meio de trabalho colaborativo entre professores da educação básica, pesquisadores da universidade e alunos da licenciatura, além de promover a formação e o desenvolvimento profissional de professores no âmbito da pesquisa colaborativa.

4 O Encine é um grupo colaborativo que tem como foco a prática social de pesquisa colaborativa situada em sala de aula, com o intuito de construir, implementar e investigar inovações educacionais.

5 Alguns integrantes desses três grupos participam, concomitantemente, de mais de um grupo. 
Por fim, a pesquisa colaborativa tem sido proposta como um meio de superar a lacuna pesquisa-prática e promover o desenvolvimento profissional docente. (EL-HANI; GRECA, 2011, 2013) Por "lacuna pesquisa-prática", entende-se o fato de que a maioria dos atores envolvidos no sistema educacional não faz uso dos conhecimentos e avanços produzidos pela pesquisa educacional. Quando o professor da educação básica é integrante de grupos colaborativos, ele se aproxima da pesquisa acadêmica e, mais do que isso, pode participar de modo legítimo destas. Desse modo, o conhecimento acadêmico pode chegar às escolas por meio desses professores, que podem ter o papel de ampliar e disseminar esse conhecimento para os outros membros da comunidade escolar, transformando a escola num espaço privilegiado de produção de conhecimento.

\section{Desafios da implementação de inovações educacionais utilizando QSC e maneiras de superá-los}

A implementação de estratégias didáticas inovadoras, utilizando QSC numa abordagem curricular CTSA, enfrenta, no contexto da educação básica, alguns desafios dignos de nota. Um dos primeiros desafios que temos visto nos espaços escolares nos quais lecionamos é a grande resistência que uma parte dos professores apresenta em relação às inovações educacionais. ${ }^{6}$ Essas resistências são descritas na literatura sobre ensino, como podemos ver, por exemplo, nos trabalhos de Carbonell (2002), Veiga (2003), Garcia (2009), Santos e Mortimer (2009), dentre outros.

Para Veiga (2003), as inovações educacionais regulatórias, impostas de fora para dentro, sem a participação ativa dos professores e desconsiderando o contexto particular de cada escola, são condenadas ao fracasso, uma vez que se constituem em prescrições descontextualizadas, as quais o professor é obrigado a implementar, muitas vezes sem nenhuma motivação. Diante desse tipo de "inovação" (que aqui colocamos entre aspas por não ser uma inovação de acordo com o conceito construído pelo CoPPEC ver nota 6), os professores desenvolvem resistências difíceis de serem superadas. Em contrapartida, Veiga (2003) propõe inovações emancipatórias, que garantam a autonomia e o protagonismo dos professores e das escolas. Esta autora argumenta que, para uma inovação alcançar sucesso, precisa ser planejada e implementada pelos atores do processo educacional, atendendo às necessidades particulares do contexto escolar no qual é desenvolvida. Esse modo de implementar uma inovação tem grande potencial de romper as resistências dos professores, porque tem como principal fator motivador

6 Adotamos, neste trabalho, o conceito de inovação educacional construído ao longo de discussões do grupo CoPPEC: "processos intencionais, sistemáticos e participativos de produção, recontextualização e disseminação de novidades, que tenham a capacidade de promover o desenvolvimento do potencial da comunidade escolar, em termos pessoais, sociais e intelectuais. Entende-se como novidade tudo aquilo que, até então, não fazia parte da prática pedagógica da comunidade escolar". (SOUSA; MUNIZ; SARMENTO, 2016, p. 118) 
a valorização do conhecimento docente na resolução de problemas educacionais complexos vividos por eles.

Outra perspectiva que julgamos importante para minimizar resistências dos professores às inovações educacionais é o trabalho colaborativo entre pares e com estudantes de graduação, pós-graduação e pesquisadores das universidades. É justamente a formação de grupos colaborativos, como discutido na seção anterior, que nos tem conduzido na implementação de experiências de sucesso na construção de inovações de nossas práticas pedagógicas.

Könings, Brand-Gruwel e Van Merriënboer (2007) apontam que algumas condições, em quatro níveis, devem ser observadas quando professores tentam implementar uma inovação educacional, tais como:

- o design educacional, pois geralmente não há interação entre aqueles que planejam as inovações e os professores;

- a escola, uma vez que os professores, na maioria das vezes, trabalham sob condições especiais, como salas muito cheias e materiais didáticos e design das salas de aula inadequados - podemos acrescentar, ao nível escolar, problemas relativos à violência, ao saneamento básico, à estrutura física da escola e à carência de recursos tecnológicos;

- os estudantes, pois sua capacidade de desenvolver as tarefas e aprender influenciam de forma preponderante a escolha e o sucesso das inovações; e

- as próprias competências dos professores, uma vez que é preciso que eles possuam e acreditem que possuem as habilidades necessárias para a implementação da inovação, tendo uma expectativa positiva em relação ao seu resultado no contexto no qual trabalham.

A esta última condição, acreditamos ser imprescindível agregar a formação continuada, a participação em grupos colaborativos e a prática da pesquisa, com as quais os professores têm maiores chances de melhorar suas práticas pedagógicas e ampliar suas habilidades para proposição e implementação de inovações.

Particularmente, em relação ao desenvolvimento e à implementação de inovações educacionais utilizando QSC, um grande desafio a ser enfrentado pelos professores é a superação da ideia da necessidade de vencer os programas curriculares, dando conta de um excesso de conteúdos. Neste sentido, Carvalho, Nunes-Neto e El-Hani (2011) estimaram que, ao longo do ensino médio, propõe-se que os estudantes aprendam (memorizando) quase 3.300 conceitos novos.

Em estudo realizado por Santos e Mortimer (2009), os professores afirmaram que uma grande dificuldade para o desenvolvimento de estratégias didáticas usando QSC decorre da carga horária destinada para as disciplinas científicas. O que percebemos, em nossas práticas pedagógicas, é uma estrutura curricular que privilegia um excesso de conteúdo a ser trabalhado numa carga horária pequena. Se os professores não co- 
locarem sob um olhar crítico a quantidade de conteúdos propostos para o trabalho em sala, isso representará, sem dúvida, uma grande dificuldade para uma abordagem QSC, a qual demanda mais tempo escolar para ser desenvolvida adequadamente. Nesse sentido, precisamos ressaltar que, ao implementar uma inovação na educação básica, há necessidade de investir tempo para explicar o novo método ao estudante, assim como tempo em sala de aula deverá ser usado para que os estudantes desenvolvam atividades com as quais não estão familiarizados, por não serem comuns num ensino que ainda é predominantemente transmissivo, tais como: leitura de textos científicos, pesquisas em jornais e revistas, discussões argumentativas, levantamento e resolução de problemas, avaliações diversificadas etc. Somado a isso, há o tempo destinado à sistematização do conteúdo teórico pelo professor. A construção dessa sistematização pelos próprios estudantes, a partir das atividades desenvolvidas em sala de aula, demanda um esforço cognitivo que, muitas vezes, não se apresenta em consonância com a experiência dos estudantes da educação básica. Além disso, não é plausível assumir que os estudantes lograrão, a partir da discussão de QSC ou do engajamento em outras metodologias ativas de aprendizagem, um grau de sistematização do conhecimento científico que foi alcançado ao longo de décadas ou mesmo séculos. Desse modo, é imprescindível que o professor se dedique à sistematização do conhecimento mobilizado pelas QSC. A alocação de tempo escolar para essas atividades demandará a liberação de tempo anteriormente destinado a outras tarefas, sendo necessário, então, repensar a quantidade de conteúdo que se poderá abordar no ano letivo.

Nessa mesma dimensão didática, os professores encontram outro desafio, que é o tempo para o planejamento das aulas. (SANTOS; MORTIMER, 2009) Desenvolver abordagens utilizando QSC requer mais tempo de dedicação para o planejamento e a construção das SD, para pesquisa e seleção de textos de divulgação científica relevantes para o trabalho com as QSC em sala e também para a elaboração de material didático empregado, quando necessário. Nesse caso, para otimizar o tempo, a solução é a busca de materiais já produzidos de forma a adaptá-los ao novo contexto. Consideramos também importante que estes materiais sejam oriundos de pesquisa educacional colaborativa, ou seja, construídos, implementados e avaliados por meio de pesquisa sistemática envolvendo professores. O engajamento em grupos colaborativos também diminui o ônus em relação à produção desses materiais, uma vez que todo o processo de produção da intervenção educacional é realizado em conjunto e há uma memória do grupo colaborativo, que pode ser acessada por seus membros. ${ }^{7}$

Um outro problema enfrentado pelos professores é o isolamento no qual geralmente se encontram nos seus locais de trabalho, sendo inexistente, na maioria das vezes, o trabalho colaborativo. Garcia (2010) aponta que o isolamento dos professores se dá em decorrência da própria arquitetura das escolas e a estrutura dos horários escolares.

7 No que diz respeito à nossa experiência, os materiais utilizados nas SD com as quais temos trabaIhado são disponibilizados na plataforma Bioemrede: <http://www.bioemrede.ifba.edu.br>. 
A organização curricular também favorece tal isolamento. (ANDRÉ et al., 2010) Isso dificulta a implementação de inovações educacionais utilizando QSC, uma vez que estas questões apresentam caráter multidisciplinar. No estudo realizado por Santos e Mortimer (2009), os professores apontaram que a ausência de uma equipe integrada nas escolas é um fator que dificulta o uso de QSC. Um trabalho colaborativo pode dar conta dessa limitação, caso os professores envolvidos tenham formações diversas, o que possibilita a troca de saberes e experiências entre os pares, dando-lhes mais segurança no uso de QSC.

Numa dimensão pedagógica, Reis e Galvão (2008) colheram evidências de que um grande desafio a ser superado pelos professores, a fim de que possam desenvolver abordagens didáticas usando QSC, é o pouco conhecimento que eles apresentam acerca dos aspectos políticos, sociológicos e éticos de tais questões. Esse problema, que tem origem no processo de formação inicial e continuada dos professores, faz com que eles fiquem inseguros para abordar tais questões em sala, uma vez que os estudantes podem trazer questionamentos que eles não sabem como responder. (SANTOS; MORTIMER, 2009) Santos e Mortimer (2009) encontraram que professores menos experientes apresentam dificuldade de explorar diferentes pontos de vistas dos estudantes, de aprofundar questões vividas pelos mesmos, de mobilizar a turma inteira para as discussões das QSC e, nestas, de desenvolver explicações dos conceitos científicos da ciência escolar. O trabalho colaborativo entre professores de diversas formações é também um meio de enfrentar esses limites, uma vez que, além da troca constante de conhecimentos e experiências, as discussões também contribuem para resolver dúvidas entre profissionais de diversas áreas.

Além disso, é importante apontar a necessidade - que cabe, em boa parte, às universidades - de melhorar a qualidade da formação dos professores da educação básica, tanto inicial como continuada, a fim de possibilitar o desenvolvimento de bons profissionais, capazes de lidar com os desafios inerentes ao trabalho docente. Em nosso entendimento, é importante que essa formação invista em três aspectos fundamentais:

- qualificação relacionada aos conhecimentos científicos necessários para o ensino de conteúdos de uma área específica;

- formação pedagógica, relacionada às habilidades que o professor precisa desenvolver para uma prática docente sistematizada;

- formação ética e política, relacionada à habilidade de promover uma educação a partir de valores morais e políticos, numa perspectiva de construção de um mundo melhor, pensando nos bens coletivos. (ARANHA, 1996)

Em vista de seu papel no desenvolvimento profissional dos professores da educação básica (e, não devemos esquecer, também dos pesquisadores educacionais), o engajamento em grupos colaborativos propicia uma via relevante de formação continuada do professor. Ele possibilita que os professores participem, como pares que trazem con- 
tribuições fundamentais, do processo de produção de conhecimento legítimo com potencial de solucionar problemas reais da prática educacional. A interação permanente entre escolas e universidades, incluindo a formação de grupos colaborativos (mas não se limitando a isso, já que há muitas outras formas também produtivas de interação), tem o potencial de melhorar a formação científica, pedagógica, ética e política dos professores e de diminuir a lacuna pesquisa-prática, contribuindo para o aprimoramento tanto da pesquisa educacional quanto da qualidade do ensino.

\section{Como escolher boas QSC}

Discutimos, acima, as contribuições e os desafios do uso de QSC em sala de aula, em $\mathrm{SD}$, visando à compreensão das relações CTSA. Adicionalmente, é importante refletir sobre alguns pontos-chave neste tipo de abordagem: como escolher uma QSC? Qual a melhor QSC para ser trabalhada numa dada sala de aula? Será que um professor pode replicar o planejamento de outro professor para o uso de QSC?

Em alguns trabalhos, como os de Sadler, Barab e Scott (2007) e Tal e colaboradores (2011), encontramos argumentos a favor de que o ensino de ciências, utilizando QSC, deva ser fundamentado num processo de negociação e envolvimento autêntico dos estudantes no processo de decisão. Contudo, no que se refere à escolha de uma QSC para abordagem em sala de aula, é comum que haja um planejamento prévio do professor ou de um grupo de professores, de forma que, nas aulas, ou seja, situações reais de ensino sejam usadas estratégias visando uma articulação entre os conhecimentos da ciência escolar e aspectos que fazem sentido para os estudantes. (FEIERABEND; EILKS, 2010; MARKS; EILKS, 2009; SADLER, 2011; SANDRI; SANTIN-FILHO, 2014) Entretanto, é possível que seja oferecida aos estudantes a opção de escolher as QSC ou que esta escolha seja proveniente de um diálogo, envolvendo todos os atores do processo. Todas estas formas apresentam vantagens e desvantagens, sendo que o mais importante é que o tema esteja relacionado à realidade do estudante e desperte o seu interesse.

Marks e Eilks (2009) indicam que as características fundamentais de uma QSC promissora são:

- autenticidade;

- relevância direta para a vida cotidiana;

- caráter aberto em relação aos questionamentos da sociedade;

- $\quad$ ser passível de discussão aberta em fóruns públicos; e

- ter uma relação clara com a ciência e a tecnologia.

Estes critérios são detalhados, discutidos e exemplificados com QSC nos trabalhos de Marks e colaboradores (2014) e Stolz e colaboradores (2013). 
Entre os pesquisadores que se dedicam ao assunto, há um consenso de que as QSC devem ser reconhecidas pelos estudantes, ou seja, relevantes para eles, vinculadas a problemas de suas vidas reais, mesmo que o professor não esteja seguro sobre qual seria sua solução. (MARKS; EILKS, 2009; PATRONIS; POTARI; SPILIOTOPOULOU, 1999; PEDRETTI, 1997; RAMSEY, 1993; SADLER, 2004) Incentivar que os estudantes tragam à tona ou desenvolvam relações pessoais com os temas discutidos potencializa sua capacidade de justificar suas reivindicações, entender e lidar com opiniões contraditórias e, principalmente, contribuir para formar cidadãos capazes de exercitar sua criticidade e de engajar-se em ações sociopolíticas. O caráter controverso que as QSC tipicamente apresentam também implica outra potencialidade importante, a de que ocorra um debate ético sobre posicionamentos, juízos de valores morais, comportamentos, julgamento e razões para avaliar determinados aspectos ou situações como certos ou errados. (CONRADO; EL-HANI; NUNES-NETO, 2013; HODSON, 2013; ZEIDLER et al., 2005)

Não basta apenas o professor sozinho escolher aleatoriamente um problema sociocientífico, sem identificar os interesses dos seus estudantes e sem ter na devida conta o contexto atual e a realidade da comunidade escolar. Também, não será o livro didático a fazer a escolha pelo professor, já que o livro, muitas vezes, não possui relação com o contexto local no qual a escola se encontra e, por vezes, nem mesmo com problemas globais que possam afligir a comunidade escolar. Não é interessante, ainda, que o professor simplesmente repita um planejamento que porventura encontre em algum livro, artigo científico ou texto de divulgação científica, sem analisar seu valor e interesse na realidade em que atua e sem fazer as devidas e necessárias adaptações. Assim, é importante que o professor seja capaz de avaliar o quanto uma QSC pode ser relevante e interessante para o contexto no qual ele a implementará.

Consideremos, por exemplo, um trabalho realizado com estudantes de Taiwan, no qual a QSC escolhida para ser trabalhada em sala de aula dizia respeito ao uso de energia nuclear e levou a resultados positivos de engajamento e aprendizagem do conteúdo com os estudantes. (WU; TSAI, 2011) Será que os mesmos resultados seriam conseguidos se esta QSC fosse aplicada em uma escola de uma cidade na qual não há usinas de energia nuclear, mas na qual há indústrias poluidoras que utilizam outras fontes de energia? Provavelmente, ela não seria tão interessante e motivadora para estes estudantes como o foi para os estudantes de Taiwan, em que existem três usinas em operação e a construção de uma quarta usina está atualmente em discussão. Para os estudantes da cidade hipotética que descrevemos acima, o debate e a reflexão sobre outras QSC teriam maior relevância.

A partir das discussões que travamos até aqui, sugerimos uma proposta de como trabalhar e organizar SD, usando QSC, com base nos referenciais teórico-metodológicos da pesquisa de design educacional (design research), como passaremos a discutir na próxima seção. 


\section{Pesquisa de design educacional e estudos de desenvolvimento}

Uma das questões debatidas na comunidade científica dedicada à pesquisa sobre ensino de ciências diz respeito ao envolvimento do professor na pesquisa educacional. (ANDERSON; HERR, 1999; LÜDKE et al., 2001) A aproximação entre a pesquisa e a prática docente ganhou notoriedade desde os estudos de Dewey (1933), que colocava o professor como produtor de conhecimento legítimo, e não apenas como mero consumidor de conhecimento oriundo do meio acadêmico. Contudo, a validade da pesquisa docente tem sido constantemente colocada em questão, gerando discussões acerca de critérios de validade que possam dar conta de um tipo de pesquisa que produz conhecimento no contexto específico da prática docente, da perspectiva de seu principal agente, o professor. Outro aspecto relevante diz respeito à possibilidade de transferir resultados da pesquisa feita num contexto da prática para outros contextos de trabalho docente.

Esses aspectos têm sido frequentemente debatidos nos grupos colaborativos de pesquisa e inovação educacional descritos anteriormente, sendo trabalhados dentro dos referenciais teórico-metodológicos da pesquisa de design educacional, que contribui para a superação da lacuna pesquisa-prática, na medida em que foca na investigação do planejamento, da implementação, da avaliação e da manutenção de inovações educacionais no contexto da sala de aula, buscando soluções para problemas reais da prática de ensino. (THE DESIGN-BASED RESEARCH COLLECTIVE, 2003) Estas inovações podem ter a forma de programas, estratégias de ensino e aprendizagem, SD, materiais instrucionais, jogos etc.

A pesquisa de design educacional tem como objetivo ampliar o conhecimento sobre os processos de planejamento e implementação de inovações educacionais em sala de aula, dando ênfase a princípios teóricos subjacentes ao planejamento, que são as características generalizáveis destas intervenções. Tais características são conhecidas como princípios de planejamento ou de design e são concebidas como produtos teóricos da pesquisa de design research, que podem constituir uma teoria de ensino específica para um dado domínio (PLOMP, 2009): por exemplo, o desenvolvimento e o uso de QSC na educação básica. Embora os princípios de design possam ser transferidos de um contexto da prática a outros, o modo como uma inovação educacional baseada neles é implementada numa dada sala de aula é específico para aquele contexto educacional.

Um tipo de estudo que compõem a pesquisa de design educacional é o estudo de desenvolvimento de inovações educacionais (NIEVEEN MCKENNEY; VAN DEN AKKER, 2006), que possibilita a construção e a validação de princípios de design que venham a constituir uma teoria de ensino domínio-específica. Estes estudos envolvem ciclos de testes de diferentes protótipos da inovação educacional em contextos diversos, com modificação de princípios de design e de sua implementação em contextos específicos, após cada ciclo de testes. Além disso, busca-se a cada prototipagem aumentar o número de participantes (professores e estudantes).

A pesquisa de design educacional é realizada por meio de três fases: 
- $\quad$ pesquisa preliminar;

- fase de prototipagem; e

- $\quad$ fase de avaliação. (PLOMP, 2009)

A fase preliminar compreende a avaliação do contexto no qual ocorrerá o estudo, a mobilização do conhecimento docente e a revisão da literatura educacional, os quais possibilitarão a construção de um quadro teórico robusto e a proposição de princípios de design que orientarão a construção da intervenção.

A fase de prototipagem compreende ciclos iterativos de análise, nos quais a intervenção é implementada e avaliada, a fim de identificar a necessidade de melhorias e mudanças nos princípios de design, ou até mesmo a recomendação de novos princípios. O replanejamento da intervenção implica novos ciclos de prototipagem.

A fase de avaliação busca responder se a intervenção satisfez os resultados esperados, ou seja, os objetivos educacionais inicialmente estabelecidos. Ela ocorre após a avaliação de vários protótipos, com refinamento da intervenção e aprofundamento da compreensão de seu planejamento, implementação e resultados. A avaliação final é realizada quando o pesquisador considera ter em mãos uma teoria de ensino domínio-específica.

Ao longo dessas três fases, são feitas reflexões sistemáticas sobre os resultados obtidos em sala de aula, por exemplo, em termos da motivação ou da aprendizagem dos alunos, com a finalidade de refinar a intervenção, modificando-se ou propondo-se princípios, e, ao final, faz-se uma avaliação de todo o processo, visando validar os princípios de design e relacioná-los sistematicamente numa teoria de ensino domínio-específica.

A questão de pesquisa de um estudo de desenvolvimento pode ser formulada nos seguintes termos, segundo Van den Akker (1999, p. 9):

Se você deseja construir uma intervenção $X$ para o propósito/função $Y$ em um contexto $Z$, então é aconselhável prover esta intervenção das características $A, B$ e $C$ [ênfase substantiva] e fazer isso por meio dos procedimentos $K, L$ e $M$ [ênfase procedimental], em razão dos argumentos $P, Q$ e $R$.

O grupo de pesquisa GCPEC, a partir de uma adaptação da formulação de Van den Akker (1999), propôs a seguinte fórmula para enunciar as questões de pesquisa num estudo de desenvolvimento:

Se você deseja construir uma intervenção X para o propósito/função Y em um contexto Z, é aconselhável:

- Adotar a característica A, para o propósito/função y1, realizando o procedimento K, em razão do argumento P;

- Adotar a característica B, para o propósito/função y2, realizando o procedimento L, em razão do argumento Q; 
- Adotar a característica C, para o propósito/função y3, realizando o procedimento $\mathrm{M}$, em razão do argumento $\mathrm{R}$ etc.

Os produtos teóricos da pesquisa de design educacional são generalizáveis, podendo ser transferidos para outros contextos de ensino. As evidências empíricas colhidas no processo de investigação podem também ser generalizadas para outros contextos, numa perspectiva de generalização situada. (SIMONS et al., 2003) De acordo com esta perspectiva, a generalização é entendida como um processo de transformação de dados produzidos num contexto em evidências transferíveis para outros contextos, desde que atores educacionais, como os professores, percebam suficiente similaridade entre seu contexto (situado) de atuação e o contexto em que a pesquisa foi feita. Essas evidências são produzidas a partir da prática docente e são entendidas como informações importantes para a construção da prática pedagógica de outros professores. No contexto de uma pesquisa de design, ao perceberem similaridades entre o contexto de suas práticas e o contexto do estudo, professores podem analisar os argumentos que apoiam o uso dos princípios na construção da intervenção e o potencial dos mesmos para solucionar os problemas da sua prática. Agindo dessa forma, as evidências são incorporadas a julgamentos prévios dos professores, orientando-os para a ação ou indicando um curso de ação. Pode-se construir, assim, uma perspectiva de ensino baseado em evidência, mas na qual a evidência é, ela própria, baseada na prática docente, no âmbito de grupos colaborativos que incluem professores-investigadores.

Contudo, para que um professor tenha informação suficiente sobre o contexto situado em que foi realizada uma pesquisa, é imprescindível que uma descrição densa (GEERTZ, 1973) seja fornecida, por meio de um estudo etnográfico do contexto do estudo. De posse de tal descrição densa, professores podem identificar variáveis contextuais compartilhadas, estabelecer semelhanças com suas situações de ensino e perceber possibilidades de implementar uma dada intervenção em suas salas de aula. (SARMENTO et al., 2013)

\section{Alguns princípios de design para a construção de SD utilizando QSC na educação CTSA}

A partir da literatura e de nossa experiência, formulamos alguns princípios de design para a construção de SD utilizando QSC na educação CTSA, empregando a adaptação, feita pelo GCPEC, da fórmula de Van den Akker (1999). Trata-se de selecionar características iniciais para a construção de SD, visando uma melhor compreensão da ciência e da tecnologia e de suas relações com a sociedade e o ambiente e a formação de estudantes da educação básica para a interpretação crítica da realidade e a ação sociopolítica. A partir destas características iniciais, protótipos de intervenções podem ser construídos e testados em sala de aula, em etapas posteriores de pesquisa. 


\section{Perspectivas inter e transdisciplinar}

Com um enfoque inter e transdisciplinar, podem-se criar condições para que os estudantes desenvolvam uma visão geral e integrada dos conhecimentos necessários a uma discussão informada sobre QSC. Para isso, é necessário o trabalho cooperativo e integrado de professores de diferentes áreas do conhecimento, promovendo debates, projetos ou atividades nos quais hajam interligações e associações entre estes conhecimentos. A principal razão subjacente a este princípio de design reside na natureza complexa e ampla das questões sociocientíficas, que requerem um olhar inter e transdisciplinar e integrado.

Este princípio visa formar os estudantes para que possam compreender e participar de modo informado dos processos de discussão e eventuais soluções de QSC contemporâneas, mobilizando conteúdos científicos de diferentes áreas do conhecimento de modo contextualizado e integrado. Perceber e mobilizar diversas dimensões dos problemas sociocientíficos poderá contribuir para o enriquecimento das perspectivas e dos horizontes dos estudantes.

Um enfoque interdisciplinar permite a integração de objetivos, atividades, procedimentos e planejamentos, visando a troca e o diálogo, em busca de uma articulação dos conhecimentos disciplinares num corpo único de conhecimentos. (CARDOSO et al., 2008; TRESS; TRESS; FRY, 2005) Como comenta Nogueira (1999, p. 26), a interdisciplinaridade pode ser entendida como "o trabalho de integração das diferentes áreas do conhecimento. Um real trabalho de cooperação e troca, aberto ao diálogo e ao planejamento". Este enfoque é importante no trabalho com QSC na perspectiva de uma educação CTSA, porque questões presentes em nossas sociedades atuais que envolvem aspectos científicos e tecnológicos demandam que os cidadãos tenham uma visão global da realidade e compreendam, reflitam e tomem decisões com responsabilidade social, ou seja, visando o bem coletivo, e não somente individual, e isso requer o entendimento de conhecimentos de diferentes áreas, produzidos de modo compartimentalizado e fragmentado ao longo do século XX.

Não se trata, contudo, de desvalorizar as disciplinas e seus conhecimentos, mas sim integrá-los num corpo de conhecimentos que os tornem compreensíveis à luz de uma dada QSC. As especificidades presentes em cada uma das áreas de conhecimento científico são mantidas, mas de maneira a valorizar a conexão entre os diferentes conhecimentos. Além disso, outros conhecimentos que não os científicos também são frequentemente necessários na discussão de uma QSC, sendo importante colocar de lado o cientificismo ${ }^{8}$ e pondo em jogo abordagens transdisciplinares do problema (TRESS; TRESS; FRY, 2005), ou seja, que mobilizem conhecimentos de outros atores sociais. No contexto escolar, isso significa ir além de uma visão disciplinar que pre-

8 Por "cientificismo", entende-se aqui uma posição na qual a ciência é usada para dominar a arena pública como se todos os demais discursos fossem de menor valor. (COBERN; LOVING, 2001) 
domina nos currículos e nas práticas docentes, em busca de uma perspectiva interdisciplinar, que nos leve a transgredir as fronteiras entre os conhecimentos escolares compartimentalizados, e transdisciplinar, que ultrapasse os muros da escola e dos conhecimentos acadêmicos.

Para exemplificar, uma das QSC mais vinculadas e discutidas atualmente na mídia e na escola é o aquecimento global. Mas como compreendê-la e agir a respeito com conhecimentos apenas das ciências naturais, sem considerar, por exemplo, conhecimentos geográficos, políticos e filosóficos? O estudante compreenderá de modo muito mais rico e informado esse problema se os vários aspectos do aquecimento global forem abordados em conjunto, e não mediante o aprofundamento numa única disciplina escolar, de uma perspectiva científica isolada. Ou ainda, pode-se facilmente vislumbrar como a aprendizagem dos estudantes, num trabalho sobre transgênicos em sala de aula, será limitada se eles tiverem acesso apenas a conhecimentos de biologia molecular e genética, mesmo que aprofundados, sem que sejam abordados aspectos éticos, econômicos, sociopolíticos e ambientais. Este é outro assunto que tem atualmente merecido bastante atenção em nosso país, por exemplo, da mídia e tem grande potencial de despertar o interesse dos estudantes, devido ao projeto de lei do governo brasileiro de retirada do símbolo que indica se determinados alimentos são transgênicos.

O enfoque inter e transdisciplinar pode também ser interessante no ponto de vista avaliativo, na medida em que os professores das disciplinas envolvidas na abordagem de uma QSC podem propor uma mesma tarefa aos estudantes, avaliando aspectos relacionados aos diferentes conhecimentos pertinentes. Desta forma, os estudantes terão menos avaliações, o que pode favorecer seu maior comprometimento, assim como uma aprendizagem mais eficaz e integrada. A realização de tal enfoque inter e transdisciplinar pode se dar por meio de projetos estudantis, como discutiremos mais à frente.

\section{Abordagem multicultural crítica}

Com a utilização de uma abordagem multicultural crítica, pode-se promover um ensino que estimule o diálogo entre as culturas representadas na sala de aula e que abarque as diferenças com o potencial de evidenciar interesses e relações de poder e descontruir estereótipos. Para tanto, as QSC devem ser discutidas e interpretadas coletivamente, pela sociedade, entre professores e estudantes, evidenciando-se os diferentes posicionamentos presentes na sociedade sem a adoção de perspectivas cientificistas e discutindo-se valores morais e perspectivas éticas dos diferentes posicionamentos. As razões pelas quais propomos esta abordagem são devidas ao fato de que: 
- a análise das QSC exige a aprendizagem não apenas sobre conhecimentos científicos, mas também sobre aspectos socioculturais, éticos e políticos inerentes a estas questões;

- consequentemente, os conceitos científicos devem adquirir sentido prático para que sejam compreendidos e mobilizados no âmbito de uma QSC, e isso implica interagir com diferentes perspectivas culturais;

- incluir um diálogo entre culturas no tratamento de QSC significa atuar em prol de uma educação inclusiva e que tenha potencial de promover a justiça social e o respeito pela diversidade cultural.

O multiculturalismo crítico, no âmbito escolar, é uma perspectiva voltada à valorização da pluralidade cultural e à superação de estereótipos, preconceitos e hierarquização cultural, motivo pelo qual se tem defendido sua inserção em currículos e práticas pedagógicas. (CANDAU, 2008; MCLAREN, 1997) Canen (2000, p. 136) ressalta que "a perspectiva Multicultural Crítica busca superar visões "exóticas" ou "folclóricas" da diversidade cultural, que a reduzem a aspectos tais como rituais, receitas e costumes de povos diversos". Além disso, é uma proposta de abrir espaço para discursos silenciados em sala de aula, escondidos e ainda vistos como tabus, de pouca importância ou não próprios aos estudantes.

A partir da teoria crítica da Escola de Frankfurt, essa perspectiva questiona as relações desiguais de poder que legitimam certas culturas em detrimento de outras, passando a questionar o contexto social. A partir disso, essa perspectiva crítica assume uma atitude avaliativa e propositiva e não apenas descritiva, concebendo o multiculturalismo não como um dado da realidade apenas, mas como uma maneira de atuar, de intervir, de transformar a dinâmica social. (FIGUEIREDO, 2013) Nesse contexto, a explicitação de valores que fundamentam a ação é essencial para a compreensão e o posicionamento individual e coletivo a respeito das controvérsias relativas às QSC, o que implica dar conta de uma diversidade de valores e perspectivas sobre o mundo representadas na sala de aula, mas sem perder de vista que se trata de ensino de ciências e, portanto, a compreensão da ciência escolar permanece como objetivo precípuo de aprendizagem. (EL-HANI; MORTIMER, 2007)

Hodson (2013), ao discutir algumas implicações curriculares para uma educação científica que vise a realização de ações sociopolíticas, defende uma forma politizada de ensino e aprendizagem, orientada por QSC, que se propõe a influenciar e preparar os estudantes não apenas para discutir QSC, mas também, e principalmente, prepará-los para o engajamento em ações sociopolíticas que possam fazer diferença no processo de transformação da sociedade. Este autor ressalta, ainda, que a probabilidade de os estudantes se tornarem cidadãos ativos é substancialmente aumentada quando tais ações ocorrem na época em que estão na escola. Isso deve ser feito oferecendo-se oportunidades para que os estudantes ajam e dando exemplos de ações e intervenções 
bem-sucedidas de outras pessoas. Eles terão, assim, conhecimento de ações que possam vir a ter impacto positivo e conhecimento de como praticá-las. Isso implica que as QSC não sejam vistas somente como recursos para uso em sala de aula, mas sejam inseridas em projetos, como discutiremos mais adiante, que incorporem a dimensão da ação sociopolítica, dentro dos limites postos para o trabalho em sala de aula e as ações dos estudantes.

Esta proposta de Hodson (2013) para a educação científica está em consonância, em nosso entendimento, com uma abordagem multicultural crítica como princípio de planejamento para o trabalho pedagógico. Isso porque a ação sociopolítica requer negociação pelos estudantes de suas diferentes perspectivas sobre o mundo, de modo que possam vir a atuar como um coletivo.

Outra razão para indicar este princípio para o planejamento de SD, usando QSC, reside no caráter multidimensional destas questões, que envolvem aspectos éticos, políticos, econômicos e culturais, entre outros. Como trabalhar com os estudantes em sala de aula, por exemplo, os impactos ambientais da construção da usina Belo Monte (Pará, Brasil) ou as diferentes alternativas de produção de energia elétrica sem discutir, posicionar-se ou até mesmo tomar conhecimento sobre as comunidades existentes nas localidades afetadas, suas culturas e como a interferência em seus sistemas socioecológicos podem prejudicá-las? Ou, ainda, como tratar de assuntos como natalidade, mortalidade infantil e aborto sem discutir as diferenças de classes sociais e as diferentes culturas existentes em cada localidade, ou ainda, o entendimento de morte e vida de cada povo ou cultura?

$\mathrm{Na}$ maioria dos casos, a escola possui um caráter padronizador, homogeneizador e monocultural, negligenciando, dessa maneira, a possibilidade de uma educação plural, que contemple as diferenças e a diversidade cultural presentes nas sociedades. (CANDAU, 2008) Uma das críticas mais contundentes à educação científica é a de que ela tem marginalizado uma grande parte dos estudantes, especialmente as minorias e as pessoas de culturas não ocidentais. (AIKENHEAD, 1997; COBERN, 1998; HODSON, 1993; PEDRETTI; NAZIR, 2011) Assim, mais uma razão para incorporar a abordagem multicultural crítica como um princípio para a educação CTSA, com a utilização de QSC, reside em seu potencial de ser a ciência mais acessível a um maior número de estudantes e, além disso, dar conta da diversidade de perspectivas representadas na sala de aula. O diálogo entre perspectivas distintas em sala de aula pode ter, além disso, uma consequência particularmente importante no mundo contemporâneo: a criação de condições para que os estudantes compreendam que, não obstante tenham suas maneiras de entender o mundo, é fundamental nutrir uma capacidade de dialogar com outras perspectivas, entendendo que, mesmo que não acreditem nelas, elas são dignas de crença e, assim, é natural que outras pessoas estejam comprometidas com elas. (SMITH; SIEGEL, 2004) 


\section{Pedagogia de projetos ${ }^{9}$}

Assumir a pedagogia de projetos como um princípio de planejamentos fornece bases para que uma educação CTSA usando QSC possa envolver o engajamento dos estudantes em ações sociopolíticas que possam fazer diferença no contexto social em que vivem. Além disso, estimula-se o protagonismo do estudante. Para tanto, a QSC deve estar relacionada à comunidade em que os estudantes estão inseridos e, a partir de sua compreensão e discussão, usando conteúdos científicos ou não científicos, os estudantes podem buscar alguma forma de participação no debate social a seu respeito e, inclusive, em seu enfrentamento, a depender das possibilidades objetivamente colocadas diante da questão. Na medida em que o estudante busca respostas e meios de ação, ele participa ativamente de seu processo de aprendizagem, bem como tem a possibilidade de adquirir conhecimentos que vão além das disciplinas escolares, de forma contextualizada e com mais sentido para a sua vida cotidiana.

A ênfase sobre o protagonismo juvenil se dá, principalmente, por conta da necessidade de promover o desenvolvimento de habilidades, atitudes e valores relacionados à cidadania nos estudantes (FERRETTI; ZIBAS; TARTUCE, 2004), sendo cidadania entendida, no presente trabalho, como explicado acima. Dentro dessa perspectiva de reforma do ensino médio, Rodrigues Anjos e Rôças (2008), por exemplo, consideram que os conteúdos programáticos devem estar atrelados aos temas sociais e, na medida em que essa lógica seja percebida, o trabalho pedagógico ganha uma nova dimensão, no sentido de criar espaço para a reflexão sobre QSC e para novas maneiras de atuação dos docentes e dos estudantes.

Assim, entendemos que uma estratégia que tem grande potencial de promover uma melhor compreensão da ciência e da tecnologia e de suas relações com a sociedade e o ambiente, é a educação através da pesquisa. Ao se engajarem em atividades de pesquisa, os estudantes deixam de ser meros espectadores na sala de aula e tornam-se participantes ativos na construção do seu conhecimento. $\mathrm{O}$ engajamento na atividade de pesquisa abre espaço para um trabalho de investigação que permite formação dos estudantes no que se refere a conteúdos atitudinais e procedimentais presentes nas formas de produção do conhecimento científico. Desta perspectiva, o estudante assume papel ativo na produção do conhecimento, cabendo ao professor o papel de mediador (orientador) deste processo. (GALIAZZI; MORAES, 2002; GÜLLICH, 2007) É importante dar espaço para uma participação ativa dos estudantes em processos de investigação de QSC, que possa implicar seu protagonismo na obtenção de informações e dados, construção de soluções para problemas reais e tomada de decisão socialmente responsável. Ao

9 Os fins previstos para um SD têm relação com as estratégias que os professores irão utilizar para conduzirem o ensino e não com os resultados obtidos a partir da implementação de tais estratégias. Deste modo, a pedagogia de projetos pode ser usada como um princípio de design para o planejamento de SD, uma vez que, num projeto autêntico, o que não pode ter fins preestabelecidos são seus resultados. 
trabalhar com QSC que se situam na interação entre CTSA, podem ser explicitados, discutidos e desenvolvidos valores e ideias por meio de estudos sobre problemas locais, políticas públicas e temas globais. (SANTOS; MORTIMER, 2002)

Como discutem Galiazzi e Moraes (2002), a atividade de pesquisa envolve o questionamento, a argumentação, a crítica e a validação dos argumentos construídos, como alicerces para o ensino e a aprendizagem de ciências. Ainda segundo estes autores, na medida em que o professor reconhece a investigação como um fazer constante da sua prática, a pesquisa acaba sendo entendida como uma dimensão pedagógica, realizada no ambiente das aulas. A educação por meio da pesquisa alia, pois, teoria e prática, num processo reflexivo e dialógico de ensino e aprendizagem (GÜLLICH, 2007), sendo, também, uma estratégia para aprender de forma crítica, participativa e cooperativa, na qual professores e estudantes estão envolvidos na aprendizagem uns dos outros.

A educação por meio da pesquisa permite que os conhecimentos formais das disciplinas escolares sejam aplicados para resolver problemas do cotidiano, no caso que aqui nos interessa, que sejam também QSC. Desta maneira, o conhecimento se torna mais próximo da realidade do estudante e, mais do que isso, criam-se condições para que, ao gerar produtos que proponham possíveis debates e soluções para uma QSC, o aluno entenda qual a utilidade e o poder do conhecimento científico, ao ser usado como meio de interpretar e agir sobre a realidade. Os resultados do projeto podem ser divulgados na forma de debates, cartas para autoridades políticas, palestras, cartilhas, panfletos podem ser disponibilizados para atores sociais, como associações de bairro, cooperativas de produtores, câmaras de vereadores ou deputados, órgãos de comunicação etc. De um modo ou de outro, é muito importante que os resultados dos projetos sobre QSC ultrapassem os muros das escolas, cheguem por alguma via à comunidade extraescolar, de modo que os estudantes entendam o efetivo poder do conhecimento que produziram, o que se perderia se a conclusão do projeto ficasse restrito à escola. Por meio de tal protagonismo engajado em projetos usando QSC, podem-se estimular os estudantes para a participação política, o desenvolvimento de valores cívicos, a responsabilidade socioambiental e atitudes positivas em relação a outras pessoas, em especial, às pessoas que são diferentes de si mesmo, em crenças, atitudes, valores etc.

\section{Uso de textos de divulgação científica}

Com a utilização de Textos de Divulgação Científica (TDCs), pode-se promover a contextualização e a sistematização de QSC no ensino da ciência escolar. Uma estratégia que pode ser usada é a leitura e a discussão, em pequenos grupos de estudantes, de TDC que tenham relação com as QSC. Por razões psicocognitivas e didáticas, os textos devem ser adequados aos contextos de ensino no qual as QSC serão usadas. O uso de TDC é um princípio de design inspirado pela literatura sobre ensino de ciências, que tem discutido seu potencial para a motivação dos estudantes, a promoção de ricos debates 
na sala de aula e a contextualização dos conceitos da ciência escolar em relação aos interesses, às experiências e aos conhecimentos dos estudantes.

A literatura sobre ensino de ciências tem discutido sobre as contribuições do uso de TDC na educação básica, com o objetivo de contextualizar os conteúdos da ciência escolar. (MARTINS; NASCIMENTO; ABREU, 2004; MELO; HOSOUME, 2003) Uma característica dos TDC que nos levam a propor esse princípio de design é o gênero de discurso que eles utilizam, mais semelhante ao modo de falar dos estudantes na sua vida cotidiana do que o gênero presente em outros textos, como, por exemplo, o livro didático. (LOIOLA; ZANCUL; BIZERRIL, 2013) Assim, os TDC têm potencial de auxiliar o desenvolvimento do discurso da ciência escolar em sala de aula e de facilitar a aprendizagem de conteúdos científicos que possam ser usados na discussão e na resolução de QSC. Estudos realizados por Martins, Nascimento e Abreu (2004), sobre o uso de TDC na educação básica, apontaram que eles podem trazer benefícios para o processo de ensino e aprendizagem, por apresentarem diferentes argumentos sobre temas recentes da ciência e da tecnologia de forma contextualizada, em relação ao cotidiano das sociedades contemporâneas. Usando TDC, pode-se, ainda, situar a construção contemporânea do conhecimento científico e tecnológico no contexto social, histórico, econômico e tecnológico que os estudantes vivenciam.

O CoPPEC tem utilizado, com sucesso, esses instrumentos de divulgação da ciência na construção de inovações educacionais (GUIMARÃES et al., 2103; MUNIZ et al., 2012; SÁ et al., 2015; SARMENTO et al., 2011, 2013), como estratégia para contextualizar os conceitos da ciência escolar e estimular a participação dos estudantes. (NASCIMENTO; ALVETTI, 2006) Temos verificado em nossos estudos, deste modo, que os TDC de fato auxiliam no ensino e na aprendizagem de ciências, apresentando grande potencial de promover ricos debates sobre QSC contemporâneas em conexão com a ciência escolar.

\section{Processos coletivos e cooperativos de aprendizagem}

A abordagem de QSC em sala de aula por meio de um processo coletivo e cooperativo de aprendizagem auxilia na construção dos conceitos no plano social da sala de aula, por meio de mediação, utilizando diversos signos presentes na linguagem da ciência escolar. Neste processo, o professor atua como mediador da interação e da discussão dos pequenos grupos de estudantes.

Embora processos coletivos e cooperativos de aprendizagem sejam defendidos desde diferentes perspectivas teóricas, em nosso caso, esse princípio de design derivou de nossa aceitação de uma perspectiva vigotskiana na compreensão da aprendizagem. De acordo com a famosa lei genética geral do desenvolvimento cultural proposta por Vigotski, a formação de conceitos ocorre primeiro no plano social (como uma categoria interpsicológica) e, posteriormente, esses conceitos são internalizados pelo indivíduo (como uma categoria intrapsicológica). (VIGOTSKI, 1981) Esse processo ocorre por meio de mediação semiótica, ou seja, envolvendo signos construídos social e cultural- 
mente, que mediam as relações entre os planos inter e intrapsicológicos (WERSTCH, 1985). Quando um indivíduo internaliza os conceitos, ele se torna capaz de operar com o pensamento conceitual de forma semelhante nas interações sociais, diante de experiências que se mostram semelhantes para os sujeitos. (MORTIMER et al., 2009)

Desta perspectiva, as interações sociais propiciam os alicerces para a atividade cognitiva, para o desenvolvimento da consciência individual e para o caráter dialógico do processo de compreensão. (BAKHTIN, 1981; VIGOTSKI, 2001) A consciência, como afirma Leontiev (1978), deve ser considerada como o resultado de um movimento interno específico gerado pela atividade humana, e não como um campo que imagens e conceitos que são projetados para serem contempladas pelos sujeitos. É pouco provável, assim, que os estudantes alcancem generalizações que lhes permitam empregar conceitos em contextos similares, caso a educação científica se paute pela repetição mecânica dos conceitos científicos e da linguagem da ciência escolar.

\section{Considerações finais}

No presente trabalho, apresentamos uma série de princípios de design que podem ser usados na construção de inovações educacionais sob a forma de SD, envolvendo QSC, no contexto de uma educação CTSA. Estes princípios podem ser aplicados em diferentes combinações, conforme a realidade do professor, o seu planejamento didático e o contexto escolar. Defendemos, também, o trabalho colaborativo entre diferentes sujeitos, com uma diversidade de saberes, como meio de construir e investigar tais inovações.

Como discutimos, muitos são os desafios que os professores enfrentam para a implementação de inovações educacionais em seu trabalho pedagógico, como, por exemplo, problemas relativos às condições gerais de trabalho, aos baixos salários, à falta de tempo para o desenvolvimento de inovações educacionais, devido a uma carga horária excessiva, à disciplinarização do currículo escolar, ao excesso de conteúdo curricular, à ênfase na preparação dos estudantes para exames, entre outros. Esses fatores, muitas vezes, impedem ou mesmo fazem fracassar iniciativas que envolvem estratégias inovadoras de ensino. Diante desses limites, o trabalho colaborativo entre professores-investigadores e pesquisadores, entre escolas e as universidades, com compartilhamento e produção de conhecimento, se torna ainda mais importante. Ele favorece a superação de tais desafios e a melhoria da educação científica dos estudantes da educação básica. Envolvidos na prática colaborativa, os professores se sentem empoderados e acabam por resgatar a sua autoconfiança em relação à importância da sua profissão para a formação de cidadãos críticos e informados, necessários para a construção de um mundo melhor. Os estudantes, vivenciando estratégias inovadoras voltadas para a ação sociopolítica, podem efetivamente construir uma identidade capaz de interferir em suas realidades de forma positiva. Professores e estudantes se tornam, assim, agentes multiplicadores de 
práticas de ensino voltadas para a formação de cidadãos críticos e informados e para a ação sociopolítica.

\section{Referências}

AIKENHEAD, G. S. Toward a first nations cross-cultural science and technology curriculum. Science Education, New York, v. 81, n. 2, p. 217-238, 1997.

ALMEIDA, M. C. Colaboração entre pesquisadores e professores de ensino de ciências e biologia: um estudo da organização e desenvolvimento da prática social do grupo CoPPEC. 2014. 113 f. Dissertação (Mestrado em Ensino, História e Filosofia das Ciências) - Universidade Federal da Bahia, Universidade Estadual de Feira de Santana. Salvador, 2014.

ALMEIDA, M. C.; SEPÚlVEDA, C. A. S.; EL-HANI, C. N. Colaboração entre professores de ciências e pesquisadores universitários: organização social e tensões na dinâmica de um grupo colaborativo de pesquisa. In: ENCONTRO NACIONAL DE PESQUISA EM EDUCAÇÃO EM CIÊNCIAS, 9., 2013, Águas de Lindóia, SP. Anais... Águas de Lindóia, SP: ABRAPEC, 2013. p. 1-8. Disponível em: <http://www.nutes.ufrj. br/abrapec/ixenpec/atas/resumos/R1415-1.pdf>. Acesso em: 26 ago. 2016.

ANDERSON, G. L.; HERR, K. The new paradigm wars: is there room for rigorous practitioner knowledge in schools and universities? Educational Researcher, Washington, v. 28, p. 12-21, 1999.

ANDRÉ, M. E. D. A. Pesquisa, formação e prática docente. In: ANDRÉ, M. O papel da pesquisa na formação e na prática dos professores. Campinas: Papirus, 2001. p. 55-69.

ANDRÉ, M. E. D. A. et al. O trabalho docente do professor formador no contexto atual das reformas e das mudanças no mundo contemporâneo. Revista Brasileira de Estudos Pedagógicos, Brasília, DF, v. 91, n. 227, p. 122-143, 2010.

ARANHA, M. L. de A. Filosofia da educação. São Paulo: Moderna, 1996.

BAKHTIN, M. M. Discourse in the novel. In: HOLQUIST. M. Dialogical imagination. Austin: University of Texas Press, 1981. p. 259-422.

BOSSÉR, U. et al. Challenges faced by teachers implementing socio-scientific issues as core elements in their classroom practices. European Journal of Science and Mathematics Education, [S.1.], v. 3, n. 2, p. 159-176, 2015.

CANDAU, V. M. Direitos humanos, educação e interculturalidade: as tensões entre igualdade e diferença. Revista Brasileira de Educação, Rio de Janeiro, v. 13, n. 37, p. 45$56,2008$.

CANEN, A. Educação multicultural, identidade nacional e pluralidade cultural: tensões e implicações curriculares. Cadernos de Pesquisa, São Paulo, n. 111, p. 135-149, 2000.

CARBONELL, J. A aventura de inovar: a mudança na escola. Porto Alegre: Artes Médicas, 2002. 
CARDOSO, F. S. et al. Interdisciplinaridade: fatos a considerar. Revista Brasileira de Ensino de Ciência e Tecnologia, Ponta Grossa, v. 1, n. 1, p. 22-37, 2008.

CARVALHO, I. N.; NUNES-NETO, N. F.; EL-HANI, C. N. Como selecionar conteúdos de biologia para o ensino médio? Revista de Educação, Ciências e Matemática, São Paulo, v. 1 , n. 1 , p. $67-100,2011$.

COBERN, W. W. Socio-cultural perspectives on science education. Dordrecht: Kluwer, 1998.

COBERN, W. W.; LOVING, C. C. Defining "science" in a multicultural world: Implications for science education. Science Education, New York, v. 85, n. 1, p. 50-67, 2001.

CONRADO, D. M.; EL-HANI, C. N.; NUNES-NETO, N. F. Sobre a ética ambiental na formação do biólogo. Revista Eletrônica do Mestrado em Educação Ambiental, Rio Grande, v. 30, n. 1, p. 120-139, 2013.

DEWEY, J. How we think-a restatement of the relation of reflective thinking to the educative process. Boston: Heath, 1933.

EL-HANI, C. N.; GRECA, I. M. ComPratica: a virtual community of practice for promoting biology teachers' professional development in Brazil. Research in Science Education, Dordrecht, v. 43, n. 4, p. 1327-1359, 2013.

EL-HANI, C. N.; GRECA, I. M. Participação em uma comunidade virtual de prática desenhada como meio de diminuir a lacuna pesquisa-prática na educação em Biologia. Ciência e Educação, São Paulo, v. 17, n. 3, p. 579-601, 2011.

EL-HANI, C. N.; MORTIMER, E. F. Multicultural education, pragmatism, and the goals of science teaching. Cultural Studies of Science Education, Dordrecht, v. 2, n. 3, p. 657-687, 2007.

FEIERABEND, T.; EILKS, I. Raising students' perception of the relevance of science teaching and promoting communication and evaluation capabilities using authentic and controversial socio-scientific issues in the Framework of climate change. Science Education International, Izmir, v. 21, n. 3, p. 176-196, 2010.

FERRETTI, C. J.; ZIBAS, D. M. L.; TARTUCE, G. L. B. P. Protagonismo juvenil na literatura especializada e na reforma do ensino médio. Cadernos de Pesquisa, São Paulo, v. 34, n. 122, p. 411-423, 2004.

FIGUEIREDO, P. S. A dinâmica discursiva nas salas de aula de ciências: contribuições teóricas e metodológicas para análise da prática de ensino sob a perspectiva do multiculturalismo na educação científica. 2013. 150 f. Dissertação (Mestrado em Ensino, Filosofia e História das Ciências) - Universidade Federal da Bahia e Universidade Estadual de Feira de Santana, Feira de Santana, 2013.

FIGUEIREDO, P. S. et al. Processo colaborativo de construção e aplicação de uma sequência didática com abordagem social e biológica acerca das bactérias. In: ENCONTRO NACIONAL DE PESQUISA EM EDUCAÇÃO EM CIÊNCIAS, 10., 2015, Águas de Lindóia, SP. Anais... Águas de Lindóia, SP: ABRAPEC, 2016. p. 1-8. 
GALIAZZI, M. do C.; MORAES, R. Educação pela pesquisa como modo, tempo e espaço de qualificação da formação de professores de ciências. Ciência \& Educação, São Paulo, v. 8, n. 2, p. 237-252, 2002.

GARCIA, C. M. O professor iniciante, a prática pedagógica e o sentido da experiência. Revista Brasileira de Pesquisa sobre Formação Docente, Belo Horizonte, v. 2, n. 3, p. 11 49, 2010.

GARCIA, P. S. Um estudo sobre a inovação como estratégia de formação contínua de professores ciências. Educação em Foco, Juiz de Fora, v. 13, n. 12, p. 161-189, 2009.

GEERTZ, C. The interpretation of cultures. New York: Basic Books, 1973.

GIROUX, H. A. Cultural studies, public pedagogy, and the responsibility of intellectuals. Communication and Critical/Cultural Studies, Oxfordshire, v. 1, n. 1, p. 59-79, 2004.

GIROUX, H. A.; GIROUX, S. S. Challenging neoliberalism's new world order: the promise of critical pedagogy. Cultural Studies/Critical Methodologies, Oxfordshire, v. 6, p. 21-32, 2006.

GUIMARÃES, A. P. M. et al. O aquecimento global como conteúdo norteador para ensinar sobre visão sistêmica do planeta terra no ensino médio. In: ENCONTRO NACIONAL DE PESQUISA EM EDUCAÇÃO EM CIÊNCIAS, 9., 2013, Águas de Lindóia, SP. Atas... Águas de Lindóia, SP: ABRAPEC, 2013. p. 1-9. Disponível em: <http://www.nutes.ufrj.br/abrapec/ixenpec/atas/resumos/R0233-1.pdf>. Acesso em: 26 ago. 2016.

GÜLLICH, R. I. da C. Educar pela pesquisa: formação e processos de estudo e aprendizagem com pesquisa. Revista de Ciências Humanas, Frederico Westphalen, RS, v. 8, n. 10, p. 11-27, 2007.

GUTIEREZ, S. B. Integrating socio-scientific issues to enhance the bioethical decisionmaking skills of high school students. International Education Studies, Toronto, v. 8, n. 1, p. 142-151, 2015.

HARGREAVES, D. H. The knowledge-creating school. British Journal of Educational Studies, Oxford, v. 47, n. 2, p. 122-144, 1999.

HODSON, D. Don't be nervous, don't be flustered, don't be scared. be prepared. Canadian journal of science, mathematics and technology education, Toronto, v. 13, n. 4, p. 313-331, 2013.

HODSON, D. Going beyond STS: towards a curriculum for sociopolitical action. The Science Education Review, Queensland, v. 3, n. 1, p. 2-7, 2004.

HODSON, D. In search of a rationale for multicultural science education. Science Education, Madison, v. 77, n. 6, p. 685-711, 1993.

KÖNINGS, K. D.; BRAND-GRUWEL, S.; VAN MERRIËNBOER, J. J. G. Teachers' perspective on innovations: implications for educational design. Teaching and Teacher Education, New York, v. 23, n. 6, p. 985-997, 2007. 
LEONTIEV, A. N. Actividad, conciencia y personalidad. Buenos Aires: Ciencias del Hombre, 1978.

LOIOLA, L.; ZANCUL, M. de S.; BIZERRIL, M. X. A. Uso de textos de divulgação científica no desenvolvimento de temas de Educação em Saúde na Educação de Jovens e Adultos (EJA). In: ENCONTRO NACIONAL DE PESQUISA EM EDUCAÇÃO EM CIÊNCIAS, 9., 2013, Águas de Lindóia, SP. Anais... Águas de Lindóia, SP: ABRAPEC, 2013. p. 1-8. Disponível em: <http://www.nutes.ufrj.br/abrapec/ixenpec/atas/resumos/ R0576-1.pdf >. Acesso em: 26 ago. 2016.

LÜDKE, M. et al. O professor pesquisador e a relação entre teoria e prática. In:

LÜDKE, M. et al. (Coord.). O professor e a pesquisa. Campinas: Papirus, 2001. p. 25-34.

MARKS, R., EILKS, I. Promoting scientific literacy using a socio-critical and problem-oriented approach to chemistry teaching: concept, examples, experiences. International Journal of Science and Environmental Education, Denizli, v. 4, n. 3, p. 231245, 2009.

MARKS, R. et al. The societal dimension in german science education - from tradition towards selected cases and recent developments. Eurasia Journal of Mathematics, Science \& Technology Education, London, v. 10, n. 4, p. 285-296, 2014.

MARTINS, I.; NASCIMENTO, T. G.; ABREU, T. B. de. Clonagem na sala de aula: um exemplo do uso didático de um texto de divulgação científica. Investigações em Ensino de Ciências, Porto Alegre, v. 9, n. 1, p. 95-111, 2004.

MCLAREN, P. Multiculturalismo crítico. 3. ed. São Paulo: Cortez, 1997.

MELO, W. C.; HOSOUME, Y. O jornal em sala de aula: uma proposta de utilização. In: SIMPÓSIO NACIONAL DE ENSINO DE FÍSICA, 15., 2003, Curitiba. Anais... Curitiba: SBF, 2003. p. 235-611.

MORTIMER, E. F.; SCOTT, P. H.; EL-HANI, C. N. Bases teóricas e epistemológicas da abordagem dos perfis conceituais. In: ENCONTRO NACIONAL DE PESQUISA EM EDUCAÇÃO EM CIÊNCIAS, 7., 2009, Florianópolis. Anais... Florianópolis: ABRAPEC, 2009. p. 1-12.

MUENCHEN, C.; AULER, D. Configurações curriculares mediante o enfoque CTS: desafios a serem enfrentados na educação de jovens e adultos. Ciência \& Educação, Bauru, v. 13, n. 3, p. 421-434, 2007.

MUNIZ, C. R. R. et al. O estudo de desenvolvimento de uma intervenção para o ensino de metabolismo energético - segundo protótipo. In: ENCONTRO NACIONAL DE ENSINO DE BIOLOGIA, 4.; ENCONTRO REGIONAL DE ENSINO REGIONAL, 2., 2012, Goiânia. Anais... Goiânia: SBEnBio, 2012. p. 1-11. Disponível em: <http://www. sbenbio.org.br/cds/4enebio/arquivos/3766.pdf>. Acesso em: 26 ago. 2016.

NASCIMENTO, T. G.; ALVETTI, M. A. S. Temas científicos contemporâneos no Ensino de Biologia e Física. Ciência \& Ensino, Campinas, v. 1, n. 1, p. 29-39, 2006. 
NIEVEEN, N., MCKENNEY, S.; VAN DEN AKKER, J. Educational design research: the value of variety. In: VAN DEN AKKER, J.; GRAVEMEIJER, K.; MCKENNEY, S. et al. Educational design research. London: Routledge, 2006. p. 151-158.

NOGUEIRA, N. R. Interdisciplinaridade aplicada. São Paulo: Érica, 1999.

PATRONIS, T.; POTARI, D.; SPILIOTOPOULOU, V. Students' argumentation in decision-making on a socio-scientific issue: implications for teaching. International Journal of Science Education, London, v. 21, n. 7, p. 745-754, 1999.

PEDRETTI, E. Septic tank crisis: a case study of science, technology and society education in an elementary school. International Journal of Science Education. London, v. 19, n. 10, p. 1211-1230, 1997.

PEDRETTI, E.; NAZIR, J. Currents in STSE education: mapping a complex field, 40 Years On. Science Education, New York, v. 95, n. 4, p. 601-626, 2011.

PLOMP, T. Educational design research: An introduction. In: PLOMP, T.; NIEVEEN, N. (Ed.). An introduction to educational design research. Enschede: SLO, 2009. p. 9-35.

RAMSEY, J. The science education reform movement: implications for social responsibility. Science Education, New York, v. 77, n. 2, p. 235-258, 1993.

REIS, P.; GALVÃO, C. Os professores de ciências naturais e a discussão de controvérsias sociocientíficas: dois casos distintos. Revista Electrónica de Enseñanza de las Ciencias, [S.1.], v. 7, n. 3, p. 746-772, 2008.

RODRIGUES, L. C. P.; ANJOS, M. B.; RÔÇAS, G. Pedagogia de projetos: resultados de uma experiência. Ciências \& Cognição, Rio de Janeiro, v. 13, n. 1, p. 65-71, 2008.

SÁ, T. S. et al. Energetic metabolism in biology classrooms: a developmental study of a teaching sequence. Procedia: Social and Behavioral Sciences, New York, v. 167, p. $50-55,2015$.

SADLER, T. D.; BARAB, S. A.; SCOTT, B. What do students gain by engaging in socioscientific inquiry? Science Education, New York, v. 37, n. 4, p. 371-391, 2007.

SADLER, T. D. Informal reasoning regarding socioscientific issues: a critical review of research. Journal of Research in Science Teaching, New York, v. 41, n. 5, p. 513-536, 2004.

SADLER, T. D. Socio-scientific issues in the classroom: teaching, learning and research. Dordrecht: Springer, 2011.

SANDRI, M. C. M.; SANTIN-FILHO, O. CTSA na formação pedagógica de licenciandos em química. In: SIMPÓSIO INTERNACIONAL DE ENSINO DE CIÊNCIA E TECNOLOGIA, 4, 2014, Ponta Grossa. Anais... Ponta Grossa: UTFPR, 2014.

SANTOS, W. L. P. dos. Educação CTS e cidadania: confluências e diferenças. Amazônia: Revista de Educação em Ciências e Matemáticas, Belém, v. 9, p. 49-62, 2012. 
SANTOS, W. L. P. dos; MORTIMER, E. F. Uma análise de pressupostos teóricos da abordagem C-T-S (Ciência - Tecnologia - Sociedade) no contexto da educação brasileira. Ensaio: Pesquisa em Educação em Ciências, Belo Horizonte, v. 2, p. 1-23, 2002.

SANTOS, W. L. P. dos; MORTIMER, E. F. Abordagem de aspectos sociocientíficos em aulas de ciências: possibilidades e limitações. Investigações em Ensino de Ciências. Porto Alegre, v. 4, n. 2, p. 191-218, 2009.

SANTOS, W. L. P. dos; MORTIMER, E. F. Tomada de decisão para ação social responsável no ensino de ciências. Ciência e Educação, Bauru, v. 7, n. 2, p. 95-111, 2001.

SARMENTO, A. C. de H. et al. Investigando princípios de design de uma sequência didática sobre metabolismo energético. Ciência \& Educação, Bauru, v. 19, n. 3, p. 573$598,2013$.

SARMENTO, A. C. de H. et al. Investigando princípios de design de uma sequência didática para o ensino sobre metabolismo energético. In: ENCONTRO NACIONAL DE PESQUISA EM EDUCAÇÃO EM CIÊNCIAS, 8., 2011, Campinas. Anais... Campinas: ABRAPEC, 2011. 2011.

SEPÚLVEDA, C. A. S.; et al. Inovando o ensino de biologia através do trabalho colaborativo de pesquisadores educacionais e professores-investigadores. Revista Eletrônica Estudos IAT, Salvador, v. 2, n. 1, p. 119-137, 2012.

SIMONS, H.; KUSHNER, S.; JONES, K., JAMES, D. From evidence-based practice to practice-based evidence: the idea of situated generalization. Research Papers in Education, London, v. 18, n. 14, p. 347-364, 2003.

SMITH, M. U.; SIEGEL, H. Knowing, believing, and understanding: what goals for science education? Science \& Education, Dordrecht, v. 13, n. 6, p. 553-582, 2004.

SOUSA, A. E. A.; MUNIZ, C. R.; SARMENTO, A. C. H. O processo heurístico da construção do conceito de inovações educacionais por um grupo colaborativo de pesquisa. In: SEPÚlVEDA, C.; ALMEIDA, M. A. (Org.). Pesquisa colaborativa e inovações educacionais em ensino de biologia. Feira de Santana: UEFS, 2016. p. 97-126.

STOLZ, M. et al. Reflecting Socio-Scientific Issues for Science Education Coming from the Case of Curriculum Development on Doping in Chemistry Education. Eurasia Journal of Mathematics, Science and Technological Education, London, v. 9, n. 4, p. 361$370,2013$.

TAL, T. et al. Enhancing the Authenticity of a Web-Based Module for Teaching Simple Inheritance. In: SADLER, T. D. Socio-scientific issues in the classroom: teaching, learning and research. London: Springer, 2011.

THE DESIGN-BASED RESEARCH COLLECTIVE. Design-based research: an emerging paradigm for educational inquiry. Educational Researcher, Washington, v. 32, n. 1 , p. 5-8, 2003.

TRESS, B.; TRESS, G.; FRY, G. Defining concepts and the process of knowledge production in integrative research. In: TRESS, B. et al. (Ed.). From landscape research 
to landscape planning: aspects of integration, education and application. Dordrecht: Springer, 2005. p. 13-26.

VAN DEN AKKER, J. Principles and methods of development research. In: VAN DEN AKKER, J. et al. Design approaches and tools in education and training. Boston: Kluwer Academic, 1999. p. 1-14.

VEIGA, I. P. A. inovações e projeto político-pedagógico: uma relação regulatória ou emancipatória? Caderno Cedes, Campinas, v. 23, n. 61, p. 267-281, 2003.

VIGOTSKI, L. S. A construção do pensamento e da linguagem. São Paulo: Martins Fontes, 2001.

VIGOTSKI, L. S. The genesis of higher mental functions. In: WERTSCH, J. V. The Concept of Activity in Soviet psychology. Armonk: Shape, 1981. p. 144-188.

VILLANI, A.; FREITAS, D.; BRASILIS, R. Professor pesquisador: o caso Rosa. Ciência \& Educação, Bauru, v. 15, n. 3, p. 479-496, 2009.

VON LINSINGEN, I. Perspectiva educacional CTS: aspectos de um campo em consolidação na América Latina. Ciência \& Ensino, São Paulo, v. 1, p. 1-19, 2007. Edição especial.

WERTSCH, J. V. Vygotsky and the social formation of mind. Cambridge: Harvard University Press, 1985.

WU, Y. T.; TSAI, C. C. The effects of different on-line searching activities on high school students' cognitive structures and informal reasoning regarding a socioscientific issue. Research in Science Education, Springer, v. 41, n. 5, p. 771-785, 2011.

ZABALA, A. A prática educativa: como ensinar. Porto Alegre: Artes Médicas, 1998.

ZEICHNER, K. M. Para além da divisão entre professor- pesquisador e pesquisador acadêmico. In: GERALDI, C. M. G.; FIORENTINI, D.; PEREIRA, E. M. de A. Cartografia do trabalho docente. Campinas: Mercado de Letras, 1998. p. 207-235.

ZEIDLER, D. L. et al. Beyond STS: A research-based framework for socioscientific issues education, Science Education, New York, v. 89, n. 3, p. 357-377, 2005. 


\title{
PERSPECTIVAS E DESAFIOS DE ESTUDOS DE QSC NA EDUCAÇÃO CIENTÍFICA BRASILEIRA
}

\author{
Wildson Luiz Pereira dos Santos \\ Karolina Martins Almeida e Silva \\ Shirley Margareth Buffon da Silva
}

\section{Introdução}

A introdução de Questões Sociocientíficas (QSC) no ensino de ciências não é relativamente nova na literatura internacional; todavia, no Brasil, é bastante recente. No presente artigo, fazemos uma caracterização da origem de estudos de QSC, revisão de seus esboços teóricos na literatura nacional e discutimos os diferentes significados atribuídos às QSC. A partir dessas caracterizações, apresentamos perspectivas e desafios tanto para a pesquisa como para o currículo de ciências. Nesse sentido, o objetivo central deste capítulo é caracterizar o campo de estudo de QSC e levantar questionamentos relativos à sua investigação e ao currículo no contexto brasileiro. $\mathrm{O}$ foco de nosso trabalho está nas relações aos estudos de QSC com a formação para a cidadania, com intersecção na educação relativa às inter-relações Ciência, Tecnologia e Sociedade (CTS), também denominada Ciência, Tecnologia, Sociedade, Ambiente (CTSA), quando se deseja enfatizar o foco ambiental que está implícito no movimento CTS desde sua origem. 


\section{Estudos de QSC como campo de investigação}

Levinson (2006) comenta que questões controvertidas foram introduzidas na Inglaterra, nos anos de 1970, no Projeto Curricular de Humanas, na escola secundária inglesa, com o objetivo de tratar tópicos polêmicos relativos à família, à pobreza, às relações raciais, às questões de gênero, leis e ordem, os quais se constituíam em tópicos que deveriam ser ensinados na escola. Conforme esse autor, essas questões continuaram a ser debatidas na década seguinte, naquele país, com aprofundamento de preocupações relacionadas ao multiculturalismo e que, nos anos 2000, questões controvertidas relacionadas à ciência e à tecnologia passaram a ter um impulso maior com recomendações curriculares específicas para o ensino de ciências.

$\mathrm{Na}$ ampla revisão que temos desenvolvido sobre movimento de educação CTS no ensino de ciências desde 1992, na literatura internacional e nacional (SANTOS, 1992, 2011; SANTOS; MORTIMER, 2000; SANTOS; SCHNETZLER, 2010), encontramos diversas citações da introdução de QSC nesse campo - ver, por exemplo, Aikenhead (1994), Kortland, (1996), Levinson (2006), Pedretti (1997, 2003), Pedretti e colaboradores (2008), Ramsey (1993) e Solomon (1990, 1992, 1993). Há, todavia, diversos estudos que têm sido desenvolvidos sobre QSC sem fazerem qualquer menção com movimento CTS - ver, por exemplo, Cross e Price, (1996), Geddis (1991), Oulton, Dillon e Grace (2004), Reis e Galvão (2004), Ratcliffe (1997), Ratcliffe e Grace (2003), Sadler e Zeidler (2004), Simonneaux (2008), Simonneaux e Simonneaux (2009) e Zeidler e colaboradores $(2002,2005)$.

Por outro lado, alguns autores têm considerado que os estudos CTS no ensino de ciências não têm abordado de maneira completa as QSC e, nesse sentido, eles têm advogado que estudos de QSC vão além dos estudos CTS. (SADLER, 2004; ZEIDLER et al., 2005) Particularmente, temos uma visão contrária a esse posicionamento e temos considerado que tal ponto de vista é, de certa maneira, uma visão limitada sobre a educação CTS, a qual não possui um foco tão restrito, como afirmam os referidos autores. Esse ponto de vista tem sido defendido por vários autores - ver, por exemplo, Hodson (2009), Mendes e Santos (2015), Pedretti e Nazir (2011) e Santos (2011). Em nosso ponto de vista, CTS e QSC são dois campos que possuem pontos em comum. Cada um dos campos, contudo, trata de temáticas específicas, que não são contempladas de forma central pelos estudos do outro campo. Logo, existem estudos curriculares de CTS que abordam questões não contempladas pelas pesquisas de QSC e vice-versa.

Atualmente, os estudos de QSC podem ser considerados como um campo de pesquisas no ensino de ciências. Eles têm se enquadrado como temática em congressos da área de ensino de ciências e têm sido temáticas de livros como este, assim como objeto de revisão de literatura. Em ampla revisão sobre QSC realizada em 27 revistas da área de ensino de ciências na literatura nacional e internacional de 1997 a 2013, encontramos 201 artigos que apresentaram descritores relativos a QSC. (SILVA; SANTOS, 2014) Particularmente, temos nos debruçado sobre estudos de QSC desde 2002. (MENDES; SANTOS, 
2013, 2015; SANTOS, 2002, 2009; SILVA; SANTOS, 2014) Sadler (2009) fez ampla revisão de literatura sobre estudos de QSC na literatura internacional. Ele considera esses estudos como um campo de QSC e, na sua revisão, agrupou os artigos que tratam sobre QSC nos seguintes temas de estudos: interesse e motivação; aprendizagem de conteúdo; Natureza da Ciência; habilidades cognitivas (argumentação, criatividade, julgamento reflexivo); prática comunitária (participação); e outros temas (papel dos professores, contexto de QSC, sensibilidade moral).

\section{Pesquisas de QSC no Brasil}

Em nossa pesquisa de 2002, identificamos que recomendações e incorporação de temas sociocientíficos estavam presentes no currículo escolar brasileiro; todavia, o seu tratamento não era ainda visto como questões controvertidas. (SANTOS, 2002) Nesse sentido, naquela ocasião denominamos Aspectos Sociocientíficos (ASC) no currículo de ciências como "[...] questões ambientais, políticas, econômicas, éticas, sociais e culturais relativas à ciência e à tecnologia [...]”. (SANTOS; MORTIMER, 2009, p. 192) Consideramos, na ocasião, que ASC podiam ser abordados no currículo de três maneiras:

[...] de forma temática, no sentido de tópico ou assunto amplo em que essas questões estão imbricadas (e.g. poluição ambiental, transgênicos, recursos energéticos etc.); ou de forma pontual, com exemplos de fatos e fenômenos do cotidiano relativos a conteúdos científicos que ilustram aplicações tecnológicas envolvendo esses aspectos; ou ainda por meio de questões [controvertidas] dirigidas aos estudantes sobre esses aspectos. (SANTOS; MORTIMER, 2009, p. 192, grifo nosso)

Durante, todavia, a segunda metade dos anos 2000, várias pesquisas nacionais começaram a tratar de questões controvertidas no ensino de ciências e, dessa forma, estudos de QSC vêm se configurando em um campo promissor na pesquisa nacional. Ao fazermos a nossa citada revisão de 1997 a 2013 (SILVA; SANTOS, 2014), identificamos na literatura nacional ${ }^{1} 19$ artigos com descritores relativos às QSC. O critério de seleção dos artigos nos periódicos nacionais foi os que apresentavam em seus títulos, resumos e palavras-chave quaisquer dos seguintes termos: questões sociocientíficas, questões sociocientíficas, temas polêmicos, controvérsias sociocientíficas e questões polêmicas. Para as buscas nos periódicos internacionais, foram feitas também buscas nos títulos, abstracts e keywords dos termos: socioscientific issues, socio-scientific issues, SSI e STS. Al-

1 Nesta revisão, foram consultados os seguintes periódicos nacionais das áreas de ensino: Ciência \& Educação, Ciência \& Ensino, Ensaio: Pesquisa em Educação em Ciências, Investigações em Ensino de Ciências e Revista Brasileira de Pesquisa em Educação em Ciências. Estes periódicos pertencem aos estratos Al e A2 da Coordenação de Aperfeiçoamento de Pessoal de Nível Superior (Capes) e se configuram nos periódicos clássicos da área. 
guns artigos não possuíam esses descritores, mas o título indicava a possibilidade de ser tema correlato. Nesse caso, procurou-se a identificação dos descritores no corpo do texto para a seleção do artigo. Os artigos mais antigos encontrados envolvendo questões controversas são de 2005 - Alves e Caldeira (2005) e Reis e Galvão (2005). No artigo de Alves e Caldeira (2005), não há menção de QSC, mas de temas polêmicos do ponto de vista ético, embora não seja tipicamente um estudo de QSC, trata-se de um estudo com forte vinculação à ideia/conceito de questão controvertida. Já o artigo de Reis e Galvão (2005) trata explicitamente sobre QSC como questão controvertida propriamente dita. A partir de 2006, de um a três artigos por ano foram encontrados nos periódicos analisados, o que, de certa forma, indica que essa temática ainda não é muito abordada no âmbito da literatura brasileira investigada.

Da análise das publicações nacionais, foi realizada uma primeira categorização dos estudos em teóricos e empíricos. Foram considerados teóricos, os artigos cujo foco central estava em torno de apresentação de descrição e/ou análise de pressupostos teóricos relativos às QSC no ensino de ciências. Os quatro artigos teóricos encontrados tratam de temas controversos - Ramos e Silva (2007), Razera e Nardi (2006), Silva e Carvalho (2007) e Vieira e Bazzo (2007) -, discutindo sobre a sua abordagem em aulas de ciências. Desses, Razera e Nardi (2006) e Vieira e Bazzo (2007) não fazem menção à QSC; já Ramos e Silva (2007) mencionam o termo em uma citação direta e Silva e Carvalho (2007) apontam as QSC como oportunidades para a aproximação das reais condições de produção da ciência e das suas relações com a tecnologia, sociedade e meio ambiente. Como estudos empíricos, foram caracterizados os trabalhos que tiveram como fontes de dados: testes, questionários, entrevistas, dentre outros.

A maior parte dos artigos encontrados na literatura revisada sobre QSC (15 artigos) foi caracterizada como estudos empíricos (Quadro 1), o que indica que esse campo vem se constituindo no Brasil a partir de investigações empíricas.

A análise dos artigos indicados no Quadro 1 revela que cinco não apresentam como foco de estudo a controvérsia científica. Esses seriam artigos de ASC que tratam de temas sociocientíficos. Observa-se, ainda, que, em oito artigos, não há menção ao termo QSC. Isso pode indicar que a pesquisa com QSC no ensino de ciências no Brasil ainda está em estado incipiente, apesar de seu crescimento enquanto campo de investigação.

Quadro 1 - Lista de artigos empíricos de QSC identificados na revisão com foco de estudo

\begin{tabular}{|c|c|c|c|l|l|l|}
\hline Revista & Ano & Vol. & No $^{\text {Autores }}$ & Título & Tema de estudo \\
\hline C\&Ed & 2010 & 16 & 2 & $\begin{array}{l}\text { GUIMARÃES, M. A.; } \\
\text { CARVALHO, W. L. P. e } \\
\text { OLIVEIRA, M. S. }\end{array}$ & $\begin{array}{l}\text { Raciocínio moral na tomada de } \\
\text { decisões em relação a QSC: o } \\
\text { exemplo do melhoramento genético } \\
\text { humano. }\end{array}$ & Raciocínio moral \\
\hline C\&Ed & 2011 & 17 & 3 & $\begin{array}{l}\text { GALVÃO, C. REIS, P. e } \\
\text { FREIRE, S. }\end{array}$ & $\begin{array}{l}\text { A discussão de controvérsias } \\
\text { sociocientíficas na formação de } \\
\text { professores. }\end{array}$ & $\begin{array}{l}\text { Formação de } \\
\text { professores }\end{array}$ \\
\hline
\end{tabular}




\begin{tabular}{|c|c|c|c|c|c|c|}
\hline Revista & Ano & Vol. & $N^{\circ}$ & Autores & Título & Tema de estudo \\
\hline C\&Ed & 2012 & 18 & 4 & $\begin{array}{l}\text { MUNDIM, J. V. e } \\
\text { SANTOS, W. L. P. }\end{array}$ & $\begin{array}{l}\text { O ensino de ciências no ensino } \\
\text { fundamental por meio de temas } \\
\text { sociocientíficos: análise de uma } \\
\text { prática pedagógica com vista à } \\
\text { superação do ensino disciplinar. }\end{array}$ & $\begin{array}{l}\text { Aplicação em } \\
\text { sala de aula }\end{array}$ \\
\hline C\&Ed & 2013 & 19 & 2 & $\begin{array}{l}\text { SILVA, P. F. e } \\
\text { KRASILCHIK, M. }\end{array}$ & $\begin{array}{l}\text { Bioética e ensino de ciências: o } \\
\text { tratamento de temas controversos } \\
\text { - dificuldades apresentadas por } \\
\text { futuros professores de ciências e } \\
\text { biologia. }\end{array}$ & $\begin{array}{l}\text { Formação de } \\
\text { professores }\end{array}$ \\
\hline C\&Ens & 2007 & 1 & NE & $\begin{array}{l}\text { NAVAS, A. M.; } \\
\text { CONTIER, D. e } \\
\text { MARANDINO, M. }\end{array}$ & $\begin{array}{l}\text { Controvérsia científica, comunicação } \\
\text { pública da ciência e museus no bojo } \\
\text { do movimento CTS. }\end{array}$ & $\begin{array}{l}\text { Espaço não- } \\
\text { formal }\end{array}$ \\
\hline C\&Ens & 2007 & 1 & 2 & $\begin{array}{l}\text { ZUIN, V. G. e FREITAS, } \\
\text { D. }\end{array}$ & $\begin{array}{l}\text { A utilização de temas controversos: } \\
\text { um estudo de caso na formação } \\
\text { de licenciandos numa abordagem } \\
\text { CTSA. }\end{array}$ & $\begin{array}{l}\text { Formação de } \\
\text { professores }\end{array}$ \\
\hline Ensaio & 2005 & 7 & 1 & $\begin{array}{l}\text { ALVES, S. B. F. e } \\
\text { CALDEIRA, A. M. A. }\end{array}$ & $\begin{array}{l}\text { Biologia e ética: um estudo sobre a } \\
\text { compreensão e atitudes de alunos } \\
\text { do ensino médio frente ao tema } \\
\text { genoma/DNA. }\end{array}$ & Ética \\
\hline Ensaio & 2011 & 13 & 2 & $\begin{array}{l}\text { PEREZ, D. M.; } \\
\text { REBECHI, D.; } \\
\text { AZEVEDO, K. L.; } \\
\text { SCHREINER, P. } \\
\text { G.; MATTIA, R. } \\
\text { C.; SLOWIK, R. e } \\
\text { OLIVEIRA, O. B. }\end{array}$ & $\begin{array}{l}\text { Temas polêmicos e a argumentação } \\
\text { de estudantes do curso de Ciências } \\
\text { Biológicas. }\end{array}$ & Argumentação \\
\hline Ensaio & 2012 & 14 & 1 & $\begin{array}{l}\text { SANTOS, M. S.; } \\
\text { AMARAL, C. L. C. e } \\
\text { MACIEL, M. D. }\end{array}$ & $\begin{array}{l}\text { Tema sociocientífico "cachaça" } \\
\text { em aulas práticas de química } \\
\text { na educação profissional: uma } \\
\text { abordagem CTS. }\end{array}$ & $\begin{array}{l}\text { Aplicação em } \\
\text { sala de aula }\end{array}$ \\
\hline Ensaio & 2012 & 14 & 1 & $\begin{array}{l}\text { BARBOSA, L. G. D.; } \\
\text { LIMA, M. E. C. C. e } \\
\text { MACHADO, A. H. }\end{array}$ & $\begin{array}{l}\text { Controvérsias sobre o aquecimento } \\
\text { global: circulação de vozes e sentidos } \\
\text { produzidos em sala de aula. }\end{array}$ & $\begin{array}{l}\text { Aplicação em } \\
\text { sala de aula }\end{array}$ \\
\hline Ensaio & 2014 & 16 & 3 & $\begin{array}{l}\text { VIEIRA, R. D.; MELO, } \\
\text { V. F. e BERNARDO, J. } \\
\text { R. R. }\end{array}$ & $\begin{array}{l}\text { O júri simulado como recurso didático } \\
\text { para promover argumentações na } \\
\text { formação de professores de física: o } \\
\text { problema do "gato". }\end{array}$ & Argumentação \\
\hline lenci & 2005 & 10 & 2 & REIS, P. e GALVÃO, C. & $\begin{array}{l}\text { Controvérsias sociocientíficas } \\
\text { e prática pedagógica de jovens } \\
\text { professores. }\end{array}$ & $\begin{array}{l}\text { Formação de } \\
\text { professores }\end{array}$ \\
\hline lenci & 2009 & 14 & 1 & $\begin{array}{l}\text { SILVA, L. F. e } \\
\text { CARVALHO, L. M. }\end{array}$ & $\begin{array}{l}\text { Professores de física em formação } \\
\text { inicial: o ensino de física, a abordagem } \\
\text { CTS e os temas controversos. }\end{array}$ & $\begin{array}{l}\text { Formação de } \\
\text { professores }\end{array}$ \\
\hline lenci & 2009 & 14 & 2 & $\begin{array}{l}\text { SANTOS, W. L. P. e } \\
\text { MORTIMER, E. F. }\end{array}$ & $\begin{array}{l}\text { Abordagem de aspectos } \\
\text { sociocientíficos em aulas de ciências: } \\
\text { possibilidades de limitações. }\end{array}$ & $\begin{array}{l}\text { Aplicação em } \\
\text { sala de aula }\end{array}$ \\
\hline lenci & 2013 & 18 & 3 & $\begin{array}{l}\text { MENDES, M. R. M. e } \\
\text { SANTOS, W. L. P. }\end{array}$ & $\begin{array}{l}\text { Argumentação em discussões } \\
\text { sociocientíficas. }\end{array}$ & Argumentação \\
\hline
\end{tabular}

Legenda: C\&Ens - Ciência \& Ensino; C\&Ed - Ciência \& Educação, Ensaio: Pesquisa em Educação em Ciências; IENCI - Investigações em Ensino de Ciências.

Fonte: elaborado pelos autores. 
Identificou-se ainda que os artigos tratam dos seguintes temas de estudo de QSC: aplicação de QSC no contexto de sala de aula, argumentação, estudos do raciocínio moral, ética, formação de professores e QSC em espaços não formais. O principal tema de estudo tem sido investigações relacionadas à formação e à prática de professores (cinco artigos) e aplicação de QSC no contexto de sala de aula (quatro artigos). Destacam-se também estudos sobre argumentação (três artigos), relativos à ética e à moral (dois artigos) e sobre QSC em espaços não formais (um artigo).

Foi constatado que as pesquisas analisadas têm tratado de diferentes temas sociocientíficos. São os seguintes temas investigados nas referidas pesquisas: aquecimento global (BARBOSA; LIMA; MACHADO, 2012), transposição do Rio São Francisco (ZUIN; FREITAS, 2007), meio ambiente e uso de novas biotecnologias (SILVA; KRASILCHIK, 2013), alimentação e vida saudável (MUNDIM; SANTOS, 2012), construção de uma hidrelétrica (GALVÃO; REIS; FREIRE, 2011), melhoramento genético (GUIMARÃES; CARVALHO; OLIVEIRA, 2010), cachaça (SANTOS; AMARAL; MACIEL, 2012), mercado de carbono e experimentação animal (PÉREZ et al., 2011), ligações elétricas irregulares (VIEIRA; MELO; BERNARDO, 2014); cuidados com os produtos químicos domésticos, nanociência e nanotecnologia, alimentos, fontes de energia, plásticos, polímeros e indústrias químicas (MENDES; SANTOS, 2013); genoma/DNA (ALVES; CALDEIRA, 2005), metais e desperdício (SANTOS; MORTIMER, 2009) e criacionismo x evolucionismo (RAZERA; NARDI, 2006).

Karolina Martins Almeida e Silva (2016), em sua tese de doutorado, analisou dissertações e teses sobre QSC. Para identificar as dissertações e teses, foram utilizados, como descritores, expressões encontradas nos títulos: ${ }^{2}$ questões sócio-científicas; questões sociocientíficas; sociocientífico; controvérsias sociocientíficas; temas polêmicos; temas controversos. Nesse sentido, ao visitar o Banco de Teses da Capes, foram identificadas apenas duas teses - Mendes (2012) e Penha (2012). Diante desse resultado, foram realizadas buscas na Biblioteca Digital $^{3}$ e também pesquisas em páginas de programas de pós-graduação. No Quadro 2, estão descritos os títulos, autores, ano de defesa e a Instituição de Ensino Superior (IES) na qual os autores estão vinculados às dissertações e teses encontradas.

2 A busca se limitou ao título, pois nem sempre se teve acesso às palavras-chaves e ao resumo.

3 A pesquisa se atentou a visitar as bibliotecas digitais de universidades brasileiras que possuem programas de pós-graduação em Educação e/ou Educação em Ciências ou para a Ciência e Ensino de Ciências e Matemática. Ressaltamos que nem todos os programas de pós-graduação possuem acesso aos trabalhos, o que, de certa forma, pode ter comprometido a pesquisa. 
Quadro 2 - Dissertações e teses brasileiras sobre QSC identificadas no período de 2000 a 2013

\begin{tabular}{|c|c|c|c|c|}
\hline Cód. & Título & Autor(a) & Ano & IES \\
\hline $\mathrm{D}_{1}$ & $\begin{array}{l}\text { A abordagem de temas polêmicos no currículo da } \\
\text { EJA: o caso do "Florestamento" no RS }\end{array}$ & Márcia Soares Forgiarini & 2007 & UFSM \\
\hline D2 & $\begin{array}{l}\text { Temas sociocientíficos: análise de processos } \\
\text { Argumentativos no contexto escolar. }\end{array}$ & Adriana Bortoletto & 2009 & UNESP - Bauru \\
\hline$D_{3}$ & $\begin{array}{l}\text { Argumentos, conhecimentos e valores em respostas } \\
\text { a questões sociocientíficas - um caso no ensino } \\
\text { fundamental. }\end{array}$ & $\begin{array}{l}\text { Érica Cavalcanti de } \\
\text { Albuquerque Dell Asem }\end{array}$ & 2010 & USP-FE \\
\hline D4 & $\begin{array}{l}\text { O conhecimento mobilizado por estudantes do } \\
\text { Ensino Médio na formulação de argumentos sobre } \\
\text { temas científicos e sociocientíficos. }\end{array}$ & $\begin{array}{l}\text { Rafael Gonçalves } \\
\text { Pereira }\end{array}$ & 2010 & USP-FE \\
\hline$D_{5}$ & $\begin{array}{l}\text { Aspectos formativos da experiência com questões } \\
\text { sociocientíficas no ensino de ciências sob uma } \\
\text { perspectiva crítica. }\end{array}$ & Nataly Carvalho Lopes & 2010 & UNESP - Bauru \\
\hline D6 & $\begin{array}{l}\text { Padrões morais, valores e conceitos empregados } \\
\text { por alunos de ensino fundamental em discussões } \\
\text { sociocientíficas. }\end{array}$ & $\begin{array}{l}\text { Bruno Cine Ribeiro do } \\
\text { Carmo }\end{array}$ & 2010 & USP-FE \\
\hline D7 & $\begin{array}{l}\text { O tratamento de questões sociocientíficas em um } \\
\text { grupo de professores e a natureza do processo } \\
\text { formativo fundamentado em uma perspectiva crítica. }\end{array}$ & $\begin{array}{l}\text { Paulo Gabriel Franco } \\
\text { Santos }\end{array}$ & 2013 & UNESP - Bauru \\
\hline $\mathrm{T}_{1}$ & Aspectos sócio-científicos em aulas de química & $\begin{array}{l}\text { Wildson Luiz Pereira } \\
\text { dos Santos }\end{array}$ & 2002 & UFMG \\
\hline$T_{2}$ & $\begin{array}{l}\text { Estudo de casos na promoção da argumentação } \\
\text { sobre questões sócio-científicas no Ensino Superior } \\
\text { de Química. }\end{array}$ & Luciana Passos Sá & 2010 & UFSCar \\
\hline$T_{3}$ & $\begin{array}{l}\text { A abordagem de questões sociocientíficas na } \\
\text { formação continuada de professores de ciências: } \\
\text { contribuições e dificuldades. }\end{array}$ & $\begin{array}{l}\text { Leonardo Fábio } \\
\text { Martínez Pérez }\end{array}$ & 2010 & UNESP - Bauru \\
\hline $\mathrm{T}_{4}$ & $\begin{array}{l}\text { Temas sociocientíficos em aulas práticas de química } \\
\text { na educação profissional: uma abordagem CTS }\end{array}$ & $\begin{array}{l}\text { Mírian Stassun dos } \\
\text { Santos }\end{array}$ & 2011 & UNICSUL \\
\hline$T_{5}$ & $\begin{array}{l}\text { Raciocínio informal e a discussão de questões } \\
\text { sociocientíficas: o exemplo das células-tronco } \\
\text { humanas }\end{array}$ & $\begin{array}{l}\text { Márcio Andrei } \\
\text { Guimarães }\end{array}$ & 2011 & UNESP - Bauru \\
\hline T6 & $\begin{array}{l}\text { A argumentação em discussões sociocientíficas: o } \\
\text { contexto e o discurso }\end{array}$ & $\begin{array}{l}\text { Mírian Rejane } \\
\text { Magalhães Mendes }\end{array}$ & 2012 & UnB-FE \\
\hline $\mathrm{T}_{7}$ & $\begin{array}{l}\text { Atividades sociocientíficas em sala de aula de física: } \\
\text { as argumentações dos estudantes }\end{array}$ & Sidnei Percia da Penha & 2012 & USP-FE \\
\hline T8 & $\begin{array}{l}\text { A constituição de associações livres e o trabalho } \\
\text { com as questões sociocientíficas na formação de } \\
\text { professores }\end{array}$ & Nataly Carvalho Lopes & 2013 & UNESP - Bauru \\
\hline $\mathrm{T}^{*}$ & $\begin{array}{l}\text { Uso do conhecimento evolutivo e ético na tomada } \\
\text { de decisão por estudantes de biologia }\end{array}$ & Dália Melissa Conrado & 2013 & UFBA \\
\hline
\end{tabular}

Notas: Cód. - $\mathrm{D}\left(\mathrm{N}^{\circ}\right)$ - Dissertação; $\mathrm{T}\left(\mathrm{N}^{\circ}\right)$ - Tese. *Tese não identificada pelos descritores de busca no título, mas que aborda QSC.

Fonte: Silva (2016).

Ao que se refere às pesquisas de mestrado, são todas de natureza empírica e oriundas das regiões Sul e Sudeste do Brasil, sendo D1 proveniente do Programa de Pós-gradua- 
ção em Educação da Universidade Federal de Santa Maria (UFSM), e as demais produções realizadas no âmbito do Programa de Pós-graduação em Educação para a Ciência da Universidade Estadual Paulista (UNESP); Bauru (D2, D4 e D6) sob orientação do professor doutor Washington Luiz Pacheco de Carvalho, e do Programa de Pós-graduação Inter-Unidades em Ensino de Ciências (modalidades física, química e biologia) - Faculdade de Educação (FE) da Universidade de São Paulo (USP) (D3, D5 e D7) sob orientação da professora doutora Silvia Luzia Frateschi Trivelato (USP).

Com relação às pesquisas de doutoramento, são todas investigações empíricas, e provenientes de programas de pós-graduação diversos situados em três regiões do Brasil: Distrito Federal, Nordeste e Sudeste (T1 - Universidade Federal de Minas Gerais (UFMG); T2 - Universidade Federal de São Carlos (UFSCar); T3; T5 e T8 - UNESP-Bauru; T4 - Universidade Cruzeiro do Sul (UNICSUL); T6 - Universidade de Brasília (UnB); T7 - USP; T9 - Universidade Federal da Bahia (UFBA). Cabe mencionar que nem todas as investigações foram desenvolvidas nas cidades em que se situam os referidos programas de pós-graduação nos quais os autores estavam vinculados. A T3, por exemplo, foi uma pesquisa desenvolvida fora do contexto brasileiro, em parceria com a Universidad Pedagógica Nacional (UPN) - Colômbia.

$\mathrm{Na}$ análise das dissertações e teses, constatou-se que as pesquisas de mestrado e doutorado têm objetivado explorar controvérsias sociocientíficas no que compete ao engajamento argumentativo e também das interações discursivas/dialógicas (Quadro 3). Isso nos leva a afirmar que as pesquisas em ensino de ciências acerca das controvérsias sociocientíficas no contexto brasileiro têm se firmado no campo da argumentação/desenvolvimento de habilidades argumentativas.

Com relação aos temas abordados, as dissertações apresentam aqueles voltados para as controvérsias socioambientais relacionados ao desmatamento e à produção de monoculturas (por exemplo: D1 e D3), e os temas sociocientíficos relacionados à produção energética (por exemplo: D2 e D5), biotecnologia e aborto (por exemplo: D4 e D6). Nas investigações de doutoramento, observamos maior diversidade de temáticas abordadas. Dois trabalhos apresentam o foco em estudos de caso, embora com fundamentações conceituais diferentes, por exemplo, na T1, os estudos de caso estão relacionados aos diferentes professores sujeitos da investigação; no caso de T2, o processo de investigação iniciou-se por meio da elaboração conjunta com estudantes de casos localmente contextualizados.

\section{Significado e objetivos de QSC no ensino de ciências}

Para Ratcliffe e Grace (2003, p. 2, tradução nossa), QSC “[...] são aquelas que têm uma base científica e um impacto potencialmente grande na sociedade”. Ainda segundo esses autores, QSC apresentam as seguintes características: 
Quadro 3 - Síntese descritiva-analítica dos objetivos e temas das dissertações e teses sobre QSC

\begin{tabular}{|c|c|}
\hline $\begin{array}{l}\text { Objetivos } \\
\text { / temas }\end{array}$ & Descrição-analítica \\
\hline Objetivos & $\begin{array}{l}\text { - Implementação das controvérsias sociocientíficas no currículo da educação básica (D1 e D7); } \\
\text { - Exploração das controvérsias sociocientíficas enquanto propulsoras de engajamento discursivo/ } \\
\text { argumentativo (D2; } D_{3} ; D_{4} ; D_{5} \text { e D6; } T_{1} ; T_{2} ; T_{3} ; T_{4} ; T_{5} ; T_{6}, T_{7} \text { e T9); } \\
\text { - Exploração das controvérsias sociocientíficas para identificar conhecimentos e avaliar a } \\
\left.\text { apropriação de conceitos científicos ( } D_{3} \text { e } D_{4}\right) ; \\
\text { - Exploração das controvérsias sociocientíficas na/para formação de professores (T3 e T8); } \\
\text { - Exploração das controvérsias sociocientíficas para evidenciar padrões morais, modos de } \\
\text { raciocínio informal, valores (D3; D6; T5; T6; T7 e T9); }\end{array}$ \\
\hline Temas & 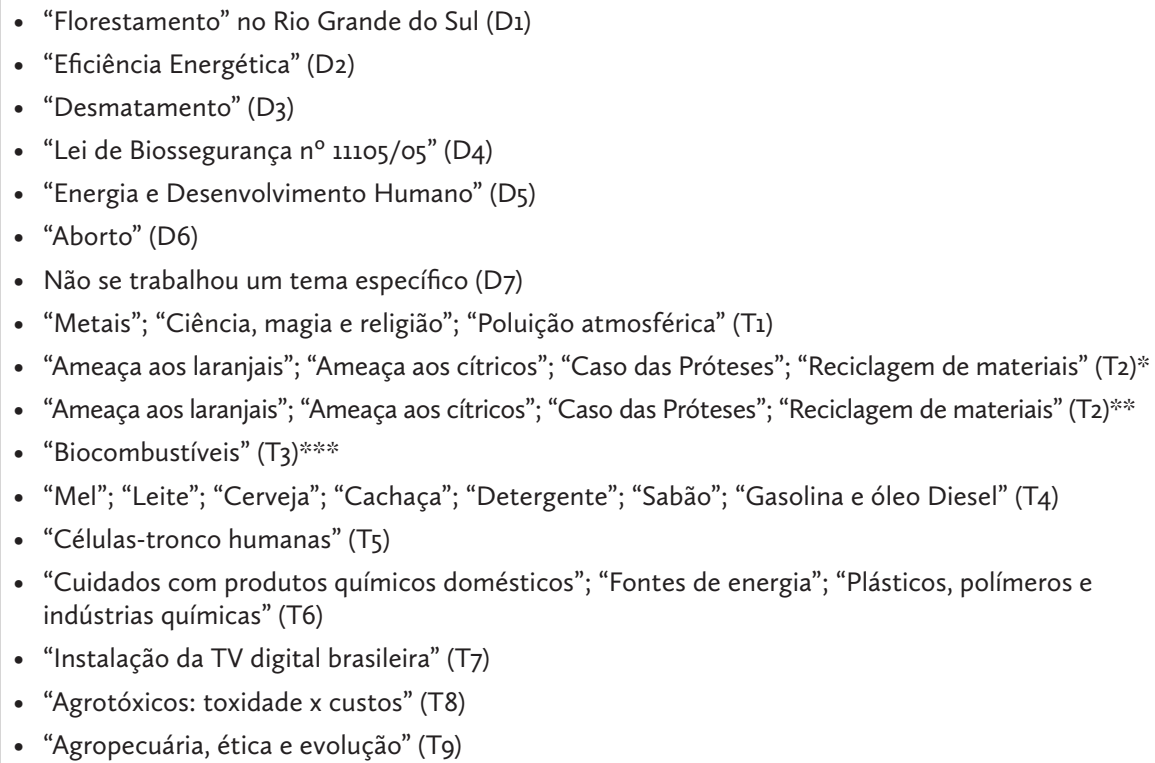 \\
\hline
\end{tabular}

Fonte: Silva (2016).

* Optou-se por exemplificar, no Quadro 3, apenas alguns dos estudos de caso que a autora Sá (2010), da T2, analisou em sua pesquisa.

** Optou-se por exemplificar, no Quadro 3, apenas alguns dos estudos de caso que a autora Sá (2010), da T2, analisou em sua pesquisa.

**** Em T3, mesmo que os sujeitos da pesquisa (professores em formação continuada) tenham levantado temas de QSC a serem abordados em sua prática pedagógica, optamos por exemplificar apenas aquele que foi trabalhado durante a disciplina de mestrado proposta pelo pesquisador e autor da referida tese, Martínez Perez (2010). 
têm uma base na ciência, frequentemente nas fronteiras do conhecimento científico; envolvem formação de opiniões, produção de escolhas no nível individual ou social; são frequentemente relatadas pela mídia, com problemas correlatos de apresentação com base nos propósitos do comunicador; lidam com informação incompleta, por causa de evidência científica conflitante/incompleta e relatórios inevitavelmente incompletos; contemplam dimensões locais, nacionais e globais, com estruturas políticas e sociais de atendimento; envolvem algumas análises de custo-benefício, nas quais os riscos interagem com os valores; podem envolver consideração de desenvolvimento sustentável; envolvem valores e raciocínio ético; podem requerer algum entendimento de probabilidade e risco; são frequentemente pontuais, transitórias. (RATCLIFFE; GRACE, 2003, p. 2, tradução nossa)

Para Sadler e Zeidler (2004), QSC são apresentadas como dilemas sociais com informações conceituais, procedimentais ou tecnológicas da ciência que levam em conta o impacto do desenvolvimento científico na sociedade, sobretudo em relação a seus aspectos éticos e morais. Simonneaux (2008) também conceitua QSC como dilemas sociais relacionados à ciência, que, em geral, são de natureza controversa. Já Reis e Galvão (2005, p. 137) destacam que QSC são dilemas sociais, afirmando que:

As questões sócio-científicas consistem em controvérsias sociais suscitadas pelas eventuais implicações (econômicas, políticas, ambientais, éticas etc.) de inovações científicas e tecnológicas e não em disputas académicas internas e restritas à comunidade científica (por exemplo, entre os apoiantes de teorias e modelos científicos concorrentes).

Em sua tese de doutorado, Shirley Margareth Buffon da Silva (2016) identificou que QSC são permeadas por questões de ordem moral, como assim também tem sido caracterizado por vários autores - ver, por exemplo, Grace e Ratcliffe (2002); Sadler e Zeidler (2004), Conrado, El-Hani e Nunes-Neto (2013) e Conrado e colaboradores (2013). Reis (2013, p. 1) afirma que QSC:

[...] consistem em questões suscitadas por interações entre ciência, tecnologia, sociedade e ambiente que dividem a sociedade e relativamente às quais diferentes grupos de cidadãos apresentam explicações e possíveis soluções que são incompatíveis, baseadas em crenças, compreensões e valores incompatíveis (Oulton, Dillon \& Grace, 2004; Levinson, 2006). Estas questões não conduzem a conclusões simples e envolvem uma dimensão moral e ética.

Essa constatação implica que estudos de QSC não podem ser considerados restritamente do ponto de vista da ciência, uma vez que, por sua natureza controversa e por definição, QSC está no campo da moral e da ética. 
Os estudos mostram a necessidade de integração da moralidade ao ensino de ciências decorrente da inclusão do contexto social e cultural em que a ciência funciona. A tomada de decisão em QSC é baseada em juízos de valor, que se apoiam em princípios morais e éticos. Tendo como pressuposto que os estudantes têm que ser preparados para lidar com dilemas morais fora da escola, esta deve prepará-los para lidar com questões de valor, para aprender a fazer julgamentos e assumir a responsabilidade por suas próprias vidas.

Compreendendo que a formação moral se deve a um conjunto complexo de atributos psicológicos que se desenvolvem ao longo da vida do indivíduo e de influências da família, escola e instituições sociais como um todo, cabe aos educadores considerar tais processos ao longo da experiência escolar, a fim de promover o desenvolvimento dos alunos. Se o nosso objetivo na educação é formar cidadãos capazes de colaborar e resolver os problemas de forma justa e equitativa, torna-se impossível separar a educação científica da formação moral e ética.

Em outro artigo, definimos QSC como questões que envolvem aspectos de natureza ambiental, política, econômica, ética, social e/ou cultural relativos à ciência e à tecnologia. (SANTOS; MORTIMER, 2009) Tomando, em conta, os achados na literatura e nossas novas reflexões, passamos a redefinir a conceituação de QSC, englobando três elementos. Elas:

- $\quad$ possuem relação com ciência ou tecnologia;

- $\quad$ se constituem em um dilema social; e

- apresentam uma controvérsia de ordem moral.

Vejamos exemplos desses elementos:

- Relação com ciência e tecnologia

Conflitos raciais e religiosos se constituem dilemas sociais que envolvem aspectos valorativos; todavia, alguns deles não se configuram em QSC quando não estão relacionados a conhecimentos científicos e tecnológicos, a exemplo divergências de interpretações bíblicas por diferentes religiões, porém, certos conflitos, que possuem natureza religiosa relacionados à ciência e à tecnologia, se configuram QSC como questões sobre controle de natalidade.

- Dilema social

Faz parte da Natureza da Ciência a controvérsia científica e é comum coexistirem teorias conflitantes, mesmo com o paradigma dominante, ao que Kuhn (1989) denominou de ciência normal. Muitas dessas controvérsias permanecem no campo interno da ciência e não se configuram em dilemas sociais, como, por exemplo, controvérsias envolvendo a natureza quântica da matéria. Essas não são QSC todavia, há controvérsias 
na comunidade científica sobre interpretações de riscos tecnológicos que se configuram em dilemas sociais como o uso de transgênicos e da energia nuclear, que se constituem em QSC.

- Controvérsia de ordem moral

O dilema da QSC implica a possibilidade de uma tomada de decisão entre mais de um possível encaminhamento. A decisão sobre qual caminho seguir vai envolver um julgamento valorativo e não meramente um reconhecimento da factualidade dos fenômenos, uma vez que o fato está entrelaçado ao valor. (PUTNAM, 2002)

No decorrer da história, as práticas inauguradas pela ciência do século XVII buscaram diferenciar as observações factuais dos juízos de valor, dicotomia esta que prevalece ainda hoje na busca pela verdade objetiva, no mito da neutralidade, enquanto os juízos de valor supostamente deveriam ficar fora da esfera científica. (MARICONDA, 2006) Entretanto, como a prática científica não é neutra, nem do ponto de vista dos valores mantidos pelos autores científicos - ver Lacey (2008) -, nem no que diz respeito às implicações éticas e sociais dos produtos científicos e de sua aplicação, qualquer tentativa de abordagem separada privilegiaria apenas um lado dessa dualidade, podendo resultar em uma apreciação incompleta, e não representativa da realidade, daí o porquê de uma QSC ter natureza de ordem ética e moral.

Nesse sentido, o terceiro elemento de nossa definição de QSC é inerente ao seu caráter de se constituir um dilema moral, característica que constitui uma oportunidade para abordar as convergências e divergências entre ciência e ética.

A consideração desses três elementos nos ajuda a refletir sobre os encaminhamentos na tomada de decisão. Frequentemente, QSC são consideradas com pontos de vista diferentes dentro da comunidade científica, de forma que não há consenso, na maioria das vezes, embora se tenha uma posição dominante. Trata-se de controvérsias de natureza sociocientífica para as quais a ciência não tem uma posição claramente definida, logo, não será exclusivamente pelo seu ponto de vista que poderemos encontrar respostas na tomada de decisão.

Por outro lado, existem QSC que se constituem em dilemas de ordem cultural ou religiosa que são compartilhados por um número inexpressivo de cientistas, como, por exemplo, a adoção de procedimentos de transfusão sanguínea. Nesse caso, a questão é mais de natureza religiosa ou cultural e o conhecimento científico poderá contribuir para uma tomada de decisão que venha aumentar a probabilidade de preservação da vida, se esse for o objetivo final.

Deve-se considerar, ainda, que o encaminhamento de decisões de muitas QSC não tem sua justificativa no conhecimento científico, pois há aquelas que não são consensuais e, ainda que assim o sejam, a sua validação é de natureza moral e ética. Esse é o centro, por exemplo, do debate sobre terapias abortivas, pois, em determinados casos, a discussão não está no grau de risco ou de sofrimento entre mãe e filho e sim no aceite 
ou não de se retirar a vida de um feto. Nesse caso, o debate tem muito mais caráter ético do que científico.

Nessa perspectiva, a discussão de QSC se enquadra no propósito mais amplo de formação para a cidadania, no sentido da preparação para a tomada de decisão - ver, por exemplo, Ratcliffe e Grace (2003) e Sadler (2004). Associado a esse objetivo central, em geral, defende-se que QSC englobam os seguintes objetivos:

- encorajar os alunos a relacionar suas experiências escolares em ciências com problemas de seu cotidiano e desenvolver responsabilidade social (PEDRETTI, 1999; RATCLIFFE, 1997);

- desenvolver nos alunos a capacidade de argumentar (GEDDIS, 1991; PATRONIS; POTARI; SPILIOTOPOULOU, 1999);

- desenvolver a habilidade de avaliar dados e informações científicas (JIMÉNEZ-ALEIXANDRE; RODRÍGUEZ; DUSCHL, 2000; KOLSTØ, 2001);

- compreender a natureza da atividade científica (BELL; LEDERMAN, 2003; ZEIDLER et al., 2005);

- desenvolver atitudes e valores (CROSS; PRICE, 1996; RATCLIFFE; GRACE, 2003; SANTOS, 2002).

O que temos defendido é que estudos de QSC possibilitam o desenvolvimento da capacidade de tomada de decisão. Este é também objetivo central da educação CTS, que engloba vários outros objetivos. (SANTOS; MORTIMER, 2000; SANTOS; SCHNETZLER, 2010) É nessa interface de QSC e CTS que temos defendido a introdução de QSC de forma mais sistemática no currículo de ciências.

Ao trazer um dilema para a sala de aula, estamos contribuindo para desenvolver no aluno a capacidade de analisar o dilema sobre diferentes pontos de vista. Na tese de doutorado de Santos (2002), foi defendido o papel humanizador de QSC no currículo. Assim, temos enfatizado ${ }^{4}$ a necessidade da abordagem de ASC no sentido de (re)significação da função social do ensino de ciências, com o objetivo de desenvolver atitudes e valores em uma perspectiva humanizadora, como a proposta por Paulo Freire (1967, 1972, 1992). Segundo este autor, a educação problematizadora, de caráter reflexivo, permite o desvelamento da realidade, por meio do diálogo, que permite a reflexão das contradições básicas da situação existencial humana.

Como afirmamos anteriormente:

[...] uma educação científica e tecnológica [humanizadora] buscaria incorporar ao currículo discussões de valores e reflexões críticas que possibilitassem desvelar a condição humana. Não se trata de fazer uma educação contra ou a favor do uso da tecnologia, mas de uma educação

4 Ver em: Santos (2002, 2007, 2008, 2009) e Santos e Mortimer (2009). 
em que os alunos possam refletir sobre a sua condição no mundo frente aos desafios postos pela ciência e tecnologia (C\&T). Isso se insere dentro do propósito de educação em ciências com função social, que também tem sido denominado de letramento científico. (SANTOS, 2007 apud SANTOS; MORTIMER, 2009, p. 192-193)

É nesse sentido que, em debates sobre a adoção do tema "aquecimento global" como QSC, destacamos a necessidade da inclusão de questões políticas que estão intrinsecamente relacionadas à dimensão moral dessas questões, constituindo uma base para sua discussão. (SANTOS, 2014) Esse é um papel-chave na educação científica que é a adoção de QSC como ferramenta para o desenvolvimento da participação do cidadão na sociedade, tomando em consideração o conhecimento científico dentro de um contexto sociopolítico e moral.

\section{Recomendações curriculares sobre uso de QSC}

Karolina Martins Almeida e Silva (2016) analisou também a presença de recomendações sobre QSC em documentos curriculares educacionais para o ensino médio Parâmetros Curriculares Nacionais para o Ensino Médio (PCNEM), 1998; Orientações Complementares aos Parâmetros Curriculares Nacionais para o Ensino Médio (PCN+), 2002; Orientações Curriculares para o Ensino Médio (Ocem), 2006, na área de Ciências da Natureza e suas Tecnologias (biologia, física e química); e o documento preliminar à Base Nacional Comum Curricular (BNCC) de 2015.

Os documentos curriculares analisados são orientações destinadas aos professores, sobre as disciplinas que compõem a base nacional comum e diversificada do currículo no contexto brasileiro. Nesses documentos, há reconhecimento de que um de seus objetivos é a contribuição das reflexões ao processo formativo dos professores frente à necessidade destes em abordar os conteúdos de forma ampla (envolvendo os aspectos sociocientíficos) e também estratégias metodológicas advindas de ações contextualizadas e interdisciplinares. (BRASIL, 1999, 2002, 2006)

Sabe-se que os mencionados documentos não têm valor legal no momento, em decorrência da promulgação, em 2012, das novas Diretrizes Curriculares Nacionais da Educação Básica, que revogaram as referidas orientações curriculares que foram elaboradas com base nas diretrizes anteriores. Todavia, pelo fato de não terem sido editados novos documentos, os que foram analisados são os que orientaram as políticas públicas educacionais dos últimos dez anos, por exemplo, os Programas Nacionais de Livro Didático, os exames de avaliação do sistema educacional, as elaborações de propostas curriculares pelos estados da federação, os programas de formação de professores. (BRASIL, 2013)

Diferente da análise com utilização prévia de "termos-chave" para serem identificados no texto, optou-se por realizar uma leitura sistemática de todos os documentos, 
de modo a realçar os elementos textuais que sinalizam a abordagem das controvérsias em cada disciplina. Cabe mencionar que os trechos identificados mediante a análise são aqueles que apresentam as descrições sobre ciência e tecnologia relacionadas aos termos: "polêmicas", "respeito a opiniões", "tomada de decisão", "avaliação de riscos e benefícios", "valores", "julgamentos”, "éticos”, "morais”.

Os elementos relacionados à abordagem das controvérsias sociocientíficas são recorrentes nas proposições curriculares da disciplina de Biologia, como podemos perceber nos trechos que se seguem:

[...] deve subsidiar o julgamento de questões polêmicas, que dizem respeito ao desenvolvimento, ao aproveitamento de recursos naturais e à utilização de tecnologias que implicam intensa intervenção humana no ambiente, cuja avaliação deve levar em conta a dinâmica dos ecossistemas, dos organismos, enfim, o modo como a natureza se comporta e a vida se processa. (BRASIL, 1999, p. 14, grifo nosso)

[...] Transmissão da vida, ética e manipulação gênica. [...] tais conhecimentos permitem que os alunos sejam introduzidos no debate das implicações éticas, morais, políticas e econômicas das manipulações genéticas, analisando-as e avaliando os riscos e benefícios para a humanidade e o planeta. (BRASIL, 2002, p. 49, grifo nosso)

De acordo com Nascimento Júnior (2011, p. 238), “[...] em síntese, os documentos curriculares identificam o conhecimento produzido pela biologia como um produto social, ou seja, entendem a biologia como uma construção social. Reconhecem as flutuações e contradições ao longo de sua história [...]”. Isso se deve, consequentemente, ao próprio conteúdo biológico que, por sua natureza, lida com questões polêmicas relacionadas à origem da vida, à evolução, à genética, à mutação, à biotecnologia, dentre outros.

No que compete ao conteúdo da física, mesmo diante da pequena quantidade de trechos que mencionam a abordagem de controvérsias sociocientíficas, identificamos, nos documentos, muitas descrições acerca da importância em se abordar o conteúdo físico de forma ampla, de modo a reconhecer o conhecimento físico para compreensão das relações entre ciência, tecnologia e sociedade, o que, de certa forma, denota a importância de se trabalhar com os ASC relacionados aos temas controversos também presentes na física, como, por exemplo, nas descrições a seguir: "[...] o desenvolvimento da comunicação via satélite, a telefonia celular, são alguns exemplos de informações presentes nos jornais e programas de televisão que deveriam também ser tratados em sala de aula”. (BRASIL, 1999, p. 27)

Do mesmo modo, assim como na análise da proposição de abordagem do conteúdo da física, também identificamos trechos que denotam inter-relações CTS nos documentos curriculares para o ensino de química. Cabe mencionar que os trechos identificados 
são aqueles que apresentam notória relação entre o conhecimento de química, as discussões dos ASC e tecnológicos e o desenvolvimento da tomada de decisão comprometida com a cidadania, como descrito a seguir:

[...] A discussão de aspectos sociocientíficos articuladamente aos conteúdos químicos e aos contextos é fundamental, pois propicia que [...] desenvolvam a capacidade de tomada de decisão com maior responsabilidade, na qualidade de cidadãos, sobre questões relativas à Química e à Tecnologia, e desenvolvam também atitudes e valores comprometidos com a cidadania [...]. (BRASIL, 2006, p. 119, grifo nosso)

De modo geral, os três documentos curriculares analisados explicitam a abordagem dos aspectos históricos, políticos, econômicos, sociais, culturais e ambientais relacionados à ciência e tecnologia. Além disso, nos $\mathrm{PCN}+$ e nas Ocem, a proposição de organização curricular em temas estruturadores e competências envolve a necessidade de se trabalhar com a "contextualização sociocultural", que, por sua vez, implica a avaliação do "caráter ético do conhecimento científico e tecnológico". (BRASIL, 2002, 2006) Essa proposição avaliativa, mesmo que implicitamente, expressa a importância de se abordar controvérsias sociocientíficas nas quais são demandadas discussões que envolvam valores éticos e morais.

Deve-se considerar, ainda, que nas novas Diretrizes Curriculares Nacionais da Educação Básica, há determinação, no Art. 12, de que "o currículo do ensino médio deve I - garantir ações que promovam: a) a educação tecnológica básica, a compreensão do significado da ciência, das letras e das artes”. (BRASIL, 2013, p. 197, grifo nosso) Neste documento das Diretrizes, no seu item 6) função do ensino médio no marco legal, há afirmação de que a finalidade da educação é de tríplice natureza:

I - O pleno desenvolvimento do educando deve ser voltado para uma concepção teórico educacional que leve em conta as dimensões: intelectual, afetiva, física, ética, estética, política, social e profissional;

II - O preparo para o exercício da cidadania centrado na condição básica de ser sujeito histórico, social e cultural; sujeito de direitos e deveres;

III - A qualificação para o trabalho fundamentada na perspectiva de educação como um processo articulado entre ciência, tecnologia, cultura e trabalho. (BRASIL, 2013, p. 169, grifo nosso)

Entende-se que a educação tecnológica e a articulação entre ciência, tecnologia e trabalho pressupõem conhecimentos, sobretudo, de QSC, que são inerentes à ciência e à tecnologia. Deve-se destacar ainda que toda a fundamentação para a organização curricular do ensino médio nas novas diretrizes está centrada no trabalho, na ciência, na tecnologia e na cultura como dimensões da formação humana. (BRASIL, 2013) A 
menção da ciência e da tecnologia como dimensão curricular está presente em diversos trechos do referido documento, como ilustrado na citação abaixo:

Os componentes curriculares e as áreas de conhecimento devem articular a seus conteúdos, a partir das possibilidades abertas pelos seus referenciais, a abordagem de temas abrangentes e contemporâneos, que afetam a vida humana em escala global, regional e local, bem como na esfera individual. Temas como saúde, sexualidade e gênero, vida familiar e social, assim como os direitos das crianças e adolescentes, de acordo com o Estatuto da Criança e do Adolescente (Lei n ${ }^{\circ} 8.069 / 90$ ), preservação do meio ambiente, nos termos da política nacional de educação ambiental (Lei no 9.795/99), educação para o consumo, educação fiscal, trabalho, ciência e tecnologia, diversidade cultural, devem permear o desenvolvimento dos conteúdos da base nacional comum e da parte diversificada do currículo. (BRASIL, 2013, p. 165, grifo nosso)

Dessa forma, pode-se afirmar que as orientações curriculares analisadas, no que diz respeito à inclusão de ASC e QSC, permanecem em concordância com o novo texto das Diretrizes Curriculares Nacionais.

Em continuidade, no ano de 2015, frente ao exposto nas Diretrizes Curriculares Nacionais Gerais para a Educação Básica e ao Plano Nacional de Educação, o Ministério da Educação (MEC) apresenta para consulta pública o documento preliminar à BNCC. ${ }^{5}$ Trata-se de um conjunto de proposições que orientam as escolhas feitas pelos componentes curriculares na definição de objetivos de aprendizagem. Visa enfatizar a consideração das dimensões ética, estética e política para efetivação dos direitos de aprendizagem relacionados às quatro áreas do conhecimento - Ciências da Natureza, Ciências Humanas, Linguagens e Matemática. (BRASIL, 2015)

O documento da BNCC prevê a padronização de $60 \%$ dos conteúdos a serem apresentados aos alunos da educação básica, ano a ano, sendo que, os outros $40 \%$ serão definidos pelas próprias instituições e redes de ensino, contemplando particularidades regionais. Sinaliza que a definição de objetivos e critérios se materializem nos componentes curriculares por meio de eixos integradores cuja função é articular tanto os componentes de uma mesma área quanto as diferentes etapas de escolarização. Essa integração é estabelecida pelos “temas integradores”. Tais temas, de acordo com o documento, dizem respeito a questões que perpassam objetivos de aprendizagem de diversos componentes curriculares nas diferentes etapas da educação básica são eles: "Consumo e educação financeira"; "Ética e direitos humanos e cidadania"; "Sustentabilidade"; "Tecnologias digitais"; "Culturas africanas e indígenas”. (BRASIL, 2015)

5 A elaboração do texto preliminar da nova proposta curricular foi realizada por um Comitê de Assessores, com 116 especialistas de 35 universidades. A proposta esteve aberta a discussões e proposições até o mês de dezembro de 2015 e pode ser acessada no portal do MEC. 
A BNCC, sobre a área de Ciências da Natureza, apresenta na seção "Componente Curricular - Biologia”, a organização do ensino do conhecimento biológico em torno de unidades de conhecimento que atendam aos seguintes critérios:

Incluam saberes conceituais que estruturem o pensamento da área, que se articulem com saberes práticos e auxiliem o exercício da cidadania e tomada de decisão socialmente responsável; permitam um tratamento progressivo e recursivo de conceitos estruturantes ao longo do currículo; Contemplem em conjunto, os diferentes níveis de organização da vida (molecular, celular, tecidual, sistêmico, populacional, ecossistêmico) e a relação entre eles. (BRASIL, 2015, p. 206)

Ainda nessa seção, explicita a importância em se abordar discussões de QSC para contemplar as dimensões sociais, tecnológicas, culturais, éticas, afetivas e artísticas. Anuncia também que as QSC são propulsoras para o reconhecimento de dimensões da contextualização histórica, social e cultural da biologia e enfatiza que sua abordagem pode contribuir para a compreensão das inter-relações CTS.

No que compete às QSC, podemos destacar que as mesmas foram evidenciadas como importantes ferramentas na abordagem de aspectos relativos à compreensão das inter-relações CTS, o que indicam a relação "CTS-QSC”. Além disso, são vistas como propulsoras para a contextualização histórica, social e cultural do conhecimento biológico. Também identificamos no referido documento a abordagem de QSC para a formação de um cidadão crítico e participativo no que compete ao ensino de química.

\section{Considerações finais: perspectivas e desafios de QSC}

O movimento de educação CTS no Brasil vem se consolidando nas últimas décadas (SANTOS, 2011) e, no seu bojo, vem se estabelecendo os estudos de QSC, que, no Brasil, embora sejam ainda incipiente, também estão se consolidando como campo de pesquisa. No presente capítulo, buscou-se demonstrar que ainda é necessário avançar em publicações sobre QSC. Deve-se considerar, todavia, que a revisão de literatura aqui apresentada ainda é limitada e mais pesquisas de revisão precisam ser desenvolvidas, ampliando o conjunto de periódicos analisados, bem como incorporando anais de eventos.

Ainda são poucos os artigos nos principais periódicos revisados e a própria denominação de QSC não está bem estabelecida, como identificamos em nossa revisão. Nesse contexto, apontamos a necessidade de uma pesquisa que abarque mais fontes como, outros estratos do Qualis/Capes e projetos de pesquisa e extensão com QSC no Brasil, a fim de fundamentar uma conclusão mais representativa com relação às QSC em âmbito nacional. O termo QSC é usado como sinônimo de tema sociocientífico e artigos de questões controvertidas não mencionam QSC. Isso indica a necessidade 
de desenvolvimento de mais pesquisas no campo e de uma melhor utilização da definição do termo QSC. Afinal, discutir controvérsias na educação científica ainda se configura em uma dificuldade no ensino de ciências. Isso implica o desenvolvimento da capacidade de argumentar e, como constataram Mendes e Santos (2013, p. 637, grifo nosso):

Promover a argumentação implica estimular a diversidade de opiniões. Sueli, César e Vilma oportunizaram a verbalização e, inclusive, utilizaram estratégias para favorecê-la. No entanto, conduziram o discurso em uma perspectiva predominantemente explicativa, visando à interpretação e ampliação do conteúdo dos materiais utilizados como apoio para a discussão - textos do LD, do artigo, do livro paradidático. Dessa forma, mantiveram-se atrelados às ideias dos mesmos, assumindo o seu discurso de autoridade. Em relação a isso, devemos levar em consideração que reproduzir o discurso de autoridade das ciências tem sido, historicamente, o que é esperado dos professores de ciências e praticado por eles. Promover a argumentação implica em romper, mesmo que momentaneamente, com essa prática, o que não é simples, mesmo para professores propensos a vivenciar novas propostas metodológicas em sua atividade docente, como esses que foram sujeitos em nossa investigação.

Essa tarefa de apresentar o caráter incerto da ciência torna-se difícil, se considerarmos que o ensino de ciências tem se constituído no ensino do conhecimento estabelecido que Kuhn (1989) denominou de ciência normal, que se refere ao saber científico dominante, já estabelecido, o qual é consensual na comunidade científica. O estudo de QSC vem no sentido de revelar a natureza incerta da ciência e romper com a tradição do discurso de autoridade do ensino de ciências. Para isso, exige-se uma mudança nas concepções de ciência do professor e na sua dinâmica de sala de aula.

Ao identificar que QSC envolve dilemas éticos, implica considerar uma importante dimensão que geralmente não está presente no campo de formação do professor de ciências. Isso aponta para a necessidade de reflexões mais amplas do professor no campo da filosofia. Discutir QSC em sala de aula é, sobretudo, discutir valores da sociedade.

Tanto a formação de professores, quanto o entendimento de como se desenvolvem discussões de QSC em sala de aula são desafios para a pesquisa em ensino de ciências, que devem contribuir para compreensão desse complexo campo.

O que as pesquisas até aqui têm apontado segue na direção do que se tem prescrito em termos de orientações curriculares no Brasil, de que a inclusão de QSC se constitui em conteúdo fundamental para a educação científica na perspectiva de letramento científico. O que se deseja de um cidadão, em nossa sociedade, é um posicionamento crítico frente aos dilemas que enfrentamos em decorrência do atual modelo de desenvolvimento científico e tecnológico que vem degradando o ambiente e aumentando as 
desigualdades sociais. Acreditamos que a introdução de QSC em aulas de ciências pode contribuir para a formação de um cidadão crítico com desenvolvimento de valores fundamentados na justiça e na igualdade social. Essa é a perspectiva que temos em mente para a educação científica brasileira, que se constitui em desafio para os educadores que pretendem transformar o espaço de sala para o aprendizado de novos saberes e a discussão de temas contemporâneos.

\section{Referências}

AIKENHEAD, G. S. STS education: a rose by any other name. In: CROSS, R. (Ed.). A vision for science education: responding to the work of Peter Fensham. London: Routledge Falmer, 2003. p. 59-75.

AIKENHEAD, G. S. What is STS science teaching? In: SOLOMON, J.; AIKENHEAD, G. (Ed.). STS education: international perspectives on reform. New York: Teachers College Press, 1994. p. 47-59.

ALVES, S. B. F.; CALDEIRA, A. M. A. Biologia e ética: um estudo sobre a compreensão e atitudes de alunos do ensino médio frente ao tema genoma/DNA. Ensaio Pesquisa em Educação em Ciências, Belo Horizonte, v. 7, n. 1, p. 19-32, 2005.

BARBOSA, L. G. D.; LIMA, M. E. C. de C.; MACHADO, A. H. Controvérsias sobre o aquecimento global: circulação de vozes e sentidos produzidos em sala de aula. Ensaio Pesquisa em Educação em Ensino de Ciências, Belo Horizonte, v. 14, n. 1, p. 103-130. jan./abr. 2012.

BELL, R. L.; LEDERMAN, N. G. Understandings of the nature of science and decision making on science and technology based issues. Science Education, New York, v. 87, n. 3, p. 352-377, 2003.

BRASIL. Ministério da Educação. Diretrizes curriculares nacionais gerais da educação básica. Brasília, DF, 2013.

BRASIL. Ministério da Educação. Documento de apresentação da Base Curricular Comum Nacional - BNCC. Brasília, DF, 2015. Disponível em: <http:// basenacionalcomum.mec.gov.br/\#/site/inicio>. Acesso em: 23 out. 2015.

BRASIL. Ministério da Educação. Orientações curriculares para o ensino médio: ciências da natureza, matemática e suas tecnologias. Brasília, DF, 2006.

BRASIL. Ministério da Educação. Parâmetros curriculares nacionais: ensino médio. Brasília, DF, 1999.

BRASIL. Ministério da Educação. PCN+ensino médio: orientações educacionais complementares aos parâmetros curriculares nacionais: ciências da natureza, matemática e suas tecnologias. Brasília, DF, 2002.

CONRADO, D. M. et al. Evolução e ética na tomada de decisão em questões sociocientíficas. Revista Electrónica de Enseñanza de las Ciencias, Ourense, p. 803-807, 2013. Edição especial. 
CONRADO, D. M.; EL-HANI, C. N.; NUNES-NETO, N. F. Sobre a ética ambiental na formação do biólogo. REMEA-Revista Eletrônica do Mestrado em Educação Ambiental, Rio Grande, v. 30, n. 1, p. 120-139, jan./jun. 2013.

CROSS, R. T.; PRICE, R. F. Science teachers' social conscience and the role of ontroversial issues in the teaching of science. Journal of Research in Science Teaching, New York, v. 33, n. 3, p. 319-333, 1996.

FREIRE, P. Educação como prática da liberdade. Rio de Janeiro: Paz e Terra, 1967.

FREIRE, P. Pedagogia do oprimido. Rio de Janeiro: Paz e Terra, 1972.

FREIRE, P. Pedagogia da esperança: um reencontro com a pedagogia do oprimido. Rio de Janeiro: Paz e Terra, 1992.

GEDDIS, A. N. Improving the quality of science classroom discourse on controversial issues. Science Education, New York, v. 75, n. 2, p. 169-183, 1991.

GALVÃO, C.; REIS, P.; FREIRE, S. A discussão de controvérsias sociocientíficas na formação de professores. Ciência \& Educação, Bauru, v. 17, n. 3, p. 505-522, 2011.

GUIMARÃES, M. A.; CARVALHO, W. L. P.; OLIVEIRA, M. S. Raciocínio moral na tomada de decisões em relação a questões sociocientíficas: o exemplo do melhoramento genético humano. Ciência \& Educação, Bauru, v. 16, n. 2, p. 465-477, 2010.

GRACE, M. M.; RATCLIFFE, M. The science and values that young people draw upon to make decisions about biological conservation issues. International Journal of Science Education, London, v. 24, n. 11, p. 1157-1169, 2002.

HODSON, D. Putting your money where your mouth is: towards an action-oriented science curriculum. Journal for Activist Science \& Technology Education, [S.1.], v. 1, n. 1, p. 1-15, 2009.

JIMÉNEZ-ALEIXANDRE, M. P.; RODRÍGUEZ, A. B.; DUSCHL, R. A. "Doing the lesson" or "doing science:" argument in high school genetics. Science Education, New York, v. 84, n. 6, p. 757-792, 2000.

KORTLAND, K. An STS case study about students' decision making on the waste issue. Science Education, New York, v. 80, n. 6, p. 673-689, 1996.

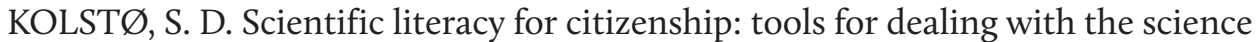
dimension of controversial socioscientific issues. Science Education, New York, v. 85, n. 3, p. 291-310, 2001.

KUHN, T. S. A estrutura das revoluções científicas. 3. ed. São Paulo: Perspectiva,1989.

LACEY, H. Valores e atividade científica 1. São Paulo: Ed. 34, 2008. (Filosofia da ciência e da tecnologia).

LEVINSON, R. Towards a theoretical framework for teaching controversial socioscientific issues. International Journal of Science Education, London, v. 28, n. 10, p. 1201-1224, 2006. 
MARICONDA, P. R. O controle da natureza e as origens da dicotomia entre fato e valor. Scientiae Studia, São Paulo, v. 4, n. 3, p. 453-72, 2006.

MARTÍNEZ PÉREZ, L. F. A abordagem de questões sociocientíficas na formação continuada de professores de ciências: contribuições e dificuldades. 2010. 351 f. Tese (Doutorado em Educação para a Ciência) - Faculdade de Ciências, Universidade Estadual Paulista, Bauru, 2010.

MENDES, M. R. M.; SANTOS, W. L. P. dos. Argumentação em discussões sociocientíficas. Investigações em Ensino de Ciências, Porto Alegre, v. 18, n. 3, p. 621643, 2013.

MENDES, M. R. M.; SANTOS, W. L. P. dos. CTS, questões sociocientíficas e argumentação na educação em ciências. In: MACÊDO, F. C. da S., GONÇALVES, T. V. O.; SOUSA, F. L. (Org.). Educação em ciências e matemáticas: fundamentos, ensino e pesquisa. Porto Alegre: ARTMED, 2015.

MUNDIM, J. V.; SANTOS, W. L. P. O ensino de ciências no ensino fundamental por meio de temas sociocientíficos: análise de uma prática pedagógica com vista à superação do ensino disciplinar. Ciência \& Educação, Bauru, v. 18, n. 4, p. 787-802, 2012.

NASCIMENTO JÚNIOR, A. F.; SOUZA, D. C.; CARNEIRO, M. C. O Conhecimento Biológico nos Documentos Curriculares Nacionais do Ensino Médio: uma análise Histórico-Filosófica a partir dos Estatutos da Biologia. Investigações em Ensino de Ciências, Porto Alegre, v. 16, n. 2, p. 223-243, 2011.

OULTON, C.; DILLON, J.; GRACE, M. M. Reconceptualizing the teaching of controversial issues. International Journal of Science Education, London, v. 26, n. 4, p. 411-423, 2004.

PATRONIS, T.; POTARI, D.; SPILIOTOPOULOU, V. Students' argumentation in decision-making on a socio-scientific issue: Implications for teaching. International Journal of Science Education, London, v. 21, n. 7, p. 745-754, 1999.

PEDRETTI, E. Decision making and STS education: Exploring scientific knowledge and social responsibility in schools and science centers through an issues-based approach. School Science and Mathematics, Menasha, v. 99, n. 4, p. 174-181, 1999.

PEDRETTI, E. Septic tank crisis: a case study of science, technology and society education in an elementary school. International Journal of Science Education, London, v. 19, n. 10, p. 1211-1230, 1997.

PEDRETTI, E. Teaching science, technology, society and environment (STSE) education: preservice teachers' philosophical and pedagogical landscapes. In: ZEIDLER, D. L. (Ed.). The role of moral reasoning on socioscientific issues and discourse in science education. Netherlands: Kluwer Academic Publishers, 2003. p. 219-239.

PEDRETTI, E. G. et al. Promoting issues based STSE: perspectives in science teacher education: problems of identity and ideology. Science \& Education, Dordrecht, v. 17, n. 8/9, p. 941-960, 2008. 
PEDRETTI, E.; NAZIR, J. Currents in STSE education: mapping a complex field, 40 years on. Science Education, New York, v. 95, n. 4, p. 601-626, 2011.

PEREZ, D. M. et al. Temas polêmicos e a argumentação de estudantes do curso de ciências biológicas. Ensaio Pesquisa em Educação em Ciências, Belo Horizonte, v. 13, n. 2, p. 135-150, 2011.

PUTNAM, H. The collapse of the fact/value dichotomy and other essays. Cambridge, MA: Harvard Press, 2002.

RAMOS, M. B.; SILVA, H. C. Para pensar as controvérsias científicas em aulas de ciências. Ciência \& Ensino, São Paulo, v. 1, 2007. Edição especial.

RAMSEY, J. The science education reform movement: implications for social responsibility. Science Education, New York, v. 77, n. 2, p. 235-258, 1993.

RATCLIFFE, M. Pupil decision-making about socioscientific issues, within the science curriculum. International Journal of Science Education, London, v. 19, n. 2, p. 167-182, 1997.

RATCLIFFE, M.; GRACE, M. Science education for citizenship: teaching socio-scientific issues. Maidenhead: Open University Press, 2003.

RAZERA, J. C. C.; NARDI, R. Ética no ensino de ciências: responsabilidades e compromissos com a evolução moral da criança nas discussões de assuntos controvertidos. Investigações em Ensino de Ciências, Porto Alegre, v. 11, n. 1, p. 53-66, 2006.

REIS, P.; GALVÃO, C. Socio-scientific controversies and students' conceptions about scientists. International Journal of Science Education, London, v. 26, n. 13, p. 1621-1633, 2004.

REIS, P.; GALVÃO, C. Controvérsias sócio-científicas e prática pedagógica de jovens professores. Investigações em Ensino de Ciências, Porto Alegre, v. 10, n. 2, p. 131-160, 2005.

REIS, P. Da discussão à ação sociopolítica sobre controvérsias sócio-científicas: Uma questão de cidadania. Ensino de Ciências e Tecnologia em Revista, Santo Ângelo, v. 3, n. 1, p. 1-10, 2013.

SÁ, L. P. Estudo de Casos na Promoção da Argumentação sobre Questões Sociocientíficas no Ensino Superior de Química. 2010. 278 f. Tese (Doutorado em Ciências Exatas e da Terra) - Departamento de Química, Universidade Federal de São Carlos, São Carlos, 2010 .

SADLER, T. D. Informal reasoning regarding socioscientific issues: a critical review of research. Journal of Research in Science Teaching, New York, v. 41, n. 5, p. 513-536, 2004.

SADLER, T. D. Situated learning in science education: socio-scientific issues as contexts for practice. Studies in Science Education, Leeds, v. 45, n. 1, p. 1-42, 2009. 
SADLER, T. D.; ZEIDLER, D. L. The morality of socio-scientific issues construal and resolution of genetic engineering dilemmas. Science Education, New York, v. 88, n. 1, p. 4-27, 2004.

SANTOS, M. S.; AMARAL, C. L. C.; MACIEL, M. D. Tema sociocientífico "cachaça" em aulas práticas de química na educação profissional: uma abordagem CTS. Ensaio: Pesquisa em Educação em Ciências, Belo Horizonte, v. 14, n. 1, p. 227-239, 2012.

SANTOS, W. L. P. dos. O ensino de química para formar o cidadão: principais características e condições para a sua implantação na escola secundária brasileira. 1992. 243 f. Dissertação (Mestrado em Educação) - Faculdade de Educação, Universidade Estadual de Campinas, Campinas, 1992.

SANTOS, W. L. P. dos. Aspectos sociocientíficos em aulas de química. 2002. 336 f. Tese (Doutorado em Educação) - Faculdade de Educação, Universidade Federal de Minas Gerais, Belo Horizonte, 2002.

SANTOS, W. L. P. dos. Educação científica: uma revisão sobre suas funções para a construção do conceito de letramento científico como prática social. Revista Brasileira de Educação, Rio de Janeiro, v. 12, n. 36, p. 474-492, 2007.

SANTOS, W. L. P. dos. Educação científica humanística em uma perspectiva freireana: resgatando a função do ensino de CTS. Alexandria, Florianópolis, v. 1, n. 1, p. 109-131, 2008.

SANTOS, W. L. P. dos. Scientific literacy: a freirean perspective as a radical view of humanistic science education. Science Education, New York, v. 93, n. 2, p. 361-382, 2009.

SANTOS, W. L. P. dos. Significados da educação científica com enfoque CTS. In: SANTOS, W. L. P. dos; AULER, D. (Org.). CTS e educação científica: desafios, tendências e resultados de pesquisa. Brasília, DF: Editora Universidade de Brasília, 2011. p. 21-47.

SANTOS, W. L. P. dos. Debate on global warming as a socio-scientific issue: science teaching towards political literacy. Cultural Studies of Science Education, Dordrecht, v. 9, p. 663-674, 2014.

SANTOS, W. L. P. dos; MORTIMER, E. F. Uma análise de pressupostos teóricos da abordagem C-T-S (Ciência-Tecnologia-Sociedade) no contexto da educação brasileira. Ensaio: Pesquisa em Educação em Ciências, Belo Horizonte, v. 2, n. 2, p. 133-162, 2000 .

SANTOS, W. L. P. dos; MORTIMER, E. F. Abordagem de aspectos sociocientíficos em aulas de ciências: possibilidades de limitações. Investigações em Ensino de Ciências, Porto Alegre, v. 14, n. 2, 2009.

SANTOS, W. L. P. dos; SCHNETZLER, R. P. Educação em química: compromisso com a cidadania. 4 ed. ljuí: Editora da Unijuí, 2010.

SILVA, K. M. A. Questões sociocientíficas e o pensamento complexo: tecituras para o ensino de ciências. 2016. 303 f. Tese (Doutorado em Educação) - Faculdade de Educação, Universidade de Brasília, Brasília, DF, 2016. 
SILVA, S. M. B da; SANTOS, W. L. P. dos. Questões sociocientíficas e o lugar da moral nas pesquisas em ensino de ciências. Interacções, Lisboa, v. 10, n. 31, p. 124-148, 2014.

SILVA, S. M. B. O lugar da moral em questões sociocientíficas no ensino de biologia. 2016. 265 f. Tese (Doutorado em Educação) - Faculdade de Educação, Universidade de Brasília, 2016.

SILVA, P. F.; KRASILCHIK, M. Bioética e ensino de ciências: o tratamento de temas controversos - dificuldades apresentadas por futuros professores de ciências e biologia. Ciência \& Educação, Bauru, v. 19, n. 2, p. 379-392, 2013.

SILVA, L. F.; CARVALHO, L. M. de. A temática ambiental e o processo educativo: o ensino de física a partir de temas controversos. Ciência \& Ensino, São Paulo, v. 1, 2007. Edição especial.

SOLOMON, J. The discussion of social issues in the science classroom. Studies in Science Education, Leeds, v. 18, n. 1, p. 105-126, 1990.

SOLOMON, J. The classroom discussion of science-based social issues presented on television: knowledge, attitudes and values. International Journal of Science Education, London, v. 14, n. 4, p. 431-444, 1992.

SOLOMON, J. Teaching science, technology and society. Buckingham: Open University Press, 1993.

SIMONNEAUX, L. Argumentation in socio-scientific contexts. In: ERDURAN, S.; JIMÉNEZ-ALEIXANDRE, M. P. (Ed.). Argumentation in science education: perspectives from classroom-Based Research. Dordrecht: Springer, 2008. p. 179-199.

SIMONNEAUX, L.; SIMONNEAUX, J. Students' socio-scientific reasoning on controversies from the viewpoint of education for sustainable development. Cultural Studies of Science Education, Dordrecht, v. 4, n. 3, p. 657-687, 2009.

VIEIRA, K. R. C. F.; BAZZO, W. A. Discussões acerca do aquecimento global: uma proposta CTS para abordar esse tema controverso em sala de aula. Ciência \& Ensino, São Paulo, v. 1, 2007. Edição especial,

VIEIRA, R. D.; MELO, V. F.; BERNARDO, J. R. da R. O júri simulado como recurso didático para promover argumentações na formação de professores de física: o problema do "gato". Ensaio: Pesquisa em Educação em Ciências, Belo Horizonte, v. 16, n. 3, 2014.

ZEIDLER, D. L. et al. Beyond STS: a research-based framework for socioscientific issues education. Science Education, New York, v. 89, n. 3, p. 357-377, 2005.

ZEIDLER, D. L. et al. Tangled up views: beliefs in the nature of science and responses to socioscientific dilemmas. Science Education, New York, v. 86, n. 3, p. 343-367, 2002.

ZUIN, V. G.; FREITAS, D. de. A utilização de temas controversos: um estudo de caso na formação de licenciandos numa abordagem CTSA. Ciência \& Ensino, São Paulo, v. 1, n. 2, 2007. 


\title{
CONTRIBUCIONES Y DESAFÍOS QUE POSEEN LOS PROFESORES DURANTE LA ARTICULACIÓN DE CUESTIONES SOCIOCIENTIIFICAS EN EL CURRÍCULO DE CIENCIAS ${ }^{1}$
}

\author{
Ingrid Ximena Arias Hodge \\ Leonardo Fabio Martínez Pérez
}

\section{Introducción}

El enfoque Ciencia, Tecnología, Sociedad y Ambiente (CTSA) en la enseñanza de las ciencias surge como una alternativa educativa para promover la participación cívica de los estudiantes en las decisiones de C\&T (ACEVEDO et al., 2005; MARTÍNEZ PÉREZ, 2012), transformando no sólo el rol del docente y del estudiante en el aula, sino que se constituye como una perspectiva de cambio en los procesos de enseñanza y aprendizaje. No obstante, a pesar de dar sentido a los procesos mencionados y perseguir objetivos claros, tuvo varias dificultades en la consolidación del currículo (MARTÍNEZ PÉREZ, PARGA; GOMEZ, 2013), por lo que, ante la urgencia de una renovación curricular y la necesidad de regenerar las actitudes de los estudiantes hacia el aprendizaje de las ciencias, se presentan las Cuestiones Sociocientíficas (CSC) y sus implicaciones ambientales como una manera de

1 Trabajo de investigácion articulado al Proyecto Colombo-brasileño de formación de professor en la interfaz Universidad-escuela, Col-UPN-531-12 Coleciencias/Capes. 
materializar en el currículo escolar los retos propuestos por dicho enfoque. Puesto que al ser situaciones controvertidas, permiten orientar la enseñanza hacia la promoción de una ciencia escolar de mayor relevancia para los estudiantes, que como ciudadanos responsables, tienen que prepararse para tomar decisiones relacionadas con asuntos científicos y tecnológicos. (MARTÍNEZ PÉREZ; PARGA; GOMEZ, 2013)

De esta manera, el presente capítulo se centra en el análisis de las contribuciones y desafíos que poseen los profesores durante la articulación de CSC en el currículo de ciencias, a partir de los resultados obtenidos en el trabajo realizado con el Pequeño Grupo de Investigación (PGI) de la Institución Educativa (IED) Fabio Lozano Simonelli, constituido interdisciplinarmente desde la interfaz universidad-escuela.

En este orden de ideas, el primer apartado gira en torno a los referentes teóricos relacionados con aspectos que caracterizan a las CSC y su importancia en la implementación de las prácticas pedagógicas, así como la investigación colectiva, una forma de fortalecer la autonomía docente y generar puentes de interlocución entre la universidad y la escuela desde la articulación de las CSC al currículo tradicional de ciencias. El segundo apartado, por su parte, pone de manifiesto la metodología que orienta la investigación y la población utilizada para el desarrollo de la investigación y, en el tercer apartado, enfatiza en torno a la estructuración de las secuencias de actividades propuestas para la articulación de las CSC en el currículo de ciencias y su abordaje en el aula, además de los aportes que trae consigo la articulación de CSC al currículo de ciencias y a la formación continuada de profesores. Finalmente, se plantean algunas consideraciones relacionadas con la importancia de fortalecer los espacios donde mediante el trabajo colaborativo se construyan proyectos educativos desde la interfaz universidad-escuela y la relevancia que poseen los currículos de ciencias cuando son planteados en torno a situaciones controvertidas.

\section{Fundamentación Teórica}

Buscando comprender los desafíos y contribuciones presentados por los profesores del PGI del IED Fabio Simonelli, durante la articulación de CSC en el currículo de ciencias, este apartado profundiza sobre las CSC y los elementos que las caracterizan, importancia de las CSC en la implementación de las prácticas pedagógicas y especialmente en el currículo, aportes de la implementación de las CSC en la formación de profesores e investigación como puente de interlocución entre la universidad y la escuela.

\section{Aspectos que caracterizan a las cuestiones sociocientíficas y su importancia en la implementación de las prácticas pedagógicas}

Formar ciudadanos capaces de intervenir y participar en las cuestiones que se presentan en la cotidianidad, es un asunto urgente que se hace indispensable para la toma de decisiones concernientes a aspectos científicos y tecnológicos contemporáneos. Ante 
esto, se recomienda el abordaje de cuestiones que interfieran en la vida del estudiante, dado que su inclusión en el aula puede significar el surgimiento de una estrategia eficaz que aumente las capacidades argumentativas, participativas, éticas, actitudinales y técnicas en el estudiante en concordancia con el desenvolvimiento científico y tecnológico.

Al respecto, las CSC, según España y Prieto (2009), son problemas abiertos, complejos y controvertidos frente a los cuales se enmarcan posturas sociales que denotan su relevancia a medida que transcurre el tiempo y aumentan los avances de la ciencia y los problemas ambientales de un lugar in situ. Al respecto, y considerando lo planteado por Martínez y Salazar (2014), al encontrarse de forma explícita en la naturaleza sociocultural del conocimiento científico, están sujetas a debates, polémicas, controversias y diversas soluciones desde diferentes perspectivas.

Desde ese punto de vista, según Ratcliffe y Grace (2003), los aspectos que caracterizan a las CSC son:

- Tienen una base científica que a menudo hace parte de investigaciones de frontera;

- Involucran la formación de opiniones;

- Son frecuentemente divulgadas por los medios de comunicación;

- Pueden tener evidencias científicas o sociales incompletas;

- Se pueden abordar las dimensiones locales, nacionales y mundiales;

- Involucran valores y razonamientos éticos;

- Pueden requerir compresión de probabilidad y riesgo.

Cuestiones que, según Reis (2009), pueden ser suscitadas de acuerdo a las implicaciones sociales, morales o religiosas en los que se construyan una teoría o se genera una práctica científica, tensiones sociales ocasionadas por los objetivos individuales, prioridades sociales, políticas, ambientales, intereses económicos y preocupaciones con respecto a los efectos secundarios que pueden generar las aplicaciones tecnológicas sobre la salud de las personas. Aspectos que, al estar asociadas a conceptos, productos, procedimientos científicos y asuntos sociales, se hace indispensable su incorporación en la enseñanza de las ciencias, para el estudiante fortalezca la comprensión conceptual (los conceptos de la genética, la ética etc.), la comprensión procedimental (cómo se genera la evidencia científica; cómo las decisiones podrían hacerse etc.) y el reconocimiento de los valores personales y sociales (la diferencia entre valor intrínseco e instrumental, como la relación entre dignidad y precio etc.); para que a partir de estos supuestos examine causas, consecuencias, ventajas y desventajas, pros y contras y en ese orden de ideas, pueda asumir una posición clara, con relación a una situación específica.

Tarea, que, al ser poco sencilla, requiere, según Reis (2009), de construcciones y procesos como: 
- Un marco de conocimientos científicos para la apropiación de un conocimiento más detallado acerca de los temas involucrados;

- Conocimiento acerca de la naturaleza, las posibilidades y límites de la ciencia, así como el desarrollo de habilidades de pensamiento crítico, toma de decisiones y resolución de problemas;

- Actitud crítica para evaluar las dimensiones éticas y morales de la ciencia y la tecnología;

- Deseo y confianza para hacer frente a cuestiones de su interés científico.

Respecto a esto, se hace indispensable que el abordaje de estas cuestiones sea interdisciplinar, dado que, al desarrollarlas a partir desde diversas áreas del conocimiento, el estudiante tiene la oportunidad de comprender las CSC de manera integral, teniendo en cuenta todas las interacciones e implicaciones en las distintas esferas sociales. Para esto, es importante que los temas sean dotados de transversalidad (es decir no pueden constituir a una sola disciplina, puesto que los temas controversiales permean todas las áreas) y deben adaptarse según las necesidades locales que el estudiante vivencia en su cotidianidad. Es así, como al tener presentes los aspectos mencionados la articulación de dichas cuestiones, resulta relevante para la transformación de los sistemas educativos, puesto que al ser asuntos cercanos a los estudiantes ofrece oportunidades para que desarrollen habilidades de discernimiento, postura crítica y responsabilidad social y ambiental en problemáticas relacionadas con ciencia y tecnología.

\section{Investigación colectiva: forma de fortalecer la autonomía docente y generar puentes de interlocución entre la universidad y la escuela}

El interés por investigar sobre la formación inicial y continuada de profesores de ciencias se generó durante el siglo XX, a finales de los años 80 e inicios de los 90 (MARTÍNEZ PÉREZ et al., 2013), a fin de mejorar la calidad de la enseñanza de las ciencias. Sin embargo, a pesar de las múltiples investigaciones que se han llevado a cabo en torno al tema, estudios recientes cuestionan aún la ausencia de discusión por parte de profesores de ciencias, con respecto a las implicaciones sociales, culturales y ambientales del emprendimiento científico y tecnológico. Pasividad, que con el paso de los años ha contribuido a fortalecer la visión tradicional de la enseñanza de las ciencias, haciendo que esta de una $\mathrm{u}$ otra manera pierda su función como agente indispensable para la construcción social y cultural. (MARTíNEZ PÉREZ; PARGA; GÓMEZ, 2013)

Razón por la cual surge la necesidad de redimensionar las propuestas de formación de profesores, ya que, a pesar de ser conscientes sobre la necesidad de cambiar la enseñanza de las ciencias, carecen de "autonomía propia" para decidir sobre tales cambios. Aspecto que puede ser fortalecido, en la medida que las iniciativas investigativas, orientadas hacia su mejoramiento se lleven a cabo desde la interfaz universidad-escuela. 
A lo expuesto, Martínez Peréz y Carvalho (2013) afirman que los proyectos de investigación, orientados hacia la mejora continua de los procesos educativos, no pueden ser desarrollados solamente en la escuela o en la universidad, por el contrario, estos deben ser uno de los medios de interlocución entre estos dos espacios de formación. Para que, mediante el consenso de las diferencias que existen en cada campo y el trabajo colectivo, no sólo se contribuya en los intereses que los profesores e investigadores, en relación con su profesión, sino que adicionalmente mejore la enseñanza de las ciencias.

\section{Aportes de la implementación de las CSC en la formación de profesores desde la interfaz universidad-escuela}

Partiendo de los referentes mencionados, no cabe duda que la construcción e implementación de las CSC resulta ser para los profesores un gran reto. Puesto que, al ser situaciones que implican conocimientos de frontera y adicional a eso, se relacionan con aspectos sociales, económicos, ambientales, éticos y morales, demandan la modificación de la enseñanza. Razón por la cual el desarrollo de este tipo de cuestiones en el aula permite que los profesores reflexionen sobre su práctica profesional y que en torno de esas modificaciones, los estudiantes cambien su actitud frente a la ciencia, logren la apropiación de algunos contenidos, fortalezcan diversas habilidades, entre estas la argumentativa y la toma de decisiones y se formen como ciudadanos críticos. (MARTÍNEZ PÉREZ; PARGA, 2013)

Con lo anterior, cabe resaltar que, dada la interdisciplinariedad de estas situaciones controvertidas, no solo pueden ser abordadas por los profesores de ciencias, sino que análogamente, pueden ser planteadas por profesores de diferentes áreas como: historia, geografía, filosofía, entre otras, además puede acompañarse por profesores universitarios durante su diseño e implementación. (MARTÍNEZ PÉREZ; PARGA; GOMEZ, 2013) Esto conlleva a compartir puntos de vista y estrategias de enseñanza, reforzar la discusión crítica, crear proyectos transversales, alcanzar una comprensión real y total de la CSC a trabajar y de esta manera renovar el currículo tradicional por medio de la articulación de cuestiones.

\section{Importancia de la articulación de CSC al currículo tradicional de ciencias}

El termino currículo ha evolucionado paralelamente con las necesidades de la sociedad y los avances tecnológicos. Si, en un principio, este vocablo era usado por los griegos para describir lo que enseñaban a sus seguidores, con el transcurrir del tiempo, el currículo era un conjunto de resultados propios del aprendizaje conforme las experiencias desarrolladas en los contextos escolares, ahora bien, Stenhouse mencionaba que el currículo es un intento de comunicar los principios esenciales de una propuesta educativa para poder ser traducida efectivamente a la práctica. (KEMMIS, 1993) Es así, como cada una de estas concepciones mencionadas dan cuenta de cómo este término se 
ha venido configurando en torno a los fines sociales, educativos, políticos y económicos específicos de cada época.

Actualmente, según La Ley General de Educación de Colombia, en su artículo 76, define currículo como

[...] el conjunto de criterios, planes de estudio, programas, metodologías, y procesos que contribuyen a la formación integral y a la construcción de la identidad cultural nacional, regional y local, incluyendo también los recursos humanos, académicos y físicos para poner en práctica las políticas y llevar a cabo el Proyecto Educativo Institucional. (COLOMBIA, 1994)

Asimismo, en el decreto 230 de 2002, se dan orientaciones para la elaboración del plan de estudios, determinando que las instituciones escolares, que ofrezcan educación formal, gozan de autonomía para organizar las áreas obligatorias y fundamentales definidas para cada nivel, introducir asignaturas optativas dentro de las áreas establecidas por la ley, adaptar algunas áreas a las necesidades y características regionales, adoptar métodos de enseñanza y organizar actividades formativas, culturales y deportivas dentro de los lineamientos que establezca el Ministerio de Educación Nacional. (QUINTERO; ZARAZO, 2009)

Desde la visión de ciclos, la Secretaria de Educación de Bogotá - SED (2007 apud QUINTERO; ZARAZO, 2009) se propone un currículo que propicie la superación de la atomización y la fragmentación de los conocimientos escolares; de igual forma, que posibilite trascender el carácter cerrado de las áreas y sus asignaturas, permitiendo construir el currículo desde proyectos o núcleos problema. En este sentido, el currículo es pensado como un contexto que se construye continuamente. El currículo propicia escenarios en donde el educando es el centro. De este modo, se trata de ofrecerle oportunidades para tomar decisiones fundamentadas y asumir sus responsabilidades, no como una tarea más, sino como el resultado del deseo por aprender.

De acuerdo con Bermúdez (2011), algunas de las tendencias actuales del currículo se sitúan en la calidad de la educación para todas y todos:

- La descentralización curricular parte de las decisiones que se toman desde distintos niveles para la elaboración del currículo; es decir, el nivel de decisión del sistema educativo le corresponde a los ministerios, comisiones de especialistas y expertos del orden nacional; otro nivel corresponde al institucional con los directivos docentes, concejos de profesores y equipos técnicos pedagógicos del orden regional; y en las instituciones educativas, las decisiones internas de la comunidad educativa para los proyectos, identidad institucional, iniciativas pedagógicas y gestión educativa;

- La formación de sujetos democráticos parte del reconocimiento del educando de cómo aprende, así como de sus referentes de vida y cómo la escuela crea una 
cultura democrática desde la apertura de la participación, los contenidos y las prácticas pedagógicas;

- La definición del núcleo curricular hace referencia a las áreas específicas para la formación de estudiantes, es decir, aquellas experiencias que son vitales para la formación "necesidades de aprendizaje", algunas de las cuales son determinadas como básicas - las que requiere aprender una persona, aunque no continúe educándose - y otras que se relacionan con los temas relevantes de la sociedad;

- La revolución científica y tecnológica se refiere a los cambios en las tecnologías, las telecomunicaciones, la internacionalización de los mercados y otros fenômenos económicos que demarcan retos para la educación;

- La gestión del currículo coloca a la escuela ante la flexibilidad curricular para la puesta en marcha de innovaciones y de integración de los distintos estamentos que integran la comunidad educativa desde la reflexión política, pedagógica y de organización.

Respecto a esto, surgen las CSC como una propuesta de innovación curricular, que, por medio de discusiones relacionadas con asuntos controvertidos de C\&T, pretenden potenciar las habilidades críticas, argumentativas y participativas en los estudiantes y análogamente cimentar la autonomía, la reflexión en la práctica y la construcción de los propios materiales de enseñanza, en los profesores.

\section{Método}

El presente trabajo investigativo se enmarcó bajo las características de un diseño de tipo cualitativo, que tuvo como objeto de estudio el Pequeño Grupo de Investigación (PGI) conformado por 12 docentes de diversas áreas del conocimiento y en específico cinco docentes del área de ciencias (física, química y biología) y matemáticas que laboran en la Institución Educativa (IED) Fabio Lozano Simonelli, ubicado en el Barrio la Fiscala de la localidad de Usme de Bogotá, a fin de analizar sus dificultades durante la implementación de las CSC al currículo de ciencias. Partiendo de esto, las herramientas empleadas, para la recolección de información durante la investigación, fueron: observación participante en el desarrollo e implementación de la CSC a trabajar en la institución, entrevistas con cada uno de los integrantes del PGI, relatorías de las reuniones del PGI, grabaciones y registros escritos de carácter descriptivo. Por medio de estos registros, se buscó consolidar información para analizar los aportes y limitaciones que poseían los profesores en el momento de articular la CSC, con los contenidos del currículo oficial.

En relación con la población escogida, se aclara que este trabajo investigativo se enmarcó dentro del proyecto de investigación que ha venido adelantando el Grupo Alternaciencias denominado: Programa Colombo-Brasileño de Formación de Profesores de 
Ciencias en la Interfaz Universidad-Escuela Col-Upn-531-12, donde los seis PGI existentes surgen de la necesidad de poder constituir asociaciones libres, en las que puedan ser discutidos temas relacionados con los procesos de enseñanza y aprendizaje y generar un cambio en la situación educativa del país desde la interfaz Universidad - Escuela. (MARTÍNEZ PÉREZ; PARGA; GARZÓN, 2015)

Partiendo de lo anterior, las fases que posibilitaron el desarrollo óptimo de la investigación fueron: fase 1: diseño de Instrumentos; fase 2: caracterización de los integrantes del PGI; fase 3: acompañamiento del PGI, en la selección de la CSC; fase 4: análisis de los diseños curriculares propuestos en el PGI; fase 5: determinación, de los aportes del PGI y el abordaje de CSC a la formación de profesores; y fase 6: establecimiento de algunas recomendaciones curriculares.

\section{Resultados y Discusión}

De acuerdo a los aspectos analizados durante las tres primeras fases de la Investigación, se pone de manifiesto el compromiso de cada uno de los integrantes del PGI, dado que cada ciclo organizó y aplicó instrumentos tipo encuesta a los estudiantes, para que desde esas particularidades pudieran plantear las cuestiones a trabajar. ${ }^{2}$ Sin embargo, según la intervención del PP5:3 "Al principio la consolidación de los instrumentos nos llevó bastante tiempo", la selección de la cuestión oportuna, según las necesidades y particularidades de los estudiantes del IED Fabio Lozano Simonelli, fue una fase de la investigación que les llevo un lapso de tiempo de cuatro meses, dado que, durante la construcción de la cuestión a desarrollar, resultó ser una tarea compleja el proponer la controversia de manera equilibrada. Al respecto, las cuestiones planteadas, por cada uno de los ciclos que conformaban el PGI, se describen a continuación:

- CICLO 3: La influencia de las fábricas ladrilleras en el medio ambiente y en la salud de la comunidad educativa del IED Fabio Lozano Simonelli;

- CICLO 3 y CICLO 4: Cómo ha evolucionado el concepto del cuerpo y cuidado a través de la parte comercial y de los productos que utilizamos hoy en día tanto para la belleza como el cuidado corporal;

- CIClO 5: Qué marcas en el cuerpo ha dejado el contexto de violencia en el que vivimos.

2 Inicialmente, los integrantes del PGI pretendían consolidar cuestiones de tipo sociocientífico en cada ciclo. Hay que precisar que los ciclos son una organización curricular de los grados de la Educación Básica Primaria, Secundaria y Media propuesta en el ámbito de la secretaría de Educación de Bogotá que organiza los grados escolares de la siguiente forma: Primer Ciclo: Grados Preescolar, $1^{\circ}$ y $2^{\circ}$; Segundo Ciclo: $3^{\circ}$ y $4^{\circ}$; Tercer Ciclo: $5^{\circ}, 6^{\circ}$ y $7^{\circ}$; Cuarto Ciclo: $8^{\circ}$ y $9^{\circ}$ Quinto Ciclo: $10^{\circ}$ y $11^{\circ}$.

3 Para la presentación de los resultados, se usan siglas de los profesores participantes PPX, diferenciándolos por número PP1, PP2... 
A lo antepuesto, con relación a las propuestas de intervención sugeridas por el PGI para abordar la CSC y CSA en el aula, cada profesor, teniendo en cuenta su área de conocimiento, propuso una serie de actividades, donde se articulaba la cuestión seleccionada con temáticas específicas. Un aspecto importante, durante este proceso, es que las actividades elaboradas fueron revisadas, evaluadas y complementadas por cada uno de los integrantes del PGI, incluyendo los dinamizadores, docentes universitarios que acompañaron el desarrollo de todo el trabajo. Las actividades se organizaron en tres secuencias didácticas, una para cada ciclo, las cuales estuvieron encaminadas a que los estudiantes participaran y generaran discusión entre ellos, para que desde estos referentes los docentes pudieran profundizar en asuntos disciplinares específicos de su asignatura. Ante esto, se presenta en la siguiente tabla (Cuadro 1), un resumen de la unidad didáctica diseñada por el ciclo 5 , a fin de ejemplificar el trabajo realizado por cada ciclo, según la CSC.

Cuadro 1 - Unidad didáctica. Ciclo V. Diseñada para el desarrollo de la CSC planteada: ¿Qué marcas en el cuerpo ha dejado el contexto de violencia y consumo en el que vivimos?

\begin{tabular}{|c|c|c|c|}
\hline $\begin{array}{l}\text { Objetivo } \\
\text { Investigativo }\end{array}$ & \multicolumn{3}{|c|}{$\begin{array}{l}\text { Relacionar las temáticas propias de las áreas del conocimiento escolar con la discusión } \\
\text { sobre la incidencia de la violencia y consumo en la construcción de las corporalidades del } \\
\text { contexto. }\end{array}$} \\
\hline $\begin{array}{l}\text { Objetivo } \\
\text { Pedagógico }\end{array}$ & \multicolumn{3}{|c|}{$\begin{array}{l}\text { Generar pensamiento crítico y posicionamiento ético en los estudiantes a través del } \\
\text { análisis de la CSC }\end{array}$} \\
\hline \multicolumn{4}{|c|}{ SECUENCIA Nº I DROGAS LICITAS E ILICITAS } \\
\hline Actividad & Descripción & Instrumento & Tiempo \\
\hline $\begin{array}{l}\text { Clasificación de } \\
\text { las Sustancias } \\
\text { Psicoactivas en } \\
\text { licitas e ilícitas }\end{array}$ & $\begin{array}{l}\text { Consultar las siguientes páginas web: } \\
\text { http://cerebroniad.blogspot.com/2013/03/la-verdad-sobre-las- } \\
\text { drogas.html } \\
\text { http://cnnespanol.cnn.com/2013/09/02/conoces-a-molly-una- } \\
\text { droga-tan-popular-como-peligrosa/ } \\
\text { http://juliocesarruizgiraldo.wetpaint.com/page/ } \\
\text { CLASIFICACION+DE+LAS+DROGAS } \\
\text { http://www.psicoactiva.com/drogas.htm } \\
\text { http://contralasadicciones.files.wordpress.com/2012/o1/leer- } \\
\text { mc3ais8.pdf } \\
\text { http://es.paperblog.com/clasificacion-de-las-drogas- } \\
\text { efectos-254588o/ } \\
\text { Teniendo en cuenta la información que aparece en las páginas } \\
\text { web, elabore una ficha didáctica de la sustancia psicoactiva } \\
\text { que le corresponda, en donde se establezca su composición } \\
\text { química, forma de consumo, clasificación, riesgos de consumo, } \\
\text { dato curioso y un dibujo alusivo. La ficha será socializada a sus } \\
\text { compañeros. } \\
\text { Después de la Socialización: } \\
\text { Clasificar las Drogas en ilícita, licitas, alucinógenas, depresores, } \\
\text { estimulantes, duras y blandas. } \\
\text { • Identificar los grupos funcionales orgánicos. } \\
\text { - Identificar el tipo de enlace. } \\
\text { • Relacionar las diferentes drogas con su grupo funcional. }\end{array}$ & $\begin{array}{l}\text { Fichas. } \\
\text { Grabaciones } \\
\text { de audio. }\end{array}$ & $90 \mathrm{~min}$. \\
\hline
\end{tabular}




\begin{tabular}{|c|c|c|c|}
\hline $\begin{array}{l}\text { Efectos en el } \\
\text { organismo de } \\
\text { las Sustancias } \\
\text { Psicoactivas (SPI). }\end{array}$ & $\begin{array}{l}\text { Se presentaran los siguientes videos } \\
\text { http://www.youtube.com/watch?v=HHD8ljcdaiQ } \\
\text { http://www.youtube.com/watch?v=WTPsowPE-aQ } \\
\text { http://www.youtube.com/watch?v=811_pKENYL4 } \\
\text { http://www.youtube.com/watch?v=IPTouT6WNwQ } \\
\text { Juego interactivo } \\
\text { http://www.cruzroja.es/juego_drogas/no_te_la_juegues.html } \\
\text { Una vez que se presenta los videos y el juego, Identifica: } \\
\text { - Los efectos más impactantes que consideras que } \\
\text { pueden causar las SPI. } \\
\text { •Cuáles son los beneficios de conocer los efectos en el } \\
\text { organismo de las SPI? } \\
\text { - Si has tenido la oportunidad de estar cerca de una } \\
\text { persona que consume SPI ¿Cuáles de los efectos } \\
\text { mencionados has podido identificar en ellos? }\end{array}$ & $\begin{array}{l}\text { Cuestionario. } \\
\text { Grabaciones } \\
\text { de audio. }\end{array}$ & $90 \mathrm{~min}$. \\
\hline $\begin{array}{l}\text { Laboratorio de } \\
\text { alcaloides }\end{array}$ & $\begin{array}{l}\text { Práctica de Laboratorio "Reconocimiento de los Alcaloides" } \\
\text { Las técnicas de reconocimiento son basadas en la capacidad } \\
\text { que tienen las sales orgánicas de los alcaloides (extractos } \\
\text { ácidos), de combinarse con el iodo y metales pesados como el } \\
\text { bismuto, mercurio y tungsteno para formar precipitados. } \\
\text { Identificar las características de los reactivos: } \\
\text { - Reactivo de Mayer } \\
\text { - Reactivo de Dragendoff } \\
\text { - Reactivo de Wagner } \\
\text { Identificar la presencia de los alcaloides en las drogas licitas y } \\
\text { las implicaciones en la salud. }\end{array}$ & $\begin{array}{l}\text { Informe de } \\
\text { laboratorio. }\end{array}$ & $90 \mathrm{~min}$. \\
\hline $\begin{array}{l}\text { Implicaciones } \\
\text { sociales de la } \\
\text { Drogadicción }\end{array}$ & $\begin{array}{l}\text { Observa la película australiana Candy. } \\
\text { http://www.youtube.com/watch?v=aGPfne-79Sk } \\
\text { Analizar el consumo de la heroína y como esta droga } \\
\text { anteriormente era considerada como licita, al mismo tiempo } \\
\text { analizar: } \\
\text { a) Los cambios de personalidad de los protagonistas. } \\
\text { b) Las implicaciones en diferentes ámbitos (social, } \\
\text { económico, familiar etc.) alrededor de la problemática. }\end{array}$ & $\begin{array}{l}\text { Grabaciones } \\
\text { de audio. }\end{array}$ & $120 \mathrm{~min}$. \\
\hline $\begin{array}{l}\text { Reconocimiento } \\
\text { de las señales y } \\
\text { de los efectos en } \\
\text { el cuerpo de una } \\
\text { persona drogada, } \\
\text { estudiándolos } \\
\text { desde la física } \\
\text { a través de los } \\
\text { conceptos trabajo, } \\
\text { energía y potencia. }\end{array}$ & $\begin{array}{l}\text { La lectura 1. Realizar un cuadro que tenga cuatro columnas } \\
\text { y el nombre de estas sea droga, señales en una persona, } \\
\text { efectos en el cuerpo y aspectos relacionados con la física } \\
\text { respectivamente. http://www.ctclearinghouse.org/topics/ } \\
\text { customer-files/Conozcamos-Acerca-Del-Alcohol-Tabaco-y- } \\
\text { Drogas-llicitas-082505.pdf } \\
\text { La lectura 2. A partir de esta sacar la definición, ecuaciones y } \\
\text { ejemplos de trabajo, potencia y energía. } \\
\text { http://www.darwin-milenium.com/estudiante/Fisica/Temario/ } \\
\text { Tema5.pdf } \\
\text { Socialización de la actividad, donde se saca un cuadro general } \\
\text { de cuatro columnas nominadas como: droga, señales en una } \\
\text { persona, efectos en el cuerpo de una persona drogadicta y } \\
\text { física (aplicación de los conceptos potencia, trabajo y energía). }\end{array}$ & $\begin{array}{l}\text { Artículo. } \\
\text { Salón de } \\
\text { clase. } \\
\text { Grabaciones } \\
\text { de audio. }\end{array}$ & $90 \mathrm{~min}$. \\
\hline
\end{tabular}




\begin{tabular}{|c|c|c|c|}
\hline \multicolumn{4}{|c|}{ SECUENCIA N .2 NEUROMARKETING } \\
\hline Actividad & Descripción & Instrumento & Tiempo \\
\hline $\begin{array}{l}\text { ¿Son las drogas } \\
\text { lícitas un gran } \\
\text { negocio? }\end{array}$ & $\begin{array}{l}\text { Se organizaran } 10 \text { grupos (3 estudiantes o máximo } 4 \\
\text { estudiantes), a cada grupo se le asignara una multinacional } \\
\text { (drogas lícitas) para realizar un exposición. Los parámetros de } \\
\text { dicha exposición fueran los siguientes: } \\
\text { 1. Presentación e introducción de la compañía } \\
\text { 2. Crecimiento y expansión a nivel mundial } \\
\text { 3. Estrategias de Marketing } \\
\text { 4. Información Financiera } \\
\text { 5. Matriz DOFA } \\
\text { 6. Conclusiones } \\
\text { 7. Bibliografía. } \\
\text { Posteriormente a las exposiciones se realizara un taller con } \\
\text { información relevante acerca de una compañía, donde los } \\
\text { estudiantes deberán analizar y argumentar a partir de la } \\
\text { información dada. }\end{array}$ & $\begin{array}{l}\text { Diapositivas. } \\
\text { Exposición } \\
\text { oral. } \\
\text { Taller. }\end{array}$ & $120 \mathrm{~min}$. \\
\hline $\begin{array}{l}\text { ¿Cómo influye el } \\
\text { Neuromarketing } \\
\text { en nuestros } \\
\text { hábitos de } \\
\text { consumo? }\end{array}$ & $\begin{array}{l}\text { Se asignara la lectura de un paper (Neuromarketing: La nueva } \\
\text { ciencia del comportamiento del consumidor). } \\
\text { Presentación, video conferencia sobre Neuromarketing } \\
\text { Conferencia Neuromarketing Jurgenklaric. } \\
\text { Link: https://www.youtube.com/watch?v=rM-4lBpoFag } \\
\text { Asignar una actividad para ser analizada y argumentada a partir } \\
\text { de la información obtenida previamente. }\end{array}$ & $\begin{array}{l}\text { Lectura. } \\
\text { Video } \\
\text { conferencia. } \\
\text { Taller. }\end{array}$ & $90 \mathrm{~min}$. \\
\hline $\begin{array}{l}\text { ¿Qué relación tiene } \\
\text { esta ciencia con } \\
\text { nuestros hábitos } \\
\text { de consumo? }\end{array}$ & $\begin{array}{l}\text { Los estudiantes elaboraran instrumentos (encuestas) para } \\
\text { indagar sobre los hábitos de consumo de ellos y de sus padres. } \\
\text { Posteriormente harán una presentación de los mismos y } \\
\text { sentaran una posición crítica frente al tema. }\end{array}$ & $\begin{array}{l}\text { Lectura. } \\
\text { Video } \\
\text { conferencia. } \\
\text { Taller. }\end{array}$ & $90 \mathrm{~min}$. \\
\hline $\begin{array}{l}\text { Reconocimiento } \\
\text { de los efectos } \\
\text { en la salud de } \\
\text { una persona } \\
\text { consumista de la } \\
\text { tecnología (celular } \\
\text { y audífonos) }\end{array}$ & $\begin{array}{l}\text { Los estudiantes deben hacer la lectura previa, luego en clase } \\
\text { se realiza una socialización de la actividad, donde se genera un } \\
\text { cuadro con las características de una persona consumista y las } \\
\text { consecuencias en la salud. } \\
\text { Lectura 1. } \\
\text { http://www3.upc.edu.pe/bolsongei/bol/29/437/Liliana\%20 } \\
\text { Alvarado.pdf }\end{array}$ & $\begin{array}{l}\text { Articulo. } \\
\text { Salón de } \\
\text { clase. } \\
\text { Grabaciones } \\
\text { de audio. }\end{array}$ & $90 \mathrm{~min}$. \\
\hline $\begin{array}{l}\text { Reconocimiento } \\
\text { de los efectos } \\
\text { en la salud de } \\
\text { una persona } \\
\text { consumista de la } \\
\text { tecnología (celular } \\
\text { y audífonos), } \\
\text { estudiándolos } \\
\text { desde la física a } \\
\text { través de las ondas } \\
\text { sonoras y de las } \\
\text { características del } \\
\text { oído. }\end{array}$ & $\begin{array}{l}\text { Los estudiantes deben hacer la lectura } 1 \text { y } 2 \text { previa, luego en } \\
\text { casa deben realizar un cuadro que tenga tres columnas y el } \\
\text { nombre de estas sea características de una persona consumista, } \\
\text { consecuencias en la salud y física (aplicación de ondas } \\
\text { sonoras y de las características del oído a Neuromarketing) } \\
\text { respectivamente. También deben escribir cuáles son los niveles } \\
\text { de sonido más altos que soporta el oído humano y los niveles } \\
\text { de sonido más bajos, explicar cómo una persona logra oír. } \\
\text { Luego en clase se hace una socialización de la actividad, donde } \\
\text { se saca un cuadro general de tres columnas llamadas como se } \\
\text { mencionó anteriormente. } \\
\text { Lectura 1. } \\
\text { http://www3.upc.edu.pe/bolsongei/bol/29/437/Liliana\%20 } \\
\text { Alvarado.pdf } \\
\text { Lectura 2. } \\
\text { http://www.fis.puc.cl/ jalfaro/fis1503/clases/osonora.pdf }\end{array}$ & $\begin{array}{l}\text { Artículo } \\
\text { Salón de clase } \\
\text { Grabaciones } \\
\text { de audio }\end{array}$ & $90 \mathrm{~min}$. \\
\hline
\end{tabular}




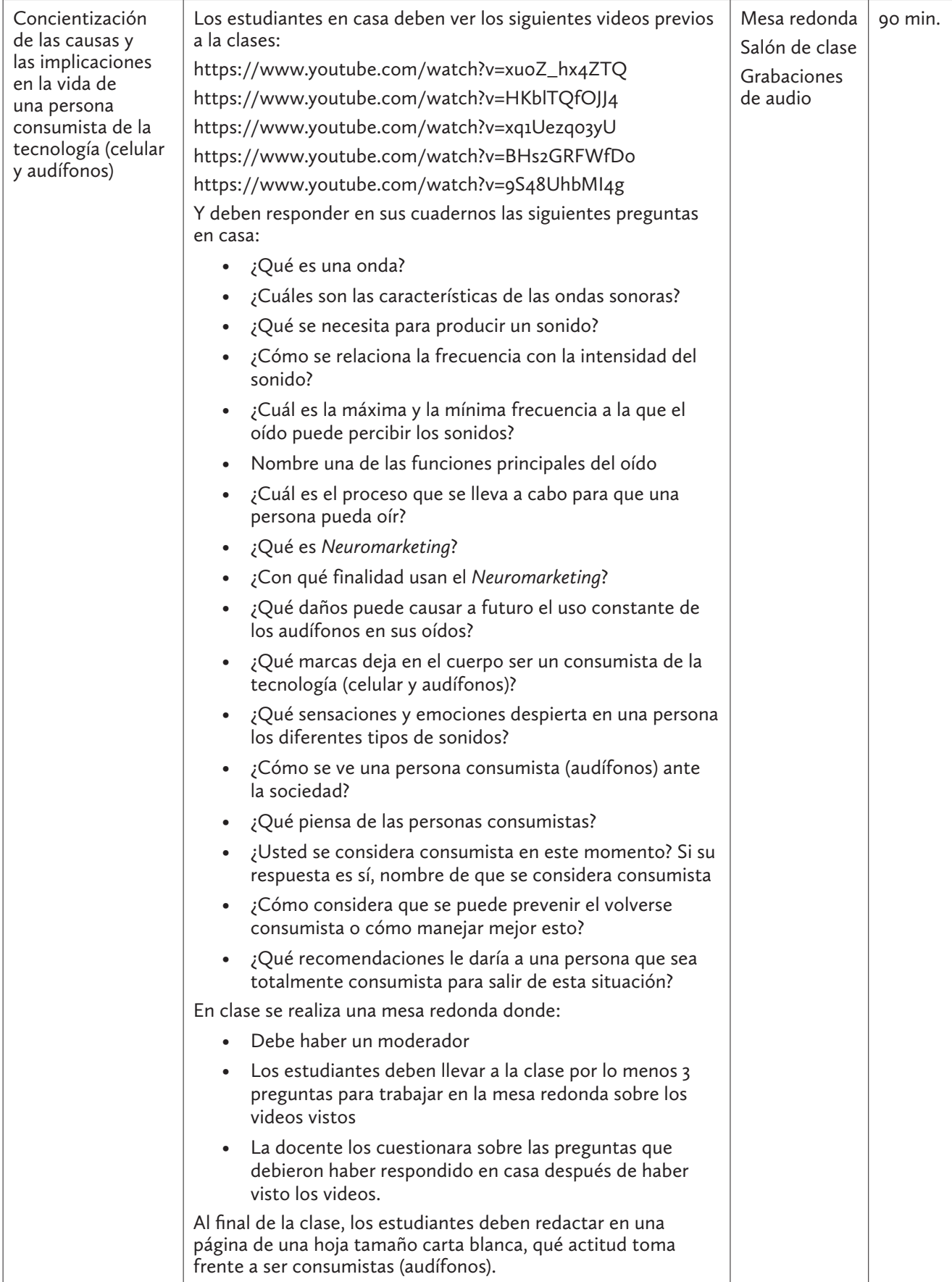




\begin{tabular}{|l|l|l|l|}
\hline \multicolumn{2}{|l|}{ SECUENCIA N'.3 CONCEPTO DE BELLEZA } & Instrumento & Tiempo \\
\hline Actividad & Descripción & 90 min. \\
\hline $\begin{array}{l}\text { Ideales de cuerpos } \\
\text { femeninos y } \\
\text { masculinos. }\end{array}$ & $\begin{array}{l}\text { Actividad 1: El trabajo se desarrollará por grupos. El grupo 1 } \\
\text { y van a tomar a uno de sus compañeros para convertirlo en } \\
\text { el modelo de mujer y hombre exitoso según los medios de } \\
\text { comunicación. } \\
\text { El grupo 3 y 4 van a tomar a uno de sus compañeros para } \\
\text { convertirlo en el modelo de mujer y hombre exitoso en el } \\
\text { contexto donde viven. } \\
\text { El grupo 5 y 6 van a tomar a uno de sus compañeros para } \\
\text { mujer. }\end{array}$ & $\begin{array}{l}\text { Ronvertirlo en el modelo de mujer y hombre perdedor. } \\
\text { Cierre: Toma de fotos, exposición de sus modelos y } \\
\text { socialización de la experiencia, reflexiones en cuanto las } \\
\text { similitudes, diferencias, problemáticas que plantean los } \\
\text { diferentes estilos de vida propuestos. }\end{array}$ & \\
\hline $\begin{array}{l}\text { Estereotipos } \\
\text { incentivados por el } \\
\text { mercado. }\end{array}$ & $\begin{array}{l}\text { Actividad 2: Se exploraran a qué responden los estereotipos } \\
\text { desde la publicidad y los medios de comunicación, haciendo } \\
\text { uso de imágenes extraídas de los mismos comerciales o de } \\
\text { personajes famosos, se analizará, cómo se van creando los } \\
\text { modelos a seguir, los ideales de exitosos y perdedores y qué } \\
\text { tiene que ver esto con los imaginarios, ideologías, las relaciones } \\
\text { de poder y el sistema de clases y como están ellos en tanto que } \\
\text { jóvenes imbuidos de estos modelos, los problematizan o los } \\
\text { aceptan. }\end{array}$ & $\begin{array}{l}\text { Accesorios } \\
\text { de hombre } \\
\text { y mujer, } \\
\text { maquillaje, } \\
\text { zapatos. }\end{array}$ & 90 min. \\
\hline $\begin{array}{l}\text { Reflexión en torno } \\
\text { a los estereotipos } \\
\text { incentivados por el } \\
\text { mercado. }\end{array}$ & $\begin{array}{l}\text { problematizará el papel de la ciencia en la modificación de los } \\
\text { cuerpos de acuerdo a los estereotipos que se masifican, el caso } \\
\text { de Michael Jackson, la Barbie y el Kent humanos, el lugar de la } \\
\text { ciencia en la contribución a la preservación de los estereotipos. }\end{array}$ & $\begin{array}{l}\text { Video Beam, } \\
\text { presentación, } \\
\text { sonido, } \\
\text { computador. }\end{array}$ & 90 min. \\
\hline
\end{tabular}

Fuente: Martínez e colaboradores (2015, p. 48).

Uno de los aspectos importantes, identificados durante la Entrevista Focal 2, es que todos los docentes de ciencias, en especial los del ciclo V, elaboraron una actividad inicial, para reconocer los conocimientos preliminares de los estudiantes en torno al tema y desde ahí partieron para introducir la controversia.

Respecto a las formas de evaluación, algunos de los profesores tuvieron en cuenta la forma y el contenido de los instrumentos físicos desarrollados por los estudiantes durante el abordaje de las actividades, entre estos se presentan: carteleras, desarrollo de talleres, resolución de preguntas relacionadas con los videos, escritos respecto a la cuestión desarrollada en el ciclo, revisión de tareas para consultar en casa, entre otros. No obstante, la participación y el discurso en las intervenciones de los estudiantes también se tuvieron en cuenta para evaluar los procesos de enseñanza y aprendizaje en los estudiantes. Aspectos que pudieron ser confirmados en las intervenciones de los docentes implicados,

PP1: La forma de evaluar es más dialógica, escuchar lo que ellos comentan y la manera como interpretan las nuevas situaciones y pues ahí darme cuenta si hay un cambio o un pensamiento distinto [...]. 
PP2: La evaluación la he planteado más hacia la parte de participación, entonces por ejemplo las exposiciones se miraba la manera como expusieron el interés que le pusieron, la atención de los compañeros, los talleres según las respuestas que ellos han dado. Pero lo he ido enfocando más hacia la participación y al interés más que los contenidos.

PP5: [...] participación en clase, pero cuando participan yo miro que sea argumentativa que den un punto crítico, que no repitan las ideas [...].

Al respecto, se percibe como los docentes implicados asocian la participación de los estudiantes directamente con los contenidos conceptuales, visión tradicional que es muy frecuente, incluso hasta en la comunidad de investigadores. Puesto que se concibe que lo que no es conceptual no es contenido $y$, por lo tanto, no tiene es obligatoriamente parte de la enseñanza. (ZABALA, 1998) No obstante, los aspectos evidenciados en las intervenciones, se relacionan con el sistema evaluativo que ha predominado en los últimos años en el Ministerio de Educación Nacional de Colombia, donde a pesar de estipularse la evaluación formativa en los establecimientos educativos, se le da mayor prioridad a la evaluación sumativa, bajo la percepción de que por medio de exámenes cuantificables es posible medir lo que los alumnos han aprendido, imputando a los centros la responsabilidad del rendimiento de sus alumnos. (CLARKE, 2004)

No obstante, partiendo de las intervenciones de los docentes, se puede evidenciar que reconocen la importancia de aplicar la evaluación formativa durante el abordaje de CSC en el aula, puesto que les permite identificar los avances de los estudiantes con relación con las habilidades fortalecidas y conocimientos apropiados durante el abordaje de CSC.

En este orden de ideas, se hace un paralelo entre el currículo propuesto por la Secretaría de Educación de Bogotá desde su plan sectorial 2008-2012, teniendo en cuenta la organización curricular por ciclos y el actual proyecto que se viene desarrollando en torno a la Educación para la Ciudadanía y la Convivencia, con las dos secuencias de actividades elaboradas y entregadas por los docentes de ciencias implicados en la investigación, ${ }^{4}$ a fin de identificar las fortalezas y posibles debilidades que puede generar la articulación de CSC al currículo tradicional. Para esto, es de vital importancia contextualizar la perspectiva con la cual los entes gubernamentales han organizado el sistema educativo, de qué forma se materializan estas políticas públicas en las instituciones educativas, cuáles son las realidades que se viven al interior de la escuela y qué aportes generan los profesores de ciencias al currículo tradicional, cuando trabajan de forma cooperativa e interdisciplinar.

4 Con relación a las secuencias de actividades, solo fueron entregadas las de ciclo tres y cinco, dado que el docente de ciclo cuatro presentó dificultades para darle término y forma a la secuencia. Sin embargo, se resalta que durante la entrevista focal semiestructurada final, el docente implicado manifestó haber implementado algunas actividades. 
Con relación a los entes gubernamentales, la Secretaria de Educación de Bogotá, desde el Plan Sectorial Educación de Calidad para una Bogotá positiva, propuso la Reorganización Curricular por Ciclos (RCC), como una política educativa que tiene como fin innovar la enseñanza y garantizar el derecho a una educación de calidad, por medio de la actualización de los programas de estudio, la transformación de la organización escolar y la enseñanza, para tener colegios de excelencia y jóvenes bien educados en el respeto a los valores y principios de la sociedad.

Ante esto, se planteó que la enseñanza debía reorganizarse por ciclos, la educación media debía especializarse y articularse con la Educación Superior, además se indicó que el docente debía tener un dominio del inglés, profundización en el aprendizaje de las Matemáticas y las ciencias, fomentar el uso pedagógico de la informática y la comunicación, aprovechar la ciudad como escenario de aprendizaje, fortalecer la formación ambiental para proteger y conservar la naturaleza y formar a las futuras generaciones en derechos humanos, democracia, participación, convivencia interculturalidad y gênero. (BOGOTÁ, 2012) No todos los aspectos mencionados fueron concretados en su totalidad en el espacio escolar. Si bien, la educación fue reorganizada en cinco ciclos, orientados bajo una impronta específica, que concibe la intención pedagógica de formación, demandas de aprendizaje de los niños y se situaron ejes temáticos específicos según la identidad, grados implicados y edades promedio de los estudiantes inmersos en cada uno de los ciclos, falta concretar estas intencionalidades en la práctica.

Las realidades que se encuentran en las instituciones oficiales, las cuales están organizadas bajo esta política educativa, en relación con las prácticas pedagógicas de los docentes de ciencias y los procesos de enseñanza y aprendizaje en los estudiantes, siguen teniendo características de las prácticas tradicionales, las cuales, al estar descontextualizadas con los avances de la C\&T y las necesidades emergentes en los estudiantes y las esferas sociales, contribuyen al incremento de los problemas de convivencia y deserción en la escuela. Este ha sido un asunto evidenciado, dado que, cuando generalmente los docentes no se encuentran en formación permanente, no poseen el conocimiento y las herramientas suficientes para que, de manera individual y autónoma, investiguen en la práctica, llevándolos a optar por transmitir a sus estudiantes conocimientos aislados que no poseen relación alguna, con la sociedad, la economía, la ética, el ambiente y la tecnología.

Es así, como partiendo del proceso vivenciado por los docentes de ciencias del IED Fabio Lozano Simonelli, implicados en el PGI en torno a la selección, articulación y abordaje de las CSC al currículo tradicional de ciencias, se llevó a cabo de manera cooperativa e interdisciplinar.

A lo antepuesto, se resalta la necesidad y la iniciativa del PGI para abordar aspectos poco divulgados en los medios de comunicación o aquellos discursos que son movilizados para fomentar el consumo en la ciudadanía. Efectivamente, dichos análisis fomentan en los estudiantes actitudes positivas o negativas, alrededor de la controversia. Teniendo en cuenta lo anterior y los datos arrojados durante la investigación, la 
articulación de las CSC, en las secuencias de enseñanza elaboradas por los docentes según el ciclo en el que se desempeñan, fue una labor que posibilitó en los docentes la oportunidad de transformar sus prácticas pedagógicas y participar de forma activa en la consolidación del currículo oficial, puesto que, para la construcción de las actividades, los docentes tuvieron en cuenta los temas propuestos en la malla curricular correspondiente al cuarto periodo escolar.

No obstante, se resalta que la articulación de CSC en el currículo tradicional debe estar orientada a las situaciones controversiales que emergen en la sociedad, para que permeen los contenidos propuestos en la malla curricular, a fin de poder vivenciar todas las implicaciones presentes en dicha cuestión.

\section{Recomendaciones curriculares, respecto a la articulación de CSC en las prácticas de enseñanza en básica secundaria}

Algunas recomendaciones curriculares que emergieron en los profesores de ciencias implicados, en relación con la articulación de CSC en las prácticas de enseñanza, tuvieron que ver con sus vivencias durante el abordaje de las actividades construidas dentro del PGI, así se pudo comprobar que las CSC permiten contextualizar los contenidos de ciencias y hacen que los estudiantes tomen una postura en relación con la situación controvertida seleccionada. Al respecto, el PP1 manifiesta que: "Las CSC son importantes porque permiten contextualizar, eso hace que los estudiantes reinterpreten situaciones y que realmente haya un proceso de aprendizaje y los estudiantes evolucionen en pensamiento [...]”.

Adicionalmente, se manifiesta que el abordaje de estas cuestiones, en la enseñanza de las ciencias, no puede ser reducida a los contenidos específicos de la ciencia, porque a pesar de ser relevantes para la educación científica y tecnológica de los ciudadanos, estos, no son suficientes para abordar las cuestiones sociales, políticas y éticas vinculadas a el progreso científico y tecnológico. (MARTÍNEZ PÉREZ; CARVALHO, 2012) Por esta razón, es de vital importancia articular los aspectos sociocientíficos en los currículos de ciencias, como un aspecto importante para la formación ciudadana, asunto que lo hace evidente el PP3: "Yo le recomendaría, al ministerio, que utilice eje articulador para que pueda trabajarse desde todas las áreas y uno de estos puede ser las CSC”. Sin embargo, el PP2 resalta que, para poder incluir las CSC y CSA en el aula de clase, debe haber "Flexibilidad en la malla curricular".

En ese orden de ideas, es de vital importancia replantear la malla curricular de ciencias y orientarla según las necesidades de los estudiantes, de manera que en su construcción participen diversas instancias educativas, tales como: los profesores de la escuela, profesores de la universidad, estudiantes de postgrado y pregrado y por supuesto las instancias gubernamentales que controlan estos estamentos, todo con el fin de favorecer el crecimiento personal y social de los estudiantes. No obstante, el Ministerio de Educación, debe ofrecer mayores incentivos y posibilidades a los docentes, para que 
estos se motiven a investigar desde la interfaz universidad-escuela y a formarse de forma permanente, debido a que el abordaje con CSC, a pesar de ser una estrategia educativa innovadora, requiere que el docente de ciencias movilice diversos conocimientos de múltiples fuentes, sobre asuntos políticos, científicos, tecnológicos, sociales, económicos, pedagógicos, entre otros.

\section{Consideraciones finales}

Si bien, el abordaje de CSC resulta para los docentes de la escuela una labor adicional que trae consigo diversas tensiones de carácter institucional, íntimamente relacionadas con el modelo educativo implantado en el país, es una oportunidad para que el docente investigue desde su quehacer docente; reflexione sobre su práctica pedagógica y participe de forma activa en la consolidación del currículo oficial. Según los docentes implicados en la investigación, este proceso se hace mucho más significativo cuando se trabaja de forma colectiva que individual, razón por la que la conformación de PGI dentro de las instituciones educativas desde la interfaz universidad-escuela es un espacio orientado a fortalecer la autonomía de los docentes.

Respecto a las experiencias desarrolladas por el PGI en torno al abordaje de CSC en la institución educativa, se resalta, en primer lugar, que el interés de cada uno de los profesores implicados para que la cuestión seleccionada por cada ciclo tuviera una relación estrecha con las realidades y necesidades de los estudiantes, a fin de que su abordaje resultara significativo y se generaran actitudes que posibilitaran la toma de posicionamientos. De igual forma, si bien, durante el transcurso de la investigación, emergieron diversas tensiones relacionadas con tiempo y concordancia con la malla curricular del periodo escolar en el que fue aplicado, fue una oportunidad para que los docentes se involucraran en la construcción de múltiples actividades focalizadas a articular la CSC seleccionada con los contenidos del espacio académico y una manera de incorporar la evaluación formativa dentro del aula, la cual se centra en el desarrollo de las habilidades de los estudiantes, más que en los contenidos de la enseñanza, teniendo como marco las competencias y haciendo que el proceso en el aula cobre un sentido distinto.

No obstante, a pesar de las limitaciones institucionales relacionadas con falta de apoyo en cuanto a la apertura de espacios para investigar y tiempo e incentivos económicos por parte de las instancias educativas, se resalta como el trabajo conjunto, generado desde la interfaz universidad-escuela, hace que los docentes implicados en el PGI del IED Fabio Lozano Simonelli, de forma consensuada, propicien soluciones ante los obstáculos emergentes y propongan nuevas estrategias orientadas a mejorar la calidad educativa. Por esta razón, resulta pertinente, necesaria y productiva la participación de docentes universitarios y de postgrados dentro del trabajo desarrollado al interior del PGI.

Con relación al diseño de las actividades, se manifestó que esta no fue una labor

sencilla, dado que al tener presente la malla curricular de ciencias establecida por la 
institución, los docentes debían elaborarlas de manera que la cuestión seleccionada y los contenidos correspondientes al periodo escolar vigente se articularan, lo cual se hizo evidente en la entrevista focal semiestructurada final, donde se alude a la dificultad que resulta pensar la práctica pedagógica y, en este caso, la elaboración de actividades, que se desarrollen de maneras distintas a las que tradicionalmente son utilizadas. En cuanto a la forma como se organizaron las actividades, se valora el interés de los docentes por potenciar en sus estudiantes habilidades argumentativas de forma paulatina, aspecto evidenciado en el orden de las actividades propuestas, las cuales se orientaron de tal manera, que el fin formulado en la secuencia de actividades se alcanzara.

Por otro lado, pudo identificarse que, a pesar de que la secretaría de educación propone una reorganización curricular por ciclos, existen muchas debilidades en torno a la preparación pedagógica e investigativa de algunos docentes, los cuales no son apoyados en plenamente para que continúen formándose permanentemente. Adicionalmente, el hacinamiento, que se presenta en muchas entidades educativas aludidas a la cobertura que de una u otra forma, termina limitando el buen desarrollo de las actividades y, por supuesto, el aprendizaje de los estudiantes y la resistencia de muchos docentes en el momento de acoger otras alternativas, impiden que esta propuesta sea desarrollada de manera eficiente. Por esto, la articulación de CSC en las clases de ciencias constituye una alternativa pertinente para materializar los fines de la reorganización curricular por ciclos. Esto podría transformar la educación en Colombia y de múltiples países, en especial los iberoamericanos, en los cuales se han realizado diversos aportes con relación a la articulación de las CSC y sus implicaciones en el aula.

\section{Referencias}

ACEVEDO, J. et al. Naturaleza de la ciencia y educación científica para la participación ciudadana: una revisión crítica. Revista Eureka sobre Enseñanza y Divulgación de las Ciencias, Puerto Real, v. 2, n. 2, p. 121-140, 2005.

BERMÚDEZ, M. Algunas reflexiones sobre el currículo en la educación, Contribuciones a las Ciencias Sociales, Málaga, 2011. Disponible en: <http://www.eumed.net/rev/ cccss/16/mba.html>. Acceso en: 17 ago. 2014.

BOGOTÁ. Secretaría de educación. Reorganización curricular por ciclos. Bogotá, 2012.

CLARKE, S. Formative assessment: improving learning in secondary classrooms. Paris: OECD, 2004.

COLOMBIA. Ministerio de Educación Nacional. Evaluación para los aprendizajes. Bogotá, 2008. Disponible en: <http://www.mineducacion.gov.co/1621/article-162342. html>. Acceso en: 1 oct. 2014.

COLOMBIA. MINISTERIO DE EDUCACIÓN NACIONAL. Ley 115. Ley general de educación. Artículo 76: currículo y plan de estudios. Bogotá, 1994. 
ESPAÑA, E.; PRIETO, T. Educar para la sostenibilidad: el contexto de los problemas socio-científicos. Revista Eureka sobre Enseñanza y Divulgación de las Ciencias, Puerto Real, v. 6, n. 3, p. 345, 2009.

KEMMIS, S. El curriculum: más allá de la teoría de la reproducción. Madrid: MORATA, 1993.

MARTÍNEZ PÉREZ, L. F. et al. Formación de profesores y cuestiones sociocientíficas: experiencias y desafíos en la interfaz universidad-escuela, de Martínez. Bogotá, Colombia: Universidad Pedagógica Nacional, 2015.

MARTÍNEZ PÉREZ, L. F. Questões sociocientíficas na prática docente: ideologia, autonomia e formação de professores. São Paulo: UNESP, 2012.

MARTÍNEZ PÉREZ, L. F.; CARVALHO, W. Contribuições e dificuldades da abordagem de questões sociocientíficas na prática de professores de ciências. Educação \& Pesquisa, São Paulo, v. 38, n. 3, p. 727-741, 2012.

MARTÍNEZ PÉREZ, L. F.; PARGA, D. L.; GOMEZ, D. L. Cuestiones sociocientíficas en la Formación de Profesores de Ciencias. Revista EDUCyT, Cali, p. 139-151, 2013. Volume extraordinario.

MARTÍNEZ PÉREZ, L. F et al. Proyecto de investigación Programa Colombo-Brasileño de Formación de Profesores de Ciencias en la Interfaz Universidad-Escuela Col-Upn-531-12.

Bogotá: Colciencias/Capes, 2013.

MARTÍNEZ PÉREZ, L. F; PARGA, D. Discurso ético y ambiental sobre cuestiones sociocientíficas: aportes para la formación del profesorado. Bogotá: Universidad Pedagógica Nacional, 2013.

MARTÍNEZ PÉREZ, L.; PARGA, D.; GARZÓN, I. Formación de Profesores y Cuestiones Sociocientíficas: Experiencias y desafíos en la interfaz universidad-escuela. Bogotá: Universidad Pedagógica Nacional, 2015.

MARTÍNEZ PÉREZ, L. F.; SALAZAR, L. V. Formación de profesores en la interfaz universidad-escuela: primeros avances. In: MARTÍNEZ PÉREZ, L. F.; PARGA, D. (Ed.). Formación permanente de profesores en la interfaz Universidad - Escuela: currículo, fundamento y roles. Una experiencia en construcción. Bogotá: Universidad Pedagógica Nacional, Fondo editorial, 2014. p. 21-38.

QUINTERO, N; ZARAZO, A. Estado actual del diseño curricular de dos instituciones educativas de Bogotá para la formación científica de los estudiantes del segundo ciclo. Bogotá: Secretaria de Educación, 2009.

RATCLIFFE M.; GRACE M. Science education for citizenship: teaching socioscientific issues. Maidenhead: Open University Press, 2003.

REIS, P. Ciência e controvérsia. REU, Sorocaba, v. 35, n. 2, p. 9-15, 2009.

ZABALA, A. La práctica educativa. Cómo enseñar. 4a . ed. Barcelona: Graó, 1998. (Serie Pedagogía, 120). 


\title{
QUESTÕES SOCIOCIENTÍFICAS EM PROJETOS ESTUDANTIS NO ENSINO MÉDIO CONSTRUINDO INOVAÇÕES EDUCACIONAIS NO PROGRAMA CIÊNCIA NA ESCOLA
}

\author{
Rosiléia Oliveira de Almeida \\ Amanda Amantes \\ Charbel N. El-Hani
}

\section{Introdução}

O Programa Ciência na Escola - Ensino Médio, voltado para a formação de professores, foi criado no ano de 2013 pelo Instituto Anísio Teixeira (IAT), órgão vinculado à Secretaria de Educação do Estado da Bahia (SEC/BA), no Brasil. Os autores do presente capítulo foram convidados para coordenar os componentes pedagógicos do programa, no que diz respeito à formação de professores de biologia, física, química e geografia. Um processo de formação foi proposto e implementado, dando aos professores de escolas estaduais da Bahia a oportunidade de se envolver em processos de construção de inovações educacionais que combinavam pesquisa estudantil e pesquisa docente. $\mathrm{O}$ programa visava desenvolver mais autonomia e empoderar os professores para implementar inovações em seu trabalho docente, assim como propiciar aos estudantes da escola básica uma participação mais ativa e crítica na vida das comunidades em que 
vivem. Trabalhar com Questões Sociocientíficas (QCS) foi o foco da pesquisa estudantil, como destacaremos adiante.

Para elaborar a proposta, partimos do pressuposto de que a melhoria da educação em nosso país envolve necessariamente a valorização, a autonomia e o empoderamento dos professores. Outro pressuposto foi o de que a pesquisa educacional, quando realizada no contexto da prática docente, requer a colaboração dos pesquisadores acadêmicos com os professores, sob pena de converter-se, ela própria, num vetor de desempoderamento, na medida em que mina, diante de estudantes, pais, diretores de escolas e outros atores do sistema educacional, o papel dos docentes no processo de pesquisa e inovação. Quando construída nos moldes de um trabalho colaborativo voltado para a inovação, a pesquisa se torna, em contrapartida, uma via de desenvolvimento profissional dos professores e não se vê acometida, como é comum ocorrer, por um distanciamento da prática que dificulta seus efeitos sobre esta, a chamada lacuna pesquisa-prática. (EL-HANI; GRECA, 2011; KENNEDY, 1997; LÜDKE, 2001; MCINTYRE, 2005; PEKAREK; KROCKOVER; SHEPARDSON, 1996; VANDERLINDE; VAN BRAAK, 2010)

De outra parte, também foi assumida, na construção do programa, a ideia do protagonismo juvenil, adotando-se o ensino e a aprendizagem por investigação como meio de engajar os estudantes num processo de apropriação e aplicação do conhecimento científico para compreender e intervir em sua realidade local. Desse modo, a expectativa foi a de contribuir, por meio do ensino de ciências, para a formação de cidadãos críticos e sociopoliticamente ativos.

Nosso objetivo, neste capítulo, é descrever a estrutura da proposta do Programa Ciência na Escola - Ensino Médio, no que tange à formação de professores de biologia, física, química e geografia, situando o uso de QSC em seu âmbito, assim como mencionar alguns resultados obtidos nas escolas.

\section{Alguns conceitos-chave}

Antes de descrever a estrutura do programa, é importante explicitarmos o nosso entendimento sobre alguns conceitos-chave que permeiam os pressupostos apresentados acima: inovação, trabalho colaborativo, protagonismo juvenil e cidadania.

É comum confundir-se inovação, no campo pedagógico, com receituários de técnicas, atividades lúdicas ou atividades experimentais. (D’ÁVILA; EL-HANI, 2017) Além de prescrições, também são frequentemente oferecidas aos professores recomendações vazias, assim denominadas por serem centradas na apresentação de resultados de experiências educacionais supostamente bem-sucedidas, sem serem acompanhadas das razões e dos fundamentos que justificam sua adoção e, tampouco, da descrição e da análise das condições de sua produção. (ALMEIDA, 2006)

Inovar significa transmutar, metamorfosear, imutar, transmudar. (AZEVEDO, 2010) Contudo, à luz do que argumentamos acima, consideramos que não é toda mudança no 
ensino que pode ser denominada inovação. Em nosso entendimento, outro aspecto importante é que a inovação educacional contribua para a autonomia e o empoderamento do trabalho docente. No âmbito de um grupo colaborativo de pesquisa educacional que reúne professores-investigadores experientes e novatos da educação básica e do ensino superior em torno da investigação de inovações educacionais, como no Grupo Colaboração em Pesquisa e Prática em Educação Científica (CoPPEC), a distinção entre mudanças emancipatórias e regulatórias nas práticas de docentes da educação básica (VEIGA, 2003) cumpre um papel central. Este grupo produziu um conceito próprio de inovação educacional capaz de oferecer parâmetros teóricos e metodológicos para a avaliação do caráter inovador das práticas por ele desenvolvidas e estudadas. (ALMEIDA, 2014; SEPÚLVEDA et al., 2012) Nos termos desse conceito, inovações educacionais são entendidas como intervenções desenvolvidas, aplicadas e avaliadas de modo colaborativo por professores de diferentes níveis de ensino para solucionar problemas da prática pedagógica e/ou da aprendizagem, com um caráter emancipatório e não regulatório. Como propõe Veiga (2003), numa inovação emancipatória (ou edificante), busca-se o diálogo com saberes e diferentes atores locais, sem perder de vista o contexto histórico e social em que a inovação tem lugar, implicando rupturas epistemológicas nas práticas educacionais e ocorrendo em situações concretas com as quais quem as aplica está existencial, ética e socialmente comprometido.

Nesses termos, uma mudança nas práticas docentes que seja imposta aos professores sem diálogo com suas perspectivas, sem um reconhecimento de seus contextos de trabalho e uma conexão efetiva com tais contextos e sem rupturas epistemológicas (ao menos, potenciais) não é considerada uma inovação, mas apenas uma mudança de caráter normativo, regulador, burocrático e uniformizador. A distinção entre mudanças inovadoras e regulatórias na prática educacional nos parece muito importante para um posicionamento crítico frente aos constantes anseios e movimentos de mudança da escola, que raramente deixam espaço para o engajamento e o empoderamento dos professores, tratados tão somente como mão de obra alienada da tomada de decisão sobre sua própria prática profissional. Essas propostas regulatórias não somente desrespeitam a construção do trabalho profissional do professor, como também tendem ao fracasso, porque não têm legitimidade frente aos próprios atores sociais que deveriam implementá-las. Elas merecem, assim, crítica vigorosa, ainda mais quando estes anseios e movimentos têm lugar dentro das universidades e no âmago da pesquisa educacional. Não podemos perder de vista, sem dúvida, que este não é um conceito de inovação pautado somente por razões de ordem teórico-epistemológica, mas exprime um posicionamento ético-político sobre a necessária relação entre o desenvolvimento e a investigação de inovações educacionais, de um lado, e o trabalho docente, de outro.

O trabalho colaborativo envolvendo professores de diferentes níveis de ensino tem sido visto como um caminho para diminuir a lacuna entre pesquisa e prática no campo educacional (EL-HANI; GRECA, 2011; HARGREAVES, 1999; MCINTYRE, 2005), 
garantir a relevância e a qualidade da pesquisa educacional (ZEICHNER, 1998); para o progresso da pesquisa em educação científica (MOREIRA, 1988); e, ainda, para promover o desenvolvimento profissional e o empoderamento do professor. (GARRISON, 1988; LÜDKE, 2005; ZEICHNER, 2003) A formação de grupos de trabalho colaborativo depende, em nosso entendimento, da observância de alguns princípios:

- um esforço de crítica e desconstrução constante das posições hierarquizadas em que frequentemente se situam professores da educação básica e pesquisadores educacionais, visando construir e manter relações colaborativas que façam justiça ao fato de que os professores e pesquisadores envolvidos são ambos membros experientes de distintas comunidades de prática e devem assim atuar como pares (EL-HANI; GRECA, 2011; LAVE; WENGER, 1991; WENGER, 1998);

- a decisão ética e política de jamais tomar o espaço do professor como responsável pela construção de seu trabalho pedagógico, planejando-se inovações sempre em colaboração com ele e à luz de suas opções, decisões e saber docente;

- $\quad$ similarmente, a decisão de jamais ocupar a posição do professor na condução do trabalho pedagógico em sala, evitando substituí-lo como ator principal de seu trabalho, sempre preservando seu protagonismo frente a seus alunos. ${ }^{1}$

O protagonismo juvenil, por sua vez, pode ser entendido como "a participação de adolescentes no enfrentamento de situações reais na escola, na comunidade e na vida social mais ampla”. (COSTA, 2001, p. 9) Trata-se de um processo no qual o jovem é simultaneamente sujeito e objeto de uma ação que visa desenvolver suas potencialidades. (MAGALHÃES, 2008) Contudo, ao tratar do protagonismo juvenil, é importante ter em vista a polissemia desta expressão, em especial evitando-se modos de entendê-la que situam a participação política como algo para o futuro, para a qual o jovem está sendo formado, e não como algo de seu presente (FERRETTI; ZIBAS; TARTUCE, 2004), o que limita o protagonismo a um jogo escolar, fomentando-se uma despolitização da participação juvenil. Não é desta perspectiva, entretanto, que entendemos esta expressão. No contexto escolar, um protagonismo que se traduza em participação sociopolítica é importante para que os estudantes compreendam o papel do conhecimento aprendido em suas vidas, como vetor de transformação individual e social. Trata-se de empoderar estudantes para que se desenvolvam como pensadores críticos, informados e, na perspectiva de uma cidadania voltada para a ação sociopolítica, engajados. Trata-se, assim, de assumir como objetivo, numa educação que visa o desenvolvimento da cidadania, uma educação para a ação sociopolítica (HODSON, 2003, 2011) ou para a tomada de decisão para ação social responsável. (SANTOS; MORTIMER, 2001)

1 Sobre o papel de grupos colaborativos na construção e na aplicação de QSC, ver o capítulo de Guimarães e colaboradores, neste volume. 
Esse protagonismo também se configura como elemento para motivá-los em sua passagem por uma escola que, tipicamente, demanda que eles se ajustem a ela, mas pouco se ajusta aos próprios estudantes, os quais conduzem suas vidas de acordo com ideias, valores, práticas que não são necessariamente as mesmas de seus pais, professores ou daqueles que decidem sobre a natureza e a estrutura de sua educação. Ao se tornarem partícipes das ações que visam desenvolver suas potencialidades, os alunos ganham algum espaço para negociar seus valores, práticas e ideias dentro do processo educacional.

Por fim, ao recorrer ao conceito de cidadania, é preciso sempre tornar claro o que se entende por ele, sob pena de se assumir visões limitadas de uma educação para a cidadania restrita ao conhecimento e ao pensamento crítico, perdendo de vista valores, atitudes e práticas. Quando se assume uma visão limitada da educação para a cidadania, são gerados processos educativos acompanhados por uma despolitização do cidadão. (GIROUX, 2004a) A concepção que desenvolvemos no âmbito do Programa Ciência na Escola se move em direção oposta a tal despolitização, entendendo que a cidadania requer participação política, ativismo, engajamento cultural, oferecendo aos estudantes a oportunidade de se tornarem agentes sociais responsáveis (GIROUX, 2004b; SANTOS; MORTIMER, 2001), valorizando a leitura crítica da realidade, mas indo além dela. Trata-se, pois, de afastar o ensino de ciências de uma pretensão de neutralidade, que o coloca na contramão de uma educação para a cidadania. Se seguirmos a autores como Giroux (2004a, 2004b), tal como fazemos, não há uma educação para cidadania possível que não seja uma educação para ação sociopolítica, uma vez que cidadania implica participação política, ativismo e engajamento cultural.

Não se pode perder de vista, afinal, que um aspecto-chave de uma educação para a cidadania em nossas sociedades contemporâneas, tão atravessadas pelo conhecimento científico, é o estímulo para que os estudantes desenvolvam a capacidade de se apropriar criticamente das relações Ciência, Tecnologia, Sociedade e Ambiente (CTSA) desde uma perspectiva equilibrada, que nem demonize nem louve a ciência e a tecnologia, e, potencialmente, de tomar decisões e engajar-se em ações informadas e socialmente responsáveis acerca de QSC. ${ }^{2}$ Daí o papel central das QSC na proposta que desenvolvemos no Programa Ciência na Escola - Ensino Médio.

\section{A proposta de formação e pesquisa}

A proposta do Programa Ciência na Escola - Ensino Médio, que contemplou a formação de professores de biologia, física, química e geografia, foi pautada pela concep-

2 Por decisão socialmente responsável, entende-se uma decisão que é tomada pelo sujeito com "consciência de seu papel na sociedade, com compromisso de cooperação e corresponsabilidade social, na busca de melhor qualidade de vida em termos coletivos, e não apenas individuais". (CONRADO et al., 2011, 2012, p. 2; SANTOS; MORTIMER, 2001) 
ção da inovação educacional como iniciativa capaz de conferir autonomia e empoderamento tanto a professores quanto a estudantes. Tratava-se, pois, de propor às escolas envolvidas um processo educacional no qual a relação entre o aprendiz e o objeto de conhecimento fosse capaz de propiciar ao primeiro um desenvolvimento como sujeito autônomo e capaz de exercer sua cidadania (entendida nos termos postos acima) e no qual os professores criassem condições para o engajamento dos estudantes em processos autênticos de investigação de sua realidade. Aos professores, por sua vez, foi posto o desafio adicional de construir um processo de pesquisa docente, investigando o engajamento dos estudantes na proposta.

Como um meio de fomentar o trabalho em equipe dos professores, rompendo com o isolamento em que, muitas vezes, se encontra em suas salas de aula, foi proposto que cada escola construísse um projeto interdisciplinar, reunindo docentes das disciplinas envolvidas (biologia, física, química e geografia). ${ }^{3} \mathrm{O}$ tema deveria ser escolhido em comum acordo com os estudantes que se envolveriam no projeto, com cinco requisitos básicos, que descreveremos a seguir.

Primeiro, deveria tratar-se de uma QSC. QSC são problemas sociais complexos, que dependem de diferentes perspectivas e conhecimentos para sua resolução, na qual os conhecimentos científicos são sempre necessários, mas não suficientes, dado que tais questões sempre envolvem outros aspectos, de natureza cognitiva, moral e afetiva. (CONRADO; NUNES-NETO; EL-HANI, 2015; JHO; YOON; KIM, 2014; SADLER, 2011; SADLER; ZEIDLER, 2004) Elas propiciam contextos férteis para uma aprendizagem ativa do estudante, que não se limita, ademais, aos conteúdos de uma dada disciplina, mas se estende a uma diversidade de conhecimentos, de natureza não somente científica, mas também ética, política e social. Tampouco se restringe à aprendizagem de conteúdos conceituais, por tais questões abarcarem também conteúdos de outra natureza, como os atitudinais e os procedimentais.

Segundo, deveria dizer respeito a uma questão socioambiental que afetasse a(s) comunidade(s) do entorno da escola, tornando o processo de pesquisa estudantil relevante para além dos muros da instituição escolar e mostrando aos estudantes o valor da interpretação e da intervenção na realidade baseadas nos conhecimentos aprendidos na escola.

Terceiro, deveria ser uma questão de pesquisa autêntica, ou seja, uma questão em aberto para os estudantes, uma vez que, se eles conhecerem o resultado a ser alcançado, o processo de investigação perderá em autenticidade e os estudantes se distanciarão de uma compreensão da natureza da investigação e de sua utilidade frente aos proble-

3 Por "interdisciplinaridade", entendemos a construção de práticas de pesquisa envolvendo aportes de diferentes disciplinas para lidar com problemas complexos, que desafiam abordagens meramente disciplinares. Busca-se construir corpos integrados de conhecimento, nos quais os conhecimentos de cada disciplina modificam os conhecimentos das demais, não correspondendo apenas a um somatório de conhecimentos disciplinares, o que caracterizaria a "multidisciplinaridade". (TRESS; TRESS; FRY, 2005) 
mas concretos que enfrentamos. (BUXTON, 2006; GRIFFIS; THADANI; WISE, 2008; TYTLER et al., 2008; VAN EIJCK; ROTH, 2009)

Quarto, embora autêntica, a questão deveria estar ao alcance dos estudantes, mostrando-se suficientemente simples e acessível, já que se tratava, afinal, de alunos do ensino médio. Ao mesmo tempo, não deveria ser uma questão trivial, visto que isso menosprezaria as capacidades dos estudantes, nas quais estamos apostando ao fomentar iniciativas que se pautam pelo protagonismo juvenil e, em especial, buscam promover a formação de cidadãos não somente capazes de ler criticamente a realidade, mas também de uma participação de natureza política na vida social.

Quinto, os professores e estudantes foram estimulados a divulgar os resultados da investigação realizada para além dos muros da escola, disponibilizando-as para instituições e atores sociais de sua comunidade, a exemplo de associações de bairro, cooperativas, postos de saúde etc. A ideia era evitar que a atividade de investigação se esgotasse dentro da escola, criando condições para que os estudantes vislumbrassem como o conhecimento construído poderia mostrar-se relevante para lidar com os problemas de sua comunidade, conferindo, assim, sentido e importância ao conhecimento científico.

Por fim, era uma intenção do programa promover interações das escolas e de seus professores e estudantes com pesquisadores educacionais de universidades da mesma região, bem como com instituições sociais que pudessem contribuir e/ou beneficiar-se do conhecimento produzido nos projetos estudantis. Embora algumas escolas tenham logrado sucesso em estabelecer tais parcerias, esta foi uma intenção não realizada em quase todos os casos, pelas dificuldades de identificar e contatar possíveis parceiros, bem como de despertar o interesse de pesquisadores e instituições pela parceria com as escolas, em especial, num projeto no qual estas eram protagonistas. Isso mostra a necessidade de novas ferramentas e mediações para a concretização desse princípio.

Além da pesquisa estudantil, o programa também propôs a realização de pesquisa educacional pelos docentes, visando a produção e a interpretação de evidências sobre as consequências da participação dos estudantes nos projetos de investigação. Tendo em vista, contudo, que não haviam sido propiciadas a quase todos os professores, em sua formação inicial e continuada, experiências de iniciação à pesquisa, assim como o curto tempo que teriam para preparar-se para a investigação que estávamos propondo, foi fundamental propor questões e procedimentos de pesquisa que fossem acessíveis a eles, sob pena de vivenciarem uma experiência frustrante que mais os afastaria da pesquisa educacional do que lhes daria oportunidade de se iniciar na mesma.

Tomou-se como ponto de partida a ideia de que os professores estariam especialmente interessados em investigar a aprendizagem, o entendimento ou o conhecimento adquirido por seus estudantes durante a pesquisa. Contudo, estes são traços ou atributos latentes, de difícil acesso e que não são passíveis de mensuração direta. (PASQUALI, 2003) Eles só podem ser inferidos a partir de manifestações observáveis que, à luz de determinada teoria, são relacionadas a eles. Um dado observável que pode ser relacio- 
nado à aprendizagem, permitindo entender o processo que leva a ela, é o engajamento escolar, que pode ser subdivido em três tipos: comportamental, cognitivo e emocional. (FREDRICKS; BLUMENFELD; PARIS, 2004) O último, que se refere às reações positivas e negativas dos estudantes em relação aos professores, à sala de aula e à escola, é de difícil investigação, pois demanda instrumentos sofisticados e validados para acessá-lo. Por isso, tal engajamento não foi contemplado na pesquisa docente que propusemos no programa. Assim, foi sugerido aos professores que investigassem uma das facetas do engajamento comportamental dos estudantes, referente à sua participação nas atividades propostas, por meio de um checklist do cumprimento das mesmas. Também foi proposto que investigassem uma faceta do engajamento cognitivo, definido em termos gerais como o investimento psicológico e esforço cognitivo visando à aprendizagem de conceitos mobilizados durante o processo de ensino, referente ao desempenho em testes desenhados para este fim.

Não há dúvida de que a pesquisa educacional proposta era bastante simples, mas não nos pareceu exequível preparar professores no decorrer de seis meses para a realização de um estudo mais complexo, que seria realizado quase simultaneamente à formação. Parece-nos que há algo importante a ser observado aí: a formação docente para a pesquisa deve situar-se ao alcance dos professores, para que seja recompensadora e fomente o desejo de continuar com tal formação. Nesse sentido, as duas dimensões do engajamento escolar, que propusemos como objetos de investigação (comportamental e cognitiva), poderiam ser acessadas por instrumentos usuais da prática docente, uma vez que já é rotineiro para os professores a proposição de tarefas para os alunos, assim como a aplicação de testes para avaliação da aprendizagem. No entanto, esses instrumentos foram discutidos em outra perspectiva durante a formação, como ferramentas que abarcam não só o caráter pedagógico como também o de pesquisa. Dessa forma, ao mesmo tempo em que foram inseridos parâmetros inovadores nas abordagens didáticas de avaliação, esses mesmos parâmetros abarcaram conhecimentos já usualmente adotados pelos professores em seu cotidiano escolar.

Os professores foram estimulados, ainda, a construir um projeto bem estruturado, que a escola pudesse realizar ao longo do ano e retomar nos anos subsequentes, respondendo a diversas demandas que lhes chegam do Ministério ou da Secretaria da Educação. A existência de tal projeto pode permitir que a escola conte com prazos mais longos para a execução dos projetos do que aqueles tipicamente disponibilizados para cumprir tais demandas, constrangidos, via de regra, pela necessidade de produzir resultados no curso de um ano letivo. Para tanto, os professores foram orientados a formular um objetivo geral claro, a partir do tema de pesquisa escolhido, bem como derivar deste objetivo geral uma série de objetivos específicos bem articulados, que, uma vez respondidos, conduziriam a uma conclusão sobre o objetivo geral. É evidente que estas são orientações bastante básicas na construção de um projeto, mas elas se mostravam necessárias, em virtude da limitada experiência de pesquisa educacional que as formações inicial e 
continuada haviam oferecido aos docentes. Como havia professores de disciplinas diferentes trabalhando com turmas diferentes de alunos, foi importante delimitar tarefas vinculadas aos objetivos específicos para os estudantes. Foi sugerido, ainda, que fossem fornecidas orientações claras aos estudantes sobre o formato final de seus relatórios de pesquisa, de modo que estes pudessem ser usados por novas turmas de estudantes que se engajassem no projeto nos anos seguintes. Afinal, se a escola decidisse dar continuidade ao projeto, novos estudantes e, inclusive, novos professores poderiam retomá-lo do ponto em que parou no ano anterior. Para isso, eram necessários não somente projetos bem construídos, mas também relatórios de pesquisa informativos, apresentando com clareza os resultados obtidos na investigação.

A realização de projetos de investigação nas escolas se torna, frequentemente, uma atividade extraclasse, com pouca ou nenhuma conexão com o tratamento dos assuntos na sala de aula. Isso conduz, primeiro, a uma falta de vínculo entre o projeto e os conhecimentos científicos que os estudantes estão aprendendo, perdendo-se a oportunidade de fomentar maior aprendizagem científica a partir do envolvimento com o projeto. Segundo, como é comum que apenas uma parte dos estudantes se envolva nos projetos, os demais alunos terminam por não se beneficiar deles, criando desigualdades nas oportunidades de aprendizagem. Para evitar esse problema, foi solicitado aos professores de biologia, física, química e geografia que identificassem conteúdos conceituais destas disciplinas que seriam trabalhados em sala de aula utilizando contextos propiciados pelos projetos de pesquisa estudantil. Dentre esses conteúdos conceituais, foi solicitado aos professores que selecionassem um deles para a investigação sobre o engajamento cognitivo dos estudantes. O engajamento comportamental, por sua vez, foi estudado com base num checklist das tarefas que seriam entregues pelos estudantes, para dar conta dos objetivos específicos do projeto. O engajamento comportamental é particularmente importante, porque permite acessar conteúdos procedimentais e atitudinais.

A execução do programa foi baseada na formação de 36 professores de ensino médio (chamados de "articuladores"), das quatro disciplinas incluídas, pelos três formadores, autores deste texto, com apoio de 18 tutores (professores de ensino médio com experiência em pesquisa). Os articuladores foram afastados da sala de aula no ano do programa. Sua formação teve lugar por meio de quatro cursos, que foram então replicados por cada articulador para 30 professores em escolas de diferentes regiões da Bahia, os quais frequentaram cursos oferecidos pelos articuladores. Desse modo, o programa foi projetado para atingir 1.080 professores. Com as desistências ao longo do tempo, ele atingiu cerca de 800 professores de 277 escolas públicas estaduais. ${ }^{4}$

4 As desistências de professores envolveram razões variadas, como, por exemplo, as muitas demandas colocadas para as escolas pelos projetos estruturantes da Secretaria de Educação; as expectativas de alguns professores de que o engajamento no programa de formação não envolveria o volume de trabalho que terminou por requerer, devido à formação para pesquisa docente; fatores internos das escolas, uma vez que muitas têm professores com contratos temporários, o que impediu sua participação, dificultando a condução de projetos interdisciplinares. 


\section{Alguns resultados}

Neste capítulo, não temos a pretensão de apresentar em maiores detalhes resultados alcançados, seja pelos projetos estudantis, seja pelos projetos docentes, nas diferentes escolas que participaram do Programa Ciência na Escola - Ensino Médio. Não podemos nos furtar, contudo, a mencionar alguns dos projetos realizados pelos estudantes sob orientação de seus professores, bem como dois exemplos das pesquisas docentes conduzidas. Todos os projetos foram realizados em escolas públicas do estado da Bahia.

O Colégio Estadual Mestre Paulo dos Anjos, localizado em Salvador (Bahia, Brasil), teve como tema investigado por estudantes e professores a ocupação urbana e a sustentabilidade no Bairro da Paz. Este projeto, coordenado pela professora Elisenilda Nunes Andrade, sob orientação da articuladora professora Angélica Moura de Souza, mostrou o alcance que podem ter iniciativas de estudantes e outros atores quando ultrapassam os muros da escola. Diante do diagnóstico acerca dos problemas socioambientais associados a um córrego que atravessa seu bairro, os estudantes saíram em passeata pelo bairro, distribuindo materiais informativos produzidos por eles, nos quais expuseram seus achados e suas preocupações, o que teve significativo impacto sobre os moradores do bairro.

Em Juazeiro (Bahia, Brasil), os estudantes e professores do Colégio da Polícia Militar Alfredo Vianna, sob a coordenação do professor Charle Jean Alves da Silva e tendo como articuladora a professora Lucila Alves, investigaram a possibilidade de implementação sustentável da orla fluvial da cidade a partir do estudo da ocupação urbana, comercial e turística ao longo de toda a sua extensão, visando fomentar a construção de possíveis soluções. Os resultados foram sistematizados em uma revista impressa, contendo todos os enfoques dados aos mais diversos temas pesquisados, sendo que os próprios estudantes foram os editores, criadores, redatores, diretores de fotografia, gerando um material muito rico, disponibilizado para a Câmara de Vereadores e comunidades escolar e local.

$\mathrm{Na}$ localidade de Jorro (Bahia, Brasil), pertencente ao município de Tucano, os professores e estudantes do Colégio Estadual Rômulo Galvão, coordenados pela professora Marileide Alves da Mata, com o apoio do professor Marcos Adriano de Oliveira Araújo como articulador, realizaram a caracterização geoambiental do escoamento das águas termais de Caldas do Jorro em uma lagoa e o estudo de possíveis formas de revitalização. A partir de uma enquete em rede social, divulgada amplamente na localidade, foram levantadas sugestões viáveis de revitalização da lagoa, as quais subsidiaram a confecção pelos estudantes de uma maquete representando a intervenção mais adequada, a qual foi apresentada ao Conselho Municipal do Meio Ambiente durante evento na comunidade escolar (Figura 1). 
Figura 1 - Apresentação da maquete pelos estudantes ao Conselho Municipal do Meio Ambiente durante evento na escola
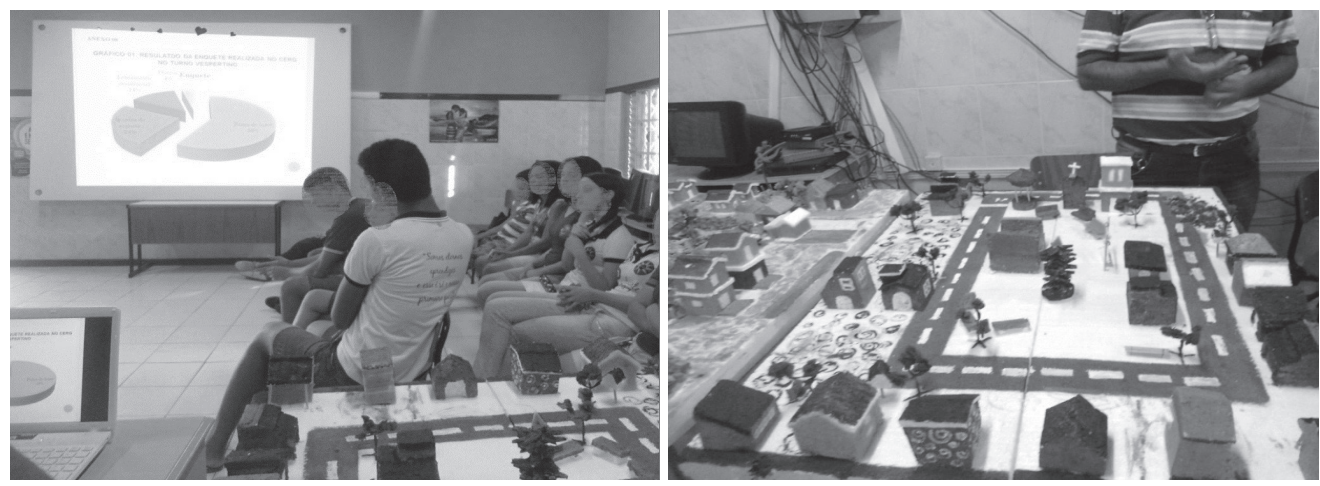

Fonte: Arquivo do Colégio Estadual Rômulo Galvão.

Professores e estudantes do Centro Territorial de Educação Profissional do Sisal (Ceteps), localizado em Serrinha (Bahia, Brasil), desenvolveram projeto sobre os impactos decorrentes da urbanização sobre o reservatório de água da cidade, o açude do Gravatá. Coordenado pelo professor Elmo José Carneiro Carvalho, sob orientação da articuladora professora Cristiane Ribeiro, o projeto propiciou a aprendizagem de habilidades pelos estudantes, como a interpretação de imagens de satélite, dando-lhes acesso a conhecimentos relativos ao sensoriamento remoto, e levou à identificação de fontes de poluição do açude. A escola estabeleceu uma rede de parceiros, constituída pela Prefeitura Municipal de Serrinha, a Universidade Estadual de Feira de Santana (UEFS), a Associação dos Moradores da Comunidade do Arco-Íris, a Fundação Nacional de Saúde (Funasa) e um laboratório de Análises Clínicas, que apoiaram a pesquisa. Os resultados, sistematizados em um banco de dados contendo mapas digitais, fotografias aéreas e imagens de satélites da cidade, modelagem de sua malha hídrica, bem como dados da análise microbiológica da água do açude, foram divulgados na comunidade escolar e local. Estes resultados podem subsidiar ações sociopolíticas bem informadas, voltadas para o manejo hídrico na localidade.

O Projeto A Cultura do Sisal na Vida da Gente, desenvolvido no Colégio Estadual Wilson Lins (Bahia, Brasil), sob a coordenação da professora Verbenia Markley Guimarães e orientação da articuladora professora Cristiane Ribeiro, visou analisar a importância do cultivo do sisal nas vertentes socioeconômica e ambiental no município de Valente. Assim como outros projetos aqui relatados, a própria escolha do tema de investigação evidencia uma ação sociopolítica, tendo em vista que a dimensão do local tem sido negligenciada em políticas públicas e muitas vezes desconsiderada no espaço escolar. Ao promover a relação entre Ciência, Tecnologia, Sociedade e Ambiente (CTSA) no estudo de uma prática produtiva local, a cultura do sisal, o projeto manifesta um reconhecimento de que a escola é um espaço para o diálogo de saberes (Figura 2). 
Figura 2 - Visita técnica à unidade de desfibramento do sisal com uso de resíduos como adubo na cultura do próprio sisal
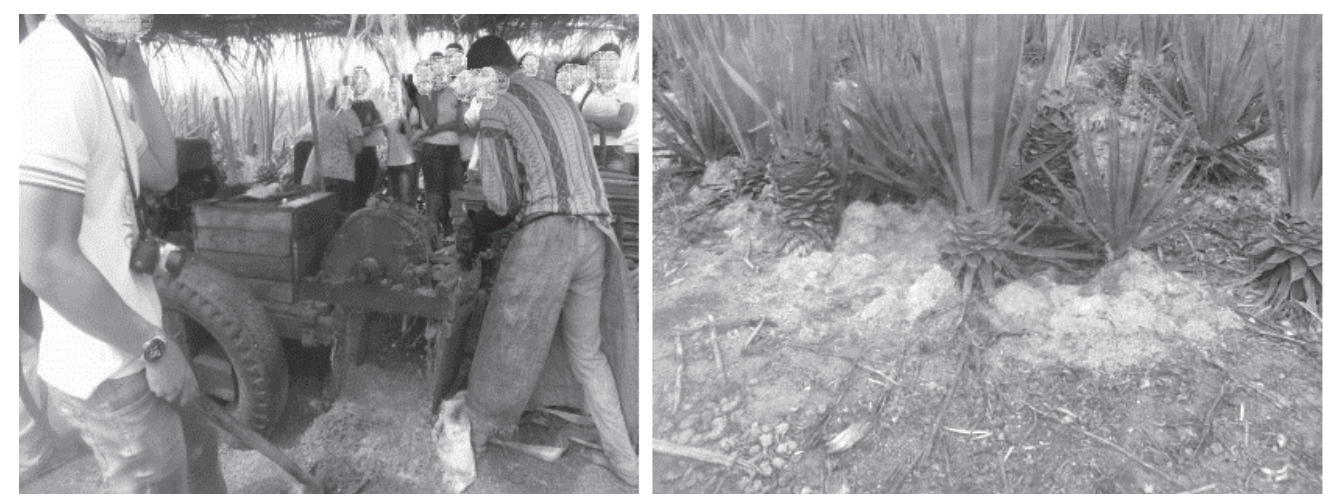

Fonte: arquivo do Colégio Estadual Wilson Lins.

Nesse projeto, conduzido pelos professores das disciplinas de física, química, geografia e biologia, foram avaliados os engajamentos comportamental e cognitivo dos estudantes envolvidos. O engajamento comportamental foi interpretado em termos de tarefas cumpridas, enquanto o engajamento cognitivo foi avaliado em termos da diferença de desempenho entre pré e pós-testes realizados em cada disciplina. Como resultado, os professores calcularam a média da turma nos testes e explicitaram a frequência de entrega nas tarefas.

A conclusão geral dos professores, reportada em seu relatório final, foi que, através das pesquisas de campo realizadas, o conhecimento sobre a realidade local proporcionou aos estudantes a percepção da relação homem-natureza numa proposta da sustentabilidade, estimulando-os a projetar possíveis ações que possam promover a valorização da cultura do sisal e contribuir para a melhoria das condições socioeconômicas e ambientais do município.

Outro exemplo de pesquisa docente se encontra no projeto desenvolvido no Colégio Estadual Carlos Barros (Bahia, Brasil), no qual estudantes e professores investigaram o impacto socioambiental da contaminação das águas no bairro de Paripe, em Salvador, lugar em que a escola se localiza. O projeto, coordenado pelas professoras Quênia Carvalho Ribeiro Lopes e Cybelle Lobão e orientado pelo articulador professor Marivaldo Claudio Braga Jr., envolveu parceria com a Universidade Federal da Bahia, a Empresa Baiana de Águas e Saneamento (Embasa) e o Instituto Brasileiro do Meio Ambiente e dos Recursos Naturais Renováveis (Ibama). As atividades investigativas propiciaram aos estudantes a compreensão das condições ambientais de seu bairro, que eram, até então, pouco conhecidas por eles, sendo que os resultados foram apresentados na Associação de Moradores de Paripe.

Também nessa escola, os professores utilizaram o engajamento comportamental e cognitivo para avaliar a repercussão do projeto, sendo que isso foi feito para as disci- 
plinas de química, geografia e biologia separadamente. Nos gráficos elaborados pelos professores dessa escola (Figura 3 e Figura 4), as informações são dispostas em relação às médias e frequências em cada disciplina, de maneira mais sintetizada. No que se refere ao engajamento cognitivo, esses professores optaram por apresentar a diferença das médias dos escores do pré e do pós-teste, em vez de plotar a média em cada momento. Os resultados do engajamento cognitivo, mostrados na Figura 3, indicam ganhos em todas as disciplinas, com mais ganho no entendimento na disciplina de química.

Figura 3 - Diferenças das médias dos escores dos alunos da turma investigada no pré e no pós-teste realizado em cada disciplina que se envolveu no projeto de pesquisa estudantil

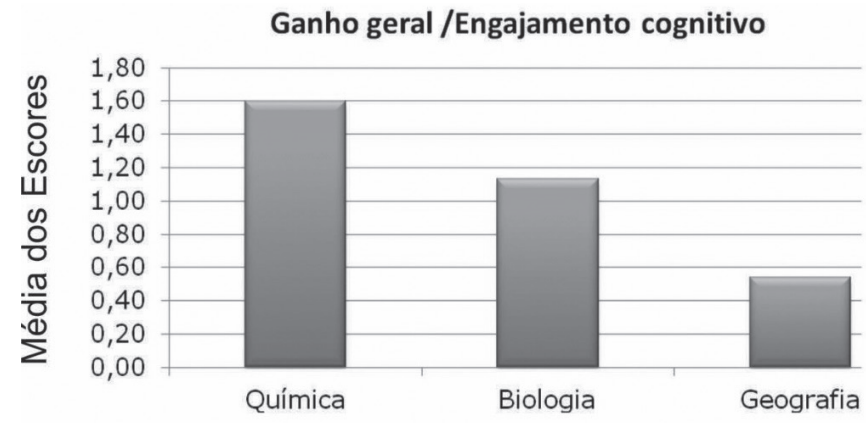

Fonte: Relatório final dos professores do Colégio Estadual Carlos Barros.

Para o engajamento comportamental, reportado na Figura 4, foram observados elevados níveis em todas as disciplinas, com pouca diferença entre elas, ainda que na de geografia tenhamos um indicativo de menor engajamento (Figura 4). Em relação ao projeto, os professores concluíram em seu relatório final: "As diversas discussões, bem como produção de relatórios e questionários sobre o tema escolhido, mostram o interesse e efetiva participação da maioria dos alunos no desenvolvimento do projeto [...]”.

Figura 4 - Escores de engajamento comportamental dos alunos da turma investigada, em cada disciplina que se envolveu no projeto de pesquisa estudantil

\section{Engajamento Comportamental}

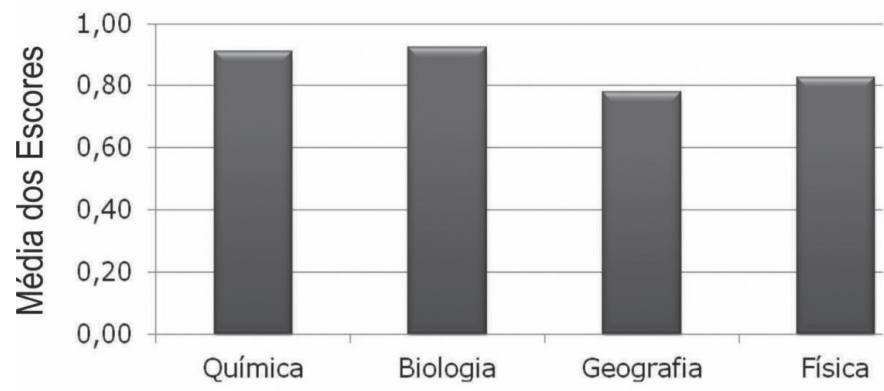

Fonte: relatório final dos professores do Colégio Estadual Carlos Barros. 
Esses exemplos ilustram a relevância das questões socioambientais escolhidas para a investigação pelos estudantes das escolas, bem como seu caráter sociocientífico e aberto. Eles mostram, ainda, a potencialidade de tais projetos para a educação de cidadãos não somente cientificamente informados, mas críticos e politicamente participativos. Além disso, a pesquisa docente proporcionou aos professores uma avaliação mais sistemática da própria prática, fornecendo instrumentos que podem ser adaptados às suas ações cotidianas. Embora as análises não tenham sido conduzidas com rigor estatístico, elas potencializaram a avaliação dos projetos, possibilitando aos professores ir além das suas inferências pessoais, ou pelo menos corroborá-las ou não, a partir de dados que revelam um aspecto da aprendizagem e do engajamento de seus alunos. De modo geral, houve grandes diferenças no modo como os professores relataram os resultados, uma vez que, apesar da inclusão de vários procedimentos na formação no Programa Ciência na Escola, eles tiveram autonomia para escolher a maneira como iriam descrever esses resultados e fazer suas interpretações. Em relação aos resultados, em termos gerais, houve projetos com grande envolvimento e aprendizagem dos estudantes, enquanto em outros o engajamento cognitivo foi pouco intenso. Contudo, o resultado em termos de motivação e aprendizagem foi positivo, tanto entre os estudantes como entre os professores e articuladores envolvidos no programa.

\section{Conclusões}

No presente capítulo, relatamos o uso de QSC para a construção de projetos de pesquisa estudantil, e não para a construção de intervenções didáticas em sala de aula, que tem sido seu uso mais comum. Descrevemos os princípios e a implementação de um programa de formação de professores de biologia, física, química e geografia, realizado pelo IAT (Instituto Anísio Teixeira, Secretaria de Educação e Cultura, Bahia, Brasil), com coordenação da parte pedagógica pelos autores do capítulo. Esperamos ter deixado clara a potencialidade do uso de projetos estudantis sobre QSC, visando a formação de estudantes informados e capazes de participação ativa na vida sociopolítica. Esta reflexão sobre os princípios de formação para a pesquisa estudantil e docente, por nós estabelecidos durante a experiência vivenciada em 2013, mostra-se especialmente oportuna ao considerarmos que eles têm balizado, desde então, em grande medida, a continuidade do Programa Ciência na Escola.

\section{Referências}

ALMEIDA, M. C. Colaboração entre pesquisadores e professores de ensino de ciências e biologia: um estudo da organização e desenvolvimento da prática social do grupo CoPPEC. 2014. 113 f. Dissertação (Mestrado em Ensino, Filosofia e História das Ciências) - Instituto de Física, Universidade Federal da Bahia, Salvador, 2014. 
ALMEIDA, M. J. P. M. de. Prescrições e recomendações ao professor na solução de problemas do ensino na educação em ciências. Ciência \& Ensino, Campinas, v. 1, n. 1, p. 47-51, dez. 2006.

AZEVEDO, F. F. Dicionário analógico da língua portuguesa. Rio de Janeiro: Lexikon, 2010 .

BUXTON, C. A. Creating contextually authentic science in a "low-performing" urban elementary school. Journal of Research in Science Teaching, New York, v. 43, n. 7, p. 695$721,2006$.

CONRADO, D. M.; NUNES-NETO, N. F.; EL-HANI, C. N. Argumentação sobre problemas socioambientais no ensino de biologia. Educação em Revista, Belo Horizonte, v. 31, n. 1, p. 329-357, 2015.

CONRADO, D. M. et al. Construção e validação de ferramenta para investigação das relações entre conhecimento sobre evolução e tomada de decisão socialmente responsável em questões sociocientíficas. In: ENCONTRO NACIONAL DE PESQUISA EM EDUCAÇÃO EM CIÊNCIAS, 8., 2011, Campinas. Anais... Campinas: ABRAPEC, 2011. p. 1-14.

CONRADO, D. M. et al. Uso do conhecimento evolutivo na tomada de decisão de estudantes do ensino médio sobre questões socioambientais. Revista Contemporânea de Educação, Rio de Janeiro, v. 7, n. 14, p. 345-368, 2012.

COSTA, A. C. G. Tempo de servir: o protagonismo juvenil passo a passo; um guia para o educador. Belo Horizonte: Universidade, 2001.

D’ÁVILA, C. M.; EL-HANI, C. N. Ensino e aprendizagem por investigação no âmbito de comunidades de prática: propostas para uma prática pedagógica inovadora. In: VEIGA, I. P. de A. (Org.). Metodologia participativa e as técnicas de ensino-aprendizagem. Curitiba: CRV, 2017. p. 203-220.

EL-HANI, C. N.; GRECA, I. M. Participação em uma comunidade virtual de prática desenhada como meio de diminuir a lacuna pesquisa-prática na educação em biologia. Ciência e Educação, Bauru, v. 17, n. 3, p. 579-601, 2011.

FERRETTI, C. J.; ZIBAS, D. M. L.; TARTUCE, G. L. B. P. Protagonismo juvenil na literatura especializada e na reforma do ensino médio. Cadernos de Pesquisa, São Paulo, v. 34, n. 122, p. 411-423, 2004.

FREDRICKS, J. A.; BLUMENFELD, P. C.; PARIS, A. H. School engagement: potential of the concept, state of the evidence. Review of Educational Research, Washington, v. 74, n. 1, p. 59-109, 2004.

GARRISON, J. W. Democracy, scientific knowledge and teacher empowerment. Teachers College Record, New York, v. 89, n. 4, p. 487-504, 1988.

GIROUX, H. A. Critical pedagogy and the postmodern/modern divide: towards a pedagogy of democratization. Teacher Education Quarterly, Claremont, v. 31, p. 31-47, 2004a. 
GIROUX, H. A. Cultural studies, public pedagogy, and the responsibility of intellectuals. Communication and Critical/Cultural Studies, Oxfordshire, v. 1, p. 59-79, 2004b.

GRIFFIS, K.; THADANI, V.; WISE, J. Making authentic data accessible: The sensing the environment inquiry module. Journal of Biological Education, New York, v. 42, n. 3, p. 119-122, 2008.

HARGREAVES, D. H. The knowledge-creating school. British Journal of Educational Studies, Oxford, v. 47, n. 2, p. 122-144, 1999.

HODSON, D. Time for action. Science education for an alternative future. International Journal of Science Education, London, v. 25, p. 645-670, 2003.

HODSON, D. Looking to the future: building a curriculum for social activism. Rotterdam: Sense, 2011.

JHO, H.; YOON, H. G.; KIM, M. The relationship of science knowledge, attitude and decision making on socio-scientific issues: the case study of students' debates on a nuclear power plant in Korea. Science \& Education, New York, v. 23, p. 1131-1151, 2014.

KENNEDY, M. M. The connection between research and practice. Educational Researcher, Washington, v. 26, n. 7, p. 4-12, 1997.

LAVE, J.; WENGER, E. Situated learning: legitimate peripheral practice. New York: Cambridge University Press, 1991.

LÜDKE, M. O professor pesquisador e a relação entre teoria e prática. In: LÜDKE, M. et al. (Org.). O professor e a pesquisa. Campinas: Papirus, 2001. p. 25-34.

LÜDKE, M. O professor e a sua formação para a pesquisa. EccoS-Revista Científica, São Paulo, v. 7, n. 2, p. 333-349, 2005.

MAGALHÃES, M. A Juventude brasileira ganha uma nova escola de ensino médio: Pernambuco cria, experimenta e aprova. São Paulo: Albatroz, 2008.

MCINTYRE, D. Bridging the gap between research and practice. Cambridge Journal of Education, Cambridge, v. 35, n. 3, p. 357-382, 2005.

MOREIRA, M. A. O professor-pesquisador como instrumento de melhoria do ensino de ciências. Em Aberto, Brasília, DF, n. 40. p. 42-54, out./dez. 1988.

PASQUALI, L. Psicometria: teoria dos testes na psicologia e na educação. Petrópolis: Vozes, 2003.

PEKAREK, R.; KROCKOVER, G.; SHEPARDSON, D. The research/practice gap in science education. Journal of Research in Science Teaching, New York, v. 33, n. 2, p. 111$113,1996$.

SADLER, T. D. (Ed.). Socio-scientific issues in the classroom: teaching, learning and research. Dordrecht: Springer, 2011. 
SADLER, T. D.; ZEIDLER, D. L. The significance of content knowledge for informal reasoning regarding socioscientific issues: applying genetics knowledge to genetic engineering issues. Science Education, New York, v. 89, n. 1, p. 71-93, 2004.

SANTOS, W. L. P. dos; MORTIMER, E. F. Tomada de decisão para ação social responsável no ensino de ciências. Ciência \& Educação, Bauru, v. 7, n. 1, p. 95-111, 2001.

SEPÚLVEDA, C. A. S. et al. Inovando o ensino de biologia através do trabalho colaborativo de pesquisadores educacionais e professores-investigadores. Estudos IAT, v. 2, n. 1, p. 119-137, 2012.

TRESS, B.; TRESS, G.; FRY, G. Defining concepts and the process of knowledge production in integrative research. In: TRESS, B. et al. (Ed.). From landscape research to landscape planning: aspects of integration, education and application. Dordrecht: Springer, 2005. p. 13-26.

TYTLER, R. et al. Engaging students in authentic science through school-community links: Learning from the rural experience. Teaching Science, [S.1.], v. 54, n. 3, p. 13-18, 2008.

VANDERLINDE, R.; VAN BRAAK, J. The gap between educational research and practice: views of teachers, school leaders, intermediaries and researchers. British Educational Research Journal, Oxfordshire, v. 36, n. 2, p. 299-316, 2010.

VAN EIJCK, M.; ROTH, W.-M. Authentic science experiences as a vehicle to change students' orientations toward science and scientific career choices: learning from the path followed by Brad. Cultural Studies of Science Education, Dordrecht, v. 4, p. 611638, 2009.

VEIGA, I. P. A. Inovações e projeto político-pedagógico: uma relação regulatória ou emancipatória? Cadernos CEDES, Campinas, v. 23, n. 61, p. 267-281, 2003.

WENGER, E. Communities of practice: learning, meaning, and identity. New York: Cambridge University Press, 1998.

ZEICHNER, K. M. Para além da divisão entre professor-pesquisador e pesquisador acadêmico. In: GERALDI, C. M. G.; FIORENTINI, D.; PEREIRA, E. M. de A. (Org.). Cartografia do trabalho docente. Campinas: Mercado de Letras, 1998. p. 207-235.

ZEICHNER, K. M. Teacher research as professional development for P-12 educators in the USA. Educational Action Research, Wallingford, v. 11, n. 2, p. 301-325, 2003. 


\title{
O DESENVOLVIMENTO DE EXPOSIÇÕES CIENTÍFICAS COMO ESTRATÉGIA DE ATIVISMO EM CONTEXTO ESCOLAR RESULTADOS DO PROJETO IRRESISTIBLE EM PORTUGAL
}

\author{
Ana Rita Marques \\ Pedro Reis
}

\section{Introdução}

Qual é a finalidade da educação no contexto das atuais sociedades modernas? Sociedades que exigem cada vez mais cidadãos ativos, autónomos e responsáveis, capazes de assumir uma atitude crítica perante os diferentes problemas, muitos deles altamente controversos e nascidos das aceleradas mudanças científico-tecnológicas que caracterizam as sociedades modernas. O que devemos pedir à escola, espaço privilegiado da educação, nos dias de hoje? E o que devemos pedir aos professores e aos alunos? A resposta a essas questões dependerá da finalidade que atribuirmos à educação. Se a entendermos como um processo de socialização através do qual cada indivíduo é preparado para assumir um lugar ativo na sociedade (MCMANNON, 1997; SHOR, 1992), depressa concluímos que as experiências educativas dos alunos terão, necessariamente, que passar pela promoção do desenvolvimento de competências de cidadania ativa que fomentem 
o seu empoderamento. ${ }^{1}$ A educação, assim entendida, terá que ser uma educação para o empoderamento (SHOR, 1992), uma educação que assuma os alunos como agentes de mudança, capazes de contribuir para a resolução dos problemas que representam ameaças ao bem-estar dos indivíduos, sociedades e ambientes. Mais do que serem encarados como cidadãos do futuro, os alunos devem ser assumidos como cidadãos do presente. (HOPE, 2012) Aguardar que cresçam e se tornem os adultos de amanhã para então exigir que saibam tomar decisões e agir perante os desafios sociais e ambientais é desperdiçar valiosas (e irrepetíveis) oportunidades de formar, já hoje e nas nossas escolas, cidadãos conscientes da necessidade de participação na vida cívica.

O desenvolvimento de uma cultura de cidadania capaz de enfrentar o estado atual e futuro da humanidade requer cidadãos cientificamente literatos. (HODSON, 2011) Nas palavras de Chen e Novik (1984 apud HODSON, 2011), o desenvolvimento de uma literacia científica representa o meio através do qual se poderão evitar situações em que os valores sociais, o envolvimento individual, a responsabilidade, a participação na comunidade e a efetiva tomada de decisões sejam dominados e praticados por uma pequena elite. Com efeito, a democracia sairá fortalecida quando todos os cidadãos estiverem preparados para confrontar e avaliar assuntos sociais controversos relacionados à ciência - confronto e avaliação fundados não apenas em emoções, mas, sobretudo, em conhecimento e raciocínio. (HODSON, 2011) No contexto da educação em ciências, partilhamos com Roth (2001) a convicção de que o modelo de ensino adotado e as estratégias utilizadas desempenham um papel decisivo na promoção de uma aprendizagem que, sendo em ciências, o seja simultaneamente em cidadania. Que modelo de ensino das ciências se coaduna com este fim? Acima de tudo, um modelo que implique um ensino contextualizado, capaz de envolver e motivar os alunos para agir perante situações específicas, permitindo que realizem, ativamente, tarefas capazes de modificar o mundo em que vivem. E, como consequência do envolvimento nessas tarefas, que aprendam. Um modelo em que os professores interpretem, gerem e adaptem o currículo em função dos alunos e dos contextos emergentes, compreendendo-o como promotor de competências socialmente relevantes para os cidadãos. (REIS, 2013a) Um modelo em que os professores propõem tarefas diversificadas que incluem problemas, investigações e projetos concebidos e conduzidos pelos alunos, atividades de discussão focadas na identificação de soluções para os problemas e na tomada de decisões e iniciativas de ativismo baseadas nos resultados das pesquisas realizadas. (REIS, 2013a) Este ativismo é aquele que autores como Derek Hodson, Larry Bencze e Pedro Reis defendem: um ativismo que se desenvolve em contexto escolar e que representa uma ação sociopolítica coletiva, levada a cabo pelos alunos, com o propósito de contribuir para a resolução de problemas sociocientíficos e socioambientais. E, principalmente, uma ação que se quer fundamentada na investigação desenvolvida pelos próprios alunos, assumidos como sujeitos, e

1 Do inglês empowering. 
não objetos, de conhecimento. (REIS, 2014) Para Hodson (2014), esta ação é uma das principais facetas, senão mesmo a principal, da literacia científica dos cidadãos.

Em contexto escolar, existem várias estratégias possíveis para alunos e professores se envolverem em ação sociopolítica, direta e indireta, sobre Questões Sociocientíficas (QSC) e socioambientais nomeadamente através:

- da organização de grupos de pressão responsáveis pela:

- redação e divulgação de cartas e petições junto do poder político ou de outras instituições e;

- pela realização de boicotes a determinados produtos elaborados a partir de práticas industriais e/ou investigativas consideradas socialmente controversas.

- da realização de iniciativas de educação junto de outros cidadãos com o objetivo de promover a mudança de comportamentos;

- da participação em iniciativas de voluntariado promotoras de uma sociedade mais justa e ética;

- da proposta de soluções inovadoras para problemas locais e/ou globais;

- da mudança dos próprios comportamentos. (HODSON, 2014; REIS, 2013a, 2014)

A realização de iniciativas de educação junto de outros cidadãos, tendo em vista promover a mudança de comportamentos, afigura-se como uma possibilidade, concretizável, por exemplo, através da realização de uma exposição.

Perante o desafio de conceberem uma exposição capaz de, fundamentadamente, alertar a comunidade para problemas sociocientíficos e socioambientais relevantes contribuindo, assim, para a sua resolução -, os alunos ver-se-ão confrontados com a necessidade de construir conhecimento que fundamente as suas escolhas. Investigando, reunirão evidências que suportem as suas opiniões, aprendendo mais sobre ciência e sobre fazer ciência. Planeando a exposição, deparar-se-ão com importantes questões: o que expor, para que público, com que finalidade, onde concretizar a exposição, como divulgar e como avaliar o impacte no visitante? Confrontados com a necessidade de produzir uma exposição interativa, os alunos questionar-se-ão sobre qual a melhor estratégia para estimular a interação entre os visitantes e entre estes e os objetos expostos. Dinamizando a exposição, os alunos confrontar-se-ão com as questões e dúvidas dos visitantes, as quais abrem portas para a reflexão e para o diálogo partilhado, transformando, alunos e visitantes em aprendentes e ativistas. (REIS, 2013b) Avaliando a exposição e o impacto nos outros, os alunos terão a oportunidade de refletir sobre a sua ação e sobre o seu papel enquanto cidadãos ativos, que procuram contribuir para solucionar alguns dos problemas das sociedades atuais. 


\section{O Projeto IRRESISTIBLE e o desenvolvimento de exposições científicas pelos alunos como estratégia de ativismo em contexto escolar}

O Projeto IRRESISTIBLE ${ }^{2}$ - Including Responsible Research and Innovation in cutting-edge Science and Inquiry-based Science Education to improve Teacher's Ability of Bridging Learning Environment - surge com a finalidade de envolver professores, alunos e público no processo de Investigação e Inovação Responsáveis (IIR). Pretende-se que alunos e professores se tornem conscientes da necessidade de cooperação entre Investigação Científica e Sociedade em prol de uma investigação e inovação que sejam, de fato, responsáveis. Para tal, é fundamental que ocorra:

- a construção de conhecimento sobre a investigação de temas científicos atuais, pertinentes e polémicos; e que

- os mesmos sejam alvo de discussão, numa perspetiva de IIR.

Os temas escolhidos caracterizam-se pela sua elevada relevância social, por serem investigados nas universidades parceiras do projeto e por poderem ser abordados nos currículos escolares. (APOTHEKER et al., 2017)

O envolvimento dos professores, alunos e público no processo de IIR é concretizado através do desenvolvimento, em sala de aula, dos módulos de ensino concebidos pelas Comunidades de Aprendizagem (CoL, do inglês Community of Learners) do projeto. Cada módulo, subordinado a um tema científico atual, implica, no contexto da estratégia Inquiry Based Science Education (IBSE), o modelo de ensino dos 5E de Rodger Bybee e colaboradores (2006): Engage, Explore, Explain, Elaborate e Evaluate. A ele foram acrescentadas duas etapas - Exchange e Empowerment - que implicam o desenvolvimento de exposições científicas interativas pelos alunos. As CoL envolvem a participação de professores de ciências, educadores em ciência, cientistas que investigam nas áreas científicas selecionadas e especialistas em educação não-formal. Cada país envolvido é responsável pela conceção de um módulo de ensino, testado pelo país autor e por países parceiros, sendo a sua implementação avaliada através de estudos de caso.

O IRRESISTIBLE pressupõe que os professores implementem módulos de ensino que impliquem os alunos numa investigação ativa sobre temas científicos atuais e controversos tendo em vista o planeamento, a construção e a dinamização de uma exposição científica final por forma a educar a comunidade e alertar para o tema estudado. Entendida,

2 Ver em: <http://www.irresistible-project.eu/index.php/en/>. O IRRESISTIBLE é uma ação coordenada e apoiada no âmbito do FP7-SCIENCE-IN-SOCIETY-2013-1, ACTIVITY 5.2.2 Young people and science: Topic SiS.2013.2.2.1-1 Raising youth awareness to Responsible Research and Innovation through Inquiry Based Science Education. Este projeto recebeu financiamento do Sétimo Programa-Quadro da União Europeia para a investigação, o desenvolvimento tecnológico e a demonstração nos termos do acordo de subvenção número 612367. 
assim, como uma iniciativa de educação junto de outros cidadãos, a concretização da exposição possibilita aos alunos participar numa ação comunitária sobre temas sociocientíficos e socioambientais controversos e motivar outros a envolver-se nela. Esta participação possibilita aos alunos aumentar o seu conhecimento acerca dos problemas em causa e desenvolver competências de investigação e cidadania participativa e fundamentada, desenvolvendo também o sentimento de poder de intervenção na evolução da sociedade. (BENCZE; CARTER, 2011; REIS, 2013a; ROTH; DÉSAUTELS, 2002)

Quando os alunos pesquisam, desenham e constroem um artefato representando o seu conhecimento, envolvem-se num processo de aprendizagem mais profundo. (PAPERT, 2008) Por outro lado, a construção de conhecimento pelo aluno manifesta-se de forma mais evidente quando este se envolve na construção de algo exterior a si mesmo ou que possa, pelo menos, ser partilhado. (PAPERT, 2008)

De acordo com Reis (2013b), o planeamento, a construção e a apresentação de uma exposição científica permitem aos alunos conceptualizar a ciência não como um produto, mas como um processo: os fatos científicos podem ser representados sob a forma de questões especulativas, o ensino deixa de ser transmissivo e os visitantes podem construir a sua própria aprendizagem. Quando apresentam conhecimento científico de ponta ou quando utilizam a exposição para levantar questões, os alunos tornam-se aprendentes com os visitantes. O desenvolvimento de uma exposição científica constitui-se, assim, como um pretexto e um contexto para os alunos investigarem sobre os seus próprios interesses (com a supervisão do professor) - questionando, colaborando e observando, formulando e revendo explicações científicas, reconhecendo e analisando explicações alternativas e comunicando argumentos científicos.

Quando bem planeadas, as exposições podem promover o diálogo entre os alunos (produtores) e os visitantes - contribuindo para o desenvolvimento de capacidades metacognitivas. Durante a preparação das exposições, os alunos:

- questionam;

- recorrem à lógica e à evidência no processo de formulação e revisão das explicações científicas;

- reconhecem e analisam explicações alternativas; e

- comunicam argumentos científicos. (REIS, 2013b)

Através da construção e da apresentação de exposições sobre QSC atuais, tanto alunos como professores têm a oportunidade de contatar com um tipo de ciência diferente da que é normalmente apresentada nas aulas de ciências. Com efeito, segundo Reis (2013b), a educação científica formal tende a focar-se numa ciência convencional, não controversa, estabelecida e confiável; já os temas científicos "de ponta”, por sua vez, realçam uma ciência de fronteira, controversa, preliminar, incerta e sob debate. 
Ao conceberem uma exposição sobre temas científicos "de ponta", os alunos são confrontados com um novo tipo de ciência e devem ser ajudados a compreender que o conhecimento científico relevante pode, igualmente, ser considerado incompleto, incerto e contestado. A preparação destas exposições ajuda os alunos a compreender que a incerteza e o risco são dimensões que fazem parte do empreendimento científico e tecnológico. (REIS, 2013b)

A discussão inerente à conceção de uma exposição científica sobre temas sociocientíficos pode ser particularmente útil, promovendo:

- a aprendizagem sobre os conteúdos, processos e a Natureza da Ciência e da tecnologia;

- o desenvolvimento cognitivo, social, político, moral e ético. (REIS, 2013b)

Encaradas como um contexto sociocultural, as exposições sobre temas sociocientíficos podem levantar questões, estimular a reflexão pessoal e o diálogo entre alunos e visitantes, transformando ambos em aprendentes e ativistas. (REIS, 2013b)

\section{Método}

No primeiro ano do IRRESISTIBLE (2013/2014), Portugal constituiu a sua CoL e dinamizou uma ação de formação, através da qual os professores puderam desenvolver conhecimento didático relativamente ao modelo ampliado dos $5 \mathrm{E}$ e à utilização das Tecnologias de Informação e Comunicação (TIC). O contacto com os cientistas da CoL durante as sessões permitiu aos professores construir conhecimento sobre tópicos científicos atuais - Ciência Polar, Extensão da Plataforma Continental Portuguesa, Biotecnologia e Bioética, e Energia e Radiação. Dos vários módulos de ensino produzidos, três foram selecionados para a fase seguinte de teste, durante a qual os professores que pretendessem continuar no projeto os implementariam em sala de aula. Assim, no segundo ano do IRRESISTIBLE (2014/2015), estiveram ativamente envolvidos na fase de teste sete professoras de ciências e respectivos alunos. Cada professora selecionou um módulo, dos três disponíveis, e o processo de implementação culminou, em cada escola, com a apresentação de uma exposição planeada e desenvolvida pelos alunos.

O estudo que apresentamos centrou-se nas percepções das professoras e dos alunos portugueses que participaram no IRRESISTIBLE no ano letivo 2014/2015 (Quadro 1), relativamente ao impacto do processo de desenvolvimento da exposição enquanto estratégia de ativismo. Os dados foram recolhidos na fase final de implementação dos módulos, após a concretização das exposições, através de entrevistas semiestruturadas realizadas a cada uma das sete professoras participantes e a grupos de alunos (cinco a dez alunos de cada professora, selecionados pela própria). As entrevistas realizadas foram conduzidas tendo por base um guião de entrevista previamente construído, suficientemente flexível para permitir ao entrevistador a recolha de dados relativos a di- 


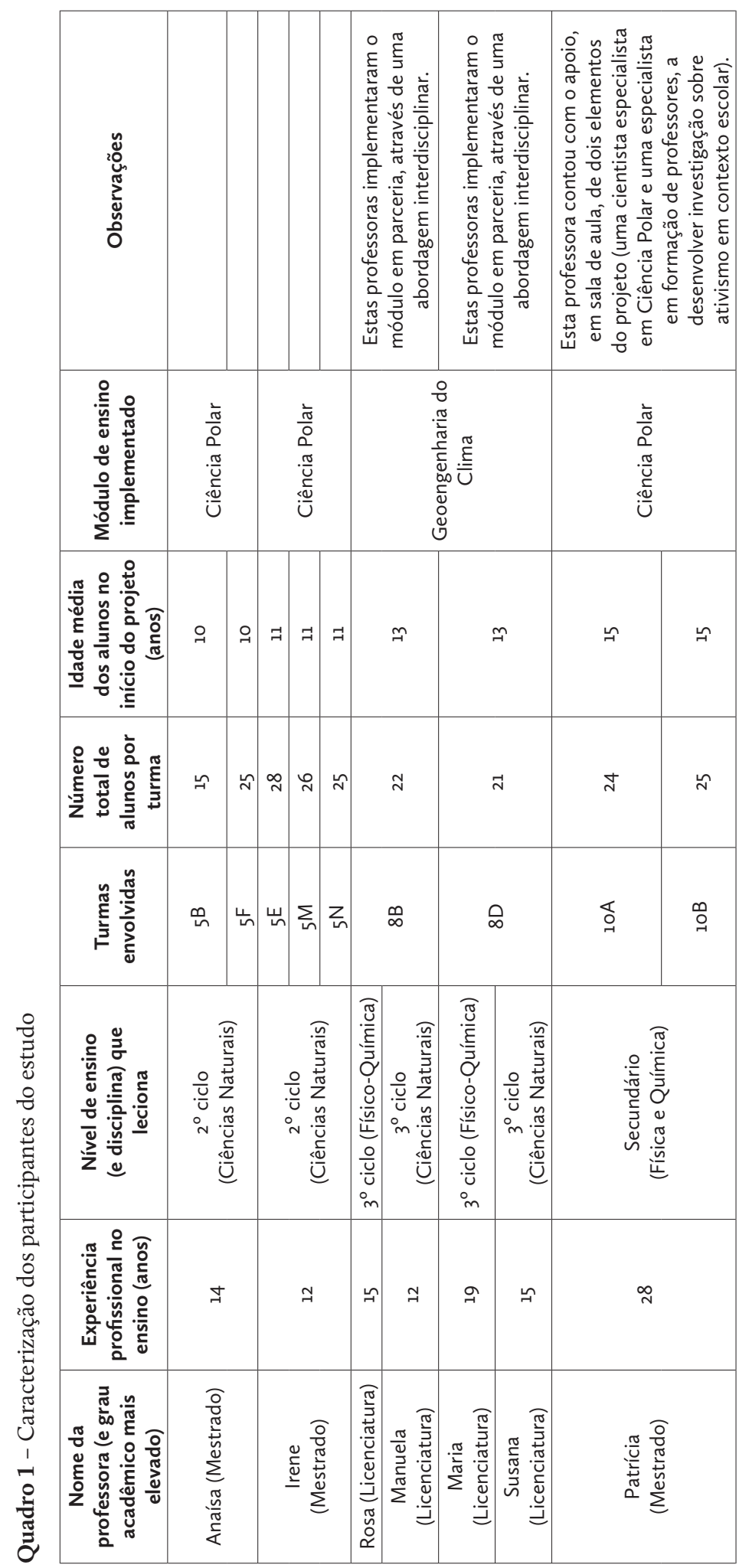

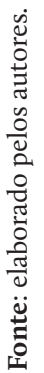


mensões inesperadas do tópico em estudo. (BOGDAN; BIKLEN, 1994; DREVER, 1995) As entrevistas tiveram como finalidade a recolha de evidências sobre a opinião de professoras e alunos acerca dos seguintes aspetos em estudo:

- abordagem realizada pela professora à dimensão "ativismo";

- capacidade dos alunos de contribuir para a resolução de problemas que afetam a sociedade;

- limitações e potencialidades do processo de construção e da exposição construída;

- aprendizagens realizadas e dificuldades sentidas.

Todas as entrevistas foram gravadas em suporte áudio, transcritas e submetidas à análise de conteúdo com a finalidade de extrair as percepções acerca dos diferentes aspetos em estudo. Esta análise envolveu a classificação de elementos significativos, de acordo com categorias que visam organizar a aparente desordem dos dados em bruto. $\mathrm{O}$ processo de construção das categorias foi guiado pelos objetivos e pelo quadro teórico do estudo.

Consideramos que a apresentação entrecruzada das ideias das professoras e dos alunos contribui para melhor elucidar os resultados obtidos, pelo que se apresentam excertos das respostas de ambos com a finalidade de ilustrar algumas aceções. De modo a preservar o anonimato, os nomes das professoras que se apresentam em seguida (e no Quadro 1) são fictícios.

\section{Resultados}

Os resultados obtidos dependem, obviamente, das particularidades do processo de desenvolvimento da exposição em cada escola, como, por exemplo, do papel dos alunos no planeamento da mesma, da existência ou não de um plano de divulgação, da presença dos alunos enquanto dinamizadores da exposição, entre outros. Uma vez que não existia, à partida, um padrão de exposição ao qual as professoras e os alunos devessem obedecer, as exposições resultantes são bastante distintas. O Quadro 2 pretende caracterizar as quatro exposições ${ }^{3}$ em função de alguns aspetos que relevam para os resultados que em seguida se apresentam.

3 Apesar de terem estado envolvidas sete professoras, quatro delas trabalharam em parceria, tendo constituído dois pares interdisciplinares (envolvendo, cada par, uma professora de Ciências Naturais e uma professora de Ciências Físico-Químicas). Essas quatro professoras e respetivos alunos desenvolveram uma única exposição, pelo que o número total de exposições foi quatro. 


\begin{tabular}{|c|c|c|c|c|}
\hline 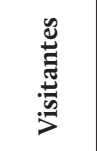 & 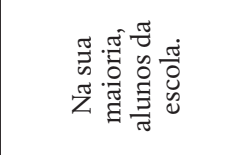 & 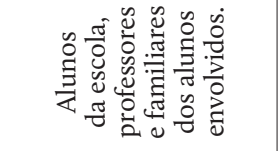 & & 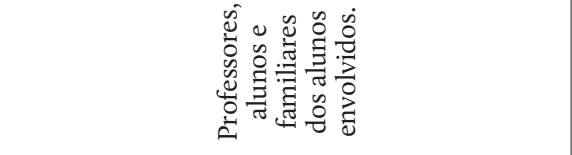 \\
\hline 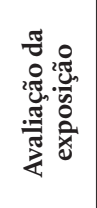 & 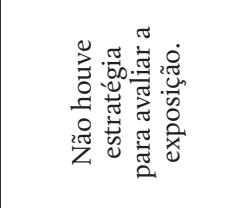 & 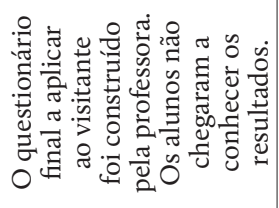 & 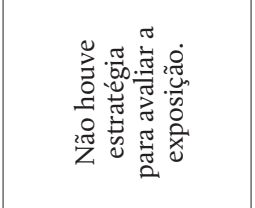 & 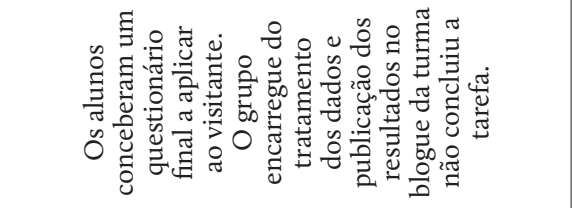 \\
\hline 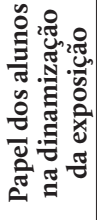 & 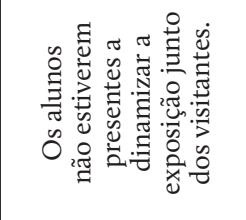 & 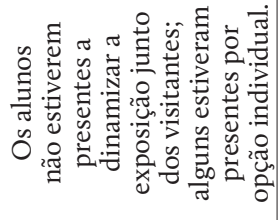 & & 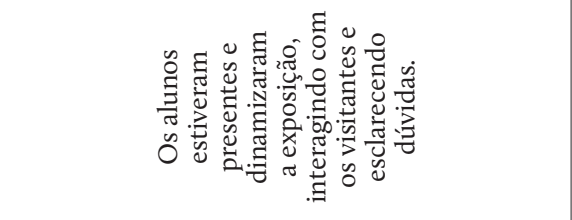 \\
\hline 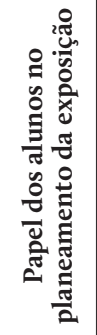 & 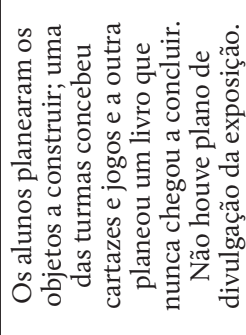 & 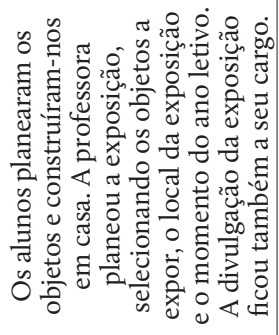 & 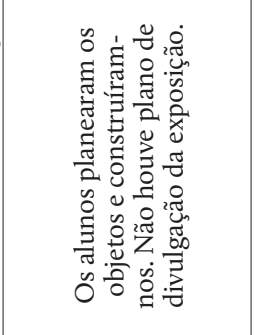 & 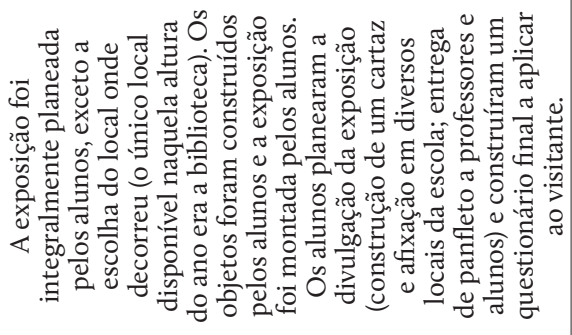 \\
\hline 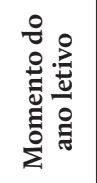 & 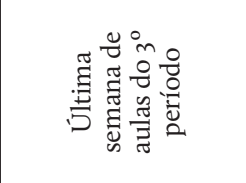 & 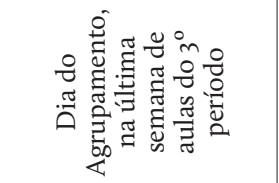 & 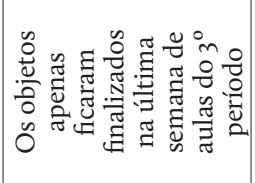 & 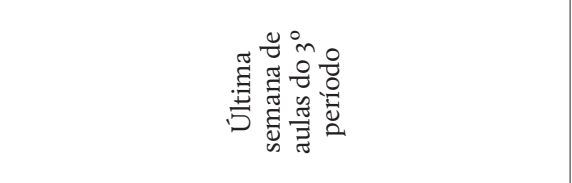 \\
\hline$\frac{\mathscr{0}}{\stackrel{0}{\circ}}$ & 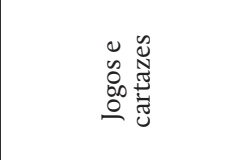 & 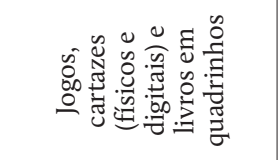 & 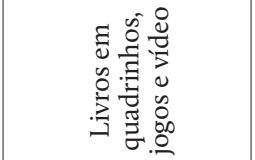 & 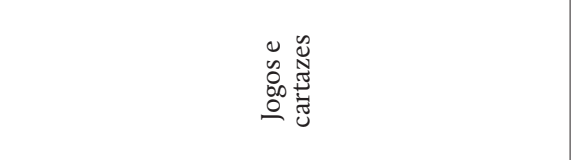 \\
\hline ฐّٓ & 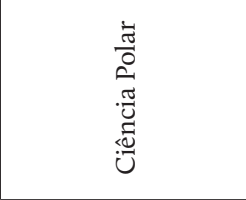 & 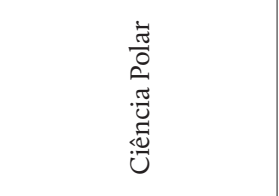 & 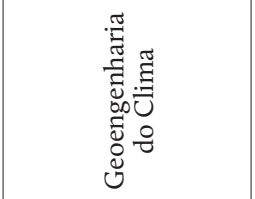 & 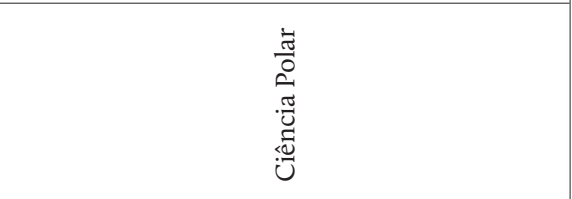 \\
\hline త్ & 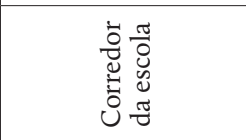 & 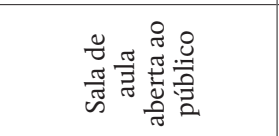 & 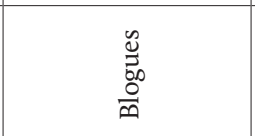 & 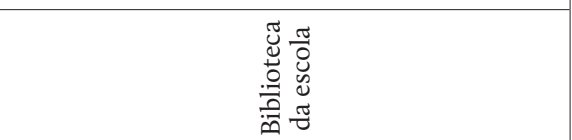 \\
\hline 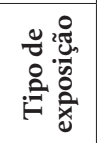 & 㞼 & 营 & 氶 & 茎 \\
\hline 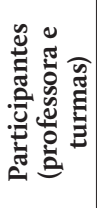 & 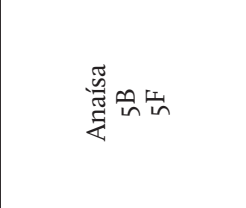 & 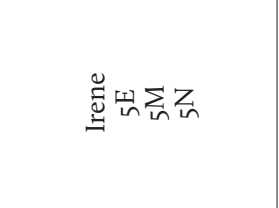 & 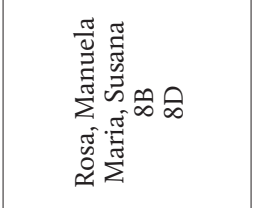 & 营 \\
\hline
\end{tabular}




\section{Abordagem realizada pela professora à dimensão "ativismo"}

Durante o processo de implementação do módulo de ensino (envolvendo o planeamento e o desenvolvimento das exposições), nenhuma professora abordou explicitamente a dimensão "ativismo" junto dos alunos. Isto é, nenhuma escolheu discutir com os alunos sobre as intervenções em sociedade e sobre as capacidades de cidadania ativa, a qual se pode concretizar através de uma exposição com a natureza da preconizada pelo IRRESISTIBLE. A única exceção diz respeito ao contexto especial de implementação relativo à professora Patrícia, que contou com a colaboração de dois elementos do projeto (uma cientista especialista em Ciência Polar e uma investigadora em Didática das Ciências, a desenvolver pesquisa sobre o ativismo em contexto escolar). Neste caso, houve uma abordagem explícita ao ativismo junto dos alunos através de uma sessão de discussão acerca do seu papel enquanto futuros cidadãos vs cidadãos do presente e da sua capacidade (ou falta dela) de contribuir para a resolução dos problemas que afetam as sociedades. Para além desta sessão, exclusivamente dedicada a este fim, o tema foi, por diversas vezes, abordado ao longo do processo de implementação do módulo e de desenvolvimento da exposição.

Relativamente às restantes professoras, os motivos pelos quais não houve uma abordagem explícita ao ativismo relacionaram-se:

- à falta de tempo, associada a uma menor atribuição de importância a esse aspeto, quando comparado com os restantes aspetos implicados na implementação do módulo; e

- $\quad$ à convicção de que os alunos compreenderiam que essa dimensão estaria implícita no seu trabalho durante o planeamento e a concretização da exposição.

Assim sendo, não haveria a necessidade de abordar explicitamente, em contexto de sala de aula, aspetos como a capacitação dos alunos para a ação ou o seu papel enquanto cidadãos do presente, capazes de contribuir para a resolução de problemas que afetam a sociedade. A seguir, apresentamos algumas falas das professoras a respeito dessa questão:

[A propósito da abordagem explícita ao ativismo] Não é que nós não tivéssemos consciência que tínhamos que o fazer, mas é que nós não tivemos tempo para fazer isso! Mas... Agora olhando para o produto final, isso devia ter sido um ponto que nós devíamos ter focado! [...] Nós vamos fazer isto com este objetivo! (Maria)

Eu não sei se [abordar explicitamente o ativismo] teria tido outro impacte, eu acho é que eles [os alunos] não têm noção do impacte que tem aquele blogue e a importância que tem aquele blogue! Eu acho que isso falhou um bocadinho. Eles se calhar pensaram: 'Pronto, fizemos o blogue, nós percebemos' e pronto. E não têm ideia de que agora o blogue vai ser visto por muitas pessoas e que 
o que lá está, no fundo, foi trabalho deles. E é importante, não é!? No fundo, eles estão a ter um papel ativo... a divulgar... na sociedade, não é!? Eu acho que eles não ficaram com essa ideia. Eles poderiam ter ficado com essa ideia, se nós tivéssemos posto às claras, alertado para essa dimensão do ativismo! Portanto, acho que eles sozinhos não chegaram lá! (Susana)

Não lhes dei a conhecer essa forma de ativismo, no sentido em que não lhes disse que a exposição era para conseguirmos chegar a outras pessoas, que era para mudar mentalidades ou comportamentos... Não, não lhes disse nada disso! Escolhi fazer dessa forma porque eu preciso de perceber se os meus alunos querem, primeiro, ou não querem abordar determinado tema! E só depois de conseguir perceber até que ponto é que eles estão ou não estão dispostos a abordar determinado tema e determinada área e a fazer determinada coisa, é que eles próprios se empenham para fazer, mostrar aos outros. Porque ninguém consegue fazer, mostrar o que seja a outra se não estiver motivado para isso! E eu primeiro trabalho com os meus alunos ao nível da motivação deles porque, depois, eles próprios se encarregam de ter vontade de mostrar aos outros e, por isso, não lhes digo isso abertamente. É uma coisa que acaba por partir deles e eu faço questão que parta deles, e que sejam eles a mostrar vontade de o fazer, $e$ não eu a dizer que serve para isto ou que serve para aquilo. (Irene)

\section{Capacidade dos alunos contribuírem para a resolução de problemas que afetam a sociedade}

Quando questionadas sobre se consideram que os alunos têm a capacidade de contribuir para a resolução de problemas que afetam a sociedade, todas as professoras assentiram. No entanto, todas partilharam da convicção de que os alunos não têm essa percepção. Este aspeto é especialmente relevante quando confrontado com o fato de nenhuma professora ter optado por uma abordagem explícita ao ativismo com a finalidade de capacitar e estimular os seus alunos para a ação. Parece-nos que, a par de envolver os alunos em projetos da natureza do IRRESISTIBLE, discutir explicitamente o seu papel interventivo em sociedade, as suas capacidades de cidadania ativa e mostrar-lhes exemplos de iniciativas levadas a cabo por outros jovens relevariam para fazer desenvolver nos alunos a percepção de que são capazes de contribuir para a resolução de problemas que afetam a sociedade.

Durante as entrevistas, todos os alunos consideraram que o projeto concorreu para que se sentissem capazes de agir e contribuir para a resolução de problemas sociocientíficos e socioambientais, fundamentando essa capacidade no conhecimento que haviam construído, fruto da pesquisa desenvolvida. Contudo, alguns deixam antecipar algumas dúvidas em virtude de serem ainda crianças, e por esse motivo não se sentirem capazes de provocar uma mudança efetiva: 
Eu acho que tenho mais capacidade porque, como já aprendi, já desenvolvi aquilo, acho que posso ensinar isso às outras pessoas! Para que conheçam esse tipo de coisas. (Aluno do 5M)

[A propósito da capacidade para a ação] A mim parece-me que sim, porque os jovens hoje em dia vão ser os futuros adultos deste mundo! E então, se nós hoje em dia fizermos alguma coisa e aprendermos com o que fazemos, futuramente será melhor para o nosso mundo e até mesmo para nós mesmos, porque estaremos a ajudar toda a comunidade. (Aluno do 10A)

Sim, muito mais. Acho que seria um pouco mais fácil [explicar o tema às pessoas], porque já tínhamos passado por essa fase, por essa situação de pensar num projeto, de darem-nos um tema, agarrarmos no tema e dali sair algo. (Aluno do 5F)

Sim, porque não sabíamos muita coisa e não tínhamos muita confiança. E agora, sinto que tenho mais confiança, não só de dar a conhecer às outras pessoas; eu também tive mais confiança em mim mesma, porque metade disto que eu fiz no livro eu não sabia! Eu fiquei a aprender com o convívio do meu grupo, dos outros grupos também, porque deram-nos a ajudar a nossa capacidade de compreender a evoluir. (Aluno do 5B)

Acho que sim, agora, como somos crianças, não temos muita capacidade, mas [...] Porque as crianças não podem fazer lá grande coisa, mas podem... As coisas que elas podem fazer podem alertar os adultos e toda a gente, as pessoas grandes. [...] Podemos falar sobre o que aprendemos das coisas ou podemos dizer aos cientistas o que é que andamos a aprender e isso tudo e eles podem ver se há algum problema dos polos, ou algum coisa assim parecida. (Aluno do $5 \mathrm{~N}$ )

Não tanto como os crescidos, mas podemos um bocado. [...] Porque, quando formos crescidos, podemos tomar nós... Podemos fazer nós as nossas coisas; ou seja, podemos mudar o nosso modo de vida, como nós queremos, como nós achamos que deve ser, enquanto agora não. Mas podemos, pelo menos, sugerir às pessoas! (Aluno do $8 \mathrm{D}$ )

Outros alunos, apesar de se sentirem mais confiantes nas suas capacidades para esclarecer a comunidade sobre o problema investigado, deixam transparecer também algumas dúvidas quanto à recetividade que os adultos teriam para acolher as suas ideias e iniciativas:

Sim, mas nem sempre, porque como nós somos crianças, há pessoas que nem acreditam no que nós estamos a dizer! Depois, também depende das pessoas; se nós formos falar a um familiar, vai-nos ouvir e vai perceber. Mas se for, por exemplo, num café ou num sítio qualquer, ele não vai querer saber, porque somos crianças. (Aluno do 8B) 
Neste momento, acho que não temos uma grande palavra, mas, se nos juntarmos todos, acho que conseguimos mudar. Conseguimos mudar a opinião das pessoas! [...] Sim, porque... Aí está, nós somos jovens, estamos a aprender. É mais difícil um adulto confiar em nós para um projeto, ou algo assim, sozinhos ou em pares! Por isso é que eu acho que, se não formos acompanhados - por exemplo, neste projeto estamos a ser acompanhados -, acho que é mais credivel o nosso projeto do que se forem só os jovens a fazê-lo! (Aluno do 10B)

Eu acho que independentemente da idade que nós temos, nós podemos sempre fazer algo para ajudar! Ok, que quando crescermos, a sociedade ouve-nos melhor quanto mais velhos nós formos... (Aluno do 8D)

É interessante destacar que alguns alunos valorizam o fato das exposições, por terem sido concretizadas por crianças/jovens, poderem surpreender os mais velhos, os adultos, que não estariam, porventura, à espera de tamanho empenho e dedicação dos mais novos a temas tão complexos:

Eu acho que, para além do que já foi dito - se nos unirmos nós, de facto, conseguimos transmitir aquilo que queremos - e se tivermos força de vontade! Porque, ao não aceitarmos as coisas como são, nós podemos, de facto, dizer que queremos algo diferente! E com estas exposições e não só este tema, mas sobre outras coisas, nós estamos na idade de ter essa capacidade, de dizer que não aceitamos, ou porque não compreendemos, ou porque pesquisamos mais e resignamos mais com aquilo que vemos e darmos a nossa opinião! E, por vezes, até pode surpreender os mais velhos, porque não estão à espera que nós vamos fazer uma coisa tão elaborada e que levemos algumas coisas tão a sério! (Aluno do $10 \mathrm{~A})$

A propósito das exposições como estratégia de ativismo - exposições fundamentadas na investigação desenvolvida pelos alunos, por si planeadas, desenvolvidas e divulgadas -, todas as professoras consideram que as exposições têm potencialidades no campo da cidadania ativa, no sentido em que podem contribuir para alertar a comunidade para problemas sociocientíficos e socioambientais, propondo, ao mesmo tempo, algumas soluções para a sua mitigação:

Eu acho que as exposições têm a capacidade para deixar a semente da curiosidade lá! Eu acho elas não têm capacidade para resolver o problema, mas elas têm a capacidade para poder abrir os horizontes e poder deixar a pessoa a conseguir ver um pouco mais além e ver por perspetivas diferentes. E deixando lá a semente da curiosidade, a própria pessoa, saindo da exposição, ela consegue ter a capacidade de ir buscar a solução para aquilo que ela procura. A exposição em si não traz a resposta, mas deixa lá a semente! (Irene) 


\section{Limitações e potencialidades do processo de construção e da exposição construída}

A maioria das professoras considerou que a exposição que os seus alunos construíram conseguiu resultar numa boa estratégia de ativismo. Os motivos apresentados prendem-se, sobretudo, com o fato da exposição ter permitido aos visitantes contatar com diferentes aspetos do problema sociocientífico e socioambiental apresentado, proporcionando-lhes momentos de discussão e reflexão:

Apesar de não ter mobilizado um número muito elevado de pessoas permitiu, às que estiveram presentes, o contacto e a sensibilização para questões que nem sabiam que existiam.

[A exposição conseguiu] Principalmente alertar porque educar requer muito mais tempo e persistência. E digo isto pelo que me foi permitido observar durante a exposição relativamente ao comportamento dos visitantes: surpresa, indignação sobre alguns aspectos, vontade em saber mais sobre o assunto... (Patrícia)

A maioria dos alunos considerou, igualmente, que a exposição resultou numa boa estratégia de ativismo, sendo que, para alguns, a qualidade dos objetos construídos e a capacidade de catalisar interações entre os visitantes foram aspetos preponderantes que contribuíram para aquele fim:

Porque eu acho que - pelo menos na minha opinião - acho que todos estamos de parabéns, porque criamos coisas muito interativas e não é normal! Normalmente, estamos sempre habituados àqueles pósteres e coisas muito chatas, mas não! Desta vez, nós conseguimos fazer coisas mais interativas e eu acho que isso é muito importante. (Aluno do 10B)

Por exemplo, no nosso caso, nós, ao fazermos a pista de lançamento de carros... pronto, acho que é uma boa forma de chamar a atenção às pessoas, porque é uma coisa que fez parte da infância de muitos de nós - pelo menos da minha fez - e associar isso a um tema, a um problema que há na atualidade acho que é muito importante, porque as pessoas se lembram - 'Ei, eu costumava usar isto quando era pequeno' - e então acabam por se interessar mais no tema... (Aluno do 10A)

Outros alunos realçam o fato da exposição ter funcionado como plataforma para poderem ensinar aos outros o que aprenderam sobre os temas e, por esse motivo, ter resultado numa boa estratégia de ativismo:

Eu penso que esta estratégia é uma boa estratégia. Não sei se será suficiente porque não abrange tanta gente como se estivesse exposta, por exemplo, no 
Fórum Romeu Correia. Mas, de qualquer forma, nós, organizando a exposição, damos a conhecer sobre o tema que estudamos e começou com os cientistas que vieram dar-nos a conhecer a nós os temas e agora nós damos a conhecer a outros, e esse conhecimento é importante, porque quando as pessoas querem tomar decisões têm que ter uma base de conhecimento! E nós também até aprendemos, tomamos mais noção de que, por exemplo, nos programas eleitorais é muito importante ver quais são os planos para a Ciência, que é uma parte muito importante e deve estar muito incluída na governação. E para tomarmos uma decisão que esteja de acordo com os nossos interesses, primeiro temos de estabelecer quais são os nossos interesses e para o fazer primeiro, temos que saber sobre o assunto em causa! E, por isso, eu acho que é importante expor aquilo que nós aprendemos aqui. (Aluno do 10A)

No caso das professoras Liliana, Carla, Margarida e Paula - cujos alunos desenvolveram produtos digitais, ancorados em blogues -, a ausência de uma divulgação mais ativa, na qual os alunos estivessem envolvidos, acabou por contribuir para que as professoras sentissem alguma frustração pelo fato do trabalho dos alunos ter "morrido na praia". Apesar de reconhecerem o esforço e a dedicação dos seus alunos e o ótimo trabalho que desenvolveram na conceção dos produtos digitais, admitiram igualmente que a ausência de tempo para a divulgação impossibilitou os alunos de poderem ter a percepção do impacto do seu trabalho nos outros:

Foi de limitação de tempo! Porque essa era a nossa intenção! Era: agora já está feito e ficou bem feito, ficou bem estruturado, está ao gosto deles; eles gastaram ali bastante tempo a criar o blogue exatamente como queriam, com as cores que queriam... Com as várias secções. Tudo! Está tudo...! Não houve falha de tempo para a construção; houve depois falha de tempo para: 'E agora, como é que vamos fazê-lo chegar aos outros?’. (Susana)

Nós precisávamos de, pelo menos, mais um mês! Porque eles agora, provavelmente, vão dizer aos amigos, vão dizer aos familiares - e esses vão ver! Nós até já temos lá alguns comentários... Mas se calhar depois fica por aí! Nós poderíamos ter arranjado outras estratégias e envolvê-los no próprio processo! E aí sim! Aí eles iam ter a percepção exata do impacto que aquele blogue... Ou melhor, a percepção de utilidade do blogue! É a utilidade de terem feito todo aquele trabalho e, depois, a repercussão que poderá ter ou que poderia vir a ter. (Maria)

Faltou-nos o tempo também da divulgação; estarmos mais tempo com os alunos para eles também participarem nesse processo. Porque eles devem participar eles nesse processo de divulgarem. Porque o objetivo é sensibilizá-los para essas dimensões e para o ativismo, não é, e nós estamos a formá-los para eles terem essa dinâmica e para tomarem essas iniciativas. Portanto, penso que é importante para eles. (Rosa) 
E para os outros também seria, para os terceiros, para os pares, porque é diferente estar um grupo de professores a divulgar um assunto e estar os pares a divulgarem a outros, iguais a eles, os temas! Portanto, seria logo um foco de curiosidade, não é, de falar de igual para igual, e eu acho que seria muito mais atrativo para o resto da comunidade se forem os alunos a divulgarem para os alunos, ou até para os encarregados de educação. Porque os professores a divulgar, eles já estão habituados; agora, serem eles a divulgarem, serem eles a dinamizarem, seria muito interessante. Alguns deles mostraram em casa os blogues, mas faltou essa parte. (Manuela)

A propósito da divulgação e do possível impacto negativo que uma divulgação insuficiente (ou até mesmo uma ausência de divulgação) pudesse ter para o resultado final, os alunos revelaram algumas opiniões interessantes, reconhecendo que a aposta na divulgação, em projetos futuros, é condição fundamental para que as exposições se concretizem como uma verdadeira estratégia de ativismo:

Acho que podíamos ter tentado passar mais a palavra para as pessoas. Por exemplo, dizer: 'Olha, não te esqueças, na biblioteca - ou ali ou aqui - vai haver uma exposição que nós fizemos, que tem isto e aquilo. Tentar, porque nem toda a gente olha para os cartazes, há muita gente que pura e simplesmente não olha! Que não... Não olha! E então... (Aluno do 10B)

Não houve aquele impacte nas pessoas que eu esperava que tivesse, porque acho que não houve uma divulgação assim tão... Pronto, como deveria ter havido... E acho que foi isso! (Aluno do 10B)

Não obstante os aspetos particulares de cada experiência, todas as professoras consideraram que a passagem dos alunos pelo IRRESISTIBLE e pelo processo de construção da exposição contribuíram para a sua capacitação para a ação. Pelo fato de terem tido a oportunidade de experimentar alguns erros, os alunos terão a oportunidade de melhorar o seu desempenho futuro e, inclusive, antecipar alguns constrangimentos aquando do processo de planeamento e construção de exposições enquanto iniciativas de ativismo:

Sem dúvida! Têm uma visão muito mais abrangente de por onde é que se pode, que tipo de coisas é que se podem fazer e desenvolver para se conseguir chegar a determinadas pessoas. Têm uma visão muito mais aberta sobre o mundo, sobre a vida! (Irene)

Eu penso que sim! Bom, primeiro porque já passaram pelo processo e já tiveram algumas dificuldades, aperceberam-se de coisas que podiam ter feito melhor ou corrigir. Portanto, voltando a fazer uma atividade deste gênero, eu penso que as coisas correriam melhor! Que eles já tinham alguma base, digamos assim. (Anaísa) 
Eu acho que se eles voltarem a estar dentro de um projeto deste gênero ou criar uma campanha de sensibilização, eles vão estar mais preparados! Disso não tenho dúvida. Eu acho que a partir do princípio... Se eles já fizeram um trabalho deste gênero, eu acho que basta fazer um! A partir deste, têm as bases para fazer outro e melhorar! (Maria)

Quando questionados sobre os aspetos mais positivos e negativos da experiência vivida durante a implementação do módulo de ensino e da etapa de desenvolvimento da exposição, os alunos salientaram aspetos distintos. Como mais positivos, destacaram:

- o convívio com os colegas durante a construção dos objetos para a exposição;

- as aprendizagens realizadas acerca dos temas investigados;

- o sentimento de ajuda e contributo para a resolução de um problema ambiental;

- a possibilidade de poder ensinar o que aprenderam, permitindo que as outras pessoas tenham mais conhecimento sobre o mundo que as rodeia;

- $\quad$ poder perceber, pelas expressões e comentários dos visitantes, o impacto do seu trabalho nos outros.

Como aspetos mais negativos, os alunos referiram:

- o processo de chegada a consenso aquando do trabalho em grupo;

- a falta de empenho de alguns colegas, que contribuiu para um produto final de menor qualidade;

- a constatação de que, na origem dos problemas investigados, estão as ações humanas;

- o local escolhido para a exposição, sendo que esta deveria ter acontecido num local que permitisse o acesso a mais visitantes exteriores à escola;

- $\quad$ a falta de tempo para a construção dos objetos e da exposição final:

Para mim, o que foi mais positivo é estar com os nossos amigos, conviver com eles num projeto em que vai ser da turma inteira. E acho que foi só mesmo só isso no positivo, porque eu adorei estar a fazer este projeto com os meus colegas! Foi um convívio em cheio! (Aluno do 5F)

O negativo é que foi um bocado difícil também chegar a um acordo e aceitar algumas ideias dos meus colegas, porque eu gosto - como eu já disse - de trabalhar sozinha. (Aluno do 5F)

Ah... De positivo, conseguimos ter mais conhecimento; agora podemos ajudar. Mas, o negativo é que algumas pessoas não querem saber. (Aluno do 5E) 
Eu acho uma coisa negativa: acho que a exposição devia ter sido lá fora, porque as pessoas andavam muito mais lá fora do que cá dentro! Não havia quase ninguém dentro das salas! (Aluno do 5M)

Eu acho que o aspeto mais positivo foi o facto de nós ficarmos a conhecer mais sobre a Ciência Polar e as regiões polares, e sobre o impacto que as alterações climáticas ou outras coisas têm! [...] E eu acho que o aspeto negativo foi mesmo a falta de tempo! Eu acho que se tivesse começado desde o início do ano teria sido mais fácil. (Aluno do 10A)

E o negativo é o facto de nem todos saberem, nem todos estarem informados sobre o tema, nem todos conseguirem contribuir, nem todos terem interesse... (Aluno do 8D)

\section{Aprendizagens realizadas e dificuldades sentidas}

Todas as professoras consideram que a passagem pelo projeto lhes permitiu:

- construir conhecimento sobre os temas científicos trabalhados (Susana, Rosa, Maria, Manuela, Anaísa, Irene e Patrícia);

- (trabalhar mais eficazmente com as ferramentas TIC envolvidas no módulo e necessárias para a construção dos objetos da exposição (Susana, Maria e Manuela);

- discutir com alunos mais novos temas científicos complexos, em virtude da sua curiosidade e da sua capacidade de colocar questões pertinentes (Anaísa);

- reconhecer a importância de capacitar os alunos para a ação (Rosa);

- construir conhecimento didático sobre o modelo dos 7E (Maria e Susana):

Para mim, foi a parte das várias ferramentas. Eu não usava aquelas ferramentas! E acho que são muito úteis. Esão apelativas para os alunos! Os alunos, quando tiveram que trabalhar nas Wikis, fizeram-no com muita facilidade; quando fizeram no Padlet, também. E eu não as usava! Porque eu simplesmente desconhecia que elas existiam. E a nossa escola propicia isso mesmo, porque nós temos computadores na sala que podíamos usar mais vezes! Para mim essa parte foi mesmo muito importante! (Susana)

Mas, aprendi também que são assuntos que podem ser perfeitamente discutidos com alunos desta faixa etária, porque eles têm, não só curiosidade, mas colocam questões que são pertinentes, aprendem e levam estas questões também a outros campos - vá, digamos assim - para além da comunidade educativa! Porque eu sei que estas conversas são tidas, também, fora da escola. (Anaísa)

Também, os alunos consideraram ter realizado aprendizagens, através da participação no projeto, nomeadamente sobre: 
- o tema científico investigado;

- a IIR;

- o trabalho em grupo; e

- o processo de desenvolvimento de uma exposição:

Então, percebemos que não é assim tão fácil organizar uma exposição para o público e que há vários passos que têm que ser seguidos e não é chegar lá e montar! É um processo longo, que vem de trás. (Aluno do 10A)

Acho que todos estamos de parabéns, porque criamos coisas muito interativas e não é normal! Normalmente, estamos sempre habituados àqueles pósteres e coisas muito chatas, mas não! Desta vez, nós conseguimos fazer coisas mais interativas e eu acho que isso é muito importante. (Aluno do 10B)

Então, tiveram mesmo de aprender a trabalhar em equipa para as coisas funcionarem bem! Dividir tarefas etc. Essa foi uma grande dificuldade, por acaso! Foi dificuldade, mas, então, ao mesmo tempo, foi uma aprendizagem também! (Aluno do 8D)

Aprendi que a geoengenharia é a ciência que estuda as alterações climáticas, através das novas tecnologias. Aprendemos algumas estratégias que estão a ser sugeridas para serem aplicadas para, pronto... Diminuir o aquecimento global. (Aluno do 8B)

$\mathrm{Na}$ opinião das professoras, os seus alunos desenvolveram competências de organização e aprenderam:

- $\quad$ sobre os temas abordados;

- a confiar nas suas capacidades; e

- a ter mais iniciativa:

Eu penso que se eles se voltarem a envolver num projeto com esta dimensão - porque isto é um projeto de longo prazo! Não é um projeto de uma aula; podíamos fazer isto em duas semanas, se calhar! Em coisas mais pequenas, pontuais... - Mas eu penso que eles não vão ter tanto receio! Da próxima vez que forem, já sabem que há várias fases e têm que passar por elas todas, não podem fugir a nenhuma! E vão estar mais focados, vão ter mais iniciativa! - eu pelo menos acredito que sim! Eu acho que eles aprenderam bastante. (Susana)

Eu acho que eles conseguiram... Uma coisa muito grande que eles conseguiram é perceber que a opinião deles conta, que alguém os ouve e aquilo que eles fazem é importante! [...] Que a opinião, apesar de pequenos, de tenra idade, que a opinião deles é válida! (Irene) 
Se não tivesse sido o empenho que eles demonstraram, não seria visível. Mas, durante o percurso que fizeram, muitas coisas aprenderam, principalmente sobre IIR e ciência polar, percebi isso nos produtos que apresentaram na exposição e na forma como os apresentaram. (Patrícia)

Todos os participantes referiram ter sentido dificuldades ao longo do processo de desenvolvimento da exposição. Para as professoras, as principais dizem respeito:

- ao pouco tempo disponível para um acompanhamento e uma orientação mais eficazes dos alunos; e

- à abordagem eficaz à IIR, através de exemplos ilustrativos que os alunos conseguissem compreender:

A primeira dificuldade que eu sinto logo é o tempo! Pronto, é sempre muito difícil conseguir gerir o tempo. Que tipo de tempo?! O tempo em sala de aula para conseguir dar atenção ao programa e dar atenção a este tipo de trabalho que, muitas vezes, se consegue tocar o programa com este tipo de trabalho, mas como vai além do programa, temos sempre que conseguir não nos desviarmose nos perdemos, porque temos um programa também a cumprir, não é?! Portanto, gerir este tempo não é fácil! Depois gerir o tempo, o tempo físico, os quatro meses em que se desenvolve o trabalho, tem que ser com tempos muito contados; os alunos têm que ter sempre, têm que saber os prazos, as datas limite em que têm que entregar! E isto para crianças de 9/10 anos, 11 vá, é complicado, porque são meninos muito novos, porque têm várias disciplinas! (Irene)

Eu acho que perceber as seis dimensões foi fácil, a ponte é que foi mais difícil! Até para nós, não é?! Mas, difícil foi arranjar exemplos para eles compreenderem melhor. (Suana)

Eu acho que eles, com o exemplo, perceberam do que é que estávamos a falar e aí começaram a participar e a lembrarem-se, eles próprios, de exemplos. Porque as dimensões, no abstrato, para eles era difícil compreender. Tinham que estar concretizadas na forma de exemplos. (Maria)

Os alunos também sentiram algumas dificuldades ao longo do processo, principalmente, na seleção da informação pertinente sobre o tema, fruto da extensão e da complexidade dos textos propostos. Outras dificuldades relacionaram-se com:

- o tempo disponível para a realização das tarefas;

- a gestão das outras tarefas escolares;

- a adequação das ideias iniciais dos objetos ao espaço da exposição, o que limitou a sua criatividade; e

- $\quad$ a gestão do trabalho em grupo: 
Os textos para a pesquisa eram muito grandes e nós tentámos simplificar ao máximo para as pessoas perceberem, mas foi difícil. Os textos eram muito complexos, muito difíceis de compreender, e foi difícil por numa linguagem mais simples. Eram muito científicos. E foi também difícil saber o que era mais importante e menos importante na pesquisa. (Aluno do 8D)

Apesar de as opiniões serem mais divergentes e, por vezes, ser mais complicado! O facto de as opiniões serem mais divergentes, é gasto mais tempo a tentar planear, a tentar conciliar as opiniões para termos um projeto em que todos gostamos, em que todos queremos participar! (Aluno do 10B)

\section{Conclusões}

Desenvolver um projeto que implique ativamente os alunos na pesquisa sobre temas científicos atuais e controversos, com a finalidade de desenvolverem uma exposição final capaz de alertar a comunidade para o problema investigado, apresenta-se como uma tarefa desafiante. Desafiante para os professores, mas também para os alunos. Um desafio comum é o de procurar compreender temas científicos que respeitam a uma ciência de fronteira; uma ciência não estabelecida e não consensual; uma ciência diferente daquela que é mais comumente abordada no ensino das ciências. (REIS, 2013b) Outro aspecto que também desafia os professores respeita à gestão do tempo, que advém, muitas vezes, da dificuldade em encontrar sobreposições do tema com os tópicos curriculares (sobreposições essas nem sempre percetíveis e imediatas), o que transforma projetos desta natureza em tarefas extra programa curricular. Para melhor lidar com este desafio, os professores têm que se assumir, cada vez mais, como construtores (e não executantes) do currículo. E mais, devem conseguir dar um passo atrás para poderem ver a big picture: projetos desta natureza não têm apenas como única finalidade a construção de conhecimento sobre os temas científicos investigados. Projetos como este têm também como importantes finalidades o desenvolvimento de competências investigativas que possibilitem aos alunos o seu envolvimento em ações comunitárias fundamentadas, através do qual possam desenvolver competências de cidadania ativa.

Para os alunos, é um desafio sentirem-se como cidadãos do presente, capazes de, a par dos adultos, contribuir para a resolução de problemas que afetam as sociedades. Se é certo que muitos se sentem capazes, é também verdade que deixam vislumbrar algum desânimo pelo fato de sentirem que, aos olhos dos outros, são ainda considerados "crianças" e incapazes de uma real e efetiva ação. A propósito dos resultados obtidos, consideramos que, a este respeito, é fundamental envolver os alunos em discussões acerca do seu papel em sociedade, da sua capacidade de ação e dos meios para que se concretize e da importância de uma cidadania ativa fundamentada. Abordar assim o ativismo, de uma forma mais explícita, recorrendo a exemplos de ações desenvolvidas por outros, possibilita aos alunos (re)pensar o seu papel em sociedade e atribuir mais 
significado às aprendizagens que realizam, já que elas lhes permitirão fundamentar as suas ações.

À exceção das duas turmas de $10^{\circ}$ ano, em mais nenhuma foi feita uma abordagem explícita ao ativismo, concretizado na forma da exposição final. Parece-nos que este aspecto releva para o envolvimento e o desempenho dos alunos, ao longo do processo de desenvolvimento da exposição, e para as suas percepções no final do projeto. Sendo certo que se tratam de alunos mais velhos (cerca de 15 anos de idade), os alunos das duas turmas de $10^{\circ}$ ano foram aqueles que, efetivamente, se envolverem em quase todas as etapas do processo: investigando, planeando a ação e desenvolvendo-a, divulgando e dinamizando a exposição. No caso dos alunos das professoras Marta e Relíquia, não obstante o imenso trabalho desenvolvido, os alunos não foram verdadeiramente implicados no processo de planeamento da exposição, não tendo contribuído para a sua divulgação nem dinamização. Coube às professoras planear a exposição, selecionando os trabalhos a serem expostos, o local e o momento do ano letivo e a estratégia de divulgação. No caso dos alunos que desenvolveram a exposição digital, concretizada através dos dois blogues, o fato de fugir ao conceito mais tradicional de exposição física tem um grande potencial. Mas para que esse potencial se concretize, a divulgação assume um papel muito importante. Mais ainda do que quando se trate de uma exposição física, que está à vista de quem passa. $O$ fato de ser uma exposição virtual, num contexto digital, tem o potencial de alcançar um universo mais amplo de visitantes e, assim, fazer chegar a mensagem a mais pessoas. Contudo, a ausência de um plano de divulgação, que atenda ao tempo disponível para o planeamento e a execução da iniciativa de ativismo, pode contribuir para deitar por terra todo o esforço e o compromisso dos alunos.

Sendo certo que as etapas de investigação e construção da exposição são fundamentais, não menos importante é a etapa de divulgação da exposição e de avaliação do impacto da mesma na comunidade. Se a exposição não for divulgada, ninguém saberá da sua existência e, seguramente, não terá visitantes, saindo gorado o objetivo de alertar a comunidade para o problema investigado. A tarefa de planear a divulgação da exposição deve caber aos alunos ou, pelo menos, envolvê-los ativamente. É importante que compreendam que, se pretendem chegar aos outros através da exposição, importa atrair a comunidade ao local. Há que pensar nestes aspetos e como os colocar em prática, e, para isso, é necessário tempo. Tempo que deve ser previsto logo desde o início do processo - o professor tem, aqui, um papel preponderante de alertar os alunos para esta necessidade.

Da nossa perspetiva, um dos aspetos passíveis de melhoria, em todos os casos, prende-se com o momento do ano letivo em que a exposição aconteceu. Com efeito, em todas as escolas participantes, a exposição teve lugar no final do ano letivo, em alguns casos, no último dia de aulas. Se, por um lado, se torna mais difícil conseguir que os alunos se mantenham focados no trabalho quando as solicitações externas são mais numerosas - o que sucede no final do ano letivo, período intenso de testes de avaliação, 
de conclusão de trabalhos e de visitas de estudo -, por outro, torna-se mais complicado garantir a disponibilidade da restante comunidade educativa para visitar a exposição. O final do ano letivo não é, também, um bom momento para a exposição, pois não possibilita aos alunos a reflexão posterior acerca do impacte do seu trabalho nos visitantes. Essa reflexão, fundamentada nos dados que os alunos devem recolher através, por exemplo, de um questionário aplicado ao visitante no final da exposição, requer tempo em sala de aula para discutirem os resultados e reconhecerem os pontos fracos e fortes do trabalho desenvolvido, numa perspetiva de melhoria futura.

\section{Referências}

APOTHEKER, J., et al. Responsible research and innovation in secondary school science classrooms: experiences from the project IRRESISTIBLE. Pure and Applied Chemistry, [S.1.], v. 89, n. 2, p. 211-219, 2017.

BENCZE, L.; CARTER, L. Globalizing Students Acting for the Common Good. Journal of Research in Science Teaching, New York, v. 48, n. 6, p. 648-669, 2011.

BYBEE, R. W. et al. The BSCS 5E instructional model: origins and effectiveness. Colorado: Colorado Springs: BSCS, 2006.

BOGDAN, R.; BIKLEN, S. Investigação qualitativa em educação: uma introdução à teoria e aos métodos. Porto: Porto Editora, 1994.

DREVER, E. Using semi-structured interviews in small-scale research: a teacher's guide. Edinburgh: Scottish Council for Research in Education, 1995.

HODSON, D. Becoming part of the solution: Learning about activism, learning through activism, learning from activism. In: ALSOP, S.; BENCZE, L. (Ed.). Activism in science and technology education. London: Springer, 2014. p. 67-98.

HODSON, D. Looking to the future: building a curriculum for social activism. Rotterdam: Sense Publishers, 2011.

HOPE, M. Becoming citizens through school experience: a case study of democracy in practice. International Journal of Progressive Education, [S.1.], v. 8, n. 3, p. 94-109, 2012.

MCMANNON, T. J. Introduction: The changing purpose of education and schooling. In: GOODLAD, J. I.; MCMANNON, T. J. (Ed.). The public purpose of education and schooling. San Francisco, CA: Jossey-Bass, 1997. p. 1-17.

PAPERT, S. A máquina das crianças: repensando a escola na era da informática. Porto Alegre: Artmed, 2008.

REIS, P. Acción socio-política sobre cuestiones socio-científicas: reconstruyendo la formación docente y el currículo. Uni-Pluri/versidad, Medellín, v. 14, n. 2, p. 16-26, 2014. 
REIS, P. Da discussão à ação sociopolítica sobre controvérsias sociocientíficas: uma questão de cidadania. Ensino de Ciências e Tecnologia em Revista, Ponta Grossa, v. 3, n. 1, p. 1-10, 2013a.

REIS, P. Projeto IRRESISTIBLE: Fundamentação do workpackage 3. [S.1.], 2013b. Projeto EU.CSA-SA_FP7-SCIENCE-IN-SOCIETY-2013-1-Project number 612367.

ROTH, W.-M. Learning science in/for community. In: CONGRESO

INTERNACIONAL SOBRE INVESTIGACIÓN EN LA DIDÁCTICA DE LAS

CIENCIAS, 6., 2001, Barcelona. Anais... Barcelona: [S.1.], 2001.

ROTH, W.-M.; DÉSAUTELS, J. Science education as/for sociopolitical action. New York: Peter Lang, 2002.

SHOR, I. Empowering Education: critical teaching for social change. Chicago: The University of Chicago Press, 1992. 


\title{
ESTUDANTES AGINDO PARA ABORDAR DANOS PESSOAIS, SOCIAIS E AMBIENTAIS RELACIONADOS À CIÊNCIA E À TECNOLOGIA ${ }^{1}$
}

\author{
Larry Bencze \\ Sarah El Halwany \\ Mirjan Krstovic \\ Minja Milanovic \\ Christina Phillips \\ Majd Zouda
}

\section{Introdução: problemas e ações sobre CTSA}

Muitas pessoas concordam que os campos da ciência e da tecnologia têm tido numerosos efeitos positivos no Bem-Estar dos Indivíduos, Sociedades e Ambientes (WISE)2.

1 O texto original foi produzido em inglês pelos autores. A tradução para o português foi realizada por Nei Nunes-Neto. (N. do O.).

2 Nota do tradutor: decidimos, no texto traduzido em português, manter a expressão WISE, acrônimo do inglês Wellbeing of Individuals, Societies and Environments, para a referência a bem-estar dos indivíduos, sociedades e ambientes, por ser esta expressão já bem conhecida como parte do modelo proposto por Larry Bencze. 
Em alguns contextos, os seres humanos desfrutam de longos períodos de vida, por exemplo, em grande parte por causa de avanços em ciências da vida, medicina e agricultura. Há aqueles que afirmam o contrário, no entanto. Muitos apontam, por exemplo, a mudança do clima como o nosso problema mais premente. (KLEIN, 2014) De acordo com o Painel Intergovernamental para as Mudanças Climáticas, ${ }^{3}$ a Terra está a caminho de uma perda catastrófica da vida e de colapsos físicos, a menos que mudanças drásticas nas políticas públicas e práticas de instituições privadas sejam feitas nos próximos poucos anos. Há muitos outros problemas potenciais, no entanto - incluindo preocupações com a saúde e de justiça social em matéria de: comida rápida (fast food; por exemplo, frango frito) e outros alimentos processados (por exemplo, os biscoitos com gorduras trans), medicamentos (por exemplo, as drogas com efeitos colaterais negativos), diversas biotecnologias (por exemplo, sementes com um gene que as tornam estéreis), produtos químicos tóxicos para tarefas do dia a dia (por exemplo, o bisfenol A em garrafas de plástico) e pesquisa e práticas agrícolas (por exemplo, agrotóxicos).

Figura 1 - Modelo para as relações entre Ciência, Tecnologia, Sociedade e Ambiente (CTSA)

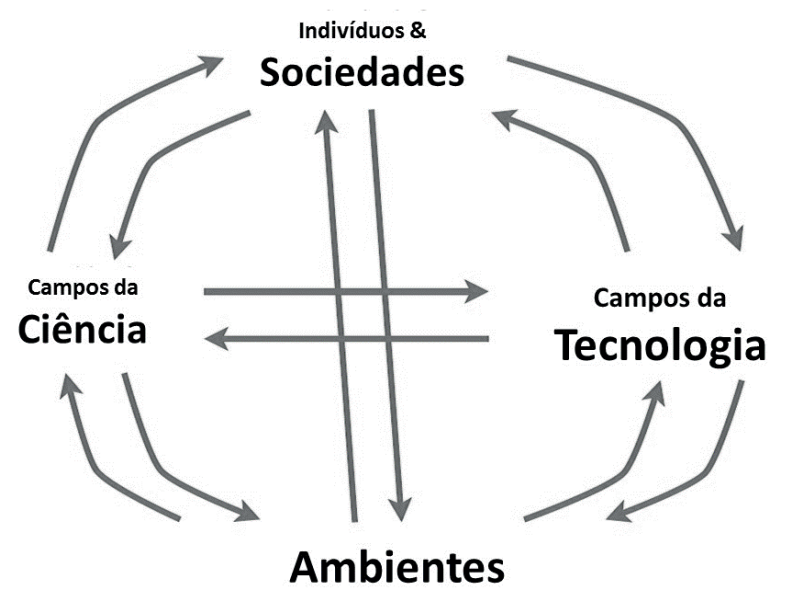

Todas as relações acima podem ser consideradas 'positivas', 'negativas' ou 'neutras'

Fonte: Bencze (2017, p. 29).

Talvez, em reconhecimento aos muitos danos potenciais para o WISE, associados aos campos da ciência e da tecnologia, os sistemas de ciência escolar, pelo menos durante os últimos 40 anos, têm colocado alguma ênfase em aulas e atividades em educação científica que envolvem a consideração das relações, como mostrado na Figura 1, entre os campos profissionais da Ciência e da Tecnologia (e da engenharia) e as Sociedades e os Ambientes. (CTSA) (PEDRETTI; NAZIR, 2011) Ao fazê-lo, tem havido uma tendência para se concentrar em controvérsias em tais relações - por exemplo, como se deve ou

3 Ver em: <www.ipcc.ch>. 
não desregulamentar usos das empresas químicas de ingredientes potencialmente tóxicos em limpeza doméstica e produtos de higiene. (LEONARD, 2010) Um movimento popular relacionado envolve o foco sobre as chamadas Questões Sociocientíficas (QSC), isto é, controvérsias sociais com base nos campos da ciência. Embora pareça haver muitas maneiras de engajar os estudantes em questões/controvérsias, os estudantes são frequentemente encorajados a considerar dados, conclusões e reivindicações de várias partes interessadas (stakeholders) (por exemplo, cientistas e políticos) e negociar com os colegas as suas posições pessoais sobre as questões. (LEVINSON, 2013) Tais abordagens de escolha pessoal para a educação baseada em QSC, aparentemente, têm levado a alguns benefícios significativos para os estudantes - incluindo o desenvolvimento de habilidades para raciocínios sociocientíficos (SADLER; BARAB; SCOTT, 2007) e a aprendizagem sobre a Natureza da Ciência - NdC, em inglês NoS para Nature of Science. (KHISHFE; LEDERMAN, 2006)

Apesar de alguns ganhos educacionais associados ao engajamento dos estudantes nas tomadas de decisão pessoais e bem informadas em questões sobre CTSA, limitar a educação baseada em QSC a abordagens de escolhas pessoais pode ser problemático. De acordo com Levinson (2010, 2013), por exemplo, práticas comuns envolvendo QSC, tendem a colocar os estudantes em papéis que enfatizam a dependência com relação a cientistas e outros especialistas para fornecer informações necessárias para a sua tomada de decisão. Tais papéis de escolha pessoal podem ser apropriados para a cidadania nas democracias representativas - em que os cidadãos exercem escolhas democráticas em grande parte através de eleição periódica dos representantes políticos, muitas vezes informados por especialistas, como cientistas, engenheiros, advogados e outros profissionais. (WOOD, 1998) Alguns estudiosos e outros sugerem, porém, que a educação científica precisa ajudar a preparar as pessoas para uma cidadania mais ativa em formas participativas de democracia. (BENCZE; ALSOP, 2014; HODSON, 2011) Por um lado, parece razoável deixar as decisões sobre questões de ciência e tecnologia para especialistas, que são altamente treinados e têm acesso a equipamentos sofisticados etc. Por outro lado, algumas pessoas estão preocupadas com as influências que membros poderosos das sociedades têm sobre os campos da ciência e da tecnologia, que frequentemente parecem resultar em vários efeitos nocivos sobre o bem-estar dos indivíduos, sociedades e/ou ambientes. (MIROWSKI, 2011) Em muitos lugares do mundo, por exemplo, as empresas têm direitos para minimizar os seus custos, a fim de maximizar os lucros. (MCMURTRY, 2013) Isto pode significar reduções nos custos do trabalho, em fases de extração de recursos, por meio de transporte, vendas e marketing, assim como sobre a eliminação de mercadorias (por exemplo, piores salários, benefícios e condições de trabalho). Custos de materiais (por exemplo, ingredientes menos dispendiosos em alimentos, às vezes com baixo valor nutricional) também podem ser minimizados. Tais reduções podem, por sua vez, levar a inúmeros comprometimentos à qualidade dos bens e serviços gerados pelos campos da tecnociência, que podem contribuir para muitos da- 
nos pessoais, sociais e ambientais. As exacerbações de tais comprometimentos parecem ter sido derivadas de decisões legais - por exemplo, em 1980, nos Estados Unidos da América (EUA) - permitindo contratos entre tecnocientistas e empresas/financiadores, que tenderam a mudar seus focos da geração de conhecimento, visando o bem-estar geral, para os interesses privados. (KRIMSKY, 2003; MIROWSKI, 2011)

Há numerosos exemplos, portanto, de comprometimentos para produtos ou serviços gerados com a ajuda de campos da tecnociência que estão ligados a vários danos pessoais, sociais e ambientais. Leonard (2010) sugere, por exemplo, que muitos produtos manufaturados contêm numerosas substâncias químicas não testadas e potencialmente perigosas. Da mesma forma, as empresas farmacêuticas, aparentemente, têm comprometido a qualidade do produto - como, por exemplo, por meio de testes de drogas com indivíduos jovens, que são menos propensos a experimentar efeitos colaterais negativos. (ANGELL, 2004) Em alguns casos de modo muito sério, algumas empresas são bem conhecidas por incentivar os engenheiros a projetar produtos para que eles falhem rapidamente - o que pode levar o consumidor a descartar as mercadorias danificadas e substituí-las pelas últimas inovações. (LEONARD, 2010) Consequentemente, os seres humanos e nossos ambientes vivos e não vivos são ameaçados por tais mercadorias comuns, como: cigarros (BARNES; HAMMOND; GLANTZ, 2006), agrotóxicos (HILEMAN, 1998), comida rápida e outros alimentos industrializados (WEBER, 2009), produtos de limpeza doméstica (VASIL, 2007), produtos petrolíferos e veículos movidos a petróleo (KLEIN, 2014) e produtos da biotecnologia. (KLEINMAN, 2003) À luz de tais problemas, que parecem originar-se, em parte, de associações "ciência-negócios", sancionadas por governos, parece claro que mais cidadãos precisam estar preparados para avaliar criticamente processos e produtos dos campos da ciência e da tecnologia e, onde eles percebam problemas, que possam desenvolver e implementar planos de ação para tentar criar um mundo melhor.

\section{STEPWISE para uma cidadania ativa}

Em 2006, a estrutura teórica do STEPWISE ${ }^{4}$ foi desenvolvida para encorajar e permitir, aos alunos, ações sociopolíticas autodirigidas para abordar os danos que eles identificam, associados aos campos da ciência e da tecnologia. Esta estrutura teórica organiza cinco domínios de ensino e de aprendizagem para indicar que eles coafetam uns aos outros (por exemplo, ensino de habilidades $\leftarrow \rightarrow$ educação CTSA); todos os domínios podem informar (e beneficiar-se de) ações sobre CTSA, dos estudantes - tais como petições, cartazes e/ou postagens em Twitter etc. para os políticos, empresas, cidadãos

4 STEPWISE é o acrônimo para Science \& Technology Education Promoting Wellbeing for Individuals, Societies \& Environments. Em português, Educação em Ciência \& Tecnologia promovendo o bem-estar de indivíduos, sociedades \& ambientes. Para aprender mais sobre esse framework para o ensino, a aprendizagem e a pesquisa e acessar recursos instrucionais relevantes, visite: www.stepwiser.ca. 
ativistas etc. Ações sobre problemas envolvendo relações CTSA estariam situadas no centro dessa estrutura teórica, indicando que os estudantes podem "consumir" algum do seu capital cultural (e social) (BOURDIEU, 1986), não apenas em si mesmos, mas também sobre os esforços "altruístas" para construir um mundo melhor.

Convencer os estudantes de que a educação que recebem pode ser usada também para ajudar outros seres vivos - incluindo ambientes - pode não ser fácil, particularmente em partes do mundo onde os cidadãos são fortemente encorajados e/ou precisam se concentrar no consumo de bens e serviços e, ainda, competem por empregos e status social. (BAUDRILLARD, 1998) Assim, um aspecto - chave do STEPWISE é encorajar e capacitar os estudantes a desenvolver a confiança, a experiência e a motivação para a pesquisa autodirigida (por exemplo, como estudos e experimentos) para aprender mais sobre as relações CTSA. Por ter maior controle das decisões sobre as conclusões de sua própria pesquisa, os estudantes podem desenvolver sentimentos de pertencimento mais profundos com relação a tais afirmações sobre questões envolvendo CTSA (WENGER, 1998) e podem, portanto, ser mais motivados a realizar ações para resolver os problemas que eles identificam. Por razões semelhantes, dar aos estudantes controle sobre as decisões acerca de como usar suas conclusões de pesquisa como base para as suas ações, mesmo que seja apenas parcialmente, pode dar-lhes fortes ligações a, e motivação para, tais ações. Com mais cidadãos preparados para avaliar criticamente as relações CTSA através da sua própria pesquisa, bem como para realizar ações, a fim de abordar os problemas que percebem neles, podemos evoluir para formas mais participativas de democracia - as quais, como já argumentamos acima, parecem necessárias, considerando que as pessoas e os grupos poderosos, nas sociedades, podem não estar fornecendo, eles mesmos, a liderança mais confiável. Estes aspectos do STEPWISE alinham-se com a recomendação de Levinson (2010) de que, para incentivar uma participação mais democrática, na qual os cidadãos monitoram e desafiam as fontes de poder, os estudantes devem engajar-se na práxis (prática crítica, reflexiva; como a pesquisa autodirigida) como parte da sua participação em situações de "dissidências e conflitos", tais como ações sociopolíticas sobre os problemas sociocientíficos.

Pouco depois de ter sido desenvolvida uma primeira versão da estrutura teórica do STEPWISE, professores em vários contextos escolares foram incentivados a usá-la como uma base para o ensino e a aprendizagem com os estudantes. Muito rapidamente se tornou evidente, no entanto, que eles perceberam a primeira versão como sendo muito complexa - preferindo um esquema mais sistemático, como aquele da Figura 2 (BENCZE; CARTER, 2011), que é um rearranjo de todos os domínios da versão original. Nesta abordagem, em geral, primeiro se apresenta, aos estudantes, um ou mais conjuntos (ciclos) de aulas e atividades de "aprendizagem mediada" para ajudá-los a ganhar experiência, confiança e motivação para, ao final, serem capazes de executar projetos de 
ação negociada e informada por pesquisa (RiNA) ${ }^{5}$ para abordar problemas de CTSA que eles próprios escolhem. O professor pode ou não optar por repetir (uma ou mais vezes) as três fases do ciclo de aprendizagem mediada, dependendo da idade e do nível de conforto dos estudantes e, de fato, o nível de conforto do professor com várias estratégias dentro do esquema (Figura 2).

Figura 2 - Estrutura pedagógica do modelo STEPWISE ${ }^{6}$

Este modelo é uma versão prática do quadro teórico STEPWISE (Educação em Ciência \& Tecnologia promovendo o bem-estar de Indivíduos, Sociedades e Ambientes;). Neste esquema, os estudantes são preparados com aulas e atividades de "aprendizagem por mediação", com suporte do professor, quando necessário, até que o professor sinta que os estudantes estão prontos para projetos de RiNA (ações negociadas e baseadas em pesquisa) autodirigidos para abordar problemas que eles identificam nas relações entre os campos CTSA.

Obviamente, não é suficiente que o professor ofereça exemplos, para que os estudantes entendam e sejam capazes de autodirigir projetos para RiNA, a fim de abordar problemas nas relações CTSA. Os estudantes frequentemente necessitam de prática; ainda que com algum suporte do professor, sempre que necessário. O professor pode, por exemplo, oferecer aos estudantes uma amostra de controvérsias CTSA, pedir a eles para conduzir uma pesquisa secundária (por exemplo, pesquisas na internet) e uma primária (por exemplo, estudos) para aprender mais sobre tais assuntos e tomar decisões sobre os problemas a abordar. Os estudantes poderiam, então, ser encorajados a projetar e colocar em prática planos de ação (por exemplo, pôsteres, petições, vídeos educacionais, apresentações, postagens online etc.) para abordar tais assuntos.
Uma vez que os estudantes frequentemente chegam nas aulas com Atitudes, Habilidades e Conhecimentos (ASK) prévios e os professores não estão conscientes de muitos deles, os professores podem estimular os estudantes a 'expressar' seus ASK em diferentes formas (por exemplo, discurso, desenhos, escrita). Aqui, os professores podem oferecer estímulos, como produtos e serviços típicos dos campos da ciência e da tecnologia (por exemplo, telefones celulares), e pedir que os estudantes expressem as relações CTSA associadas a tais produtos e serviços, além de problemas para o bem-estar de indivíduos, sociedades e ambientes (WISE), possíveis ações para abordar estes problemas e, por fim, a preparação (por exemplo, em termos de pesquisa) que eles precisam realizar para executar tais ações.

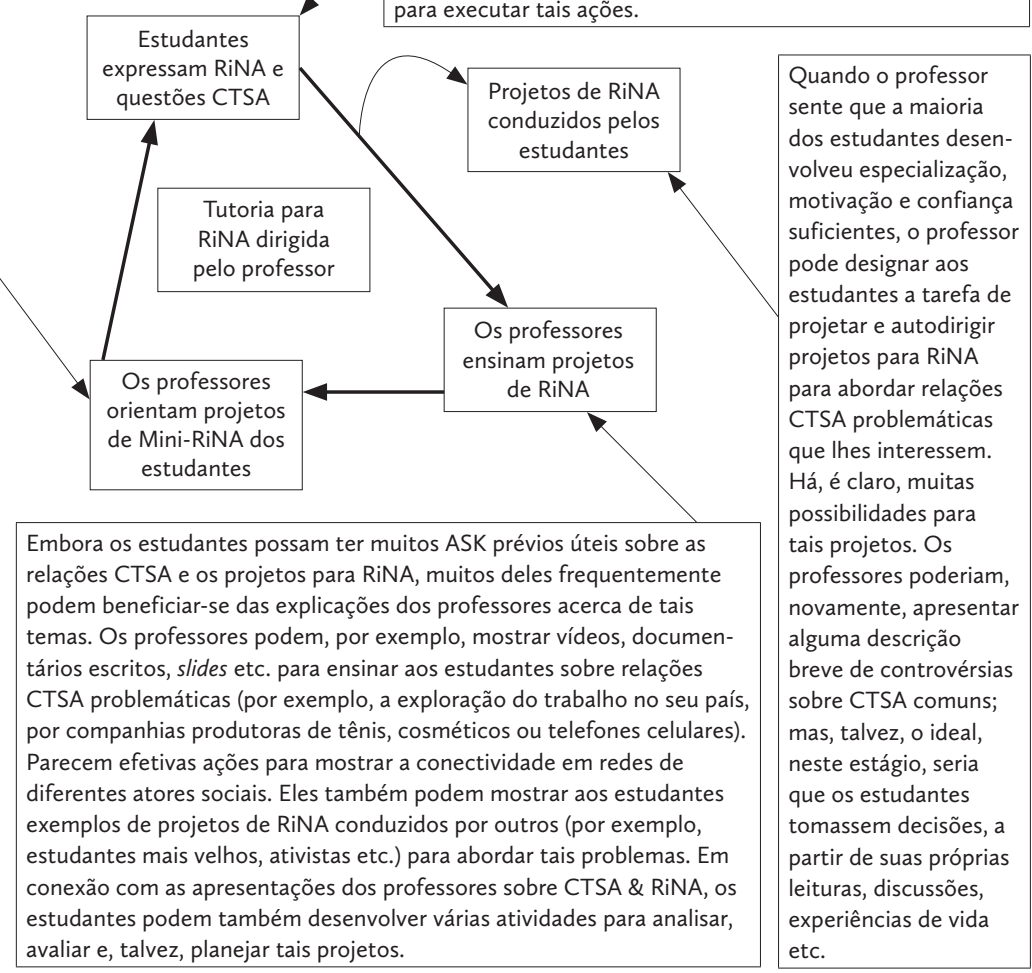

Fonte: elaborada pelos autores.

5 Ao longo do texto, utilizaremos a expressão RiNA, um acrônimo que se refere à expressão original, utilizada pelo autor, em inglês, Research-informed and Negotiated Action. (N. do T)

6 Ver em: <www.stepwiser.ca>. 


\section{Aprendizagem mediada: expresse, aprenda, aplique}

A aprendizagem mediada em três fases, ${ }^{7}$ representada na Figura 2, é baseada na teoria construtivista básica da aprendizagem (OSBORNE; WITTROCK, 1985), o que sugere que os aprendizes frequentemente têm Atitudes, Habilidades e Conhecimentos (ASK) que interagem com a informação recebida das situações de aprendizagem (por exemplo, comportamento observado de imãs) para formar, isto é, construir ASK, que são únicos para cada estudante ${ }^{8}$ e, criticamente, podem não coincidir com os do professor, dos cientistas ou de outros profissionais. Uma vez que as noções prévias dos estudantes sobre os fenômenos são muitas vezes subconscientes, práticas pedagógicas informadas pelo construtivismo, por vezes, envolvem o pedido para que os estudantes "expressem" (por exemplo, descrever em palavras, desenhos, modelos 3D etc.) os seus ASK pré-instrucionais. Assim, conforme detalhado abaixo, a aprendizagem mediada pode começar por pedir aos estudantes que expressem suas noções prévias sobre questões CTSA e projetos de RiNA. Dado que os estudantes muitas vezes podem se beneficiar de desenvolver outros ASK sobre estas (questões CTSA), então, o professor poderia conduzir aulas e atividades estudantis para "ensinar projetos de RiNA". Finalmente, uma vez que os estudantes estejam mais ligados a questões e ações, por serem dadas mais responsabilidades para as decisões sobre elas, o professor, então, envolveria os estudantes em projetos de mini-RiNA - com a orientação do docente, conforme necessário. No final de um destes ciclos, os estudantes podem ser conduzidos para a primeira fase do ciclo; isto é, para novamente "expressar questões CTSA e RiNA". Nesse ponto, o professor pode, então, julgar se deve ou não continuar com um segundo conjunto de aulas e atividades de aprendizagem mediada ou, como indicado na Figura 2, se deve envolver os estudantes em projetos de RiNA, conduzidos por eles mesmos.

\section{Aprendizagem mediada: estratégias de ensino e aprendizagem}

Para ajudar os educadores a implementar o esquema da Figura 2, algumas sugestões concretas são fornecidas abaixo para cada fase da aprendizagem - bem como alguns exemplos de projetos de RiNA, liderados por estudantes. No entanto, os professores, ao final, precisam ter mais controle sobre o desenvolvimento e a implementação de tais atividades pedagógicas - para não apenas abordar um repertório mais amplo de temas, mas também para desenvolver uma compreensão mais profunda sobre um determinado

7 As três fases, representadas na Figura 2, podem, não necessariamente, durar a mesma extensão de tempo; além disso, elas não devem ser consideradas completamente em separado. Pode haver sobreposições entre quaisquer duas fases, tais como ensinar aos estudantes sobre estratégias particulares de pesquisa, logo antes de que eles pratiquem.

8 O construtivismo social afirma que, a despeito da separação dos nossos cérebros, nós compartilhamos muitos ASK - através, por exemplo, dos usos comuns da linguagem. Logo, o grau em que nossas construções podem ser consideradas completamente únicas, de cada indivíduo, é questionável. 
tema, assim como certos compromissos com tais práticas de ensino e aprendizagem. A seguir, detalhamos alguns aspectos referentes às três fases.

\section{Estudantes expressam questões sobre CTSA e RiNA}

Resumidamente, esta fase destina-se a estimular os estudantes a "expressar" (por exemplo, dizer, desenhar, construir etc.) seus ASK pré-instrucionais sobre problemas relacionados a poder e/ou questões nas relações CTSA (consulte a Figura 1) e as ações que eles podem realizar para abordar os problemas de interesse para si mesmos (bem como as preparações que eles devem realizar antes de tais ações).

\section{Aspectos problemáticos da Ciência \& Tecnologia: atividades para expressar concepções prévias}

Antes de prosseguir com exemplos, pode ser útil, para os professores, pensar em uma versão mais reduzida das relações CTSA da Figura 1; isto é, algo como: $C \& T<[+/-] \rightarrow S \& A$.

Nessa concepção, reconhecemos que os campos da Ciência e da Tecnologia $(\mathrm{C} \& \mathrm{~T})$, muitas vezes, colaboram um com o outro. Como resultado, podemos imaginar os campos de C\&T sendo influenciados por e tendo efeitos positivos ou negativos sobre as Sociedades (e os indivíduos nelas) e os Ambientes (S\&A). Podemos, então, usar várias estratégias para conseguir que os estudantes expressem seus pontos de vista sobre tais relações. Os professores podem, por exemplo, "expor" os estudantes a vários aspectos de C\&T e pedir-lhes para avaliar os seus efeitos sobre o WISE e o que pode ser feito para resolver quaisquer problemas que eles identifiquem. Embora possa, por vezes, ser impraticável, por exemplo, levar os estudantes para lugares onde os cientistas e/ou engenheiros fazem os seus trabalhos, os professores podem conectar os estudantes com produtos dos trabalhos desses profissionais; por exemplo, leis, teorias e invenções ou inovações. Como as leis e teorias são relativamente abstratas, no entanto, talvez, possa ser melhor, em primeiro lugar, expor os estudantes a várias invenções ou inovações. De fato, como mencionado acima, a ênfase que se dá atualmente à $C \& T$ parece favorecer a geração de produtos e serviços inovadores para a venda (mercadorias). Conseguir que os estudantes interajam com mercadorias comuns poderia ser feito de uma forma relativamente personalizada, pedindo aos alunos para nomear, listar, trazer para a aula etc. produtos e serviços que eles e/ou membros da sua família compram/usam - como carros, bicicletas, telefones celulares, cosméticos, artigos de higiene, comida rápida e alimentos manufaturados etc. Isso poderia ser complementado com imagens ou outros meios de comunicação veiculando mercadorias (por exemplo, vídeos de pessoas a usá-los). Os estudantes poderiam, então, ser solicitados a avaliar tais produtos/serviços/mercadorias - em primeiro lugar, de forma muito ampla; por exemplo, perguntando: “O que é 'bom' e 'mau' com relação a estes __ [produtos/serviços] __?”. Depois de 
algum tempo, o professor poderia, então, fazer-lhes perguntas mais convergentes, como: "De que formas este __ [produto/serviço] __ poderia ser bom e/ou mau para WISE? Explique”, "Que indivíduos e/ou grupos são, provavelmente, os maiores responsáveis pelos problemas que você nota? Explique", "Explique o que você acha que precisa mudar sobre este __[produto/serviço]__ para que o mundo seja melhor?”, "Como você pode aprender mais sobre este __[produto/serviço]_- para tomar decisões sobre como ele deveria ser alterado?”. E "de que maneira você poderia encorajar as pessoas e/ou grupos poderosos para agir a fim de melhorar este __[produto/ serviço]__?”.

Talvez depois de focar na atenção dos estudantes sobre os produtos da C\&T, o professor possa voltar a atenção daqueles para os problemas comuns para WISE ligados aos campos da C\&T. Os estudantes podem, por exemplo, buscar, por si próprios, ou receber, dos professores, imagens de vários problemas que afetam WISE, tais como: águas poluídas; lixo em recipientes para reciclagem; taxas de câncer pelo fumo; trabalhadores pobres (que trabalham jornadas longas), produzindo mecardorias manufaturadas para pessoas ricas; imagens de ensaios brutais em animais (com as devidas advertências); etc. Com o tempo, o professor pode prosseguir com o pedido de que os estudantes avaliem as ações que poderiam ser tomadas para abordar os problemas aparentes. Estas ações poderiam incluir questões sobre vários atores sociais (stakeholders) relacionados à mercadoria; tais como: "Os governos devem definir leis mais fortes para controlar o que as empresas de alimentos podem colocar em comidas rápidas e manufaturadas?", "Adolescentes maiores de 16 anos devem poder fumar cigarros sem o consentimento de seus pais/responsáveis?" e "Os adolescentes devem escrever cartas aos gerentes/administradores/gestores de cinemas, pedindo que removam anúncios violentos e sensuais?”.

\section{A natureza das atividades de aprendizagem mediada: modelo do controle de aprendizagem}

No geral, no planejamento e na análise/avaliação das atividades para esta fase da aprendizagem mediada (e as outras fases e projetos dos estudantes), o esquema da Figura 3 tem sido útil. (LOCK, 1990) Ele é composto de dois eixos contínuos, que se cruzam, para julgar a natureza e a extensão do controle da aprendizagem do estudante. No eixo horizontal, as escolhas dos tópicos e métodos podem ser totalmente dirigidas pelo professor (TD, de Teacher-Directed) ou totalmente dirigidas pelo estudante (SD, de Student-Directed) ou alguma combinação dos dois. O contínuo no eixo vertical, por sua vez, permite rastrear as conclusões a partir das atividades - desde o tipo fechado (CE, de Closed-Ended), o que significa que há apenas uma conclusão pré-determinada (normalmente definida pelos professores e livros), até de tipo fim-aberto (OE, de Open-Ended), nas quais há muitas conclusões possíveis (geralmente determinadas por julgamentos dos estudantes, com base em evidências e teorias disponíveis). Para a 
primeira fase (os estudantes expressam as questões CTSA \& RiNA) da aprendizagem mediada, na Figura 2, parece que muitas atividades devem ser principalmente SD/OE. Claramente, no entanto, para estimular os estudantes a reagirem a fenômenos (por exemplo, imagens de mercadorias), deve haver algum direcionamento do professor e, sem dúvida, as conclusões dos estudantes podem não ser totalmente abertas (por exemplo, por causa das decisões dos professores sobre os estímulos a oferecer). Mas, se essas atividades são sobre estudantes expressando suas próprias noções prévias, as atividades devem ser primariamente SD/OE. Assim, quando os professores avaliarem as respostas dos estudantes às suas instruções ou perguntas nesta fase, parece que, principalmente, deve ser dado a eles o crédito pelos esforços legítimos que eles demonstram em suas respostas - ao invés de ter respostas "corretas" (o que seria tornar as questões de fim fechado, CE).

Figura 3 - Modelo do controle de aprendizagem

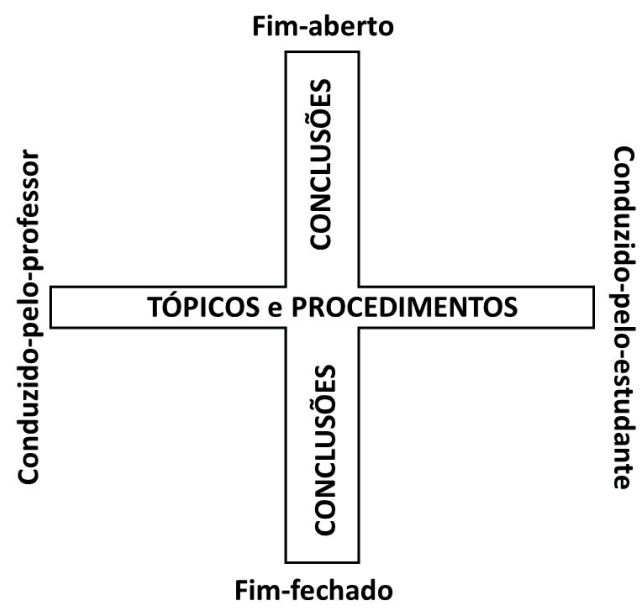

Fonte: Bencze (2018).

\section{Os professores ensinam projetos de RiNA}

Embora a primeira fase da aprendizagem mediada, na Figura 2, possa ajudar o professor e os estudantes a se tornarem mais conscientes das noções prévias dos estudantes sobre as relações CTSA e possíveis problemas e ações, os estudantes ainda podem se beneficiar de ter o professor ensinando alguns problemas relacionados com questões de poder, nas relações CTSA específicas, e sobre projetos de RiNA eficazes realizados por outros para enfrentar tais problemas. Tal ensino não se destina a substituir noções prévias dos estudantes, que devem ser dignificadas, mas destina-se a expandir os repertórios deles. Para garantir que os estudantes desenvolvam, pelo menos, uma compreensão dos ASK específicos pretendidos pelo professor, aulas e atividades devem ser relativa- 
mente dirigidas pelo professor (TD) e com fim fechado (CE), em termos de conclusões sobre as relações CTSA e abordagens de RiNA.

Normalmente, os professores vão ensinar os estudantes sobre questões, pesquisas e ações relacionadas a CTSA, no contexto do tema "produtos" (por exemplo, leis e teorias) da C\&T para unidades particulares em estudo - como aquelas sobre biologia celular, circuitos elétricos ou reações químicas. Ensinar sobre RiNA e CTSA não deve, contudo, ser utilizado como base para os estudantes "descobrirem" produtos da C\&T. Frequentemente, os estudantes (particularmente os mais desfavorecidos) possuem limitações em relação a tais descobertas. Assim, para que o conhecimento de tais produtos não seja um fator limitante na educação envolvendo RiNA e CTSA, o ensino sobre esses produtos deve ocorrer separadamente, embora em paralelo, ao ensino de RiNA e CTSA.

\section{Atividades para ensinar sobre RiNA e CTSA: casos e métodos de estudo de caso}

Entre as abordagens para ensinar RiNA sobre CTSA, é muito popular o uso de "casos" e "métodos de estudo de caso" - com o primeiro sendo um documentário das relações CTSA e/ou projeto de RiNA relevantes e o último sendo um conjunto de instruções e/ou perguntas para engajar os estudantes em interações com os casos, a fim de alcançar resultados de aprendizagem desejados. Para esta segunda fase da aprendizagem media$\mathrm{da}$, aulas e atividades devem proporcionar aos estudantes oportunidades para desenvolver compreensão e atitudes sobre:

- $\quad$ problemas ligados a questões de poder nas relações CTSA;

- métodos de divulgação de pesquisa primária e secundária; e

- ações sociopolíticas para abordar problemas de CTSA identificados.

$\mathrm{Na}$ terceira fase da aprendizagem mediada (ver abaixo), aos estudantes será dado maior controle sobre as decisões acerca destes três componentes, de modo que os estudantes possam aprofundar os seus ASK sobre eles.

Os casos de CTSA aparecem em vários formatos ou meios (media formats). Casos tradicionais "baseados em texto", com textos "estáticos” e imagens, ainda são muito usados. Eles costumam fornecer alguns detalhes (por exemplo, dados e invenções) sobre C\&T, relacionando-se a um fenômeno e a correspondentes relações sociais e ambientais. Muitas vezes, problemas, em tais relações, são identificados nos casos, e também são descritas indicações de ações, incluindo a preparação, como a pesquisa primária e secundária, que pessoas e/ou grupos têm realizado para abordar esses problemas. Um exemplo disso é o caso exposto no Apêndice A sobre os, assim chamados, "diamantes de sangue"; isto é, diamantes extraídos às custas de vidas e bem-estar de muitos trabalhadores pobres. Os professores podem usá-lo, por exemplo, em coordenação com o ensino sobre o elemento carbono. 
Em muitos contextos, é muito comum o uso de casos multimídia e métodos de estudo de caso para a educação CTSA. Se um professor está ensinando sobre biologia, por exemplo, uma excelente fonte de casos é a Action Bioscience. ${ }^{9}$ Há, no entanto, muitos outros sites na internet, e os professores podem encontrar muitos através de pesquisas no YouTube. Enquanto mostrar aos estudantes vídeos de questões e ações desenvolvidas por adultos pode ser útil, os estudantes podem ser particularmente atraídos por aquelas iniciativas produzidas por outros estudantes de idades similares. Por exemplo, após um professor ter mostrado aos estudantes vídeos de discursos feitos pela Royal Society for the Arts (RSA), ${ }^{10}$ em que o áudio está sincronizado com animações relevantes, os estudantes criaram um vídeo semelhante ${ }^{11}$ sobre os efeitos das mudanças climáticas relacionadas a automóveis movidos a combustíveis fósseis em comparação com outros modos de transporte. Além de sua natureza criativa, este vídeo poderia ser usado para ensinar sobre todos os três objetivos (acima) da segunda fase da aprendizagem mediada. Em termos de relações CTSA problemáticas, por exemplo, os estudantes claramente enfatizaram os problemas ambientais (por exemplo, mudança climática) derivados de produtos da tecnologia (por exemplo, carros). Eles também ilustram consideráveis pesquisas secundárias (por exemplo, as estatísticas sobre o uso do carro nos EUA) e primárias (por exemplo, opções de transporte para a escola de meninas versus de meninos). As escolhas de ações deles incluem modos ecologicamente mais sustentáveis, incluindo o uso de bicicletas e transporte público. Apesar de não ser crucial, no entanto, o professor pode apontar para os estudantes que eles poderiam ter feito mais referências a questões de poder, na produção do vídeo, tais como a (des)regulamentação governamental das indústrias de automóveis que favorecem os veículos movidos a petróleo. O professor pode, assim, apontar outras formas de ação que os estudantes poderiam usar - tais como: fazer lobby para pessoas influentes (power-brokers) (por exemplo, petições e cartas aos governos e empresas de automóveis), educação das comunidades (por exemplo, campanhas online) e engenharia de formas de transporte mais sustentáveis (por exemplo, cadeiras de rodas eficientes, movidas a pessoas, talvez com volantes e engrenagens eficientes).

Como observado acima, para garantir que os estudantes obtenham concepções dos três objetivos desta fase da aprendizagem mediada, nós recomendamos que os professores mantenham um controle considerável da aprendizagem. Dito isto, a motivação dos estudantes para essa aprendizagem, muitas vezes, refere-se à proporção em que eles são autorizados a tomar decisões relevantes. Assim, parece louvável oferecer aos estudantes instruções e perguntas para que se engajem de modos mais pessoais com os casos. Alguns destes podem focar, é claro, a compreensão, enquanto

\footnotetext{
9 Ver em: <http://actionbioscience.org>.

10 Ver em: <https://www.thersa.org/discover/videos/rsa-animate/>.

11 Ver em: <https://www.youtube.com/watch?v=cfD-_p-2ux0>.
} 
outros podem encorajar os estudantes a analisar situações desconhecidas, propor alternativas e avaliar alegações. Para os três desdobramentos acima, algumas instruções e perguntas podem incluir:

- $\quad$ problemas nas relações CTSA ligadas a questões de poder: "resumidamente, explique como os diamantes são formados"; "explique por que alguns diamantes podem ser considerados sangrentos"; e "usando setas, mostre uma sequência de pessoas envolvidas com diamantes do "começo ao fim";

- pesquisas primária e secundária e métodos de divulgação: “com base neste caso, como podem os pesquisadores aprender sobre a violência relacionada à mineração de diamantes?", "liste dois fatos sobre as mudanças climáticas que os estudantes provavelmente determinariam por meio de pesquisa secundária” e "para saber sobre o conhecimento dos seus colegas acerca dos problemas com a mineração de diamantes, apresente um par de variáveis que você poderia monitorar em um 'estudo correlacional' (comparação de possíveis efeitos de uma variável que está naturalmente mudando com outra variável)”; e

- Ações Sociopolíticas para abordar problemas CTSA percebidos: "deveriam os governos rotular cuidadosamente diamantes que foram extraídos em áreas em conflito?"; e "deveriam os governos tornar a mineração de diamantes ilegal, obrigando as empresas a substituí-los por diamantes sintéticos?”.

\section{Expandindo a educação CTSA para RiNA: usando a Teoria Ator-Rede}

Talvez porque educadores em ciência podem não querer mostrar uma imagem negativa da CT, um problema comum com casos de RiNA e CTSA é que eles podem não fazer referências adequadas a certas entidades potencialmente embaraçosas - como corporações que podem ter reduzido os custos para aumentar os lucros. Desta perspectiva, Pierce (2013) recomendou que os educadores em ciência ensinem os estudantes sobre Teoria Ator-Rede (TAR) (LATOUR, 2005) e, consequentemente, construam mapas de ator-rede para representar as relações CTSA (e, presumivelmente, projetos de RiNA). A TAR propõe que todas as entidades (actantes) fazem parte de múltiplas relações recíprocas envolvendo entidades simbólicas, assim como entidades vivas e não vivas. As relações CTSA podem, portanto, consistir em actantes humanos não normalmente descritos nos contextos tradicionais de educação científica - como organizações econômicas transnacionais, incluindo, por exemplo, as corporações transnacionais, o Banco Mundial, o Fundo Monetário Internacional, a Organização Mundial do Comércio e a Organização para a Cooperação e o Desenvolvimento Econômico. Enquanto isso, entidades/actantes não-humanos, que podem ser incluídos em redes, podem consistir em: softwares e equipamentos de computadores utilizados em laboratórios de ciência; objetos de estudo (por exemplo, peixes, moléculas, quarks); acordos de comércio transnacional (por exemplo, Acordo de Livre Comércio da América do Norte); e, em particular, 
no caso de anúncios, actantes simbólicos idealizados, como "legal", "picante" e "sexy", associados a mercadorias como perfumes, carros e roupas.

Apesar de que pode ser mais democrático ajudar os estudantes a aprender sobre a TAR, construir mapas ator-rede não é fácil - por causa, por exemplo, da sua natureza complexa, incerta e dinâmica. Uma série de apresentações, discussões e atividades estudantis sobre TAR é, portanto, provavelmente necessária. Uma técnica comum é nomear uma mercadoria muitas vezes utilizada pelos estudantes, tais como um telefone celular, para conduzir uma aula socrática com eles - em que o professor e os estudantes constroem um mapa simples da rede que representa actantes simbólicos vivos e não vivos conectados à mercadoria. Em associação com tal instrução, os estudantes poderão ser convidados a assistir o vídeo A História das Coisas (The Story of Stuff), ${ }^{12}$ seguir algumas instruções do professor e responder a perguntas feitas pelo professor e por eles. Para complementar este trabalho, um excelente conceito para ensinar aos estudantes é o de como mercadorias, muitas vezes, são como um "cavalo de Tróia"; isto é, enquanto os consumidores se concentram em actantes simbólicos positivos - tais como "sexy", "poderoso" e "inteligente" - que podem ser evidentes "por fora" das mercadorias, eles podem estar distraídos e não perceber actantes nocivos "no interior" (por exemplo, produtos químicos tóxicos, substâncias que causam dependência e subprodutos poluentes). Depois de tal instrução e de uma pesquisa secundária relacionada, três estudantes do $1^{\circ}$ ano do ensino médio, de um curso de ciência preparatório para a universidade, desenvolveram o mapa ator-rede, reproduzido na Figura 4. Tendo aprendido sobre problemas com spray de cabelo comercial, os estudantes, em seguida, conduziram uma pesquisa primária - na forma de pesquisas acerca dos conhecimentos e usos de sprays de cabelo pelos colegas. Baseados em seus resultados de pesquisa e, provavelmente, nos seus ASK prévios sobre sprays de cabelo, eles, então, desenvolveram e testaram uma fórmula caseira de spray de cabelo que eles consideraram segura e ambientalmente saudável. Para promover esta ação, então, eles anunciaram seu produto, usando cartazes, como o mostrado na Figura 5. Estas ações tiveram alguns elementos da TAR, no sentido de que um cartaz foi combinado com informação, com uma invenção e com fotos de sujeitos testados.

12 Ver em: <http://storyofstuff.org/movies/story-of-stuff/> e <https://www.youtube.com/watch?$v=7 q F i G M S n N j w>$. 
Figura 4 - Um mapa ator-rede dos estudantes sobre o spray de cabelo

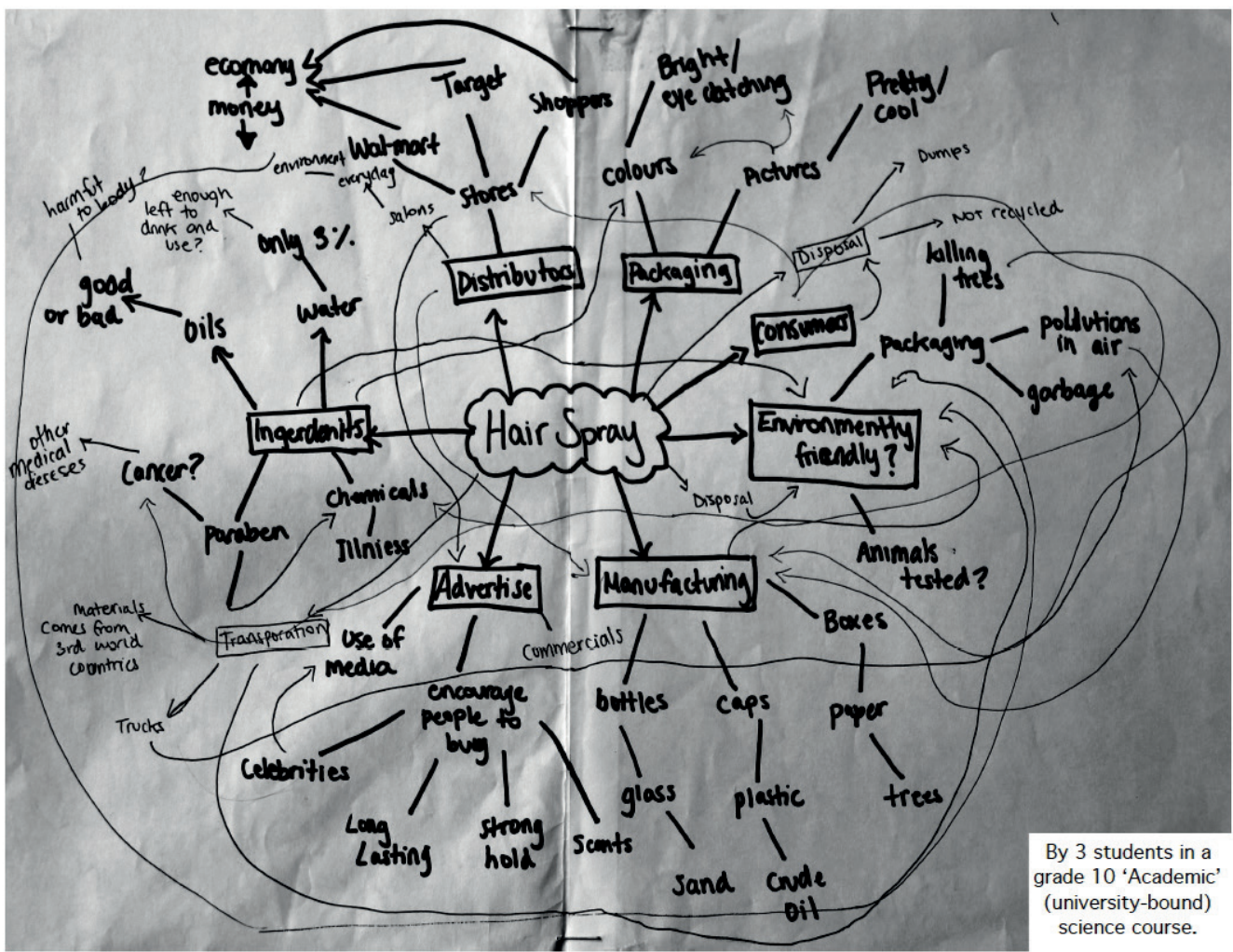

Fonte: Bencze e Krstovic (2017, p. 242). 
Figura 5 - Ações dos estudantes sobre o spray de cabelo

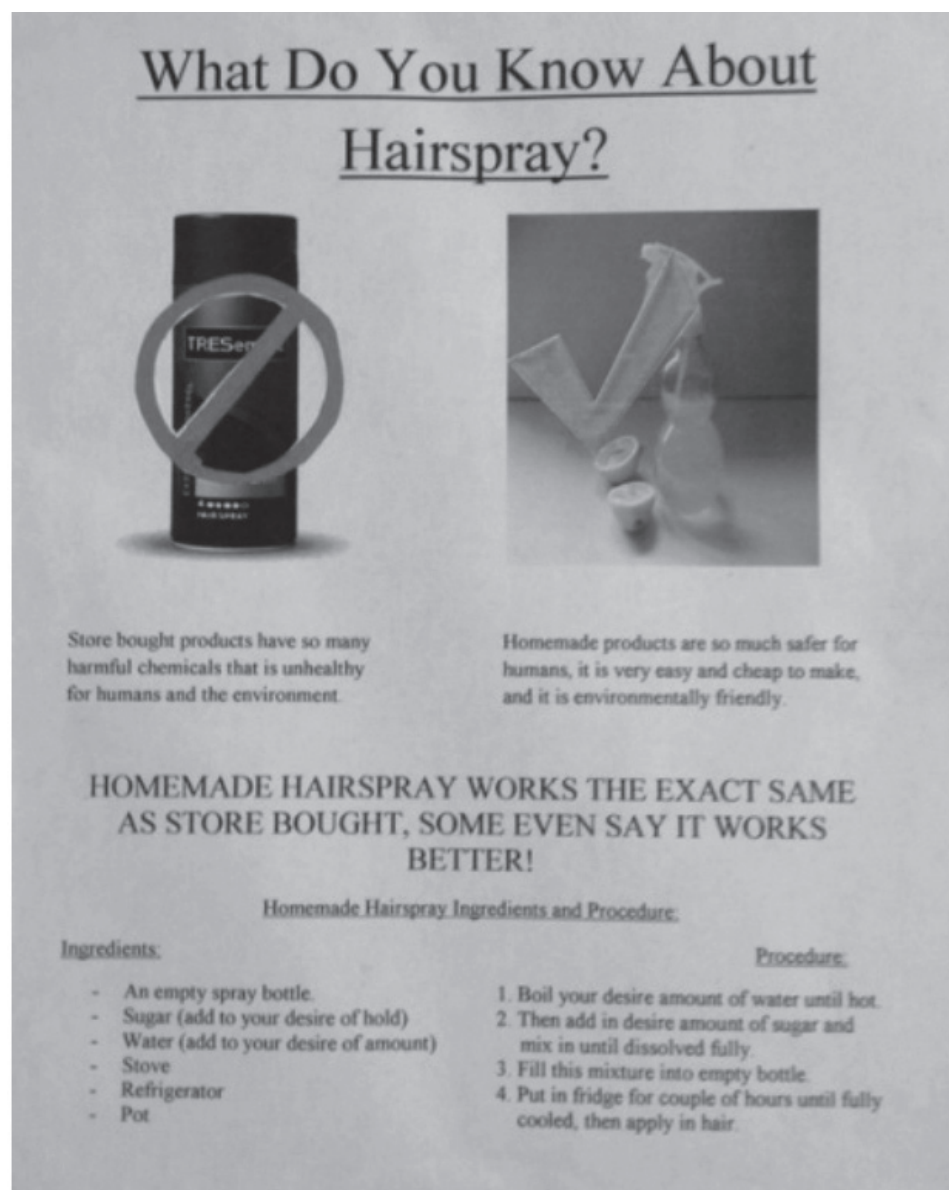

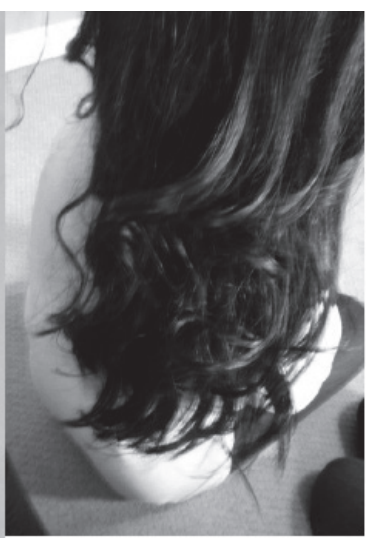

Commercial Hairspray

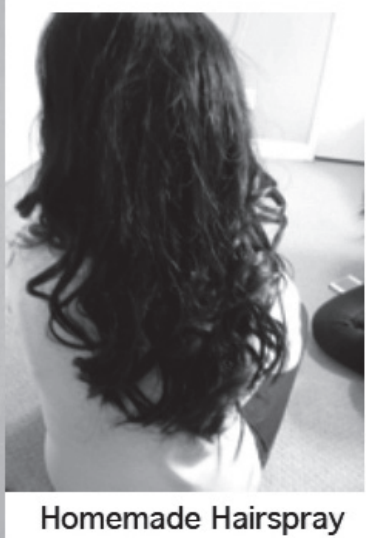

Fonte: elaborada pelos autores.

Através do ensino e da aprendizagem associados às sugestões acima, os estudantes podem desenvolver novas concepções de relações entre CTSA decorrentes do exame dos actantes poderosos (por exemplo, corporações transnacionais com o apoio do governo) e de ações baseadas em pesquisa realizadas por grupos de pessoas, para abordar os problemas de CTSA. É improvável, contudo, que os ASK deles a este respeito sejam totalmente alterados ou formados após essas aulas e atividades. Isso pode exigir oportunidades, como as descritas na próxima subseção, para que eles se engajem em projetos de RiNA facilitados pelo professor, para abordar questões de CTSA de sua própria escolha (e, mais tarde, projetos liderados por estudantes deste tipo). 


\section{Ensinando Natureza da Ciência: o Perfil da Teoria Científica}

Antes da próxima fase desta aprendizagem mediada, os educadores podem querer ajudar os estudantes a desenvolverem as suas concepções sobre a $\mathrm{NdC}$ (e, em certa medida, sobre a natureza da tecnologia também). As escolas tendem a promover crenças em métodos científicos relativamente lógicos e imparciais que levam a conclusões, relativamente certas, sobre o mundo - pontos de vista não bem suportados por estudos em história, filosofia e sociologia da ciência. (HODSON, 2008) É conveniente pensar em tais pontos de vista em termos do Perfil da Teoria Científica (STP, do inglês, Scientific Theory Profile), de Loving (1991), representado na Figura 6. Como o quadro da Figura 3, o STP é constituído por dois eixos contínuos em interseção; neste caso, para representar diferentes visões sobre a $\mathrm{NdC}$. O eixo horizontal diz respeito aos pontos de vista sobre o quanto os cientistas usam lógica "pura" para fazer julgamentos sobre as teorias (muitas vezes relevantes para os dados). Em um extremo, os "racionalistas" alegam que os cientistas baseiam estritamente seus julgamentos na lógica, na razão e no pensamento sistemático. No outro extremo, os "naturalistas" alegam que, além de lógica etc., os cientistas não podem deixar de ser influenciados por uma série de fatores psicológicos e sociológicos - como gênero, humor, desejo e, em termos de perspectivas mais abrangentes, de cultura, política, economia etc. Enquanto isso, as posições sobre o "valor de verdade" das alegações dos cientistas são consideradas no eixo vertical. Os "realistas" afirmam que as alegações dos cientistas (por exemplo, leis e teorias) podem corresponder às entidades em estudo; enquanto "antirrealistas" acreditam que as alegações dos cientistas não podem corresponder a fenômenos do mundo, muito embora possam construir aproximações que podem ter o apoio de um grupo de colegas. Tais pontos de vista sobre a ciência podem ser úteis na consideração de relações entre CTSA e ações subsequentes para abordar os problemas percebidos. Embora haja muitos aspectos da $\mathrm{NdC}$ a serem considerados usando o STP, as relações entre financiadores, corporações e cientistas (e engenheiros) e suas respectivas instituições podem ser de interesse particular para a educação CTSA. Parece claro que os indivíduos (incluindo estudantes) que ocupam posições racionalistas-realistas sobre a ciência não apoiarão, tão provavelmente quanto os naturalistas-antirrealistas, as alegações de que os cientistas muitas vezes são significativamente influenciados pelo setor privado e que, além disso, muitas dessas influências podem comprometer a integridade dos campos da C\&T, que muitas vezes resultam em danos ao bem-estar dos indivíduos, sociedades e ambientes. (KRIMSKY, 2003; MIROWSKI, 2011)

Dependendo das posições dos educadores sobre o STP, eles podem ajudar os estudantes a entender as posições naturalistas-antirrealistas - que, novamente, podem 
levar os estudantes a aceitar a existência dos problemas resultantes de parcerias entre ciência e negócios. Embora existam várias abordagens à educação para NdC, talvez os estudantes possam se beneficiar da estratégia chamada Imersão Dialética Indutivo-Dedutiva (IDDI, do inglês Inductive-Deductive Dialectic Immersion). (BENCZE; ELSHOF, 2004) Isso pode ser pensado como uma abordagem construtivista aplicada, em que os estudantes exploram (indutivamente) suas noções prévias sobre NdC; nós, professores, ensinamos algumas perspectivas sobre $\mathrm{NdC}$; e, em seguida, eles têm oportunidades para avaliar (dedutivamente) - e, talvez, descobrir novas perspectivas sobre NdC, através de investigações científicas realistas e atividades de aplicação. Isso pode começar, por exemplo, por envolver os estudantes no "jogo de troca de cartões", no qual eles:

- posicionam-se sobre seis declarações sobre NdC (em cartões separados) em termos daqueles mais alinhados com as suas opiniões sobre a ciência;

- tentam trocar com colegas os cartões que contêm declarações com as quais concordam menos (recebendo, em troca, cartões com declarações, com as quais estão mais de acordo); e

- reúnem-se com os colegas que sustentam opiniões semelhantes para escrever uma declaração geral sobre NdC. (COBERN; LOVING, 1998)

Eles podem (ou não) concluir, por exemplo, que declarações como as seguintes se alinham com pontos de vista naturalistas-antirrealistas:

- o financiamento influencia a direção da ciência em virtude das decisões que são tomadas sobre que pesquisa apoiar;

- o empreendimento científico está situado em contextos históricos, políticos, culturais e sociais específicos; assim, questões, métodos e resultados científicos variam de acordo com o tempo, o lugar e o propósito da pesquisa; e

- cientistas de um grupo de pesquisa tendem a ver as coisas de modo similar, de modo que até mesmo grupos de cientistas podem ter problemas para ser inteiramente objetivos.

Na sequência, ao ensinar aos estudantes sobre vários casos envolvendo CTSA, os professores podem, então, apontar exemplos em que diferentes comportamentos dos cientistas (e, talvez, de engenheiros, também) se alinham com as diferentes posições sobre o STP. Posteriormente, quando engajados em diferentes projetos de RiNA, que lidam com relações CTSA específicas, os professores podem, então, encorajar os estudantes a reconsiderarem seus pontos de vista sobre NdC relevantes para o STP. 
Figura 6 - Perfil da Teoria Científica

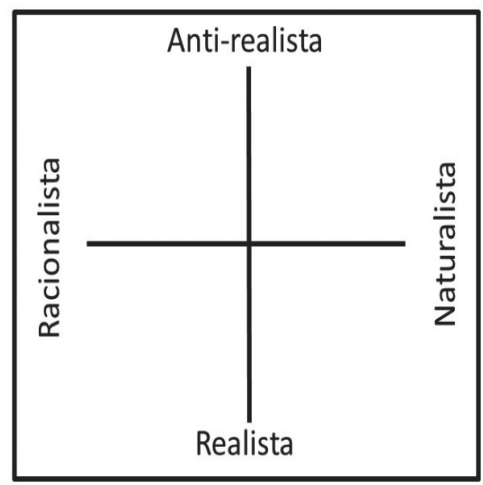

Fonte: Bencze, Bowen, Alsop (2006, p. 406), com base em Loving (1991).

\section{Os professores orientam os projetos mini-RiNA dos estudantes}

Aulas e atividades descritas na subseção acima tendem a ser relativamente mais TD/ CE. Os estudantes precisam, no entanto, de oportunidades para assumir mais controle sobre as decisões acerca das relações CTSA e projetos de RiNA, a fim de desenvolver uma maior compreensão acerca deles, assim como um comprometimento mais profundo para com eles. Assim, nesta terceira fase da aprendizagem, o professor pode pedir aos estudantes para desenvolver e implementar um projeto de RiNA em pequena escala a fim de abordar uma questão de CTSA de seu interesse, fornecendo orientação sempre que necessário. Dependendo da idade e dos estágios dos ASK dos estudantes com relação a RiNA sobre CTSA, os professores podem variar o grau do seu apoio a decisões relevantes dos estudantes. Em outras palavras, em termos do framework da Figura 3, as atividades abaixo podem ocorrer em algum lugar no meio de cada contínuo - embora, para alguns estudantes, sob algumas condições, os professores possam permitir mais controle por parte deles mesmos (SD/OE).

\section{Atividades para a escolha de questões sobre CTSA: pensando sobre mercadorias}

Os estudantes que necessitam de pouca orientação podem ser capazes de autodeterminar seus problemas e questões sobre CTSA, desenvolver métodos adequados de pesquisa e, em seguida, desenvolver e implementar ações adequadas com base nos resultados encontrados. A maioria dos estudantes, no entanto, parece exigir, pelo menos, uma lista de possíveis controvérsias - especialmente se esta é a primeira vez que eles passam por uma aprendizagem mediada. Os estudantes podem, por exemplo, ser ca- 
pazes de ter uma ideia geral sobre o assunto, a partir do conjunto de tecnologias e/ou ações da primeira fase da aprendizagem mediada, descrita acima. Os professores também podem ser capazes de desenvolver listas de problemas para determinadas áreas de conteúdo. Estas poderiam ser questões tão simples quanto "Até que ponto deveria ser permitida a extração de petróleo e gás nas regiões polares?”, "O que deveria ser feito para minimizar influências das corporações sobre escolha dos temas, sobre os métodos, resultados e divulgação dos resultados da ciência e da tecnologia?" ou "Até que ponto os governos deveriam investir o dinheiro na exploração do espaço?”. Ou, ainda, os professores podem desenvolver descrições de pequenos casos ou controvérsias, tais como estes:

- bebidas energéticas: as bebidas energéticas, que contêm altos níveis de cafeína, açúcares e sabores, são projetadas para melhorar o estado de alerta e aumentar o desempenho cognitivo. O consumo excessivo, no entanto, pode levar a efeitos colaterais negativos, incluindo insônia, irritabilidade, ansiedade, arritmia e dores de estômago. Além disso, há controvérsias nos nomes e slogans de diferentes bebidas voltadas aos adolescentes (por exemplo, Rockstar, Monster, Big Buzz, Cocaine). Grupos de pais estão se mobilizando para proibir a venda de bebidas energéticas para menores; e

- rótulos de alimentos para lanches (snacks): como os consumidores estão cada vez mais conscientes da sua saúde, muitas empresas estão tentando fazer com que seus produtos pareçam mais nutritivos, incluindo frases como: grãos integrais, baixo teor de gordura, feito com fruta natural e orgânico em seus pacotes. Um olhar mais atento para os ingredientes e as informações nutricionais revela que muitos desses produtos não são tão saudáveis como eles possam parecer.

\section{Atividades para escolher questões CTSA: Documentários Multiactantes}

Uma abordagem muito mais detalhada, mas que ainda exige que os estudantes aprendam mais através da pesquisa, está em apresentar aos estudantes Documentários Multiactantes (MAD, do inglês Multi-Actant Documentaries), como um tipo de caso, e fornecer-lhes métodos de estudo de casos que requerem que eles realizem uma pesquisa e, finalmente, ações para abordar os problemas que lhes interessam. Como descrito acima, é evidente que os interesses do setor privado muitas vezes impedem que os cidadãos se concentrem em certos actantes potencialmente problemáticos - como corporações transnacionais e acordos comerciais transnacionais. Para proporcionar aos estudantes representações mais realistas de contextos de CTSA, portanto, nós preparamos MAD para várias mercadorias. Usando a ferramenta online, Prezi, nossos MAD oferecem curtos documentários multimídia para alguns actantes simbólicos vivos e não vivos - um 
dos quais é ilustrado, na Figura 7, para comida rápida e alimentos manufaturados. ${ }^{13}$ Fundamentalmente, nós temos propositalmente omitido linhas entre os actantes que poderiam sugerir relações entre eles; e, assim, recomendamos aos professores que peçam aos seus estudantes para estudar actantes individuais em qualquer ordem e por períodos de tempo que lhes interessem. Nós sentimos que isso vai dar aos estudantes uma maior possibilidade de escolha e maior motivação para o desenvolvimento de ações para controvérsias e/ou problemas que eles identifiquem.

Figura 7 - MAD: alimentos rápidos e manufaturados

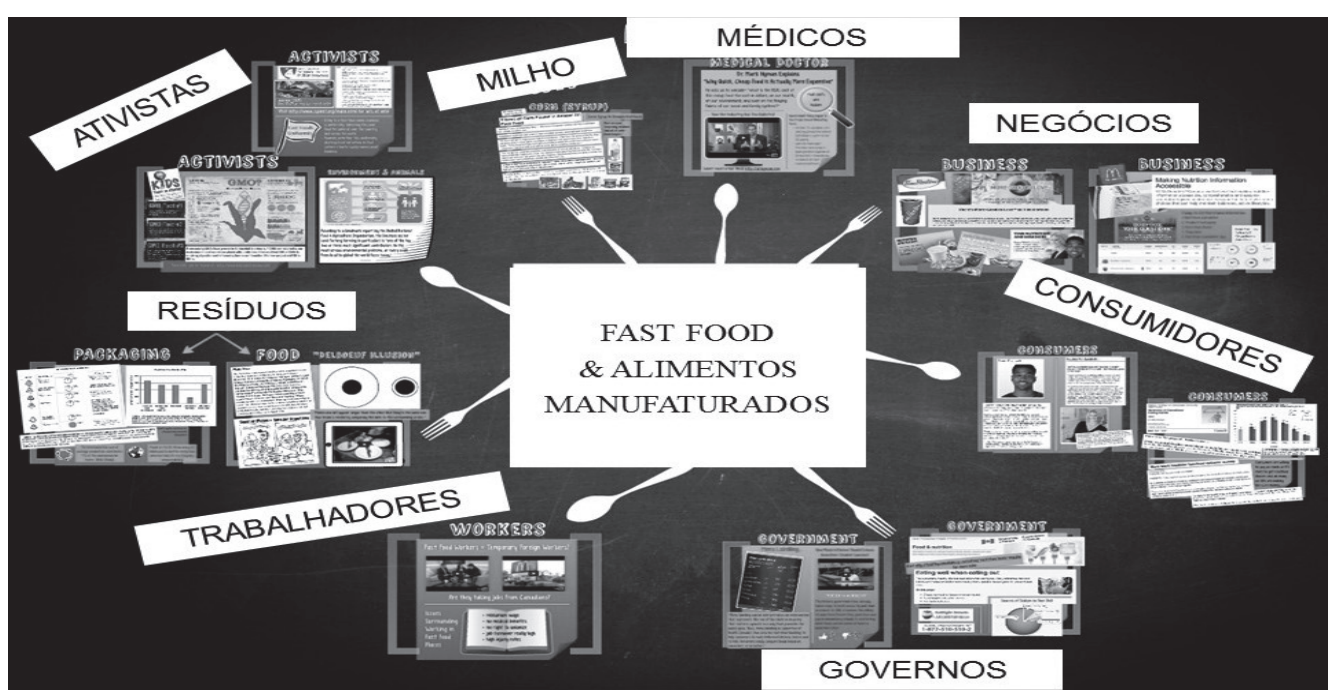

Fonte: elaborada pelos autores.

\section{Apoiando habilidades para RiNA sobre CTSA: experimentos e estudos}

Uma vez que os estudantes tenham questões CTSA para explorar, a partir dos recursos como aqueles acima, eles, então, poderiam começar a planejar e implementar pesquisas para saber mais sobre estas questões CTSA e determinar problemas particulares para resolver. Tendo aprendido mais sobre a questão, eles, então, conduziriam a sua própria pesquisa e, finalmente, usariam as suas descobertas para informar as decisões sobre ações para desenvolver e implementar. Para orientar os estudantes em tais projetos para RiNA, os professores podem usar um formulário de planejamento e avaliação, como aquele apresentado no Quadro 1. Como já indicado, o grau de orientação, em tais formulários e nas interações entre o professor e os estudantes que estão trabalhando em projetos de RiNA, dependerá das idades dos estudantes e dos estágios de familiaridade e conforto com ASK dentro destas aprendizagens mediadas dos estudantes.

13 Ver em: <https://prezi.com/th-fzepweg8w/fast-manufactured-foods/>. 
Um aspecto da ciência e/ou tecnologia frequentemente não abordado nas escolas, mas que muitas vezes é uma limitação em projetos de RiNA, dos estudantes, é a experiência, a confiança e a motivação para atividades de pesquisa e divulgação (e ação) autodirigidas. Assim, muitas vezes, é necessário proporcionar aos estudantes aulas e atividades de aprendizagem mediada a este respeito - especialmente no início de suas experiências com STEPWISE. A primeira consideração, ao longo destas linhas, no entanto, é determinar o que ensinar; incluindo decisões sobre quais habilidades, estratégias etc. cientistas normalmente usam em investigações científicas e atividades de divulgação. Gott e Duggan (2003) sugeriram, por exemplo, que os cientistas podem usar vários "conceitos de evidência", tais como controle de variáveis, duplicação de testes e erro instrumental (versus erro humano), em muitas investigações científicas. Estas são, às vezes, colocadas em sequências, como aquelas representadas na Figura 8. Tais listas e sequências devem ser usadas com cautela, no entanto, uma vez que estudos de cientistas em ação sugerem que eles podem nem sempre usar todas essas habilidades, estratégias etc., ou utilizá-los em sequências específicas, dependendo de vários fatores. Por conseguinte, parece melhor ensiná-los no contexto da investigação científica como um todo e/ou de projetos de desenhos tecnológicos. (HODSON, 2008) À medida em que surgem as dificuldades, nos projetos de estudantes, o professor pode usar combinações de "modelagem" e "prática guiada", como consta do Apêndice B. Um ponto de partida simples para começar, dependendo das idades dos estudantes, está em vários brinquedos, tais como helicópteros de pape $1^{14}$ - que são feitos de folhas soltas de papel dobrado e cortado para formar um par de "lâminas" e um "rotor" que pode girar no ar, à medida em que são soltos, a partir de diferentes alturas. O professor pode pedir aos estudantes para fazer uma chuva de ideias (brainstorm) sobre os fatores (variáveis) que poderiam influenciar a velocidade de queda dos helicópteros, tais como: massa (com clipes de papel adicionados); comprimento da lâmina; altura; ventos cruzados; espessura do papel; cor das asas etc. Por meio de tentativa e erro, o professor pode debater com os estudantes conceitos mencionados no Apêndice $C$ sobre experimentos, tais como: a duplicação de testes; o controle de variáveis; e a gama de valores relacionados à variável causadora. Dependendo da idade e do estágio dos ASK dos estudantes, e considerando as habilidades e estratégias, como aquelas na Figura 8 e no Apêndice $\mathrm{C}$, os professores podem envolvê-los ainda mais nessas atividades relativamente guiadas, a partir de outras fontes.

14 Ver em: <http://home.frognet.net/ ejcov/helicopter.html>. 
Quadro 1 - Guia de planejamento e avaliação de projetos de RiNA

\begin{tabular}{|c|c|c|c|c|}
\hline $\begin{array}{l}\text { Critérios para pesquisa secundária (1- Emergente; } 2 \text { - Proficiente; } \\
3 \text { - Altamente treinado; } 4 \text { - Exemplar) }\end{array}$ & 1 & 2 & 3 & 4 \\
\hline \multicolumn{5}{|l|}{$\begin{array}{l}\text { A questão CTSA e as possíveis causas da questão estão claramente } \\
\text { descritas em suas próprias palavras }\end{array}$} \\
\hline \multicolumn{5}{|l|}{$\begin{array}{l}\text { Você identificou os atores com poder e suas influências na sua questão } \\
\text { sobre CTSA }\end{array}$} \\
\hline \multicolumn{5}{|l|}{$\begin{array}{l}\text { Você explicou o que você já sabe sobre a questão CTSA na sua } \\
\text { introdução }\end{array}$} \\
\hline \multicolumn{5}{|l|}{$\begin{array}{l}\text { Você abordou algumas (duas ou três) consequências negativas sobre o } \\
\text { bem-estar de indivíduos, sociedades e/ou ambientes }\end{array}$} \\
\hline \multicolumn{5}{|l|}{$\begin{array}{l}\text { A informação que você pesquisou é relevante, detalhada e precisa e } \\
\text { está resumida em aproximadamente } 750 \text { palavras (ou em } 2,5 \text { páginas, } \\
\text { com espaçamento duplo) }\end{array}$} \\
\hline \multicolumn{5}{|l|}{$\begin{array}{l}\text { Você tem ao menos três referências diferentes e usou um formato de } \\
\text { referência apropriado (por exemplo, estilo APA) }\end{array}$} \\
\hline \multicolumn{5}{|l|}{ NÍVEL GERAL DE ALCANCE PARA A PESQUISA SECUNDÁRIA } \\
\hline \multicolumn{5}{|l|}{ Critérios para pesquisa primária } \\
\hline \multicolumn{5}{|l|}{$\begin{array}{l}\text { Sua investigação ajuda a responder uma questão original de causa e } \\
\text { efeito relacionada a sua questão CTSA? (isto é, há correlação entre } \\
\text { gênero [ou idade] e quantidade de comida rápida consumida por } \\
\text { semana?) }\end{array}$} \\
\hline \multicolumn{5}{|l|}{ Sua descrição da sua pesquisa deve ser clara e lógica } \\
\hline \multicolumn{5}{|l|}{$\begin{array}{l}\text { Sua pesquisa é válida e confiável (o tamanho da amostra é grande o } \\
\text { suficiente, ampla variedade de variáveis independentes usadas, na } \\
\text { medida do possível etc.) }\end{array}$} \\
\hline \multicolumn{5}{|l|}{$\begin{array}{l}\text { Seus dados devem ser claramente mostrados em tabelas e gráficos } \\
\text { com as variáveis causa e efeito claramente definidas, junto com as } \\
\text { variáveis controle apropriadas, identificadas abaixo da tabela/gráfico. }\end{array}$} \\
\hline \multicolumn{5}{|l|}{$\begin{array}{l}\text { Seus resultados devem ser interpretados em um texto escrito de } \\
\text { aproximadamente } 300-350 \text { palavras. } \\
\text { - Esboce uma conclusão sobre os possíveis efeitos da variável } \\
\text { causa sobre a variável efeito com uma explicação (sua teoria/ } \\
\text { hipótese) } \\
\text { - Discuta possíveis limitações nos seus resultados ou métodos }\end{array}$} \\
\hline \multicolumn{5}{|l|}{ NÍVEL GERAL DE ALCANCE PARA A PESQUISA PRIMÁRIA } \\
\hline \multicolumn{5}{|l|}{ Critérios para o ativismo sobre CTSA } \\
\hline \multicolumn{5}{|l|}{ Duas ações diferentes são propostas para lidar com a questão CTSA } \\
\hline \multicolumn{5}{|l|}{$\begin{array}{l}\text { As possíveis ações sobre a questão são lógicas (isto é, elas fazem } \\
\text { sentido) }\end{array}$} \\
\hline \multicolumn{5}{|l|}{$\begin{array}{l}\text { Os materiais da ação são prontos para usar, estão facilmente } \\
\text { disponíveis }\end{array}$} \\
\hline \multicolumn{5}{|l|}{ As ações atingem vários grupos, incluindo pessoas no poder } \\
\hline \multicolumn{5}{|l|}{$\begin{array}{l}\text { As ações fazem excelente uso das informações de pesquisas secundária } \\
\text { e primária }\end{array}$} \\
\hline \multicolumn{5}{|l|}{ As ações são bem defendidas na apresentação oral da ação } \\
\hline NÍVEL GERAL DE ALCANCE PARA O PLANO DE AÇÃO & & & & \\
\hline
\end{tabular}

Fonte: elaborado pelos autores. 
Figura 8 - Habilidades e estratégias para a C\&T

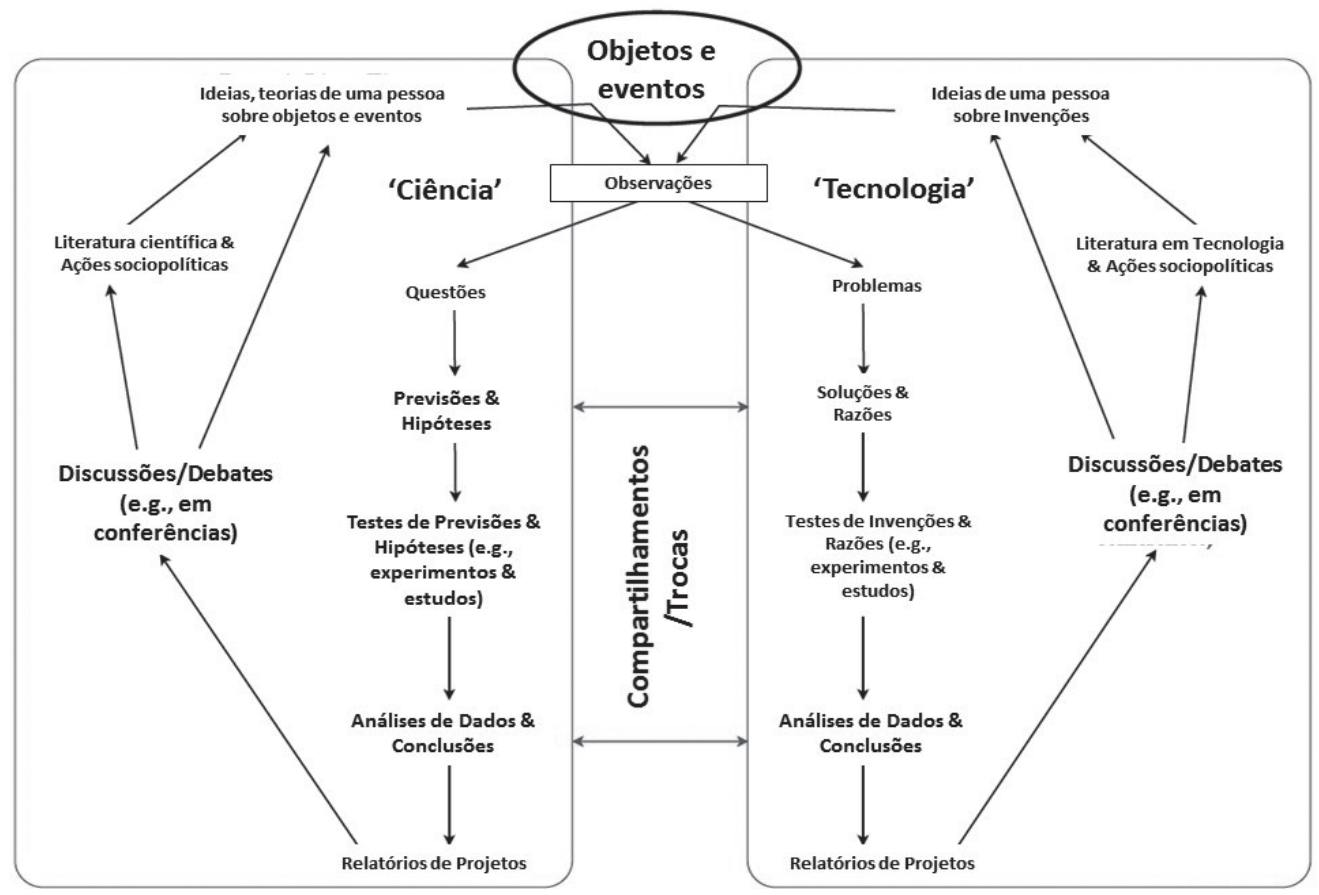

Fonte: elaborada pelos autores.

Ao investigar as relações CTSA, muitas vezes, é particularmente importante a realização de estudos (métodos de pesquisa não experimentais), em vez de experimentos. Devido ao fato de muitas variáveis das relações CTSA serem potencialmente prejudiciais (por exemplo, o desenvolvimento de câncer), é mais ético observar (estudar) mudanças naturais nelas do que forçá-las a ocorrer (como na experimentação). Os estudos podem ser qualitativos e/ou quantitativos. Qualitativamente, é muito comum, por exemplo, entrevistar pessoas (por exemplo, sobre suas opiniões a respeito dos usos de garrafas de água) e/ou para descrever mudanças na natureza (por exemplo, vários processos de envelhecimento em seres vivos). Em termos de análise quantitativa, por sua vez, os investigadores usam frequentemente estudos de correlação; ou seja, investigações empíricas em que os pesquisadores medem variáveis que mudam naturalmente e, em seguida, comparam as alterações entre tais variáveis para determinar a extensão em que as mudanças em uma variável parecem estar influenciando mudanças em outra variável. Tal como acontece com a experimentação, os professores podem usar diferentes abordagens para apresentar aos estudantes estudos de correlação - os quais tendem a não ser enfatizados na educação científica, talvez por causa da relativa facilidade do controle de variáveis em experimentos, quando estes são comparados com estudos não experimentais. (BENCZE, 1996) Uma maneira comum de apresentar estudos, em comparação com experimentos, é perguntar aos estudantes como eles podem determinar as relações en- 
tre as variáveis que envolvem resultados prejudiciais, tais como a forma de descobrir até que ponto os dedos dos fumantes de cigarro se tornam amarelados com o aumento do tabagismo. Alguns estudantes podem rapidamente sugerir que se pergunte às pessoas que já fumam se elas permitem que um investigador meça (por exemplo, com paletas de cores) o amarelecimento dos seus dedos, após o que a pessoa iria ser perguntada quantos cigarros ele/ela fuma, em média, por dia. O professor poderia, então, mostrar aos estudantes exemplos de gráficos de diferentes estudos, tais como: as taxas de câncer vs distância de linhas de energia/eletricidade; taxa de fumo de cigarro vs taxa de câncer; e, número de assentos do automóvel vs pegada de carbono média. Em seguida, os estudantes poderão ser convidados a completar o exercício no Apêndice D - que os provê com alguma prática para o uso de conceitos associados aos estudos de correlação.

Abordagens como aquela acima tiveram um sucesso notável em termos de serem capazes de ter mais controle sobre projetos para RiNA acerca de problemas de CTSA de seu interesse. Um bom exemplo de tal projeto foi realizado por uma estudante do $1^{\circ}$ ano do ensino médio que conduziu uma pesquisa primária e secundária sobre cosméticos e encontrou, por exemplo, vários problemas pessoais, sociais e ambientais associados a esses produtos; e, ainda, que a propaganda foi uma influência esmagadora sobre adolescentes em sua escola, na escolha para utilizá-los. Então, depois de uma análise de rede das relações CTSA sobre cosméticos, ela produziu um vídeo ativista ${ }^{15}$ muito sofisticado e postou no YouTube. Este vídeo ilustra claramente potenciais problemas relacionados com influências de pessoas ou grupos poderosos sobre a C\&T. Apesar de não ter sido evidenciada a pesquisa primária que a estudante, de fato, realizou e descreveu no seu relatório do projeto, o vídeo foi destinado ao público adolescente mais jovem - aqueles que sua pesquisa indicou como mais vulneráveis à publicidade.

\section{Apoiando habilidades para RiNA sobre CTSA: prática reflexiva}

Claramente, nem todos os estudantes são capazes de desenvolver tais vídeos ativistas sofisticados ou outras formas de ação. Tal como acontece com muitas turmas em variados contextos, o alcance dos objetivos está distribuído em uma curva normal (curva de sino) - com alguns poucos projetos "pobres", muitos outros "médios" e alguns trabalhos "excelentes". Quando isso ocorre, os professores podem relutar em pedir a todos os estudantes que autodirijam projetos de RiNA sobre questões CTSA de sua própria escolha (como indicado na Figura 2). Para tornar isso mais viável, no entanto, uma abordagem que parece ter sido bem-sucedida em preparar os estudantes para projetos autodirigidos é pedir a eles que reflitam e compartilhem perspectivas sobre a natureza das relações CTSA e projetos para RiNA. Esta aderência é baseada na metacognição, a ideia de que desenvolver ideias gerais sobre a própria aprendizagem e, em seguida, usá-las (possivelmente revistas pelo pensamento e pela discussão) para guiar a aprendi-

15 Ver em: <https://www.youtube.com/watch?v=WhN6PS1GT9c>. 
zagem futura. (NIEMI, 2002) Por exemplo, em uma aplicação dessa abordagem em sala de aula, após seu segundo conjunto de projetos guiados de mini-RiNA, os estudantes foram convidados a preencher o formulário de avaliação, no Quadro 2, seguindo a ideia do "pense-discuta-compartilhe" (think-pair-share) - com os estudantes, inicialmente completando o formulário de forma individual e, em seguida, compartilhando as suas respostas com os membros do grupo. Isto foi, então, utilizado como base para uma discussão com toda a turma, em que o professor (Krstovic) convidou os estudantes para compartilhar as respostas às suas perguntas e ofereceu algumas ideias novas - como o possível papel das emoções em tais projetos - para consideração do estudante.

Quadro 2 - Formulário para reflexão do estudante sobre projeto de RiNA

\begin{tabular}{|c|}
\hline Reflexão sobre RiNA: para cada questão, indique uma nota e uma breve justificativa \\
\hline Refletindo sobre questões CTSA \\
\hline $\begin{array}{l}\text { Como você se sentiu quando você teve controle sobre que questão CTSA explorar? } \\
\text { [5=muito bem }] \text { o }-1-2-3-4-5\end{array}$ \\
\hline $\begin{array}{l}\text { O quão confiante você está de que você entendeu a controvérsia envolvida na questão que você } \\
\text { estudou? } \\
\text { [5=muito confiante] } 0-1-2-3-4-5\end{array}$ \\
\hline $\begin{array}{l}\text { O quanto as emoções (por exemplo, versus a lógica) influenciaram neste projeto? } \\
{[5=\text { muito }] 0-1-2-3-4-5}\end{array}$ \\
\hline Refletindo sobre a Pesquisa \\
\hline $\begin{array}{l}\text { O quão confiante você está para projetar um estudo válido? } \\
\text { [5=muito confiante] } 0-1-2-3-4-5\end{array}$ \\
\hline $\begin{array}{l}\text { O quão confiante você está nos resultados do seu estudo? } \\
{[5=\text { muito confiante }] 0-1-2-3-4-5}\end{array}$ \\
\hline $\begin{array}{l}\text { O quão confiante você está sobre os achados da sua pesquisa secundária (isto é, pesquisas na internet) } \\
\text { [5=muito confiante] o }-1-2-3-4-5\end{array}$ \\
\hline Refletindo sobre Ações \\
\hline $\begin{array}{l}\text { O quanto sua pesquisa primária e/ou secundária motivou e/ou dirigiu suas ações? } \\
\text { [5=Muito } 0-1-2-3-4-5\end{array}$ \\
\hline $\begin{array}{l}\text { Quanta confiança você tem no que você está recomendando às pessoas (isto é, suas recomendações } \\
\text { de ação)? [5=Muita] o - 1-2-3-4-5 }\end{array}$ \\
\hline $\begin{array}{l}\text { O quanto você sentiu que o modo que você apresentou sua informação teve um efeito (positivo ou } \\
\text { negativo) na sua audiência? } \\
\text { [5=Teve um grande efeito] } 0-1-2-3-4-5\end{array}$ \\
\hline $\begin{array}{l}\text { Em que medida você sente que suas ações alcançaram pessoas com poder? } \\
\text { [5=Muito] } 0-1-2-3-4-5\end{array}$ \\
\hline $\begin{array}{l}\text { O quanto você sente que suas ações (por exemplo, seus pôsteres, vídeos, folhetos, panfletos etc.) se } \\
\text { tornaram parte de uma rede que modifica as mensagens dominantes (por exemplo, apesar de comida } \\
\text { rápida ser saboroso, seus pôsteres/folhetos/panfletos/vídeos etc., se tornaram representações que } \\
\text { desafiam a mensagem dominante, propagada pelas companhias de comida rápida)? } \\
\text { [5=Muito] } 0-1-2-3-4-5\end{array}$ \\
\hline Refletindo sobre Colaboração \\
\hline $\begin{array}{l}\text { O quanto a colaboração de pares (isto é, trabalho em grupo) funciona bem para este tipo de projeto? } \\
{[5=\text { Muito Bem }] \circ-1-2-3-4-5}\end{array}$ \\
\hline $\begin{array}{l}\text { Em que medida o compartilhamento/colaboração com outros grupos ativistas afeta este trabalho? Se } \\
\text { sim, apresente exemplos. [5=Muito] } 0-1-2-3-4-5\end{array}$ \\
\hline O que todos estes projetos de RiNA tem em comum em termos de questões, pesquisa e ações? \\
\hline
\end{tabular}

Fonte: elaborado pelos autores. 


\section{Projetos de RiNA liderados por estudantes: desafios e oportunidades}

Uma vez que o professor tenha decidido que os estudantes estão prontos para essa nova etapa, ele deve apresentar a eles um projeto de RiNA liderado por estudantes para resolver um problema CTSA de interesse deles. No contexto da sala da aula, no entanto, é muito difícil para os professores, inseridos nos sistemas educativos formais, separarem-se totalmente dos projetos dos estudantes. Um dos maiores desafios é encorajar a tomada de decisão dos estudantes, ao mesmo tempo em que se proporciona a eles um esquema que será utilizado para avaliar cada etapa do projeto e, abertamente, para motivá-los para concluí-las. O projeto de RiNA, fornecido no Apêndice E, representa uma tentativa de equilibrar a tomada de decisão do estudante e as intenções das escolas para avaliar e registrar o desempenho destes. Devido à necessidade de avaliar e registrar o progresso do estudante, em grande medida, a independência proporcionada por esses projetos dependerá da flexibilidade do professor em aceitar uma variedade de níveis de desempenho como "satisfatórios". Tais julgamentos são, sem dúvida, complexos - feitos com base em vários fatores, tais como julgamentos dos professores sobre as capacidades dos estudantes, em termos de suas idades, estágios de aprendizagem etc. e, como já referido acima, também dependem das crenças do professor sobre a Natureza da Ciência. Os professores com posições mais naturalistas-antirrealistas sobre a ciência são, sem dúvida, mais propensos a aceitar uma maior variedade de desempenhos dos estudantes do que professores que aderem aos pontos de vista mais racionalistas-antirrealistas.

A partir das nossas experiências, se existe o alinhamento de uma gama de condições, incluindo ter um professor comprometido com uma educação CTSA crítica e projetos de RiNA autodirigidos, o pessoal de suporte da escola (por exemplo, administradores e colegas professores) e encargos curriculares para a educação CTSA e para a pesquisa liderada por estudantes, é muito provável que os estudantes sejam capazes de realizar projetos de RiNA autodirigidos, de alto nível, sobre questões CTSA de sua própria escolha, depois de apenas uma ou duas séries de aulas e atividades de aprendizagem mediada (estudantes mais velhos parecem precisar de apenas uma série de aprendizagem mediada). Evidências de tais alcances podem ser encontradas em uma edição especial do periódico Journal for Activist Science and Technology Education (JASTE), ${ }^{16}$ uma revista de código-fonte aberto, não arbitrada, com artigos escritos por estudantes do ensino médio sobre os seus projetos de RiNA. Esta edição especial, editada por Mirjan Krstovic, tem atraído consideráveis elogios de várias fontes, incluindo os colegas de ensino e de administração de Mirjan, assim como os colegas de Larry, local e internacionalmente. A um nível mais local, enquanto isso, Mirjan e seus estudantes receberam considerável apreciação dos projetos apresentados na biblioteca da escola em uma feira sobre RiNA e CTSA (algo como uma feira de ciências). Os professores, que excursionaram os projetos em exposição - incluindo o ilustrado na Figura 9 -, fomentaram o engajamento dos

16 Ver em: <http://jps.library.utoronto.ca/index.php/jaste/issue/view/1560>. 
estudantes em discussões sobre os seus projetos e ficaram muito impressionados com a criatividade, a experiência e o compromisso dos estudantes para lidar com controvérsias sobre CTSA complexas e importantes.

Figura 9 - Feira sobre RiNA e CTSA: consumo de cigarros

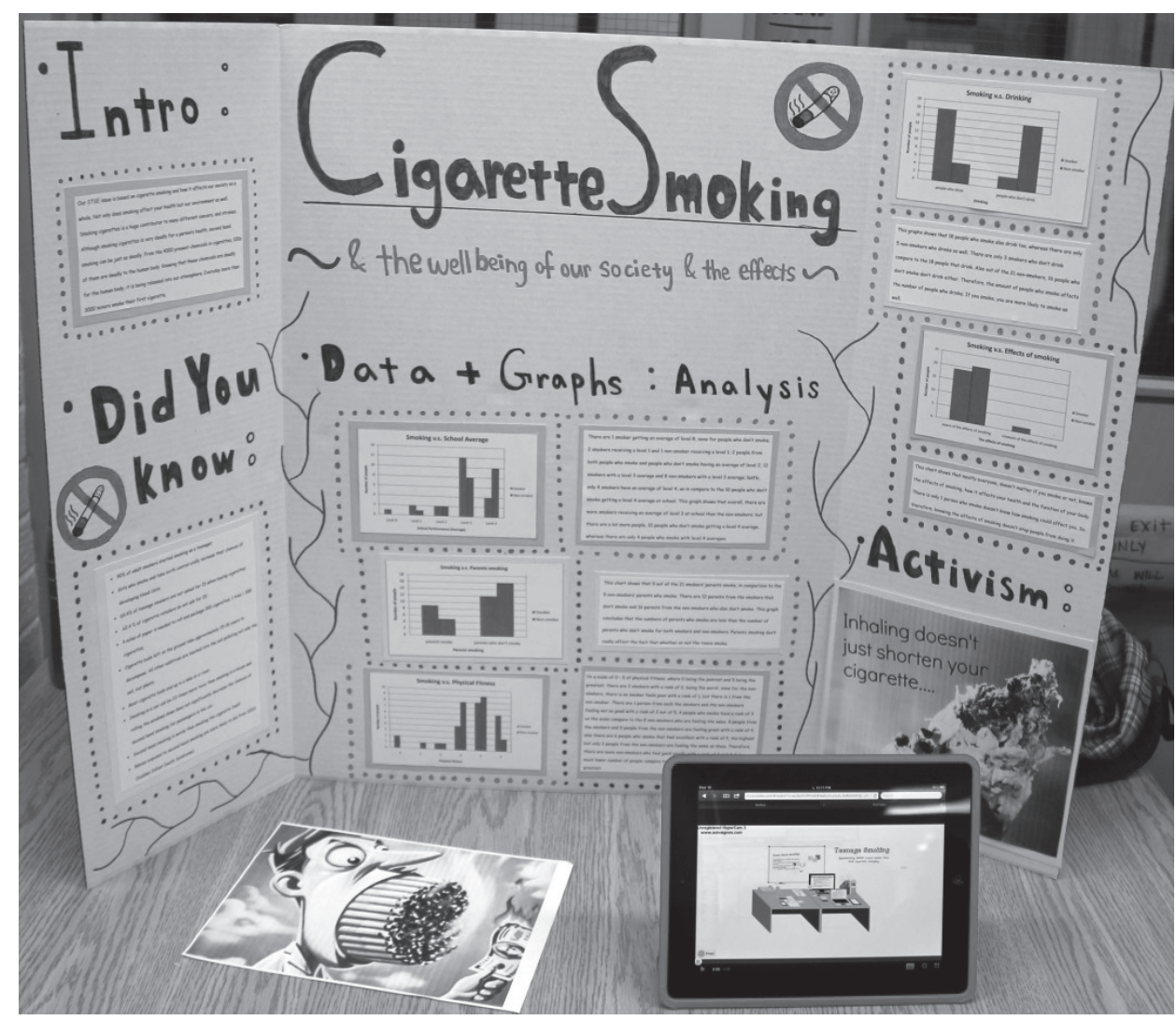

Fonte: elaborada pelos autores.

\section{Síntese e conclusões}

O framework STEPWISE tem permitido aos estudantes desenvolver e implementar planos de ação que "consomem" ao menos uma parte do letramento deles na tentativa de abordar problemas que eles identificam nas relações entre os campos CTSA. Em muitos casos, os estudantes parecem desenvolver uma preocupação genuína pelo bem-estar do outro; por exemplo, outras pessoas e outros seres vivos e não vivos que parecem estar em risco nas relações CTSA. Talvez relacionada a tal empatia, os estudantes pareçam desenvolver entusiasticamente a própria perícia de que eles precisam para aprender mais sobre tais riscos e, com base nos conhecimentos e atitudes disponíveis, podem realizar ações para abordar os problemas identificados. 
Em outras palavras, sementes são plantadas nas mentes de muitos estudantes prontos para desenvolver e nutrir a si mesmos e a outros em vários contextos importantes. Nós temos visto, além disso, algumas situações melhorarem - tais como autoridades escolares aperfeiçoando seus programas de reciclagem de lixo - em virtude de ações dos estudantes.

Embora seja difícil medir, é evidente que as ações dos estudantes, ao mesmo tempo em que entusiasmadas, muitas vezes possuem efeitos relativamente pequenos, além de seus ambientes mais imediatos da casa, da escola e das comunidades locais. Por exemplo, não que esta seja a melhor ação de um estudante de nossa pesquisa, mas muitos acadêmicos, professores e outros a quem temos mostrado o vídeo ativista sobre cosméticos (ver acima) têm elogiado esta ação; mas, ainda assim, ele foi visto por apenas pouco mais de 500 vezes (até 17 de setembro de 2017). Ele não se tornou viral. Estamos interessados, portanto, em novas abordagens, que possam gerar benefícios mais generalizados a partir das ações dos estudantes. Em um recente estudo em curso de ações baseadas em pesquisa por cidadãos, para buscar resolver um caso de contaminação ambiental em sua comunidade local, no entanto, tornou-se evidente que grande parte dos sucessos dos cidadãos parecia se relacionar com a criação de redes de suas ações. (BENCZE; POULIOT, 2017) Ou seja, depois de um ato inicial de pagar um laboratório local para testar a poeira que estava se acumulando em seu ambiente, uma rede complexa de actantes vivos (por exemplo, cidadãos e grupos de colegas), não-vivos (por exemplo, um site ativista) e simbólicos (por exemplo, um sentimento de indignação) se alinharam em apoio a uma causa relacionada (por exemplo, ações de mitigação cívicas e corporativas). Esta rede de ação (action-network) pareceu resultar em algumas respostas positivas, incluindo mudanças no monitoramento da qualidade do ar e redução do nível mínimo permitido de poluentes. (POULIOT, 2015) Assim, parece claro que os educadores podem querer incentivar os estudantes a trabalhar em rede tanto nas suas pesquisas sobre as relações CTSA (PIERCE, 2013) quanto sobre suas ações. (BENCZE; POULIOT, 2017)

Encorajar e permitir ações negociadas e informadas por pesquisa, autodirigidas e em rede, pelos próprios estudantes, para abordar os problemas CTSA, embora aparentemente possível em alguns contextos, parece ser uma tarefa assustadora. Como mencionado acima, tem sido a nossa experiência que a realização de tais projetos críticos e altruístas é algo raro - exigindo o alinhamento de uma grande variedade de actantes, incluindo um professor com experiência, confiança e motivação correspondentes, colegas e pessoal administrativo, além de encargos curriculares, que oferecem suporte. Além disso, as perspectivas para as suas formações parecem particularmente ameaçadas nos últimos anos - talvez simbolizada melhor pela rápida emergência e pelas influências generalizadas da educação para Ciência, Tecnologia, Engenharia e Matemática (STEM). Embora pareça haver justificativa significativa para a integração e/ou inter-relações entre os quatro campos STEM na educação, incluindo em termos de relações profissionais (RENNIE; VENVILLE; WALLACE, 2012), estudos de documentos e políticas curricula- 
res em apoio a este tipo de educação, muitas vezes, parecem indicar que eles priorizam o ensino e a aprendizagem das habilidades e dos conhecimentos amplamente aceitos e competências dos campos da educação STEM, enquanto, aparentemente, com uma atenção zelosamente omitida sobre os problemas associados às relações entre CTSA e ações para resolvê-los. (GOUGH, 2015; ZEIDLER, 2016) Aparentemente, uma chave para o que pode estar conduzindo a educação STEM não reside tanto nos campos incluídos; mas, sim, naqueles que são excluídos. Particularmente ausente nesta combinação, estão os campos das ciências humanas e sociais. Os discursos em políticas educacionais e em documentos de currículos parecem suportar esta conclusão e, além disso, apontam orientadores socioeconômicos da educação STEM. O Conselho Nacional de Pesquisa dos EUA (NRC, 2011), por exemplo, que ajudou a facilitar o desenvolvimento dos padrões curriculares Next Generation Science Standards (Achieve, uma empresa privada), no seu documento, denominado educação STEM bem-sucedida, declara que:

[O] principal motor da economia do futuro e concomitante criador de postos de trabalho será a inovação, em grande parte derivada de avanços em ciência e engenharia... 4 por cento da força de trabalho do país é composta de cientistas e engenheiros; este grupo cria desproporcionalmente postos de trabalho para os outros 96 por cento. (NATIONAL RESEARCH COUNCIL, 2011, p. 2)

Tal discurso parece sugerir que a educação STEM está principalmente preocupada em identificar e educar relativamente poucos profissionais da educação STEM que podem desenvolver e gerir mecanismos e pessoal para a produção e o consumo de bens e serviços que possam enriquecer financistas e empresas que financiam em grande parte o trabalho daqueles. (MEANS, 2013; PIERCE, 2013) De forma mais ampla, como McLaren (2000, p. 196) afirmou, parece que "[...] o principal propósito da educação é tornar o mundo seguro para o capitalismo global”.

Os educadores, implementando programas críticos e altruístas, como o STEPWISE, podem ter que enfrentar um "Borg"17 virtual; ou seja, um "complexo homem-tecnologia" agindo como um único ser que ameaça assimilar tudo em seu caminho para a sua rede. Em um estudo de instituições educacionais em relações as entidades do setor privado, por exemplo, Ball (2012) concluiu que os membros deste setor mantêm seu poder e influência sobre as sociedades em grande parte através de uma vasta e crescente rede interconectada de actantes alinhados para apoio ao lucro privado. No estudo mencionado acima, das ações dos cidadãos para eliminar o que eles concluem ser poeira tóxica que está sendo espalhada em toda a sua comunidade, estes cidadãos têm expressado preocupação de que as ações para eliminar a poeira são mínimas - em grande parte devido ao poder de uma rede pró-capitalista de actantes, como o governo local, prio-

17 Ver em: <https://en.wikipedia.org/wiki/Borg_(Star_Trek)>. 
rizando empregos e receitas fiscais e as empresas associadas mais estreitamente com a dispersão de poeira tóxica que estão priorizando a expansão de seus lucros e operações. (BENCZE; POULIOT, 2017) Sob esta perspectiva, parece que, talvez, a única saída, para aqueles que apoiam programas educacionais críticos e altruístas, como os baseados no STEPWISE, seja, talvez ironicamente, imitar o setor privado - no sentido de reunir muitos actantes para suas causas. Tal projeto não seria como uma batalha de "David contra Golias"; mas, ao contrário, pode ser visto mais como um movimento de massa - com perspectivas e práticas "de ir se tornando viral", ao engajar uma grande variedade de adeptos.

\section{Referências}

ANGELL, M. The truth about the drug companies: how they deceive us and what to do about it. New York: Random House, 2004.

BALL, S. J. Global education Inc.: new policy networks and the neo-liberal imaginary. Abingdon: Routledge, 2012.

BARNES, R. L.; HAMMOND, S. K.; GLANTZ, S. A. The tobacco industry's role in the 16 Cities Study of Secondhand Tobacco Smoke: Do the data support the stated conclusions? Environmental Health Perspectives, Research Triangle Park, n. 114, v. 12, p. 1890-1897, 2006.

BAUDRILLARD, J. The consumer society. London: Sage, 1998.

BENCZE, L. Student-led learning for 'altruistic' socio-political actions. In: SHAPIRO, B. (Ed.). Actions of their own to learn. Rotterdam: Sense, 2018. p. 177-198.

BENCZE, L. Correlational studies in school science: Breaking the science-experimentcertainty connection. School Science Review, London, v. 78, n. 282, p. 95-101, 1996.

BENCZE, L. STEPWISE: A framework prioritizing altruistic actions to address socioscientific issues. In: BENCZE, J. L. (Ed.). Science \& technology education promoting wellbeing for individuals, societies \& environments. Dordrecht: Springer, 2017. p. 19-45.

BENCZE, L.; ALSOP, S. (Ed.). Activist science \& technology education. Dordrecht: Springer, 2014.

BENCZE, L.; BOWEN, M.; ALSOP, S. Teachers' tendencies to promote student-led science projects: Associations with their views about science. Science Education, Leeds, v. 90, n. 3, p. 400-419, 2006.

BENCZE, L.; CARTER, L. Globalizing students acting for the common good. Journal of Research in Science Teaching, New York, v. 48, n. 6, p. 648-669, 2011.

BENCZE, L.; ELSHOF, L. Science teachers as metascientists: An inductive-deductive dialectic immersion in northern alpine field ecology. International Journal of Science Education, London, v. 26, n. 12, p. 1507-1526, 2004. 
BENCZE, L.; KRSTOVIC, M. Resisting the Borg: Science teaching for common wellbeing. In: BENCZE, J. L. (Ed.). Science \& technology education promoting wellbeing for individuals, societies \& environments. Dordrecht: Springer, 2017. p. 227-276.

BENCZE, L.; POULIOT, C. Science \& technology promoting wellbeing for individuals, societies \& environments. In: BENCZE, J. L. (Ed.). Science \& technology promoting wellbeing for individuals, societies \& environments. Dordrecht: Springer, 2017. p. 381404.

BOURDIEU, P. The forms of capital. In: RICHARDSON, J. G. (Ed.). The handbook of theory: Research for the sociology of education. New York: Greenwood Press, 1986. p. 241-258.

COBERN, W. W.; LOVING, C. C. The card exchange: Introducing the philosophy of science. In: MCCOMAS, W. F. (Ed.). The nature of science in science education. Dordrecht: Kluwer, 1998, p. 73-82.

GOTT, R.; DUGGAN, S. Understanding and using scientific evidence: how to critically evaluate data. London: Sage, 2003.

GOUGH, A. STEM policy and science education: Scientistic curriculum and sociopolitical silences. Cultural Studies of Science Education, Dordrecht, v. 10, n. 2, p. 445-458, 2015.

HILEMAN, B. Industry's privacy rights: Is science short changed? Chemical \& Engineering News, Washington, p. 36, v. 76, n. 36, 1998.

HODSON, D. Looking to the future: building a curriculum for social activism. Rotterdam: Sense, 2011.

HODSON, D. Towards scientific literacy: a teachers' guide to the history, philosophy and sociology of science. Rotterdam: Sense, 2008.

KHISHFE, R.; LEDERMAN, N. G. Teaching nature of science within a controversial topic: integrated versus nonintegrated. Journal of Research in Science Teaching, New York, v. 43, n. 4, p. 395-418, 2006.

KLEIN, N. This changes everything: capitalism and the climate. Toronto: Simon \& Schuster, 2014.

KLEINMAN, D. L. Impure cultures: University biology and the world of commerce. Madison, WI: University of Wisconsin Press, 2003.

KRIMSKY, S. Science in the private interest: has the lure of profits corrupted biomedical research? Lanham, MD: Rowman \& Littlefield, 2003.

LATOUR, B. Reassembling the social: an introduction to actor-network-theory. Oxford: Oxford University Press, 2005.

LEONARD, A. The story of stuff: how our obsession with stuff is trashing the planet, our communities, and our health - and a vision for change. New York: Free Press, 2010 . 
LEVINSON, R. Science education and democratic participation: An uneasy congruence? Studies in Science Education, Leeds, v. 46, n. 1, p. 69-119, 2010.

LEVINSON, R. Practice and theory of socio-scientific issues: An authentic model? Studies in Science Education, Leeds, v. 49, n. 10, p. 99-116, 2013.

LOCK, R. Open-ended, problem-solving investigations: What do we mean and how can we use them? School Science Review, London, v. 71, n. 256, p. 63-72, 1990.

LOVING, C. C. The scientific theory profile: A philosophy of science model for science teachers. Journal of Research in Science Teaching, New York, v. 28, n. 9, p. 823-838, 1991.

MCLAREN, P. Che Guevara, Paulo Freire, and the pedagogy of the revolution. Lanham, MD: Rowman \& Littlefield, 2000.

MCMURTRY, J. The cancer stage of capitalism: from crisis to cure. London: Pluto, 2013.

MEANS, A. Creativity and the biopolitical commons in secondary and higher education. Policy Futures in Education, Oxford, v. 11, n. 1, p. 47-58, 2013.

MIROWSKI, P. Science-mart: Privatizing American science. Cambridge: Harvard University Press, 2011.

NATIONAL RESEARCH COUNCIL - NRC. Successful K12 STEM education: Identifying effective approaches in science, technology, engineering, and mathematics. Washington: National Academies Press, 2011.

NIEMI, H. Active learning-a cultural change needed in teacher education and schools. Teaching and Teacher Education, New York, v. 18, n. 7, p. 763-780, 2002.

OSBORNE, R.; WITTROCK, M. The Generative Learning Model and its implications for science education. Studies in Science Education, Leeds, v. 12, p. 59-87, 1985.

PEDRETTI, E.; NAZIR, J. Currents in STSE education: mapping a complex field, 40 years on. Science Education, Salem, v. 95, n. 4, p. 601-626, 2011.

PIERCE, C. Education in the age of biocapitalism: optimizing educational life for a flat world. New York: Palgrave Macmillan, 2013.

POULIOT, C. Quand les citoyen.ne.s soulèvent la poussière: la Controverse Autour de la Poussière Métallique à Limoilou Montréal: Carte blanche, 2015.

RENNIE, L.; VENVILLE, G.; WALLACE, J. (Ed.). Integrating science, technology, engineering and mathematics: issues, reflections and ways forward. New York: Routledge, 2012.

SADLER, T. D.; BARAB, S. A.; SCOTT, B. What do students gain by engaging in socioscientific inquiry? Research in Science Education, Amsterdam, v. 37, n. 4, p. 371391, 2007.

VASIL, A. Ecoholic: Your guide to the most environmentally friendly information, products and services in Canada. Toronto: Vintage, 2007. 
WEBER, K. (Ed.). Food inc.: how industrial food is making us sicker, fatter, and poorer - and what you can do about it, a participant media guide. New York: Public Affairs, 2009.

WENGER, E. Communities of practice. Cambridge: Cambridge University Press, 1998.

WOOD, G. H. Democracy and the curriculum. In: BEYER, L. E.; APPLE, M. W. (Ed.). The curriculum: problems, politics and possibilities. Albany: SUNY Press, 1998. p. $177-$ 198.

ZEIDLER, D. L. STEM education: A deficit framework for the twenty first century? A sociocultural socioscientific response. Cultural Studies of Science Education, Dordrecht, v. 11, n. 1, p. 11-26, 2016. 


\section{Apêndice A - Estudo de caso da QSC}

\section{DIAMANTES DE SANGUE}

\section{Introdução}

Os diamantes são, essencialmente, formas comprimidas de carbono - formados naturalmente como estruturas cristalinas cúbicas em grandes profundidades no manto da Terra ao longo de pelo menos um bilhão de anos, em condições de alta pressão e temperatura. Eles podem aparecer perto da superfície da Terra por meio de erupções vulcânicas. Então eles podem ser extraídos. Engenheiros também podem produzir diamantes e substâncias similares através de diferentes técnicas.

Os diamantes têm sido valorizados pelas pessoas durante séculos, por causa, por exemplo, de suas propriedades reflexivas e dispersivas (por exemplo, brilho e espectros de cor em gemas), condutividade eléctrica (por exemplo, em semicondutores) e dureza (por exemplo, para uso em brocas). Por causa do valor atribuído a eles, as pessoas, as organizações e os países associados a eles têm aumentado a sua riqueza e prosperidade. As pessoas têm, assim, apreciado diamantes para seu uso em vários ornamentos, inclusive na forma de anéis de casamento e decoração em relógios de pulso.

Apesar dos valores associados aos diamantes, sua extração, sua distribuição, seu processamento e sua venda não ocorrem sem controvérsia. Ironicamente, enquanto eles podem trazer grande felicidade para algumas pessoas (por exemplo, noivas em casamento), eles podem causar grande dor para aqueles envolvidos na sua extração. Consequentemente, há muitas questões complexas para várias partes interessadas - incluindo mineradores, empresas de mineração, governos, varejistas e agências de publicidade. Como os campos da ciência e da tecnologia estão envolvidos de vários modos, e porque há diferenças de opinião sobre o mérito das decisões que as pessoas podem tomar com relação a diamantes, este tema é um excelente exemplo de uma questão sociocientífica.

\section{Problemas dos Diamantes}

Há vários problemas ou potenciais problemas que estão associados com a mineração, a distribuição, o refinamento, o marketing e as vendas de diamantes etc. Alguns deles são brevemente apontados a seguir:

\section{A fixação dos preços}

Os diamantes são, geralmente, muito caros - alegadamente porque eles são relativamente raros e caros para minerar e processar. Contudo, em 2004, De Beers, uma empresa gigante de diamantes, confessou culpa por fixação de preço - por meio, por exemplo, de retenção dos diamantes para criar a ilusão de escassez. Quando a oferta de uma mercadoria é alta, pode fazer parte dos interesses de uma empresa com fins lucrativos criar uma ilusão de escassez para justificar aumento de preços.

Em grande medida, para aumentar artificialmente os preços e, por conseguinte, aumentar os lucros, muitos tipos de empresas contratam empresas de marketing ou empregam técnicas de marketing para criar a ilusão de necessidade; por exemplo, os desejos nos consumidores. (BARBER, 2007) Esta parece ser uma importante estratégia das empresas de diamantes - a tentativa de convencer os parceiros de casamento, por exemplo, de que é natural que anéis de diamantes sejam trocados por votos de casamento. ${ }^{2}$ No entanto, há a sugestão de que, uma vez comprado e adquirido de uma loja de jóias, o valor dos diamantes deprecia.3 Sob esta ótica, os diamantes podem não "ser para sempre", como os comerciantes afirmam frequentemente. Finalmente, parece existir uma canalização do preço do diamante, à medida em que os benefícios financeiros crescentes advêm das pessoas envolvidas diretamente na dura produção de diamantes para as vendas e os ganhos financeiros dos acionistas. Este parece ser um arranjo estrutural típico do capitalismo; aqueles que possuem e fornecem os meios de produção colhem o máximo de benefícios às custas dos verdadeiros trabalhadores.

\section{Ética da externalização}

Uma estratégia importante das empresas e dos financiadores para maximizar o lucro é evitar proativamente vários tipos de custos sociais e ambientais, agindo para garantir que outros assumam a responsabilidade por eles. Bakan (2004, p. 20), em A Corporação (The Corporation), por exemplo, provocativamente sugere que "a corporação ... é uma máquina de externalização, da mesma maneira que um tubarão é uma máquina de matar" e que isso a torna "potencialmente muito, muito prejudicial para a sociedade". A ética subjacente parece ser que efeitos colaterais negativos, pelos quais outros seriam os responsáveis, é uma parte natural de se fazer negócios - para garantir que acionistas obtenham os retornos máximos em seus investimentos. 
A mineração de diamantes apresenta muitos riscos significativos para ambientes locais. Os problemas potenciais do Projeto Victor Mine no Nordeste de Ontário 4 apresentam um exemplo relevante, levando potencialmente a uma série de problemas ambientais, incluindo: i) adição de sal a rios locais, ii) redução da vazão de rios locais, iii) remoção de vegetação natural, iv) interrupção dos movimentos de aves migratórias. Apesar dos riscos potenciais, é evidente que De Beers vai colher os seus lucros durante a vida prevista de 15 anos da mina e, em seguida, deixará as pessoas locais e o governo de Ontário para que lidem com quaisquer efeitos colaterais negativos. No entanto, o governo de Ontário tem, aparentemente, geralmente ignorado as avaliações ambientais e permitido que a operação da mina continue. ${ }^{5}$

A localização de depósitos de diamantes, muitas vezes cria situações em que as pessoas, incluindo os povos indígenas, são deslocados de suas terras. Muitas famílias indígenas, por exemplo, foram deslocadas de suas terras no Zimbabwe ${ }^{6}$ por causa das operações de mineração. Por outro lado, estes povos ${ }^{7}$ recentemente ganharam acesso aos lucros das empresas de diamantes - embora isso possa ser um pequeno consolo para os custos ambientais e sociais já existentes ou ainda por vir.

Talvez o aspecto mais preocupante do negócio de diamantes esteja nas atrocidades frequentemente sofridas pelas pessoas mais pobres. Entre 1971 e 2001, por exemplo, a guerra civil assolou Angola ${ }^{8}$ enquanto governos e as forças antigovernamentais (rebeldes) disputaram o controle das operações de mineração de diamantes. Da mesma forma, a guerra no Congo levou a milhões de mortes. ${ }^{9}$ Uma prática ultrajante dos rebeldes era mutilar milhões de cidadãos, cortando suas mãos, ${ }^{10}$ de modo que não poderiam trabalhar nas operações de mineração patrocinadas pelo governo.

O público em geral tem se tornado consciente da natureza terrível do conflito sobre os lucros dos diamantes, em particular através de filmes como Diamante de Sangue (Blood Diamond) ${ }^{11}$ e organizações como a Global Witness. ${ }^{12}$ Como consequência, um esquema de certificação governamental internacional, conhecido como o Processo Kimberley' ${ }^{13}$ foi lançado, em 2003, para garantir que "diamantes de conflito" não cheguem ao mercado para as vendas. No entanto, já que seu foco está nos diamantes brutos (uma vez que grande parte da regulação não é obrigatória e também porque nem todos os países aceitam o esquema de certificação), os diamantes de conflito parecem continuar a chegar aos mercados. ${ }^{14}$ Ao mesmo tempo, é também evidente que as práticas nas minas de diamantes, como em muitas outras indústrias, muitas vezes empregam crianças ${ }^{15}$ que oferecem um custo baixo por sua mão de obra, para maximizar o lucro.

Por causa dos muitos problemas potenciais associados com diamantes, muitos grupos e indivíduos, como um blogueiro, ${ }^{16}$ estão convocando boicotes à indústria do diamante, se as regulações não aumentarem.

\section{Referências}

BAKAN, J. The corporation: the pathological pursuit of profit and power. Toronto: Viking, 2004.

BARBER, B. R. Consumed: how markets corrupt children, infantilize adults, and swallow citizens whole. New York: Norton, 2007.

\section{Notas:}

$1 \quad$ http://www.corpwatch.org/article.php?id=11431

2 http://science.howstuffworks.com/environmental/earth/geology/diamond5.htm

3 http://www.theatlantic.com/magazine/archive/1982/02/have-you-ever-tried-to-sell-a-diamond/4575/

4 http://www.wildlandsleague.org/display.aspx?pid=231\&cid=233

5 http://www.miningwatch.ca/en/home/country/canada/ontario/victor-project

6 http://www.dailynews.co.zw/opinion/218-displaced-communities-need-protection.html

7 http://www.galdu.org/web/index.php?odas=5116\&giellal=eng

8 http://wwwl.american.edu/ted/ice/angola.htm

9 http://www.msnbc.msn.com/id/15842522/ns/world_news/t/diamonds-journey-beginning/

10 http://www.un.org/peace/africa/Diamond.html

11 http://en.wikipedia.org/wiki/Blood_Diamond_(film)

12 http://www.globalwitness.org/campaigns/conflict/conflict-diamonds

13 http://www.globalwitness.org/campaigns/conflict/conflict-diamonds/kimberley-process

14 http://www.hrw.org/en/news/2009/11/06/kimberley-process-zimbabwe-action-mars-credibility

15 http://en.wikipedia.org/wiki/Child_labour_in_the_diamond_industry

16 http://feministilicious.tumblr.com/post/6356286137/10-reasons-why-you-should-never-buy-diamonds 


\section{Apêndice B - Aprendizagem mediada para habilidades de investigação, projetos, comunicação \& ações}

Para ajudar os estudantes a desenvolver Atitudes, Habilidades e Conhecimentos (ASK) que, ao final, serão relevantes para que eles autodirijam pesquisas científicas a fim de aprender mais sobre os fenômenos, comunicar seus resultados a outros e, quando eles detectam problemas, desenvolver ações pessoais e sociais (incluindo petições, cartazes \& invenções novas/melhoradas), os professores podem conduzir aulas pertinentes de aprendizagem mediada, com atividades dos estudantes. Estes devem começar por perguntar aos estudantes sobre suas ASK pré-instrucionais relacionando-as à investigação, ao projeto e às ações. Mas, então, para ajudar a melhorar os seus ASK, os professores devem "modelar" (ou demonstrar) diferentes ASK e, em seguida, dar aos estudantes a oportunidade de praticá-los em situações significativas, com a orientação que for necessária.

\begin{tabular}{|c|c|c|}
\hline $\begin{array}{l}\text { Habilidades de } \\
\text { Investigação, Projeto, } \\
\text { Comunicação \& } \\
\text { Ações }\end{array}$ & $\begin{array}{c}\text { MODELAGEM } \\
\text { (Demonstrações interativas do professor) }\end{array}$ & $\begin{array}{c}\text { PRÁTICA GUIADA } \\
\text { (Prática do estudante, com assistência } \\
\text { do professor) }\end{array}$ \\
\hline $\begin{array}{l}\text { Observações } \\
\text { qualitativas vs } \\
\text { quantitativas }\end{array}$ & $\begin{array}{l}\text { - Defina o conceito de "variável" e fale aos } \\
\text { estudantes sobre os dois tipos de observações, com } \\
\text { exemplos; em seguida, leve-os a contribuir, cada um } \\
\text { com suas observações baseadas na unidade. } \\
\text { - Demonstre várias habilidades de medição } \\
\text { e descrição; por exemplo, o uso de cilindros } \\
\text { graduados; os usos dos cinco sentidos para } \\
\text { observações qualitativas. }\end{array}$ & $\begin{array}{l}\text { - Peça aos estudantes para brincar } \\
\text { com fenômenos simples - como } \\
\text { balões - e listar cerca de cinco tipos } \\
\text { de observação. } \\
\text { - Peça aos estudantes para medir } \\
\text { quantidades específicas com } \\
\text { aparelhos; por exemplo, a medição do } \\
\text { diâmetro com um micrômetro. }\end{array}$ \\
\hline $\begin{array}{l}\text { Questionamentos, } \\
\text { predições e } \\
\text { levantamento de } \\
\text { hipóteses }\end{array}$ & $\begin{array}{l}\text { - Apresente e discuta as relações entre } \\
\text { variável causa (independente) e variável efeito } \\
\text { (dependente), usando fenômenos comuns, de } \\
\text { rápida visualização, como fenômenos visuais; } \\
\text { por exemplo, mergulhador Cartesiano ou ludião, } \\
\text { balões etc.; } \\
\text { - Mostre-lhes, com exemplos, listas de possíveis } \\
\text { variáveis de causa e variáveis de efeito que } \\
\text { podem ser combinadas para desenvolver } \\
\text { questões e previsões. }\end{array}$ & $\begin{array}{l}\text { - Coloque os estudantes para } \\
\text { desenvolver questões sobre relações } \\
\text { causa-efeito, previsões e hipóteses } \\
\text { com fenômenos comuns; } \\
\text { - Peça aos estudantes para completar } \\
\text { declarações sobre relações de } \\
\text { causa-efeito; por exemplo, quanto } \\
\text { maior _-_________, mais dura será a } \\
\text { gelatina. }\end{array}$ \\
\hline $\begin{array}{c}\text { Projetar e conduzir } \\
\text { experimentos; isto é, } \\
\text { testes empíricos dos } \\
\text { efeitos de mudanças } \\
\text { intencionais em uma } \\
\text { possível variável causa } \\
\text { sobre mudanças em } \\
\text { uma possível variável } \\
\text { efeito. }\end{array}$ & $\begin{array}{l}\text { - Conduza demonstrações interativas (por } \\
\text { exemplo, bolas quicando em superfícies diferentes) } \\
\text { que ilustram e justificam vários fatores a levar em } \\
\text { conta em projetos de estudos e experimentos; } \\
\text { incluindo: i) utilizar um amplo intervalo de } \\
\text { valores (quantidades) da possível variável causa; } \\
\text { ii) duplicar o teste de cada quantidade/valor; iii) } \\
\text { medir e descrever variáveis, onde for apropriado; } \\
\text { iv) checar duplamente cada medição e/ou } \\
\text { descrição (confiabilidade); v) controlar os efeitos } \\
\text { de variáveis intervenientes; vi) comparar variáveis } \\
\text { de resultados para verificar a validade. }\end{array}$ & $\begin{array}{l}\text { - Forneça aos estudantes materiais } \\
\text { e descrições de experimentos para } \\
\text { eles projetarem e realizarem os seus } \\
\text { próprios; por exemplo, efeitos de } \\
\text { diferentes variáveis; por ex.: i) massa } \\
\text { do helicóptero de papel vs taxa } \\
\text { de descida; ii) espessura de faixas } \\
\text { elásticas vs distância percorrida } \\
\text { quando esticado e liberado; iii) dureza } \\
\text { da superfície (por exemplo, tapete vs } \\
\text { madeira) vs altura de pulo da bolinha } \\
\text { etc. }\end{array}$ \\
\hline $\begin{array}{l}\text { Projetar e conduzir } \\
\text { estudos de correlação; } \\
\text { isto é, testes empíricos } \\
\text { dos efeitos de } \\
\text { mudanças naturais } \\
\text { em uma possível } \\
\text { influência da variável } \\
\text { causa sobre mudanças } \\
\text { em uma possível } \\
\text { variável efeito. }\end{array}$ & $\begin{array}{l}\text { - Pergunte aos estudantes como eles iriam } \\
\text { testar efeitos de mudanças em uma variável } \\
\text { que podem levar a efeitos prejudiciais; por } \\
\text { exemplo, efeitos de fumar maconha na tosse de } \\
\text { adolescentes. Através da discussão, ajude-os a } \\
\text { compreender a necessidade de estudar variáveis } \\
\text { que mudam naturalmente, tanto por razões } \\
\text { éticas quanto práticas. Com exemplos, explique } \\
\text { a eles como os estudos funcionam; } \\
\text { - Forneça exemplos de estudos, com dados } \\
\text { amostrais; por exemplo, a quantidade de } \\
\text { fumantes vs as taxas de câncer; populações } \\
\text { predador-presa vs tempo. }\end{array}$ & $\begin{array}{l}\text { - Mostre aos estudantes como medir } \\
\text { diversas variáveis sobre os seres } \\
\text { humanos e em seguida, conduza-os } \\
\text { a realizar um estudo destas variáveis, } \\
\text { construindo gráficos para pares de } \\
\text { variáveis que eles acreditam serem } \\
\text { causalmente relacionadas; por } \\
\text { exemplo, idade, sexo, comprimento } \\
\text { do dedo etc., como eles afetam o } \\
\text { tempo de reação etc.; } \\
\text { - Peça aos estudantes para projetar } \\
\text { e realizar estudos com base em listas } \\
\text { variáveis de causa e efeito. }\end{array}$ \\
\hline
\end{tabular}




\begin{tabular}{|c|c|c|}
\hline $\begin{array}{l}\text { Habilidades de } \\
\text { Investigação, Projeto, } \\
\text { Comunicação \& } \\
\text { Ações }\end{array}$ & $\begin{array}{c}\text { MODELAGEM } \\
\text { (Demonstrações interativas do professor) }\end{array}$ & $\begin{array}{c}\text { PRÁTICA GUIADA } \\
\text { (Prática do estudante, com assistência } \\
\text { do professor) }\end{array}$ \\
\hline $\begin{array}{l}\text { Desenvolvimento de } \\
\text { Gráficos, mapas e } \\
\text { esquemas }\end{array}$ & $\begin{array}{l}\text { - Demonstre, preferivelmente com dados que } \\
\text { eles tenham coletado, como construir estas } \\
\text { representações. }\end{array}$ & $\begin{array}{l}\text { - Proporcione dados aos estudantes; } \\
\text { peça-lhes para preparar gráficos, } \\
\text { mapas e esquemas. }\end{array}$ \\
\hline $\begin{array}{l}\text { Desenvolver } \\
\text { conclusões prudentes }\end{array}$ & $\begin{array}{l}\text { - Proporcionar aos estudantes investigações por } \\
\text { amostragem, com dados e, em seguida, inferir } \\
\text { conclusões. Enfatizar que o projeto ou desenho } \\
\text { do teste deve ser avaliado e criticado antes da } \\
\text { extração da conclusão com base nos dados. }\end{array}$ & $\begin{array}{l}\text { - Forneça aos estudantes amostras } \\
\text { de pesquisas e, então, peça-lhes para } \\
\text { tirar conclusões prudentes. }\end{array}$ \\
\hline $\begin{array}{l}\text { Preparar relatórios } \\
\text { escritos }\end{array}$ & $\begin{array}{l}\text { - Proporcionar aos estudantes um checklist } \\
\text { para a produção de relatórios, assim como um } \\
\text { exemplo simples de relatório. }\end{array}$ & $\begin{array}{l}\text { - Forneça aos estudantes exemplos } \\
\text { de relatórios para avaliar cheklists. }\end{array}$ \\
\hline Debater conclusões & $\begin{array}{l}\text { - Proporcionar aos estudantes uma lista de } \\
\text { sugestões para debater de forma eficaz e usar } \\
\text { estes, como uma aula, para criticar um debate } \\
\text { gravado em vídeo. }\end{array}$ & $\begin{array}{l}\text { - Peça aos estudantes para debater } \\
\text { questões provavelmente importantes } \\
\text { para eles; por exemplo, o mérito de } \\
\text { pedalar ou caminhar para a escola vs } \\
\text { ir em um carro. }\end{array}$ \\
\hline $\begin{array}{l}\text { Distinguir objetivos de } \\
\text { pesquisa científica de } \\
\text { objetivos de projetos } \\
\text { tecnológicos }\end{array}$ & $\begin{array}{l}\text { - Ajude os estudantes a distinguir entre } \\
\text { interesses (objetivos) "científicos" e } \\
\text { "tecnológicos", discutindo com eles o que } \\
\text { "cientistas" poderiam fazer com objetos; por } \\
\text { exemplo, balões. }\end{array}$ & $\begin{array}{l}\text { - Peça aos estudantes para } \\
\text { determinar um objetivo de pesquisa } \\
\text { (científico) e um objetivo tecnológico } \\
\text { para cada um dos seguintes } \\
\text { fenômenos; por exemplo, sementes. }\end{array}$ \\
\hline Determinar problemas & $\begin{array}{l}\text { - Mostre que "problemas" são muitas vezes as } \\
\text { relações entre causa e efeito com resultados } \\
\text { "ruins". Mostre a eles como as "neuras" são } \\
\text { assim. }\end{array}$ & $\begin{array}{l}\text { - Peça aos estudantes para fazer uma } \\
\text { chuva de ideias sobre suas "neuras" } \\
\text { e decompor cada uma delas em uma } \\
\text { causa e um efeito "ruim". }\end{array}$ \\
\hline $\begin{array}{l}\text { Desenvolver soluções/ } \\
\text { invenções }\end{array}$ & $\begin{array}{l}\text { - Aponte que soluções podem ser desenvolvidas } \\
\text { por: i) uma chuva de ideias (brainstorming) sobre } \\
\text { as possíveis causas dos resultados "ruins" e, em } \\
\text { seguida, a partir da superação destas causas; ii) } \\
\text { uma combinação de velhas invenções com novas } \\
\text { formas de fazer etc. } \\
\text { - Aponte que inventar envolve tentativa e } \\
\text { erro e compromissos para alcançar a "melhor" } \\
\text { combinação de resultados; por exemplo, } \\
\text { inventar uma bicicleta de baixo peso pode fazer } \\
\text { com que ela seja frágil. }\end{array}$ & $\begin{array}{l}\text { - Coloque os estudantes para fazer } \\
\text { uma chuva de ideias sobre inventos } \\
\text { "velhos" e combinar estes inventos de } \\
\text { maneiras novas e úteis; } \\
\text { - Peça aos estudantes para } \\
\text { desenvolver invenções que atinjam } \\
\text { dois resultados concorrentes; por } \\
\text { exemplo, um paraquedas que desce } \\
\text { lentamente e com precisão. }\end{array}$ \\
\hline $\begin{array}{l}\text { Avaliar os efeitos } \\
\text { sociais e ambientais } \\
\text { negativos das } \\
\text { invenções }\end{array}$ & $\begin{array}{l}\text { - Discutir os efeitos negativos que eles associam } \\
\text { com várias invenções. Fornecer alguns estudos } \\
\text { de caso de outras invenções; por exemplo, danos } \\
\text { ao ouvido relacionados com música alta. } \\
\text { - Descrever estudos experimentais e de } \\
\text { correlação para avaliar invenções. }\end{array}$ & $\begin{array}{l}\text { - Peça aos estudantes para estudar } \\
\text { os efeitos de soluções salinas no } \\
\text { crescimento de feijoeiros (isto é, } \\
\text { imitando efeitos de escoamento do } \\
\text { sal da estrada); } \\
\text { - Coloque os estudantes para } \\
\text { conduzir um estudo comparativo } \\
\text { entre fumantes e não fumantes. }\end{array}$ \\
\hline $\begin{array}{l}\text { Desenvolvimento e } \\
\text { execução de ações } \\
\text { para melhorar as } \\
\text { coisas }\end{array}$ & $\begin{array}{l}\text { - Mostre aos estudantes exemplos de RiNA de } \\
\text { outros, executadas para melhorar as situações } \\
\text { de indivíduos, sociedades e/ou ambientes; por } \\
\text { exemplo, o estudo da reciclagem levando a } \\
\text { ações. }\end{array}$ & $\begin{array}{l}\text { - Peça aos estudantes para projetar } \\
\text { estudos e fazer pesquisas na } \\
\text { Internet para aprender sobre o } \\
\text { tabagismo; e, em seguida, que eles } \\
\text { projetem e desenvolvam uma ação } \\
\text { antitabagismo. }\end{array}$ \\
\hline
\end{tabular}

Fonte: Bencze (2015). 


\section{Apêndice C - Exemplo de atividade sobre "experimentos"}

Nome

Ciência: planejando experimentos

Ideias de cientistas e inventores

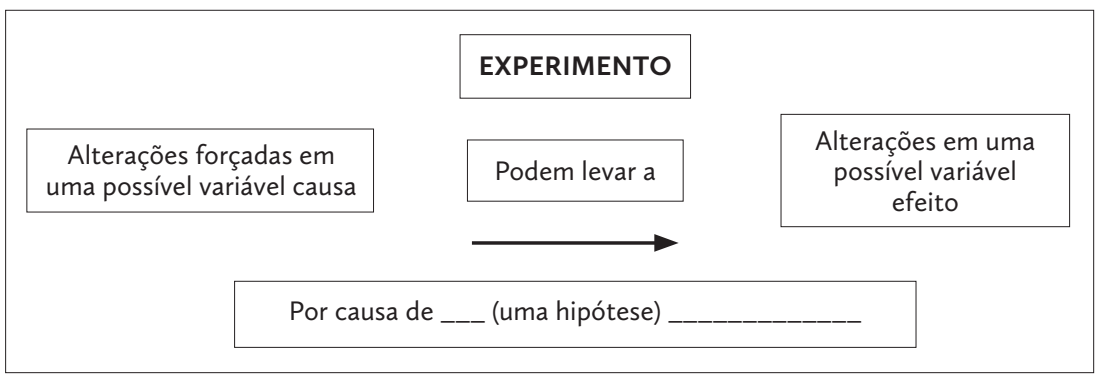

Para que as pessoas acreditem em certas ideias, elas geralmente querem ver evidências. Na ciência e na inovação, frequentemente elas vem de experimentos. Um "experimento" é um teste de uma previsão na qual uma possível variável causa é forçada a mudar para que nós possamos verificar o que esta mudança causa a uma possível variável efeito. Em vez de esperar que dois produtos químicos misturem-se um ao outro, por exemplo, nós forçaríamos diferentes quantidades da mistura. Ao longo dos anos, cientistas e inventores tentaram muitos modos diferentes de desenhar ou construir experimentos. $O$ exemplo abaixo mostra alguns tipos de métodos que muitos tentam seguir ao planejar experimentos úteis.

\section{Agora, faça você!}

Um exemplo de experimento para testar como diferentes tamanhos (circunferências) de balões influenciam na rapidez com que eles caem é mostrado abaixo. Seguindo as sugestões para o desenho/ projeto deste experimento, planeje um experimento sobre um tópico sugerido por seu professor.

\begin{tabular}{|c|c|c|}
\hline Fatores do desenho & Amostra do experimento & Teste \\
\hline Use diferentes valores da possível variável causa. & Circunferências $(\mathrm{cm}) 10,15,20,25,30,35,40 \mathrm{~cm}$. & \\
\hline $\begin{array}{l}\text { Use ao menos cinco cópias de cada quantidade } \\
\text { da possível variável causa. }\end{array}$ & $\begin{array}{l}\text { Haverá cinco balões similares inflados a diferentes } \\
\text { tamanhos: } 10,15,20,25,30,35,40 \mathrm{~cm} \text {. }\end{array}$ & \\
\hline Meça as possíveis variáveis causa e efeito. & $\begin{array}{l}\text { Tamanhos medidos com fitas métricas; tempo } \\
\text { para pouso com cronômetro e uma pessoa } \\
\text { dizendo, "comece!" e "termine!" }\end{array}$ & \\
\hline Repita cada mensuração e encontre a média. & $\begin{array}{l}\text { Duas pessoas farão cada mensuração; então será } \\
\text { calculada a média. }\end{array}$ & \\
\hline $\begin{array}{l}\text { Mantenha todas as outras variáveis causas } \\
\text { conhecidas não modificadas. }\end{array}$ & $\begin{array}{l}\text { Use o mesmo tipo de balão; solte-os da mesma } \\
\text { altura; certifique-se de que não há nenhuma brisa; } \\
\text { certifique-se de que a temperatura é a mesma. }\end{array}$ & \\
\hline Mensure uma segunda possível variável efeito. & $\begin{array}{l}\text { Meça a distância percorrida por um balão a partir } \\
\text { de um certo ponto. }\end{array}$ & \\
\hline $\begin{array}{l}\text { Planeje fazer descrições de possíveis variáveis } \\
\text { causa e efeito. }\end{array}$ & $\begin{array}{l}\text { Descreva a cor e o formato dos balões de } \\
\text { diferentes tamanhos; observe qualquer oscilação à } \\
\text { medida em que o balão cai. }\end{array}$ & \\
\hline Planeje uma tabela de coleta de dados. & Refira-se a uma tabela do professor. & \\
\hline
\end{tabular}




\title{
Apêndice D - Exemplo de atividade sobre "experimentos".
}

\author{
$\mathrm{SCH}_{3} \mathrm{U}$ - Introdução a Estudos de Correlação
}

Sr. Krstovic

\section{Parte I) Introdução a Estudos de Correlação e de Variáveis}

Um experimento é uma atividade em que uma ou mais variáveis independentes (causa) são forçadas a mudar. Por exemplo, para testar o efeito de diferentes tipos de solo sobre o crescimento de plantas de feijão, podemos conduzir um experimento usando diferentes tipos de solos (variável independente causa) e medir a altura resultante da planta de feijão (variável dependente - efeito).

Ainda, nós podemos encontrar algumas plantas de feijão na natureza, medir suas alturas e examinar o tipo de solo em cada. Nós podemos, então, ver se há uma relação entre a altura da planta e o tipo de solo. Este tipo de pesquisa seria um estudo, não um experimento. Permite-se que a variável independente (causa) mude naturalmente. Também seria um estudo de correlação, porque nós estaríamos comparando (correlacionando) como mudanças em uma variável (por exemplo, tipos de solo) pode afetar mudanças em outra variável (por exemplo, altura da planta).

Estudos de correlação são úteis quando não é recomendado eticamente medir as mudanças na variável efeito, resultante de certas variáveis causa. Com tipos de solo e crescimento de plantas de feijão seria melhor conduzir um experimento. Entretanto, se desejamos estudar a relação entre fumo e pessoas que desenvolvem câncer de pulmão, então nós conduziríamos um estudo. Não é correto (eticamente) forçar um grupo de pessoas a fumar e observar se eles desenvolvem câncer de pulmão.

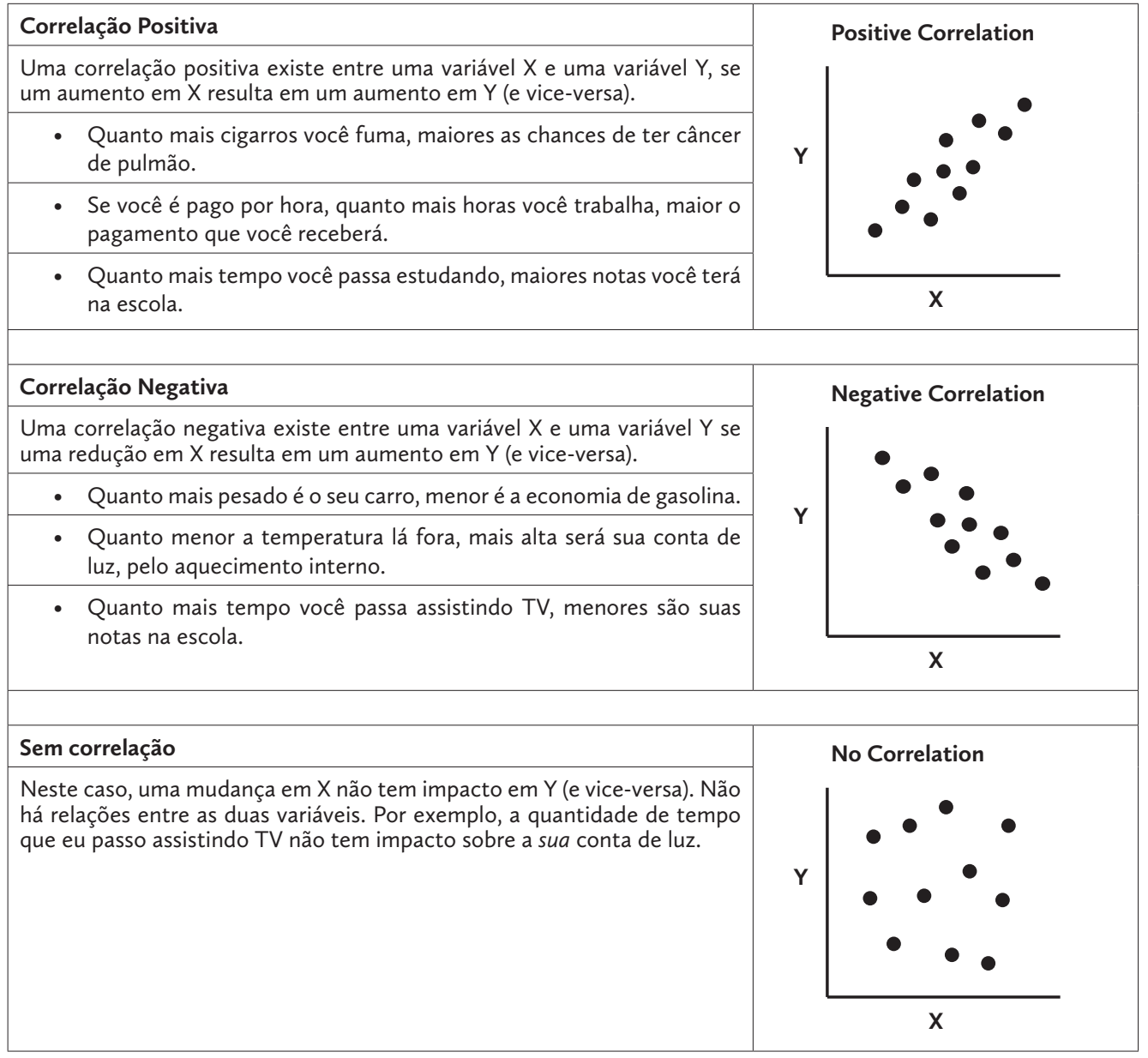

554 | Larry Bencze / Sarah El Halwany / Mirjan Krstovic / Minja Milanovic / Christina Phillips / Majd Zouda 
1) Usando a seguinte tabela, ligue cada variável causa a sua variável efeito. Pode existir mais de uma resposta possível.

\begin{tabular}{|l|l|}
\hline Variáveis causa (independentes) & Variáveis efeito (dependentes) \\
\hline Vegetarianismo & Audição de adolescentes \\
\hline Música de rock & Aprendizagem de adolescentes \\
\hline Exercício & Altura da planta \\
\hline Hormônios & Crescimento de bactérias \\
\hline Drogas & Comportamento agressivo \\
\hline Assistir TV & Forma física \\
\hline Temperatura & Força muscular \\
\hline
\end{tabular}

2) Como você poderia conduzir as investigações a seguir? Você realizaria um experimento ou conduziria um estudo? Identifique as variáveis independente (VI) e dependente (VD) em cada caso. Além disso, pense naquilo que você teria que controlar!

a) Os efeitos do consumo de cigarros sobre a frequência de tosse

\begin{tabular}{|l|l|l|l|}
\hline Estudo & Experimento & VI: & VD: \\
\hline
\end{tabular}

b) Solubilidade do sal em várias temperaturas

\begin{tabular}{|l|l|l|l|}
\hline Estudo & Experimento & VI: & VD: \\
\hline
\end{tabular}

c) Quantidade de tempo em frente ao computador e qualidade do sono

\begin{tabular}{|l|l|l|l|}
\hline Estudo & Experimento & VI: & VD: \\
\hline
\end{tabular}

d) O efeito do $\mathrm{pH}$ sobre a corrosão do metal

\begin{tabular}{|l|l|l|l|}
\hline Estudo & Experimento & VI: & VD: \\
\hline
\end{tabular}

e) Tempo que você passou jogando video game e suas notas na escola

\begin{tabular}{|l|l|l|l|}
\hline Estudo & Experimento & VI: & VD: \\
\hline
\end{tabular}


Parte II) Preparando-se para executar um estudo - Praticando a coleta de dados em aula e determinando a correlação entre duas variáveis

Questão 1: há correlação entre gênero e memória?

Questão 2: há correlação entre tamanho da mão e habilidade para equilibrar uma régua de um metro, verticalmente na ponta do dedo médio da mão com a qual você escreve?

Tabela de coleta de dados:

\begin{tabular}{|l|l|l|l|}
\hline $\begin{array}{l}\text { Nome do estudante } \\
\text { (Gênero) }\end{array}$ & $\begin{array}{l}\text { Número médio de } \\
\text { cartas memorizadas }\end{array}$ & $\begin{array}{l}\text { Comprimento } \\
\text { da mão (cm) }\end{array}$ & $\begin{array}{l}\text { Tempo em } \\
\text { equilíbrio (s) }\end{array}$ \\
\hline & & & \\
\hline & & & \\
\hline & & & \\
\hline & & & \\
\hline & & & \\
\hline & & & \\
\hline
\end{tabular}

Análise:

1) Construa um gráfico de barras para mostrar o número médio de cartas memorizadas por mulheres e homens. Diga se há qualquer correlação entre gênero e memória em nossa turma.

2) Construa um gráfico com pontos plotados do tempo de equilíbrio (eixo-Y) e tamanho da mão (eixo-X). Determine se há correlação entre tamanho da mão e tempo de equilíbrio para os estudantes em nossa turma. 


\title{
Apêndice E - Projeto de Ação Negociada e informada por pesquisa (RiNA) sobre mudança climática
}

\author{
Ciências ( $1^{\circ}$ ano do ensino médio*)
}

\section{Introdução}

A mudança climática é uma das questões mais importantes que a humanidade enfrenta e continuará a enfrentar no futuro. Neste projeto, você terá uma oportunidade de realizar ações para abordar algumas das questões relacionadas à mudança climática.

Passos para o Projeto de Ação sobre CTSA e mudança climática

1) Selecionar seu grupo e sua questão: recentemente você completou a atividade da pegada de carbono na qual você determinou a quantidade de dióxido de carbono que você produz através de várias atividades, e como sua pegada de carbono se compara à média no seu país. Nesta atividade você respondeu questões que se relacionam às questões do dia a dia como transporte, consumo de água, reciclagem, alimentação etc. Você e seu grupo (máximo de 4 pessoas) irão escolher uma destas atividades que contribui para a mudança climática, e seguir os passos esboçados aqui para completar este projeto de RiNA. Dois grupos podem explorar a mesma questão.

2) Expressando as suas ideias: antes de começar uma nova pesquisa sobre sua questão selecionada que contribui para a mudança climática, você deve expressar o que você já sabe sobre a questão (por exemplo, o que faz disso uma questão relevante? Quem são os grupos poderosos que suportam e que se opõem a esta questão? Quais são as consequências sobre o bem-estar de indivíduos, sociedades e ambientes?). Inclua suas ideias sobre como abordar alguns dos problemas que surgem a partir destas questões (por exemplo, Como encorajamos mais pessoas a reciclar na escola durante o almoço?)

3) Pesquisa secundária: aprenda mais sobre a questão. Você terá algum tempo em aula para conduzir uma pesquisa na internet (alguma informação pode ser encontrada também em seu livro didático). Você deve abordar as seguintes perguntas ou áreas sobre a questão:

i. Como a sua questão se relaciona à mudança climática? Por exemplo, como a sua escolha de consumir mais carne aumenta a sua pegada de carbono? Explique os conceitos científicos relevantes (por exemplo, efeito estufa antropogênico).

ii. Quem são os atores sociais (stakeholders) relevantes? Identifique grupos poderosos que apoiam a questão (por exemplo, companhias de petróleo, governos) e grupos que se opõem à questão (por exemplo, ambientalistas, ativistas). Explique as posições deles. Declare a sua posição sobre a questão.

iii. Pesquise ao menos três (3) fatos interessantes! Por exemplo, se você está explorando a questão do transporte, quantos carros estão em circulação por dia? Quanto $\mathrm{CO}_{2}$ é emitido por carro? Se você está aprendendo sobre consumo de água, que país consome mais água por pessoa? Quanta água seria economizada se chuveiros de baixa pressão são usados ao invés de chuveiros de alta pressão?

iv. Explorando consequências adicionais e ações: quais seriam as outras consequências que a sua questão selecionada pode ter sobre o bem-estar de indivíduos, sociedades e ambientes? Por exemplo, muitas aves se enganam com tampas de garrafas d'água e sacolas de plástico, e por isso, morrem após comer tais objetos. Portanto, é muito importante que estes itens não terminem indo para os nossos ambientes naturais. Também, você deve buscar o que já tem sido feito para abordar sua questão. Por exemplo, veículos híbridos são produzidos como alternativas para veículos movidos apenas a gasolina.

4) Conduzindo um estudo: seu grupo desenvolverá um levantamento de informações consistindo de três a cinco questões para aprender mais sobre o assunto. Sua variável independente (variável causa) pode ser gênero, idade ou nível de estudo. Sua amostra deve ser composta de aproximadamente 25-30 estudantes, no entanto, quanto maior o tamanho da amostra mais confiáveis serão seus resultados.

* Nota do tradutor: traduzimos para o equivalente no Brasil. No original, os autores se referem ao $10^{\text {th }}$ grade (Sophomore), do ano escolar norte-americano. 
5) Análise dos dados: você deve calcular os seus resultados, colocar os dados em um gráfico (por exemplo, em um gráfico de barras) para mostrar se há alguma correlação entre gênero (ou idade/ nível de educação etc.) e quaisquer variáveis dependentes (variáveis efeito) que você estudou (por exemplo, modos de transporte, escolhas alimentares etc.).

6) Proponha e execute suas ações: você e seu grupo proporão cursos práticos de ação para abordar suas questões (por exemplo, desenvolver um folheto ou vídeo, influenciar grupos poderosos, criar cartazes atraentes sobre reciclagem na escola, escrever uma carta a um jornal local etc.). Sua pesquisa (tanto em buscas de internet quanto em estudos de correlação) deve informar a escolha de sua ação.

7) Agindo: uma vez que você preparou suas ações, você terá que colocá-las em prática. Esta é a parte emocionante! Se você fez um folheto, você precisa distribuir diretamente às pessoas na escola, ou na comunidade. Se você fez um vídeo, você pode postá-lo no YouTube e pedir a seus amigos para compartilhá-lo nas mídias sociais.

8) Defenda suas ações: durante a aula, sua equipe terá 10-15 minutos para defender suas ações. Você nos contará que questão da mudança climática você estudou, o que você aprendeu do estudo que você conduziu e que ações seu grupo executou para abordar a questão.

9) Entregue o seu projeto de ação sobre a mudança climática: cada pessoa terá que entregar um relatório escrito após a finalização do seu projeto de ação sobre CTSA. Por favor, veja a ficha de avaliação para uma lista de itens que precisariam ser abordados no seu relatório.

\section{Critérios de sucesso para pesquisa secundária (em internet, livros didáticos, artigos etc.)} (1- Emergente; 2 - Proficiente; 3 - Altamente treinado; 4 - Exemplar)

\begin{tabular}{|c|c|c|}
\hline \multirow{4}{*}{ 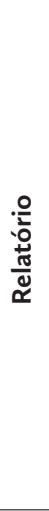 } & $\begin{array}{l}\text { 1.1. Introdução: a questão CTSA é claramente descrita em suas próprias palavras } \\
\text { 1.2. Conexão com a mudança climática: a conexão da questão com a mudança } \\
\text { climática é evidente na sua descrição } \\
\text { 1.3. Fatos e detalhes: ao menos três fatos e detalhes interessantes sobre sua } \\
\text { questão estão presentes }\end{array}$ & 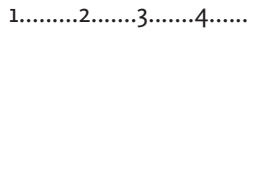 \\
\hline & $\begin{array}{l}\text { 2.1 - } 2.3 \text { Consequências negativas: explicações claras e completas de uma } \\
\text { consequência negativa sobre o bem-estar de indivíduos, sociedades e/ou } \\
\text { ambientes e sugestões claras (ao menos uma) para lidar com a questão }\end{array}$ & 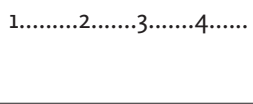 \\
\hline & $\begin{array}{l}\text { 3.1 Tomadores de decisão importantes/atores sociais poderosos: você identificou } \\
\text { claramente os atores sociais poderosos (tomadores de decisão/stakeholders } \\
\text { relevantes) e suas influências }\end{array}$ & $1, \ldots \ldots \ldots .2 \ldots \ldots .3 \cdots \cdots \cdot 4 \cdots \cdots$ \\
\hline & $\begin{array}{l}\text { A informação que você pesquisou é relevante, detalhada e precisa com } \\
\text { referências presentes (ao menos duas); está sintetizada em aproximadamente } \\
400-500 \text { palavras (ou 1-1,5 página, espaçamento duplo) }\end{array}$ & 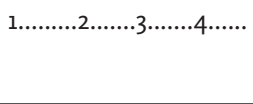 \\
\hline \multicolumn{2}{|r|}{ NIVVL GERAL DE ALCANCE PARA A PESQUISA SECUNDÁRIA } & $1 \ldots \ldots \ldots . .2 \ldots \ldots . \cdots 3 \cdots \cdots . \cdots \cdots$ \\
\hline \multicolumn{3}{|c|}{ Critérios de sucesso para pesquisa primária (estudos de correlação) } \\
\hline \multirow{5}{*}{ 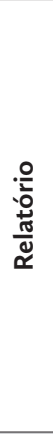 } & $\begin{array}{l}\text { 4.1. Foco do estudo: o foco do estudo estava claramente enunciado e suas } \\
\text { variáveis (causa/efeito) são identificadas. O método para o seu estudo está } \\
\text { claramente descrito em um parágrafo curto (cerca de } 100 \text { palavras) } \\
\text { 4.2. Análise de dados: seus dados são claramente mostrados nas tabelas; há } \\
\text { gráficos apropriados com títulos claros, eixos identificados e uma legenda }\end{array}$ & 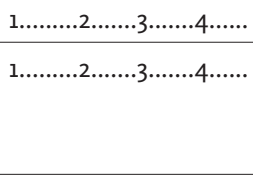 \\
\hline & \multirow{4}{*}{$\begin{array}{l}\text { 5.1. Sumário de resultados: sintetize seus resultados em um parágrafo curto } \\
\text { (cerca de } 100 \text { palavras) } \\
\text { 5.2. Interpretação dos resultados: proponha uma explicação clara e profunda para } \\
\text { seus resultados (cerca de } 100 \text { palavras) } \\
\text { 5.3. Sugestões para melhorias: discuta possíveis limitações nos seus resultados/ } \\
\text { métodos e sugira ao menos um caminho para melhorar seu estudo (cerca de } 100 \\
\text { palavras) }\end{array}$} & 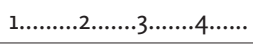 \\
\hline & & 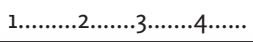 \\
\hline & & 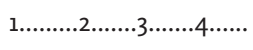 \\
\hline & & \\
\hline \multicolumn{2}{|r|}{ NIIVEL GERAL DE ALCANCE PARA A PESQUISA PRIMÁRIA } & 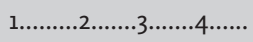 \\
\hline
\end{tabular}


Critérios de sucesso para pesquisa secundária (em internet, livros didáticos, artigos etc.) (1- Emergente; 2 - Proficiente; 3 - Altamente treinado; 4 - Exemplar)

\section{Critérios de sucesso para as ações propostas e executadas}

\begin{tabular}{|c|c|c|}
\hline \multirow{2}{*}{$\frac{\frac{n}{\pi}}{\frac{\pi}{2}}$} & $\begin{array}{l}\text { Suas ações propostas são lógicas e com um foco claro que é negociado e } \\
\text { informado por pesquisa }\end{array}$ & 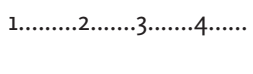 \\
\hline & $\begin{array}{l}\text { Seus materiais disponíveis são apresentáveis (boa qualidade), completos e estão } \\
\text { incluídos em seu relatório (por exemplo, uma amostra de um folheto, um link para } \\
\text { seu vídeo no YouTube etc.) }\end{array}$ & \\
\hline \multirow{3}{*}{ 象 } & $\begin{array}{l}\text { 6.1. Implementação da ação: descreva como sua ação foi (ou será) implementada } \\
\text { e como ela contribuiu/contribuirá para uma mudança positiva para o bem-estar } \\
\text { de indivíduos, sociedades e ambientes }\end{array}$ & 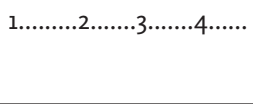 \\
\hline & $\begin{array}{l}\text { 7.1. Reflexão: reflita sobre experiência de aprendizagem abordando as seguintes } \\
\text { questões: }\end{array}$ & 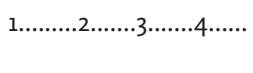 \\
\hline & $\begin{array}{l}\text { i) O que você aprendeu executando este projeto? } \\
\text { ii) De que modo este projeto foi diferente de outros projetos que você já } \\
\text { participou no passado em ciências (ou outros cursos)? } \\
\text { iii) Você estaria interessado em executar um outro projeto como este em sala de } \\
\text { aula? Por que sim ou por que não? } \\
\text { (observação: estas questões não têm uma resposta certa ou errada, sua resposta } \\
\text { honesta e completa lhe dará pontuação total) }\end{array}$ & \\
\hline \multicolumn{2}{|r|}{ NÍVEL GERAL DE ALCANCE PARA O PLANO DE AÇÃO } & 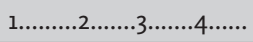 \\
\hline \multicolumn{3}{|c|}{ Avaliação da comunicação oral } \\
\hline \multicolumn{3}{|c|}{ Sua parte da apresentação alcançou os seguintes critérios } \\
\hline \multicolumn{2}{|r|}{ Foi organizada, lógica e numa duração de tempo apropriada } & 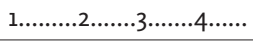 \\
\hline \multicolumn{2}{|r|}{ Você falou claramente, em bom tom - foi fácil ouvir e entender você } & 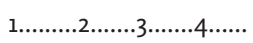 \\
\hline \multicolumn{2}{|r|}{$\begin{array}{l}\text { Você estabeleceu um bom contato visual com um mínimo de leitura ou uso dos } \\
\text { apontamentos escritos }\end{array}$} & 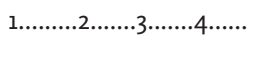 \\
\hline \multicolumn{2}{|r|}{$\begin{array}{l}\text { Você foi confiante com relação à informação que apresentou e se questionado sobre } \\
\text { algo, respondeu bem }\end{array}$} & 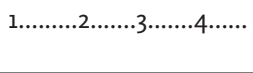 \\
\hline \multicolumn{2}{|r|}{ O conteúdo da apresentação foi preciso e apropriado para a audiência } & 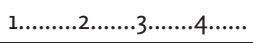 \\
\hline \multicolumn{2}{|r|}{ NIVEL GERAL DE ALCANCE PARA A COMUNICAÇÃO ORAL } & 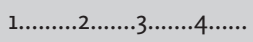 \\
\hline
\end{tabular}




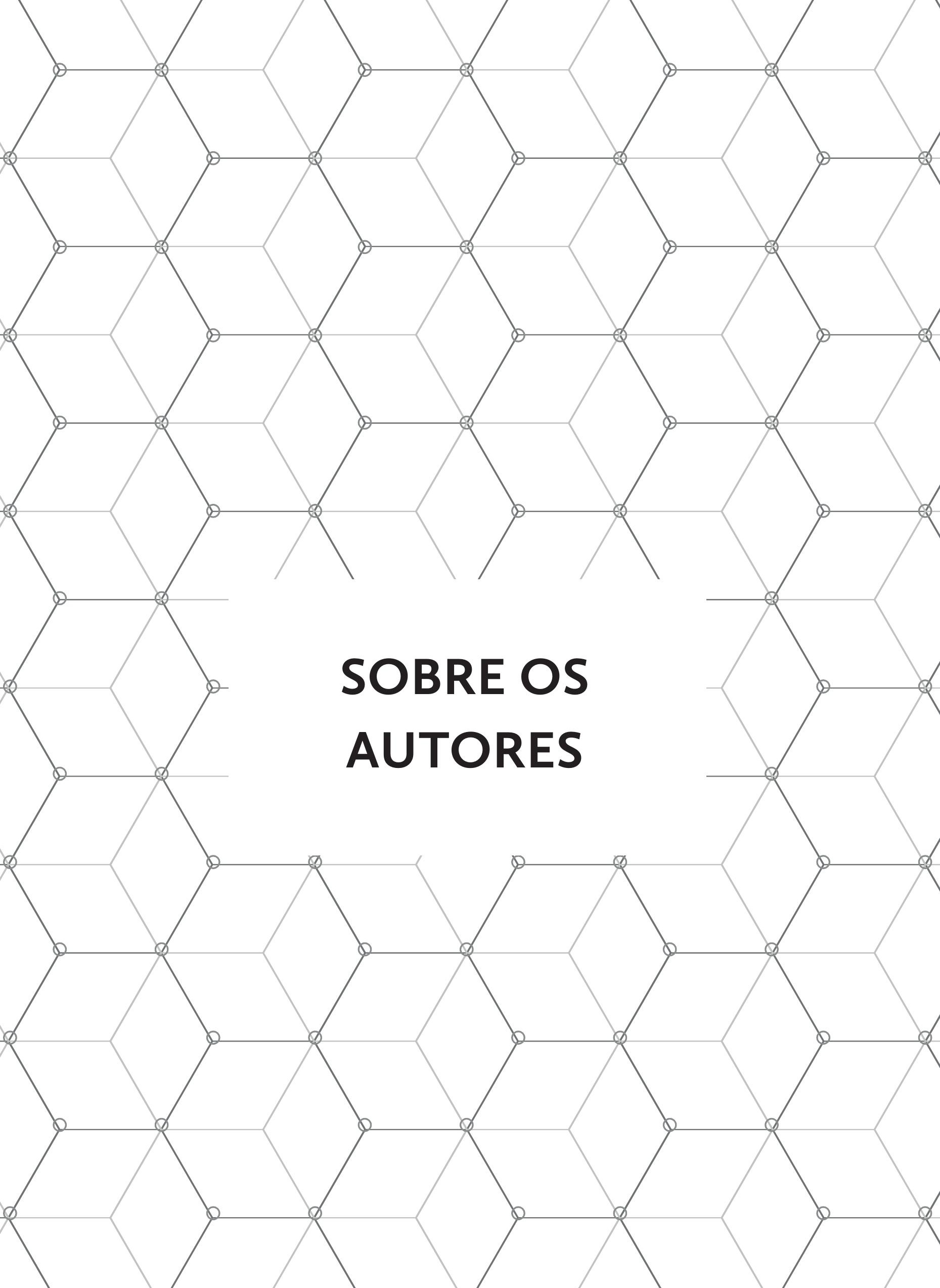




\section{Amanda Amantes}

Física. Doutora em Educação. Integrante do grupo de pesquisa em Ensino de Ciências e Matemática (EnCiMa) e Coordenadora do LAMPEMEC da Faculdade de Educação (Faced), Programa de Pós-Graduação em Educação da Universidade Federal da Bahia (UFBA). Programa de Pós-Graduação em Ensino, Filosofia e História das Ciências (PPGEFHC) da UFBA e Universidade Estadual de Feira de Santana (UEFS), na Bahia. E-mail: amandaamantes@gmail.com

\section{Ana Paula Miranda Guimarães}

Bióloga. Doutora em Genética e Biologia Molecular. Professora no Instituto Federal de Educação, Ciência e Tecnologia da Bahia, (IFBA), campus Camaçari, Bahia.

E-mail: apmguima@gmail.com

\section{Ana Rita Marques}

Bióloga e Professora de Biologia e Geologia. Doutoranda em Educação na especialidade da Didática das Ciências no Instituto de Educação da Universidade de Lisboa, Alameda da Universidade, Portugal.

E-mail: arlm@campus.ul.pt

\section{Anna Cássia Sarmento}

Bióloga. Doutoranda em Ensino, Filosofia e História das Ciências do Programa de PósGraduação em Ensino, Filosofia e História das Ciências (PPGEFHC) da Universidade Federal da Bahia (UFBA) e Universidade Estadual de Feira de Santana (UEFS), na Bahia. Professora no Colégio da Polícia Militar (CPM), Unidade Dendezeiros, Salvador, Bahia. E-mail: anna.cassia01@gmail.com

\section{Blandina F. Viana}

Agrônoma e Bióloga. Doutora em Ecologia. Pesquisadora PQ 1D do CNPq. Professora Titular do Instituto de Biologia e coordenadora do Laboratório de Biologia e Ecologia de Abelhas (LABEA), da Universidade Federal da Bahia (UFBA).

E-mail: blande.viana@gmail.com

\section{Cássia Regina Reis Muniz}

Bióloga. Mestre e doutoranda em Ensino, Filosofia e História das Ciências do Programa de Pós-Graduação em Ensino, Filosofia e História das Ciências (PPGEFHC) da Universidade Federal da Bahia (UFBA) e Universidade Estadual de Feira de Santana (UEFS), na Bahia. Professora do Colégio da Polícia Militar (CPM), unidade Dendezeiros, Salvador, Bahia.

E-mail: casmuniz@gmail.com 


\section{Charbel N. El-Hani}

Biólogo. Doutor em Educação. Pesquisador PQ 1B do CNPq. Professor Titular do Instituto de Biologia Geral e coordenador do Laboratório de Ensino, Filosofia e História da Biologia (Lefhbio) e coordenador do INCT em Estudos Interdisciplinares e Transdisciplinares em Ecologia e Evolução (INCT IN-TREE), da Universidade Federal da Bahia (UFBA).

E-mail: charbel.elhani@gmail.com

\section{Christina Phillips}

Bacharel em Ciências/Biologia. Licenciada em Biologia e Química. Mestre em Conservação Florestal. Doutoranda em Educação no Instituto Ontário para Estudos em Educação, na Universidade de Toronto. Professora monitora do Departamento de Educação da Universidade de Iorque, Toronto, Ontário, Canadá.

E-mail: c.phillips@mail.utoronto.ca

\section{Claudia Sepúlveda}

Bióloga. Doutora em Ensino, Filosofia e História das Ciências. Professora Titular do Departamento de Educação e coordenadora do Grupo Colaborativo de Pesquisa em Ensino de Ciências (GCPEC) da Universidade Estadual de Feira de Santana (UEFS), Bahia.

E-mail: sepulveda.cau@gmail.com

\section{Clívio Pimentel-Júnior}

Licenciado em Biologia. Mestre e doutorando em Educação do Programa de PósGraduação em Educação (PPGE). Professor Assistente na Universidade Federal do Oeste da Bahia (UFOB) e colaborador do grupo de pesquisa Formação em Exercício de Professores (FEP) da Faculdadede Educação da Bahia (Faced), Universidade Federal da Bahia (UFBA).

E-mail: clivio.pimentel@gmail.com

\section{Dália Melissa Conrado}

Bacharel e licenciada em Ciências Biológicas. Doutora em Ecologia. Doutora em Ensino, Filosofia e História das Ciências e pesquisadora do Laboratório de Ensino, Filosofia e História da Biologia (Lefhbio) e do INCT em Estudos Interdisciplinares e Transdisciplinares em Ecologia e Evolução (INCT IN-TREE) da Universidade Federal da Bahia (UFBA).

E-mail: dalia.ufba@gmail.com 


\section{Derek Hodson}

Bacharel em Química. Mestre em Ensino de Ciências pela Universidade de Wales. Doutor em Química pela Universidade de Manchester. Professor de Educação Científica da Faculdade de Educação, Universidade de Auckland, na Nova Zelândia. Professor emérito do Instituto de Ontário para estudos da Educação. Universidade de Toronto, Canadá.

E-mail: d.hodson@auckland.ac.nz

\section{Felipe Melo Souza Santos}

Psicólogo. Mestrando pelo Programa de Pós-Graduação em Psicologia, da Universidade Federal da Bahia (UFBA).

E-mail: felipemelo@outlook.com.br

\section{Grégory Alves Dionor}

Licenciado em Ciências Biológicas. Mestrando em Ensino, Filosofia e História das Ciências pela Universidade Federal da Bahia (UFBA) e Universidade Estadual de Feira de Santana (UEFS).

E-mail: gadionor.bio@gmail.com

\section{Helaine Silva Souza}

Licenciada em Matemática. Mestre em Ensino, Filosofia e História das Ciências. Professora de Matemática do Ensino Fundamental e Médio da Secretaria de Educação do Estado da Bahia, Salvador, Bahia.

E-mail: helainessouza@hotmail.com

\section{Ingrid Ximena Arias Hodge}

Licenciada em Química pela Universidade Pedagógica Nacional. Mestranda em Educação nas Ciências pela Universidade Regional do Noroeste do Estado do Rio Grande do Sul. Pesquisadora do grupo Alternaciencias, na Universidade Pedagógica Nacional, Bogotá, Colômbia.

E-mail: mena.45@hotmail.com

\section{Ítalo Nascimento de Carvalho}

Biólogo. Mestre e doutorando em Ensino, Filosofia e História das Ciências.

Pesquisador do Laboratório de Ensino, Filosofia e História da Biologia (Lefhbio) da Universidade Federal da Bahia (UFBA).

E-mail: italonc@hotmail.com 


\section{Jéssica Santos}

Bióloga. Mestre em Ensino, Filosofia e História das Ciências. Professora de Ciências do Ensino Fundamental da Secretaria de Educação do Estado da Bahia. Salvador, Bahia.

E-mail: jjcsanto@gmail.com

\section{Jordi Solbes}

Licenciado em Física. Doutor em Física. Professor Titular de Didática das Ciências Experimentais e Sociais da Universidade de Valência, na Espanha.

E-mail: Jordi.solbes@uv.es

\section{Juanma Sánchez Arteaga}

Biólogo. Doutor em Ciências Biológicas pela Universidade Autônoma de Madrid. Professor adjunto no Instituto de Humanidades, Artes e Ciências Professor Milton Santos (lhac) da Universidade Federal da Bahia (UFBA). Pesquisador do Laboratório de Ensino, Filosofia e História da Biologia (Lefhbio), da UFBA.

E-mail: juanma.ufba@gmail.com

\section{Karolina Martins Almeida e Silva}

Licenciada em Ciências Biológicas. Mestre em Educação em Ciências e Matemática. Doutora em Educação pela Universidade de Brasília (UnB). Professora do curso de licenciatura em Biologia da Universidade Federal do Tocantins (UFT), campus de Araguaína.

E-mail: karolinaeducabio@gmail.com

\section{Kelly Meneses Fernandes}

Licenciada em Ciências Biológicas. Mestra pelo Programa de Pós-Graduação em Educação, Contextos Contemporâneos e Demandas Populares (PPGEduc) da Universidade Federal Rural do Rio de Janeiro (UFRRJ).

E-mail: popovi12@gmail.com

\section{Larry Bencze}

Bacharel em Biologia e licenciado em Biologia e Química. Mestre em Genética Molecular. Doutor em Educação Científica. Professor associado do Instituto Ontário para Estudos em Educação (OISE) da Universidade de Toronto, Ontário, Canadá. E-mail: larry.bencze@utoronto.ca 


\section{Leonardo Fabio Martínez Pérez}

Licenciado em Química. Doutor em Educação para a Ciência. Mestre em Docência da Química. Professor do Departamento de Química e do Doutorado Interinstitucional em Educação e Diretor da Faculdade de Ciência e Tecnologia. Universidade Pedagógica Nacional. Coordenador do Grupo Alternaciencias, Bogotá, Colômbia.

E-mail: lemartinez@pedagogica.edu.co

\section{Liziane Martins}

Licenciada em Ciências Biológicas. Doutora em Ensino, Filosofia e História das Ciências pela Universidade Federal da Bahia (UFBA) e Universidade Estadual de Feira de Santana (UEFS). Professora assistente do curso de licenciatura em Ciências Biológicas da Universidade do Estado da Bahia (UNEB), Departamento de Educação (DEDC), campus X), Teixeira de Freitas, Bahia.

E-mail: lizimartins@gmail.com

\section{Lucas Vinícius Ferraz}

Licenciando em Ciências Biológicas pela Universidade do Estado da Bahia (UNEB), Departamento de Educação (DEDC), campus X), Teixeira de Freitas, Bahia.

E-mail: lucasbio93@gmail.com

\section{Luciana Passos Sá}

Licenciada em Química e Doutora em Ciências (Universidade Federal de São Carlos). Professora Titular na Universidade Estadual de Santa Cruz, Ilhéus, Bahia, Brasil. E-mail: lucianapsa@gmail.com

\section{Majd Zouda}

Bacharel em Microbiologia. Mestre em Microbiologia Médica pela Universidade do Kuwait. Doutoranda em Ensino de Ciências no Instituto Ontário para Estudos em Educação (OISE), na Universidade de Toronto, Ontário, Canadá.

E-mail: majd.zouda@mail.utoronto.ca

\section{Maria Aparecida da Silva Andrade}

Licenciada em Ciências Biológicas. Mestre e doutoranda pelo Programa de PósGraduação em Ensino, Filosofia e História das Ciências (PPGEFHC). Professora assistente da Universidade Federal do Recôncavo da Bahia (UFRB). Pesquisadora do grupo de pesquisa em Ensino de Ciências e Matemática (EnCiMa) da Universidade Federal da Bahia (UFBA).

E-mail: cidaandrade88@hotmail.com 


\section{Martha Nury Bonilla Castañeda}

Licenciada em Química. Doutora e mestre em Docência da Química. Professora da Secretaria de Educação de Bogotá. Grupo Alternaciencias, Bogotá, Colômbia.

E-mail: manubocaagua@hotmail.com

\section{Mateus de Mattos Souza}

Psicólogo. Mestre em Ensino, Filosofia e História das Ciências. Professor do curso de Psicologia da Universidade Estadual de Feira de Santana (UEFS), Bahia.

E-mail: mateusmatt@gmail.com

\section{Maurício Cardoso Borges Lacerda Moura}

Psicólogo. Mestrando pelo Programa de Pós-Graduação em Psicologia da Universidade Federal da Bahia (UFBA), Salvador.

E-mail: mcblmoura@gmail.com

\section{Minja Milanovic}

Bacharel em Biologia. Departamento de Biologia Celular e de Sistemas. Instituto Ontário para Estudos em Educação (OISE), Universidade de Toronto, Ontário, Canadá.

E-mail: minja_2003@hotmail.com

\section{Mirjan Krstovic}

Bacharel em Ciências e licenciado em Biologia e Química. Mestre em Educação. Professor de Química do Colégio Erindale, Mississauga, Ontário. Instituto Ontário para Estudos em Educação da Universidade de Toronto, Ontário, Canadá.

E-mail: mirjan.krstovic@peelsb.com

\section{Mônica Silveira}

Engenheira eletricista. Mestre em Regulação da Indústria de Energia pela Universidade Salvador (UNIFACS). Doutoranda em Ensino, Filosofia e História das Ciências pela Universidade Federal da Bahia (UFBA) e Universidade Estadual de Feira de Santana (UEFS). Professora do Instituto Federal da Bahia (IFBA), campus Simões Filho, Bahia. E-mail: monica.silveira@ifba.edu.br

\section{Nei Nunes-Neto}

Biólogo. Doutor em Ecologia. Professor adjunto Il do Instituto de Biologia, coordenador do Laboratório de Ensino, Filosofia e História da Biologia (Lefhbio) e 
pesquisador do INCT em Estudos Interdisciplinares e Transdisciplinares em Ecologia e Evolução (INCT IN-TREE) da Universidade Federal da Bahia (UFBA).

E-mail: nunesneto@gmail.com

\section{Nidia Torres}

Licenciada em Biologia e Química. Doutora em Didáticas específicas: Ciências Experimentais. Faculdade de Educação. Universidade Pedagógica e Tecnológica da Colômbia, Tunja, Boyacá, Colômbia.

E-mail: nidia.torres@uptc.edu.co

\section{Pedro Reis}

Biólogo. Doutor em Didática das Ciências. Professor associado e subdiretor do Instituto de Educação da Universidade de Lisboa. Co-coordenador do Programa de Doutorado em Didática das Ciências, Alameda da Universidade, Lisboa, Portugal. E-mail: preis@ie.ulisboa.pt

\section{Regina Palácio}

Economista. Mestre em Regulação da Indústria de Energia pela Universidade Salvador (UNIFACS). Doutoranda pelo Programa de Pós-Graduação em Ensino, Filosofia e História das Ciências (PPGEFHC) da Universidade Federal da Bahia (UFBA) e Universidade Estadual de Feira de Santana (UEFS). Professora do Instituto Federal da Bahia (IFBA), campus Simões Filho, Bahia.

E-mail: reginapalacio@ifba.edu.br

\section{Rosiléia Oliveira de Almeida}

Bióloga. Doutora em Educação. Professora adjunta da Faculdade de Educação da UFBA e dos Programas de Pós-Graduação em Educação (UFBA) e Ensino, Filosofia e História das Ciências (UFBA/UEFS). Pesquisadora do grupo de pesquisa em Ensino de Ciências e Matemática (EnCiMa) da Universidade Federal da Bahia (UFBA), campus do Canela, Salvador.

E-mail: rosileiaoalmeida@hotmail.com

\section{Salete Linhares Queiroz}

Graduada em Química Industrial. Doutora em Química pela Universidade Estadual Paulista Júlio de Mesquita Filho (UNESP). Livre docente do Instituto de Química de São Carlos, Universidade de São Paulo (USP), São Carlos.

E-mail: salete@iqsc.usp.br 


\section{Sarah El Halwany}

Bacharel em Biologia. Mestre em Educação pela Universidade Americana de Beirute.

Doutoranda em Estudos Curriculares e Desenvolvimento Docente no Instituto Ontário para Estudos em Educação (OISE), Universidade de Toronto, Ontario, Canadá.

E-mail: sarah.elhalwany@mail.utoronto.ca

\section{Shirley Margareth Buffon da Silva}

Licenciada em Biologia. Mestre em Biotecnologia Genômica. Doutora em Educação pela Faculdade de Educação da Universidade de Brasília (UnB). Professora da Secretaria de Educação do Distrito Federal.

E-mail: shirleybuffon@yahoo.com.br

\section{Thiago Leandro da Silva Dias}

Licenciado em Ciências Biológicas. Mestre em Ensino, Filosofia e História das Ciências. Professor de Ciências e Biologia da Educação básica e da rede estadual e de cursos pré-vestibulares. Membro do Grupo Colaborativo de Pesquisa em Ensino de Ciências (GCPEC), Feira de Santana, Bahia.

E-mail: thiagosankofa@gmail.com

\section{Tiago Alfredo da Silva Ferreira}

Psicólogo. Doutor pelo Programa de Ensino, Filosofia e História das Ciências (PPGEFHC) da Universidade Federal da Bahia (UFBA) e Universidade Estadual de Feira de Santana (UEFS). Professor do Instituto de Psicologia da UFBA.

E-mail: taferreira@ufba.br

\section{Wellington Bittencourt}

Biólogo. Mestre em Ecologia e Biomonitoramento. Doutor em Ensino, Filosofia e História das Ciências. Professor da Universidade Federal de Goiás (UFG). Pesquisador vinculado ao Laboratório de Ensino, Filosofia e História da Biologia (Lefhbio) da Universidade Federal da Bahia (UFBA).

E-mail: biowell@hotmail.com

\section{Wildson Luiz Pereira dos Santos (in memoriam)}

Licenciado em Química. Doutor e mestre em Educação - Ensino de Ciências.

Professor da Divisão de Ensino de Química no Instituto de Química da Universidade de Brasília (UnB), Distrito Federal.

E-mail: wildson@unb.br 
